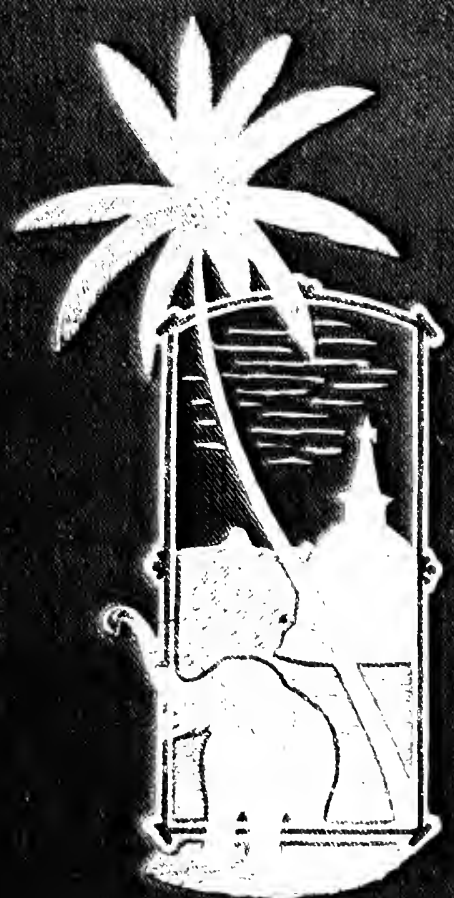




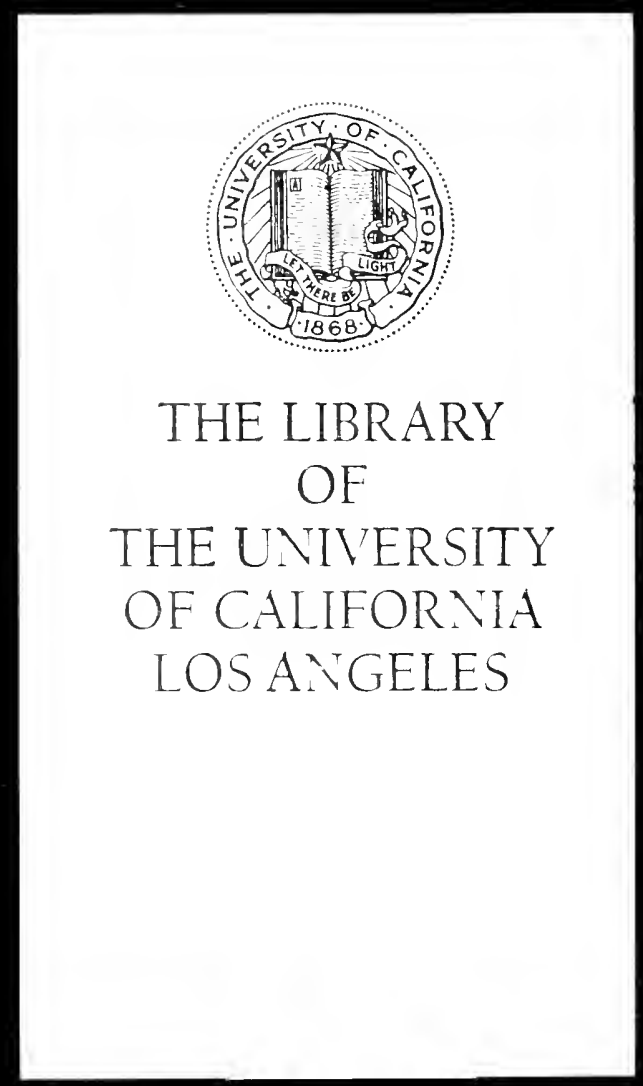


ige 



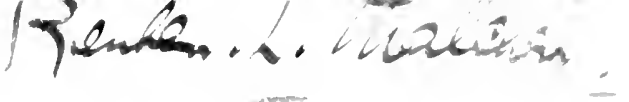

Fen 150. 



\title{
CEYLON
}

\section{A HANDBOOK FOR THE RESIDENT AND THE TRAVELLER}

\author{
BY \\ J. C. WILLIS, Sc. D., F.L.S., \\ (Director of the Royal Botanic Gardens, Peradeniya.)
}

[ALL RIGHTS RESERVED]

Printed by the Colombo Apothecaries' Co., and published by them, and by the author at Peradeniya. To be obtained from any of the bookselling agencies, and in London from Messrs. Dulau \& Co., 37, Soho Square, W.

1907.

This is not an Official Publication.) 



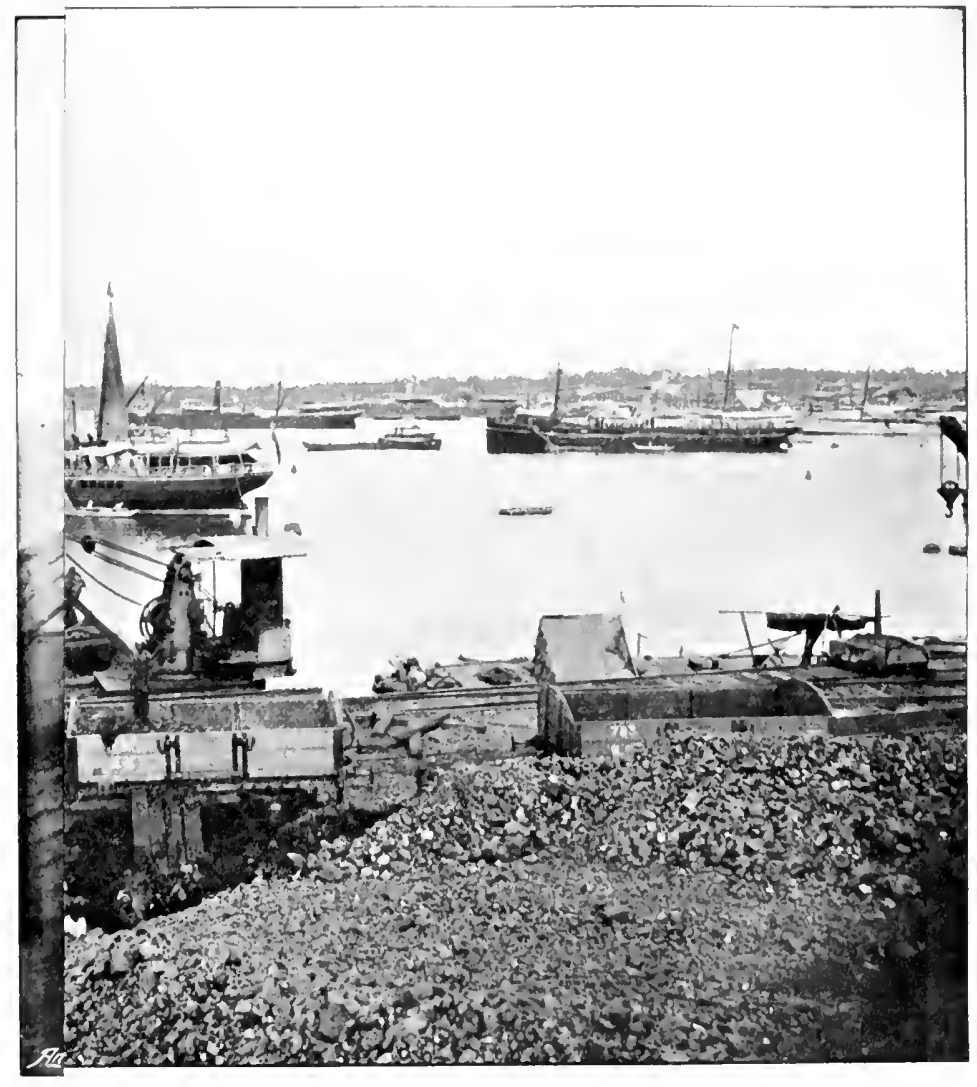

opinions upon things, and consequently the book could have 


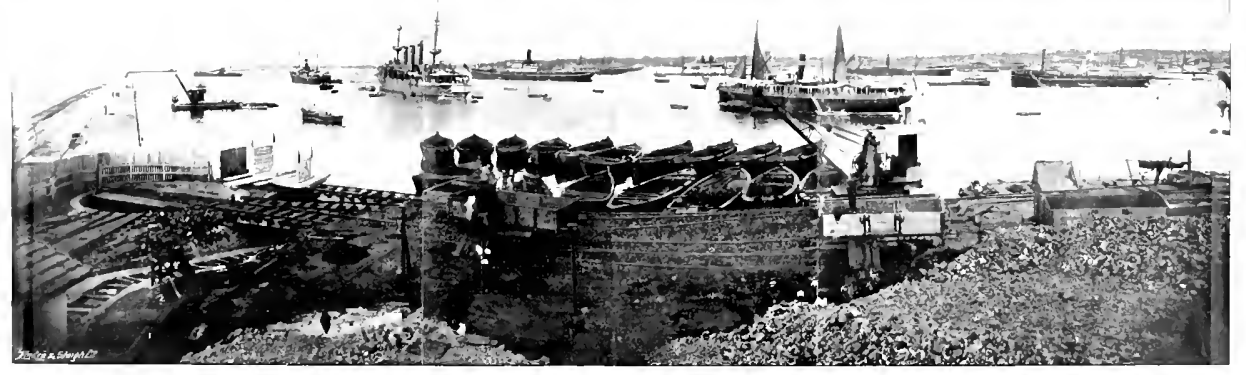




\section{PREFACE.}

SOON after my arrival in Ceylon in 1896 , I was forcibly $\mathcal{S}$ struck with the absence of any reliable modem handbook of the island, and about seven years ago began to collect notes for such a book, jotting down upon memorandum tablets all those items which l considered ought to be included. As these accumulated, they were sorted under heads, and the chapters gradually took shape in outline. After r gor two or three books upon the island appeared, notably the excellent handbook for the St. Louis Exhibition, which in some ways fulfilled my idea of what was wanted, but was written for people outside the colony. Ilaving in vain endeavoured to persuade one who was much better qualified than myself to write a book upon Ceylon, 1 at last decided to do so, and began in 1905, but was interrupted by a serious accident.

Commencing with the idea of writing a comprehensive work of perhaps 1,000 pages, I devoted my leisure from October i 905 to a chapter on the agriculture of the colony. To get this into a form comparatively satisfactory tw myself took no less than eight months, and it would have covered 125 pages of the present book. It consequently seemed to me advisable to work this up into a book upon agriculture in the tropies generally. This was done, and the book will, I hope, shortly appear. If now my own subject were to take so long, and oceupy so much space, it was very evident that I could not hope to complete the work under ro years, and when completed, it would be so bulky that no one would read it, while the keeping up to date of the clapters allealy written would be a most formidable task. Not only so, but my position as a Government servant debarred me from linely expessing my opinions upon things, and comsequently the book conld have 
but little vahue. Again, Mr. Still was writing about the ruins, 1). Coomara-wamy about the art, Mr. Storey about the sport, and so on. I therefore decided to curtail my book, and to write a strictly elementary account of the island, dealing with crery subject in as popular a manner as was consistent with accuracy, aroiding the exaggerations and mis-statements which are only too common in books upon Ceylon.

That my book is as accurate as it is - for I camnot hope to have escaped errors-l owe to the kind help of many friends who have read the manuscript of the different chapters, and added many corrections and notes. I would most especially thank the Hon. Mr. I. P. Lewis, C. C. S., Goremment Agent of Kandy; Mr. Ilerbert White, C. C. S., Government Agent of Badulta; Mr. J. Hawward, C. C. S., Director Public Instruction; Mr. Il. IV. Codrington, C. C. S., Assistant Govermment Agent of Kegalle; Mr. T. J. St. A. Campbell, Conservator of Forests; Mr. II. T. S. Ward, Director of Irrigation; Dr. A. Willey, Director of the Colombo Museum; Mr. J. l'arsons, Director of the Mineral Survey; and Mr. E. E. Green, Government Entomologist. I cannot lupe to have pleased all these gentlemen with what I have written, but I am indebted to them for its comparative ficedom from error. Mr. Harry Storey has rery kindly written for me the clapter upon sport with the gun, and I am also much indebter to Sir Everard im Thurn for allowing me to copy his very interesting sketch of the Pearl Fishery. To my wife I owe a very considerable am unt of help; she has especially relieved me of some of the most wearisome parts of the work, such as preparing the index, tables, ace. In order to sccure as complete accuracy as psisible as soon as may be, only a small edition has been printed, and I shall be most grateful for corrections or notes towards a second.

The attractivencess of the book is greatly culnanced by the numerous excellent illustrations, and my most grateful thanks are due to the Covernment hor the lonan of the blocks from the I Handbooks for the Paris and St. Louis Exhibitions, and to 
the Colomber Apothecaries' Co., Mr. J. S. Crardiner, and Messers. F. Skeen d Co., for others. I have aloo much pleasure in expressing my acknowledgment of the admirable manner in which the Printing J epartment of the Colombe Apothecarice Co. has executed the work.

In weler to make the bork as uselul as possible to the travelles as well as to the resident, I have incorporated an account of the roats, railways, and towns as well as general reference information.

$$
\text { I. C. W. }
$$

Peradeniva, Norember, 100\%. 


\section{CONTENTS.}

PART I.-PIYSICAL FEATURES.

Chaprer I. Geology and Geographis.

II. The Climate.

III. Zoologr.

IV. Botani, Vegetation and) Agriculture.

V. The Forests.

VI. IRRIG.LTION.

PART II.-HISTORY, PEOPLE, ARCIIEOLOGY, \&c.

Chapter vil. mistory.

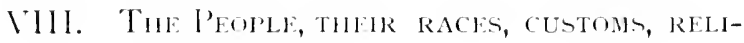
Gans, de.

IX. Archeologi:

X. Governarit.

PAR'T HI.-IIESCRIPTIVE.

Chaptik XI. THE RoADs.

Xll. THE Ranways.

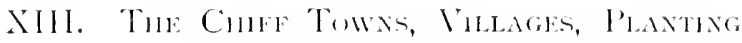
DISTRLTS, de, ALPHABHICALLY ARRANCIED.

PART IV.-SPOR'T.

Chapter XIV. Siorf wth the Gux, by Ilarry Storey. AV. Ganis ini SPORTS.

\section{PART Y.MISCELIANEOUS.}

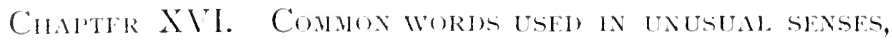
dic.

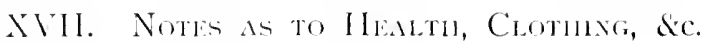

avili. Lifreature. 


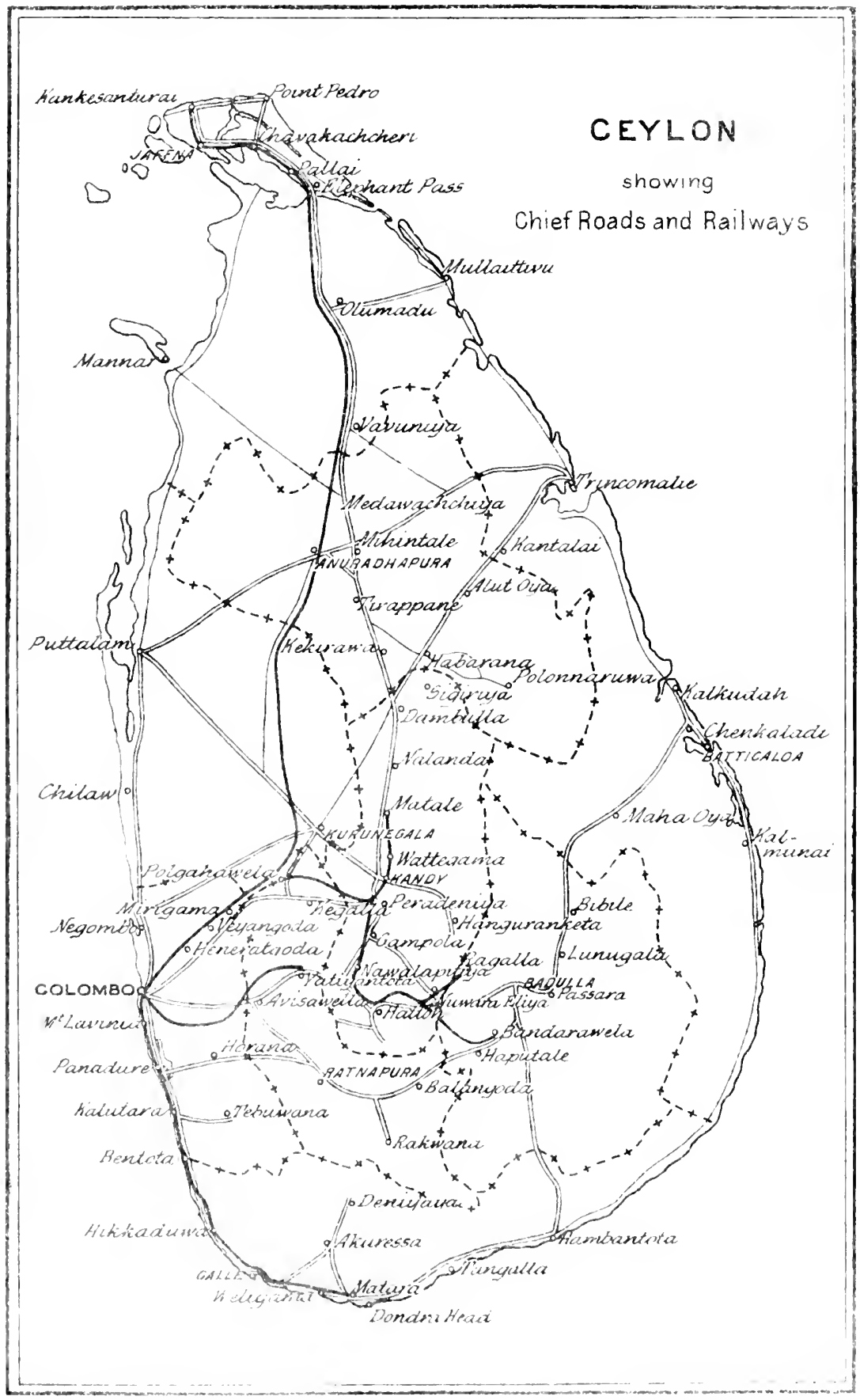





\section{AREAS AND POPULATIONS.}

PROVIXCE.

Caital.

Arlat.

Pupllathox.

Western

Colombo

.. $1,432 \mathrm{sq} .111$.

025,212

Central

Kandy

. 2,290

$622,8_{32}$

Northern

Jatina

Galle

. $3.363 \quad$ " . 342,109

Southern

Batticaloa

. $2,1,40$

Eastern

Kumunegala

. 4,036

566,600

North-WVestern. .

Sabaragamuwa . .

Uva

Ratnapura

Badulla

. 2,996

174,156

North-Central .

Anuradhapura 4,002

353,703

321,262

191,925

79,101

25.329

$3,576,990$

\section{POPULATION BY RACES AND RELIGIONS.}

$\begin{array}{lrrllr}\text { Europeans } & \ldots & 6,300 & \text { Christians } & \ldots & 349,239 \\ \text { Burghers } & \ldots & 2,3,482 & \text { Buddhists } & \ldots & 2,141,404 \\ \text { Simhalese } & \ldots & 2,330,807 & \text { Mindus } & \ldots & 826,826 \\ \text { Tamils } & \ldots & 951,740 & \text { Mohammedans. } & 246,118 \\ \text { Moormen } & \ldots & 228,034 & & \\ \text { Malays } & \ldots & 11,902 & & \\ \text { Veddahs } & \ldots & 3,971 & & & \\ \text { Others } & \ldots & 9,718 & & \end{array}$

\section{AREAS CULTIVATED AND VALUE OF EXPORTS DURING 1906.}

\begin{tabular}{|c|c|c|c|c|c|c|}
\hline Rice & 610,000 & acres & $\cdots$ & $\cdots$ & & nil \\
\hline Other grain & I 20,000 & " & . & . & & . nil \\
\hline Coconuts & 750,000 & , & .. & . . & R. & $2,3,119,600$ \\
\hline Other palms & 140,000 & , & $\ldots$ & . & , & $18,6,30$ \\
\hline Tea & 380,000 & " & . & . & ", & $61,380,765$ \\
\hline Rubber & 150,000 & , & . & . & , & $1.482,000$ \\
\hline Cacao & 35,000 & ,. & . & . & , & $2,052, .100$ \\
\hline Cimnamon & 45,000 & , & . & . & , & $2,6,42,000$ \\
\hline 'Tobacco & 25,000 & , & . & . & ," & 75,607 \\
\hline Cardamoms & 10,000 & , & . & . & . & $5^{85,755}$ \\
\hline Citronella & 40,000 & , & .. & . & , & $1,204,764$ \\
\hline
\end{tabular}




\section{CLIMATE.}

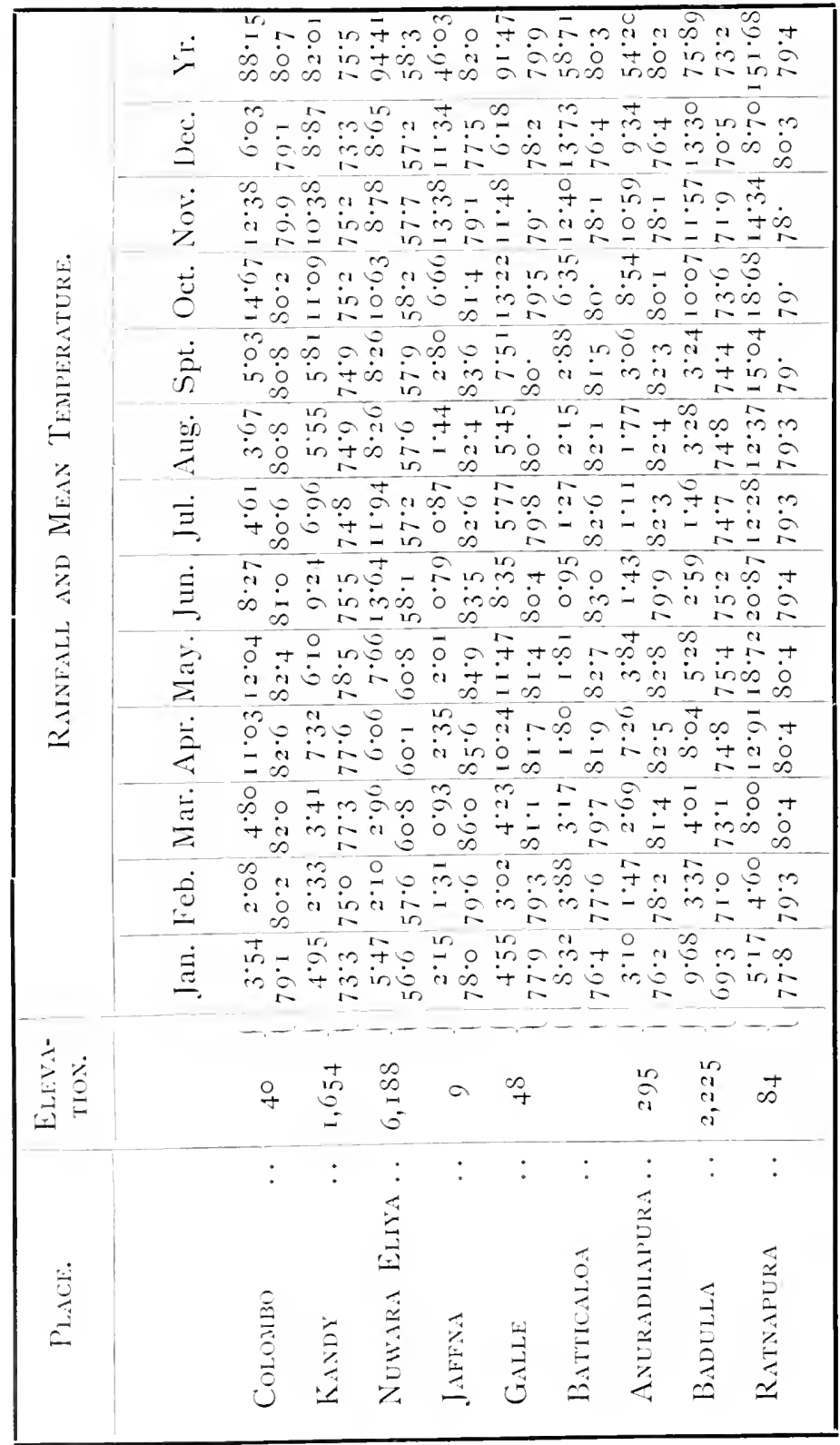




\section{RIVERS.}

Name.

Mahaweli-ganga

Malwattu-oya

Kelani-ganga

Deduru-oya

Walawe-ganga

Maha-1)ya

Kafu-ganga

Gin-ganga

Pedurutalagala

Kirigalpota

Totapela

Adam's Peak

Great Wentesn

Malakudagala

Naminalinlikanda

Konuckles

Ihmasgiriya

Etapola

Nagala
Moutu Nenk.

lrincomalie

Nannar

Cinlomben

Chilaw

Il lambantota

Negombo

Ralutara

fialle

\section{MOUNTAINS.}

8,206 feet.

$7,8,32$

$7.6+6, \quad$.

$7.35 .3 \quad$.

$7.26 .+1$

$0,1901 \quad .1$

$6,6,80 \quad$.

$0,115 \ldots$

$4,155 \quad \cdots$

$1.1 .43,$.

$3,31.1 \quad$ 


\section{COST OF COMMON NECESSITIES, \&C.}

\section{Pasienger ashore 25 cents.}

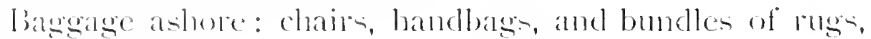
with owner, fice

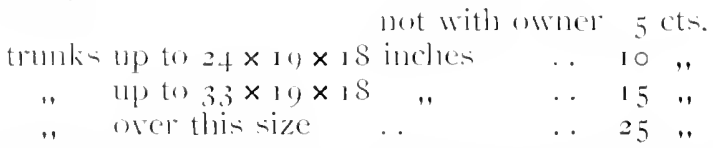

biagratge fiom Jettr to a carrage, light packages + echts, heary 10 cents.

baggige form Jetty to (i. O). II., light packages 6 cents, heary 12 cents.

Rick-haw per half hom 25 cents ; after first hour, 10 cents.

Glarri per lalt hom 50 cents; after first hour 50 cents an homs.

Peelrom boy at hotel, one day, 25 cents; two or three days, 50 cents cach. l'outers ic cents.

Railway porter, one box, 5 cents; two or three, 10 cents.

Return fase to Kandy, Rs. 9; to Anumadhapusa, Rs. 1530.

l'lantains on platforms, $1-1 \frac{1}{2}$ cents each; creonuts 10 cents.

for shari and rickshaw rates, see towns. There is no necel to pay more than these, beymul a reasonable tip of 25 or 50 cents to the driver.

MONEY. El gold 15 rupees. I rupee 100 cents, the coins being 50,25 and 10 cents in silver, and 5,1 and $\frac{1}{2}$ cents in copper.

WEIGHTS and MEASURES. As in England, thongh there are also many native weights and measures in use.

POSTAL RATES. letters (Ceylon) 5 cents an ounce; (ludia), 5 cents a half wunce; foreign o cents a half onnee.

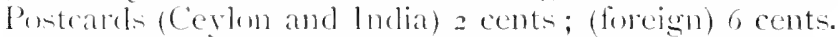

l'rinted matter (Ceyour), 5 o\%. 2 cents; 10 o\%. 5 cents; 1 1b. 10 conts, cach extra 1b. 10 cents ; (foreign) $20 \% .3$ cents and each aclditinal $20 \% .2$ cents.

l'ascels (ceylon) + oz. 5 cents; S oz. 10 cents; 1 lb. 15 contis; cach cxtra lb. I5 cents; (foreign) see Post Office Gilide.

Telesurnms, orlinary, 25 cents for 8 words, and 5 cents a worel berond; 11 went, 75 sents and ro cents. 


\section{HOW TO SPEND THE TIME AVAILABLE IN CEYLON TO THE BEST ADVANTAGE.}

A good deal will depend upon the risitor's tastes. If he in mainly interested in archoology, buildings, sce, he slunld visit Galle, Kandy, Lankatilake, Cradaladeniya, Nluwihare, de., 1)ambulla, Sigisiga, l'olumaruwa, Kalawcwa, Anuradhapura, Mihintale, and the Colombo Museum. But if he be, as most visitors are, simply anxious to see the island senerally, then he should leave Colmonbe till his return, and visit Kandy, Peradeniya, I latton (for Aclam's l'eak), Nuwara Eliva, Bandarawela, Badulla, Anumadhapura, Cialle, Matara, Kalutara, and $\mathrm{Colmmbo}$.

1 few suggested tours are hore given:
() net lleek.
Geneml.
Ariberlosical.

1 Kandy by 7 - 30 train and Peradeniya.

2 Nuwara Eliya.

3 Hakgala de.

4 to Anuradlapura.

5 Anmadhapura.

6 to Colombo, ol I lenaratsoda ancl Colombo.

7 Colombor A Mt.lavinia.

Taro It eeks.

1 Colombro.

2 Kandy.

3 Peradeniya sc.

4 Ilatton and Maskeliya.

5 Idam's Peak d l latton.

6 Bandarawela.

7 Nuwasa Eliga, I lakgala.

8 Numala lidisa.

9) to Anmathripura.

10 Ambadhapular and Milintale.

11 to Colomboby later train

i2 Galle ancl Matioril.

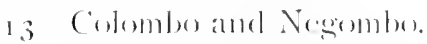

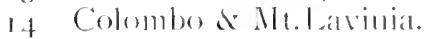

Cinombo Museum.

Gadaladeniya, Lankatilake, de.

Aluwilare, Landy temples, sc.

Anuradhapura.

Anuradhapura a Mihintale.

to Galle.

Matara and Colombo.

Cinombor Nuseum, de.

Kandy.

Lankatilalke, de.

Matale o Nuwihare.

Notor to I Jambullat and Sigiviva.

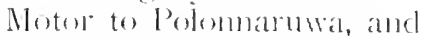
back to llabalance.

Meter to Kalawewa, and back we kekirawa or Amuratilapuma.

Aumadhapura.

- Intratdhapmora.

Mihintale and bx uight mail (1) llatton.

Aclams's Peak.

Nuwara Elivi.

Nuwara Elica, I lakgala, de. To (a)omlor 



\section{PART 1.-PHYSICAL FEATURES.}

\section{Chapter I.}

\section{GEOLOGY AND GEOGRAPHY.}

CEYLON, as is partly indicated by the nature of the rocks of which it is mainly composed, is a very ancient island, and has probably been land for a vast period of

time. At the same time, it has by no means always had its present shape or size, but probably was for a long time at the outer end of a long projecting peninsula stretching from Africa eastwards. In those days, geologically described as towards the end of the secondary period, and in actual fact some time before the chalk hills of southern England were constructed at the bottom of the sea, it is generally supposed that South America and Africa formed one continent called Brazilia-ethiopica, which had an eastward projection towards Inciia and Nalaya. Continuous or almost continuous sea ran round the world at the equator, and the tides must in consequence bave been of extraordinary violence. By the agency of subsidence and the wast of the tides the land comnection from Cerlon to Africa was lroken into a series of islands, and finally destroyed, the present reefs of the Maldives, Chagos, dce perhaps laving formed on some of the highest hand, which was last to disappear.

It is this former land connection which explains why in Ceylon, and Soutl India, there are many animals and plants whose nearest relatives at the present time are in Mauritius, Marlagascas, dec.

ROCKS. All the rocks of Cerlom, exeepting a small areat in the extreme north, and a narrow belt round the coast, where recent coral and sandstone deposits oceur, are of igneous origin, that is to say, have comsolidated from al molten condition in past ages. (O) cooling, the varions minerals have more or less separated in bands, which often gire the impression that the rocks have been laid down moder waterand thus become stratified. Such rocks may be alled gneisses; they are much too old to contain fossils, and belong to the wery early periods of the earth's history. They clocely 
resemble the rocks of South India, and like those may be said to belong to the Charnockite series. The typical Charnockite rock is rery dark, hard, and compact, and consists mainly of the minerals felspar, quartz, and pyroxene. Other common minerals are mica, hormblende, and iron ores. Some of the band consist almost entirely of mica and pyroxene, and are dark in colour, others are almost pure quartz, and are quite white. Such quartz bands should be distinguished from reins of reefs of quattz.

Bands of crystalline limestone occur with the gneiss, and with the included minerals form beautiful specimens. The finer grained varieties may be called marble. Veins of mica are rery commonly found near the limestone, though seldom in it.

Another important class of rocks in Ceylon, also of igneous origin, is the pegmatites, consisting of veins intruded into the gneiss after it liad consolidated, and composed usually of felspar and quartz, while large crystals of hornblende and mica are common. Some of these pegmatites appear as regular granites like those of Dartmoor, as at Balangoda. These rocks are probably the source of the gems for which Ceylon is famous, and of minerals containing thoria, while graphite is also found in association with them.

Both gneisses and pegmatites decompose very readily on the surface under the influence of the weather, and from their felspar is formed kaolin or china clay. This decomposition may be well seen at Nuwara Eliya. Another mode of alteration results, especially in the low-country, in the formation of laterite or kabuk, a reddish rock rich in iron, and containing roundish white concretions. It is soft when dug, but soon bardens and is used as bricks for building. It may later prove useful as a source of aluminium.

MINERALS. 'The most important mincral mined in Ceylon is graphite, otherwise known as plumbago or blacklead. 23,943 tons were exported in 1903 , of a value of about Rs. 500 a ton. The mines are of a somewhat primitive nature (Plate 1I), and are chiefly to be found in the west and south of the island. The mineral is roughly cleaned at the pit's head, packed in barrels, and finally cleaned, or cured, as it is called, in Galle or Colombo. Graphite is used for the manufacture of erucibles, as well as for lead pencils and as black-lead.

Mica occurs fairly commonly, and good uncracked sheets are of considerable value, mainly for use as insulators in dynamos and motors. Pits for mining it are sunk in the veins where it occurs, mainly as above stated in the neighbourhood of the crystalline limestone. 


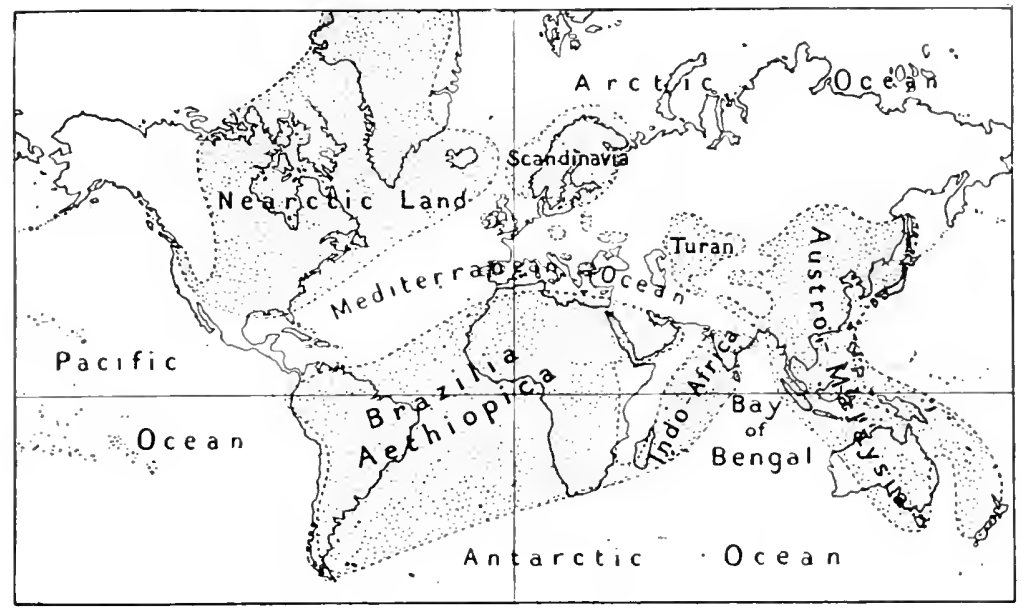

Probable distribution of land at the end of the Jurassic Period.

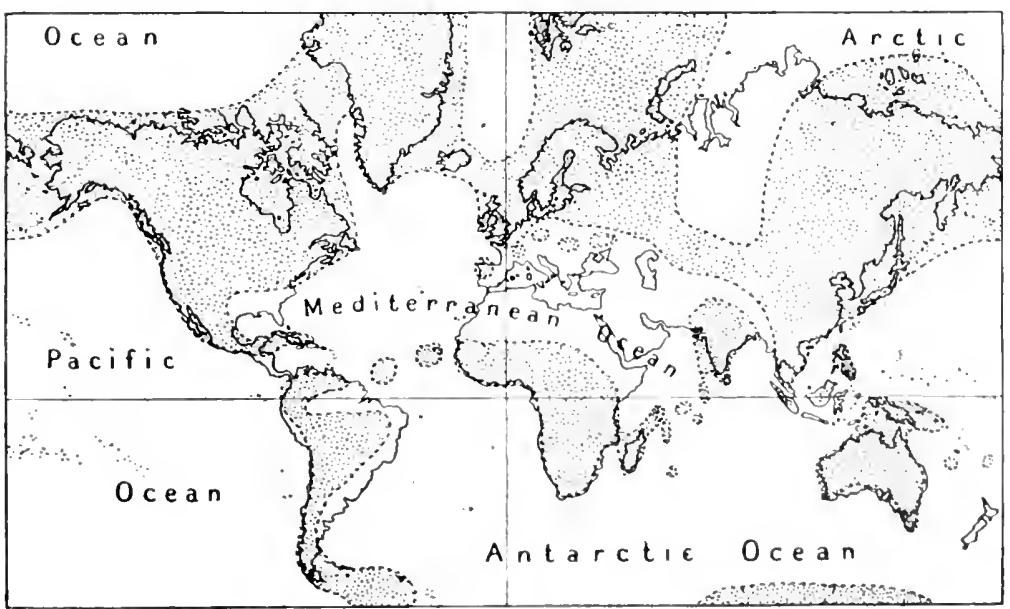

Probable distribution of land at the end of the Eocene Period (much later.)

(See page 1.)

[From the Royal Geographical Socictv's Journal, by kind permission of the Society and of J.S. Gardiner Esq.] 

Asbestos is found in the island, but is not mined commercially. Apatite occurs in lovely blue crystals near Hakgala, and elsewhere.

Ceylon is not rich in metallic minerals. Gold has been found in the gravels and clays underlying the soil in vallers and paddy fields, and in the beds of rivers, but never in paying quantity. Sir Samuel Baker was perhaps the only man who ever approached success, in gold mining near Nuwara Eliva, by the aid of Australian miners. The last boom in sold mining was started during the residence of the Boer prisoners, but came to nothing.

Traces of platinum have been found in the alluvial deposits. Molybdenite, which is used for hardening steel, has also becn found, and cassiterite or tinstone occurs in small quantities. Iron ore is abundant in places. It was formerly smelted by the Sinhalese, and the at is not yet quite extinct, 6.3 . in the Balangoda district. The ore is of excellent quality, and good steel has been made from it, resembling the old Shefficld toml steel. Tools made of such steel are highly valued, but the imported steel is now so cheap that local manufacture does not pay.

GEMS or Precious Stones. The island has been famous for gems from very carly times. They are mostly found in the alluvial plains to the south-west of the Adam's Peak range of mountains.

A gem may be defined as a mineral which for beauty of colour, transparency, or lustre, may be cut as an ornament, and it is also essential that it should posiess sufficient hardness to be durable. Rarity is a further quality that enlances the price, and such beautiful gems as the moonstone suffer considerably in general estimation becanse they are common.

Pits are sunk to a deptly of 2 to 100 feet into a lower laver of gravel in which the gems are mostly found, and the lighter sand and small particles of earth and gravel are washed away in baskets in the stream, and the gems carefully souglit for in the residue. The work is done mainly by the Sinhalese, to whom its ambling nature stronsly appeals, and in the driel weather of the rear from December to Marcl.

What may be called the "gem minerals" of Ceylon are:

(1) Corundum. When oparpuc, it is only used, (1) account of its ereat harelness, for abrasion. Transparent $10 m$ cormundum occurs in a variet of colours. When colourtess it is known as the white sapplive, a stone possessing soleat brilliance, and used instead of diamonds as a setting for other gems.

When red and transparent, cortundum is known as mbl, and this is the most raluable of the Ceylon gems, esperially if 13. 3 
of a pure crimson or "pigenn's blood" colour. Most Ceylon stones have a tint of blue, and must tirst of all be burnt to get rid of this.

When blue, corundum forms the blue sapplare, one of the most beautiful of Ceylon gems, and produced here best in the world. l'blet or purple sapplaires are known as oriental amethysts, and good specimens are of considerable value. The orienial emeretd or sret'n sapphire also occurs here, but is rare. The velloa or orange sapplaires, sometimes known as oriental topa: are also beantiful stones, and may be obtained at a moderate price. The so-called king lopas of the jewellers is not true topaz, but a cross between the yellow sapphire and the ruby, and has a fine orange red tint.

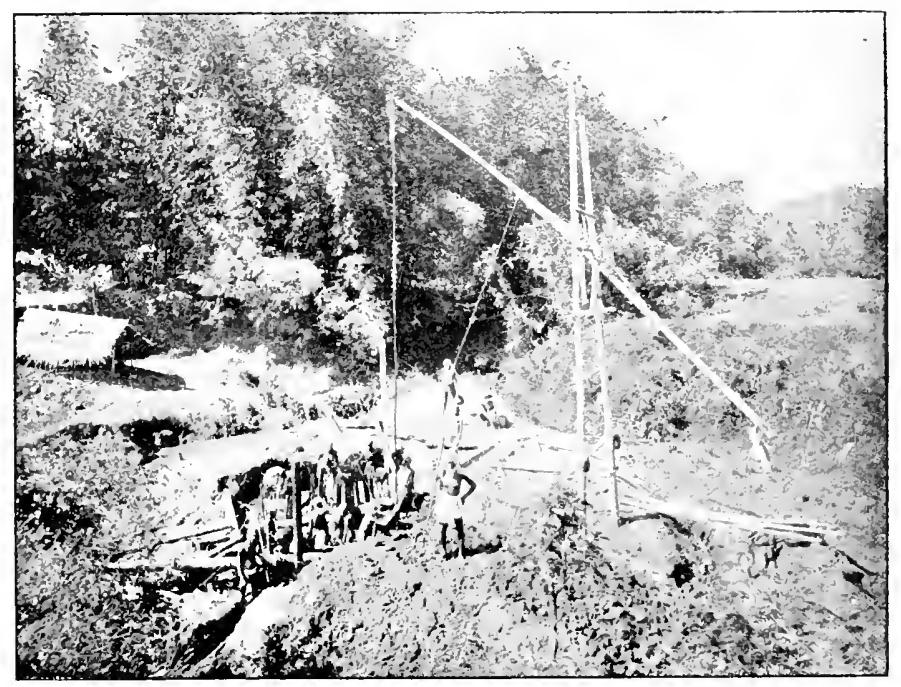

A MOONSTONE PIT.

The ruby and the sapplire have often a milkiness or "silk;" when eut in a rounded or "cabechon" form they show a star, and are known as star molies or supphires, forming beautiful and interesting stones, only to be found in Cevlon.

In the travels of Marco Polo, about $1292 \mathrm{~A}$. I)., occuss the following deseription of the great rubs of the king of Cevlon: "the king is said to have the very finest ruby that was ever seen, as fong as one's land, and as big as a man's arm, withont spot, shining like a tire, not to be bought for money. CublaiKhan sent and offered the value of a city for it ; but the king 
answered he would not give it for the treasure of the world, nor part with it, because it had been his ancestors.".

(2) Zircon. When transparent and of fine colous this is commonly cut as a gem, and usually forms the greater part of a parcel of "Ceylon tancy stomes." Such stones are indiseriminately clased with toumalines by the Sinhalese under the name "tommalli." The formmaline when cut as a gem usually has a dull grecon colour, which changes its tint according to the direction in which the light passes through it. Zircons aceur of a fine leat-green colour- the most valuableand yellow or orange, of red, when they are buown as jocinth or lisacinll, the garenom of the jewellers.

The so-called Hatara thamond, which is set in cheap and pretty forms of native jewellery, is colnurless zircon, obtained by buming pale and pormy coloured stomes.

(3) Garnet. Thene stones are gond and cheap in Ceylom. Many of the rucks along the rivers abont Kandy and elewhere sparkle in the sum from the inmumerable sarnets contained in them, but these camnot be olstained in gond condition. The

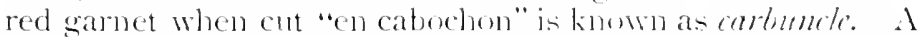
buown garnet is known as cimmomen stome. A magnificent flame red stone, a sarnet containing mansanese, is sometimes seen, and commands a high price.

(4) Topaz. This is either white or pale-gecn. The white stome is cleap, being practically only woth the cost of cutting. The pale-sreen one is sold as amumarim, which is howeres, properly the berel.

(5) Beryl. Lare pale-secen specincens are common,

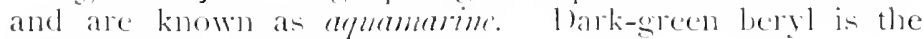
emerald, very rape in Cevlon.

(6) Chrysoberyl. This is a pale-ereen of rellow stone, with a fine luste, but showe pourly by artificial light. A

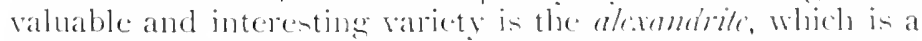
dark-geen by daylight, and crimson by artificial lishe Nhen

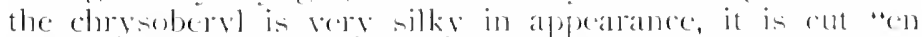

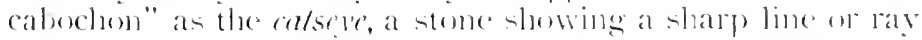
of light along the midelle. The cat's eve is almost peruliale to Ceylon and is most prized when of a fine green entorm with a shajp ray.

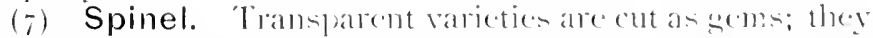

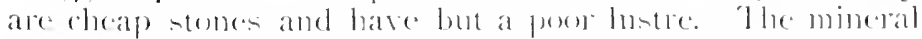
oecurs in red, blue, violet, and serens fine red of blue

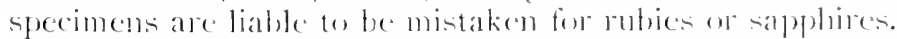

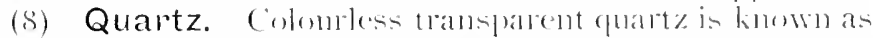
rock crystal; when vellowish hown in colom it is colt as a

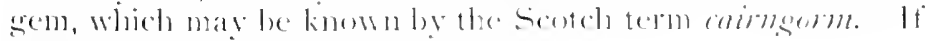
violet it is knowill ats ammethasl. 
(9) Felspar. Some of the Ceylon orthoclase felspar, especially in the Kandy district, is semi-transparent, and shows a peculiar sleen, sometimes blue (the more valuable), sometimes white, and is cut as moonstome. 'This is a very beautiful gem, and it is to be regretted that its comparative cheapress causes it to be undervalued.

(io) Cordierite. This mineral is sometimes cut as a gem, being known as anter supplive, a name often incorrectly given by the jewellers to the white topaz. It is rarely met with.

(1 I) Andalusite. 'This is a somewhat rare and curious stone; when cut in an oblong shape it shows a pale-green colour with red patches in the four comers.

Gems are cut in Ceylon on lead wheels or laps, as a rule, with powdered cormindum, but moonstones ale cut with wooden laps and powdered garnet. When the right shape has been given to the stone, it is polished on a copper lap, by the aid of the ash of paddy straw. It is worth paying a visit to the lapidaries' quarter in the Pettal in Colombo.

The jewellery trade is mainly in the hands of the Moormen or Molammedans, who lave numerous shops in the hotel verandahs and elsewhere in the larger towns. The visitor must always renember in dealing with these folk that the price they lirst ask is from two to ten times what they will ultimately take. He should not show himself too eager to buy, and when he has made what he considers a fail offer, he should even go away, when he will quite likely be followed with an offer of the stone at his own price. In sencral there

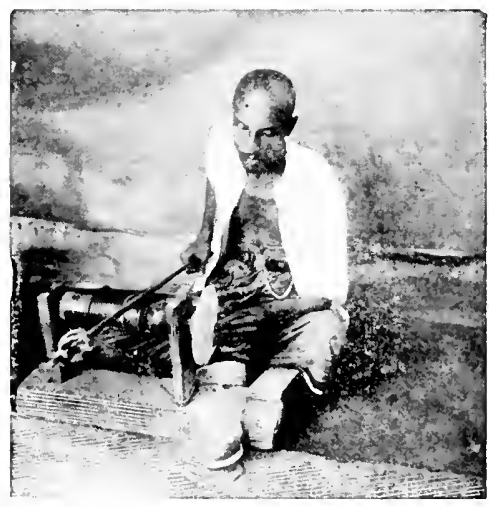

A LAPIDARY.

are few bargains in jewellery to be picked up in Ceylon, many of the men here having of course their agents in London and elsewhere.

The weak point in Ceylon-made jewellery is the setting, which in imitations of Eumean goods, in which the most of the trade is done, is usually poor, and fiequently the cutting of the stones, for the native lapidary usually cuts so as to leave the maximum of weight, and very often the stone can be much improved by further cutting. For use in rings \&c., 


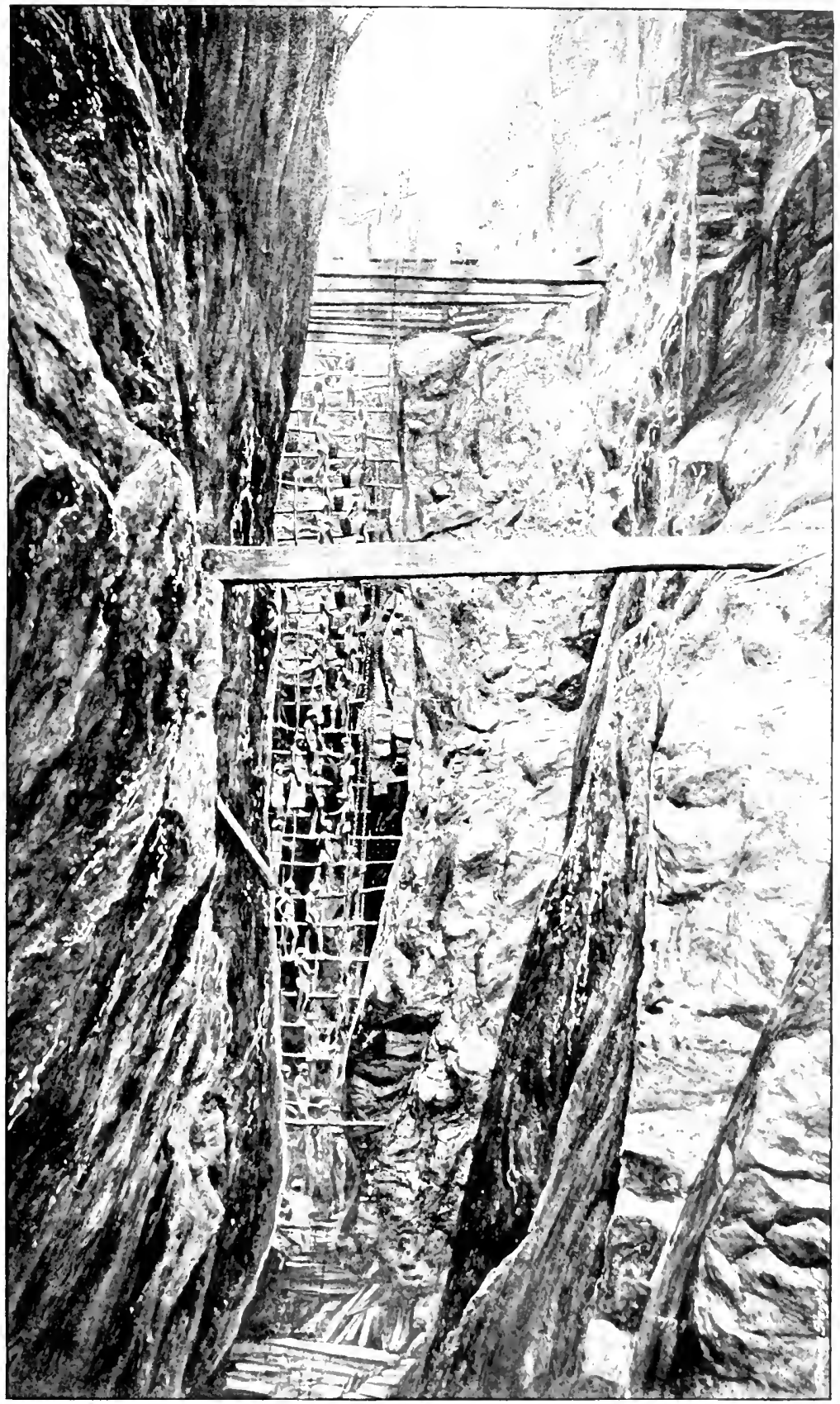



it is commonly best to buy the stones here, and get them set in Europe, but Ceylon has many peculiar pattems of jewellery, some of which are very artistic, and which cannot be got elsewhere. Such are the bangles of mixed Cevlon stones, which can be bought for Rs. 50 to 100 , necklaces of the same, the bangles of Kandyan work, and so on.

The most valuable stone of Ceylom is the ruby, but the price depends on the colour; a bluish tinge detracts greatly from the value. A good pigeon's blood coloured ruby about $\frac{3}{8}$ to $\frac{1}{1}$ inch in diameter is worth about Rs. 300 to 500 . The next most valuable stone is the blue sapphire, and one of fine colour is worth almost as much as a ruby. There are also pink sapphires, worth Rs. 10 to 15 and white sapphires, worth even less. Topazes of fine colour are worth about Rs. 6 upwards, garmets Rs. 3 to 5 , catseyes Rs. 5 upwards, amethysts, cimnamon stones or tourmalines Rs. i upwards. A good blue moonstone, about $\frac{1}{3}$ to $\frac{1}{2}$ an inch long, is worth about Rs. 1 upwards, while a white one is worth from 25 cents upwards.

THORIA-BEARING MINERALS. Reference should be made to certain valuable minerals of this class which have lately been discovered in Ceylon. Thoria is the main constituent of the mantles of the familiar incandescent gas lamps, and hitherto has only been obtainable from monazite, found in Brazil and Carolina, a mincral containing from 3 to 5 per cent. of it.

In 1903 a new thoria bearing mineral was discovered in Ceylon, which contains over 75 per cent. of thoria. It is called thorianite, and is obtained by washing gem gravels. It has sold for as much as fSo per cut. in London. Another mineral containing thoria is thorite.

GEOGRAPHY. The Hindus made the meridian of lanka the native name of the island-pass over Ceylon, but they made the comtry much too large, and their descriptions partake of the nature of fables. The small size of the present jsland some of them explain by legends of submergence, which also are found in Ceylon, and which, as indicated above, may have a foundation of truth.

The Greek geographers are vague, but Ptolemy gives a comparatively accurate accomt of the island, which he would appear to have derived from the naratives of traders and others in Alexandria, where he lived. Ilis acount served for centuries as the source from which other Gock writers drew their information about the country. The nest author to give a good account was Cosmas, in the reigu of Justinian, who from the great extent of his travels received the surname or patronymic of Indicopleustes. At this time a considerable 
trade with the east, conducted through Ceylon, was springing up, but with the rise of the Mahommedan power, all the old trade, and the routes by which it was conducted, was altered, and the new direction of commerce was through Bassora and the Persian Gulf. Ceylon, however, remained the great mideastern port of interchange. The writers who deal with the jsland $f \mathrm{f}^{\circ}$ the next many centuries are consequently mainly Arabian and l'ersian [cf. the adrentures of Sindbad the Sailor, who visited Ceylon.]

Galle would appear to have been the centre of the great and lucrative trade that went on between the east and the west, and has been identitied by many witers with the larshish of the Bible-and there is evidence in support of this view. It lies at the extreme south of the island, and in these early days the population and agriculture was probably mainly in the north. Curious confimatory evidence of this is to be found in the statement of nearly all the earlier writers that the natives when they wished for an exchange of produce, brought the article to be exchanged to a convenient spot, with a description of what they wished in return for it, but were not themselves to be seen. This is to this day the custom of the Veddas or aborigines of Ceylon.

The Chinese also give descriptions of Cevlon and that not inaccurately. $\ln$ r $40 S$ in revenge for insults to their enroys the Chinese sent an expedition and carried the king captive from Certon to China, to which country the island was subject for a good many years.

Atter this there is but little to relate till modem times, which have given us the survey of the island. It is just 270 miles long, and 1 to miles in breadth at the widest part, while the area is 25,481 square miles, or about fire sixths the size of lieland.

The greater part of the island is tlat or gentiy undulating, but about 4,000 square miles in the South-west, lying at a distance of 25 to 50 miles from the sea on the South-west coast, consists of a momtain region rising fairly abruptly fiom the plains to a height of two to five thousand feet and undulating above that to a maximum height of 8,296 feet in Pidurutalagala, while Adam's Peak, which is by far the most conspicuous momntain in the island, on account of its somewhat isolated position and sharply conical top, is 7.353 feet high.

The mountain region of Ceylon consists of a series of ridges having a general direction from southeast to northwest. The rocks were thrown into folds having this direction, and subsequently carved out by water and atmosplueric action. The ridge form thus produced may be well seen on looking from lady I Iorton's WValk at Kandy. 
PLATE 111.

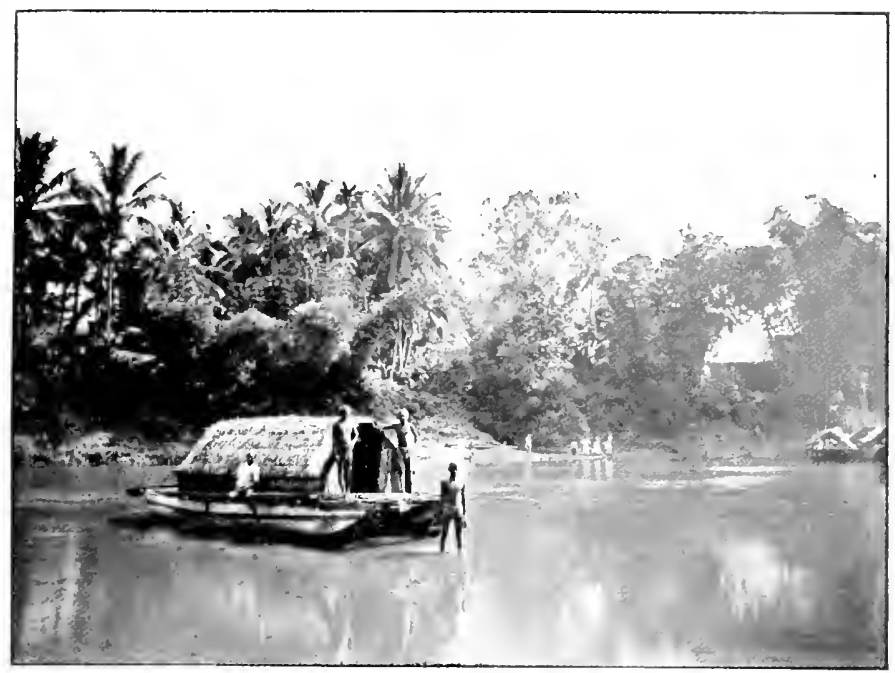

VIEW ON THE KELANI RIVER.

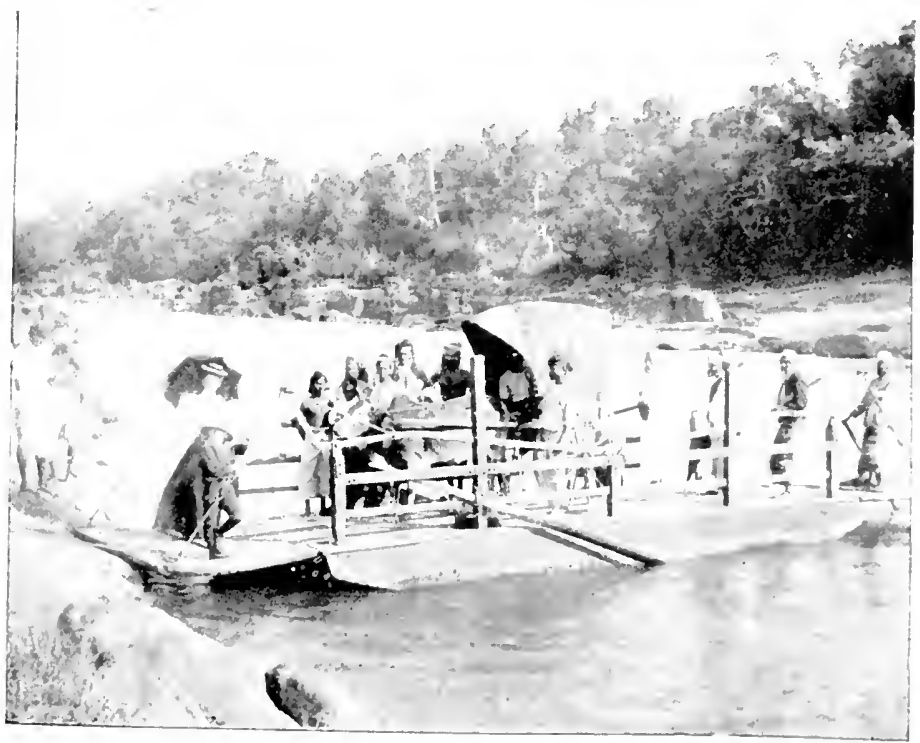

CROSSING A RIVER IN CEYLON.

(See page 9.) 

To the west the ascent to the hill country is very precipitous and the only practicable passes for roads are the Kadugannawa pass, by which the railway runs to Kandy, and the Kitulgala pass, leading up to Nawalapitiya.

The rivers are mostly only of a moderate size, and very rapid, and in consequence not ea-ily navigable, at any rate up-stream. The chief is the Mahaweli-ganga (great sandy river, which drains the bulk of the hill country, and after

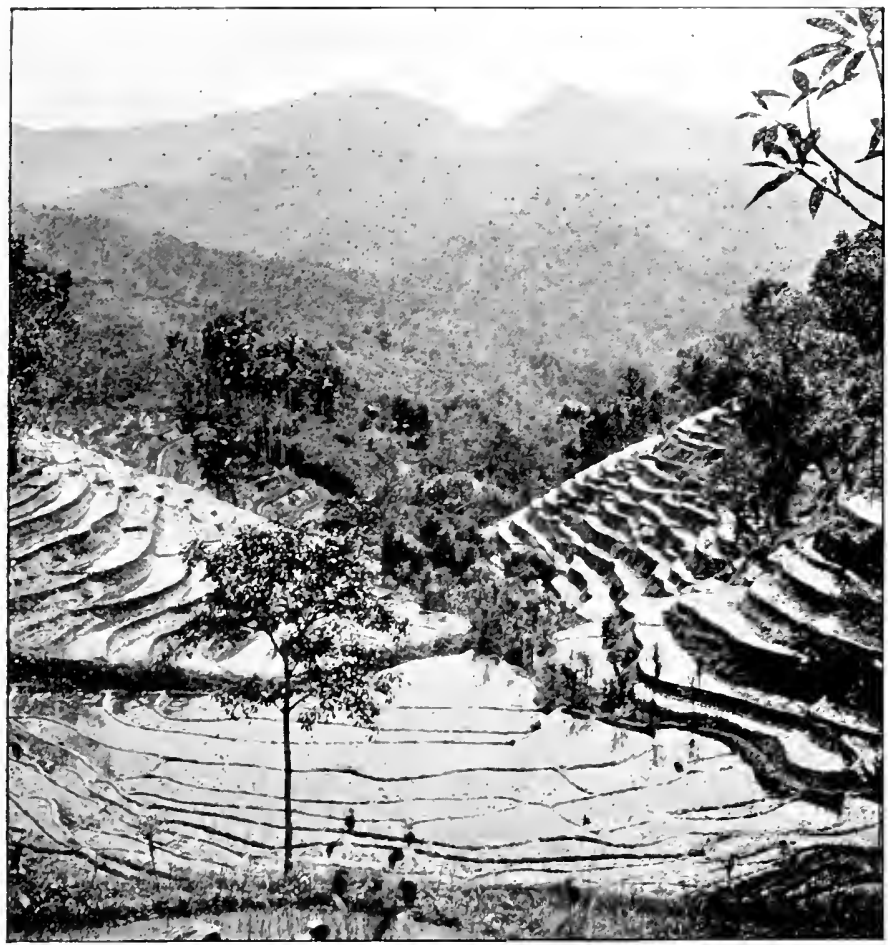

\section{VIEW IN THE MOUNTAINS NEAR KANDY.}

a course of 206 miles enters the sea near lincomalce. Others of importance are the Kelani-ganga, 90 miles long, entering the sea at Colombo, and crosied on the kindy raibay a few miles from Colombo, the 1)eduru-Oya, the Walawe-gainga, the Maha-Ova (passed near Alawwa on the Kancly railway), the Kalu-ganga, the Malwatte-Oya, and the (iin-ganga.

Lakes, other than artificial ones which are both large and numerous do not orcur in Cerlon, but lagoons, such 
as the Colombo Lake, are common all round the coast, being apparently die to the throwing up of sand barriers to the rivers by the action of the sea.

Canals were made by the Dutch between many of these lagoons and rivers along the coast, e.g. the canal by which the steamers run from Colombo to Negombo.

The chief towns are Colombo with a population of about I 65,000, Jaffina 48,000, Galle 39,000, Moratuwa 30,000 , Kandy 28,000, 'l'rincomalee 1 2,000 and Nuwara Eliya 5,000.

The island has 56.3 miles of railway of which 68 are on the narrow gauge of $2 \frac{1}{2}$ feet, the remainder being on the broad gauge of 5 feet 6 inches. This is the standard gauge

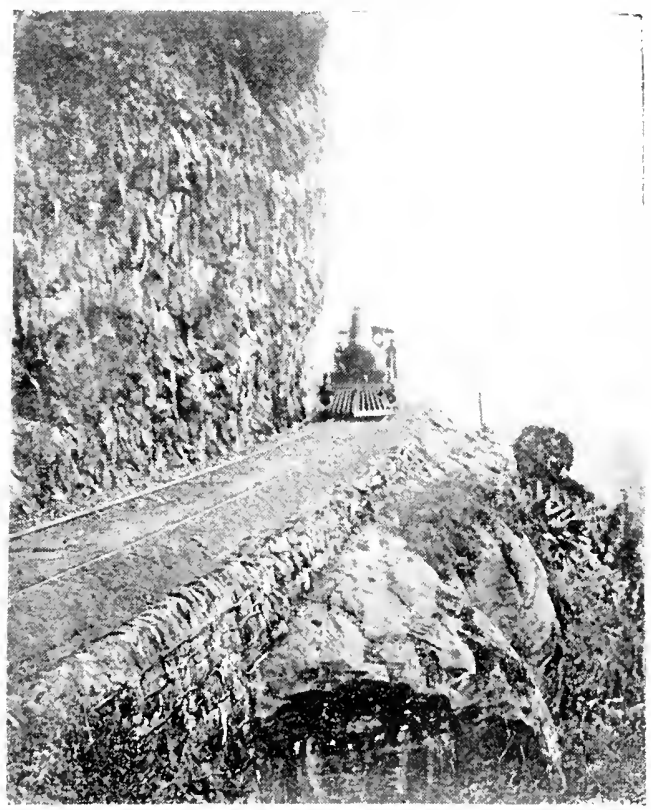

THE RAILWAY TO KANDY.

of India, at least of Northern India, and the Ceylon railways were made of the same gauge in riew of a possible ultimate connection across the sea at Mannar. Unfortunately the most of the railways in South India, including that which runs down to a point opposite Mannar, have since been made upon a gauge of one metre, so that in any case should the junction be made across the strait, there must be break of gauge. The island also has about 4,000 miles of road partly metalled 


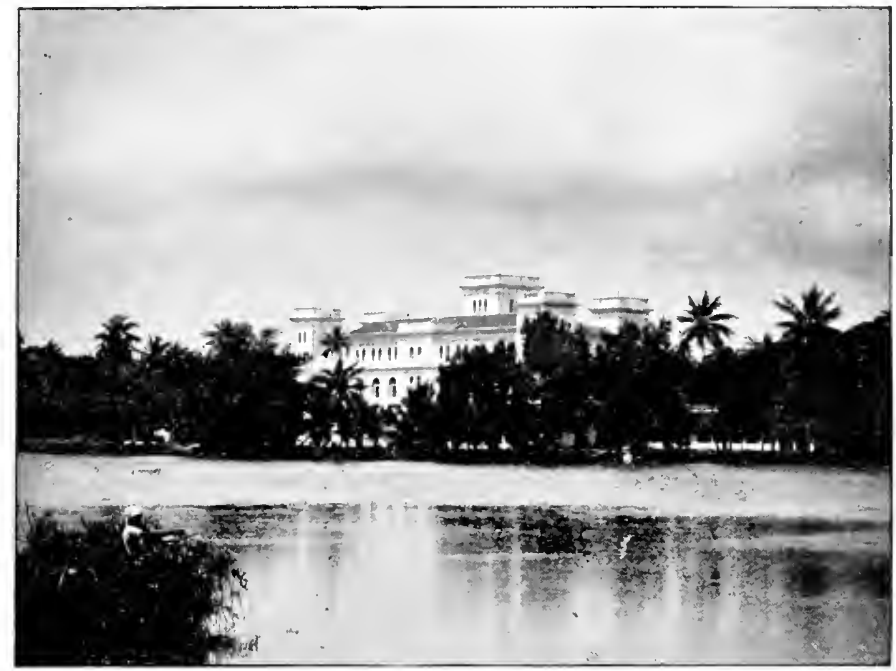

COLOMBO LAKE AND ST. JOSEPH'S COLLEGE.

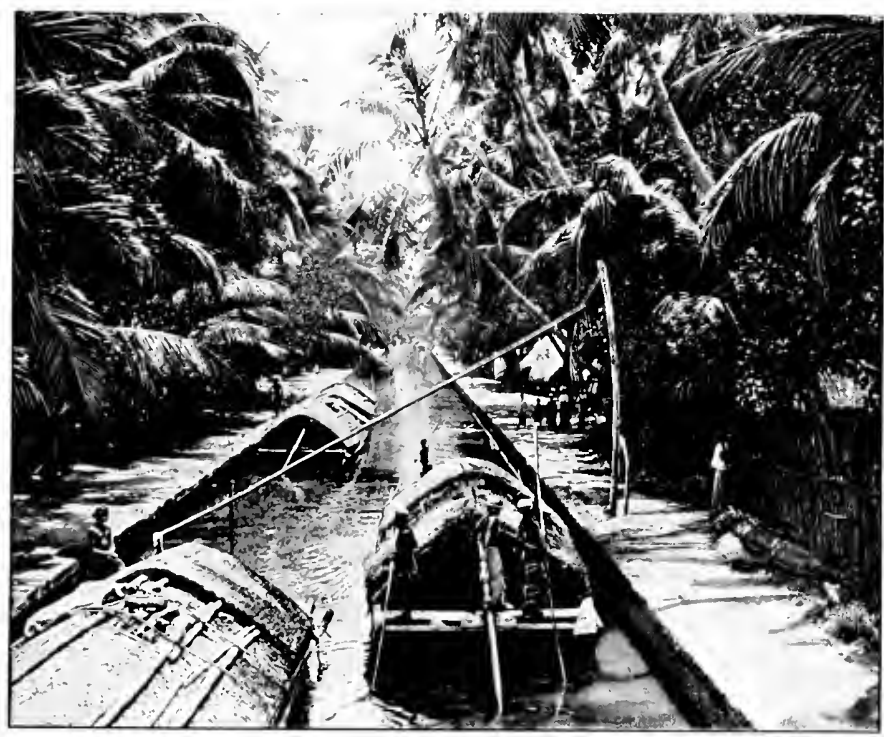

VIEW ON THE NEGOMBO CANAL.

(See page i0.) 

and partly gravel; the metalled roads are in general of firstclasis quality and a motor-car can travel almost thromghrout the island by their means.

The area cultivated in Cevlon is only 3,650,000 acres. while the area possible of cultivation is at least four times that amount. The cultivated areat lies in the West, South and Centre of the island and also in the extreme North, while the rest of the island is mainly covered witl forcst. The chief areas under cultivation are rice 600,000 acres, coconuts 750,000 acres and tea 380,000 . 


\section{Chapter II.}

\section{THE CLIMATE.}

$\mathrm{T}$ IE climate of Ceylon varies very much in the different parts of the island, but in any one part, except to some slight extent in the dry country to the morth and east, it is very similar all the year round, and we do not get seasons in the sense in which that word is used in the temperate zones, although we do get farly well marked seasons in the sense of a difference between wet and dry, for twice a year, with the onset of the monsoons, there is fairly wet weather, passing into drier as they go by. At no time of year in southern Ceylon is there any long dry season, such as there is further north, in India for instance; but the months of January, February, and to some extent March, are fairly dry, the showers in them being but few and far between, and the air being drier.

The marked features of the climate in southern Cevlon are the great constancy of the temperature-whether the whole year be compared, or only one day - the small daily range of the temperature, the dampness of the air, and the changes of the monsoons in April and October.

In Colombo, for example, the highest temperature ever recorded was only $95 \cdot 8$, while the lowest ever recorded was $65^{\circ}$. In Kandy the highest and lowest records are $9^{6 \cdot 2}$ and 49.5. This is at an elevation of 1,600 feet, and the greater range is to be accominted for by the fact that the air gets drier, being further firm the immediate influence of the sea. At Nuwara liliya the range is from $81 \cdot 8$ to $28 \cdot 2$; and the still greater range here is mainly explained by the fact that the place lies upon an open plain, where radiation can go on very freely. At llakgala, close by and a few hundred feet lower down, but upon a steep slope, the range is only fiom $79 \cdot 0$ to $37 \cdot 3$.

The average langes of temperature are of course smaller than these, which represent the extremes over long periods of years. The drier the air may be, the greater is the range of the temperature; thus in Nuwara Eliya, in the dry month of liebruary, when the dampness of the air is only from 50 to $60 \mathrm{per}$ cent. of saturation during the day, the range of 
temperature is from 45 to 70 ; while in the damp month of June (dampness from so to 90\%) the temperature merely ranges between $55^{\circ}$ and $65^{\circ}$.

The air in Ceylon, and in almost all parts of it, is always very damp, the degree of moisture in it on the average ranging from 75 to $S_{5}$ per cent. of the total amount that could be held in it. This is a high percentage, and taken together' with the warm temperature, encourages the growth of every kind of mould on every kind of substance, so that boots or anything else left out of sight for a day or two are very commonly to be found after that time covered with a white fungus growth.

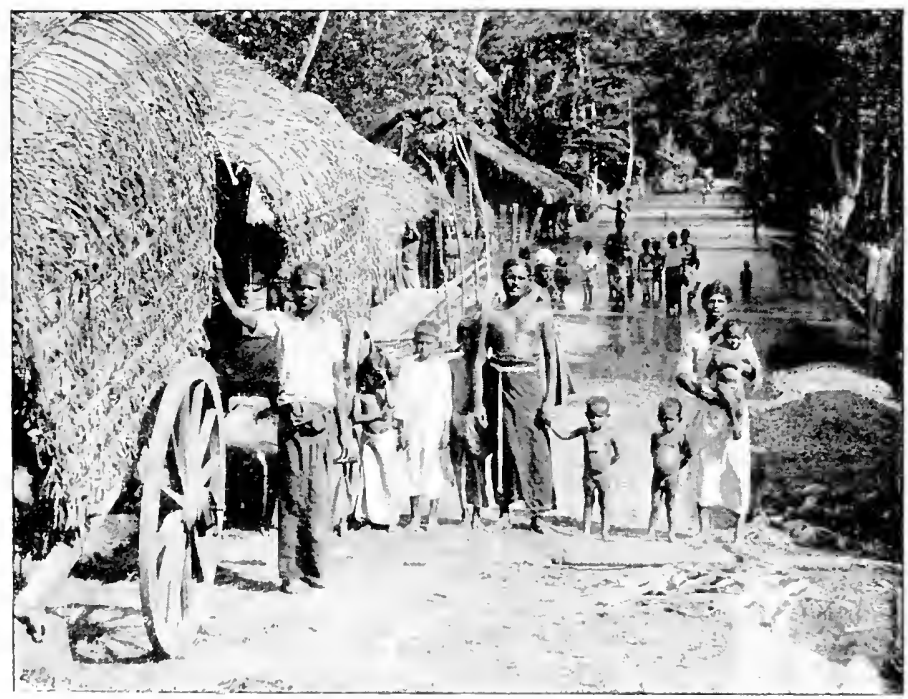

FLOODS IN COLOMBO IN THE S.W. MONSOON.

In January there is a fair breeze blowing firom the north or northeast, the N. E. Momsoon in fact, and this blows with gradually decreasing force until some time about the begimning of April, when the wind becomes more of less variable, the sun being then directly overhead. Presently it sets in fairly steadily from the sonthwest, as the sun goes northward, and the S. IV. Monsoon is said to have hegun. The first onset of the monson is very gentle, and nsially goes in Ceylon by the name of the "little" monsoom; aboit six weeks later it begins to blow and rain mold mole strongly, the change often coming on rather suddenly, and being ushered in by thunderstorms, and the "big" imonsoon is said to 
have "hroken." The southwest wind continues until about September, when it becomes variable again, and then in October, to the acempaniment of many thunderstorms, the wind once more changes, when the sur has gone overhead ayain to the southward, to the northeasterly direction, and the N.E. Monsoon is said to have broken.

The wind on the whole is stronger during the southwest monsoon, but at sea level in Certon it is nowhere of any serions violence, and never appioaches the strength of the wind in a gale in England. Cevlon lies too near to the cquator to be within the zone of cyclones, though when one nceurs unusually far south in the Bay of Bengal, there is sometimes a gale of wind in the north or east of the island, and in 1007 a cyclone actually touched the coast near Batticaloa, and clid considerable damage. At higher levels in the mountains, of course, the wind may be much stronger, and at places like I Iakgala may reach a velocity of 60 miles an hour. This is casily to be understood, for the wind is so to speak condensed, all the wind from all the levels having to get over the top.

The island may be rery sharply marked out into climatic zones, for it is not flat - in which case the climate would be much alike all over-but has a high range of mountains crossing the line of the monsoons more or less at right angles. The damp wind coming from the sea is thus forced upwards and cooled, and in consequence parts with a good deal of its moisture in the form of rain or mist. As it passes down the wther side of the hills the air gets wamed again, and as it now contains less mojsture than before it struck the hills, it becomes a more or less dry wind. Thus it is that in the southwest monsoon there is heary rain on the western side of the hills, but not on the castern, where there is a dry wind, while in the northeast monsoon, especially in the latter part of it, the reverse is the case.

It thus comes about that we can divide Cevlon into zones, which are roughly the wet low-countrs, the dry low-country, the wetter western up-comatry or hill-country, and the drier eastern up-comntry. We may also, if we wish, divide the conler high levels of the hills from the warmer low levels below 4,000 feet.

The wet low-comntry comprises the country up to the font of the hills, from Colombo to Matara which lies at the extreme southern point of the island. Here, owing to the nearness of the hills, there is a good deal of rain at practically all times but in the first three months of the year, and even then there are showers at intervals of a couple of weeks or so. The seneral character of the climate may be sampled in 
PLATE V.

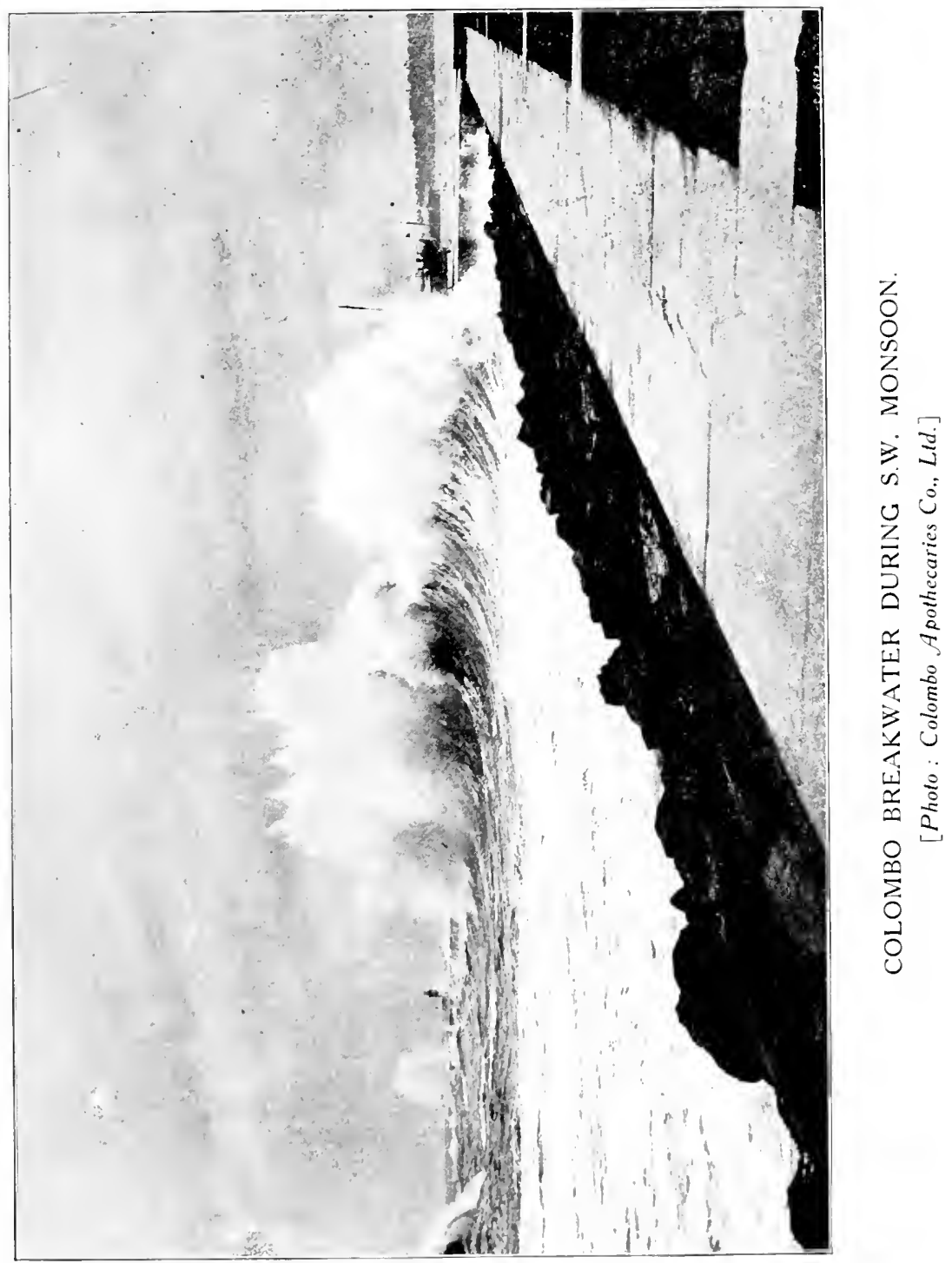



Colombo, though it is rather hotter and more steamy there than in the more inland stations, such as Avisawela or Ratnapura, owing to the greater open paved spaces in the town, which always get hot, and the nearness of the sea, which keeps the air damper.

In Colombo, Jamuary is one of the coolest months of the year, there being usually a considerable brceze from the north. The newcomer will probably like this wind, but the old resident dreads the "long-shore" wind as he calls it, which gives rise to theumatic and other complaints, like the east winds in England. In February and March the wind dies away, and with the continual sunshine of the dry season, the weather gets hotter and hotter, and all who can afford the time and money go away to the hills. In April the little monsoon begins, and affords a temporary relief, but it becomes cloudy, so that now, though the days are a trifle cooler, the nights are hotter, and April and May are perhaps the most unpleasant months of the year. In the end of May the big monsoon comes on, and from that time till the end of August or September the weather in Colombo is very pleasant for a tropical town, there being a continual breeze from the sea, and the weather being much cooler and more equable. September, being dry, is generally warmer again, but soon the northeast monsoon comes on, and there is pleasant showery weather till Christmas, about which time the long-shore wind begins again.

In the dry low-country, which ocempies all the north and the country below the momntains on the east, the bulk of the rain is in the northeast monson from September to January, though there is often a goud deal in the early part of the southwest monsoon in April, in the more southern parts between Anuradlupura and Kurunegala. louring the rest of the year there is but little rain, especially from May to September, and it gets steadily warmer from February onwards, thongh the strong breeze from the southwest moderates the heat after April.

On the western side of the mountains, the heaviest rain falls during the southwest monsoon, though there is usually a good deal during the first three months of the northeast, so that except in January and lebruary there is rain almost all the time. The general characters of the months are thus very like those of the Colombo climate, but cooler and cosler the ligher one goes. Whereas, on the castern side, the rainiest weather is in the northeast monsoon, and the drier season is from Jume to September, a rather longer dry season than that on the western sicle, so that there is more dry and open country. The flowering seanons of a gleat many plants 
are six months or so different on the eastern side from those on the western, just as if one had passed into the southern hemisplere; thus Para rubber ripens near Colombo in July, at Badulla in February.

It might be imagined that the wet country of the west would pass very gradually into the dry countiy of the east during the S. WV. Monsom, but this is by no means the case. Driving from Nuwara Eliva over the watershed to the east, c.s. a few miles below Hakgala gardens, one comes almost suddenly out into blue sky and sumshine, leaving the gloomy atmospliere and the rain behind. This is sometimes to be secu in the most striking way at the tumnel between Pattipola and Ohiva stations. On the nne side it mar be wet and dismal, on the other fine and sumny. 
PLITE VI.

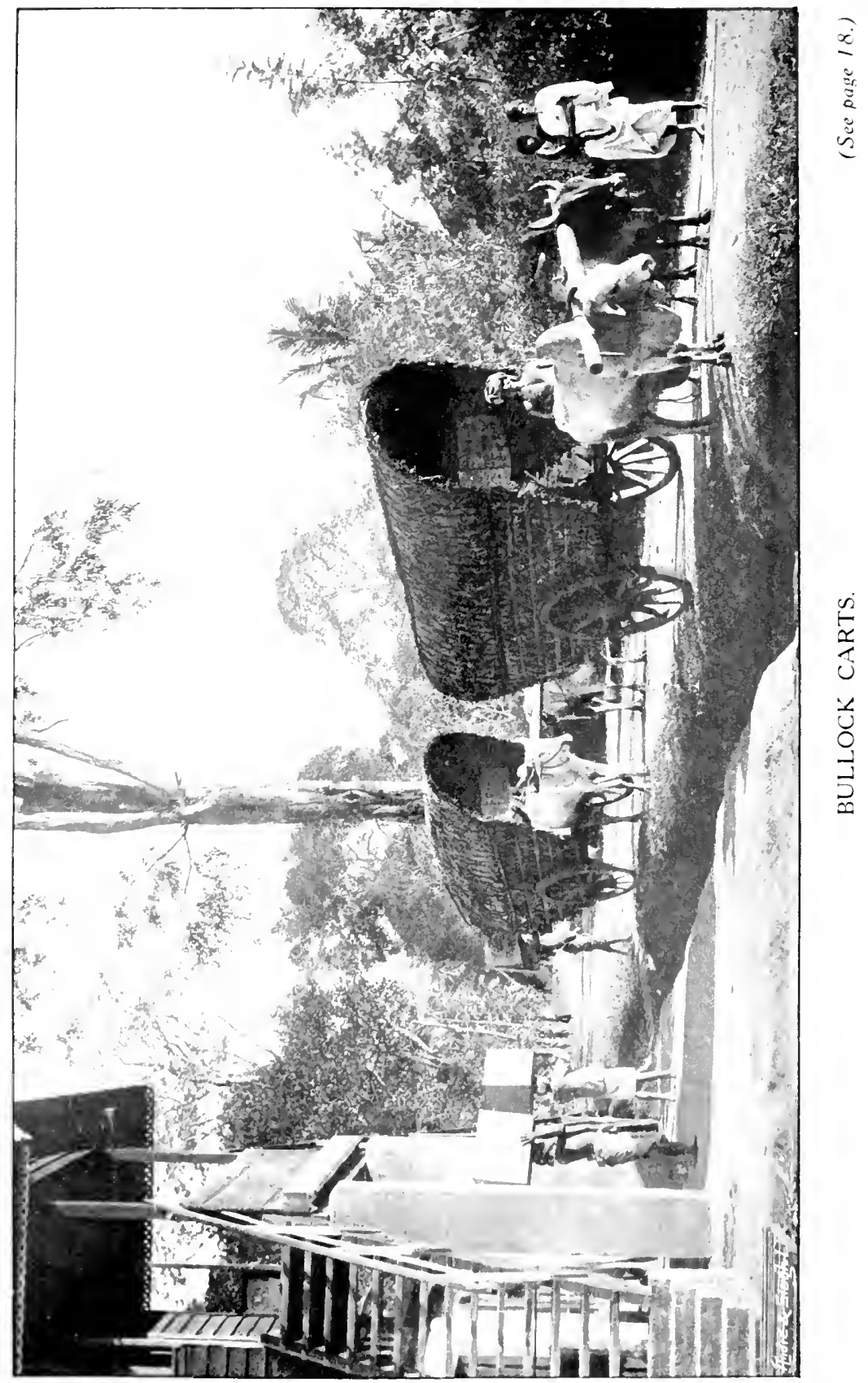





\section{Chapter III.}

\section{ZOOLOGY.}

$\mathrm{T}^{\mathrm{H}}$

IE zoology of Ceylon is of considerable interest, but as the animals are in general less accessible than the plants of the island, we need say less about it. To a large extent Ceylon is a smaller edition of India, but there are also a number of animals whose nearest relatives are African or Malayan, whose presence here is to be attributed to the former land connection (p. 1).

The centre, west and south of Ceylon are so much cultivated and civilised that we find in them few other animals than noctmmals, or pariah-dogs, flying-foxes, jackals, snakes, rats, mice, and other animals that accompany man. In the up-country districts, especially about Nuwara Eliya, one still finds the leopard, the elephant, the deer, the pig and other wild animals in the forests that there remain untouched, while in the extensive forests in the low-country of the north and east, and especially in the two game preserves which have been created in the southeast and northwest, there are still a considerable number of wild animals of many kinds.

We slall deal with the commoner animals in order, aranging them partly by their natural affinities, and partly in alphabetical order; but it must be made quite clear that Cerlon is really very rich in animal life, and that these are only the "obvious" amimals-(and see chapter on sport, below).

MAMMALS (those giving suck to their young).

Bats. There are many kinds of small bats to be seen flying about at dusk, but the kind which is of special interest is what is usually known as the flying-fox, a very large bat which may measile as much as three leet across the wings. They hang in lofty trees during the day, in great numbers (a colony is often to be seen in the gardens at Peradeniva), and hy away at dusk to get their food, which consists almost entirely of firut, the varions wild figs being special lavomites.

Bear. The Ceylon bear is rather small and hlack. It lives largely upon honey, and is common in stony places in the northern jungles. It is a somewhat dangerous animal to meet, as when suddenly disturbed it does not run away, but stands upon its hind legs and claws the assailant. 
Buffalo. The wild animal is only to be seen in out of the way jungles or grassy spots in the diry country, particularly in the southeast, where it affords very good sport, but the tame buffalo is used in every paddy field in the island for ploughing, and may be met on every road. lt is not a safe animal for the white man to interfere with, though a small native child can readily handle it. When not employed, the buffalo usually lies in water, with only its head appearing above the surface.

Bullocks. These are universally used in Ceylon for all draught work. The native bull is small, the "coast" or Indian

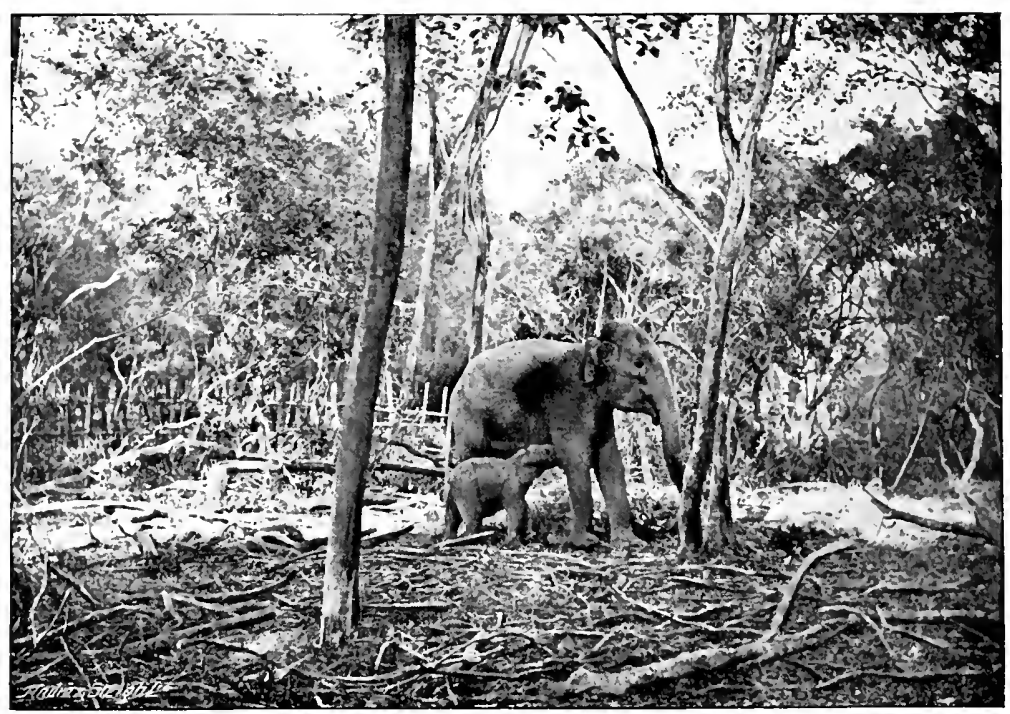

ELEPHANT AND YOUNG.

bull larger and usually more or less white. Both are of the "yak" type with a large hump, in firont of which the beam by which they draw is placed. They are very commonly branded in various ways. Sometimes the marks are caste or ownership marks, and sometimes they are put on, as directed by native doctors, for the cure of ailments.

Deer. Ceylon contains five species of deer. The axis deer is very common in the dry country, ruming in large herds. The sambur, or elk, as it is locally miscalled, is found in the up-country districts, where it is hunted with packs of dogs, the huntsmen going upon foot. $\Lambda \mathrm{fter}$ a run, often of considerable length, across country, the decr usually 


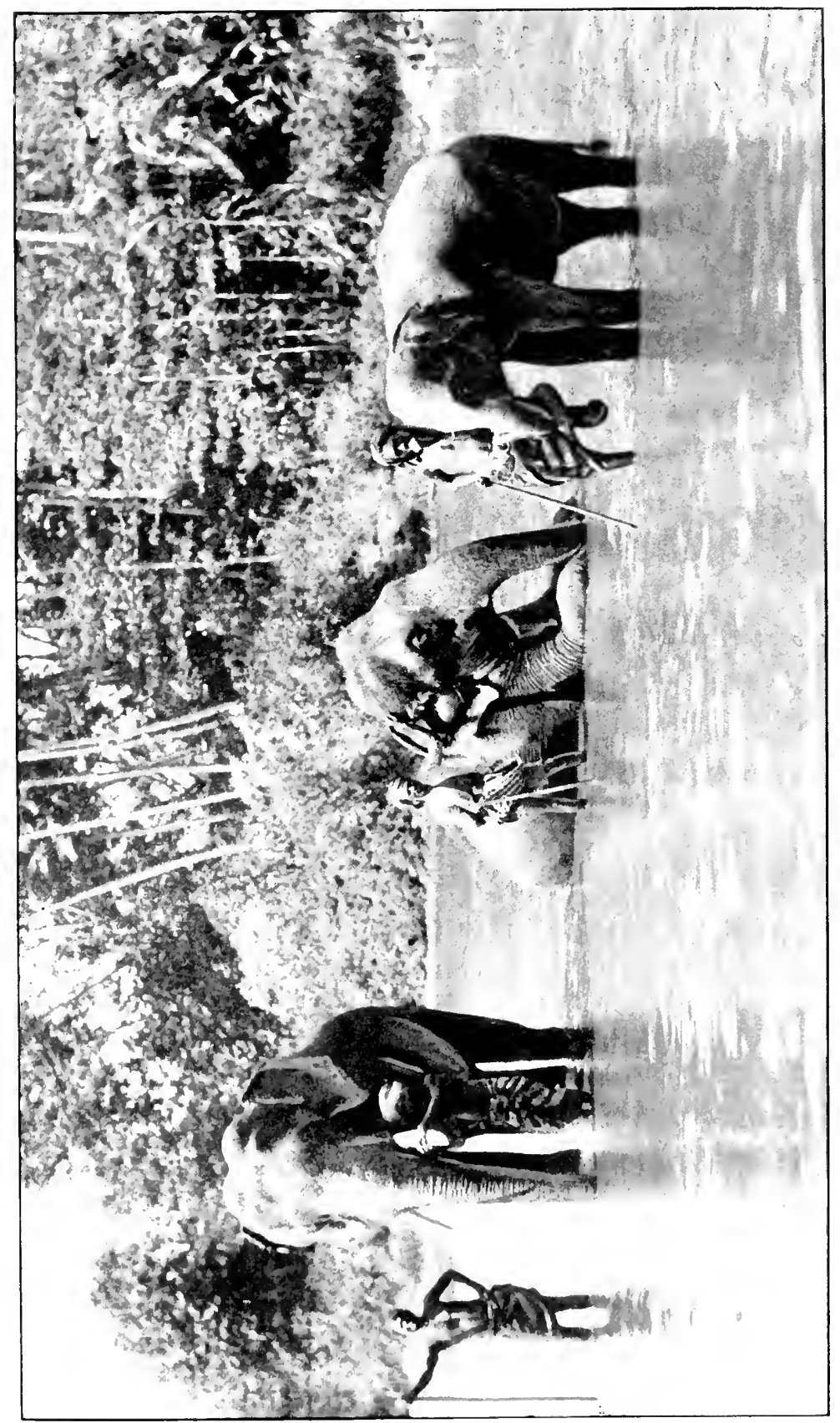

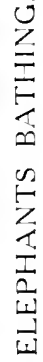



comes to bay in a pool upon a river, and is killed with the hunting knife. The mouse-deer, a tiny deer about 18 inches high, is very common up-country, and is so small that it can get under or through most fences.

Elephant. This animal is very common in Ceylon, whence many of those in use elsewhere are procured. The Ceylon elephant is smaller than the African, and is rarely provided with large tusks. It roams about in herds, which cover a considerable area of country in their wanderings. It is strictly preserved, and can only be shot by the holder of a license.

Every few years an "elephant kraal" is held in some part of Ceylon, usually by one of the Kandyan cliefs. A large stockade is erected in a central place, and the elephants are driven into this by thousands of beaters who beat the jungle in a steadily decreasing area for weeks. Finally the elephants are driven into the kaal, where they are then captured by tame elephants and tied up until they become tame enough for removal and training.

The elephant is a remarkably clever animal, and it is wonderful to see it obeving the word of command given by its mahout or driver. It may frequently be seen in Ceylon uprooting trees, piling timber, carrying stones, or drawing heary machinery to up-country factories. A farourite place for the visitor to see elephants is in the river at Katugastota, near Kandy, where some elephants kept by a Kandyan chief may be seen bathing almost every afternoon.

Jackal. This is very common in all parts, and looks not unlike a rather hairy pariah-dog. It hunts at night, with a sustained howling and barking.

Leopard. The leopard, often miscalled here the clseetah, is still very common in the up-country jungles, but does not attack man unless driven to bay. It is frequently caught in dead-fall traps, which are baited with live goats.

Monkey. Ceylon contains five kinds of monkey, the most common of which is perhaps the large wanderoo, often to be seen among the coconut or other palms on the beach, leaping from tree to tree with wonderful agility. 'The rillow or macaque is very common at Anuradhapura, $\bullet . s$. in the enclosure round the sacred bo-tree, where the monkeys are so tame that they will often sit and look at the visitors, "striking matches on the legs of their trousers." The young are carried by the mothers beneath their own bodies.

Mongoose. This animal is not often seen wild, being mainly nocturnal, but every snake-charmer carries one about with him, and for a consideration will allow it to fight with the cobra he also carries. The animal is not unlike a large 
squirrel, and is wonderfully actire, leaping about with such rapidity that the snake can but rarely strike it.

Otter. This is found in a good many streams in Ceylon, and is hunted with otterhounds in some of the planting districts.

Pariah-dog. This animal, which is very abundant in every rillage in Cerlon, is not a real native of the island, but was fong ago introduced. It is usually a thin, mangy, half-starred disreputable beast, slinking away almost at a look, and barking at erery passer-br, but if well fed and cared for from a pupps, it is quite a handsome animal, and is said to be a good hunting dog.

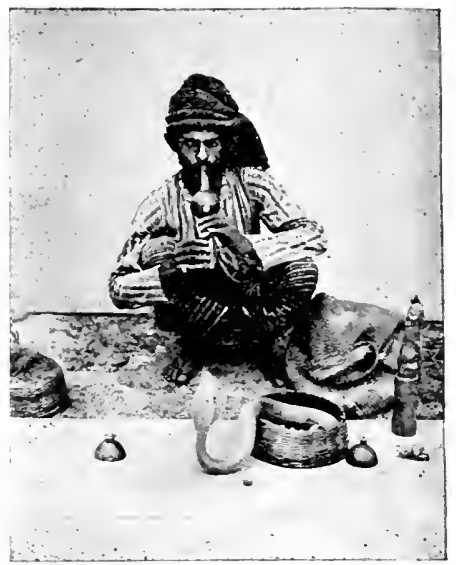

SNAKE CHARMER AND COBRA.

Porcupine. This is a very common and troublesome animal in the planting districts, being a great uprooter and devourer of garden and field plants, while owing to its covering it is protected against dogs, which, should they unwisely attack it, are liable to be severely injured by the long quills. There is quite a small industry locally in making workboxes kc., from these quills.

Squirrel. This is perhape the commonest animal in Ceylon. It is not quite so large as the English squirrel, but is prettily marked with three black stripes along its back. The current legend about these is that the devil in trying to catch the animal, missed, but burnt three lines upon it with his fingers. There is a larger and rery handsome rocksquirel in the up-country jungles.

Rats and Mice. These are common in all inhabited parts of Ceylon, but need no further mention. An enormous rat, the bandicoot, sometimes does damage to plants.

\section{BIRDS.}

These are fairly numerous in the island, but there are comparatively few of gorgeous colouring, and people often complain of the absence of bird life. The clearing of the timber in the planting districts of course drove away most of the birds there, but with the large planting of sliade trees that has gone on in recent years many have returned. 
Some of the commoner or more important birds are described below:

Coppersmith or Barbet. This is very common up to moderate elevations, in scveral species, and is a small green bird, with a erest. It has sereral notes, but that to which it owes its name is a continuous "tonk, tonk, tonk."

Flamingo. These visit Ceylon in large numbers during the N.E. Monsoon, and wade in the salt lagoons about Hambantota, and elsewhere.

Golden Oriole or Mango Bird. This is a bird about the size of a blackbird, with a fine yellow and black plumage, and may be seen about Kandy and elsewhere.

Jungle Fowl. This is a very common bird, and affords good sport, being very sly and quick on the wing. It is very common in the up-countly jungles when the nelus (see below, under Botany) are in fruit.

Lark. Very common on the patanas at high levels.

Magpie Robin. A small black and white bird, not unlike the English magpie, very common about houses, and with the same habit of stealing brightly coloured articles. A very salley bird.

Night-jar. Very common, and may be heard "singing" in the dusk. The notes are like the throwing of stones over thin ice "tap _ tap - tap - tap-tap, tmmor."

Paradise Flycatcher. This bird is not infrequent about Kandy and Peradeniya in the N. E. Monsoon. It has a brown body when young, grey when older, with two very long white feathers in its tail, which give it a very curious look when flying.

Parrot. A small green parot or parroquet, with a red bill, is very common and has a screaming note. It feedi upon fruit.

Peafowl. Common in the east of Cevlon. During the day it feeds upon the ground, but at night it roosts in the trees.

Sparrow. 'The same as the English sparrow, and equally common everywhere that man is, but very rarely to be seen anywhere clse.

\section{REPTILES.}

Cabragoya. A huge lizard, about four feet long, and black, is not infirequently to be seen near streams in the lowcountry.

Crocodile. A large crocodile, about 15 feet long, is common in many rivers, and another species in the tanks in the dry country. Bathing places in crocolile-infested rivers, es. by the bridge at Matara, have to be protected with stoekades. 
Frogs and Toads. Common everywhere. The frogs are rery largely small tree frogs, making a kind of plaintive "chirpp" at night. Some can jump to a considerable height and stick on. Toads are common round the walls of rooms at night, catching insects, and occasionally breaking out into a kind of brrmrry noise.

Lizards. These are very common. The most interesting are perhaps the large "bloodsucker," a long green lizard which turns brown if it lie upon the roadside, green if upon the grass, while when exeited its head turns red, and the gecko, or house lizard, a little yellow creature, which runs over the walls at night catching ilies.

Snakes. There are many of these in Cevlon, both in kind and number, but the popular ideas in England are not borne out; it is rare to see a snake, as it is a very timid animal, and gets out of the way when it hears any one coming. There are several poisonous kinds, such as the cobra, the tic-polonga (a very deadly and rather dangerous snake, though rare, because it is very sluggish, and does not readily move away; recognised by its stumpy tail, and dark blotches on a yellowish ground), Se. The commonest snake is the rat-snake, a large snake which hunts rats dce, and very often lives above the ceiling eloth in a bungalow. It is mole often seen than any other, being a harmless and privileged snake. The python is sometimes to be seen in the dry country.

\section{$\mathrm{FISH}$.}

There is a large fishing industry on the Ceylon coast, and fish of every kind may be seen in the markets at the seaside, but the usual fish eaten in bungalows is the seer, a large fish not unlike a cod, and which will carry better than most in this warm climate. There are some very remarkable fish in the island, which walk, climb, or sing. The walking fish is sometimes to be seen in the north, travelling from one tank to another; the climbing fish is common along the southwest coast, and climbs by bringing its tail round to its lead, and then moving the head forward; the "singing fish" (perhaps a molluse) is to be heard in the lagoon at Batticaloa on clear moonless nights, and makes a noise like distant motor horns. The most interesting fishery is the Pearl Fishery, described below.

\section{INSECTS.}

The island contains a fair wealth of insect life. There are many very large and beautiful moths and butterflies, which exhibit a peculiarity not seen in England, in that they 
PLATE VIII.

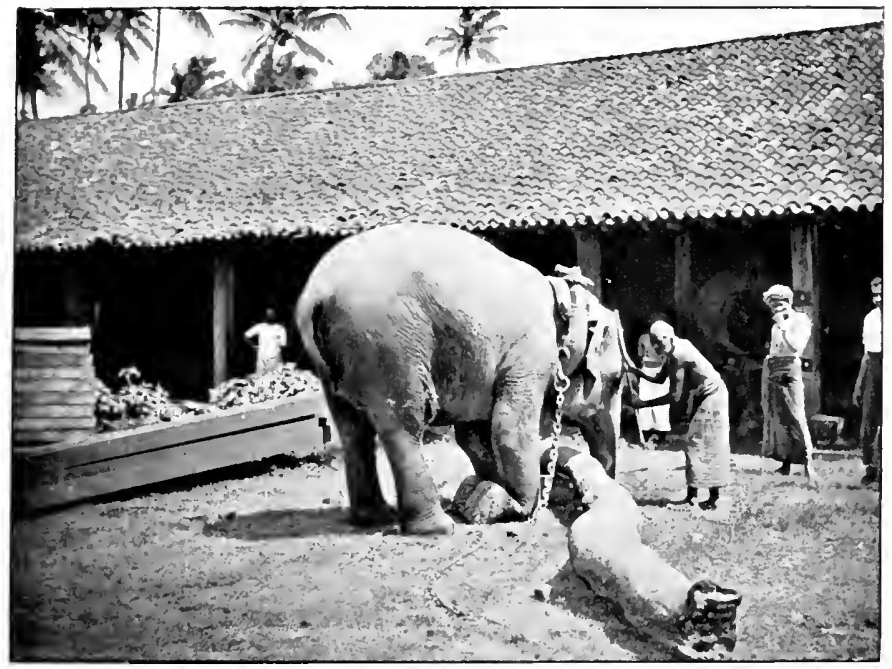

ELEPHANT LIFTING TIMBER.

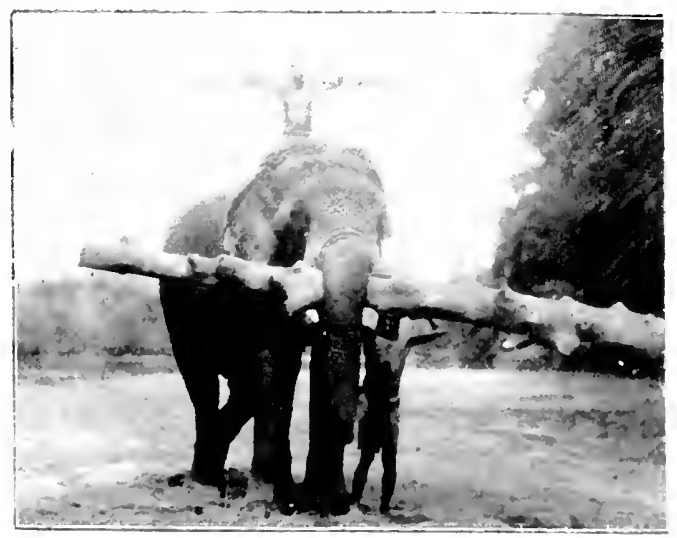

ELEPHANT CARRYING TIMBER.

(See page 19.) 

can, and frequently do seem almost to soar with their wings nearly motionless. Leaf insects, which exactly mimic the leaves of the common guava, are common, but rarely seen, as they keep rery still, and are so exactly like the leares. Stick insects, whose legs lic parallel with their bodies, are also common. Ants abound; one of the most interesting is the common red or tiger ant, a creature about half an inch long, and very fierce. It ties leaves of mangoes and other trees together into nests, which may be seen in many trees. If a couple of leares be gently torn apart, the ants may be seen to repair them, standing along the edges and so to speak taking hands across to pull them together, while the larve are carried backwards and forwards across the rent, spinning web, until it is repaired. White ants, or termites (they are not true ants) are rery common up to about 4,500 feet above the sea, and build large more or less conical nests, usually with one or two chimneys. In the chambers of the interior they grow fungi upon a sponge-like mass of vegetable matter, their own excreta from feeding upon decaying organic matter (usually vegetable.) They act as scavengers for decaying substances, always making tunnels of earth up to and over them. They are never to be seen in the light, being very liable to attack by the tiger ant, but always keep inside the tunnels.

Large spiders are very common in Ceylon, and some make enormous webs of great strength across wide spaces. Fireflies are very common at the lower levels, and are especially well to be seen after rain on open lawns. At night there is a continuous buzz in the air, from crickets, tree frogs, and other things. A fairly common insect, which makes a tremendous noise during the day, is the cicada, which buzzes like a policeman's whistle.

The scorpion may also be mentioned here. Ceylon has many kinds, of which the commonest are a large dark metallic green one, and a small brown one.

\section{MOLLUSCS.}

The only thing that requires mention under this head is the large snails in spiral shells which may be seen crawling upon the palm trees, and which lay large white eggs almost as large as sparrow's eggs.

\section{PEARL FISHERY.}

The two most interesting "zoological" events in Ceylon are the Elephant Kraals, and the Pearl Fisherics. The best account that has been written of the latter is quoted below, by permission of the author, and of 1)r. Willey, from "Spolia Zeylanica." 


\section{A SKETCH OF THE CEYLON PEARL FISHERY OF 1903 .}

\section{By Everard im Thurn, C.B., C.M.G.}

It is difficult to imagine a more picturesque incident than the "harvest of the sea," when pearls are the crop gathered in. The scene is in the shallow tropical sea which is shut in by Ceylon on the east, the coast of Southern India on the west, and on the north by "Adam's Bridge," a reef partly just awash and partly cropping up in the form of a chain of islands which connects Ceylon with India. In the Gulf of Mannar thus formed it was found at least some 300 years before Christ that there is an abundant growth of pearl-producing mussels-locally called oysters. The banks or "paars" on which these bivalves grow lie from five to ten fathoms below the surface of the water. Thither for 2,000 years, when the rumour goes abroad that the harvest is ripe, divers have come together from the Red Sea and the Persian Gulf and the coasts of India, as well as from Ceylon itself, to gather in the Orient pearls which have been distributed to adorn stately men and beautiful women in many a function throughout the civilized as well as the barbaric world.

The coast lands of Ceylon nearest to the oyster paars are for the most part very sparsely inhabited, and, like the opposite coasts of Southern India, consist chiefly of rolling sand plains, with here and there a little coarse grass or low sparse vegetation or even occasional scrubby jungle. For some mysterious and hitherto unexplained reason this harvest of the sea has always been an uncertain one, apt suddenly, and at any stage in its growth, to disappear; and often it is many years before it re-appears. At most times of the year, and sometimes for years together when the oyster crop is known to have failed, the adjacent shore is a desert in which a human being is rarely to be seen. But nowadays, and throughout the past century, as each November comes round, an official from Colombo visits the paars, takes up a certain number of oysters from each, washes out the pearls, submits these and the facts connected with them to experts, and the Ceylon Government thus decides whether or not there shall be a fishery in the following March and April.

If the decision is in the affirmative preparations have to begin at once. The fact that there is to be a fishery is made known throughout India and the Eastern world, and even in Europe. This is done partly by the prosaic system of newspaper advertisement, partly by that far more wonderful passing of the word from man to man which, as is now well 


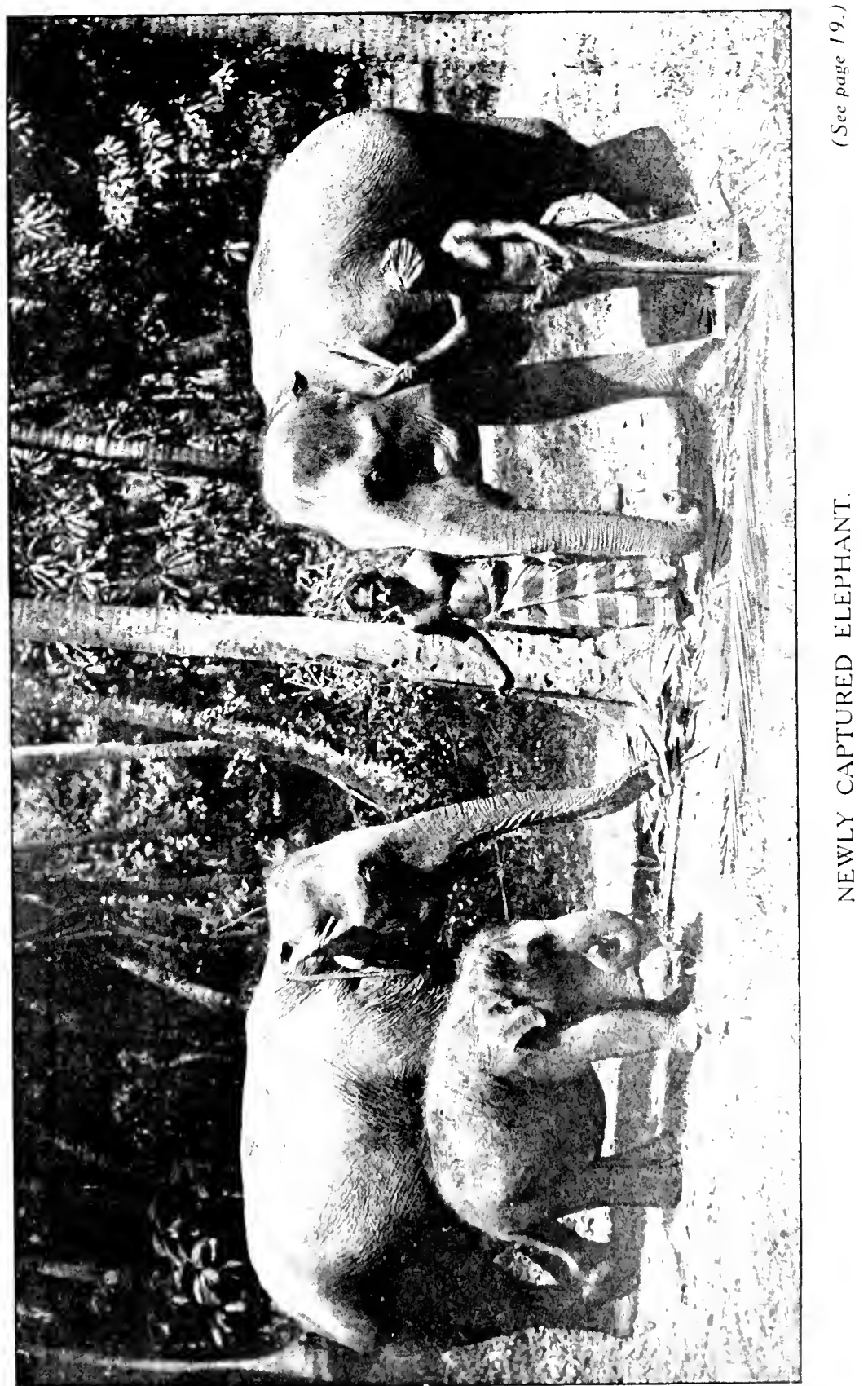



known, can carry news across a continent with amazing speed. On land which is at the moment a desert an elaborate set of temporary Government buildings have to be erected for recciving and dealing with many millions of oysters and their valuable if minute contents. Court-houses, prisons, barracks, revenue offices, markets, residences for the officials, streets of houses and shops for perhaps some thirty thousand inhabitants, and a water supply for drinking and bathing for these same people have to be arranged for. Lastly but, in view of the dreadful possibility of the outbreak of plague and cholera, not least, there are elaborate hospitals to be provided.

After an interval of eleren years it was announced at the end of 1902 that there would be a fishery in the following spring. The difficulty of making the above-mentioned preparations in due time was enormously increased by the fact that so long an interval had clapsed since the last fishery, and that so few persons were conversant with what had to be done......

A fleet of some 200 large fishing craft had gathered, and with the help of an occasional steamer from Colombo had brought together, chiefly from India but partly from Ceylon, a population which during the course of the fishery varied from about 25,000 to perhaps 35,000 or 40,000 souls-men, women and children.

It was my great good luck to pay two visits of considerable duration to the camp and, especially as I had had considerable part in arranging for it, to see it thoroughly ... .

Another great adrantage I had... . On a suggestion made to me I gladly provided for the supply of diring dress and apparatus; and these being on the spot my innate curiosity induced me on several occasions to put on this dress and go down to visit the paars and see for myself how the oysters grow......

The dress once donned and one's heavily encumbered body once got over the side of the ship and on to the ladder, the rest is easy. All that is necessary is to keep one's feet well down when descending the ladder and until one is entirely under water. Neglect, or rather ignorance of this precaution on one occasion brought me into difficulties. Haring secu the professional diver swing himself off the ladder instead of first going patiently down to the lowest rumg, I thought I would do the same; with the result that I fell on my back into the water, and that the air distributed within the dress instead of being forced gradually up from feet to head, as would have been the case if 1 had gone down feet foremost, was forced to the front of chest and legs and kept me kicking on my back on the water. 
Atter leaving the ladder feet downward pure passivity is to be recommended until one reaches the bottom. My first depth was 9 fathoms, but it certainly seemed to me to take a very long time to get down those $5+$ feet, and on the first occasion or two the pain in my ears was intense. . . The most surprising thing to me was that as soon as the bottom was once reached all sensation of pain ceased - it was perlaps overwhelmed by the undoubted delight at the novelty of one's sensations and to exasperation at the small control one had at first over one's morements under that pressure of water. I could not by any effort keep my feet quite firmly on to the ground; and each twitel which the man who played Providence to me at the other end of the rope gave-doubtless in his nerrous anxiety to guide me aright - had the unfortunate effect of throwing me over on to my back or my side or $m y$ face. Finally 1 found that getting about on all fours was the proceeding which gave me the greatest control over my own movements.

The light was wonderfull y good, as a full green twilight, and I could distinctly see the ship 9 fathoms over my head. It is curious that at the same depth in different parts of the sea the quantity of the light varies considerably. This is probably due to the greater or less quantity of matter floating in the water.

The bottom where I first went down was a sandy, slightly undulating plain. Here and there at distances of a foot or so apart were small groups of from six to a dozen oysters, each group fastened by the byssus to a stone or piece of loose coral or dead shell; as far as I could see, no oyster's were fastened to the actual bottom. Scattered about among the oysters on the sand were mushroom-shaped and other loose-growing corals, and here and there was a branched coral fastened to the bottom. The fishes and shrimps swam about utterly oblivious of one's presence, especially a lovely little ultramarine blue fish with golden yellow tail. It was somewhat exasperating to throw an oyster at a fish and to find that the missile instead of going towaids the fish dropped languidly to one's feet. Of big fish 1 hardly saw any, and of sea suakes, generally very plentiful in those parts, I saw only one, and that was while I was on my way down one day. Crabs were fairly abundant, and I came across a striking-looking-indeed vicious-looking -animal of this sort (Rhinolambrus contrarius).

To one like myself who has as long as he can remember found a peculiar joy in sceing Nature from new points of view, it is pure delight to make one's way along the bottom of the sea picking up shells, corals, starfish (very abundant), sea urchins, and a lost of other things which had always before been to one lifeless "curiosities." 
One of my chief purposes in going down was to see the divers actually at work. In but a few moments from leaving the ship and the world to which I had long been accustomed I reached a quite new world and, as it seemed, one apart from all other human beings. Then from the gloom of the distance -it was easier to see upwards than for any distance along the ground - some big thing came rapidly towards one; it might have been a big fish, but as it came quickly nearer it proved to be a naked Arab swimming gently but rapidly towards me, his rope between his toes, and his hands and arms rapidly sweeping oysters into the basket which hung round his neck. I tried to speak, forgetting that my head was buried in my helmet, but he glided close past me without taking any more notice of me than did the fish. He had perhaps thirty to forty oysters in his basket by that time. But his time was upafter all he could only stay down from 50 to So seconds, while I without inconvenience could stop down for half an hour. In an instant he had changed from a swimming to a standing position, and he was rapidly hauled up from me towards heaven, his feet being the last part to disappear.

As 1 gazed up after him something dark came down through the water and nearly hit me. It was a stone at the end of a rope thrown down for another diver. It was a warning that 1 had wandered from my own ship till I was under one of the diver's boats; and I beat a hasty retreat.

I had but to give a pull at the rope, a signal, and I felt myself being pulled rapidly up through the water. 1 went faster than the bubbles of air which had been rising from my dress, and was carried up through a stream of these bright bubbles. Suddenly it was very light, and some big dark broad thing covered with bubbles was directly above me, and the next moment I hit against it. It was the bottom of the launch, and my next task was to guide myself till I came to and with difficulty succeeded in getting on to the ladder. Then as I stood on the ladder, while the helmet was unserewed and taken off and the fresh air came, I knew how good fresh air is.

While down on the first oceasion or two my nose bled rather unpleasantly, but as this never happened to me afterwards I put it down to the fact that on those first occasions I had a heavy cold in my head.

1 was once more back on the Master Attendant's barque, moored in the middle of the fleet on which the divers were all burrying up to complete their day's load within the given time.

By noon most of the divers are tired ont and, if it has been a fairly successful day, the boats are fairly loaded up. Moreover, at noon at this time of the year the wind almost 
invariably changes its direction and blows towards the land. At noon, therefore, a gun fired from the Master Attendant's barque gives the signal for pulling up the anchor, hoisting the sails, and beginning the run home. If the paar which is being fished is some distance from the land, the run home may take any time, according to the strength of that fair wind, from three to five hours.

The run home is, 1 am afraid, a busy and, from a Government point of view, a bad time. The men, other than the tired out divers, occupy themselves nominally in picking over their oysters, throwing away stones, shells, and other useless things which in the hurry have been gathered in with the oysters, and in preparing the loads for easy transport from the boats to the shore. But, as a matter of fact, it is well known that this opportunity and these hours are employed in picking over the oysters in a different sense. The finest pearls almost invariably occur just inside the edge of the shells, where they are held in position by so thin a membrane that they appear ready to fall out at any moment. There is no doubt that many of these finest, roundest, and best coloured pearls are picked out during the run home and concealed about the persons of the boat's crew, and this, despite the fact that each boat has a so-called Government guard on board, and that a further check is supposed to be provided by the Government steam launches which rm in with the fleet, and the crews of which are supposed to keep their eyes very wide open for the illicit practices indicated. It is in this iniquitous practice of picking over that one chief reason why the Government does not get its fair share of the pearls lies.

It is as pretty a sight as one can well imagine, this homeward race before a strong wind and over a tropical sea of a hundred or so of ruddy-sailed craft, orientally fantastic in colour and shape, and each deck crowded with a motley crew of brownskinned men and boys naked but for a few rags of brilliant coloured cloth. Each crew strives to get in first, in order to get first attention and so soonest to dispose of their loads and thus gain rest after a day of really hard labour. There is no lowering of sails as the shore is approached, no slackening of the speed till, as often as not, each boat buries its bows deep in the high sandbank which forms the shore, and comes with a sudden thud so violently to a stand that the expectant crew, each man already loaded with his basket or netted pack of oysters, is almost hurled into the narrow openings in the high wattle fence which surrounds the Government "kottus," the sheds where the oysters are first deposited and divided.

Inside this fence is the huge wattle-walled and palmthatched warehouse, where the division of the oysters between 
the divers and the Govermment is carried out. It is a rast rectangular building divided by rough posts and rails into long straight arenues of square pens, each pen numbered and provided with its Government clerks and counters.

The crew of each boat in some way gets itself, or is got by the officials, into a separate pen and there dumps down its oysters. Then the orsters are divided between the divers and the Government, in the respective proportion of one-third and two-thirds, by a process of quite admirable simplicity and ingenuity. The divers themselres, and massisted, separate their own oysters into three heaps, roughly, but as accurately as possible under the circumstances. Then the Govermment clerk in charge of that particular pen, entirely at his own discretion, assigns one of these heaps to the divers, and this is forthwith bagged or basketed and carried off by them through the exit on the landward side from the enclosme. The actual process of exit is a little trying, for within this namow opening in the wattle enclosure a small posse of Government officials with occasionally a few police stand on guard to keep order and to exercise a sort of rough search for illicitly concealed pearls. It is a rough and noisy but rery good-humoured crowel ; and in the comse of this proceeding not a few pearls are in some mysterious way discovered and confiscated. If the departing crew is ton obstreperous they are detained for such time as is necessary to deprive them of all their oysters. That this last proceeding is nothing more than rough justice is, I think, shown by the fact that the divers recognize it as such, and seldom or mever emplain once they have bost their wsters.

But even wifen a company of divers has sucesefully passed through the krottus and escaped through the narow wicket wate on the landward side of that for an hour of two each day seething mass of humanity and oysters, theip troubles of the day are not over, for they are at once swallowed up in a surging corowd of natives eager to buy fiom them their ovsters by the dozen or the half-dozen, of exen lo twos and ones. The prices then given for each individual oyster or handful of oysters are comparatively enormous, and the orster bearer has often divested limselfat highly lemuncrative rates of his whole burden before he emereses at the other side of the thong. If he has any left, he hurries to a mative burer and disposes of the remainder. Them le lumpes to wash the brine off his tired limbs in one or other of the tanks specially reserved for the purpose; and at last follows much-meeded rest.

In time every boat has reached the slowe and every boat's crew has, as aboue described, passed though the kottus. 
No sooner has the load of any boat been deposited, divided into lots, and the diver's lot carried off, than the Government counters begin to count the share left for Govermment, and, by using an ingenious system of tallies, do this so quickly that the millions of oysters which generally form the Govermment share of a day's take are counted with remarkable accuracy within a couple of hour's or so. Each counter reports his total to the representative of the Government Agent sitting in one corner of the kottu enclosure, and by eight or nine o'clock almost the exact numbers composing the great heaps of oysters on the kottu floor is known and reported. The kottus then are closed for the night, and a few sentries are left throughout the night to watch by the light of the long lines of dimly burning cocoanut oil lamps to see that none of the bivalves are removed or tampered with.....

At about 9 P.s. each night the Government Agent repairs to the court-house, where are collected all who wish to buy oysters wholesale. The Government Agent first announces how many of the bivalyes are lying in the kottus and puts these up for sale by the thousand. Any number of thousands, from one to perliaps fifty thousand or more, are taken by individual purchasers or by syndicates. The prices in a single night vary curiously and inexplicably; a high price, say, Rs. 35 per 1,000 , may be given at the beginning of the evening, lates not more than Rs. 22 can be extracted, and yet again later higher prices prevail. There is keen and zealous competition, the larger buycrs competing against the smaller, or all combining in a ring against the Government auctioneer. The day's catch is, however, generally sold within the same night, but if not the balance is disposed of privately the next morning.

Quite early the next morning each purchaser comes to the Government Agent for an order for the number of oysters knocked down to him the previous night, and at once sets to work to remove these to his own private shed; and before noon the Government Kottu is cleared and ready for a fresh supply in the evening.

Meanwhile, at about the previous midnight or soon after, the wind then at that season of the year beginning to blow from the land out to sea, another fleet of boats starts out for the paars, reaches its destination by daybreak, anchors, and waits for the sea to become smooth and the light sufficient. While waiting, a narrow plank or bamboo platform is let down and fastened over each ride of the ship; and on these platforms, when the day has advanced far enougb, the divers rest squatting between their dives. And then the history already told of the previous day's take is repeated. 


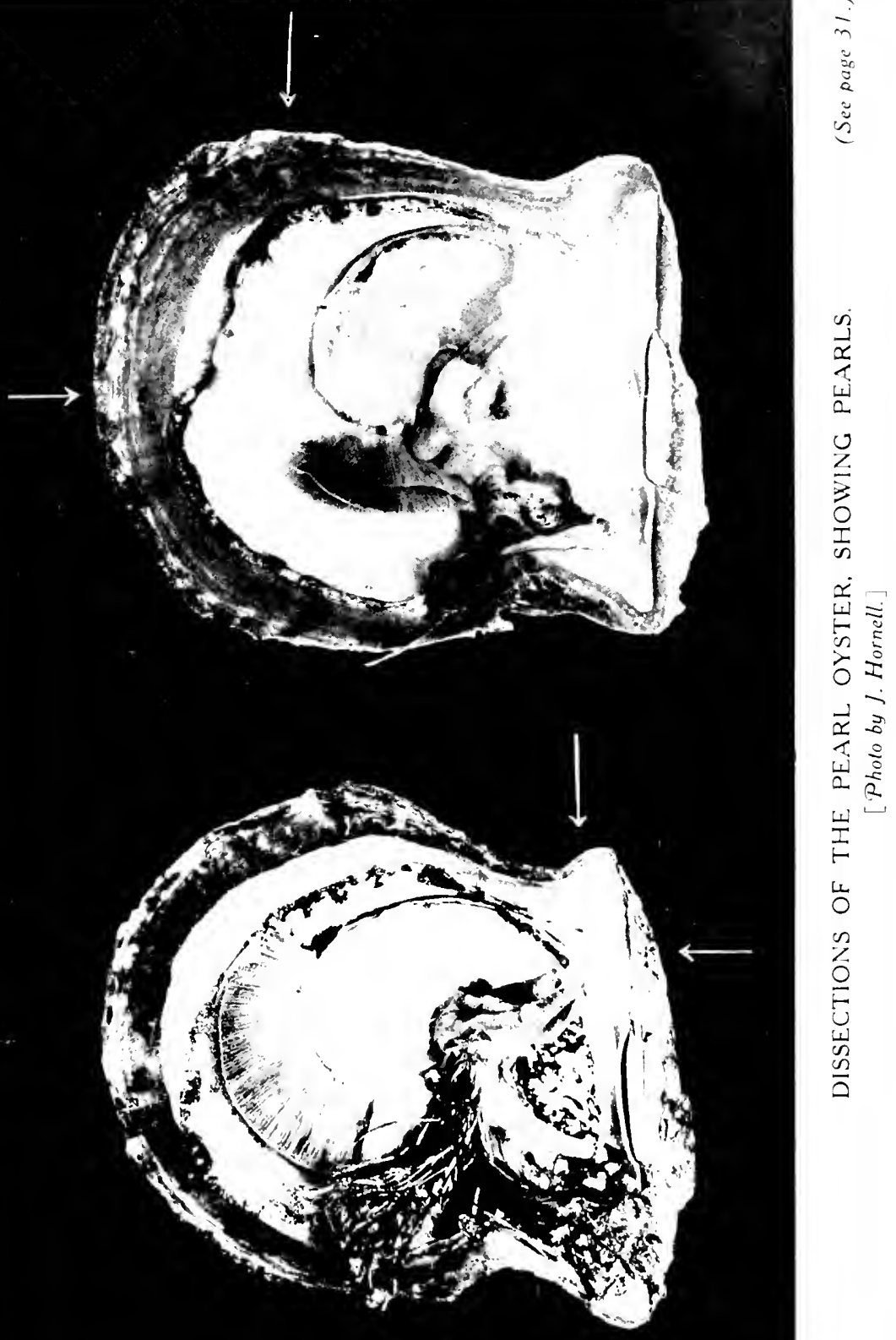



The washing of the pearls from the oysters is a most tedious, primitive, and somewhat disgusting process. The oysters are simply left to rot, the process being much assisted by the vast clouds of a black "housefly," which after the first day or two permeates the whole camp. After a week's rotting the seething and disgusting residue is sorted by hand, and the pearls, or such of them as are of sufficient size, picked out. The residue is then dried in the sun and becomes what is known as "sarakoo." This sarakoo is at leisure sorted and winnowed and examined over and over again till the smallestsized pearls have been extracted.

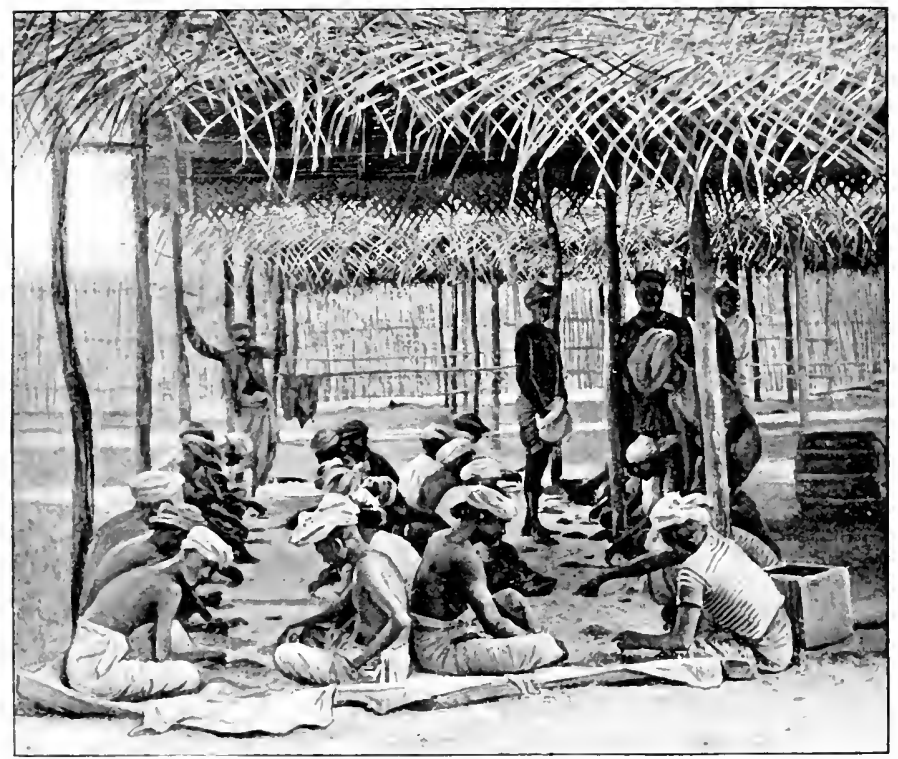

\section{GOVERNMENT DIVERS PICKING OUT PEARLS FROM OYSTER WASHINGS.}

Many of those who have come to the camp have come not to buy oysters, nor to wasls them, but only to buy pearls. Of these, some are small people, but most are wealthy capitalists from the great towns of Inclia and fom Colombo. They live in two special streets, where all day long they sit on the ground in their open-fironted shops, toying with pearls spread on the dark coloured cloth which lies for that purpose on the ground in front of them. On the cloth, too, is a delicately formed copper scoop, shell shaped, for lifting the 
pearls, neat little scales with a quaint-shaped case to hold them and with weights, the larger of agate, the smaller of bright scarlet seeds, also a set of basket-shaped sieves for grading the pearls. When no one is present to sell they minutely weigh again and again the larger of the pearls, sort them according to size, colour, texture, and roundness, tie up the better specimens carefully in little screws of linen, put them away in the great strong box, which forms almost the only furniture of the shop, take them out again, and discuss each one orer again with their partners and friends. Then some washer comes along with pearls to sell, and the whole joy of chafering begins, and lasts till one is tired of watching.

Meanwhile along the street a busy crowd is always passing in front of the shops. Many carry great brazen ressels of water from the tank, others drive home bullocks with loads of firewood or poles and palm leaves for new huts. Farther down the street are the shops of the silk or cloth seller, the brass and tin workers, and countless provision shops.

Here and there in the middle of the broad street squat groups of pearl cutters, whose business it is on small wooden tables and with a primitive bow-drill to pierce pearls for stringing and to cut into something like presentable roundness the rough irregular pearl-like lumps which are found not in the flesh of the orster, but attached to the inside of the shell.

So for some two months the business goes on, till the divers are worn out by diving and the pearl merchants are satiated with their purchases. Then the Government Agent is appealed to to proclaim the closing of the camp, and when he does so almost in a day the whole big population "fold their tents like the Arabs and as silently steal away, " and in a very few days the once busy camp is left only to the jackals to scavenge up the refuse and to prowl among the great mounds of fiesh oyster shells which have just been added to the accumulations of so many rears fishing.

The whole thing is intensely interesting and picturesque, but afterwards it leaves much to think about and much to hope for. The thing has been going on in the same way for centuries, and would so continue if the busy. WVestern mind were not now turning to thoughts of how to improve on this old system, to make the harrest of the sea more regular in its occurrence, to economize the present vast expenditure of human energy now wasted in fetching up the orsters from the depth of the sea, and to extract the pearls from the orster's with greater rapidity, certaintr, and with greater security that the Government gets its proper share, and with greater regard to sanitary conditions.

The whole thing in now at last about to change, and the prints which I have just enumerated are to be attended to. 
Professor Ilerdman, with Ml. Hornell, is about to give us a long and full report on their careful investigations of the lifehistory of the pearl oyster in these seas; they are about to tell us why the crop is so uncertain, and how it may be made more continuous. . . . . .

Professor Herdman of Liverpool, with his assistant Mr. Hornell, made an exhaustive enquiry into the pearl fishery, with the special object of discovering how the pearls were

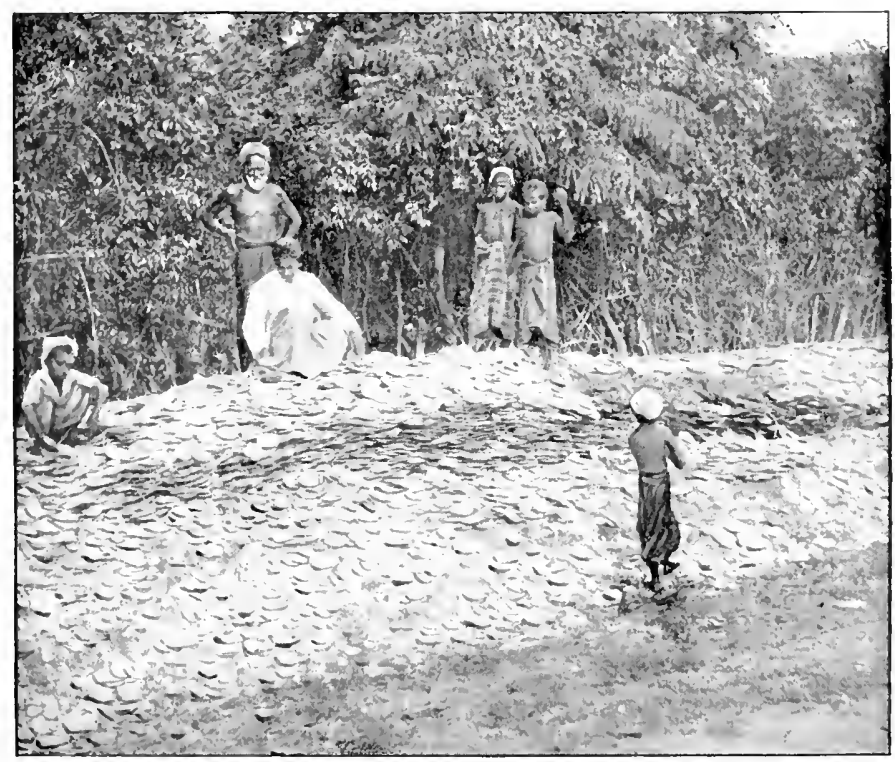

SHELL HEAP OF OYSTERS AT LAKE TAMPALAKAM.

formed, and the life-listory proved of great interest. The fine "orient pearl" as it is called, as distinguished from the small seed pearls, is due to the irritation caused in the oyster (really a mussel) by the presence of the dead bodics of tapeworm larve. The living larva gets into the body of a trigger-fish, which feeds upon the pearloystert, and from them into large rays, which feed upon the trigger-fish. Fom the ray, in which the organism becomes sexually mature, the embryos re-enter the oyster. 
Lately, the pearl fisheries, after some local opposition, have been leased to a London company, and the fishery is more carefully conducted. The Company holds the lease for twenty years, upon condition of spending so much a year upon the scientific treatment of the banks, by transplanting oysters, and in other ways.

Another pearl is obtained at Tampalakam bay from the window-pane oyster (Placuna placenta), but is of Jittle value, except that some Hindoos value the lime made by burning them for chewing with betel.

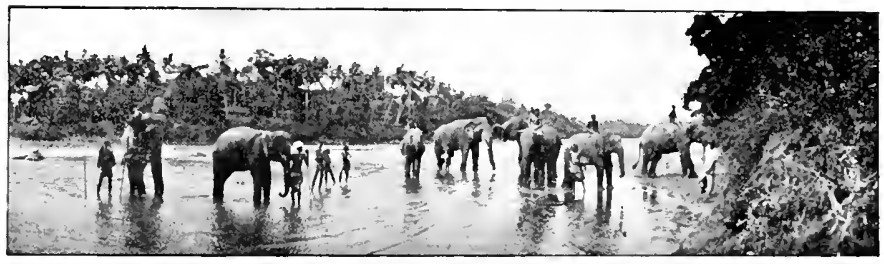




\section{Chapter IV.}

\section{BOTANY, VEGETATION AND AGRICULTURE.}

\section{BOTANY AND VEGETATION.}

CEYLON, though small, has a great variety of climates, due to differences in rainfall and elevation, and with them a corresponding variety of vegetation. The flora of the island seems at first sight comparatively rich, being no less than 3,000 species of flowering plants and ferns, but Ceyton as a matter of fact lies in the poorest part of the lndomalayan region, and has but a scanty flora compared with some of the Malayan islands, such as Java. At the same time, there is much of interest about it. Many of the plants are the same as, or closely related to, those of the peninsula of southern India. 'This is especially the case in the dry north and east of the island, which have a poorer edition of the flora of the eastern Madras Presidency. A large number of species in Ceylon, mainly in the wet southwest region, show close relationship to those now existing in the Malay Peninsula, Java and Sumatra. And yet others show relationsips to the plants of the Mfrican islands, Madasasear, Mamritius, de. The mosses, liverwolts, seaweeds, and fungi of the Cevlon flora have as vet only been very incompletely worked up,

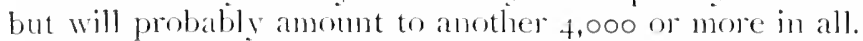

The chief deteminant of the climates is the position of the mountain mass of south-central Cevlon across the line of direction of the two monsonss. The southwest monson brings much rain fiom April to September to the western side of the hills and to the south-western plains, but little chewhere. The northeast momson, from October to Mareh, brings a gond deal of rain at first to all parts of the island, but after Christmas chiefly to the eastero side of the hills.

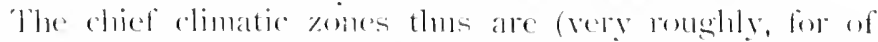
comse there ato mans lonal peculialities) the "wet lowcountry" foom Colombe to Mitars and inland as far as the

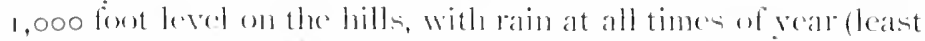

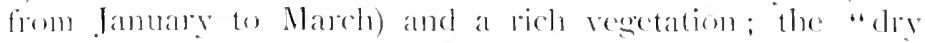


low-comntry," comprising the rest of the plains, principally in the morth and east, with rain mainly from October to January, and not infrequently in $\mathrm{April}$ also (neares to the momntains), and the rest of the rear dry; and tice "montane zones" of varions elevations, iften divided into two chief zones, an! upper montane above 5.000 feet, and a lower montane below that elevation. The eastern side of the mountains is rather drier than the western, and gets its dry season rather in the southwest than the northeast monsom, so that the periods of flowering and fruiting of the plants differ by several months

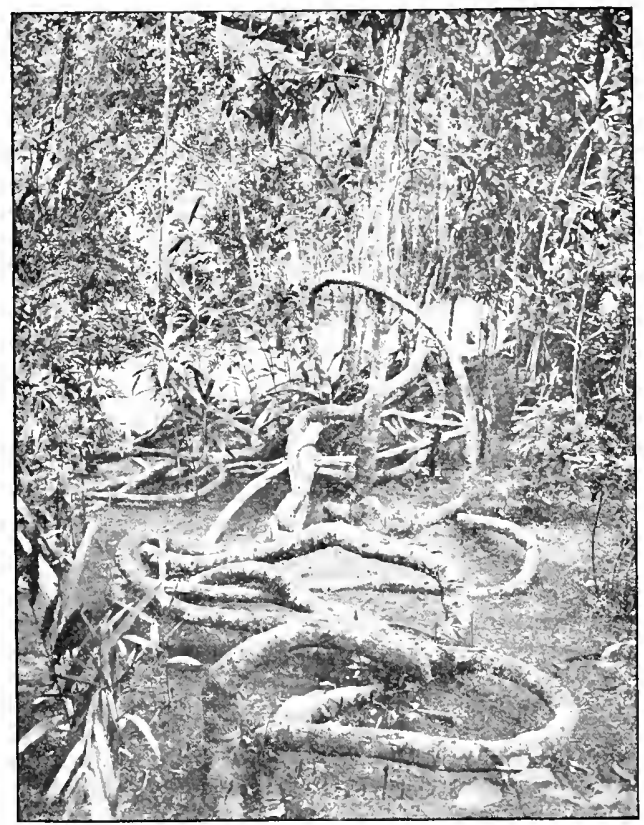

A WOODY CLIMBER.

in the two resions, the eastern side of the monntains laving in fact the climatic periodicity of the sonthern side of the equator. Para rubber, to take an example, ripens its seeds at Badulla in February, near Colombo in July.

To briefly describe the resetation of the zones in order, the wet low-comotry is the most thickly populated part of Ceylon, and one that has to a large extent been a long time under cultivation. It was, there can be little doubt, once entirely, or almost entirely, covered with a sheet of dense forest, but of this only portions now remain, as for instance 
the Singla Raja forest to the south of Ratnapma, and the forests on the lower slopes of the Adam's l'eak range. Even these are hardly comtinuous forest for any gyeat distances. Lately, with the great extensions of rubber cultivation that are going on, a good deal of the remaining forest in this zone has been cleared for planting, and before lons there will be few isolated pieces leit, but omly the larger forests just mentioned.

Where the forest does stil] exist, owing to the heary and well distributed rainfall the regetation is rery rich, and there are many very large and well grown trees, matted together with a great number of climbers, often very stout and woody, and with a faily dence undersowth upon the sround. The forests are trpical equatorial, evergreen forests, the main mass of trees running up to a considerable and rery uniform height, and a number of smaller trees forming a kind of upper undergrowth. Among the larger trees the family of the Dipterocarps takes a rery prominent place, being represented by numerous species of lowna, Shorea, sc., trees with tall simaight trunks, vielding useful timbers and resins. The forests contain numerous trees of comomic value, but as the more accesible timber trees were largely reduced before the Government underton a proper conservancy, they do not as yet yield tosuch profit as might be expected firm a comparison with the forests of India, (cf. Chap. I.)

One sreat canse of destruction of the forests of Cevlon has been the wasteful native practice of chene. This is now perforce extinct in the westem plorince, but may be secm evervore else, $e . s$ on the foothills coming up to kandy by the railway. The natives cut down the smaller trees and bushes in a pateh of forest, and then in dry weather set fire to it, usually killing the larger trees by so doing. On the ground thus cleared, and which of course contaius a large quantity of decaring organic matter, and is thus rich in plant food, the villaser then grows two or sometimes there cops of cereals of other things and then abandons the land, which grows up in scrubby regetation, and seldom, if ever nowadass, goes back to forest. last areas of gond land have been wasted in Cevlon by this destructive practice, and in the sonthem province, especially, there ale almost hundereds of squale miles cosered with a serub of small bambers, gerowing on old chenas. Chema is a far as possible prevented on crown land mowadays, and this is one of the sictances of the native against British fincrument, for he comsiders that so long as there is land left to chema, he should be left fice to chena it. There are of comlse vast aleas of chena in private ownership, with which the fovernment camnot interfere, and experiments 
are in progress to see whether by some system of rotation of crops it might not be possible to utilise this land in a more permanent and profitable way.

\section{AGRICULTURE.}

Ceylon owes practically all her agriculture to the introduction of what we may term in a general way " new products," i.e. products not previously cultivated there. The earlier pre-Sinhalese inhabitants must have had a very poor food supply, and in fact can hardly have been so well off as the Veddahs of to-day. The island contains in its uative flora but few food yielding plants of any value, though there are many yams and other roots. Wijayo, the Sinhalese conqueror of 500 years B.C., is said to have introduced rice from India, and this soon became, and has remained, the national cultivation, in spite of the poor yield obtained lere. As the Sinhalese are said to have landed in the north, and spread southwards, this was also probably the first real cultivation in the island, though cinnamon, which grows in the southern parts of Ceylon, is an actual native of the comtry. As the Sinhalese spread into the south, they probably discovered the uses and qualities of cimnamon, and got the spice from the jungle trees.

Soon after the conquest of the north, the Sinhalese began the construction of the wonderful irrigation works, whose ruins, or restorations, cover that part of the country. These are described in another chapter and need only be mentioned here. There is little doubt that their primary object was to irrigate the country for the cultivation of rice, and they must, when in full working order, have done this very efficiently, though absurd exaggerations have been current about the population supported on the land, and it has been put down at as many as ten to twenty millions. A very slight calculation will suftice to show the untenableness of this position. Assuming that one half the total area of the dry low-country of Ceylon was arailable for rice, the other half of course being occupied by the hills or ridges and by irrigation tanks, we have an area of 10,000 square miles. Assuming the very dense population of 600 to the square mile, we only get a total of six millions, which is probably the outside figure that at any time represented the number of people in the island.

As the Tamil invasions progressed, the people were driven into the south, and probably greatly reduced in number, and rice cultivation in the wetter regions became the national task. The irrigation works in the north, probably from want of care, were reduced to ruins, and the country once more grew up in the forest which to-day covers all but small portions of it. 
In early times there was probably no export trade whatever, and in fact there was probably but little intercourse with Ceylon, except perhaps at Galle (which is sometimes supposed to be the biblical Tarshish) at which the products of west and east were exchanged, though probably there was but little Ceylon produce among the total, until cinnamon and precious stones began to be traded in. This would happen as the Sinhalese came more into the south, and by the time of the Portuguese, a few hundred years after the collapse of the northern Sinhalese kingdoms, there was already an appreciable trade.

Until English times, there was but little export trade from Ceylon in any other agricultural product than cimnamon. Its cultivation was a strict Government monopoly, first under the Dutch, and then under the British Government. At one time the possession of a stick of cinnamon was an offence punishable by death. "The trade was at its height when Nees wrote a disquisition upon it in 1823 ; but opinion was already arraying itself against the rigidly exclusive system under which it was conducted. This was looked upon as the more unjustifiable, owing to the popular belief that the monopoly was one created by nature; and that prohibitions became vexatious where competition was impossible. Accordingly in 1832 the odious monopoly was abandoned; the Government ceased to be the sole exporters of cinnamon, and thenceforward the merchants of Colombo and Galle were permitted to take a share in the trade, on paying to the crown an export duty of three shillings a pound, which was afterwards reduced to one.

"The adoption of the first step inevitably necessitated a second. The merchants felt and with justice that the struggle was unequal so long as the Government, with its great estates and large capital, was their opposing competitor ; and hence, in 18.10 , the final expedient was adopted by the crown of divesting itself altogether of its property in the plantations." (Tennent).

From that time the cultivation has steadily increased, mainly on the sandy soils between Colombo and Galle, and at present there are about 40,000 acres of cinnamon in cultivation, Ceylon still holding a practical monopoly of this trade.

For many years after the arrival of the English, the colony went on in the old way, witl but little export trade, and not paying its way as regards the expenses of Government. The clange, from an insignificant eastem possession to the richest and most prosperous of the crown colonies, dates from the time of Governor Sir Edward Barnes, who, soon after the capture of the Kandyan kingdom, opened, in 1824 , 
the first plantation or "estate" in the hills. Here he tried sugar and many other ludian crops, the general idea then held being that Indian crops would succeed in the very different climate of Ceylon, but after a while it was discovered that the hills were eminently suited to coffee, and with this the "planting" cra began, to continue to the present day, when it is in the most stable and prosperous condition it has ever known.

The time was favourable, the duty on coffee in England had just been reduced, its consumption was increasing in Europe, and the West Indies were handicapped by difficulty with the slaves. By 1838 the success of the industry was assured, and in that year 10,401 acres of Crown forest land were sold to planters, while in ${ }_{84} \mathrm{I}$, when the rush was at its height, no less than $78,68_{5}$ acres were disposed of. "The coffee mania was at its climax in $18+5$. The Governor and the Council, the Military, the Judges, the Clergy, and one-half the Civil Servants penetrated the hills and became purchasers of Crown lands....... capitalists from England arrived by every packet...... So dazzling was the prospect that expenditure was unlimited; and its profusion was only equalled by the ignorance and inexperience of those to whom it was entrusted. The rush for land was only paralleled by the movement towards the mines of California and Australia, but with this painful difference, that the enthusiasts in Ceylon, instead of thronging to disinter, were hurrying to bury their gold." (Tennent.)

The inevitable collapse soon followed, and for some years the coffee industry was almost paralysed, but by 1855 it had more than recovered the lost ground, and was conducted on more practical and economical lines. From that date to about I 882 it was the staple export industry of the Colony, reaching its maximum in I875, when almost $1,000,000$ cuts. of coffee were exported. About i 870 the plants began to be noticeably attacked by a fungus blight-I Iemileia vastatrix; the coffee leaf disease -which spread steadily and iresistibly over the rast sheet of coffee plantation in the mountains, and was disregarded until too late. By isso the industry, though still considerable, was in a parlous condition, and the planters in great distress, but with the most commendable pluck they set themselves to redeem their fallen fortunes, aided by the efforts of the Botanical Department of the Government. Cinchona tices the source of the valuable alkaloid quinineintroduced by Government years before, but disiegarded so long as coffec was profitable, were now the salvation of the island. Large areas were planted with this product, and at first large profits were realized, but soon over-production 
rapidy brought down the price of quinine, to the incalculable benefit of sufferers all over the world, but to the ruin of the profitableness of the Ceylon bark industry - a ruin consummated by the attacks of a canker disease and the competition of better barks from Java. The gap, however, was bridged and by the time that cinchona had passed its zenith it was clear that tea was the industry of the future, and large areas were being rapidly planted up in it, while an appreciable export trade was beginning. The extension of tea cultivation went on very rapidly until about isg6, when it stopped, and since then there has been a little depression from overproduction, but this has now passed by, and at the present monent the industry is in a very prosperous condition. About 3 So,000 acres are planted in tea, a larger amount than was ever in coffee-now practically an extinct industry here -while at the same time, so much better is the prosperity of the island distributed, and so many more strings are there to the bow, the export of tea makes less than half the proportion of the total exports that coffee once made. Coconut products, cacao, rubber, cardamoms and many other things now take an important part in the total value of the exports.

At the same time that tea was coming in, and cinchona failing, many other products were being carefully tried, and some of these have, so to speak, come to stay, es. cacao, cardamoms, Sc. Quite important subsidiary industries have grown up in cacan and cardamoms, and Ceylon cacan gets about the lighest prices upon the market.

Steadily pushed by the Botanical department, yet other industries have been formed during the last ten vears. Thus coca, the source of the raluable drug concane, is now cultivated in Ceylon, and the coca exported hence forms the standard of the market. Camphor, too, has been steadily taken up since I901, and now there are about 1,000 acres deroted to this product, which at present is paying very well. Vanilla was largely taken up a few years ago, but the production of the artificial vanillin has destroyed its profitableness.

The great new industry of recent rears, not only in Ceylon, but also in Malaya and other tropical countries, is undoubtedly rubber. In is 75 the Fovernment of India sent an expedition to the Amazon valley to set seeds and plants of the raluable rubber trees that grow there, and which still supply about half the worl's consmmption. These were successfully brought to Kew and thence to Ceylon, India not then having any Botanic Crardens with a suitable climate. In 1 $897-9$, seed begimming to be plentiful, the Botanic Gardens made numerous experiments upon the methods of tapping, 
showed that improved yields could be got by taking advantage of the wound response-or increased flow that comes in a few days from any part of the bark that is tapped - and worked out the best way of coagulating the rubber into biscuits, as they are called upon the London market. The result was the taking up of rubber cultivation by the planting community, slowly at first, but with increasing rapidity as seed began to be available in larger quantity, until in 1906 the area planted in rubber was about 120,000 acres, and extension was still going on rapidly. Exports of rubber began some years sooner, and very high prices were obtained.

While all these "new products" have been introduced and spread, mainly by the botanical department located at Peradeniya - as to which one still occasionally hears the enquiry as to what good it is-the older products of the island have also extended their range, more especially coconuts, which at present occupy the largest area in the island under any one crop (perhaps 750,000 acres.) The vast area of this palm seen along the southern coast line from Colombo to Matara was largely planted in Dutch times almost at the point of the bayonet, the natives being averse to anything of the kind, but now they have learnt that there is money in coconuts, and extension of planting is continually going on, while European planters have also embarked a good deal of money in this cultivation, which is often called the consols of Ceylon planting. The area under rice, on the other hand, increases with extreme slowness, and this is hardly to be wondered at when it is remembered that this cultivation, in Ceylon at any rate, is extremely unremunerative.

Not only is the native of Ceylon what may be called a lazy, happy-go-lucky agriculturist on his own account, but he will not readily take up even the plentiful labour provided by the numerous European planting estates, and these are worked almost entirely by imported labour from South India, the Tamil coolies - as they are called, kuli being the Indian word for a man on daily pay - of the Madura and other districts coming over in tens of thousands to work on the tea and rubber and other estates.

The advent of the English planter has been of the greatest value and importance to the island in many ways, for it has vastly increased its wealth, and enabled public works of general utility to be carried out in all directions.

\section{TYPES OF VEGETATION AND AGRICULTURE.}

As the main types of regetation, and most kinds of agriculture, may be seen from the railway carriage, it may be well to describe them in very brief outline. Following the 


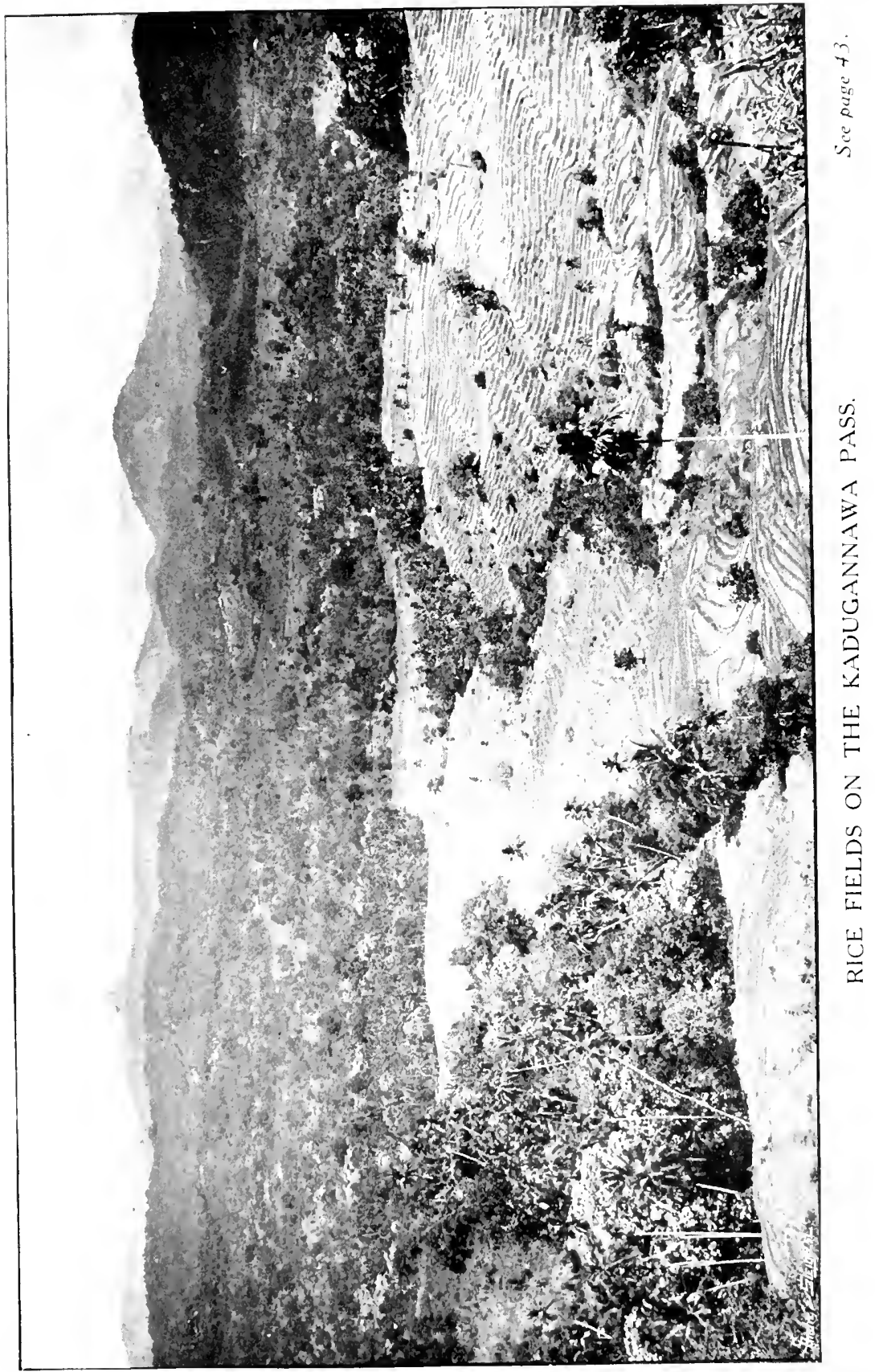



order in which they appear on the railway, going first of all to Kandy, they are described below in the following sequence:

Rice Fields

Coconut Estates

Mixed Garden Cultivation

Chenas

Plantains

Rubber

Arecanuts

Tea

Cacao

Cardamoms

Up-country forest
Up-country Patanas

Cimnamon

Shore Vegetation and Mangroves

Citronella

Dry Country Forest and Chena

Palmyra Pahms

Gardens in the Jaffina Country

\section{RICE OR PADDY FIELDS.}

After crossing the Kelani river, on the Kandy railway the country is of very uniform look for about 30 miles. The vallers, rarely more than a few hundred vards in width, are filled with paddy or rice "fields," the "high lands" between them occupicd with coconut palms, or with the characteristic mixed garden cultivation of the Sinhalese villager. The paddy fields may frequently be seen in almost all stages, from the ploughing to the ripening, on the same journey, for there are two crop seasons in the year, one from January to March, (the Maha crop as it is locally called) one from August to October, (the Yala crop). The beautiful rich green of the paddy fields makes them a very pleasant sight while in growth, and many picturesque sights are to be seen in the harvesting. The water is let out of the fields, and the grain ripens on the dry soil. Mowing with any form of machinery is of course far beyond the native, could he even afford it, and the grain is reaped with sickles. It is thrashed in the old biblical manner by the aid of buffaloes or eattle, which are marehed round and round over the grain lying on the gromed, and winnowed by throwing it up into the air from flattish basket-work trays, and catching it again.

The whole process of padely husbandry is primitive and old world in the extreme, and from its having been the national pursuit for so many generations, it is herged round with all kinds of superstitious observances. It may not be amiss to quote some of these from a paper by Pohath, describing those of the Kandyan momtaineers.

"The goiya (eultivator) presents limself before the Neketrala (village astrologer) on a Monday or a Weduesday with the customary offering of forty betel leaves and arecanuts 
and expresses his wishes in a humble attitude. The Neket-rala then informs his petitioner, after certain astrological calculations, of the circumstances upon which the success or failure of his undertaking depends. On an auspicious day (according to the Neket-rala) the goiya, after partaking of the morning meal, wends his way to his land with a mamoti (a kind of large hoe), his face turned towards the favourable direction of the horizon as indicated by the astrologer. Should the goiya on this journey cncounter sights or sounds which portend failure, f.s. the hooting of an owl, the cry of a house lizard, the growling of a dog, the sight of persons carrying weapons capable of inflicting injury, de., he immediately turns back and retraces his stepi homewards. Again the Neket-rala

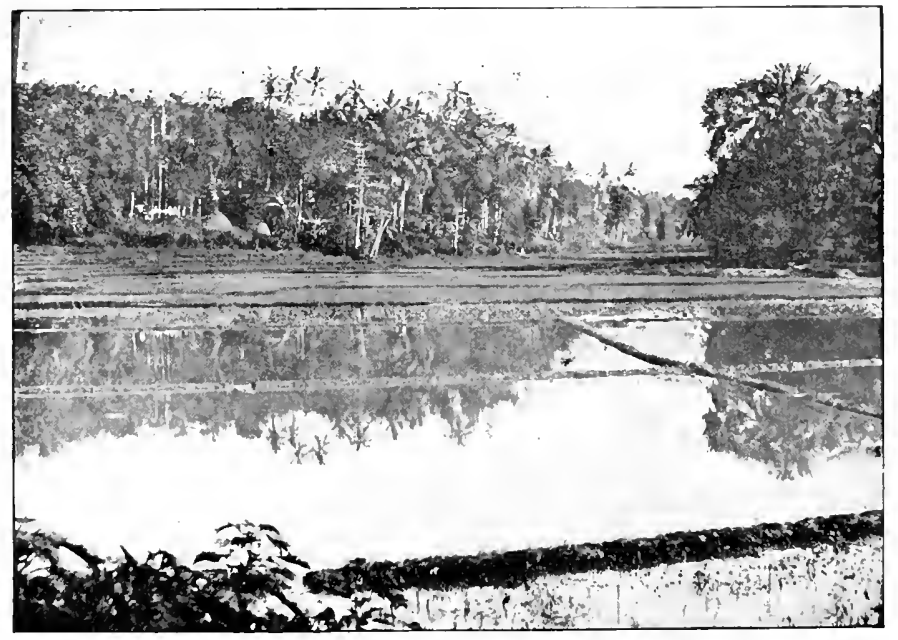

HIGH LANDS AND PADDY FIELDS.

has to be approached in the manner before described, and consulted as to a lucky hour. WVere the goiya to meet with a milk cow, vesiels filled with water, men dressed in white, \&c., when he sets out towards his land, it is considered very propitious........ On the following day the goiya entertains such of his fellow-villagers with rice cakes, milk rice, \&c., as are willing to co-operate with him in the cultivation of his field. At the lucky hou these villagers armed with mamoties proceed to the land, headed by the owner, and tuming their faces in the direction of Adain's leak give out the cry of Ha pura hodai (lla, a good beginning.)....... When the ficld is ready for sowing,.... On the advent of a lucky hour, 
the goiva leaves bis dwelling after having recited a number of religions stanzas, bearing an arecanut flower and a pata (handful with the finger's stretched out) of paddy (rice in the husk). I laving arrived at his field, with his eyes turned towards the favourable region of the skr, he buries the paddy in a corner of a ridge, having first moulded the earth at the spot so as to resemble a peculiarly shaped srmbolic figure, and lays the arecanut mower on the top of the mound.......

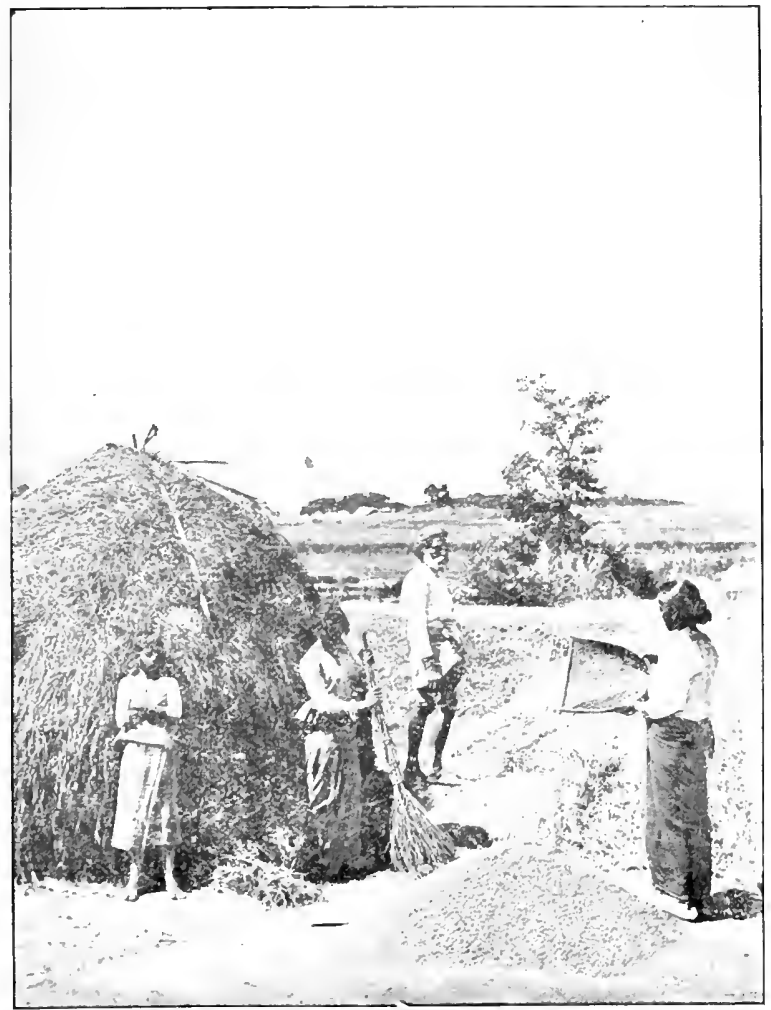

WINNOWING PADDY.

"The time of ploughing is one of great solementy to the Kandyan parldy conltivatur. The Neket-lala is again consulted for the purpose of fimeling a lucky hour. . . . . .

"Thimning is dene by the women when the padely is about three montlos eld . . . No one liare crose the ridges with an open monbella white the women alre at work, unlesis there be 
urgent need for so doing, and permission be first obtained, otherwise mud \&c., are thrown on the intruder whoever he be...........

"When the paddy is approaching maturity, other ceremonies are gonc through; the goiya after purification, places three ears of grain on a leaf of the Bo-tree, which is held in great veneration for reasons too well known to need mention* and buries them in the kalavita or threshing floor, at the same time chanting some mystic words, invoking the gods to protect the crop firom flond, fire, birds, and wild beasts..... the Neket-rala, attired in fantastic dress, describes a peculiarly shaped figure with ashes on the kalavita with a view to preventing sorcery and other evil influences........"

When such complicated ceremonies are gone through for such simple operations as are involved in the cultivation of paddy, it is not surprising to find that the methods of cultivation are also very old and leave much to be desired in matters of economy and efficiency.

The fields are cleverly terraced, and supplied with water from the impounded streams in the valleys. Two crops of rice are in general obtained in the wet districts of southern Ceylon, one in each monsoon. The heary rains of the beginning of the monsoon are allowed to go by, and the fields are ploughed in its second or third month, with "a very primitive plough, consisting practically only of two stakes fastened together at right angles, and drawn by buffaloes, which on account of their love of watery and muddy places are the animals always employed in the cultivation of rice. The seed is sown broadcast on the wet mud obtained by ploughing and hoeing, and soon afterwards the water is allowed into the field, and the paddy grows to maturity standing in a few inches of continually changing water. A little before it is ripe, the water is rum off, and the grain ripens on the dry ground. It is then cut with sickles, and threshed, as above mentioned, by treading it out with buffaloes or cattle, or in some districts with the feet of men holding on to a bar fixed above the ground at a height of about 6 feet.

The visitor, secing the lowlands of Ceylon covered with rice fields, will naturally be supprised to tearn that the island imports enormous quantities of rice, but such is nevertheless the case. The villager has no rice to sell, only, with the very por vield ohtaned here, having conough for his own wants, and all the rice used by the townstolk, and by the hundreds of thonsandi of Tamil conlies cmployed in Ceylon, is imported

Under this tree Gautama attained his Bukdha-hood, and it is sacred in Ceylon. there is a very famous old tree in Anurathapura. 
PLATE XII.

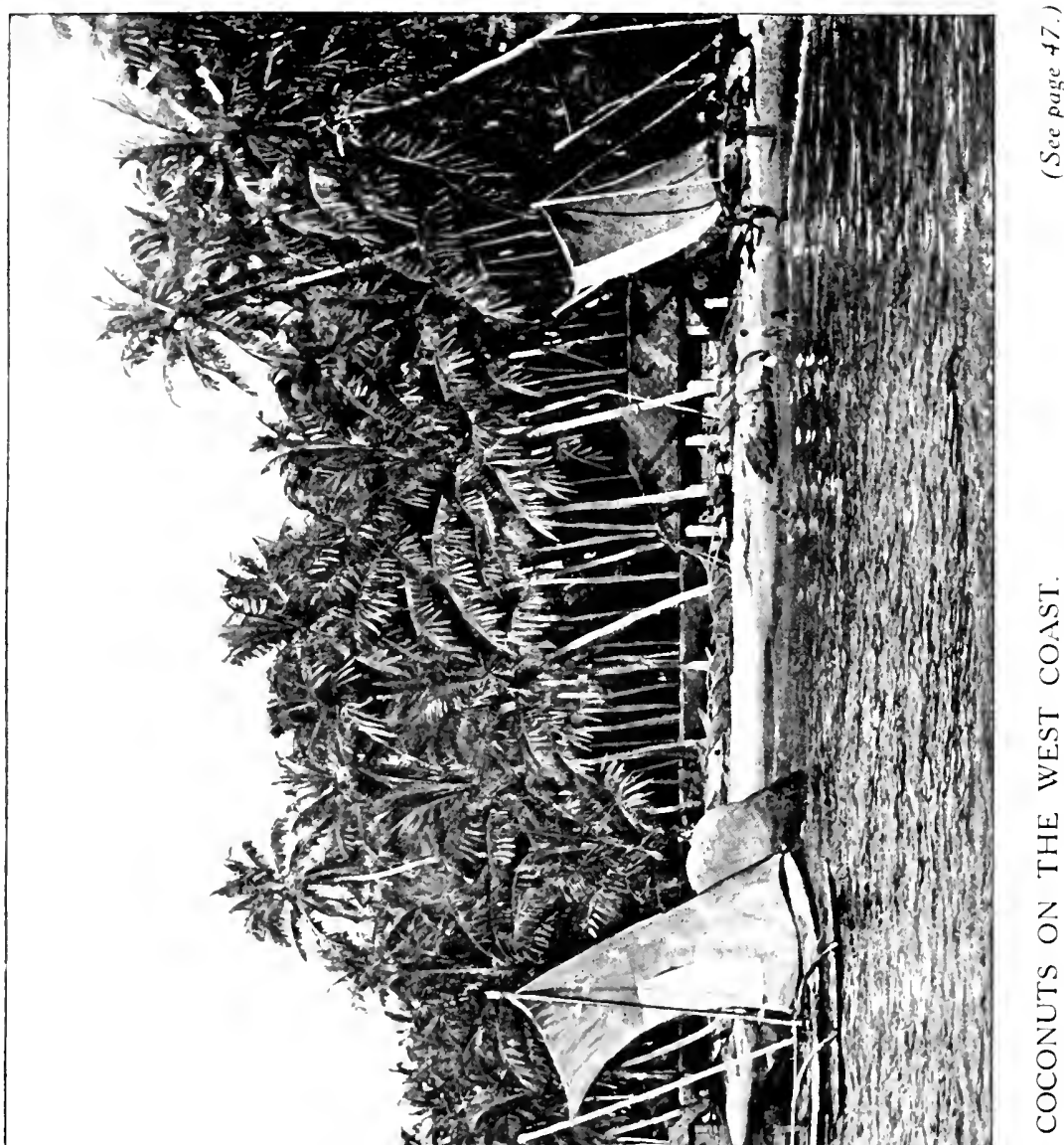



from lndia, the island importing as much as it grows. The duty on this import is one of the main sources of revenue of the local Government.

\section{COCONUT ESTATES.}

Between the paddy fields are rather higher grounds, the ridges between the valleys in fact, and in very many cases, along the Kandy railway, these are covered with estates or plantations of coconut palms. This palm, with its curved stem, large, nearly splierical head of long feathery leaves, and big green or yellow fruits, is one of the most characteristic features of Ceylon, and occupies an enormous area in the island. Not only are there vast spaces covered only with this palm, but almost every rillager has more or less of the palms around his drelling.

This palm is found crerywhere on tropical coasts around the world, the large woody firuit, covered with a fibrous husk, being easily floated without damage for enormous distances. Ceyton perhaps contains the ofdest and largest cultivations of it, but it is extensively grown in every tropical comtry, and the

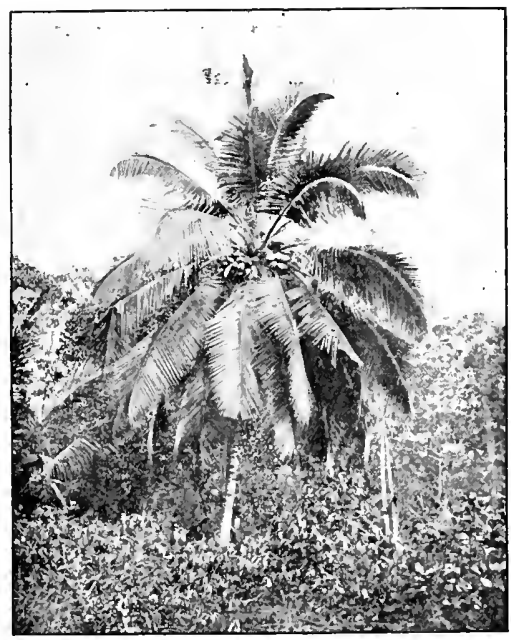

A COCONUT PALM. cultivation is comtinually extending, new uses being found for its products.

There is probably no single plant whose proflucts are capable of sogreat a vallety of uses as the coconut palm. The villager obtains from it many of the necessaries of life. The large leaves are woyen into "cadjans" for thatehing, and into mats, baskets, se., their stalks and midribs make fences, bromms, vokes, and many other utensils. 'The trunk affords rafters, loams, tomshs, canos, and many articles of fumiture. The bud of "calblage" at the apex of the stem makes an excellent regetalle, and is male into preserese. Whou the palm in flowering, the main llower stalk cam be tapled for "toddy," the juice rumbing up to the flowers, which exuder 
in large quantity, and contains a lot of sugar. Evaporation of this furnishes a coarse but good sugar known as jaggery, and its fermentation produces an alcoholic drink, from which distillation produces the strong spirit known as arrack, while further fermentation yiclds vinegar.

The voung fruits (locally known as lemrumbes) contain a pint or more of a cool swectish watery fluid, affording a most refieshing drink, and the only unboiled drink to be obtained in most country places which it is safe for a European to inclulge in. As the nut ripens the water decreases and the kernel hardens. The nuts are gathered at about ten months old. Their kernels are eaten raw, in curries, and in other ways, milk is expressed form them for flavouring curries and other purposes, and wil is extracted from them by boiling. The commercial oil, in which there is a very large trade, is obtaincel by first drying the kernels in the sun or by artificial means till they form what is termed copra, and thei pressing this copra in mills. About two-thirds of the weight is obtained as oil, and the refuse "cake," on pomac, forms a raluable fattening food for cattle and poultry. The oil is occasionally used for lighting, but its great use, especially in Europe, is for soap making; it also forms a good lair dressing, and is lasecly used for the manufacture of candles, as it separates under pressure into a hard wax-like body, stearine, and a liquid oleine. The shell of the nut, after the kemel is taken out, forms drinking cups, bowls, spons, handles, and many othes things; it also makes an excellent smokeless fuel, and yields a good charcoal.

In recent vears a large industry has sprung up in desiccated coconut, i.e., the kernel of the nut, with some of the oil expressed, sticed and dried in special desiccators. The product is soldered up in lead-lined boxes and exported for use in confectionery.

The thick outer husk of the coconut, rarely seen in America or Europe, contains a large number of "long stout fibres running lengthwise. The villagers obtain these by splitting the husks, rotting them in water, and then beating out the soft tissue from the fibres. There are also many large mills where special machinery is used for preparing coir, as this fibre is called. The uses of coir are many; the fibres are graded according to their stoutness, and used for making brushes, yarn, rope, mats, and for many other purposes. There is a large export to Europe and America.

It is supposed that the coconut palms of the island produce about $800,000,000$ nuts annually, and that about half of the crop is used locally. The export trade is very large, and during 1903 the chief elements of it were as follows:- 


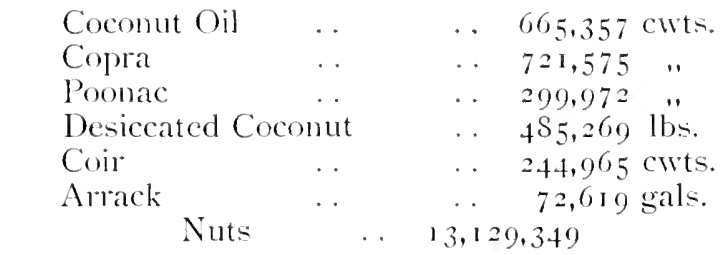

\section{MIXED GARDEN CULTIVATION OF THE SINHALESE.}

We have used this term to describe the type of cultivation which may be scen on much of the high land between the paddy ficlds. It is somewhat complimentary to call it cultiva-

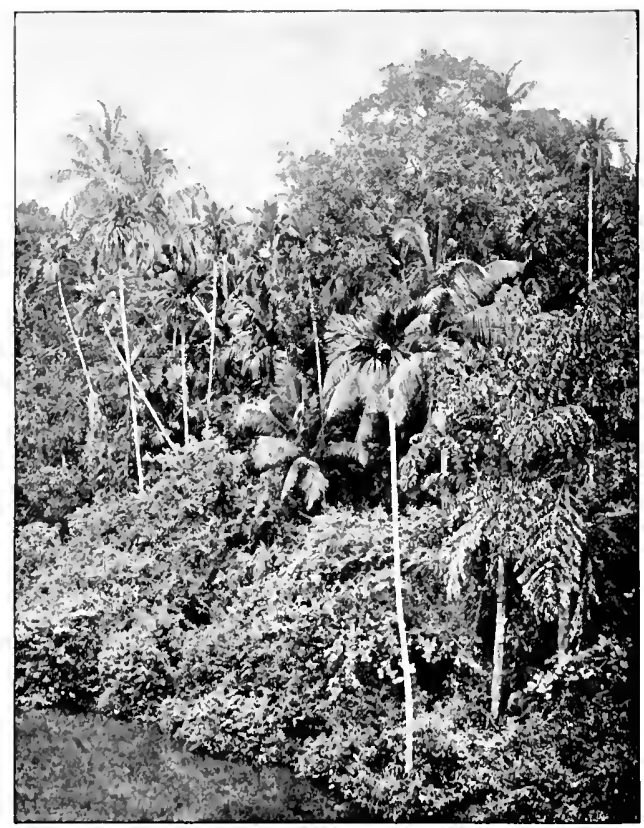

MIXED GARDEN CULTIVATION.

tion, when it consists of simply sticking in the trees and shrubs and allowing them to grow, but that may pass. Enormous areas are thus covered. At first sight there appears to be a miscelianeous jungle upon the land, but on closer inspection this resolves itself into an admixture of a few dozen (at most) 
of sorts of trees, shrubs and herbs. Conspicuous among them are the coconut (see above), which supplies many of the necessities of life to the villager, the jak, the mango, the areca palm, and less so the silk-cotton, the papaw, the plantain or banana, the orange or lime, the breadfruit, the kitul or toddy palm, Ace, while among the herbs are yams of sorts, and other things. The general composition of this mixture, in any one district, is much the same, and once planted, it will go on for many years without attention. This it is, perhaps, which so appeals to the villager in this method of "cultivation," for of course the yield is but small, and as a rule his plants are of but poor varietics.

Beyond Veyangoda the railway passes into the foot hills of the mountains and other cultivations begin to appear, as well as patches of actual forest (p. 37). This is a more thinly peopled district, and one may still see considerable areas of clsena, either in actual cultivation or abandoned and growing up in scrub in the ordinary way.

\section{CHENAS.}

This is the favourite mode of cultivation among semicivilised and eastern peoples (p. 37). On many hill slopes, cleared patches may be seen. These may be new clearings for planting, or (at higher levels) newly-pruned tea, but in the low-country are often chenas. The old chenas are corered with a miscellaneous scrub of many kinds of bushes and small trees.

\section{PLANTAINS.}

Bevond Polgahawela the line passes through large plantations of plantains - as they are universally called in Ceylon-or bananas, as they are called in England and the IVest Indies. These are not cultivated here for export to Europe, but for the supply of the towns, such as Colombo. On a rich soil, such as they get in this district, they do very fairly well, and yield good profits. The cultivation is entirely in native hands.

\section{RUBBER.}

Between Polgaluawela and the next station, the line passes on the right a plantation of rubber - the socalled Para variety

made by the Govermment Forest Department some years ago, but now in private hands. This product is now one of great importance in Ceylon, and is rapidly rising to the third place in the export lists, tea and coconut products occupying the first two places. Its history almost reads like a romance. 
PLATE XIII.

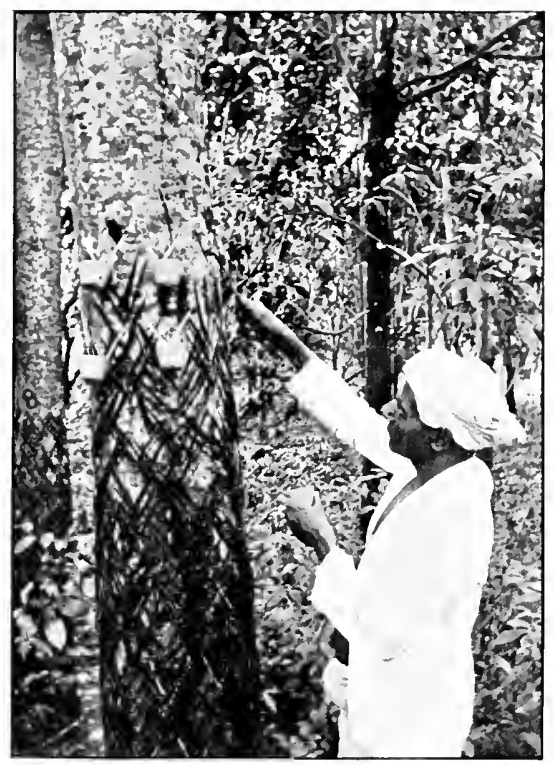

TAPPING RUBBER IN V's.

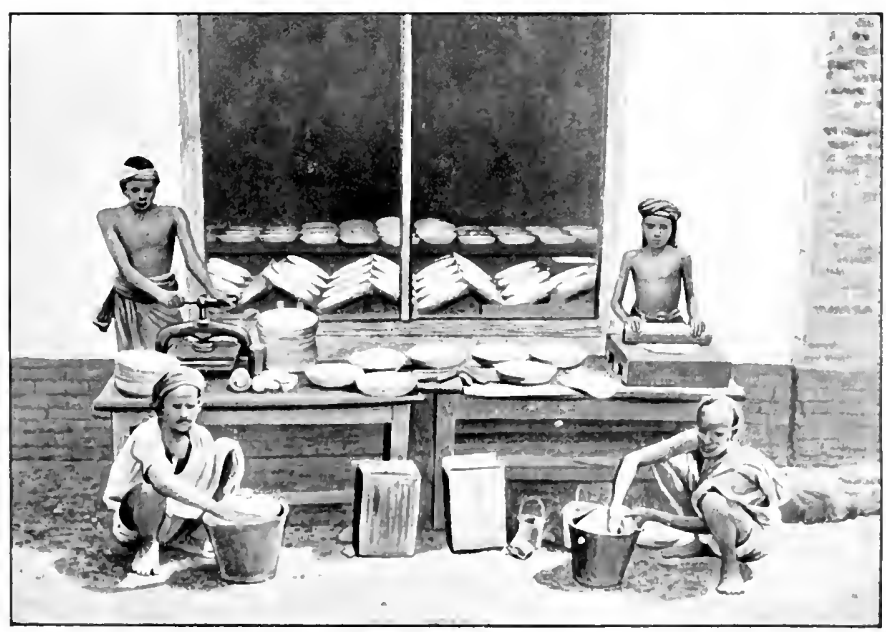

MAKING BISCUITS ON THE SMALL SCALE.

(Sec page 52.) 

Thirty years ago an expedition was sent by the Government of India to the valley of the Amazon to collect seeds and plants of the rubbers there growing, and they returned with seeds of this and other rubbers to Kew, from whence the plants were sent to Ceylon in 1876 . Until 1897 the supply of seed was but small, and no one knew whether any profitable return might be looked for in growing these plants. In that year the writer made the first experiments with the trees growing in the Botanic Garden at Ileneratgoda, and found that a return of perhaps r 20 lbs. of rubber per acre per annum might be expected. It proved that all previous experiments had given too small results, because the remarkable phenomenon

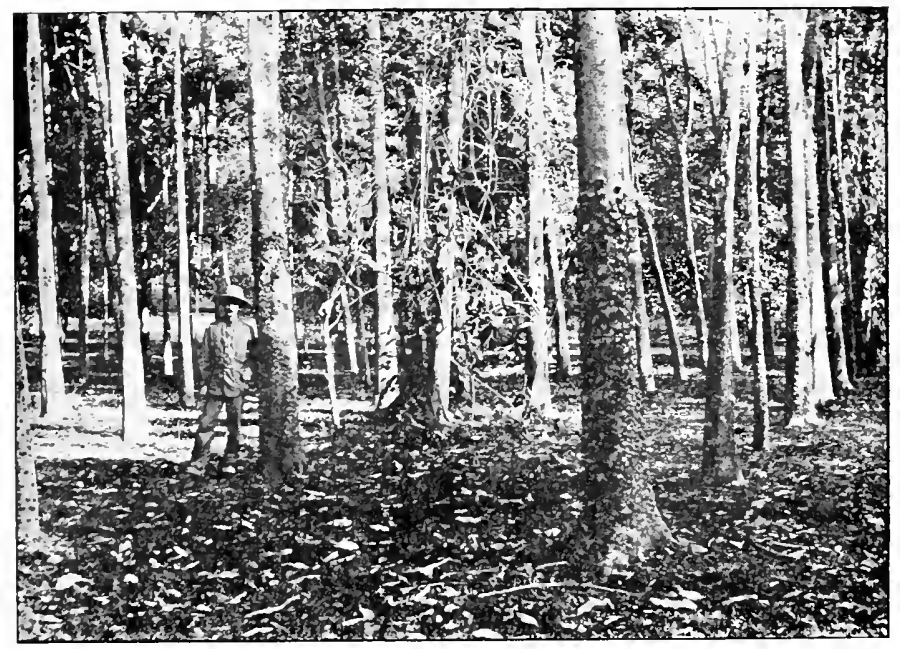

RUBBER PLANTATION AT HENERATGODA.

of the "wound response" lad not been noticed. If a tree be tapped within ten days near the same spot at which it was first tapped, the yield of rubber is alout twice as large. This was a very important discovery, and made the cultivation profitable. From that time it las been tilken up here, with increasing rapidity as large quantities of seed becanc available, and now there are about 150,000 acres in Ceylon alone planted to rubber, hesides about 200,000 in other tropical countries. The price of rubber is at present very high indeed, and the pionecrs of the cultivation have made profits at the rate of even $E_{60} \mathrm{per}^{\circ}$ ace per anmum, but of course this cannot be expected to last. 
Not only did the Botanic Gardens introduce and pioneer this cultivation, but they have also shown how best to get the rubber, how best to prepare it for the market, and many other things, so that the whole large and prosperous industry is the ereation of this department of the Gorermment.

Rubber is obtained from the trees by tapping. Spiral or herringbone cuts or more rarely large I's are made in the tree to the height of about six feet, and the milk that runs down is collected in tins, removed to the factory, mixed with creosote and acetic acid, and clotted into sheets of rubber which are dried and exported, or better still immediately placed in the hydraulic press, and compressed into blocks about two inches thick. The wounds on the tree are reopened at the next tapping by shaving off a small slice. Lately a new method of tapping by simply cutting a large $Y$ at the base of the tree and renewing this, is coming into favour, as it requires much less labour, and labour is none too plentiful.

\section{ARECA-NUTS.}

Along this part of the railway line, too, we come on large quantities of areca-nut palms, though of course these are evervwhere common in the villagers" gardens or "jungles." In this neighbourhood they are cultivated for sale and for export to South India. The palm is a tall, slender, graceful tree, with a tuft of feathery leares at the top, and is compared by native poets, not inelegantly, with "an arrow shot from heaven."

The nuts of this plant supply the bulk of the material of the universal "chew" of the eastern native; they are cut into slices, and mixed with a little lime-or chunam, as it is called here and usually tobacco or other condiment or spice, to give a tla vour, and then the whole is wrapped up in a leaf of the betel pepper and chewed. It colours the saliva a disgusting red, like blood, and the practice is a decidedly dirty one, the posts of every building in Ceylon being covered with white smears where the natives have wiped the lime off their fingers, and the ground covered with stains like blood from their spitting upon it. At the same time, the practice has, in an eastern country, much to recommend it, for it supplies the people with the lime which is decidedly lacking in their normal diet, and it is also said to be a preventive of dysentery. It is of late showing a tendency to disappear in favour of smoking, but unless this is accompanied by a change in diet to provide lime, the results are likely to be decidedly harmful.

From the wood of the areca paim, the native makes the pingo or yoke with which he carries things to market and 
PLATE NIV.

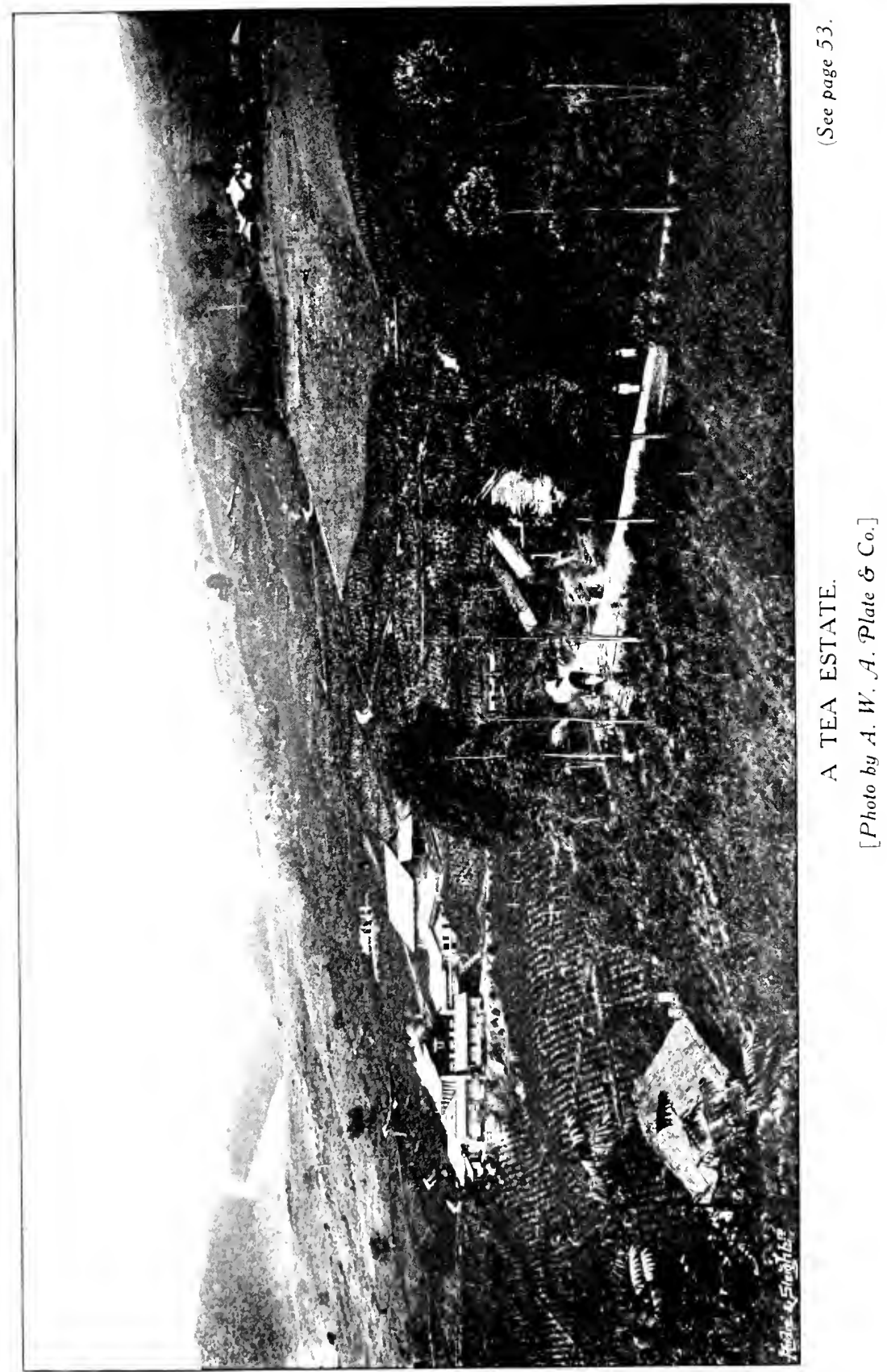



other places. This is simply a stick, about four feet long, flattened, and he carries it over one shoulder, with a burden attached to either end. When tired, he swings it round behind him, on to the other shoulder. By long practice, and by a judicious swaying of the pingo, the native is able to carry considerable loads for long periods by a method which to the unskilled man is extremely fatiguing.

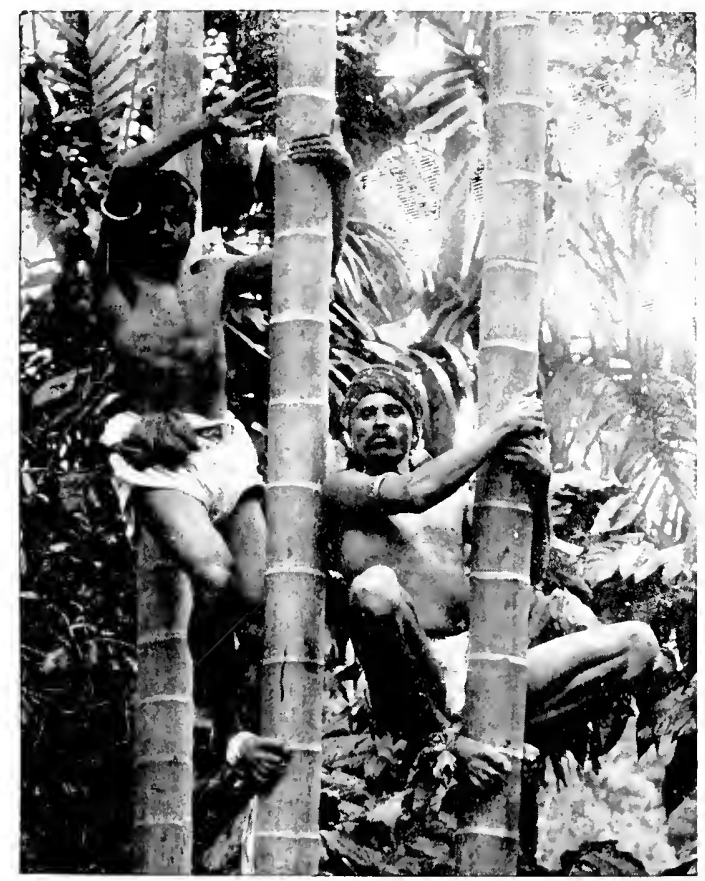

CLIMBING ARECA PALMS.

TEA.

At Peradeniya the first important plantation of tea is come upon, and beyond this, especially on the way to Nuwara Eliya, there are al vast number of plantations. Tea cultivation was first seriously taken up in Ceylon, to which the plant is not native, about i 875 , and spread rapidly firom i 880 to about 1895 ; there are now about 380,000 acres of land in the island devoted to it, and it forms the principal export commodity. The average size of a tea estate is a few bundied acres, though of late the tendency is to unite estates in groups for 
cheapness and convenience in working. Each is usually under a European superintendent or "planter," sometimes the proprietor of the estate, but now more usually a salaried employe of a London company, and if the estate is large enough, there may be one or more assistants. The principal planter, or chief superintendent, is usually known in Ceylon as the P.D., short for "periya durai," (pronounced "perria dorry,") the Tamil for "big master ;" the assistants are each an S.D. or "sinna durai" (little master), while the pupils, to be found on many estates, are known as "creepers."

The estate is usually under the agency of some firm of agents in Colombo, which manages its shipping and export business, rice supply, \&c., and also supervises the actual working of the estate by means of its V.A. or "visiting agent "- a planter of long experience, who goes over the estate at intervals, inspecting its working, estimates, accounts, \&c.

The labouring force of an estate-almost the most important part of its aetual working-is usually made up, not of the Sinhalese native to the island, who will not readily go out to work, but of Tamil coolies from the Madura and other districts of South India, who come to Ceylon as to a kind of El Dorado, where both men and women, to say nothing of the children, may make good wages for work which after all is by no means exlausting, though they work from 6 N.N. to 4 P.M. at a stretch. The coolies work in gangs under overseers, locally termed kanganies, by whom, as a matter of fact, they are generally recruited from their villages in India. As a rule, they return to India after a time with their savings, but a few settle in Ceylon. There is a very heavy traflic of coolies all the time on the boats sailing to Tuticorin in South India.

The rate of wages, being only 30 to 50 cents a day of Ceylon money, or $5 d$. to $8 d$. English, may seem to the newcomer mere starvation, but when one considers that at home the same people would not be able to eam more than about one-third of that, it assumes the guise of actual wealth. The coolies are housed and medically attended at the cost of the estate, and schools are usually provided for the children, so that they have nothing to complain of, and the visitor who holds up his hands in horror at the small accommodation provided must remember that this is almost palatial compared to their own homes, and that they do not like large and airy quarters.

The coolie is a very docile and obedient labourer, and gets attached to places where he is well treated. Not only so, but he gets attached to particular districts, especially to the upcountry districts, where he finds, that once he is acclimatised, his health is better, and if he be tempted by more money to work for a time on a low-country place, he frequently finds 


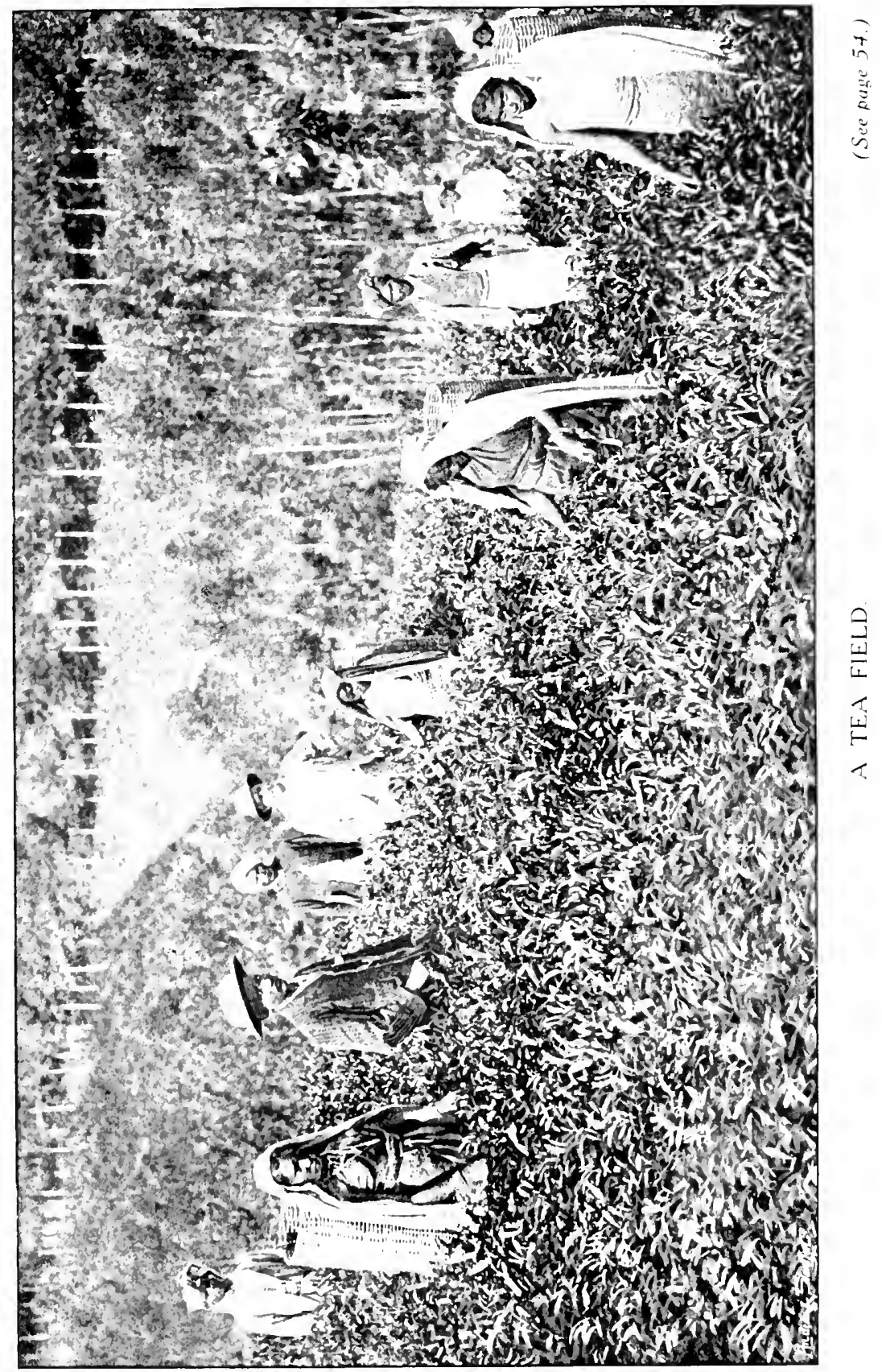



that he gets so much fever, that he is glad to return upcountry. Of course, even though in most places up-country there are no ferer-carrying mosquitoes, the coolie is in general saturated with malaria, and this will come out on him when he gets a chill or is otherwise below par; but on the other hand his clance of re-infection is very small, and with care he need hardly suffer from fever at all, whereas in many low-country estates he is continually ill from this cause, for he will not take any precaution against the bites of the mosquito. Lately an oil, giving protection against mosquitoes, has been introduced for the coolies to rub themselves with, and it may be hoped that this will have some good effect.

In its wild state the tea plant is a small tree, and there are several varieties, but in Ceylon the Assam variety, or a hybrid of it with the China, is almost exclusively cultivated, and the plant is so constantly pruned that it never grows to any lueight. It is planted out in long rows at four feet apart, and the new-comer will be suprised to see in what apparently inhospitable places the plant will yet thrive on rocky land, on precipices, and on the very poorest soil.

The bushes are subjected to a severe pruning every eighteen months to four years-less frequently the higher above the sea level and every stalk is cut off, down to a height of about a foot above the ground. Jn this condition the fields look almost as if the bushes were dead, for not a leaf is left on them. Rapidly they recover themselves, and soon the "flushing," as it is termed, is going on more merrily than before. from the upper part, or tlattish surface of the bush, there continually sprout out long, green, tender shoots, bearing young leaves. These are termed the flush, and the whole object of the cultivation is to ensure regular, frequent, and vigorous flushing. It is from the flusily that the tea is obtained. 'The bud at the tip, and one, two or three leaves below it

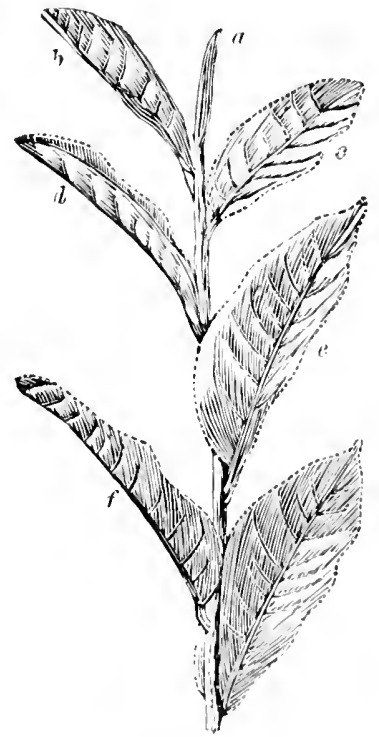

A TEA SHOOT: $a, b, c \& c$. Successively Older Leaves. are nipped off by the skilful fingers of a coolie woman or child. When the bud and one leaf are taken, the plucking is tromed fine, when two leaves, medium, when three, coarse. Medium 
plucking is perhaps the commonest course. The work is done by the women and children, working in gangs under kanganies, and they soon become very quick and expert at it. They pick off the flush with both hands, and throw it into large baskets which they carry suspended from their heads.

Fine plucking produces the various teas known as "pekoes," which in the days when tea came from China were supposed to come from a special variety of the plant. The older leaves give souchong and congou teas. Pekoes composed only of the buds or tips are known as "flowery," those containing also the first young leaf as "orange" pekoes.

At 4 p.m. the coolies bring in their day's plucking to the factory which is usually a large and well equipped building,

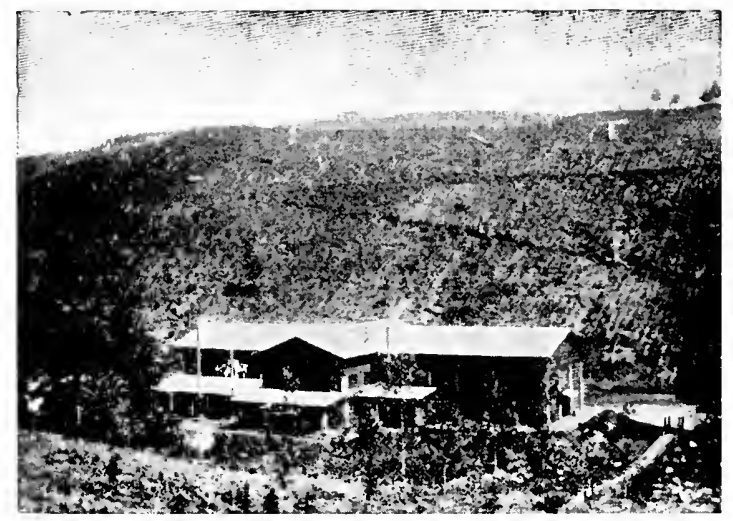

\section{A TEA FACTORY}

containing the most modern machinery, and worked by steam or water power. The "leaf" is cxamined and weighed and the amount plucked by each cooly recorded, the wage depending partly on the amount plucked.

After this, the leaf is taken to the upper floor of the factory, and thinly spread out on light canvas (jute hessian) shelves, known as tats, to wither. In good weather it becomes limp and flaccid in about is hours, but in wet weather artificial heat is employed, and a current of warm dry air is drawn through the withering loft. The properly withered leaf is next thrown down through shoots into the rollers or rolling machines on the ground floor of the factory.

A roller consists essentially of a table witl a central depression to hold the leaf, and a hopper above it, the two moving over one another with an eccentric motion. Pressure to any required extent can be put upon the mass of leaf that is being 


\section{PLATE XVI.}

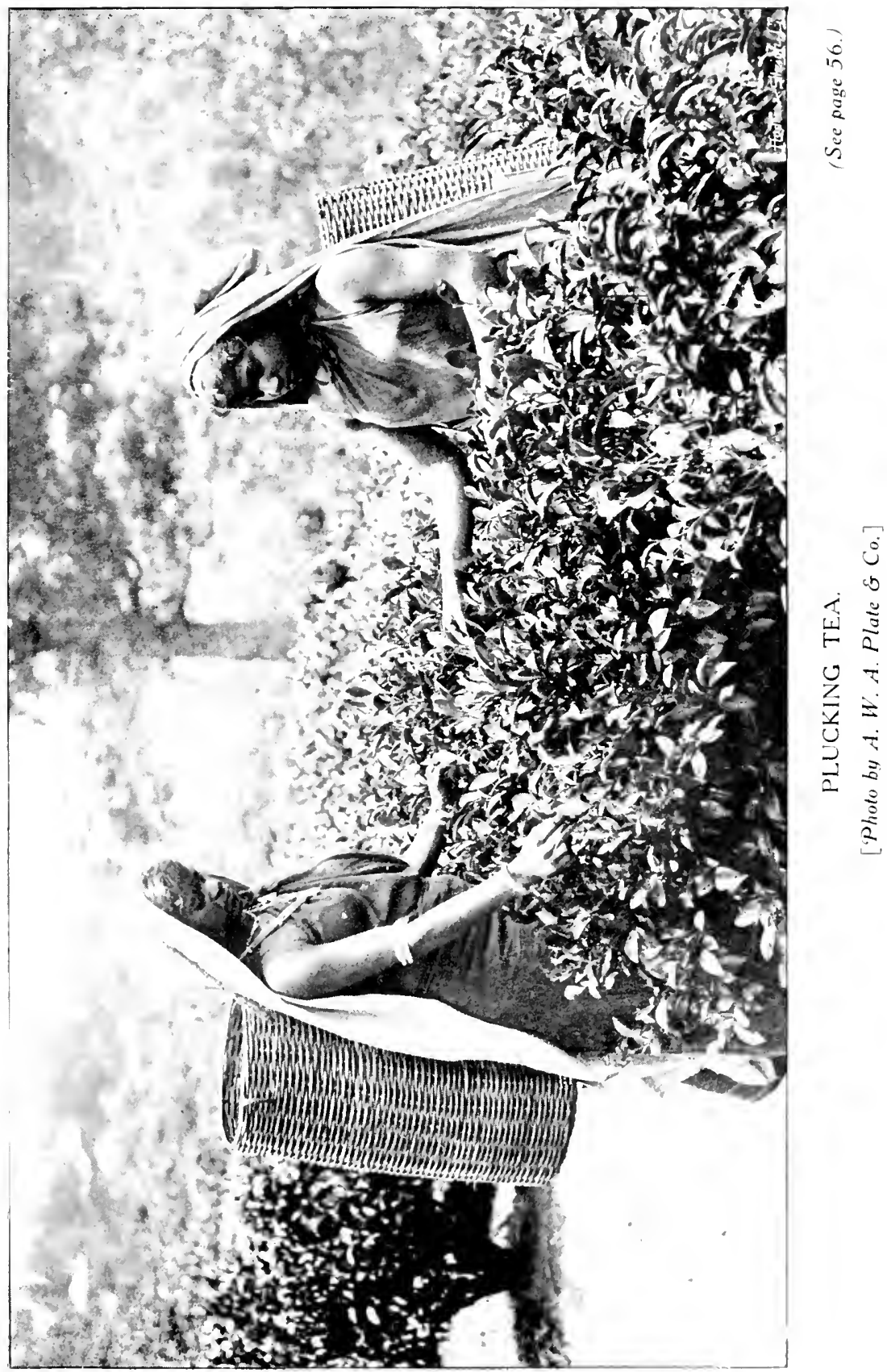



rolled, and at the end of an hour or so the door in the bottom of the table is opened, and the "roll" falls out, as a lump of more or less crumpled and twisted leaves, that hang together in masses. These are then broken up in a machine called a "roll breaker," to which is usually attached a sifter that separates the coarser leaf from the finer.

After this the leaf is piled in drawers or on mats to ferment or oxidize, with free access of air. This process is omitted in the manufacture of green tea. In a couple of hours or so, depending on the weather, the leaf assumes a coppery colour, and gires out a peculiar smell. Experience is required to determine the exact point at which to check the fermentation and place it in the firing or drying machines. There are many types of these machines, but all act by passing a current of hot dry air through the damp fermented leaf until it is

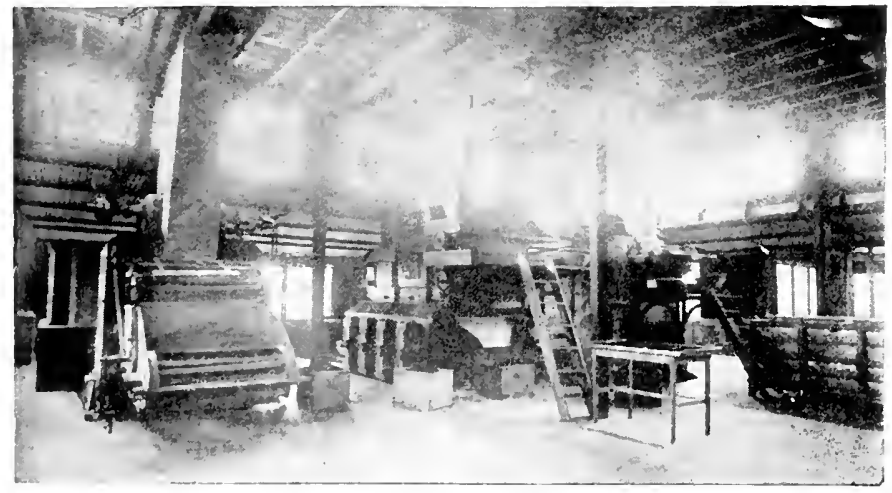

FIRING MACHINES.

dry and brittle, when it is removed, sifted into grades by a machine composed of a series of moving sieves of different sizes of mesh, and finally bulked (i.e., the whole mass of each grade made on one or more days is thorougluly mixed together, so as to secure as great uniformity of quality as possible), packed in lead-lined boxes of about 100 lbs., soldered up, labelled with the name of the estate, and despatched to the port for shipment.

The grades of tea usually prepared in Ceylon are known (in order of quality and valuc) as orange-pekoe, pekoe, pekocsouchong, souchong, congou and dust.

Green tea, made in the same neneral way as black, but withered by means of steaming, and prepared without fermentation, is graded as young hysom, hyson ( 1 and 2), gunpowder, and dist. 
While until the last few years tea was usually grown in large open fields, and presented much the look of the gooseberry orchards of the valley of the Clyde, it is nowadays nearly always to some extent shaded with Grevilleas, Albizzias, or other trees, and is also very commonly cultivated with green manures, i.e. other plants, usually belonging to the leguminous family (that of the beans, peas, clover, \&c.) are grown amongst it, and presently ploughed in, to improve the quality of the soil by providing it with more decaying organic matter. The leguminous plants are generally chosen for this, because they have the power of absorbing nitrogen from the air-the most valuable and expensive constituent of an ordinary manure-and thus the soil is enriched in nitrogen at a small cost.

\section{CACAO.}

Along the upward joumey from Rambukkana to Kadugannawa, and beyond the latter place, and most especially from Kandy to Matale along the branch line, may be seen plantations of cocoa or chocolate, better perhaps spelt cacao as there happen to be so many other things with similarnames, and to this day the cacao tree is confused with the coconut palm. Ceylon now has about 35,000 acres under this crop, mostly in the Matale and Badulla districts, and Ceylon cacaos fetch about the highest prices upon the European market.

The plant itself ( Theobroma Cacas the food of the gods) is a graceful little tree or shrub about I 2 to 6 feet high, much branched and spreading out, and is grown under

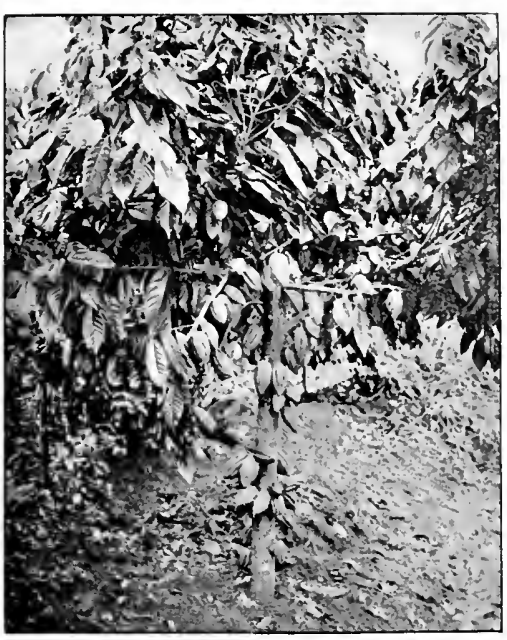

CACAO IN FRUIT. the shade of other trees, as it will not stand exposure to sun or wind. The shade trees used to be almost exclusively dadap (Erythrina), but now it is by no means uncommon to use rubber.

The plant flowers, not on the twigs, as it would do in Europe, but in the way so very common in the tropics, on the 


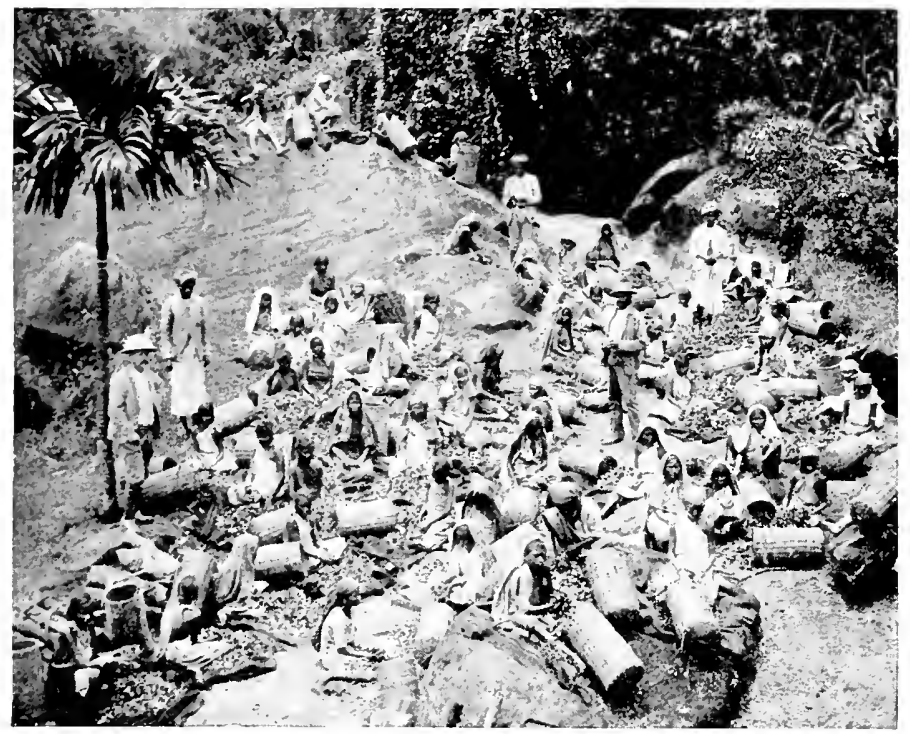

SORTING LEAF IN THE FIELD.

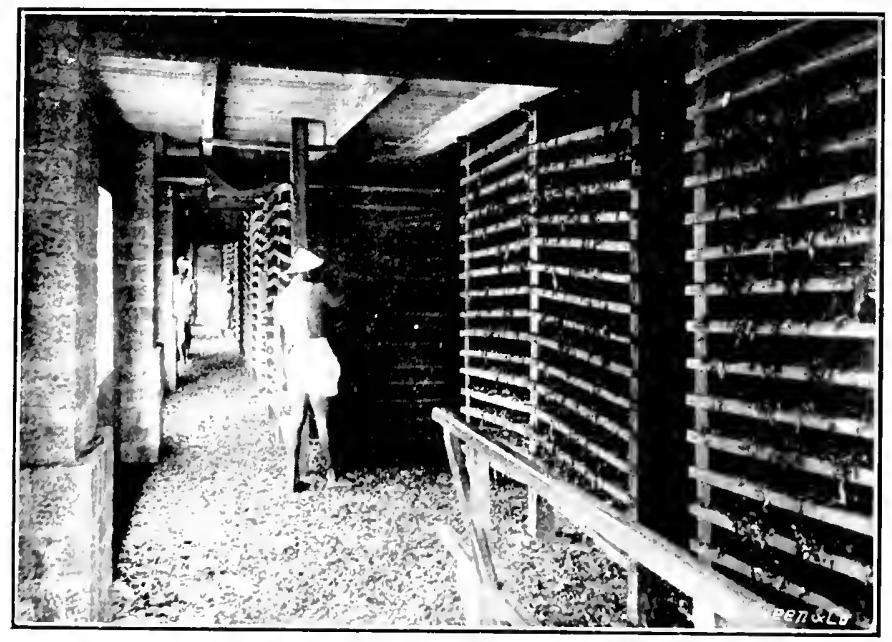

A WITHERING LOFT. 

old mature wood, and the flowers are followed by large pink, yellow, or green fiuits, with rather fleshy rind, and containing about 30 bean-like sceds. The fruits are picked and cut open, the seeds piled in heaps under plantain leaves to ferment the mucilage that coats them, then washed and spread out in the sun for a few hours a day for several days to dry them. When dry they are despatched to Europe, but of late a factory

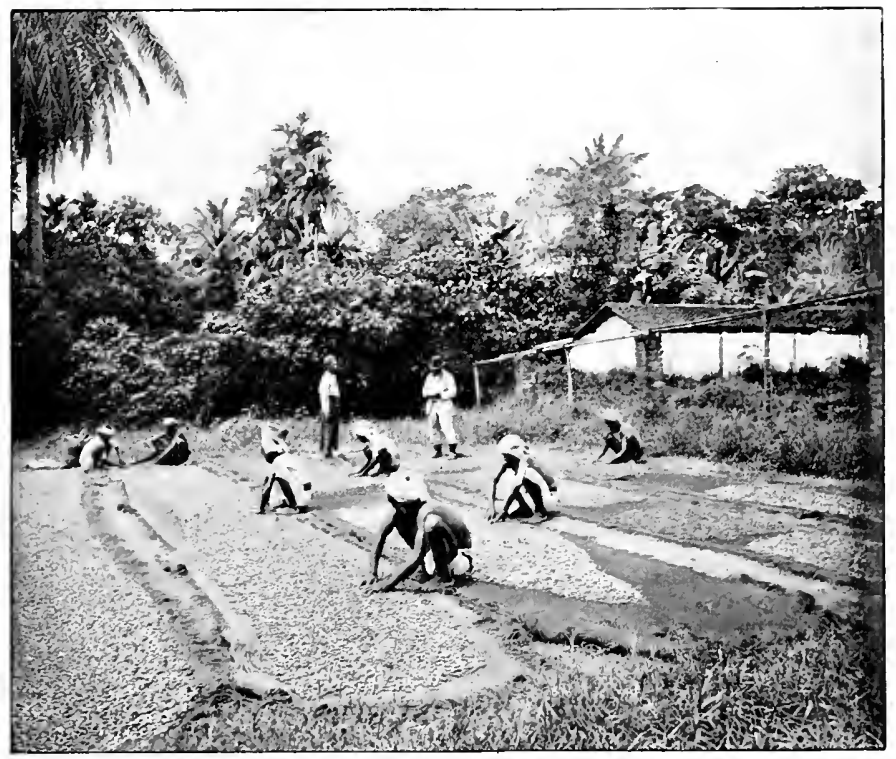

DRYING CACAO.

for the manufacture of cocoa and chocolate has been opened in Ceylon by Mr. Barber at Ukuwela.

\section{CARDAMOMS.}

This crop is not to be seen along the railway. 'Though at present fifth in importance among the exports due to the planting industry, this spice is still but little known in Europe or America. It is chicfly used in India for cooking, confectionery, and masticating, but is coming steadily into use elsewhere, and deserves to be more widely known. About 10,000 acres, chiefly in the mountain districts nortlu-cast of Kandy, at an elevation of about 3,000 to 4,000 feet, are now devoted to this spice. The plant itself (Elethria Cardamomum belongs to the gringer family, and is not unlike ginger in 
appearance, but very much larger, growing to a height of ro feet. It is cultivated in clumps under the shade of the trees of the forest, which has its molergrowth thimned ont to make room for it. The flowers are borne on stalks rising from the ground, and succeeded by little capsule fiuits, which are cut off with scissors, spread out in trays or on barbecues (drying grounds), and slowly dried and bleached. The essential part of the spice is the seed contained in the capsules, but the latter are always dried with the seeds, and so far as possible without splitting. If the seed were sold without the capsules, they could be easily adulterated with other similar and less valuable seeds.

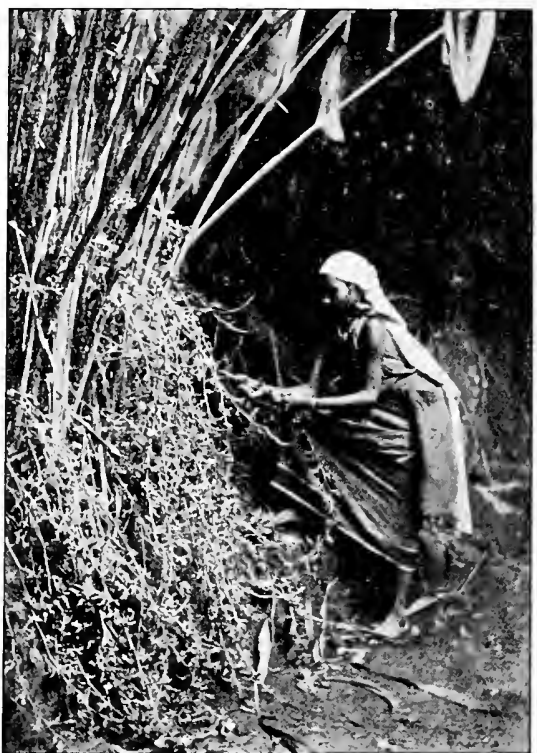

PICKING CARDAMOMS.

The export of cardamoms in 1903 was 909,418 lbs. but has since decreased.

\section{UP-COUNTRY FOREST.}

Up to Nanuoya nearly all the forest has been cleared from the hills in the earlier days of the planting industry, and one now sees nothing but the merest fragments. Fortunately in 1875 Sir Joseph Hooker got the Colonial Office to enact that no further land should be sold in Ceylon above the elevation of 5,000 feet, and as cinchona and tea were only just coming in at that time, and coffee would not succeed at high levels the great bulk of the high-lands of Ceylon remain untouched. Beyond Nanuoya, both on the lines to Bandarawela and to Nuwara Eliya, the forest may be seen to advantage, more especially on the former. By this means the water supply to the lower levels is conserved as much as possible, for of course the rain does not instantly drain off to the rivers 
PLATE XVIII.

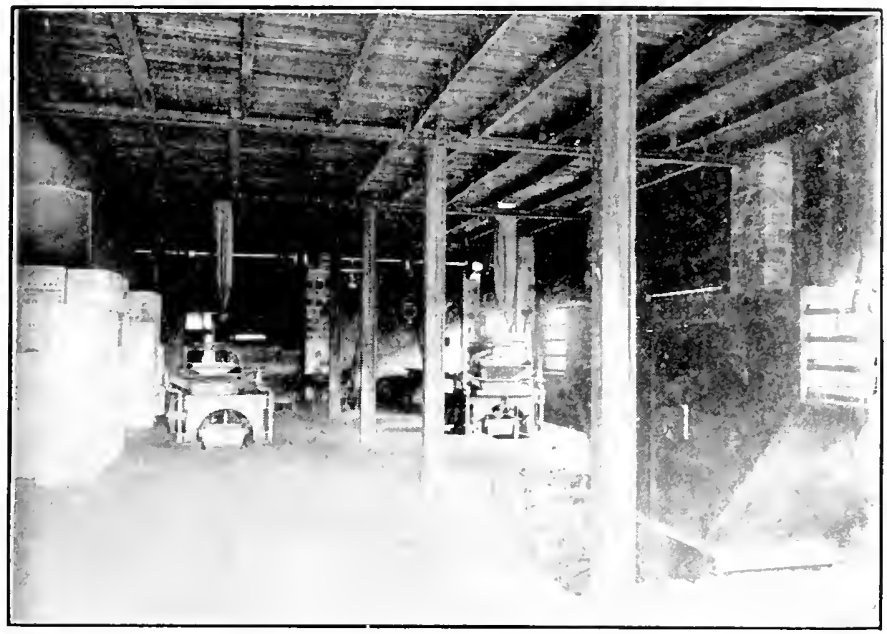

ROLLING AND BREAKING TEA.

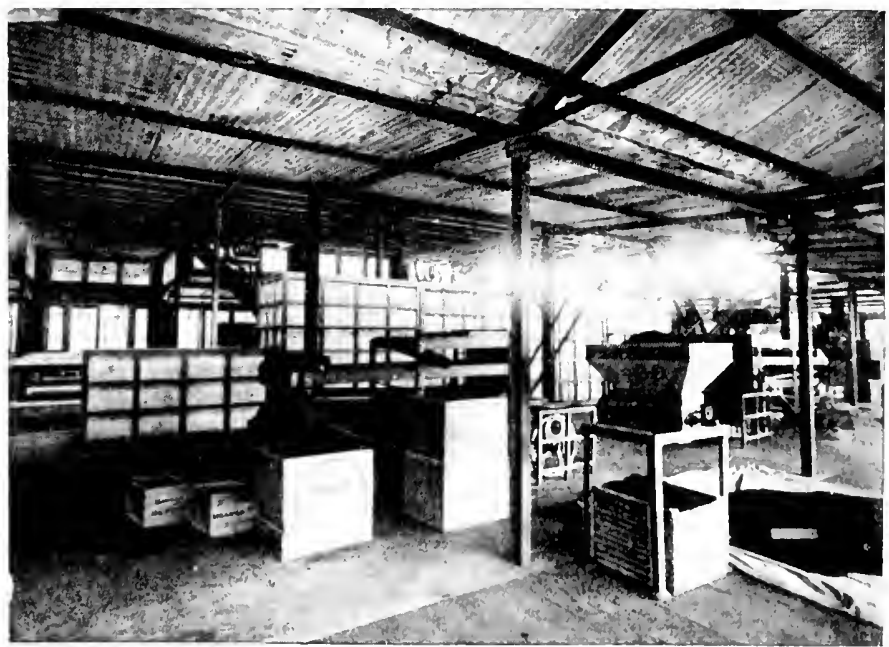

TEA SIFTING MACHINES.

(See page 57.) 

from ground covered with forest, as it does from open tea land, but drains gradually and evenly into them.

The trees of this forest are surprisingly low in stature, and much snarled and twisted, and all grow to much about the same height. Their low stature is perhaps due to the violent wind that sweeps over the hills in the southwest monsoon. Under the trees are many shrubby plants, more especially many species of that known to the Sinhalese as nelu. Of this plant, which may usually be recognised by its growing in an almost unbroken mass through large areas of forest, and to a beight of 5 to is feet, and by its large oval leaves, there is rarely more than one species in one region, though there are some 30 or more $^{-}$ species altogether. 'They grow up from the seed, without flowering, for 6 to 16 years, and then, all at once, a whole patch of a species will burst into simultaneous flower, producing an extremely pretty effect, and attracting thousands of bees, who are soon followed by numerous natives, on honey-seeking bent. When the seeds are ripe, the plants all die down, and the jungle is full of dead sticks. Numerous

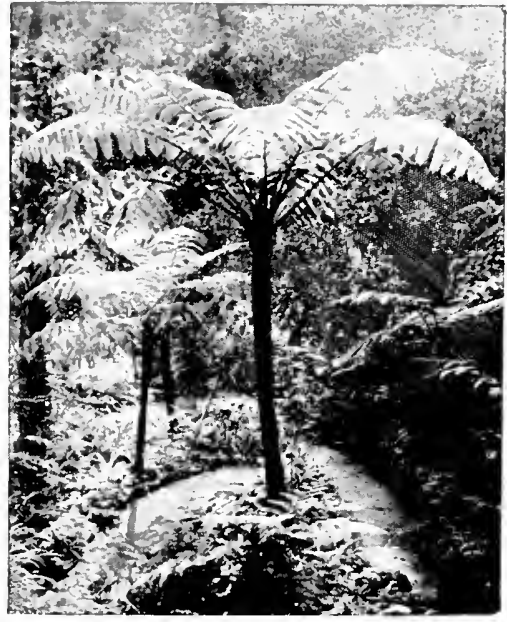

TREE FERNS. jungle fowl come up to feed upon the seeds. Yet another very common undergrowth is the dwart bambon, which also occurs in unbroken masses over large areas. Orehids, perched upon the trees, are very common, but there are but few of striking or gaudy effect. Tree ferns are frequent.

\section{UP-COUNTRY PATANAS.}

Towards Nuwara Eliva, or near Ambewela, according to which line of rail is followed, we come upon the first well marked examples of what are known in Ceylon as patanasopen grassy plains, usually (at high elevations) sprinkled with Rhododendron trees. On the western side of the main range these patanas are of limited extent, and are surromeled by forest. The boundary between the forest and the patana 
is remarkably sharp, large trees growing right up to the very edge of the forest, so that one may pass in two strides from one kind of country to the other. Passing eastwards along the railway to Bandarawela, so soon as we have crossed the main ridge by the tumnel, the area of patana begins to increase rapidly, while that of jungle decreases, and by the time that we have got about as far as Iaputale, the area of the forest is rery limited indeed, being reduced to little patches in the vast extent of patana.

Many theories have been put forward to account for this striking feature in an otherwise forest clad country. The one with most to be said for it supposes that the patanas began as small patches, and have been gradually extended to their present enormous extent by the continual firing of them which is done by the graziers, for cattle will not eat the coarse mature grass which grows upon them, but will only eat the roung and tender shoots that spring up after a fire. Every year the graziers burn the patanas, and every year in consequence their soil becomes more thin and poor.

Among the grass may be seen many flowers, and at certain seasons the patanas are comparatively gay with blossom. Among the plants that are to be found at high levels are many northern ones, such as gentians, buttercups and sundews.

The patanas up to about 5,000 feet are largely covered with mena grass, a tall coarse grass with a scent like citronella. 'The latter grass indeed is simply a variety of mana.

\section{CINNAMON.}

In the southeastern suburbs of Colombo lie the old "cinnamon gardens" and all the way down the southwest coast are large or small plantations of cimmamon, which is one of the most important minor cultivations of the island, and though not very remuncrative, is still extending its area. Cimmamon is the oldest export - of regetable produce-from Ceylon, and was practically the only export until about $18_{40}$, except elephants, ec. Until the Govermment monopoly was given up (p. 39), the trade however was but small, and the price high. Since that time it has steadily increased.

In olden times the spice was got from the bark of jungle trees, but now the plant is coppiced down like osiers in Emope, and the long twigs that are sent up have their bark peeled off, and rolled up into quills, onc piece inside another, while an inferior quality is sold as chips.

\section{MANGROVES, AND SHORE PLANTS.}

Along the coast line south of Colombo, the railway mainly passes through plantations of coconut palms, but 
PLATE XIX.

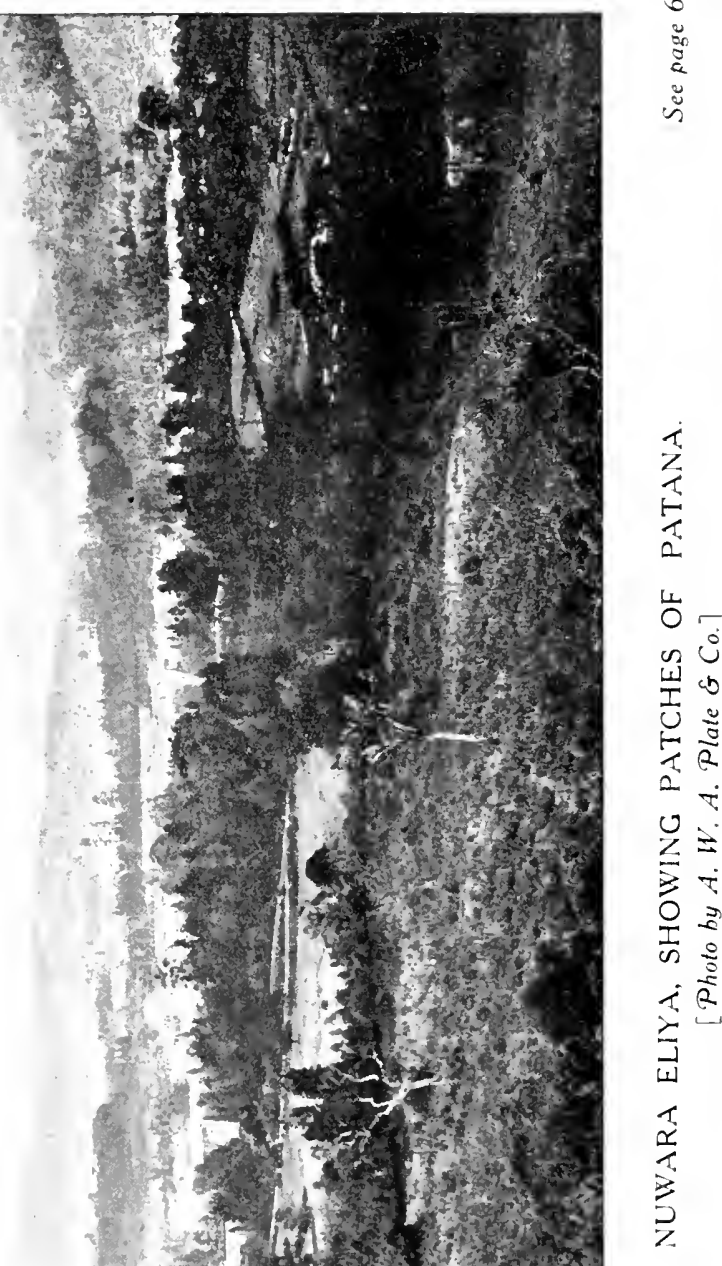



especially in the more southem part, along the lagoons south of Ambalangoda, there are patches of mangrove vegetation. This presents a rery characteristic appearance. It occupies only the large lagoons, the banks of rivers, and other places within reach of the tides, but free of any surt.

The characteristic appearance is of numerous shrubs looking not mlike laurels, but with many roots springing from the lower part of their stems and bearing them up as if on stilts. In many cases the seeds sprout while yet within the fruit, so that one finds large seedlings langing upon the trees; they ouly drop off when perluaps a foot or more long, and then fall straight downwards, and float in this position in the water. In this way their chance of sticking into a hole is much greater. The tide usually leares the mangroves almost bare during some part of the day.

Among the taller shrubs grow other plants, among them for instance very commonly a blue Acantlus, which with its holly like leaves forms a very pretty object.

Along the sandy beaches of the southwest is a characteristic regetation of small herbs, which is much the same on every tropical coast. Among the most striking plants are the Ipomaca biloba, a pink-purple flowered convolvulus with twolobed leaves like a goat's foot, Spinifex, a grass with a curious prickly fruit head with long spikes, that falls off bodily and rolls along before the wind, and many others.

\section{CITRONELLA.}

In the country north and east of Galle and Weligama, a large area is devoted to the cultivation of citronella grass, which is a cultivated variety of the mana grass that is so common on the patanas and the waste grass lands in other parts of the country. The grass grows in large tussocks about 4 feet high. It is cut every three months of so, and placed in a large still, through which steam is passed, and the resulting oil is condensed in a worm in cold water in the ordinary way. The oil is largely used in Europe and America for making the cheaper scented soaps, and having of late been rather over-produced in Ceylon, the price is lom, and the cultivation not specially remunerative. Lemongrass, a mearly related grass, with a somewhat more lemon-lıke smell, is also cultivated in places.

\section{DRY COUNTRY FOREST AND CHENA.}

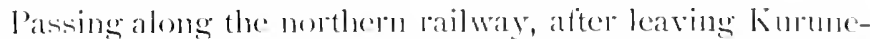
gala, the line rums mainly thoough low clsena serub, composed 
of low prickly bushes, but every now and then a piece of original forest is passed. There is little in this to tell the casual visitor that he is not in a wet zone forest, excepting the greater opemness of the forest, and the thinner undergrowth. In places some magnificent trees of kumbuk or other kinds may be seen, and it is in this forest that most of the valuable timber trees of Ceylon - the ebony, the halmilla, the satinwood, and the rest -are to be found.

\section{PALMYRA PALMS.}

In the extreme north of Ceylon we come upon an entirely new type of regetation, giving an altogether different look to the secnery. This is the great stretches of country in which the palmyra palm takes the place of the coconut palm of the south. It is a straight stemmed palm, with a stiff crown of fan shaped leaves, and large reddish-purple or brownish firuits, and is the great staple of cultivation of the Jaffina country, though eren there the coconut is a good deal cultivated. The uses of this palm are many, and an old Tamil song in its praise enumerates no less than 801 . Just as is the case with the coconut, the natives there use it for every conceivable purpose, making fibre, mats, thatch, buckets, \&c., from the leares, using the stems for rafters and other parts of houses, utensils, dre, and eating the fruits.

\section{GARDEN CULTIVATION IN THE JAFFNA COUNTRY.}

Unlike the Sinhalese, the northern Tamils, in their poor soil and dry country, make good and careful agriculturists, and the whole of the far northern peninsula of Ceylon is cultivated like a garden, with every possible kind of crop grown in straight rows, as in Europe, carefully watered and otherwise tended. Tobacen, recognisable by its very large leaves on plants about 2 feet high, is largely cultivated, but there is no export to Europe, the product being too coarsely cured. There is, however, a considerable trade with southern India.

\section{THE COMMON CULTIVATED OR WILD PLANTS OF THE ISLAND.}

Most of those of great importance have been dealt with above, but there are a few about which a few words must be said, and it will be convenient to arrange them, both those already described, and those which have not been mentioned in alphabetical order. 


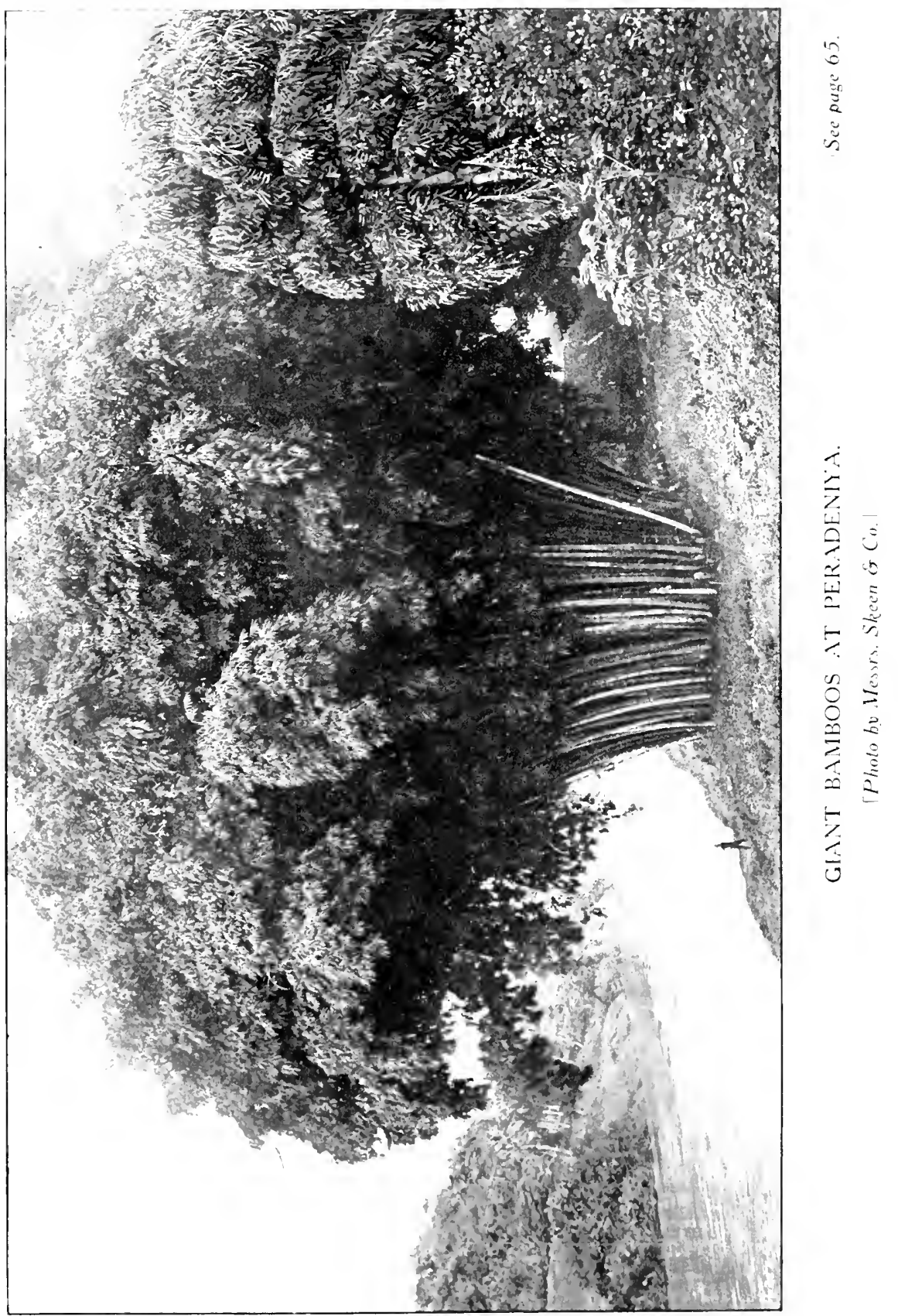



Acalypha. A verg common omamental shrub, recognisable by its thin leaves with blotehes of yellow or brown.

Amherstia. Terhapi the most beautiful tree in the toppics, common in the Peradeniva gardens. Very difficult to propagate. It flowers all the vear round, and the splendid pink flowers have a superficial resemblance to orchids. The young leaves hang down in a bunch in a curious way.

Areca-nut palm. See page 52.

Bamboo. Several kinds are grown in Ceylon, but the commonest are the vellow stemmed bamboo, about 40 feet high, and the giant bambon, of which there are many magnificent clumps at Peradeniya. Bamboos are used for scaffolding, for flower pots, mats, gutters and innumerable other uses. but Cevlon is not so marlicdly a bamboo country as Java, Assam, or Japan. (See plate XX.)

Bo. The Indian pipul, the sacred tree of the Buddhists (Gautama is said to have attained his Buddha-lood under one, and there is a very famous old specimen at Anuradluapura) and Hindus. Recognisable by the unique shape of the leaves. which taper in hollow curves to a point $2-3$ inches long.

Breadfruit. A native of the Pacific islands, cultivated along the S.W. coast and elsewhere. The fruit, fried, is good eating.

Cacao. See page 5 S.

Camphor. Now besinning to be cultivated up-country, and recognisable by the smeli of the crushed leaves. The twigs are cut and distilled with steam, when the camploor passes nver.

Cardamoms. Sec page 50.

Castor-oil. A common weed, and grown in nearly every native gaden, for the oil obtained by crushing or boiling the secds.

Ceara rubber. The first rubber cultivated in Ceylon, but now largely abandoned in favour of l'ara rubber: it grows in dry districts, and up to 4000 fret.

Cinnamon. A native of southern Ceylon, cultivated along the S. IV. coast. See prige 62.

Coconut. See page 47 .

Coffee. Form 18,35 to 1875 the mainstay of planting in Cevlon, but now almost extinct, exeept in native gardens about Bandarawela de.

Cotton. A poor quality is grown by matives all over the dry comtry, but lately cotton of good yuality (Sea lsland) is being takcilup.

Cotton-tree. (13ombax malabariom). Perbaps the most striking tree in S. IV. Cevlon during January and lebruary. The leaves fall completely at the end of becember, thus 
making this tall tree very conspicuous, and in January there appear a rast number of red flowers as big as tulips, followed in March by pods which when they burst scatter cotton broadcast.

Croton. What are known by this name are really forms of Codiaeum. They are favourite garden shrubs, occurring in great variety of variegated and variously shaped leares.

Dadap. The commonest shade tree in cacao, and sometimes among tea, with splendid red tlowers, and leaves with 3 leaflets.

Exacum. One of the most beautiful native flowers; the up-country (patana) form is now common in Europe. It grows about a foot high, and produces a bunch of lovely azure-blue flowers.

Furcrea. 'The Mauritius hemp, planted along the rail side and elsewhere, but not used here for fibre. Recognisable by the dense rosette of long thick sword like leaves at the base.

Grevillea. The Australian Silky-oak. Introduced here years ago, and now planted in millions in the tea country, as shade and for the timber. Leaves much divided featherwise.

Jak. Cultivated in every native garden up to about 4000 feet. The large irregular yellow fruits are produced, not on the twigs, but on the old stems - a not uncommon phenomenon in the tropics-and grow to a very large size, sometimes two feet in length, and 40 lbs. in weight.

Kitul. This palm is commonly cultivated in the Kandyan country, $c . s$. up the Kadugannawa pass. The leares are twice branched, and are spread out over the top ro-2o feet of the tree, so that it does not look like a "palm." "Toddy is obtained from the stalks of the flowers, just as in the coconut (page 47), and a fibre, largely used in Europe for making stiff brushes, is got from the bases of the leaves.

Lagerstroemia. This tree, with its splendid red-pink flowers, is very comspicuous along the railway to Kandy, especially between Rambukkana and Peradeniya Junction, from March to July.

Lantana. This is one of the commonest weeds in Ceylon, but is really a native of Mexico, as are so many of the common roadside plants here. Ceylon was once forest covered, so that it had no weeds capable of spreading on the cleared ground, and the American weeds from open country got a good chance to spread, so that now there are scores of them among the commonest plants of Ceylon. The Lantana, which is really a very pretty plant and popular in European hothouses, is said to have been introduced by the wife of Sir Hudson Lowe about $182 S$ and rapidly spread through the island, covering liundreds of square miles of waste land, from 
which it is now being ousted by the sunflower, a more recent arrival from Mexico. It is recognisable by its prickly stems, and bunches, about $1 \frac{1}{2}$ inches across, of small orange flowers.

Love-grass. The commonest grass in open turf; its name is supposed to be due to the partiality displayed by its fruits for clothing. They are barbed, and stick into the clothes if one walk through the grass.

Loranthus. Common here, growing parasitically like mistletoe.

Mana-grass. Covers the patanas, and waste grass lands. The leaves have a lemon-like smell, really that of citronella oil. A cultivated variety of the grass yields the citronella oil of commerce (page $6_{3}$ ).

Mango. Cultivated in nearly every garden, yet rarely does one find a good mango, partly because the climate is too damp, partly because the natives will not take the trouble to bud or graft. The fruits are lop-sided, green or yellow or pink, usually several inches long.

Mangroves. These occupy large areas of the banks of lagoons and backwaters on the coast. They are at once recognisable by the numerous roots that project downwards from their branches into the mud, and often by the fact that their seeds germinate on the plant, so that quite large young plants may be seen dangling (page 62).

Mikania. The last new weed, which has lately begun to spread rapidly, and is now common from Kandy down the railway as far at any rate as Polgahawela. It scrambles over the vegetation to a considerable height, and has dingy white flowers.

Mussaenda. Common along the kandy railway, and noticeable for the large white leaves among the flowers.

Orange, Lime, \&c. Everywhere cultivated in ones and twos. The best orange here is in general the mandariu, recognisable by the nipple at one end, but the Cotta orange is very good, though a trifle papery. Oranges here remain green, and do not turn yellow.

Paddy or Rice. See page +3 and plate Xl.

Palmyra palm. See page 64.

Papaw. Introduced by the Portuguese, and one of the commonest trees in the island. The large melon-like fruits are very good eating, especially for early tea. The loaves and the unripe fruits contain a digestive ferment, which forms the basis of many of the digestive salts used in Europe. If meat be buried with a leaf wrapped romel it, it soon becomes tender by partial digestion.

Para rubber. See page 50. 
Pepper. In former times an important crop in Ceylon, but now only cultivated on a small scale, though it is increasing. The berries if dried as they are form black pepper, if skinned white pepper.

Pithecolobium. P. Samam, often called Inga Saman, is the most common tree planted for shade by the sides of the roads.

Plantain. See page 5o.

Rhododendron. Very common on the patanas at high levels e.g. about Nuwara Eliya, and one of the finest of all Rhododendrons when covered with the great masses of scarlet flowers. Grows into a tree as much as 18-20 feet in height.

Sensitive Plant. A common object of interest in European greenhouses, but here one of the commonest and most troublesome weeds. By careful poking of the end leaflets, the leaflets may be made to close up pair by pair from top to bottom, and often the leal will subsequently bend down, or it may be made to do this by gently stroking it under the joint on the stem without touching the leaflets.

Sapu. Very common, but not a native tree. The sweetly scented flowers are largely used as offerings in Buddhist temples.

Shoe Flower. One of the handsomest flowering shrubs in gardens. The natives use the large red funnel-shaped flowers for staining fruit \&c., in cooking, and for cleaning shoes.

Silk-Cotton Tree. Cultivated on a small scale round most native dwellings in the low-country, and at once to be recognised by its lorizontally spreading branches. The cotton obtained from the pods is exported to Europe under the name kapok, and is also used locally for stuffing pillows \&c.

Sunflower. A Mexican weed, now perhaps the commonest weed in Ceylon, and very conspicuous from its large yellow flowers.

Talipot. The largest of palms. It grows without flowering for $40-90$ years, and then comes out with an enormous mass of whitish flowers at the top, in a plume perhaps to feet high, and then dies as soon as the fruits are ripe. The leaves are used, in small pieces, as umbrellas, and strips of them form the "olas" on which the old native scriptures and other books are written. (Plate XXI).

Tamarind. Common in the north, where splendid trees may be seen in almost every village. The fruit is edible, but somewhat aperient.

Tea. See page 53 .

Temple Tree. One or two may be seen near every temple in Cevlon. The sweetly scented yellowish flowers are used as offerings. The tree is often leafless. 


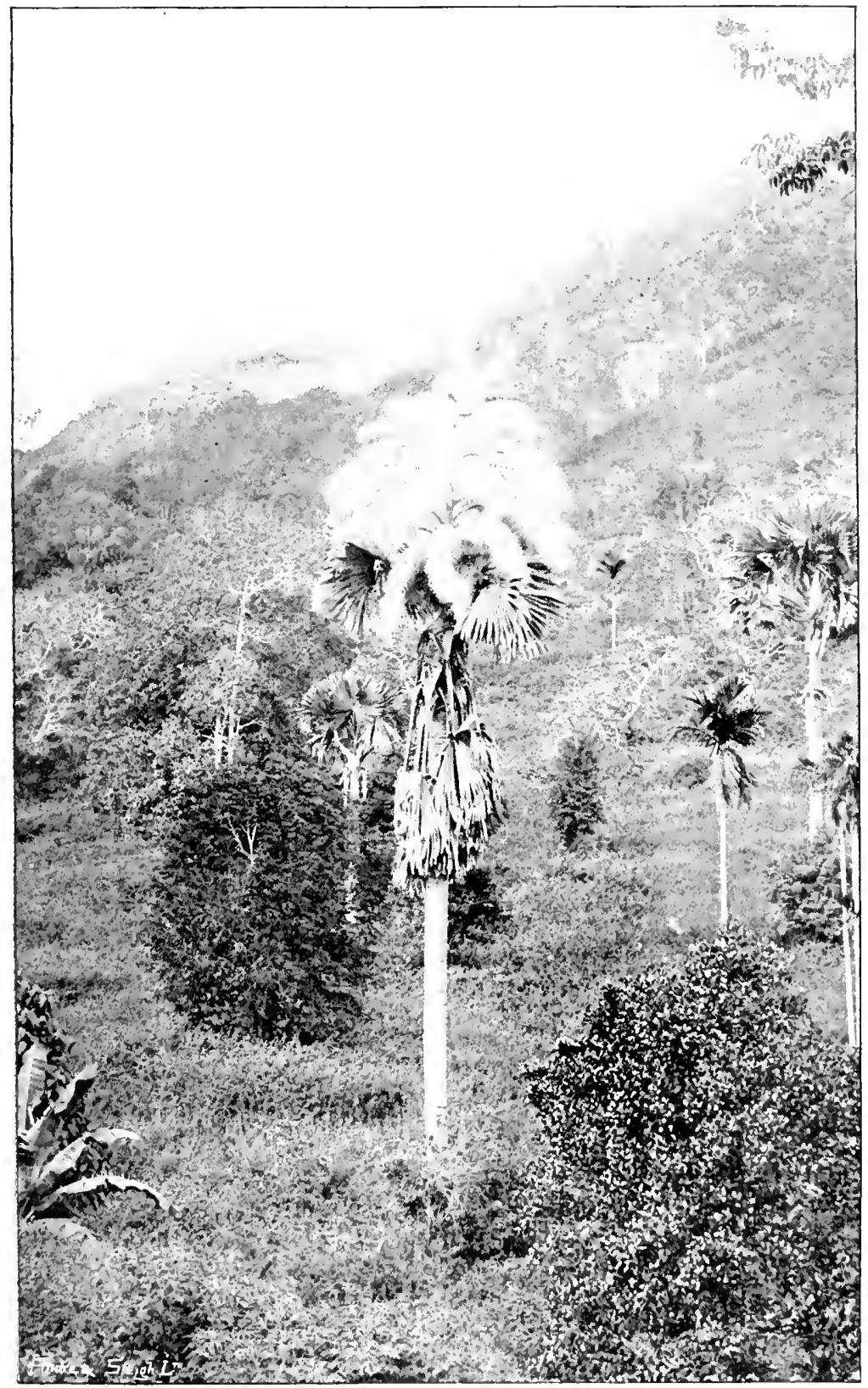



Tree Ferns. Common in the jungles, especially near water courses, at high elevations, and perhaps the most beautiful of all the tree ferms. A fine field of them may lic seen about thee miles from florton Plains Reethouse on the path to Haldhmmulla. (Fige. on p. () ).

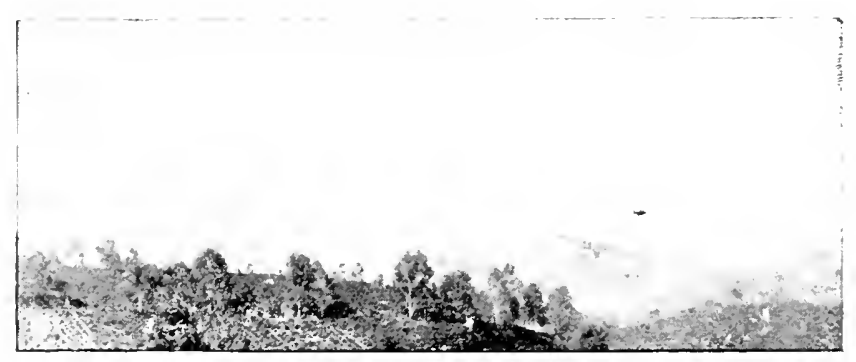




\section{Chapter V.}

\section{THE FORESTS.}

EXCEPT in the dry zone, these are most conspicuous by E their absence, though with the proper conservancy that is now adopted, it is to be hoped that the reckless destruction that characterised former years is at an end.

Previons to the British occupation there were large areas of "ligh" or original forest in Ceylon. There was a belt

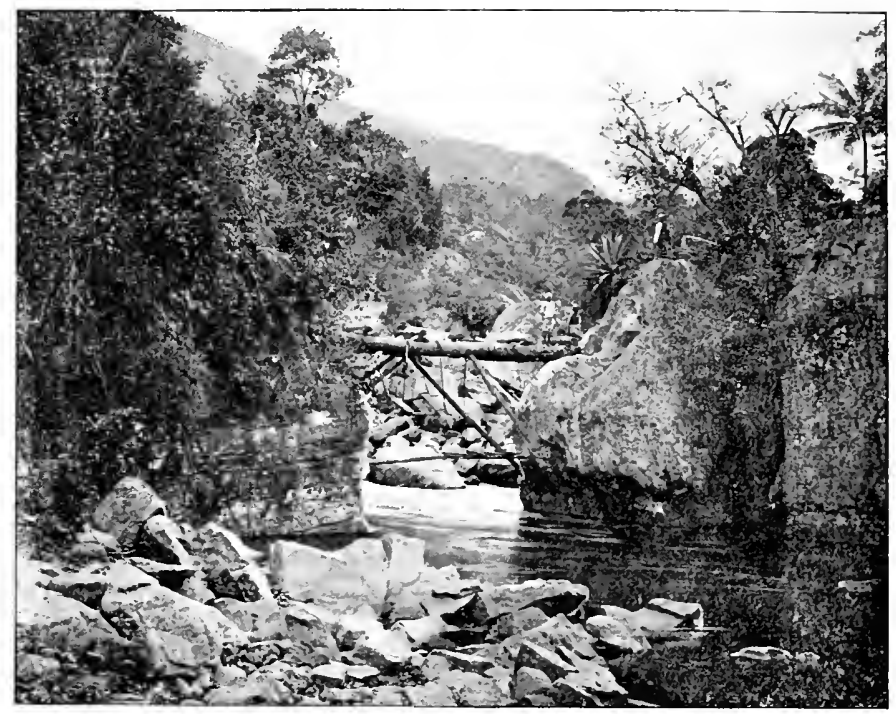

A FOREST BRIDGE.

about 30 miles wide dividing the Kandyan country from the low-country, and this was kept up by the kandyan kings as affording perhaps the best means of defence of their country against invaders. Until about 1830 or 1840 the population was ton small to make the terrible inroads upon the forest that it has since made, by the agency of chena cultivation (p. 37). It is true that in early times the dry country to 

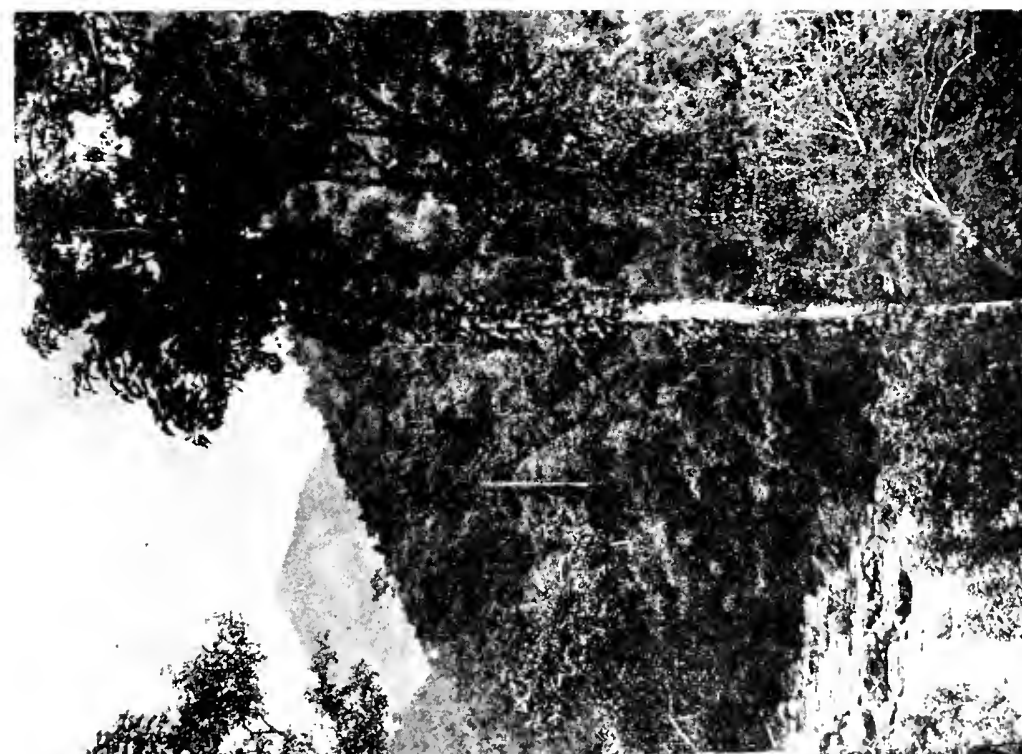

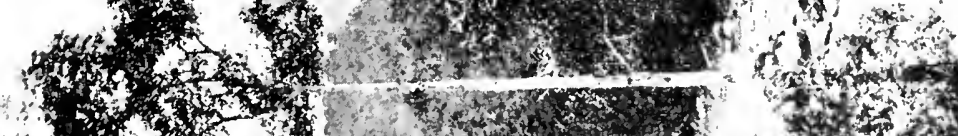
r. 1.

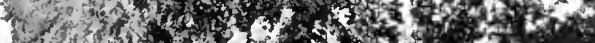

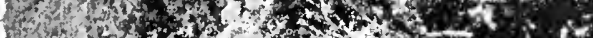

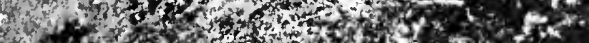

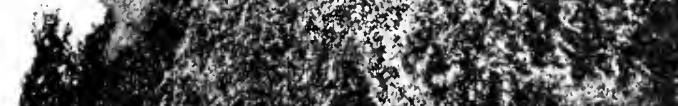

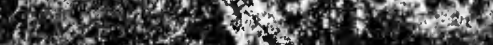



the north and east was comparatively thickly populated, but there must have been some patches of forest, at any rate, for the country after its abandonment became once again covered with a thick and raricd forest, which would not have been possible luad all the original forest been cleared.

At about the same period, say 1830 , the two principal causes of the great clearance of the forests began to be conspicuously operative, viz. coffee planting and chena cultivation. The former was responsible for enormous clearances in the hills up to about 5000 feet, while the latter cleared hundreds and even thousands of square miles both in the low-country and the luils. During the coffee period, up to about is 80 , these two agencies had practically cleared away all forest growth from 1000 to 5000 feet, and at about that time tea and cinchona began to come in proving to be cultivable at even higher elevations than coffee. Ilad it not been for the action of Sir Joseph Hooker, at that time Directorof Kew Gardens, it is by no means unlikely that Ceylon would have been cleared to the smmmits of its highest mountains, but about 1875 an arrangement was sanctioned by the Secretary of State, according to which mo land was to be sold above

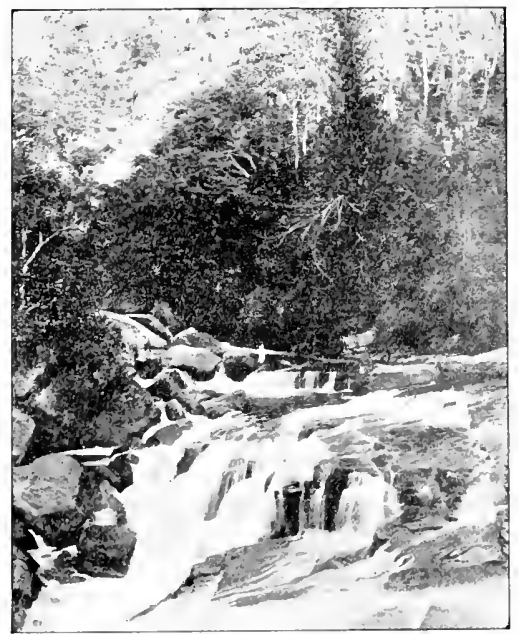

A STREAM IN THE FOREST. the limit of 5000 feet, and this has since been rigidly adhered to, except as regards the sale of building lots in Nuwara Eliya sc., resulting in the preservation of some 90,000 acres of original forest at high levels,and the retaining of the very beautiful natural features of the combtry, whels, when once lost, can never be regained, for the regetation of Anstralian trees in no way replaces the much more sraceful and prettily colomed trees of the natural forest, to say nothing of the losis of most of the interesting undererowtl.

Up to this period there had been no proper conservancy of the forests, and timber was sold to anyone who liked to take out a permit, the result being the loss to the Govermment of a valuable source of revenue, for the taker of a permit 
matmally got all the timber that he could without paying any more rovalty than he could help. In $1892 \mathrm{M}$. Vincent was burowed firom the Forest l)epartment of lndia to report up m the forests of Cevlon, and he drew up a very valuable rep nt, in which he pointed out that the abuse of the permit sistem, together with mme-tricted chena, and reckless clearing of the mountains for coffec, tea, and cinchona, had already resulted in the losis to the island of nearly all its valuable forests, for even in the comparatively small areas left in miginal forest most of the valuable trees had been removed by permit holders and other thiceses. Chena he stigmatiscd and rightly, $a=t h c \quad w a r i t$ offender, for thousands of square miles of what had once been good forest weresimply covered with the uscless serub that fillowis chena.

Conservancy wis obvinusly an wrent necesity. I Forest Ordihithee mas pascied in 1855 , for the purpose of bringins matters into better trim, and in 1887 a definite lorest Department was formed, abuut ,30yearstoo late, it istrue, but

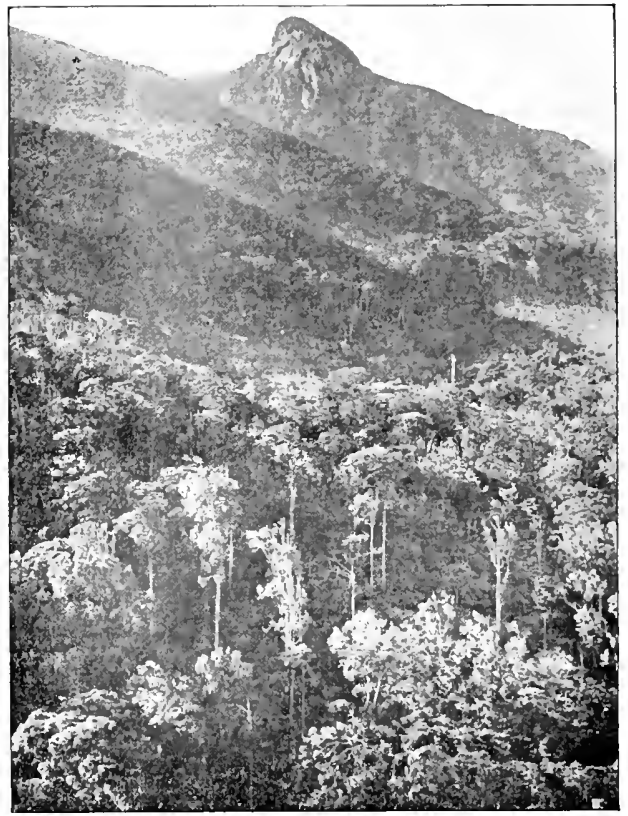

MOUNTAIN FOREST. mome the less in time to save the last werke of what were once the fine natmal foreste of cerlon. Ender this department a large area of forest comntry has been proclamed "reserve forest" asd protected form the elepelation of chena cultivators, timber and fireworl supply has been taken in hand, and of late the railway hat been iupplied with large quantitice of sleepers. The department has met with a good deal of friction in its workins, owing to the kind of dual control - by the chief Conservator, and by the Goremment Agents that has had 


\section{PLATE XXIII.}

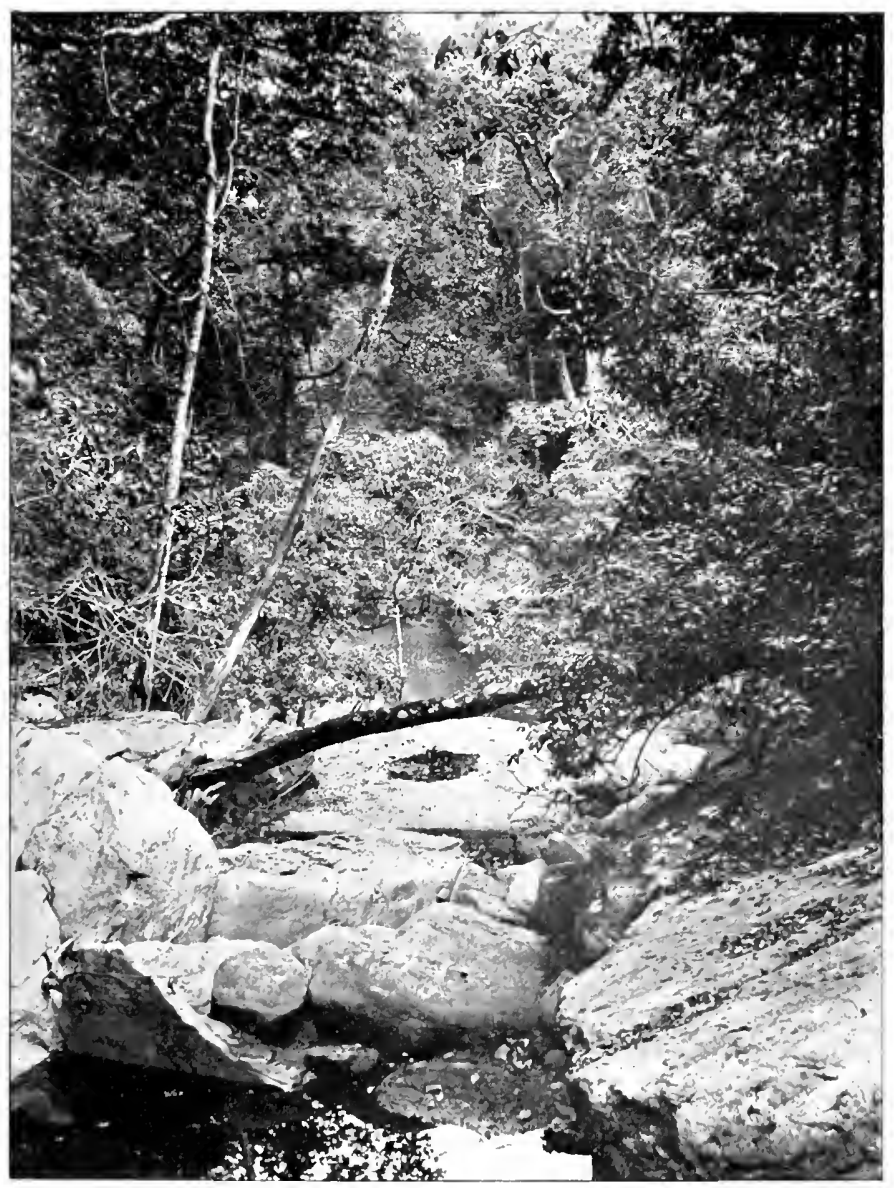

A FOREST GLEN. 

to be excreined, but at la-t a gend workins arrangement appears to hase been amived at, and it maly le hoped that matters will work smosthly and well in the future. The

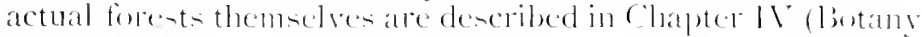
sc., P. 3i). 


\section{Chapter VI.}

\section{IRRIGATION.}

$\mathrm{T}^{\mathrm{T}}$

IE casual traveller in the wet southwestern districts of Cevlon would hardly think that irrigation was necessary, but rice is the national crop and must in any case be irrigated, while in the dry zones (see Chap. II) irrigation is almost a necesity for any crop unless one only grown in the rainy season.

The whole of the morth and east, which were first settled and cultivated, is strewn with irrigation works the ruins of ancient tanks or reservoirs-on a larger seale than anything recently constructed or restored. Thessistem adopted in very early times for the first tank was constructed in 50.4 B.C.was to comstruet carthen bunds or dams across the beds of the streams to hold up and retain a portion of the flow during the wet season, allowing the surplus to run over a spill or maste meir, constructed of masmm. This suplus was usually conducted into other tanks lower down the vallev, so that no water was wasted. From the tank, on either side, sluices fed the water channels which ran along the sides of the valley at a much flatter slope than the rirer ruming down the centre of the valler, and thus a continually widening area of land was obtained for irrigation, the waste water passing into the river in the middle, and being causht in the next tank together with the overtlow from the first one. Ls it flowed downwards this water was very commomly diverted by dams, and taken to water some of the lower lying lands.

From many of the larser tanks, e.s. Kalawewa, the streams were of great size, and as they flowed along the sides of the main valley, they crossed the licads of muncrous minor valleys, and some of their water was if necessary diverted to fill smaller tanks in these valless. This system mav be seen in operation at the present day along the Jodi-ela, the great canal that leaves the north side of halawewa tank.

The bunds being made of earthwork could not of course be readily put across permanent streams of any magnitude, and Cevion contains but few irrigation works of this kind, though there are a few ruined ones. 
In this way a perfect system of irrigation was formed, and at one time almost the whole of northern and eastern Ceylon was covered with hundreds, cren thousands, of tanks, feeding the paddy fields beneath them.

With the Tamil invasions these went, whether slowly or rapidly we do not know, into distepair. The ancient spills are very narrow, and it is quite possible that they were too narrow to carry off all the water during heary rains, without

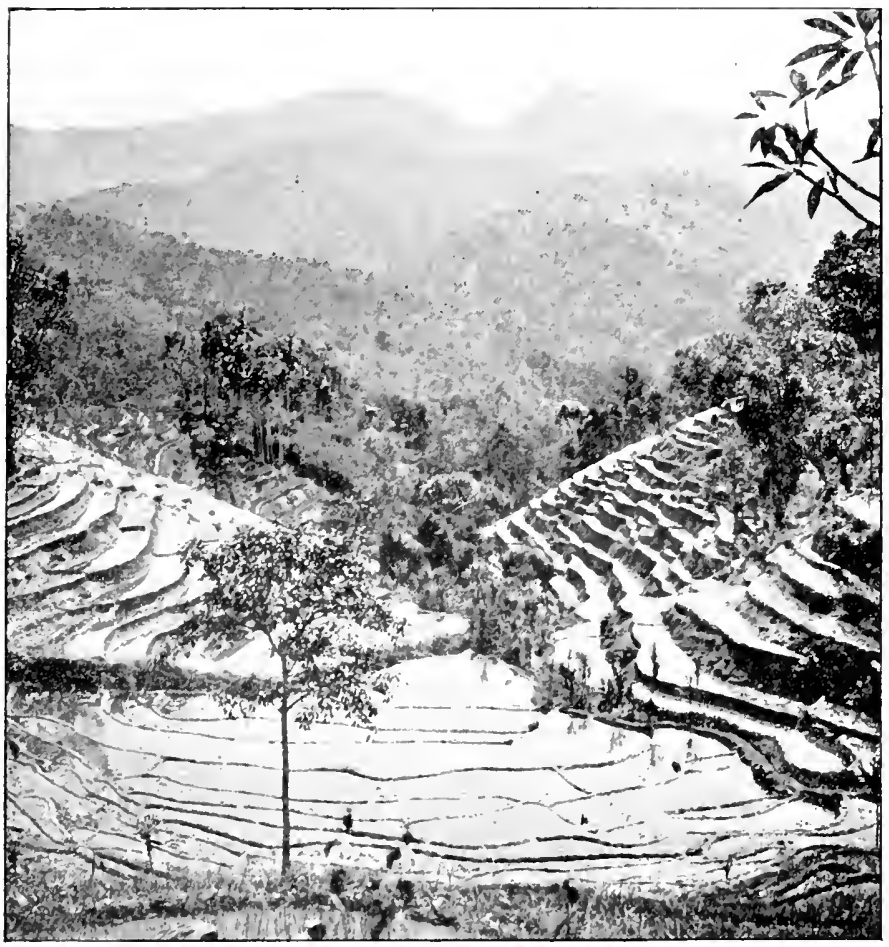

\section{RICE FIELDS NEAR KANDY.}

assistane from the areat side canals which like the Vodi-ela carried water to minot tanks. If this was so, of combe ats

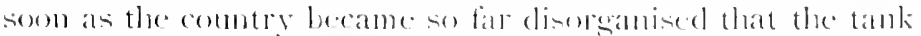
guardians left theje pones, the uppere tanks womlet fill and burst, and the rosto of water thes sent dewn the valley would bur:t those belose.

Only in comparatively recent times lias any attempt lecom made to restore some of the tanks to the ir ancient usefulness. 
and a ret most of this once populous country lies under a thick envering of forest, and is ecidedly malarions and molealthy. The first lane tank to be restored was Kanthalai near Trincomalee, in 1860 . Thowgh the heasl of water held up is only 25 feet, while in ancient times it was 50 feet, the tank now waters large tracts of fertile land. Other large tanks have been restored in the Trincomalee, Batticaloa, and llambantota districts. In r 896 Ralawewa in the North Central l'rovine was restored, and a masonry spill built of 600 feet long. The area of water is 4.425 acres, and the head depth at the sluice 22 feet. Other large tankis are the Giant's Tank near Mannar (4,425 acres), Minneriya, one of the most beautiful slueets of water that can be imagincel (4,500 acres), Nuwara IVewa near Anuradhapural (2,000 acres) and Nachchiyaduwa near Anuradlipura $(3,020$ acres. $)$

Irrigation is of course extensively pursued in the wet southero country but on a comparatively small scale, though clas, or irrigation streams, are carred for rery long distances over sery rough mountain country to bring the water of the purmanent mountain streams dowis to the paddy fields. Some particulary good examples of such work call be seen in the Uva plateau comtry between I lakgala and Badulla. 


\section{PART II.-HISTORY, PEOPLE, ARCHAEOLOGY, \&c.}

\section{Chapter VII.}

\section{HISTORY.}

U

NLIKE many oriental countries, of which there is little or no written history, Ceylon possesses a long historic epic poem, the Mahawansa, written in Pali, the sacred language of the Buddhist priests, and there are also other historical poems and documents.

The Mahawansa, being more or less figurative, was difficult to understand until about i 826 Turnour found the key to it in the rumning commentary or tika, which contains a literal version, and supplies many illustrations. Written by different authors at different times, the great prem covers the period from about 543 P. c. to 1758 A. I. or almost the entire history of native rule in Ceylon, and by its means one can trace dynasties with over ifo kings, beginning with Wijara, the first Sinhalese monareh; though it must be admitted that the record of their deinges is in seneral both dull and uninteresting.

It is probable that the earliest inluabitants of the island of whom we have any knowledge were the ancestors of the present Veddahs a small tribe of huntsmen with the bow and arrow still surviving in some of the eastern jungles. The brother Sarasin laving recently found palaeolithic stone implements buried in some of their caves, it would secm probable that these men must have been in the istand for a vast length of time. The carly inhalitants found here by the Sinhalese were called by their confunerors the Vakkhas or I emons, and the Naigas of Suakes, and their method of barter seems to have resembled that of the Vedelahs of the present day.

The Sinhalese period begins with the more or less fabulous landing of Wijaya about $543 \mathrm{Br}$., with a small troop of followers, but it is probable that this was antedated to synchronise with the "parinibbana" of lunddha. The current legend in Ceylon is that he came from Bengal, and this is 
supported by the similarity of the Sinhalese and Bengali languages, but fairly good evidence is also being brought forward to show that he came from the Bombay side of India, and of course the Indian populations themselves have moved about a good deal in the course of time. The Sinhalese language on the whole is an Aryan tongue, whereas the Tamil and Malayalam languages of South India are Dravidian. It would seem probable therefore, that the Sinhalese at any rate came from a considerable distance.

Where they landed is also in some doubt, but fairly good cridence can be brought forward to show that it was near Puttalam on the northwest coast. The later Sinhalese kings (even the last king of Kandy made the attempt) used to tie on a royal sword at Puttalam. Wijaya, the leader of the Sinhalese, married a daughter of one of the local chiefs, and with her aid mastered the island. Later on he deserted her for a 'Tambl princess of southern India. He seattered his followers over a large part of the island and started agriculture here, while several of his adherents also formed petty kingdoms.

A little later Cerlon was divided into three divisions usually employed in the native histories, viz. the Ruhunu Rata from 'Trincomalie to Kalutara south of the Malnaweli and Kalugangas and below the mountains; the Maya Rata from the Kaluganga to the Deduru-Oya near Chilaw, and including the mountains; and the Raja Rata, the remainder of the island to the north. In those days the Raja Rata was by far the most important, whereas nowadays the bulk of the population and agriculture is in the Maya Rata.

The patriarchal village system which still exists in most of the island was also introduced about the same time. In the greater part of Ceylon a village is less a little street of houses than a division of comntry, under a headman who is responsible to higher officials. It corresponds more to an English parish.

About 504 13. C. the successor of Wijaya opened the first tank or irrigation-lake near Anuradhapura, and from that time onwards the construction of these tanks, and the consequent opening up of more and more country for the cultivation of rice was an object of great solicitude to the more capable lings.

At the beginning of the third century 13. C. Ceylon was converted to Buddhism by the preaching of Mahinda, the son of the great Buddhist emperor Asoka, who reached the island in 307 , being fabled to lave descended upon Mihintale. In $2 S S$ B. C. a branch of the sacred bo-tree of North lndia, under which Gautama Buddha had attained his Buddha-lood, was 
brought with great pomp to Anuradhapura, and there planted; it survives to this day, and is almost the oldest tree of which we have any listorical record, though by no means the oldest tree in existence.

Soon after this the erection of dagobas began all over the island. These are the curious bell-shaped solid constructions, surmounted by a kind of spike, which may be seen near every temple. There is a very good specimen almost opposite to the temple of the tooth at Kandy. Each dagoba was supposed to contain a relic of Buddha or something of the sort. Monasteries were also erected in great numbers for the very numerous people who preferred the monli's life of meditation and alms-seeking to a productive life of industry.

The history of ancient Ceylon is largely a history of Malabar or Tamil invasions, conquests, and usurpations, and these began about 237 B. C., in which year two youths of position in the cavalry and the navy revolted, and conquered the island by aid of the Tamil mercenaries already employed in large numbers by the unwarlike Sinhalese kings. They remained in power for more than 20 years, and then followed a short period of Sinhalese monarchy, ended by the accession of Elata, a Tanjore Tamil who administered the country with great success and impartial justice.

Elala after a reign of 40 years was defeated and slain by Dutugemunu, one of the great Sinhalese heroes of Ceylon. So struck was he with Elala's bravery that he erected a monument to him on the spot where he fell and for centuries passers by in vehicles used to alight and walk past this.

Eager to display his zeal for the ancient religion Dutugemunu built the Ruwanweli Dagoba at Anuradhapura, still one of the great places of pilgrimage. He also built the great monastery known as the Brazen Palace (from being roofed with brass). It was nine stories high and splendidly ormamented within and without. At present nothing remains of it but a forest of stone pillars, $\mathrm{r}, 600$ in number.

After the death of Dutugemumu there is very little of interest in the history but Malabar or Tamil invasions, and the construction of tanks. The latter went on for centuries, especially under Buddhist influence. The number of priests became so great that the kings could not support them with food, and took to giving them grants of land, often or usually in waste districts where as a rule they also made a tank to water them. Thus Minneriya, one of the largest and finest tanks in Ceylon, was built for and conferred upon the Jetawanarama Dagoba at Anuradhapura.

The enormous work of building the great bunds to hold up the waters of these tanks was largely performed by forced 
labour, the Yakklias or aborigines being compelled to work at bund building, brick making for dagobas and other things. The process of amalgamation between this race and the Sinhalese was slow and imperfect, and it is probable that in the Veddalss and low caste Sinhalese of to-day we may still see some of their descendants.

After about 300 or $400 \mathrm{~A}$. D. intercourse began with China, the sister Buddhist country, and to the works of Chinese historians we are indebted for a good deal of confirmatory knowledge of Ceylon in its early days.

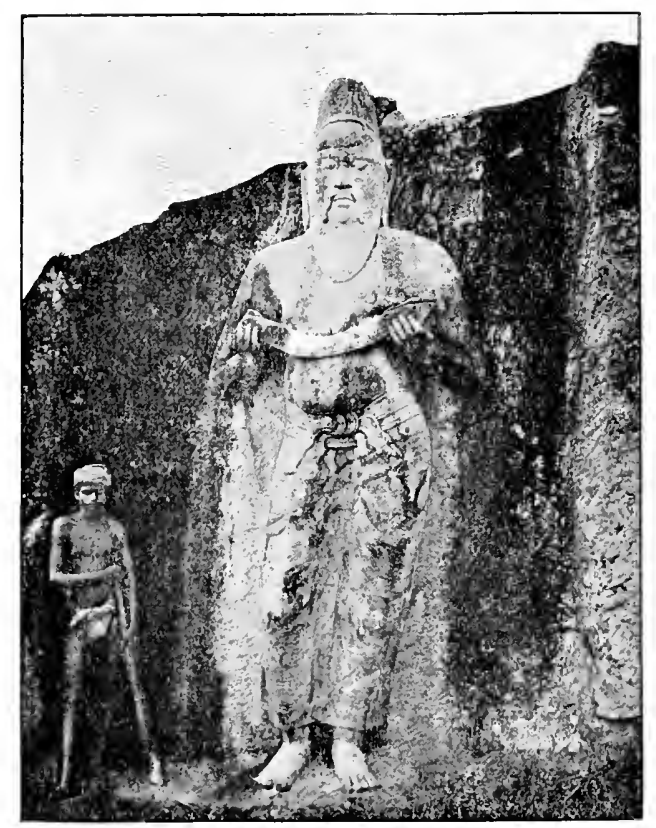

STATUE OF PARAKRAMA BAHU.

In A. D. 459 the King Dhatu Sen was murdered by his son, who seized the throne and called himself Kasyapa the first. Ilis brother whom he also attempted to murder escaped to lndia. Kasyapa was driven from the capital by the indignation of his subjects and seized upon and fortified the wonderful isolated rock of Sigiri where he was comparatively safe from aggression. His crimes, however, weighed upon him, and he endeavoured to atone for them by building 


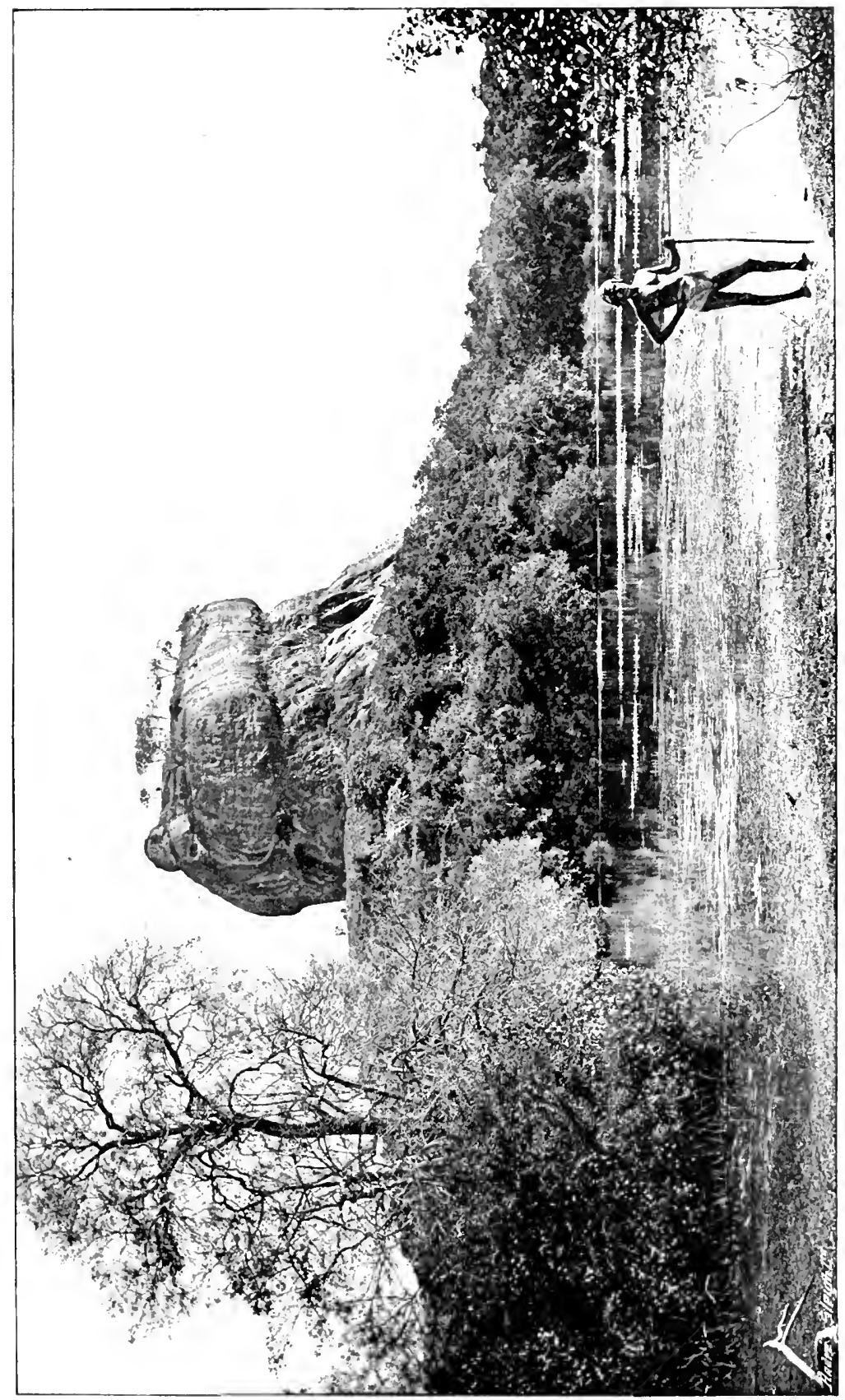



monasteries and in other ways. After i 8 years he was slain in battle by his brother who had returned from India.

At this time the invasions of the restless and more warlike Malabars (chictly lamils) became more fiequent, and every now and then Ceylon was subject to the rule of a foreign usurper. By 700 A. D the invaders had to a large extent got control of the north of the island and in 769 Polonnaruwa, Jying much further to the south and east than Anuradhapura, was made the capital, but in 1023 a Malabar ruler established himself even there and ruled for 30 years.

In ro7r there arose a dynasty which for a time rescued Ceylon from foreign invaders and conferred a new glory upon her history. The first of these was Wijaya Bahu who was succeeded by Parakrama Bahu, the greatest name in the long line of kings, and of whom a fine statue can still be seen near Polonnaruwa. He was crowned sole king of Lanka in 1 I 55. The island being rendered tranquil, he devoted himself to the restoration and construction of great irrigation works and of religious monasteries. Later on he ventured abroad, a thing rarely done by the Sinhalese, and raided Cambodia and the Tamil kingdoms of the mainland of India.

Within 30 years of Parakrama Bahu's death the kingdom had so far deteriorated that the Malabars once more landed and conquered it, obtaining possession of all the north, while the Sinhalese capital was moved further and further south, finally in $1+10$ reaching Kotta, now an eastern suburb of Colombo. The Malabars had their capital with a king at Nallur near Jaffna, and the Jaffina district is to this day almost purely 'Tamil.

About 1408 the island was conquered and Wijaya Bahu V'I deported by the Chinese in revenge for an insult to one of their Ambassadors, and for 30 years paid tribute to China.

In 1505 the first l'ortuguese appeared in Ceylon, and 12 years later the Viceroy of Goa ordered a Fort to be erected at Colombo. At this period the trade of the Indian Ocean was mainly in the hands of the so-called Noors or Moormen of Western India and Ceylon, but it was soon diverted, after the arrival of the Portuguese, to the route round the Cape of Good Hope.

The history of the 150 years of the Portuguese occupation of Ceylon is one with comparatively few redecming features. War, trade and religion were the three main features in it: They were continually fighting with the kings of kandy and the other minor kingdoms of Ceyton, to such an extent that the island probably cost them far more than it was wortly. Towards the end of their time they captured Jaffina, and then owned practically the entire coast of Ceylon, but they never 
had 'much control inland. The trade of the island was comparatively small, for as yet agriculture for export purposes wat unknown. Religion was vigorously pushed, the most famous of the misionaries being St. Fancis Xavier.

Ibout 1639 the Dutch began to attack Ceylon and in that year they took Batticaloa and Trincomalee, while in 1656 Colombo surrendered to them atter a long siege, only 73 Portuguese soldiers finally marching out, while of the Dutch only 1,200 remained sut of 8,350 . In 1658 Mannar and Jaffna were captured and the whole coast of the island thus fell into the hands of the loutch.

There is but little to record about the period of I Dutch rule. Unlike their predecessors, who resented every supprsed attack upon their dignitr, and were constantly fighting, ther rather devoted their attention to trade, and tended to be as subservient to the kings of Kandy as the English in Bengal once were to the Great Moguls.

In 1753 , Kirtti-sri, King of Kandy, restored the Opasampadawa or suecession of Buddhist priests by bringing ordained priests from Siam. A large number of the temples in the Kandyan provinces were built or restored by him.

In August - September I 795 English forces took Trincomalee and Jaffna, and in February 1796 Colombo surrendered witlout a blow.

As to the work of the two nationalities that preceded the British we camnot do better than quote Sir Emerson Tennent "The dominion of the Netherlands in Ceylon was nearly equal in duration with that of Portugal, about one hundred and forty years: but the policies of the two countries have left a very different impress on the character and institutions of the people amongst whom they lived. The most important bequest left by the utilitarian genius of Holland is the code of Roman-1)utch law, which still prevails in the supreme courts of justice, whilst the fanatical propagandism of the Portuguese has reared for itself a monument in the abiding and expanding intluence of the Roman Catholic faith. This flourishes in every hamlet and provinee where it was implanted by the Franciscans, whilst the doctrines of the reformed church of Holland, never preached beyond the walls of the fortresses, are already almost forgotten throughont the island, with the exception of an expiring community at Colombo. Already the language of the 1)utch, which they sought to extend by penal enactments, has ceased to be spoken even by their direct descendants, whilst a corrupted Portuguese is to the present day the vernacular of the lower classes in every town of importance. As the practical and sordid government of the Netherlands only recognised the interest of the native 
population in so far as they were essential to uphold their trading monopolies, their memory was recalled by no agreeable associations: whilst the Portuguese, who, in spite of their cruelties, were identified with the people by the bund of a common faith, excited a fecling of admiration by the boldness of their conflicts with the Kandyans, and the chivaluous thoush ineffectual defence of their beleagured fortresses. The butch and their procecdings have almost ceased to be remembered by the lowland Sinhalese: but the chiets of the south and west perpetuate with pride the honorific title bon, accorded to them by their first European conquerors, and still prefix to their ancient patronymics the sonorous Christian names of the Portuguese."

The island laving been taken by the forces of the East India Company was at first governed from Madras and the civilian placed in charge introduced the Madras revenue system with a host of Malabar collectors. This system was so entirely opposed to anything hitherto known in Ceylon, that the result was a rebellion and in 1798 the Colony was placed directly under the British Crown, the Hon. F. North, afterwards Lord Guildford, being the first Governor.

Meanwhile the last king of Kandr, Sri IVikrama Raja Sinha, was exasperating and alienating his subjects by brutality, license, and wastefulness, and at last, after one or two previous conflicts, in s 815 a British Army marched upon and captured Kandy. A rebellion ocemed in $1817-19$, but since that time, with the exception of the socalled Matale rebellion in 18.4 , the Kandran provinces have been peaceful. The construction of a road fiom the coast right through the Kandyan teritory contributed in mo small degree to this.

In I 824 planting by linopeans began for the first time in the East, and 30 years later the momtain province of Kandy was the scene of a large industry in coffece and the island began to be very prosperous. From 1875 to 1885 the coffee industry was almost exterminated by an attacli of discase which proved to be a blessing in disguise, tea, cocoa, cardamoms, rubber and other things being taken up in its place, so that the island has mow a much more varied and general prosperity.

ln isog the first railway was opened to Kandy and extension has gone on ever since, though with no seat speed, until now a sood part of the island is probably more generally prosperous than it has ever previously been, but it must be remembered that a very sreat part of the prosperity is due to the large planting enterpirise kept up by Europeans. 


\section{Chapter VIII.}

\section{THE PEOPLE, THEIR RACES, CUSTOMS, RELIGIONS, \&c.}

$\mathrm{T}^{\mathrm{I}}$

IIS chapter is not intended to be an exhaustive treatise on the subjects with which it deals, but a brjef account of the more prominent and noticeable features, one to appeal to the ordinary resident or tourist, and readers must keep this in mind.

The inhabitants of Ceylon are divided by the census into Europeans, Burghers, Sinhalese (low-country and Kandyan), Tamils, Moormen or Moham medans, Malays, Veddahs, and "others" - a miscellaneous assortment mainly composed of the various races of India, among whom the most prominent are the "Afghan" moneylenders, whose powerful figures, picturesquely but somewhat warmly dressed, are very familiar in Colombo, Kandy, and elsewhere, and the Chetties, who have most of the money

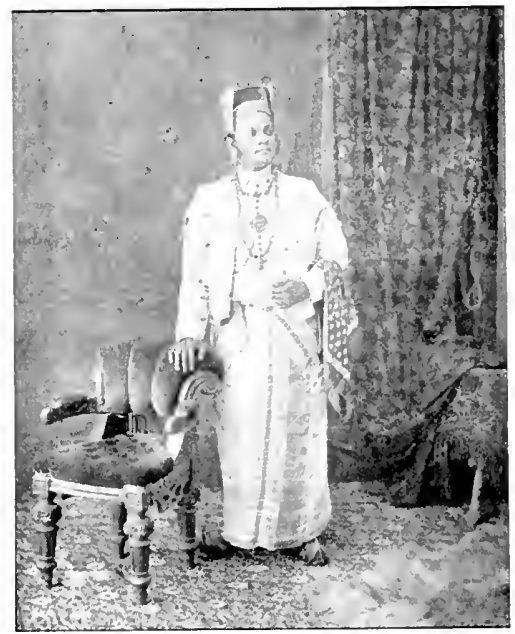

A COLOMBO CHETTY. lending of higher elass in their hands.

Europeans. To deal first with the masters in the island, there are about 7,000 Europeans, nearly all of British nationality, but including a few Germans, French, and others, in Ceylom. The largest part of these consists of the great planting community-perhaps 1,S00 planters, many of whom have families. Then follow the commercial comminity of Colombo and to a less extent other towns, the Govermment servants, a few missionaries, soldiers, and others. Only in Colombo, and 
to some extent in Kandy and towns of similas size is there any appreciable European society. Though the governing race, and the only one in Ceylon with much enterprise or foresight, they do not thoroughly acclimatize to the country, but must be contimully recruited from Europe. With reasonable precautions, and observance of the rules of tropical bygienc, adult Europeans may retain their health here as well as in Europe, but children do not thrive after about the serenth to the tenth rear, and must in general be sent to Europe, muless they cain be kept above 5,000 fect. Even in the latter case their accent, their education, and their morale are liable to suffer.

The greater part of the export-trade agriculture, i.e., the cultivation of tea, rubber, cacao, caldamoms, vanilla, camphor, de., is in Eumopean hands, and secms likely to remain so for a long time yet. The larger commereial businesses, and many of the largest and best shops and stores are also in their. hands, though the native shopkeepers of the Pettah of Colombo, and similar places, are steadily gettims hold of more and more business. The bulk of the superior officers of Government are also Europeans, and in spite of the increasing good education of the native are likely to remain so, for the native is not in general fond of respomsibility, and cocs not readily rise to it.

Burghers. This term, dating foum the dars of the Jutch, is commonly applied in Ceylon to people of mixed European and native descent, in fact as the term Eurasian is used in India, but strictly it applies to descendants of the loutch, some of whom are quite white, and have no native blow in their reins. Unlike their confieres in India, the burshers are in a very powerful position in Ceylom, and have a member in the Legislative Council. In Colombo especially, the Burglers mav almost be divided inter two classes, the ponrer l'ortuguese Burghers, many of whom speak to this clay a dialect of Portuguese, and the richer l )utch burghers, who form a seat community largely filling the posts of clerks in offices, and have been described as the brazen whels of the executive that kcep the golelen lands in motion.

The great line of work adopted by the better-to-do burghers is the practice of ome of the professions of law of medicine, and many of the ablent lawyers, physicians, and surgeons in the island belong to this race.

Sinhalese. The Sinhalese form the hulk of the population of Ceylon, themgh the other races are slightly gaining on them. They are now divided into two sections, the lowcomntry Sinhalese, most of whose men weal the comb in the hair, who have probably mixed a gond real with other races, 
and who inhabit mainly the W'estern and Sonthern, and coast of the North-Western Provinces, and the Kandrans of the purer Sinhalese race, who inhabit the Central, Ura, Sabarasamuwa, North-Central, and part of the North-VVestern Provinces. The name has nothing to do with the English name of the town of Kandy, which is called by the natives Maha-nuwara, the great city, but applics to all the dwellers in the ancient Kandyan kingdom, and practically at this day, with few exceptions, to the dwellers in the hills or "kanda." The Kandyans are a very conservative and feudal race, but of recent vears the more enterplising fow-country men have settled among them to a considerable extent, and have got possesion of much business, and often eren of the ancestral lands of the Kandyans.

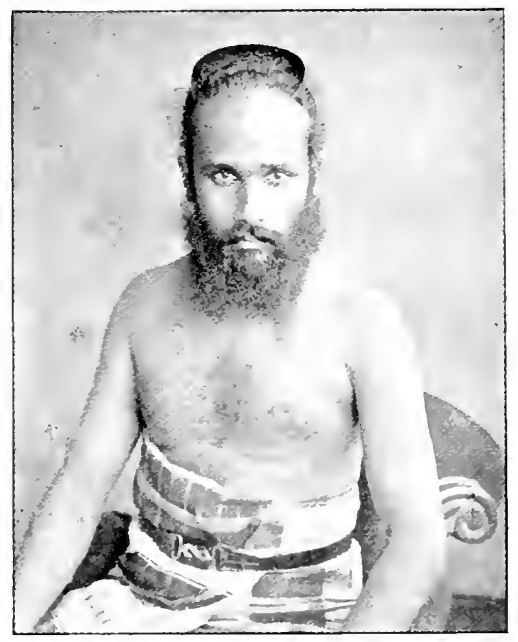

A SINHALESE VILLAGER

Tamils. The Tamils of the island are of two kinds, usually known as Jaffina Tamils and estate coolies, the former only beins real natives of the island. The so-called Jaffina Tamils oceupy the Northern and Eastem Provinces, being especially crowded about Jatina and Batticaloa. They are the descendants of the old concueroms of Ceylom, who mostly came from fairly far noth in Southern India, and display more variety of easte than the coolies, while in plyssique and presence they are lecidedly superior. The sitate coolies, on the other haind, are temporary migranti from the extreme 


\section{PL.ITE INV:}

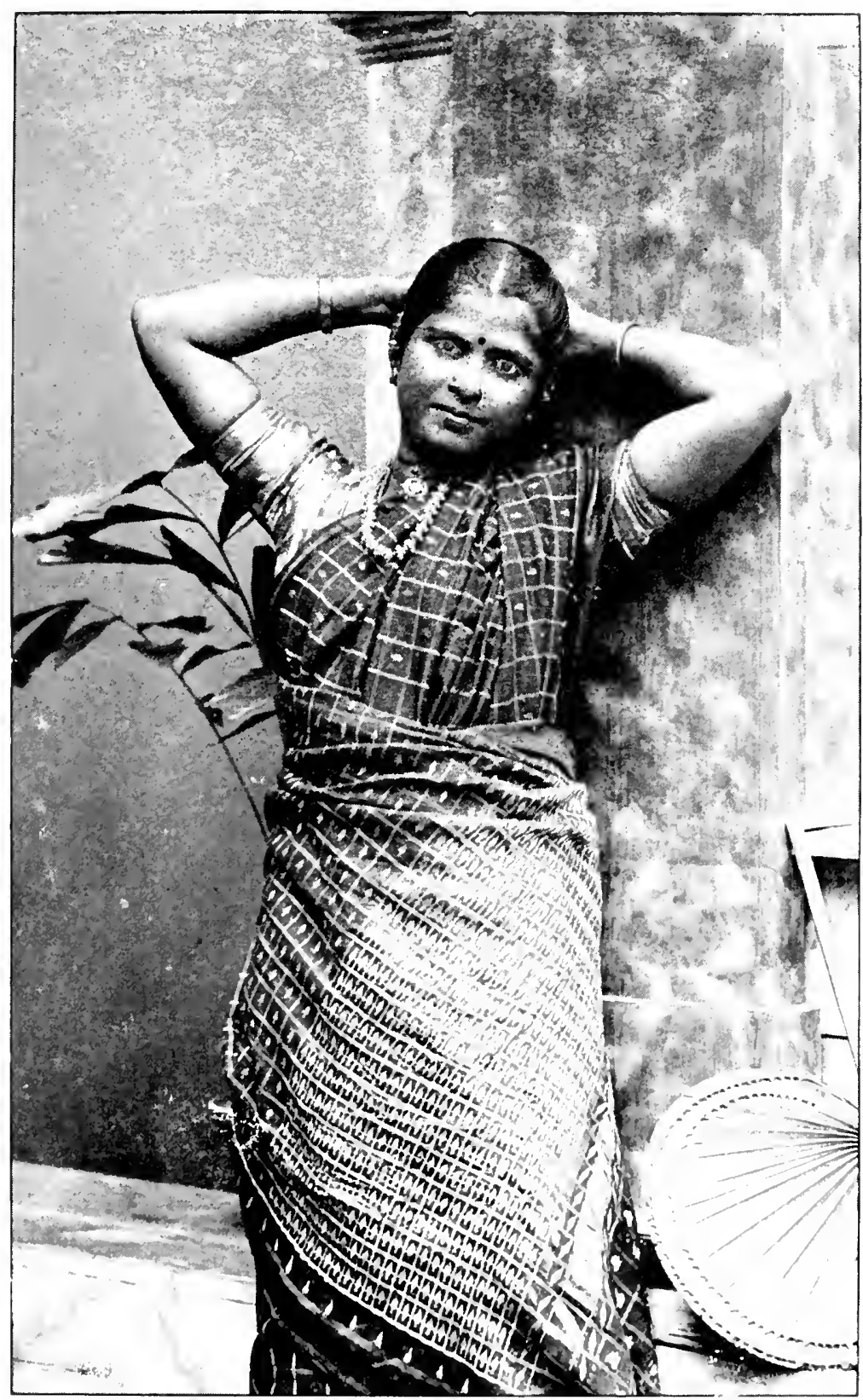

A TOML BE 12 TY'

Photo be Mesws A. H. A. Plate of Co. 

south of India (p. 54), are men of very low caste, usually of rather poor plyssique and presence, and rery dark in colour.

Besides these Sinhalese and Tamils who keep to their own language and costume, there are the Colombo and Galle Chetties of Tamil race who speak Sinhalese by preference, and wear their hair long and fastened in a knot in the Sinhalese fashion, and the nominally Sinhalese fisluer caste people of Negombo, who wear combs, but talk Tamil.

Mohammedans. These men, the Noormen, as they are usually called locally, are supposed to be the descendants of the old Arab traders or conquerors of very early times, who intermarried with Tamil women, and settled along the coasts of India and Ceylon. They usually speak Tamil as their mother tongue, and are men of finer ploysique and presence than most of the natives of Ceylon. Ther are in general, in the Sinhalese districts and in all the towns the traders and small shop keepers, while in the Tamil country, especially about Batticaloa they also go in largely for agriculture. In the interior Kandyandistricts they talk Sinhalese and assimilate more to that race.

Malays. The Malays of Ceylon are very largely the descendants of the old soldiers of the disbanded "Ceylon Rifles" of thirty year's ago, who have settled bere, and are largely employed as hotel servants, watchmen, police, sc., besides having a business

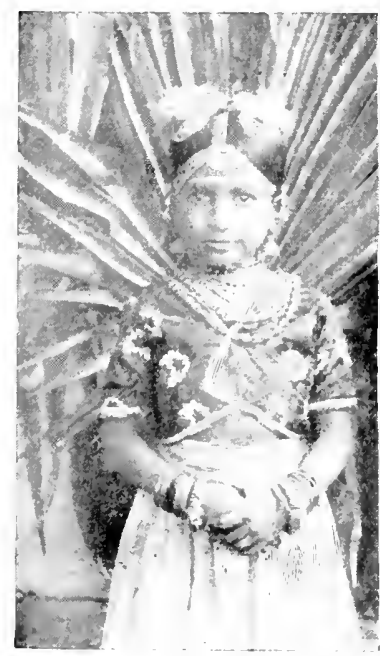

A TAMIL GIRL, EASTERN PROVINCE.

that of working in rattan which they have made expecially their own. They are more courageous men and more anenable to discipline and training than the real natives of Ceylon, and this accomuts for their large employment as policemen and watchmen.

Veddahs. These are a curious savage but hambess race living in the more dense and ont of the way lorests of the Eastern Province. They are but few in number, and are dying out, or intermarrying with their neighbours. The real rock Veddahs, now but a few, live on lunere and on meat of animals slain with the bow and arrow. It has for long been a matter of discussion whether these men represented the real 
aborigines of Ceylon, but the recent discovery by the brothers Sarasin of buried palaenlithic stome implements in some of their cares would seem to set their antiquity beyond doubt.

Clothing. Every stage may be seen in the amount of clothing worn, from the mere rag tied round the middle of the body of a coolie in the low-country, to the interminable yards of muslin wound around his person, and the otherwise complicated costume of a kandyan chief in full dress. In general the dress of the poorer classes, and of the villagers in the low-country, consists simply of the cloth, a petticoat made of a few yards of cotton cloth, fastened round the waist. This is commonly called in Ceylon the comboy, or some-

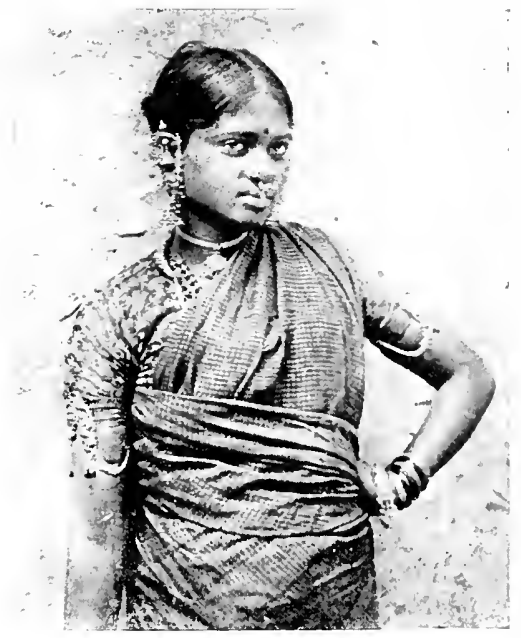

A KANGANI'S WIFE.

itmes sarong (the Malay word), but comboy (kambaya) literally means chintz. "To this is added for low-country women a jacket or bodice with low neek, which as a rule does not reach the cloth by a few inches. Most of the higher caste Kandyan women wear one length of cloth, which is wound round the body below, and one end of which is thrown over one shoulder, and they also sometimes wear a jacket with short sleeves, while the lower caste women wear two cloths, one round the waist, and one oxer the bodr, but many now assume the single clotl. The 'lamil women, at least the coolies, also usualiy wear the single cloth, while the Jaffira women commonly wear a somewhat ungraceful dress, consisting of a cloth fastened round the body higher up. 


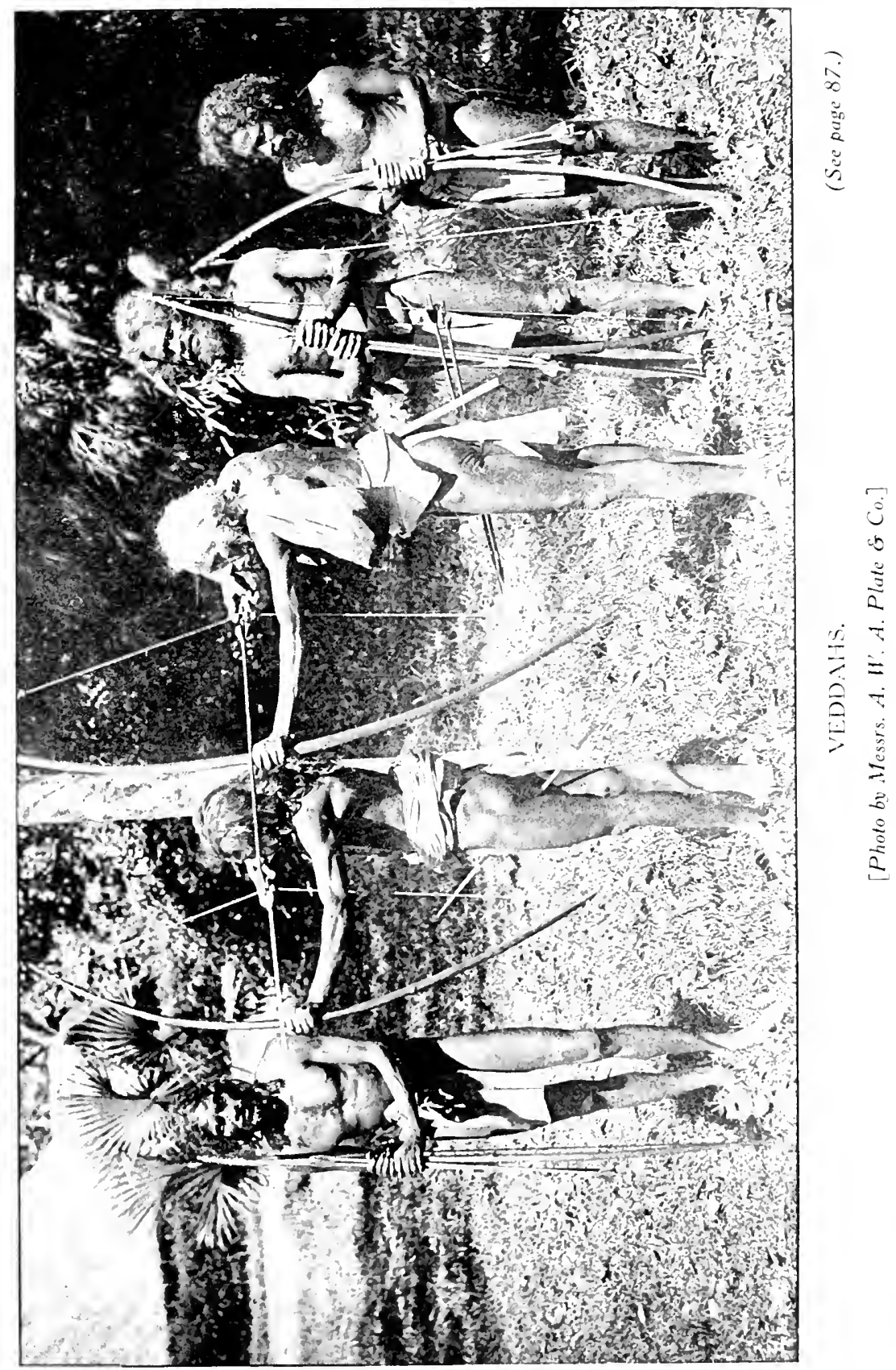



Bungalow servants, and those coming into contact with Europeans or upper class natives, usually add to the cloth, for men, a plain jacket or undervest of European design, made of drill or calico, while clerks and other more anglicised matives commonly wear European clothes, often of khaki or drill at low levels, of flamel at higher.

The great majority of costumes in Ceylon, other than the simple cloth, have been more or less hybridised with European dress, and one can very rarely see real native dress in the country. Even the extraordinary attire of the Kandyan chiefs is partly European, the hat-of a pincushion shape being a form of the biretta or barett cap, one of which was given by a Portuguese captain to a king of Kotta, and the coat being European. The muslin worn round the middle, often making the body into a kind of peg-top slape, and the pantalettes, are rather of native origin, however.

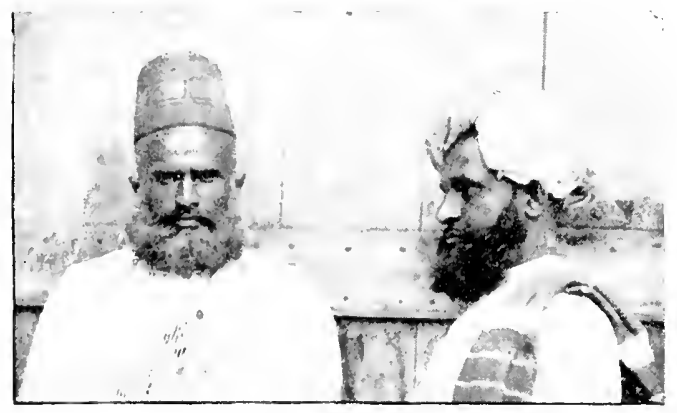

MOORMEN.

The feet are usually bare, though many natives, especially the Moormen, often wear sandals, which are supposed to be left outside on entering the chamber of any one of position, e.s., a European. The more anglicised native of course wear's boots or shoes.

The headdress shows some variety, apart fiom the wearing of hats or topees (sun-lats) by the anglieiserl natives. 'The low-country Sinlalese usually wear simply a comb of tortoiseshell, as nearly borizontal as pessible, but those of the higher ranks, such as Arachehies, Mulandirams, or Mudaliyars, Wear combs more like a lady's comb, standing nearly rertically in the back hair, and larger the higher the rank. The women usually wear no head covering at all.

The ordinary low-country Sinhalese villager wears his hair long, and ties it up in a knot or kondé behind. This is tied 
in a moment and keeps firm though the hair is well oiled, and it might be worth while for the European woman to learn how to tie it. During the heat of the day the natives may often be seen with their hair untied and hanging loose.

The Kandyans wear a cloth or handkerchief round the head, looking very like a turban, and in the higher castes this is supposed to leave the top of the head uncovered.

They part their hair in the middle, and tie it in a knot behind, but do not wear the comb. The headmen and chief men wear a round hat, red or white, or with' a pattern of sold or other colours, on ceremonial occasions. These hats are made by the dhobies, except in the outlying districts where they are not expert.

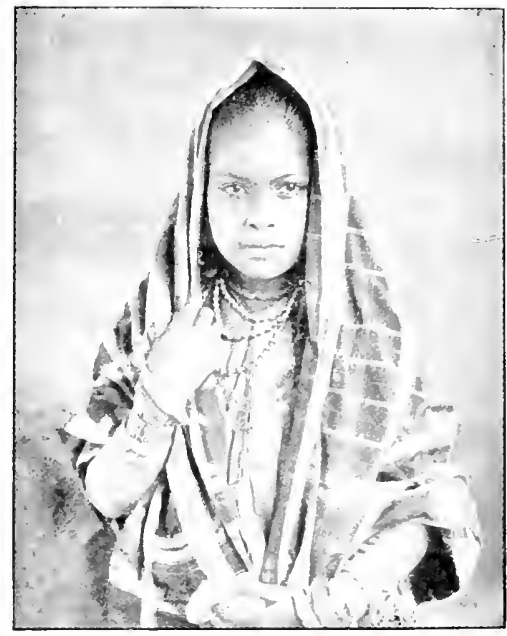

\section{A MALAY GIRL.}

The low-comntry Sinhalese in the interior villages also very generally wear the turban.

The Tamits usually wear a turban which in the case of the coolies is ofter made of a towel or other convenient cloth, but in the case of the Jaffina 'Tamils, especially their headmen and ehief men, is often very elaborate and handsome, with red or gold stripes through it. They commonly wear the hair short, and ofter sluve a portion of their heads, usually the front, entirely, but sometimes they tie the hair in a knot behind.

The loomen usually shave their heads completely, and wear some kind of distinctive lat, usually the "beehive" 


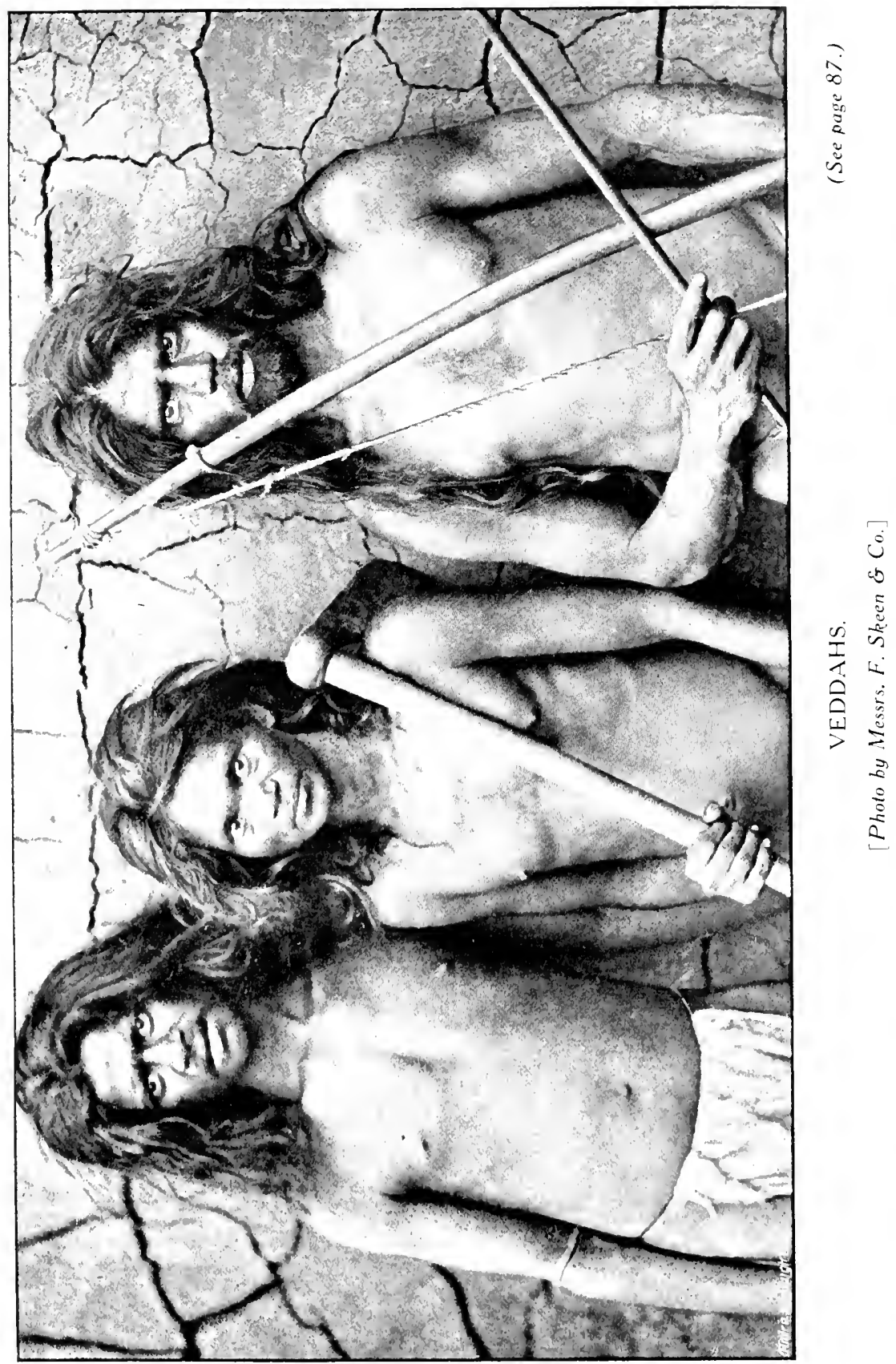



which is made of silk of different colours, woven into various patterns, and costs from Rs. 14 to Rs. 25. These hats come from Calicut in South India, where they are made. Owing to their cost they are specially affected by the well to do men, and many content themselves with a small white cloth cap, of pork pie shape, not much larger than a skull cap, and just large enough to stick on the shaven crown. The younger generation of Monmen, however, affect the fez, and it is to be regretted that this importation seems likely to supersede the silk toppi, which is distinctive of the Ceylon Moormen. The Moormen of Sruth India wear a silk cap made in the same way, but of different shape-not tapering, but of pork pie

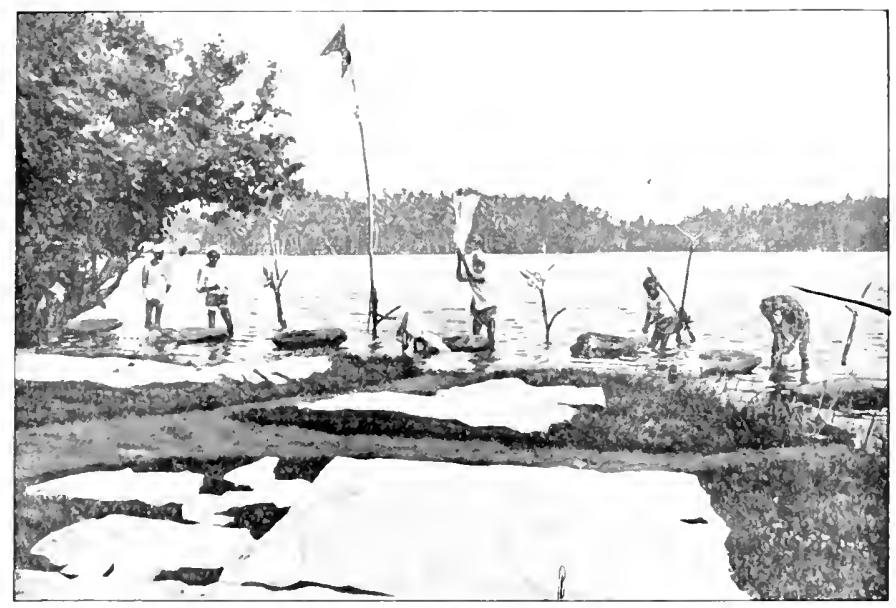

DHOBIES AT WORK.

shape. This hat, though more popular in South ludia, has not established itself among the Ceylon Woormen, who prefer the "beehive."

Clothing in Ceylon is washed by the dhoby or washerman, whose method is simple, but tring to flimsily constructed garments. He wets the clothes, solps them, dips them in the water, and beats them with a drawing motion upon a smonth flat stone. At the same time, it must be made clear that it is the fashion to abuse the dholsy, anel it is really rather cloubtful if he: actually lame elothing of the simpler kinds so mueh as a steam laundry. For line things be is, however, destructive, and usually lacking in the skill to "do them up" at all pioperly. 
Bathing. Cleanliness is next, or even superior, to godliuesi in the view of the native, fortumately, and though he does not, if poor, keep his elothes very clean, he is particular to keep himself well washed. As a general rule lue bathes himself all over once daily, except on Tuesdays and Fridays which are unlucky days, most often at sundown, and in the nearest river or stream, wasling himself down with soap, and pouring water over himself from al chatty, or ducking himself in the water.

Eumpeans rarely care to bathe in the streams, but take their baths in their own bungalows. As a general rule up-country at least the bath is taken "with the chill off," enough warm water being added to remove any chilly sensation, as after a time in Cevlon one begins to fiind it too great a nervous strain to batlie in cold water; and it is often taken before dinner rather than in the morning.

At Negombo, Mt. Lavinia, Ambalangoda, Galle and elsewhere along the coast, excellent bathing is to be had in places safe from sharks, and the water is of such a pleasant temperature that one can stay in for a considerable time without injury. It is not infrequent to risit Galle or Ambalangoda for the express purpose of sea bathing.

Houses. The better class of natives live in several roomed houses, of more or less European pattern, and usually of early Victorian style of fumishing, but the villagers, and the poorer class generally, wecupy one or two rom houses which are practically only sheds closed in at the sides. As a rule they are built of wattle and daub, or mud and wattle (both expressions are used) that is to say of a slight framework of bambon or other wood, filled in with mud, and are roofed with thatch, cadjans (plaited coconut leaves) or' half-cylindrical tiles. The foont is nsually boaleded up at night with planks standing closely against one another, and numbered in arabic numerals to facilitate placing them in order. The average mative is very much afraid of cool air, and likes to shut himself up very closely at night. In the mornings, at kandy or at any higher elevation, he may be seen muffled up in a cloth or shawl to avojed the cold.

The Kandyan house is built romnd a small compound, or rather impluvium like those at Pompeii, with no windows on the outside. In some parts of the north-western, north-central and northern provinces, each house or set of houses is surrounded by a fence, and the whole village, which is compact, $i$ s smrounded by a similar fence, outside of which is the lisbumba or clearing before one reaches the jungte.

The houses being mainly used to sleep in, contain but little fumiture, and life is mainly conducted in public on the 
PLATE XXVHI.

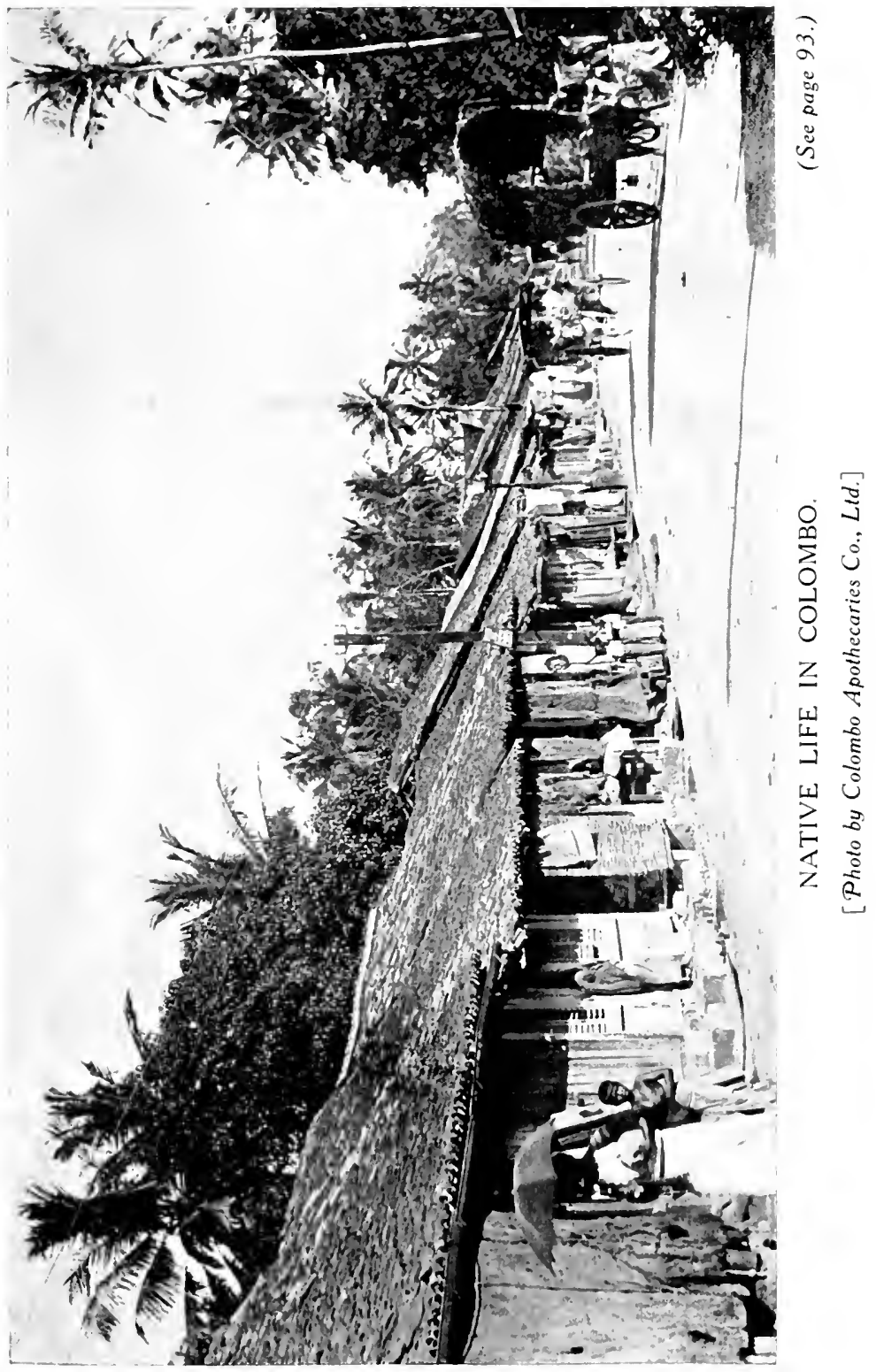



little rerandah in front, where the children may be seen running about, the women of the household pounding rice in a mortar, the man sleeping in peace, and everything else going on.

As the native advances in life, he is naturally anxious, like the white man, to move into better and better houses. Near Ambalangoda, and in other places amusing illustrations of this may be seen. There are so many unfinished houses that one's first impression is that the district must be decaying but in actual fact these are houses begun by better to do people, and left unfinished for want of funds, the native not being very remarkable for foresight.

Furniture in Ceylon is in general poor, and made very largely of unseasoned wood, though there are some pretty pieces of furniture, especially made in Dutch times, to be

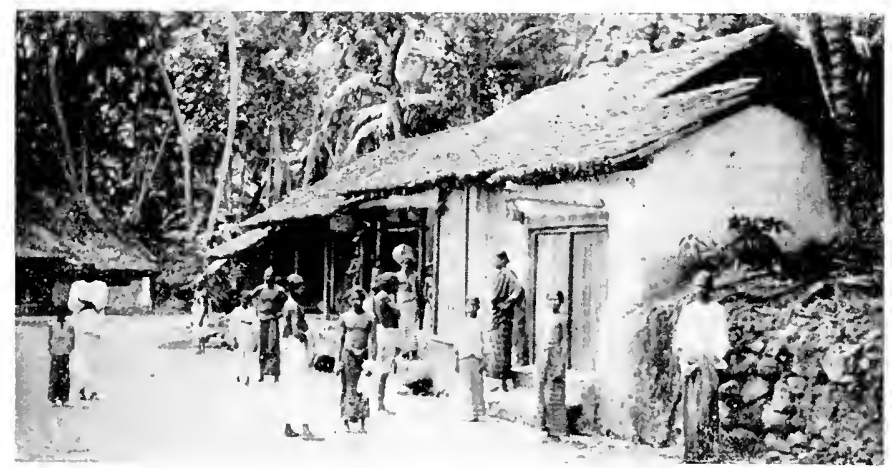

A VILLAGE STREET.

had. Most Europeans move so constantly that they usually sell their furniture at each move, and buy fiesh, and only in a few houses does one see really good and tasteful furniture, well matched.

Food. The great staple of diet of the native of Cerlon is rice, and the common dish rice and curry, thongh other foods and other dishes are common enough. Curry in Europe, being made with dry "curry powder"-the ingredients of curry dried and powdered - has of course but little variety, but in the East this is not so, and a wonderful assortment of dishes can be made by varying the ingredients and their proportions. The commonest of these "curry-stuffs," as they are ealled, are chillies, coriander, garlic, turmeric (locally known as saffion), fenugreek and caraway seeds, green ginger, onions, curry leaves of various kinds (most common that of Mumava Koenigii) limes and coconut. 
The corry unually consists of a dish of regetable curry one of meat cury, and the rice (boiled). To these are usually added small dishes of sambals, which commonly consist of garlic and chillies, surounded by wated coconut, and also, not infiequently, popadams, lasege dry crinkled biscuits supposed to be made of turtle's eggs, pulses or lentil flour, fried in oil.

Poor coolies are often unable to afford good curries and simply eat the boiled rice with salt. Well-to-do people usually demaind two regetable currics with one of meat.

Every kind of meat and regetable is put into cury. One of the commonest ingredients is the umpleasantly odoriferous dried Maldirian fish to be seen in every shop. Europeans who have lived for a long time in the island are often very fond of rice and curry, and if not made too hot with chillies it is a healthy and easily digested dish.

The common drink of the native is of course water, though he also consumes toddy, arrack, and gin, as well as other drinks if he be a little anglicised. He is not particular as to his water, and such refinements as boiling or filtering even the most impure water are unknown to him, or if known, regarded as amiable fads of the European. In country that is in any way hilly, one of the commonest sights is a little stream pouring over the side of the road upon a cut picce of a Pandanus leaf or other leat, under which

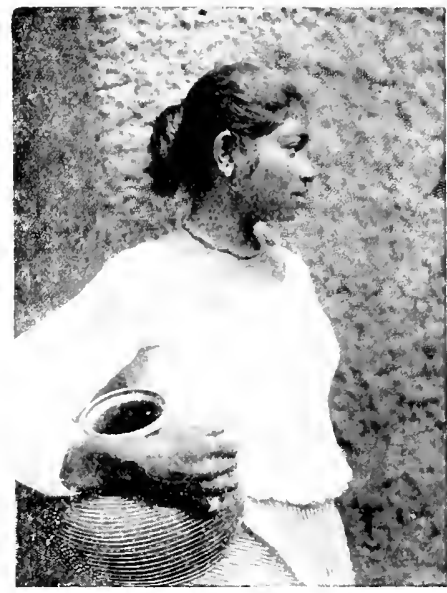

SINHALESE GIRL WITH CHATTY. a bucket, or most often an earthenware pitcher, or chatty as it is locally called, can be placed.

The native is very partial to tea and coffee, and the local sale, especially of tea, is continually increasing.

Europeans in Ceylon live much as in Europe, but rather with French than English hours for meals, the general times up-country being "early tea" about 6.30-7, "breakfast" 11 -12, afternoon tea 4 , dimner $7: 30-8$.

Physique. In this respect the average native of Ceylon is far belnind the Chinaman or the native of nosthern India, though he is in general well developed, and thanks partly to the habit of carrying goods upon his head, of very straight 
carriage. One rarely sees in Ceylon the stunted, undersized specimens of the race that one may see every day in a town in Europe, food and fresl air being in general plentiful and easily attainable in this comtry. Some of the low castes, such as toddy drawers, whose nceupation gives them a bent back, are misshapen, and many low-country Sinhalese are often undersized.

The children here are generally allowed to run naked for some years; they begin rery early on a rice diet, and become very "pot-bellied," but this passes off as they grow older. When quite young their mothers cary them astride upon their hips, with one arm round them. Speaking generally, the children are decidedly pretty, but as they grow to maturity they often lose their good looks. The old women are usually very hag-like in appearance, while the old men, especially those of high easte, are often very handsome, and some of the Kandyan chicfs are among the handsomest men to be seen in the world.

The native of Ceylon is not blessed with any very great physical strength, and cannot cary anything like the load that coolies in Assam or Malaya can manage. About $40-50 \mathrm{lbs}$. is usually as much as he can carry, and the amount must be reduced at high levels, on

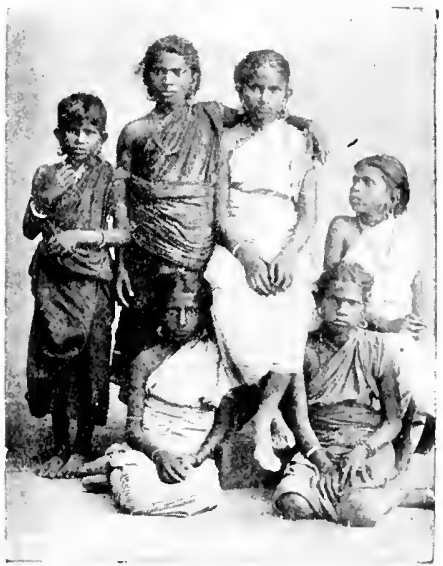

TAMIL COOLY CHILDREN account of the diminished capacity for exertion in the rarefied air.

The native is unusually flexible in his person, and it is surprising to see the attitudes in which an ordinary cooly can work with comfort. A common thing is to see then weeding with their backs actually hollowed and their legs straight, an attitude that no white man could maintain. It light exertions such as walking, the native is musually good, and even a woman will walk long distances without any apporent fatigne. The ordinary native will walk the white man dow'il.

Names. The name of the average native, and that the more the higher his position, is rather a monthful for the European. Totake a few at random fiom the Covon directory, 
we have, as common Sinhalese surnames (really patabendi names, used as surnames in imitation of the European eustom), Amarasekara, Bandaranayaka, Dharmaratna, Gunasekara, Gunawardana, Jayatilaka, Karunaratıa, Rajapaksa, Seneviratne, \&c. These, especially if the man be of high caste, are prefixed by numerous others, often equally long, so that the whole name becomes somewhat formidable. But, on looking through the directory, one soon notices that the most common names are Portuguese, c.g. de Alwis, de Livera, de Silva, Perera, sc., and that there are several common Dutch names also, e.g. Bartholomeusz or de Hoedt. In the latter case, the names are generally those of Burgher families, but this is by no means the case with the Portuguese names, which are very commonly borne by pure Sinhalese. They were taken in the time of the Portuguese, and sometimes indicate a trace of mixed blood, sometimes the taking of a European name at baptism or its purchase with the title of "Don;" and not uncommonly they have been taken simply from a desire to rise in the world by appearing of higher rank or easte than that in which one was born.

In the Kandyan districts there may be village names, e.g. Nugawela, used by the chicfs, much as by Scoteh lairds, patabendi names, e.s. Chandrasekara, given by the kings, gedara names, e.gr. Thalagedara, and personal names, $\ell . g$. Punchirala or Kaluwa. The first two are not borne by low castes, or only rarely.

The Tamils and Mohammedans have also, long names: in the case of the former, the 'sumame' comes first, $e . g$. Arunasalam Vyremuttu is Vyremuttu son of Arunasalam.

Caste. The common impression, fostered by many things, and especially by the conversation of the ordinary clerk or similar person, is that caste is dying out in Ceylon, but in actual fact this is by no means the case, though it was never so strong among the Buddhists (where it is social) as the 1 lindus (where it is religious). Only among the Mohammedans is there no caste, and this perhaps accounts, in India and Ceylon, for the readiness with which the religion makes converts, for the new believer becomes a member of a powerful body which all stands together like one caste.

There are a large number of castes among both the Sinhalese and the Tamils, though in actual practice the bulk of the Tamils one meets, i.e. the estate coolies, are of the very lowest eastes. Beyond the fact that meat can only be carried by a low caste cooly, that certain servants will not do certain duties, and in a few other ways, the existence of caste rarely affects the risitor or resident in Ceylon, and we need not therefore go into the question. 
PLATE XXIX.

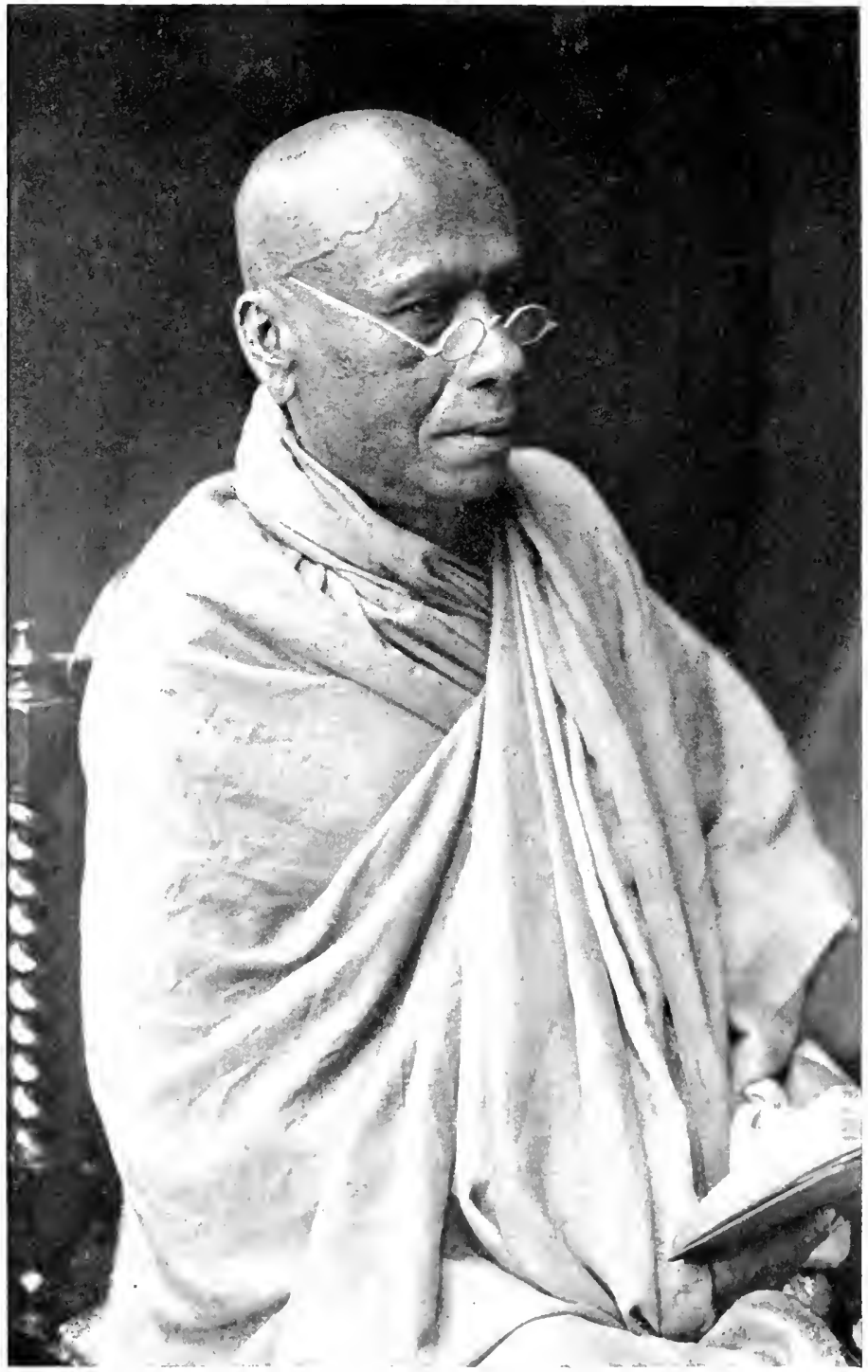

THE HIGH PRIEST OF NDAM'S PEAK.

[Photo by A.W. A. Plate \& Co.] 

An interesting body is the Rodiyas, an outcast race living in the Kadugammana and other districts, and remarkable for the handsomeness of the women, and often for fine plysique. They are said to be descendants of outcast royal and other families.

Religion. Ceylon being the home of the three greatest non-Cluristian religions besides containing numbers of Christians, the question of religion is one of some interest. The majority of the Simhalese are Buddhists, of the Tamils Ilindus, of the Moormen Mohamme dans, while a number of each, and the Burghers and Europeans, are Christians, more especially Roman Catholics. It is of course impossible, within the limits of the present book, to gire more than the barest outline of the beliefs and customs of the different religions, and we may commence with the Buddlist, this being professed by the majority of the inhabitants of Ceylon.

The central figure of Buddhism in the present age of the world (the Buddhists believe that there are many) is Gautama Buddha, who lived in the sixth century B.C., and died in 478 B.C., teaching in Northern 1ndia. Tle attained his Buddhahood under a bo-tree, which is consequently rery sacred in Ceylon, and of which a rery ancient example still survires at Anuradhapura. The cardinal points of his teaching were that all life is suffering arising from the indulgence of desires, and that the aim of existence should consequently be to suppress desire; as this is done Nirvana, or a state of blissful unconsciousness, is attained, and this interrupts the succession of lives through which one would otherwise pass.

Gautama is said to have visited Ceylon on three occasions, and on the last to have ascended from Adam's l'eak, where his footstep is still worshipped by crowds of pilgrims, but 130 permanent trace of his religion was to be found here till the risit of Mahinda in 307 B. C. This prince alighted on Mihintale, it is said, and preached the new religion to the king and peofle, with wonderful success, and fiom that time forwards the national religion of the Sinhalese has been Buddlism.

Buddhist priests, or rather monks, soon became rery numerons, the life rather appealins to the habits of the Sinhalese, and to this day there are very numerous monasteries all over the istand, while the monks in their yellow mobes, often with begsing bowl under their arms, form a very consicuons and picturesque feature in the life of the combtry. The monk is supposed to live rery simply, in a pansala (literally drelling of leaves) and bes all his fool ; but in actual fact some of the monasteries are now faily wealthy, thomgly with the recent revival of Butelhism due to the work of the Theosoplucal 
$9 S$ THE PEOPL, THFIR RACES, CUSTOMS, RELIGIONS, \&C.

Society, the monks show more sign of living exactly up to their iules. There are three sects of these monks; the Siamese, mostly in the hill country, who wear their robes so as to leave the right arm bare, the Amarapura, who have the right arm covered, and the Ramanina.

In actual fact, in most villages, Buddhism expresses itself in simple life, and in periodic risits to the temples, especially at the period of full moon, when flowers are offered at the dagobas and shines. The ordinary villager has by no means got over his belicf in devils, and the devil dancers, as they are called, are still a numerous body in the island. They are

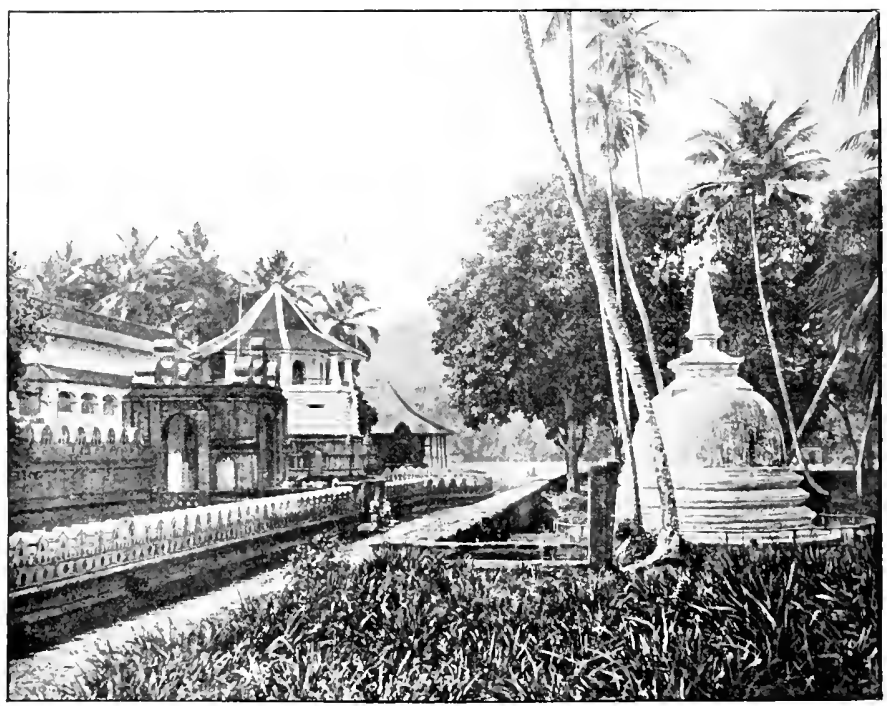

TEMPLE OF THE TOOTH AND DAGOBA, KANDY.

especially employed in cases of disease, which is put down to posiession by some particular devil. Masks are worn over the face, varying according to the disease, and jingling bells and other adormments on the body, and great dances are kept up in the patient's house to drive away the devil concerned. Devil dancers also take part in peraheras and other functions. The perahera is a native religious procession, and the principal one takes place in Kandy every August for a fortnight, ending at the full moon. It is a great procession of elephants (dressed for the occasion), chiels, devil dancers, \&c.

Not only is there this admixture of devil worship, but the Buddhist religion has undoubtedly been more or less 


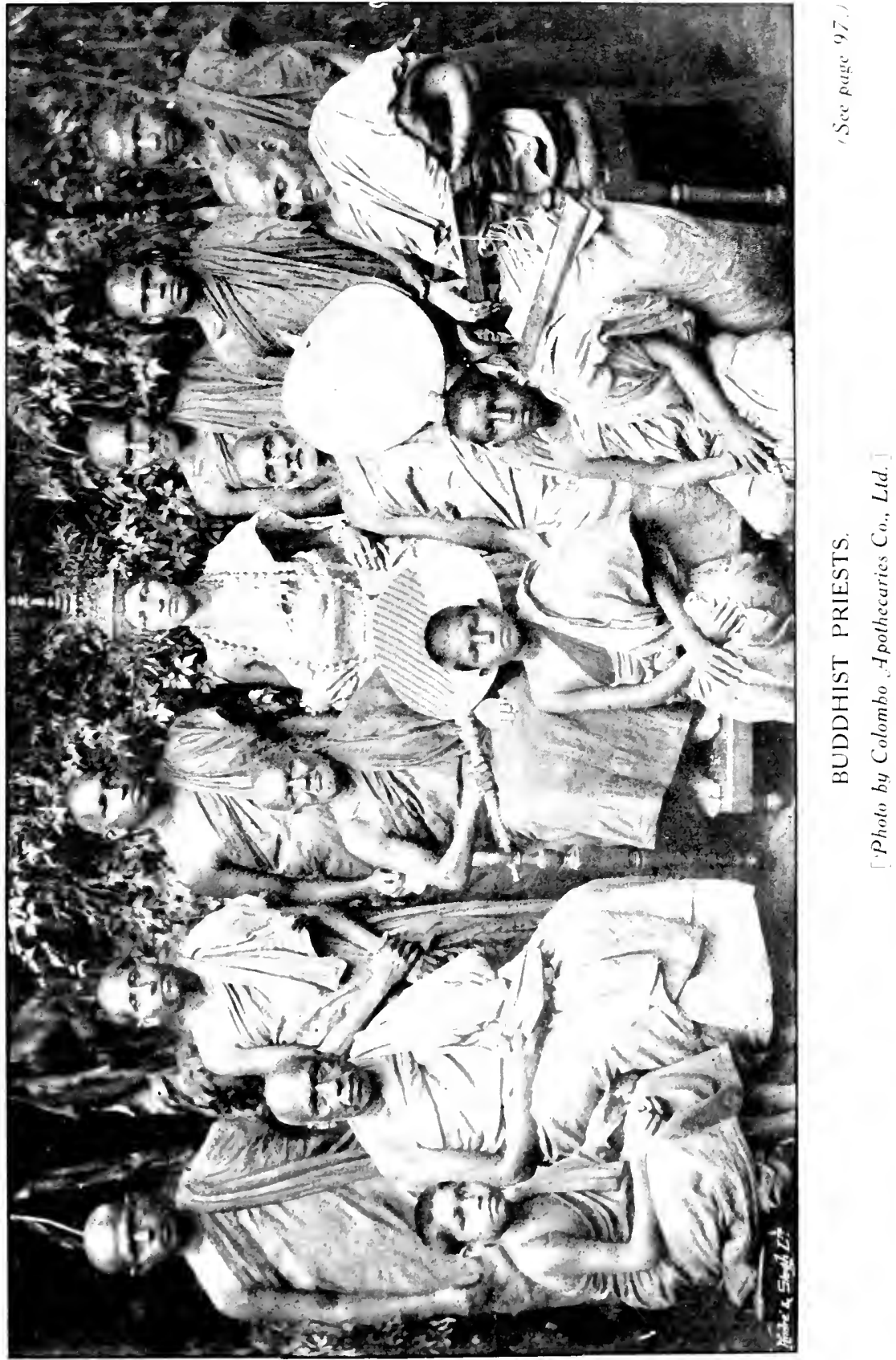



hybridised with the Hindu, as may be seen in the frescoes on the Kandy and other temples.

Among the numerous precepts of Buddha is one forbidding the slaughter of animals, and in consequence of this it is very hard to get a native to kill anything, while they may be seen sitting by the roadside exploring one another's foliage, and in other ways preserving animal life.

Turning now to the Ilindu religion, which is professed in Ceylon by the native Tamils of the north and east, and by the numbers of Tamil coolies employed on the estates and elsewhere, there is no doubt that the earlier simpler religion laid down in the V'edas or sacred books has become much more complex, that new gods have been added, and the religion altered and hybridised in other ways. Strictly speaking, there is one god, Brahma, with three manifestations, Brahma the creator, Vishnu the preserver, and Siva the destroyer, but in actual fact Brahma is now very rarely worshipped, and the religion is divided into two main sects, worshippers of Vishnu and of Sira, and each sect attributes to its own chief deity some at least of the attributes of the other two. 'The worshippers of Vishnu are distinguished by the mark that they bear upon their forelseads, and which is often erroneously called a caste mark, viz., two white rertical lines, with a red or yellow one betwcen them. The worshippers of Siva vary in their markings, but the most common is to smear the forehead with white ashes and draw horizontal lines across it.

Yishnu is supposed to luave gone through various incarnations, the most famous of which is that of Rama, whose struggle with Ravana, the demon king of Lanka or Ceylon, for the recovery of his wife Sita, is the subject of the great Indian epic poem the Ramayana. Ramasami-the god Rama -is perhaps the commonest name among the 'Tamil coolies, and is used like "Tommy Atkins" as a kind of generic name for the whole lot of coolies. In a similar way, the human soul is supposed to go through a vast series of incarnations, millions in number, commencing with low forms of life, working up to low caste human beings, then to higl caste, and finally being absorbed into Brahms.

Among the lower orders of llindus, belief in devils and other minor deities is universal, and all kinds of gods luave to be propitiated, such for instance as the godeless of small-pox. One of the commonest sights in Ceylon is a smami-tree, a tree in which some spirit or other is supposed (1) have taken up his abode, and bencath which is a little altar, often simply of a brick or two, upon which offerings of flowers, rice, sc., are made. 
The cow is a particulaly sacred animal to the Hindu religion, and none but a cooly of the lowest caste will carry beef.

To turn lastly to the Molammedans, their creed may be summed up in the words "there is one God, and Mohammed is his prophet, or apostle." Mohammed was born at Mecea in 570 A.D. and maried lihadija. At 40 years of age he receired his first divine communication. I le was accepted as a prophet at Medina, to which he fled, and died there in 632 A.D.

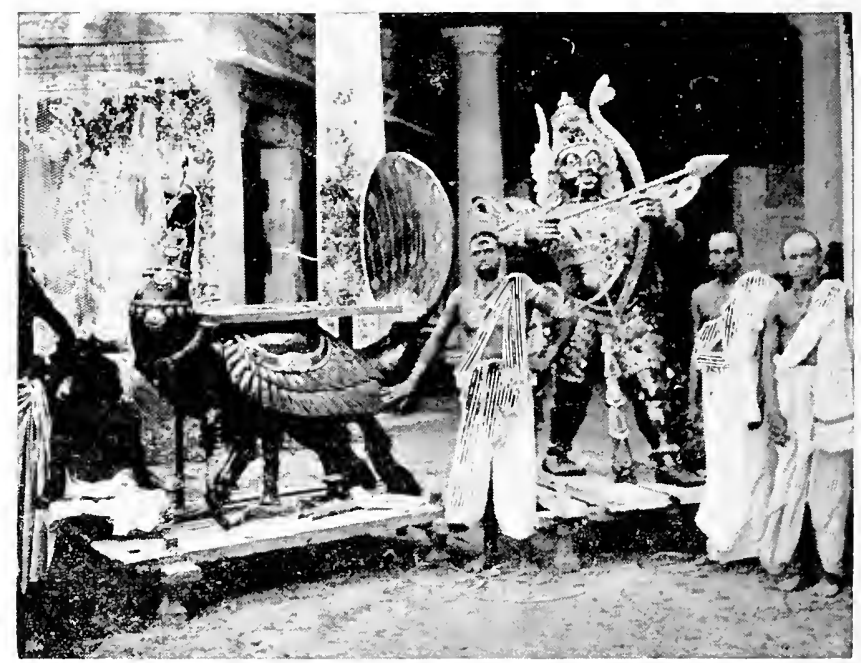

THE HINDU GOD KANDASWAMY.

The Mohammedan luas fou great duties, to offer prayer five times a day, to give alms, to keep the fasting month of Ramazan, and to make a pilgrimage to Mecca. The returned pilgrim is known as I ladji, and may wear a green turban as a mark of his sanctity. Such pilgrims are comparatively rare in Ceylon, where the Mohammedans are not of the strenuous type so usual in Mohammedan comntries.

The Mohammedan is allowed four wires, but in Ceylon one only is the rule. He arrives ultimately at a hearen of sensuous delights, while a separate heaven is assigned to those women who mar be worthy of it. The most important Mohammedan festival is Muharram, a fast in remembrance of the death of Hasan and Husain, the grandsons of Mohammed. It lasts ten clays. Later on there is the month's fast of Ramazan. 
PIATE XXXI.

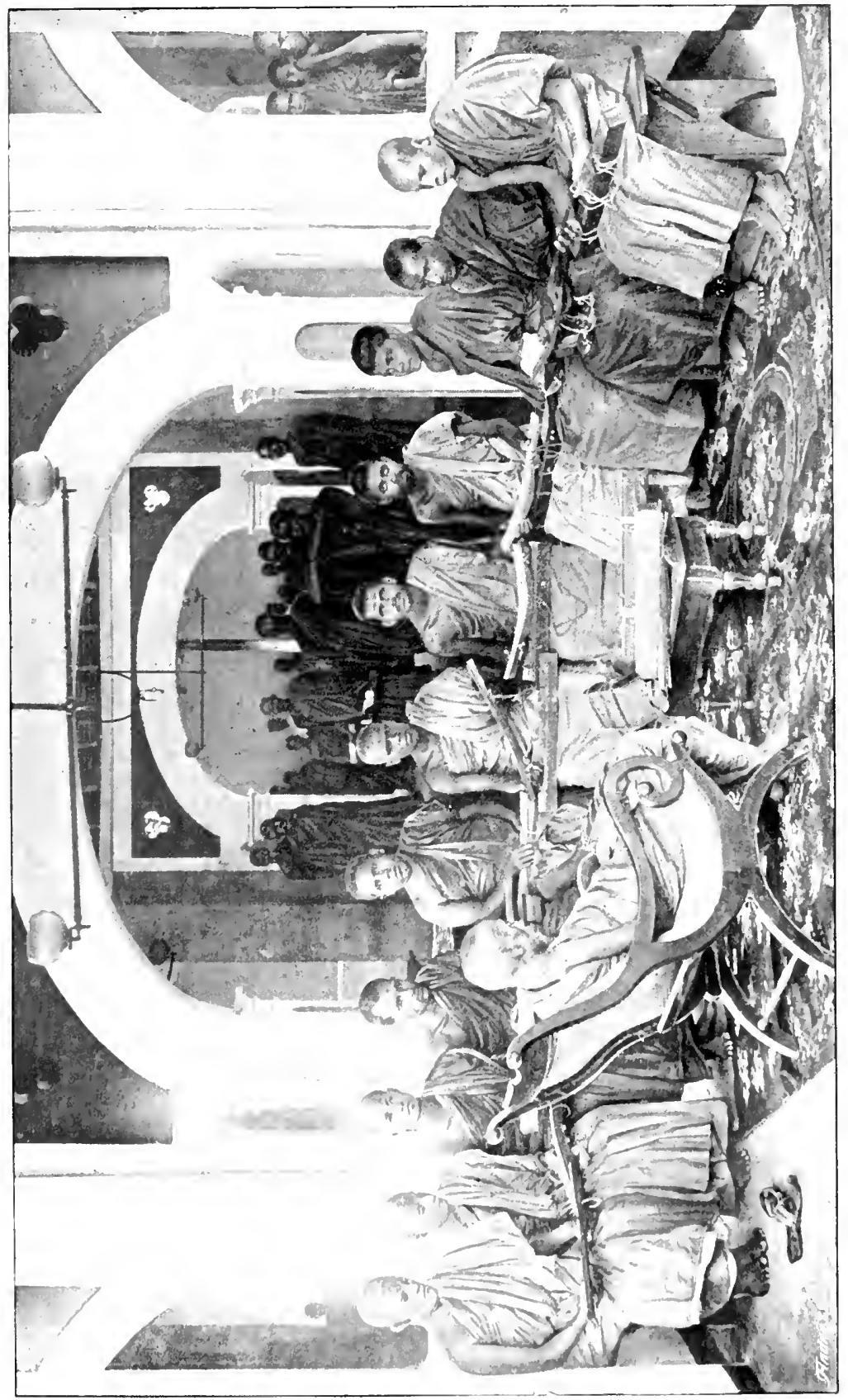

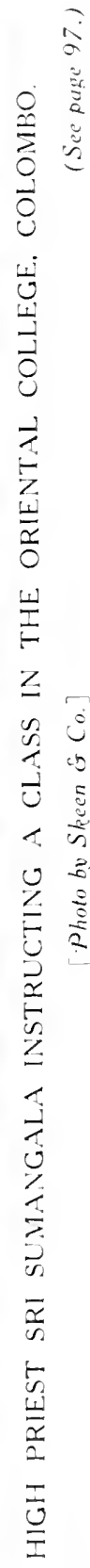



Christianity is strongly represented in Ceylon, especially by the Roman Catholics, who include a seat number of the fishermen and others. Every important religious community from the Church of England to the Salvation Army, is represented in the island, usually by missionaries, and application should be made to the heads of these communities by those wishing to see the work that is going on.

Education. Thes is a most difficult subject to handle. were one concerned with mone than the mere facts of the education that is actually soing on in the colony. Cevlon has definitely decieled for an education of the European pattern: and on the one hand, it is by no means certain that an English education as such is calculated to bring out to the best advantage the good points of an oriental people, who have a very different outlook on life, while on the other hand, Cevlon is very much anglicised, and is oser-run with English people and tomrists, so that an English education is alone fitted, as matters at present stand, to qualify a native for employment in anything but ordinary native agriculture or other pursuit.

Be this as it may, however, the education is at present English, in the towns and in the upper schools, and it must apparently continue to be so, English being the language of commerce and travel.

It would seem natural and right, in the case of a race like the Sinhalese or the Tamils, who have a language, literature, history, and culture of their own dating very far back, that these subjects should, as far as may be, be utilised in education, instead of European versions of similar subjects as they relate to England or other countries; but to properly devise a scheme of education best suited to the wants of the people of Ceylon is a big task to put before any one.

There is, in Cevlon, no gencral type of erlucation emploved in all the schools, but one mar find every kind, from the higher classes of the Royal Cinllege, conducted in English, and learning conic sections or a play of Aeschylus, to the simple pansala school, where a few boys are taught by a Buddhist priest, by means of ola or palim leaf manuscripts, in the vernacular. Some schools are Covernment, some belong to onc, some to another mission body, of which Ceylon has mans.

Under the loutch, education was carefully systematised, and attendance at the schools was mate compulsoly. The teaching was largely religions, and formed part of the general scheme mucle which the Dutch luped to convert all the natives of Ceylon to their own religion. When the English captured the colong in a 796 , they neglected chlucation for many years, but about fo years later the question was taken up by the 
102 TII: I'FOPLI, TIIEIR RACFA, CUSTOMS, RILJGIONS, AC.

British Govermment, though in the mcanwhile a good deal had been done by various missionary bodies. The first Government institution to be started was what is now the Royal College in Colombo, whose object then was to give a simple but sood education in English, Classics, Mathematics, and Religious Knowledge. A little later a kind of amateur cducational commision was stalted, and in $\mathbf{8} 867$, finally, the department of 'sublic fnstruction, under a Director, was commenced, and endures to this day.

The schools of Ceylon may be primasily divided into two classes, those kept up by the rarious mission bodies, and

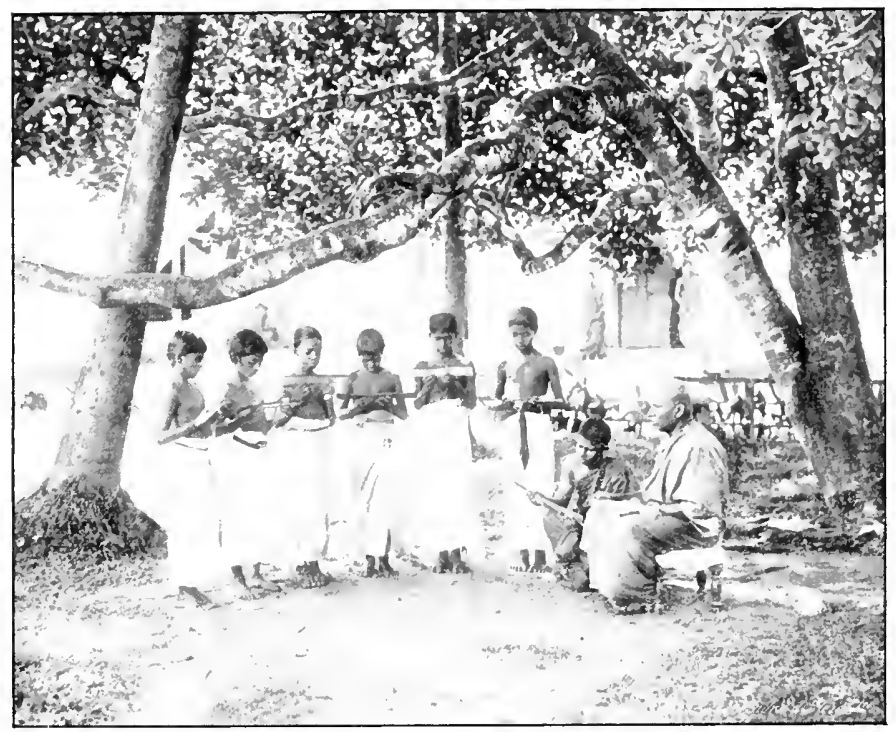

PANSALA SCHOOL.

those kept up by the department. They are all examined by Government inspectors, and to those that have earned them, srants in aid of maintenance are made, this constituting a considerable part of the now heary expenditure under the head of education. In 1 yoz there were 515 Government schools with 5\%,512 scholars, and 1,424 mission schools receiving grants in aid, with 129,891 scholars. There is no rule in Cevlon enforcing compulsory attendance, so that this number of seholars must be looked upon as very satisfactory, and in fact, considering the short period during which many children an to school, it represents a very good proportion of the children of schon age. 


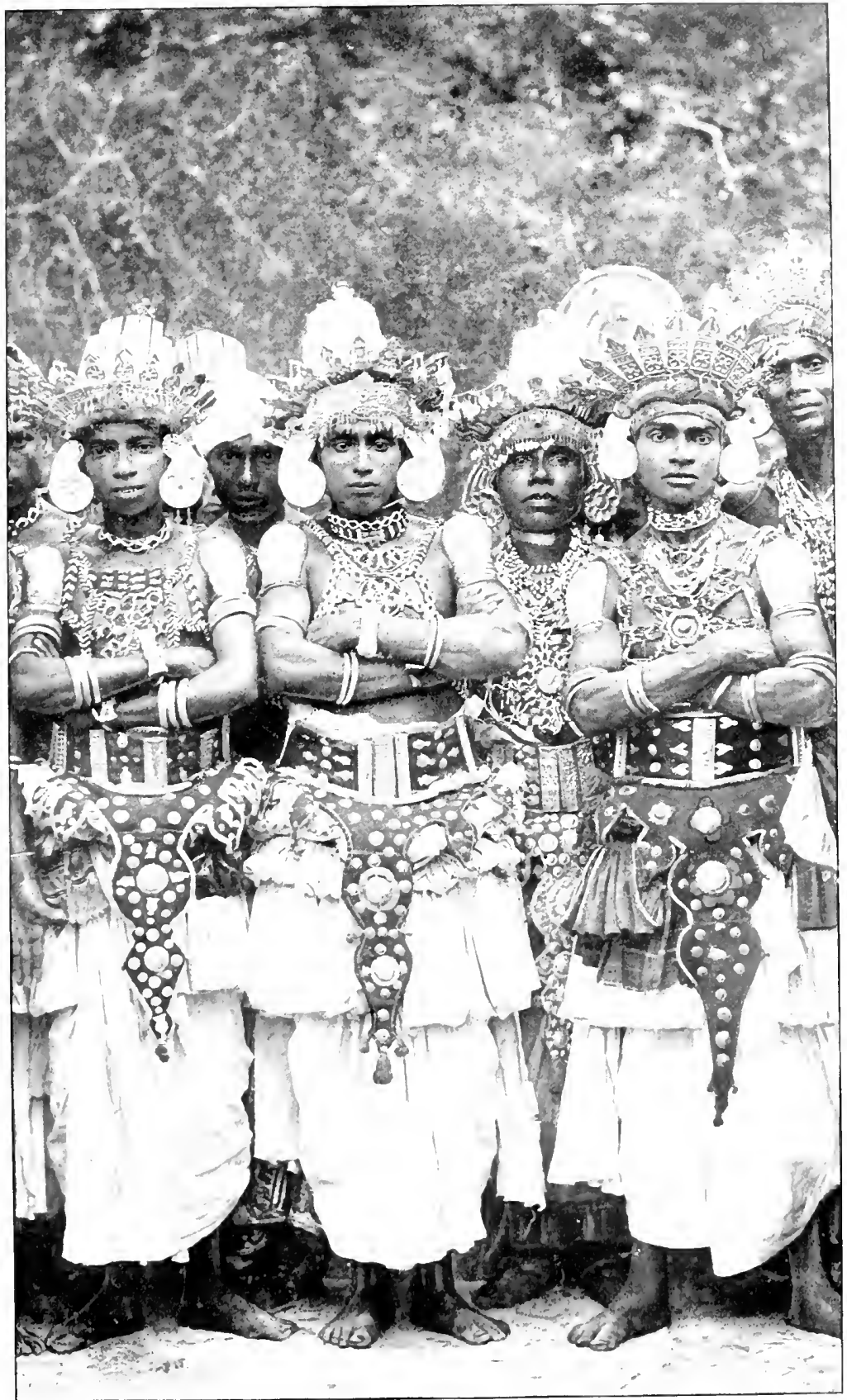



Whilst in the country places the education is of course given in the vernacular, in the larger towns, and eren in some of the villages, there are definite English schools, in which instruction is given in English, or in which, as in the Roval, St. Thomas', St. Josepl's and Wesley Colleges in Colombo, the whole of the teaching is conducted in English. Other still higher instruction is giren at the Technical and the Medical Colleges.

Physical training is not left out of sight; the boys at many of the larger schools are excellent players of fontball, cricket, and other games, while cadet battalions also exist in some of

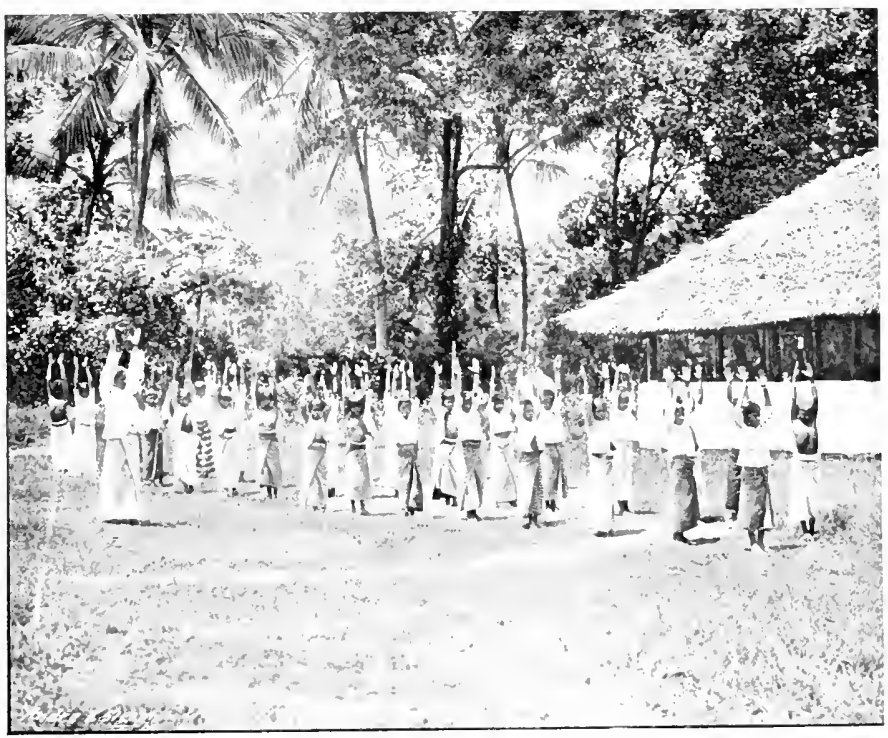

PHYSICAL DRILL.

them. Agricultural teaching, as such, is not giren in the schools, it being too early for most boss, and the teachers beine untrained in the alt, but a rerveffertive substitute is to be folnd in the school arolens, which ate now in existonce in a latere number of the village selools. These are little wardens, kept up by the master and the scholars, in which are cultivated plants which are not mow staples in the cultivation of the distriet in which the schos lies, and which may consequently form new rultivations there as they are taken up, while they do not invite comparison with local asricultural rork. 
Those who wish to see for themselves how teaching is conducted in Ceylon should apply at the office of the Director of Public lnstruction in Colombo, or to the heads of the various mission bodies.

Occupations. Here again we must be very brief. The great and honourable occupation of this country is agriculture, but a distinction is drawn in that it must be upon the man's own land, and not serving as a cooly upon other people's land. Ilence it is rery difficult to get the natives of Cevlon to go out to work upon the European estates. About three fourths of the people are engaged in agriculture, but, as mentioned above under agriculture, their methods are simple, inefficient, and old-fashioned.

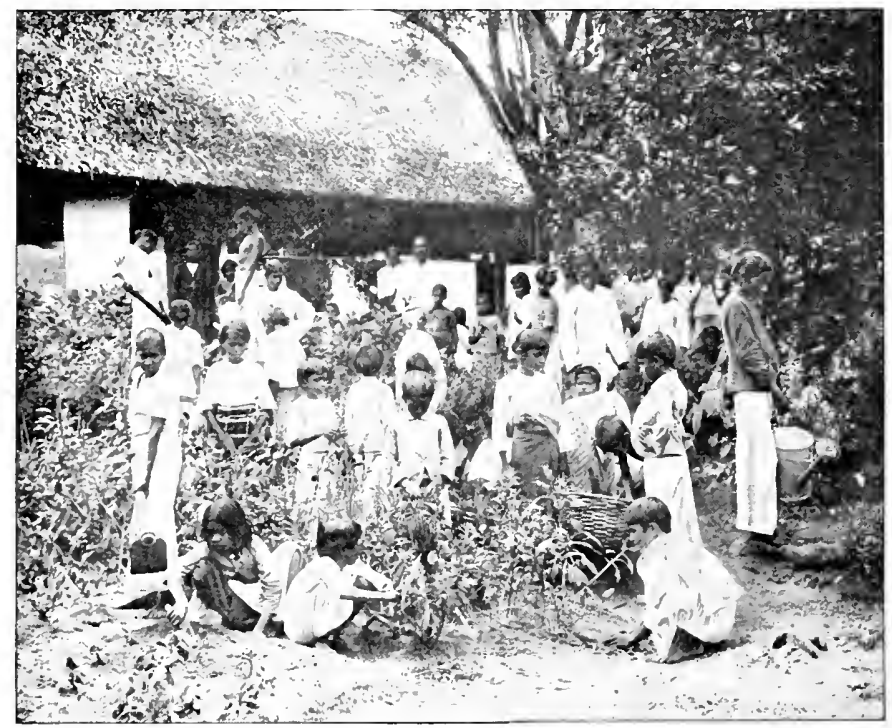

A SCHOOL GARDEN.

A very targe number of people are employed upon work subsidiary to agriculture, such for instance as the transport of goods. This is usually done in Ceylon by the aid of the slow-moving double bullock cart (Plate V'I), upon the pole of which the carter sits. The bulls ale strong on the whole, but only go at a rate not cxceeding two miles an hour, and cannot do imore than about 14 miles in the day-or very often night, for the native is rery fond of travelling then. Goods are carried down the larger rivers by means of pada boats, which are 


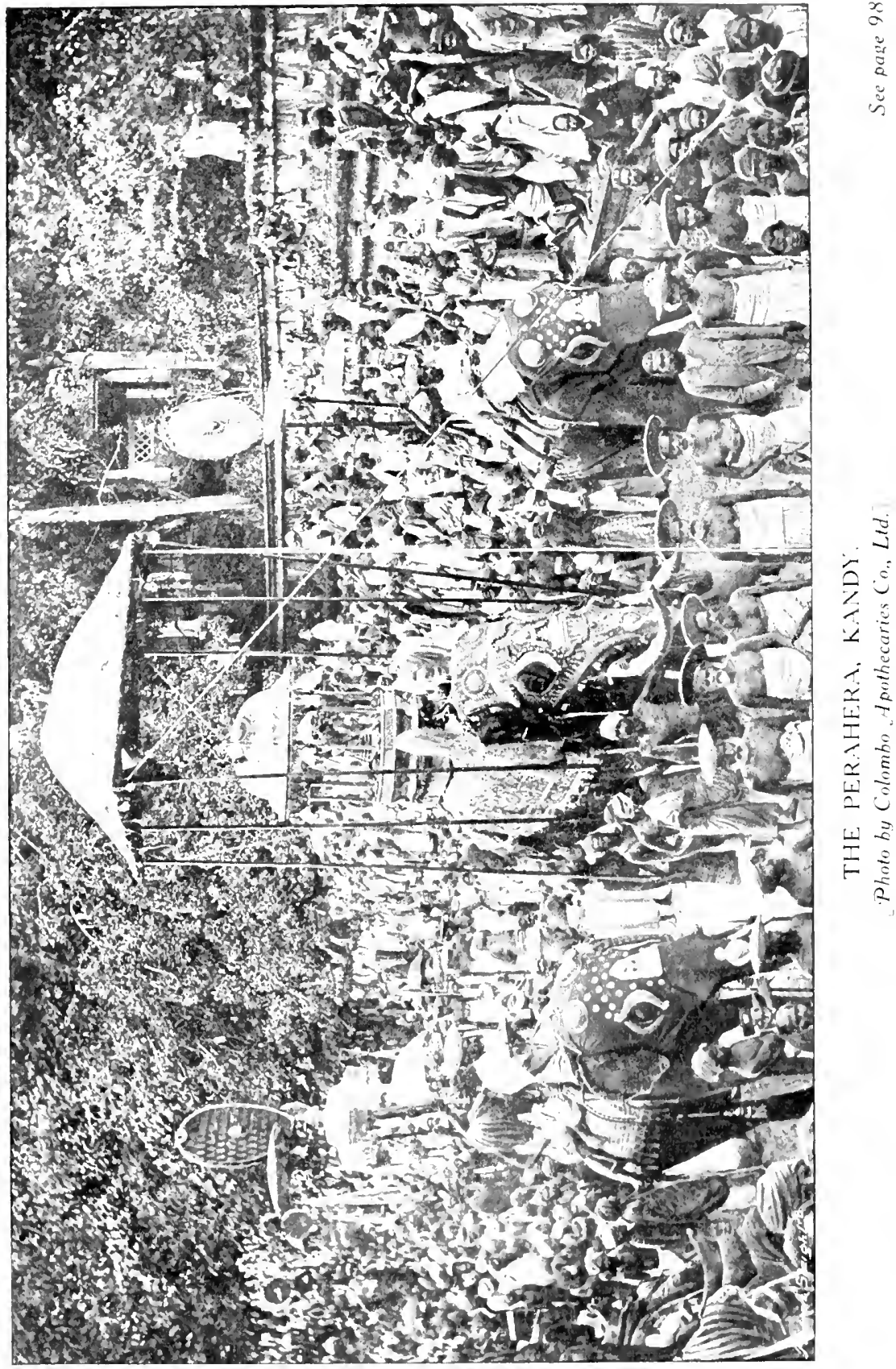



simply double canoes, the two canoes some distance apart with a platform and roof on the top of them. For mallere loads and shorter distances the single canoe with outrigger is usually employed. In outlying districts carriage is still performed by pack (lavalam) bullock with panjers on either side, and in the towns very commonly by women.

Another very common occupation is fishing, and the great caste of the fishers is mainly to be found along the coast. The common boat is the large single canoe, with outrigger on one side, and large square sail. "lhe outrigger is always kept to windward, and the boat is sailed eitler end first. In strong winds one of more men sit upon the outrigger, and wind may be descrilsed as a one-man breeze, two-man breeze,

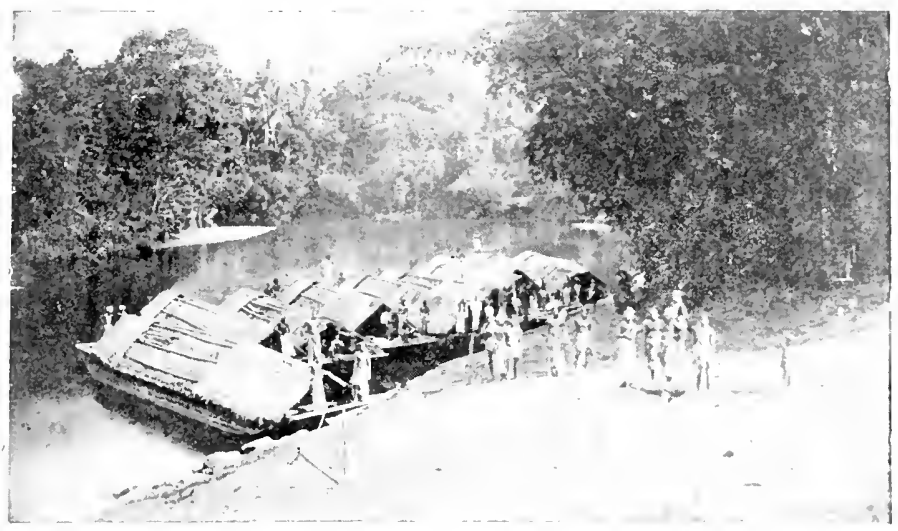

PADA BOATS.

se. During the strong winds and hears weather of the southwest monsonn many of the west coast fishermen go round to the other side of the island.

Vet another common occupation is shopkepping in the very broadest sonse. While in Colombo there are many large and well equipped shops kept by natives, in the smaller villages the shops deteriorate into little stalls with a few curry stulfs, cloths, oil, sc. In Sinhalese villages they are usually known to Europeans as boutiques (Portuguese betico), in Tamil as kaddies. $\Lambda$ good deal of sellims is also dome by the roadside, and itincrant vendor of betel "chews" (sold on little stands, in which the leaves of betel are bent upwade between upright sticks placed in a row), rasted gram (a wain not unlike peas), drinks of sorts, sweetmeats, and other things, are very common. 
Owing to the openness of the ordinary native houses many necupations may be seen going on in the full light of day., e.g. that of the barbers, the lace makers, the weavers, and others.

House servants form quite an important class, as more servants are needed here than in an establishment of the same size in Europe, though not so many as in Northern India. The chief servant is usually known as an appu, and under him there are often a second boy (housemaid), a cook, a kitchen conly who does the heary work in the kitchen, and sometimes others. An ayal is usually cmployed in houses where there is a baby, or where the mistress wants a personal maid, and there is commonly a muttu or horsekecper, who is usually a Tamil, while the rest may be either Sinhalese or 'Tamil, though usually all in a house are of the same nationality. In economical homselolds of Europeans, as e.s. an estate assistant's, the servants are usually only an appu and a kitchen cooly.

Many men are employed in mines of plumbago, or of gems ác. (Plate li), and others are employed in the trades of baker, butcher, caspenter, toddy drawer (who climbs the palms and taps them for toddy;

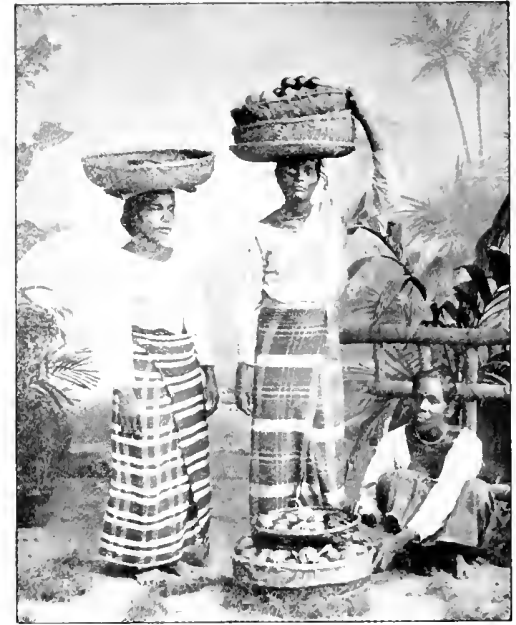

BASKET WOMEN. see $\mathrm{p} .47$ ) and so on. Yet others are engaged as jugglers or as devil dancers (p.os).

Coolies, ie. literally men on daily pay, form a very important class in Ceylon. Most are Tamils cmployed on the tea and other estates (p. 5t), where they live in little one-soomed dwellings called lines. Many are engaged in rickshaw pulling, road making, and other menial occupations.

Lastly we come to the professions and other oceupations of those if a higher class. A vast number of men are cmployed as clerks, and the abler ones take especially to law and medicine as protessions. The lower ranks of the Government service are filled by natives, but these do not very often oceupy the highest posts, except in the legal profession. 
PLATE XXXIV.

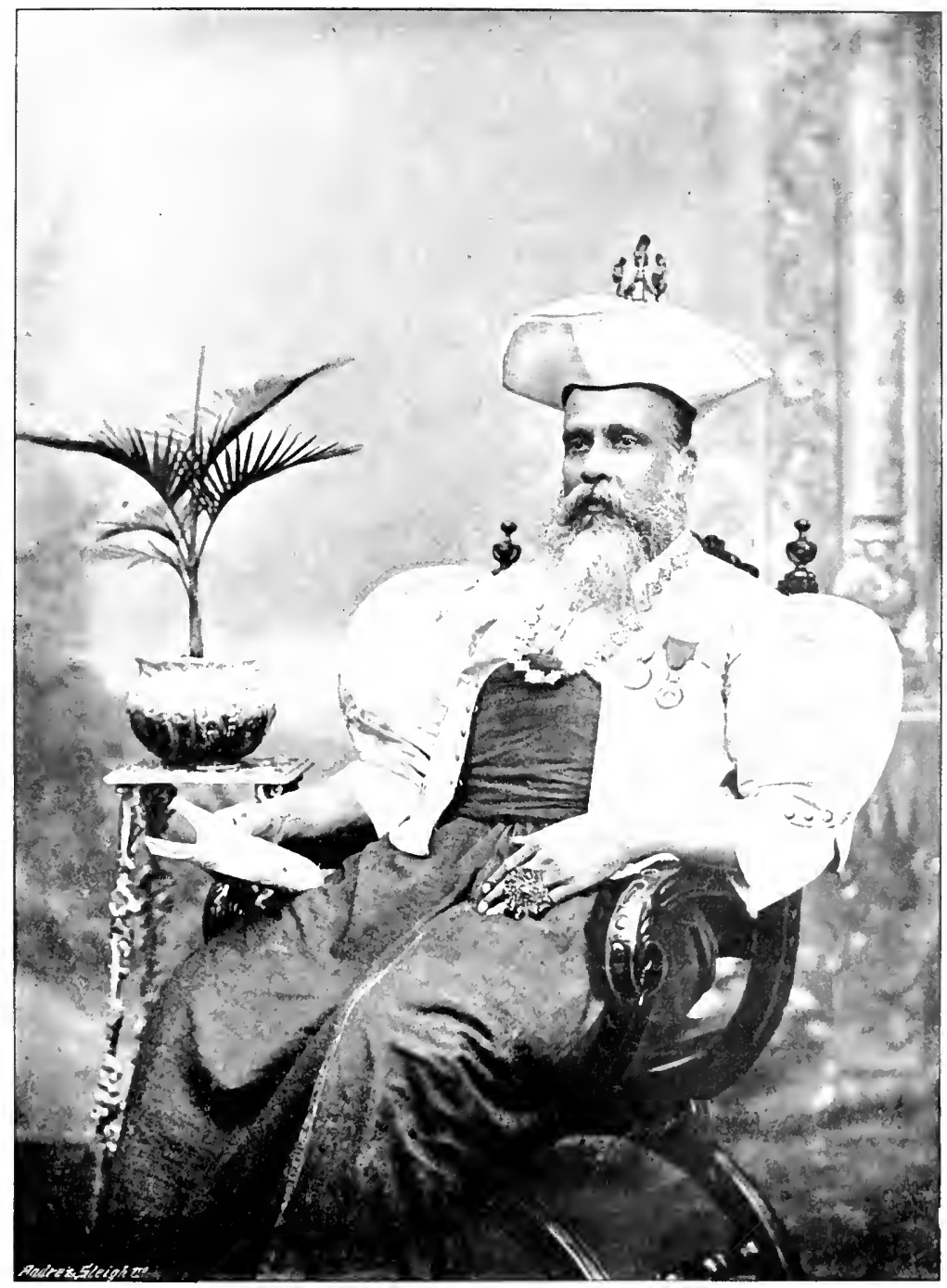

KANDYAN CHIEF,

(See page 88.) 

THE PEOPLF, THFIR RACK, CLSTOMI, RLLIGIONS, dic. 107

Language. Several languages are spoken in Cerlon, and a eandidate for a post, e.s. on the railway or in the post office, must frequently be able to speak the three tomgues Finglish, Sinhalese, and Tamil. The most usual native language fon the European to learn is Tamil, but not what is often called "book Tamil," the language of the higher class Tamils of the nortl and of Madras, and the language nsed in an extensive literature. The planter who used this language to his coolies would soon be in sreat difficulty, and ther require to be addressed in the dialect of the Matura or wher divisions of Southern India. As the great majority of the sinlualese up-comtry also learn this clialect, it is the common means of communieation emplosed in Cevlon, but the moment that one leaves the planting districts and the chief towns, it becomes useless and one requires the Sinhalese or Tamil spoken in the particular distriet in which one may be.

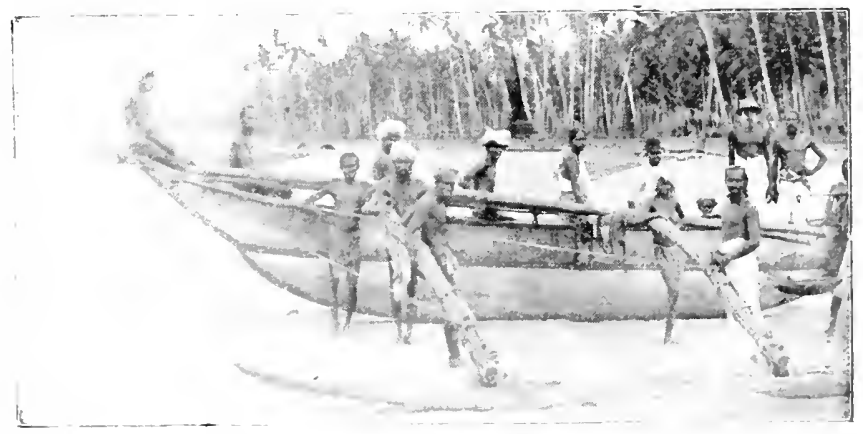

FISHING CANOE.

Sinhalese is usually supposed to be an Aryun language, allied to the Sanskrit, and indeed the roste of very many words are the same as those of the furopean words, as ma! be recognised for instance in the numbers, which rum eka, deka, tuna, hatara, and so on, while many worke, f.s. Ama, a door, watura, water, and others, hase settleel down imto a

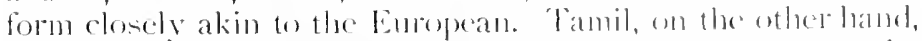
is a loravidian Janguane, and the routs are discimilar, e.s. Uhe numbers rum ondu, irandu, mundu, malu de.

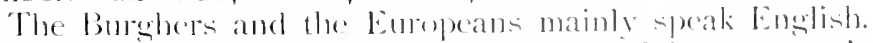
Dutch loas died ont, but a comoupt patois of l'ortuguese is to this day spoken by many of the kner chasi l'ortusulese Burchers in Colombor.

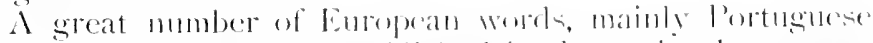
of Dhitch, lave become establishert in the native languases, 
especially such as relate to houses, furmiture, and meals, e.s. almira (Scotel awmry) for cupboard, kantoor for office, coachee for railwar carrage, to take one each fiom Portuguese, I) otch and English.

Art. Ceylon in old times was probably, like India, a very artistic country, but with the continual intercourse with Europeans, and still more with the commercial spirit of modern times, and the ease and cheapness with which inartistic European goods can be bought, its art is decaying, and the old arts and crafts are all but extinct. How best to revive them is rather a problem. The Kaudy museum, with its attached craftsmen, were it better known to and supported by, visitors to the island, would do a good deal, but it would seem probable

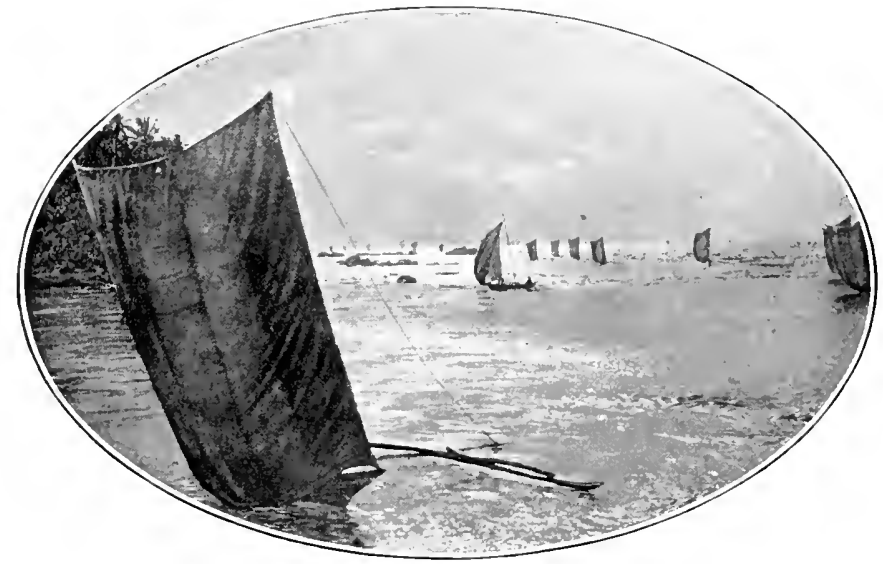

CANOES AT SEA.

that a central depot for ant work in Colombo, accompanied by the distribution of prettily illustrated advertising "folders" upon the steamers, showing what kind of work could be had, and approximately at what prices, would do more. There are probably more people among the passengers to Ceylon with a feeling for true art than among the residents in the island, and there is certainly more money among them available for spending.

The native who has lost his taste for his own art is in regard to whatever style of art he adopts among the most inartistic people on the face of the easth, as one glance into any native bouse furnished in European style will show. Many are in the very worst st vle of early Victorian, whereas a native house furnished in the old native manner is a pleasing sight. 
PLATE XYIV.

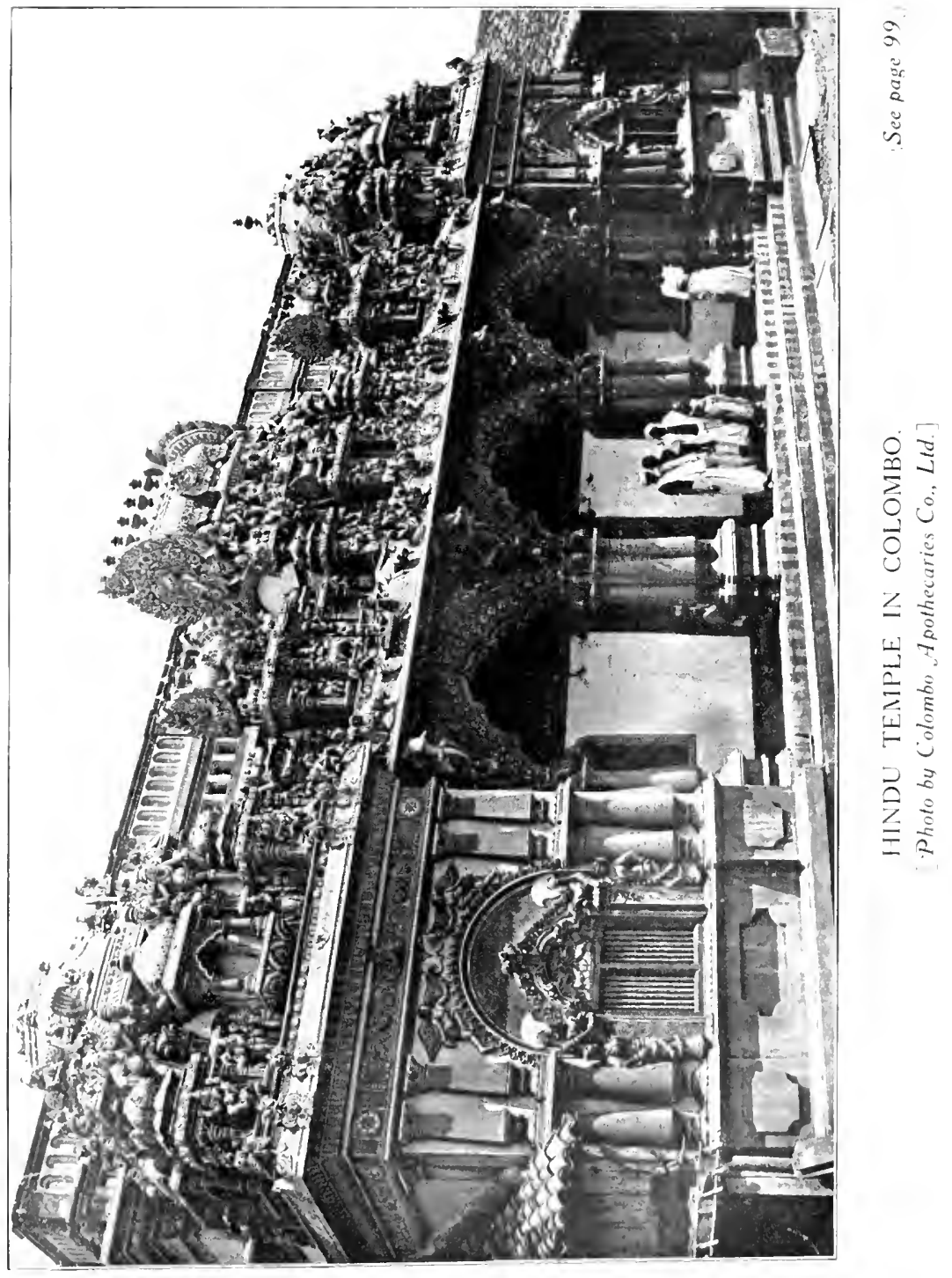



Sinhalese art is without doubt originally North Indian Buddhist, but rery largely modified by centuries of intercourse with South India, and it now has a decided distinctive character of its own, Buddhism having died out upon the neighbouring continent. The artists, other than the potters and wearers, formed a caste, which was fairly high.

The principal art perhaps was architecture, and very good examples may be seen in the Buddhist temples in the Kandyan districts, such as lankatilake, Kandy itself, \&c. A temple usually consists of a vihara or house for the images, a dagoba (p. 79), a bo-tree with a platform built around its base, and a pansala or dwelling of the priests, while there may also be halls for preaching or confession.

Painting, again, may best be seen in the temples, where the walls and roofs are ornamented with fresco-like paintings, illustrating events in the life of Buddha \&c. The older paintings are better than the modern ones, which are done with

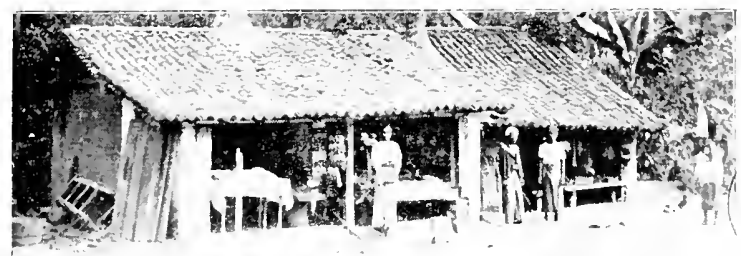

\section{VILLAGE BOUTIQUES.}

too large and too garish a range of colour, while the older are mostly in black, white, yellow and red.

Ceylon has some very fine work in joory, while the brass and silver work, in which there is still a large trade with tourists, is on the whole decidedly good. There ale two classes of it, usually known as Kandyan and Negombo work. The former is beaten out 11 oon a pattorn, as may be seen in the Art Museum in Kandr, the latter is cast in monlels.

Local jewellery, so far as not spoiled he imitation of European work, is very good and artistic, and some of the jewels worn by the Kandyan chefs are very effective. Workmanship rather than weight is regarded in the manufacture. Most of the jewellery sold in the shops, however, is simply in imitation of European gonds, though there are one or two which secm local, such a the pretty bangles and necklacesof mixed stomes, which are however momeded in westem style.

lacquer work survesonly in a very few families; walkine" sticks for Kandyan chicts, and other lacquered articles are 
still made in small quantity. Weaving also is all but extinct, though the "Dumbara mats" and other articles of native manufacture can still be purchased,and the Tamils of Batticaloa still do quite a trade in cloths \&c.

Music. This is not rery largely practised in Ceylon, though there is a good deal. Native music differs from European in the shorter length of the intervals, so that local tunes all sound as if in a minor key. There are but few peculiar instruments. One of the commonest is the kind of flageolet, with a swetling in the centre of the tube, used by snake charmers and other musicians (fig. on p. 20).

Games and Sports. The natives of Ceylon are not what would be termed a sporting race, ret they have many games among them which deserve a word of notice. Marbles, played with a different method of propelling the marble to what obtains in England, are a favourite pursuit with the young Leaplirog, also played differently in detail, is not infrequent. The "frogs" first lie down, then sit up, then hold out their arms over their legs, and lastly stand up. A great national game, which has lately been revived at agricultural shows de., is ankelive, of which we may quote the following description from Le

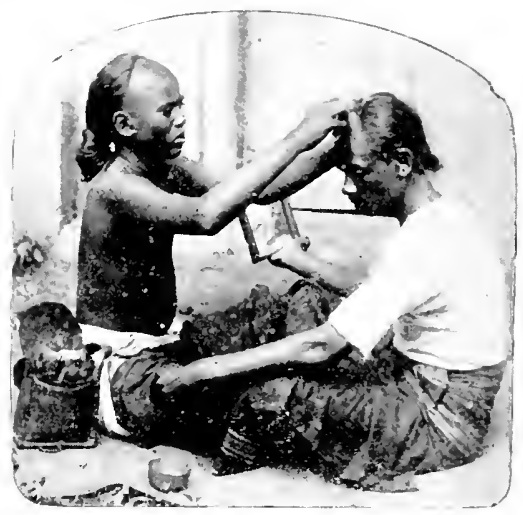

A TAMIL BARBER. Mesurier's "Manual of the Nuwara Eliya District."

"It was, and is for the most part still, a purely religious game, sacred to the goddess Pattini, and is usually performed on the occasion of some epidemic ascribed to her interference ........ its mythological origin is as follows:- The goddess Pattini was out one day with her husband Palanga, gathering sapu flowers. To enable them to reach the flowers, they had long hooked sticks, and while they were stretching out together their two sticks caught in each other in the tree, and they could not extricate them. While they were considering what they should do, the three sons of Maha Tishnu came by, and on being appealed to by the goddess, they goodnaturedly took hold of the ends of the two sticks, and with "a long pull, a strong pull, and a pull altogether" broke the crook of the husband's stick, and so liberated them both. 


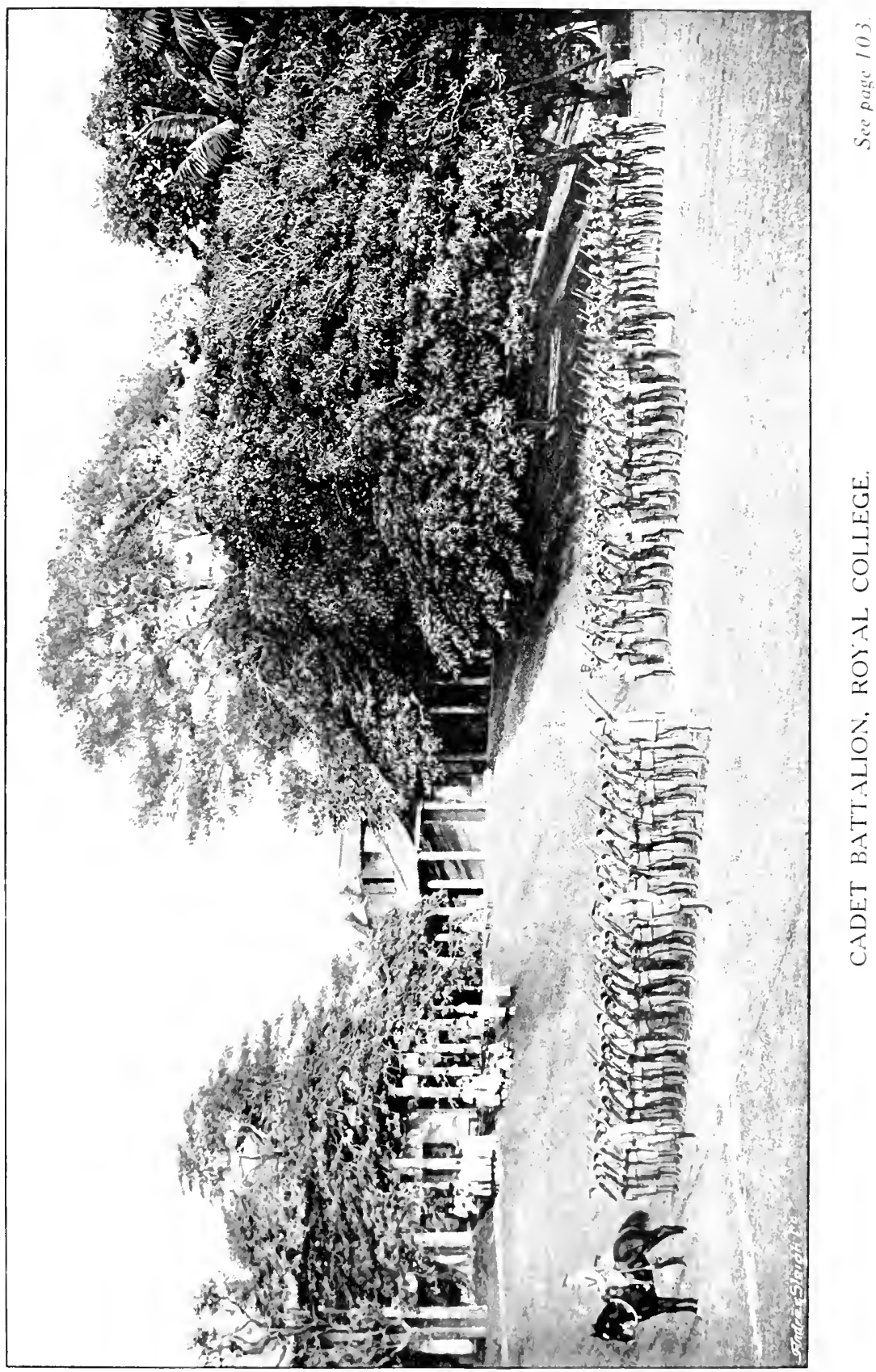



The goddess was so pleased with the performance that she suggested a game after the model of what she had just seen. So the game of ankeliva was inaugurated, and whenever it is necessary to appease the goddess, the game of which she is said to be so fond is performed to propitiate her and to rid the country of the particular scourge which she is considered in her anger to have brought upon it.

"The game is played as follows:-A flat piece of ground having been selected, the trunk of a large tree is planted in the centre (unless there is a large enough tree growing there already) and strong coils of jungle creepers........ are wound round its base. About 4 or 5 yards in front of this tree an oblong hole is dug, 6 or 7 feet long by 3 or $3^{\frac{1}{3}}$ feet broad, and from 4 to 5 feet deep ........ the sides are lined

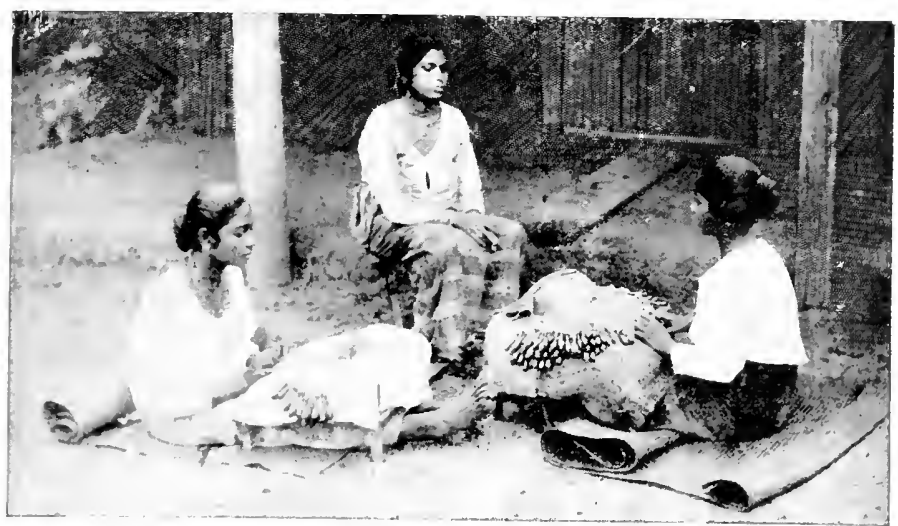

LACE MAKERS.

with coconut stumps, and inside it is erected upside down a $\log$ of a coconut tree, about 24 feet long, with the roots shaved so as to leave a heavy top ...... to add to the leverage and strain on the horns ...... strong bands of creepers are coiled loosely round the base, a short clistance above the level of the ground, and two long and strong ropes of jungle creepers are tied to the top ...... to be held by the persons taking part in the game, about fifteen rards off. . . . . . .

"In some places deer horns are used........ when the game is played on a small scale ....... but in ankeliya proper many kinds of ronts are in use ....... the thentest care is taken in selecting and preparing these, for the slightest flaw or split in the horn would seal its fate in the game ...... When required for use they are tied to the centre of long and 
stout pieces of wood prepared for the purpose ..... . a horn 6 inches in girth would require a support of $7 \mathrm{or}^{\circ} \mathrm{S}$ feet long, and about $1 \frac{1}{2}$ foot round. ....... These supports are called an-mola. ........"

The only other requisites are two coils of rope containing a specified number of coils, with a stick attached in such a way as to admit of its twisting the coils tightly when necessary. These are called the waram, and their size and strength depend on those of the horns.

The horns are then borne in procession to the place of contest, and the aram having been arranged, the horns hooked together, the opposing parties pull at the ropes till one horn brealis. If this does not occur, the coils round one horn are attached to those round the standing tree, and those round the other to the erect coconut stem, and both parties take hold of the ropes attached to the latter, and pull till one of the horns breaks, when there is a rush to see which it is.

The men of the upper horn, and the men of the lower horn, belong to these parties by hereditary descent, so that a given family is always of one horn or the other. The losing party are confined by a rope, and the winners dance round them with insulting language, to which they are obliged to submit in silence. The game is repeated on the following day, and so on till the upper horn breaks twice, or the lower thrice, rumning, or until it is found impossible to break a horn."

To quote another author:- "A procession is soon formed. A canopy is arranged so that the victorious horn may be duly hononred by being borne under it. Then the peralum parades the village, singing, dancing, gyrating in frenzied evolutions and shouting forth strange words with demoniacal gestures, all proclaiming their victory, the exaltation of their horn and the humiliation of that of their rivals. The excitement grows so intense that the victors foam at the mouth and shout themselves hoarse. Wherever the procession goes, it is supposed to carry blessings with it, especially protection from illness and disease. Every house in the village, which aspires to the honour of a visit fiom the ansa must be cleaned; its inmates muit bathe and don clean garments; the compounds must be swept and all rubbish and dirt burnt the previous day. In times of pestilence, the villagers at once proclaim an ankeliya.

"The consequence is that the place is thoroughly cleansed and purified. The pestilenee natmally abates. Of course the result is ascribed to the beneficent influences of the devas who preside over the anterlin. During epidemies, the ankeliya is held over and over again until the upper horn breaks three times in succession. When that rare coincidence occurs, it is believed that not another man, woman or child will succumb 


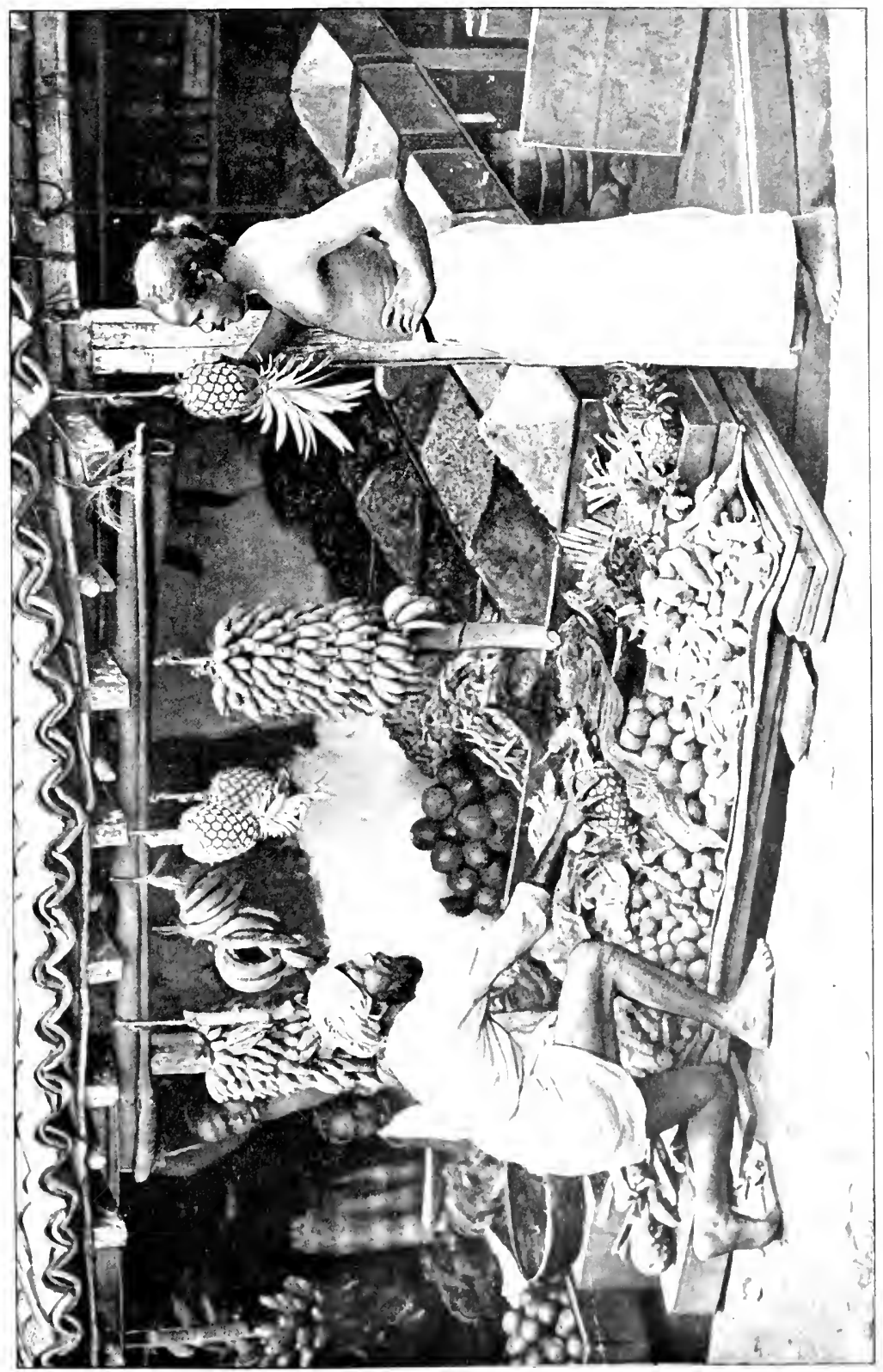

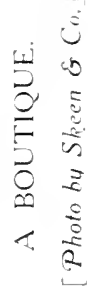



to the sickness. Very olten, by the time the upper hom breaks thrice, the village is so often cleansed, and perfect sanitary conditions unconsciously established, that the sickness does natually disappear.

"It would seem therefore that there is more wisdom in the ankelise than a superficial obcerver might be inclined to fancy, so it is a game which deserves to be preserved and encouraged."

Travelling. The native is capable of covering very long distancesupon foot, and walking is a rery farourite method of travelling, and often performed at night. Better to do people travel largely in the light bullock carts or lackeries, like a knife board in wheels, with a corer orer them, drawn by the little trotting bullocks, which can go rery fairly well for a few miles. Travelling by train is rery popular in the Sinhalese

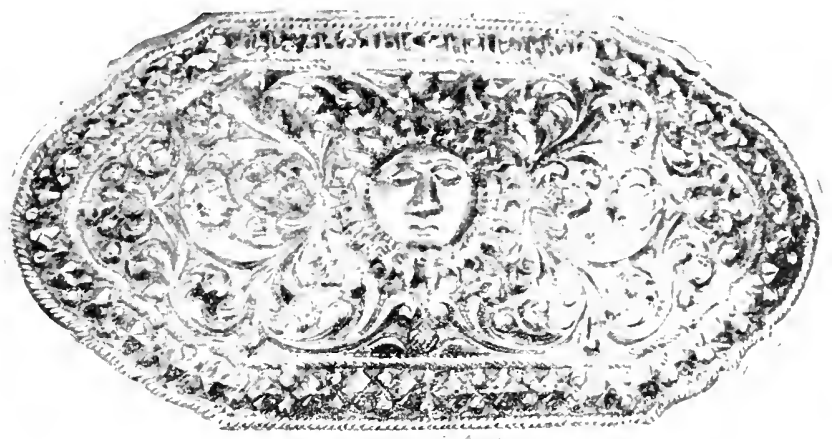

DESIGN ON LID OF A KANDYAN SILVER BOX.

districts, but not in the 'Tamil, where the people are more careful and saving. "The native is usually at the station lone before the train is due to start.

Medical Treatment. Ceylon speaking gencrally, is not an wuhealthy countey for thuse who are willing to conform to the rules of tropical hygiene. The natives themselves are senerally healthy, and would be mote more so were they willime to take precantions astimst attack of malaria and

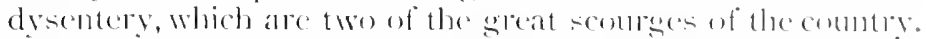
But in fact this is the last hing they would most of thein dream of doing, and thes reaged any leanings in this diection on the part of buropeans as an ambals erecontricits. So much is this the rase, that in honses where careful santation is desired, it must he persemally serente by the mistress. Phe

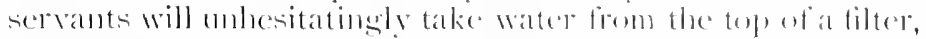
and swear that it has becin filtered, or put elean water into a dirty vesiel. 
There are good hospitals all over the country, and in many of these, e.s., that of Colombo, or that of Kandy, European patients will be received on payment, and this is in general the best thing to do when one is seriously ill. Nurses are supplied by the Nursing Home at I latton to European patients. The Tamils are in general willing to go to hospital, or to be treated by western trained physicians, but the Sinhalese villager is commonly averse to this, and prefers to be treated by the Vedarala, or native doctor.

Customs, \&c. The country is so to speak full of curious customs, and it would lead much too far to describe all of these, were we even competent to do it. Gencrally speaking astiology is at the base of most of these, and most of the larger villages, at any rate, possess an astrologer. From before a man's birth until after his death, many ceremonies, usually varying in form according to the dictates of the astrologer, are performed over or by him. As an illustration of what is meant, the customs connected with rice cultition, described on p. 43 , may be mentioned.

Among the habits and customs that at once strike the ordinary visitor or traveller, may be mentioned the fact that the native does not like to be seen cating, that he is very much afraid of the evil eye, and commonly (especially the Tamil

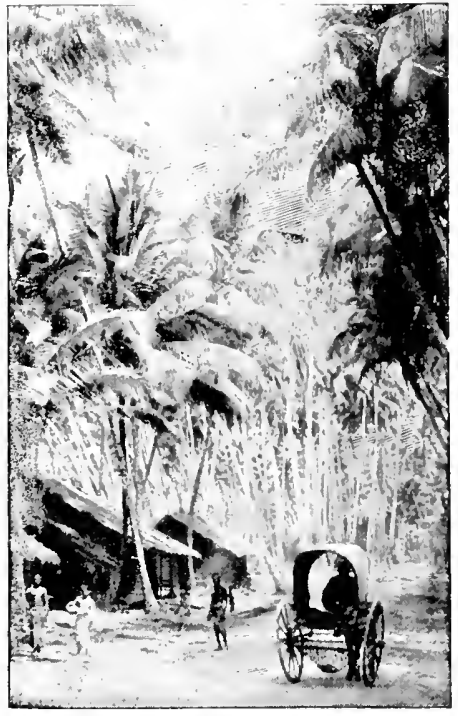

HACKERY ON THE WEST COAST ROAD. coolie) puts up in his garden a chatty with white spots upon it to catch the first glance of the passer by, and that he has, like the Romans of ancient days, rather a weakness for being buried in public places. The graves of the estate coolies may be seen along every road up-country.

General Habits of Mind and Body. The European does not usually understand the native of Ceylon, nor aice a'ersa, and much misunderstanding, and not a little undeserved dislike and contempt springs from this, which might to some extent be avoided. It should be clearly recognised that the eastern native is not of the European type, and that efficicncy, economy of time and labour, and other characters upon which 
PLATE XXXVIII

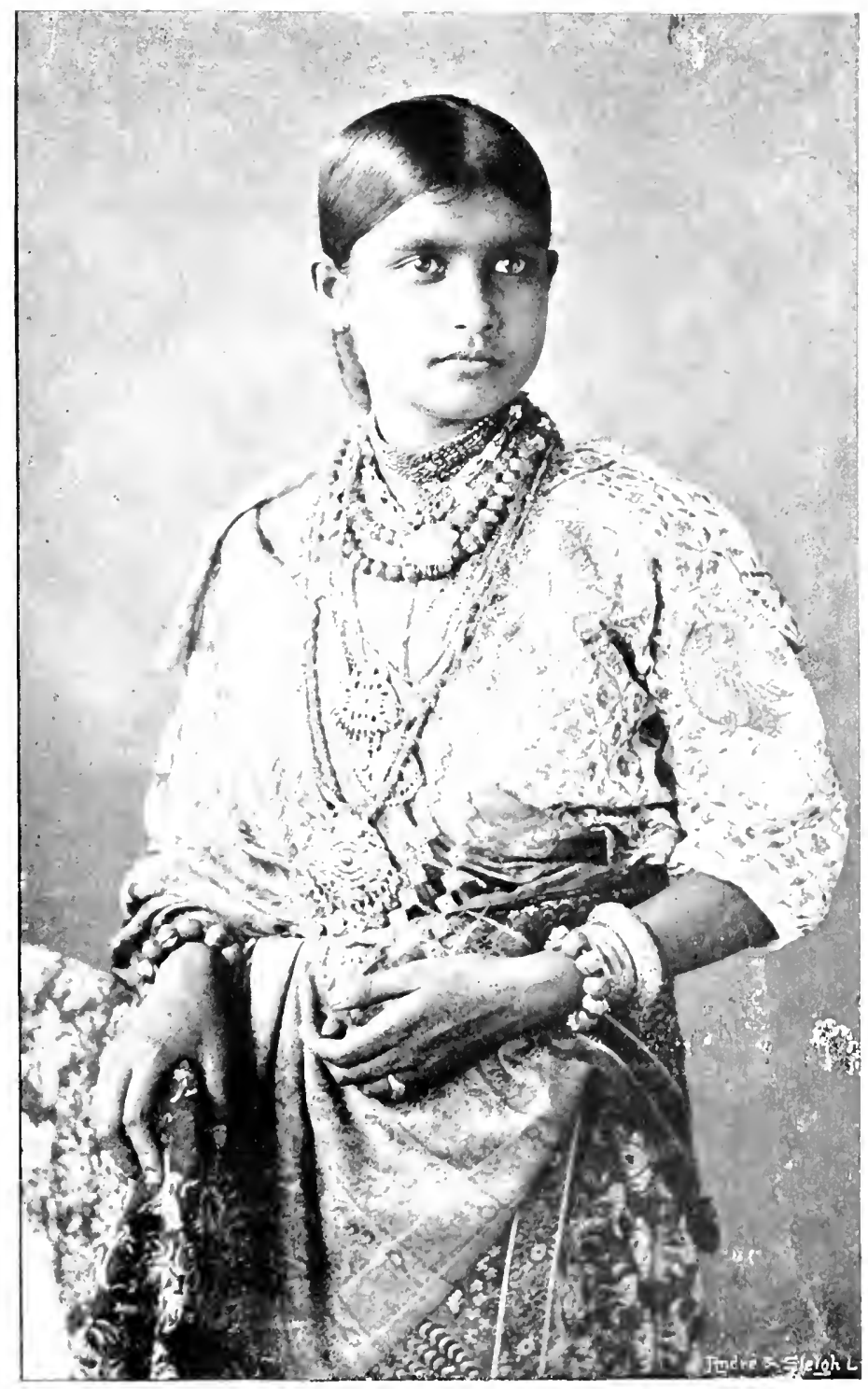

A KANDYAN LADY Note the Jewellery.

[Photo by Colombo Apothecaries Co., Ltd.] 

the white man prides himself, slould uot be looked for in the same degree in the native of Cevton. No amount of education will in general conform the native to the European wpe more than simply on the surface.

Another way in which the native imitates the ordinary European is by his "laziness;" it is usually difficult to get out of him what the white man, accustomed to a hard northern country, considers a fair day's work. It must be remembered that in Ceylon life-sustaining is easy enough in most places with the minimum of labour, and that making monce, which would seem to be the mainspring of the labour of the white man, is not much of an object with the native, who probably on that account has a happier life.

The native, at least the ordinary run of the lower castes, also dislikes responsibility, and does not rise to meet it, but rather tends to shirk it. For this reason, white mon must at present, and for a long time to come will probably continue to, fill most of the responsible posts in the colomy. Lying, again, is reduced to a fine art in this combry, but it must not be supposed that the native lics because he would rather not speak the truth; it is rather in many cases, an expression of politeness; the engurirer gets the answer that the man who is spoken to thinks that he wants, or the speaker lies from a desire not to give away any of his own personal movements, intentions, or desires.

Feudalism is still very prominent among the Kandyansor mountaneers at any rate, and the relative distinctions of rank are there very marked, whole districts being subject in a sense- to the local chicfs.

What would be termed in Europe bribery, but what is lere looked upon rather as a natural payment for service dome, is extremely eommon in Ceylon. This las been the national custom from time immemorial, and the native sece nothing woros in it.

Rajakariya, or fored labour for the benefit of the Goremment, is now comparatively extinct in the island, thomgle erey adult male must pay a road-tax of Rs. 150 w wolk for 6 days on the roads every yeal. Theore is rery little eloubt that a considerable amomint of service of this kind is aot he the lightere classes from the lower, and indeced it was by this metlond that the great dagobas, irrigation works, dec, in the north were built in ancient times.

The native is fond of plocessions, peraleras, and othere tamashas as they are often callecl locally. Ho has a weaknesis for employment moder (iovermment, like the Fromoman, and is ereat at petitioning the powers that be, often in the moset remarkable binglish, composed hy the petition drawer. 


\section{Chapter IX.}

\section{ARCILEOLOG'.}

C EVION is a very old comtry, with an art borrowed, introdueed, or derived from lndian, it is true, but ret mone the lesis distinctive and characteristic. It was a higluly civilised country 2,000 vearsaso, and has been more of lesidecastug for the last 1,000 rears. As is not infrequently the case in a decaring country, alt flominhed considerably, until about 6o to 100 vears ago, but now seens all but extinet. What the reason of this may be is doubtful. It may be that the taste for artistic work among the people is deal of dring, for the less said about the tastelesi way in which they frequently arrange their houses in what they are pleased to call European strle the better. Or again, it may be that the people cannot afford to buy artistic things, for of course, cheap though they may be, they can hardly compare in this respect with the Manchester and German gonds which the natives chietly affect. Or vet again, it may be that the natres wish to appeal like Europeans by copring their strle, thomsh they do this in por taste. The fact that the so laisely wear European clothes they generally explain in this way, and there is 10 doubt that should a clerk mow dress in native attire he would find it more difficult to obtain employment.

The fact then remains, that native ast is now very largely lead or dring, and that the penple in seneral are or seen to be content with Eurpean art if art it can be called of a cheap and tawdry kind. It is therefore largely amome the ruins and the old buildings that one must look to find really sond of satistactory examples of native art. There are extensive ruins at Anuradhapura, Mihintale, sigiriva, Polonnaruwa, de., and many line old buildings round Kandy and lumunegala and elsewhere.

The numerous ruins existines all over the morth, and other parts of the island are now beins excavated and conserved in as sond condition as posible by the agency of the Archeolosical surver kept up by the Gremement, and directed by Mr. I. C. I'. Rell, whose annual leports should be read by ans one particularly interested in archaeology. 
We may commence a sketchy acenunt of Cevlom ardachlogr by dealing brietly with Antradhapun, which is much the most accessible of the eld cities of the island.

\section{ANURADHAPURA.}

Going from the station to the town we come list of all upon the ruins, or rather remains, of the Brazen l'alace, a rast assemblage of 1,600 large monoliths, partly buried in the ground, and standing vertically like those of Stonchenge. Upom these there once stood the Lowa Maha l'ava or Brazen Palace, which appeass to have been in reality a momastery, erected by king Intugemunu, who came to the thome about 161 B.C. It is said to have been nine stories high, and to hare been roofed with brazen tiles, besides being rery splendidly omamented.

Turning to the right past this, we proceed along the Sacred Road, trodden by pilerims for hundreds of years, towards the Resthouse, and on the belt is a larege grassy plain or esplanade, more or less corered with ruins, usually in the last stages of decar, and represented by mmerous eject or sloping pillars, and by llights of steps and bases of walls. Just opposite to the road leading to the Resthouse is the Ruwanweli dagoba (p. 79), the great work of King loutugemumu, built between 161 and 137 B.C., rather spoiled by modem attempts at restoration, carried ont by the monks. It is said to have been 270 feet high, but is mow far short of that height. The entrance gate has been restored, and to the right of it is a poktma or bathing tank of a mique conical pattem. There are two platforms romed the dasoba, thomeh only the upper ome is in good condition, and upon this, to the left of the entrance, ane sereral statues of more than life size; the largest of which is popularly supposed to be that of King lhutugemunts. Much of the earlier part of the Mahawansa chronicle is taken up with descriptions of the construction of this dasolua, and it is related among other things that the people being poor, the bricks were miraculously made near Anmathapura he a mod, and pointed

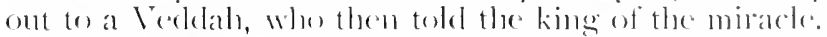

South-west of the Ruwanweli, at some distance, are two polimas, one on either side of the road leading to the Kaclederi; the mertlerm one has been patially restomed, and

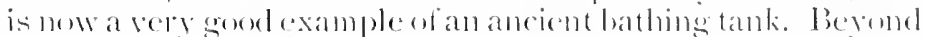
this the roid passes between the Kacheheri and the l'ost Office, and tums to the left, passing hetween there latere tanks in which there is water at poresent. The uppermost is for drinking, the next for washing, and the thind for allobies.

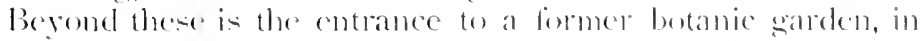


which the new hotel is being built, and yet further on is the Miriswetiva dagoba, partially restored by the king of Siam.

Berond the Ruwanweli to the north is Thuparama dagoba, the oltest in Anuradhapura, built in B.C. 307 by King Dewanampiya Tissa, to contain the right collar bone of Buddha. It is the most revered dagoba in Ceylon, and 50 rears ago was recoated with chunam (lime plaster) by a monk who collected offerings for this purpose. It is a small dagoba compared to many in the neighbourhood, being only 63 feet high, and round it are three rows of singularly graceful monolithic pillars, while at the sides of the flights of steps there are some fine "janitor stones."

About 100 yards to the east, and on the north side of the road, there is a beautiful carved cistern of stone, said to date from the time of King Dutugemunu. It is cut from a single block of granite, and is ten feet long, and very thin. Near it in a dreing ressel with a bollow at one end to contain the dye, and at the other end a flat surface upon which the monks' robes were laid out to have the dye worked in with rollers.

Returning to the Resthouse, in its very compound there has been excarated, in a comparatively complete state of preservation, the ruins of an almshouse, in which the monks used to be provided with food. There were probably many such refecturies in Anuradhapura.

Proceeding again northwards past the Thuparama, we soon

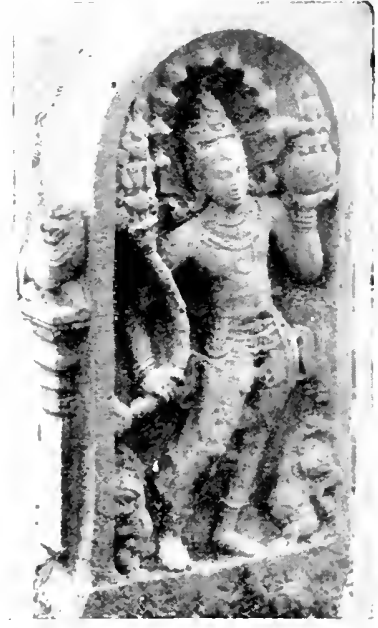

JANITOR STONE. come to the Lankarama dagoba, an ancient small ruined structure, the side of which has fallen away on the north, exposing the manner in which these dagobas were erected. Beyond this we come to the Circular Road, and if the path on the farther side be followed for about 50 yards a jungle path, rumning to the right, will be met with, and this leads to some ancient cave dwellings.

Returning to the Circular Road, and turning castwards, we sron come to a ruin popularly known as the Queen's Palace, but in reality a vihara (p. rog). Leading up to it there is a flight of steps with a "moonstone" at the base. These moonstones, which are semi-circular, are common in Anuradhapura, 


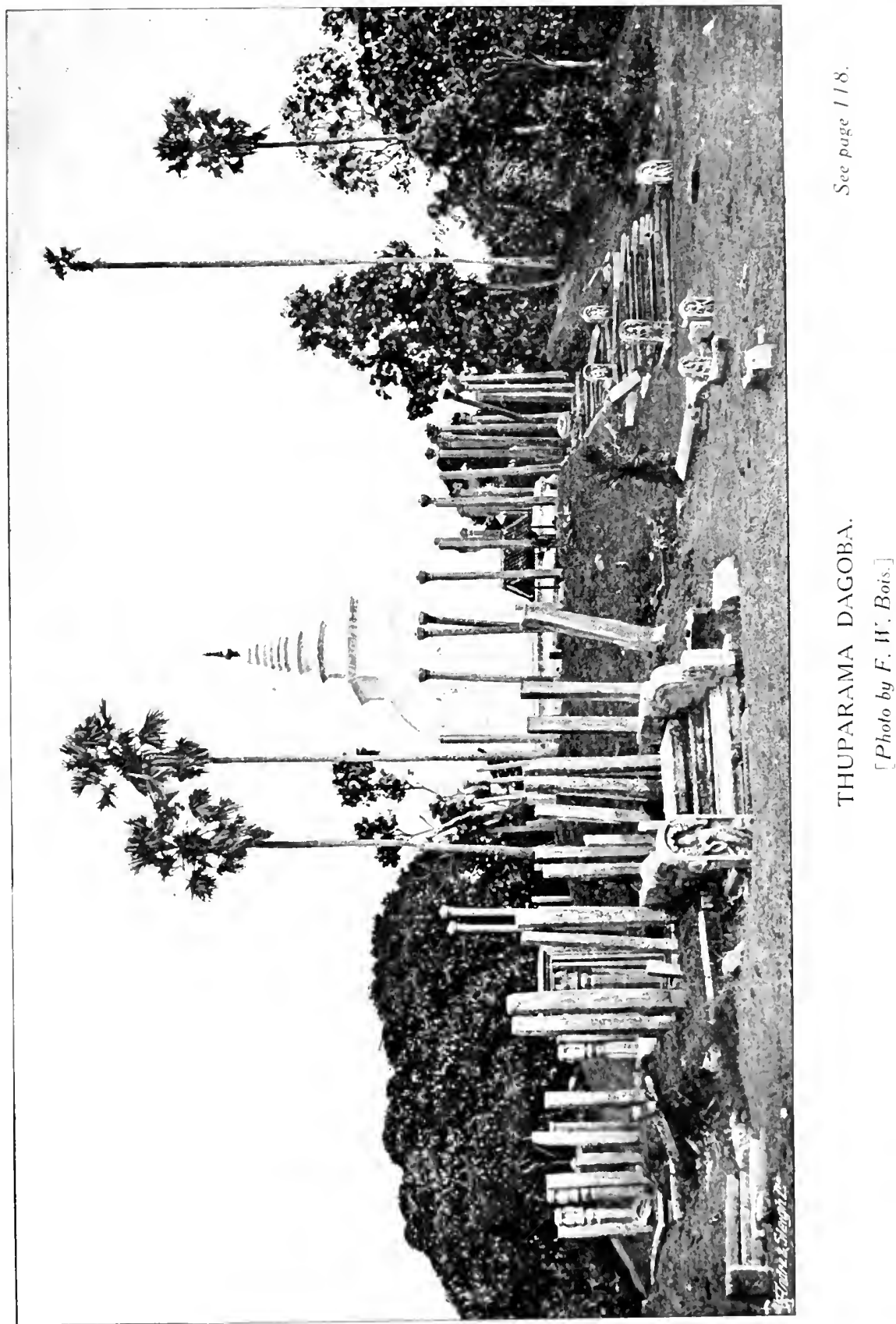



and the best of all may be seen at the King's Palace (below). Ther are all of much the same design; the onter' border usually shows the elephant, horse, lion, and Brahmany bull in procession, and is followed, proceeding towards the centre, by circles with designs from the lotus flower, a procession of the sacred goose or hansa bearing lotus buds, and more lotus designs.

A little further on, at the $3 \frac{1}{2} \mathrm{~m}$. post, there is a square stone with nine cubical holes cut in its upper side at remular intervals. There are several of these stones in Anuradhapura, alwars quite regular, with 9 or $^{*} 5$ holes cut in them, and what may have been their use or object must for the present lemain doubtful.

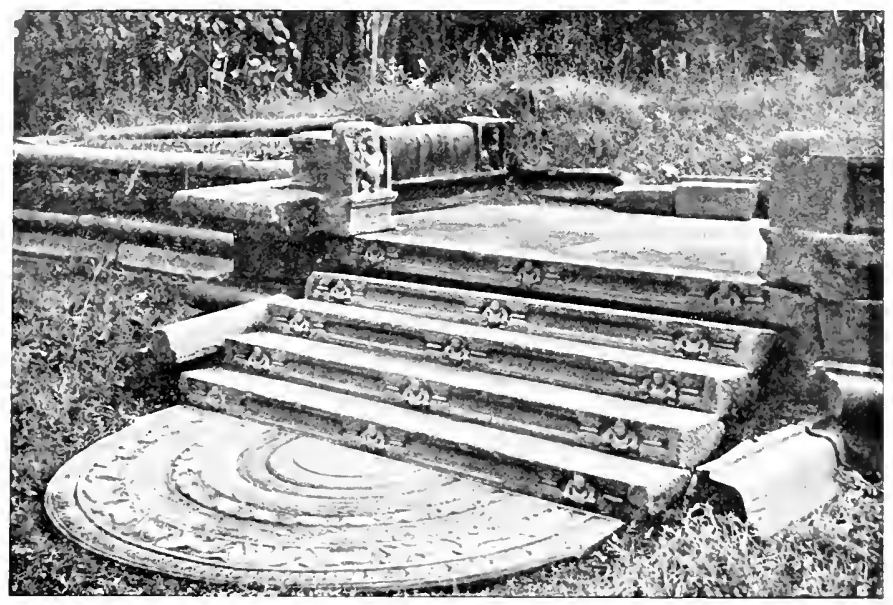

FLIGHT OF STEPS AND MOONSTONE.

Near to this, on the south side of the road, is a larege pokuna or bathing tank, of which there are many in the town. Nearly opposite to this is a fine stone canoper, which has been restored. Near to it are three sambas or inseribed stonces. These are monsually fine specimens, but steh inscribed stone tablets are common in Ceylon. A little further on we come to the well known "stone canoes," thee emomous loblow stones, two of them momolithis, which ate supposed to have been the receptacles of the fond given by the king to the monk:.

Further aboug this road is the socalled Kinges l'alace, another vihara, with the finest monstone and steps that have

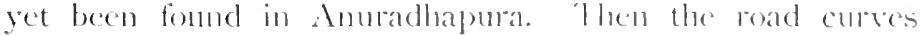


Found the Jetawanatama daguba, built by King Maha Sena about 300 A.1). It height was 249 feet, but it has sunk from that, and is now coreled with trees, and in a general state of ruin.

Just berond the fourth mile is a large sedent statue of Buddha, a specially fine one, which is an object of great veneration to the innumerable pilgrims who visit Anuradlua pura.

At $4 \frac{1}{4}$ m. we come to the Kuttam Pokuna, or twin bathing tanks, one of which has been more or less restored, and is in rery good preservation, and the carring on which is specially woitly of examination.

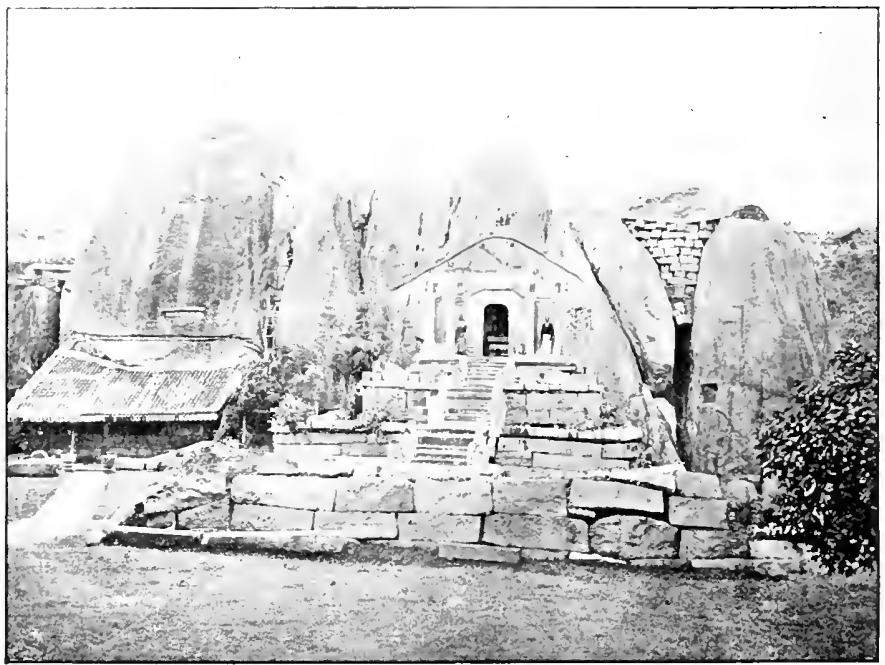

ISURUMUNIYA TEMPLE.

The road now roms on for some distance till it reaches the Abluargiriva dagoba, the largest in Ceylon, and once 405 feet high, but now reduced to $23 \mathrm{r}$. It was falling down, and was partially restored by prisom labour some time ago, but is still somewhat unsafe. It was built by King Walgam Bahu about So B.C. Finm its summit one obtains a fine view of Anuradhapura and the surounding eountry. The chapel on the western side shows some fine carving, especially a large seven headed naga of cobra.

Not far from this dagoba, on the south side, is a huilding in which may be seen (partly restored) a beantiful Buddhist stone railing. 
PLATE XL.

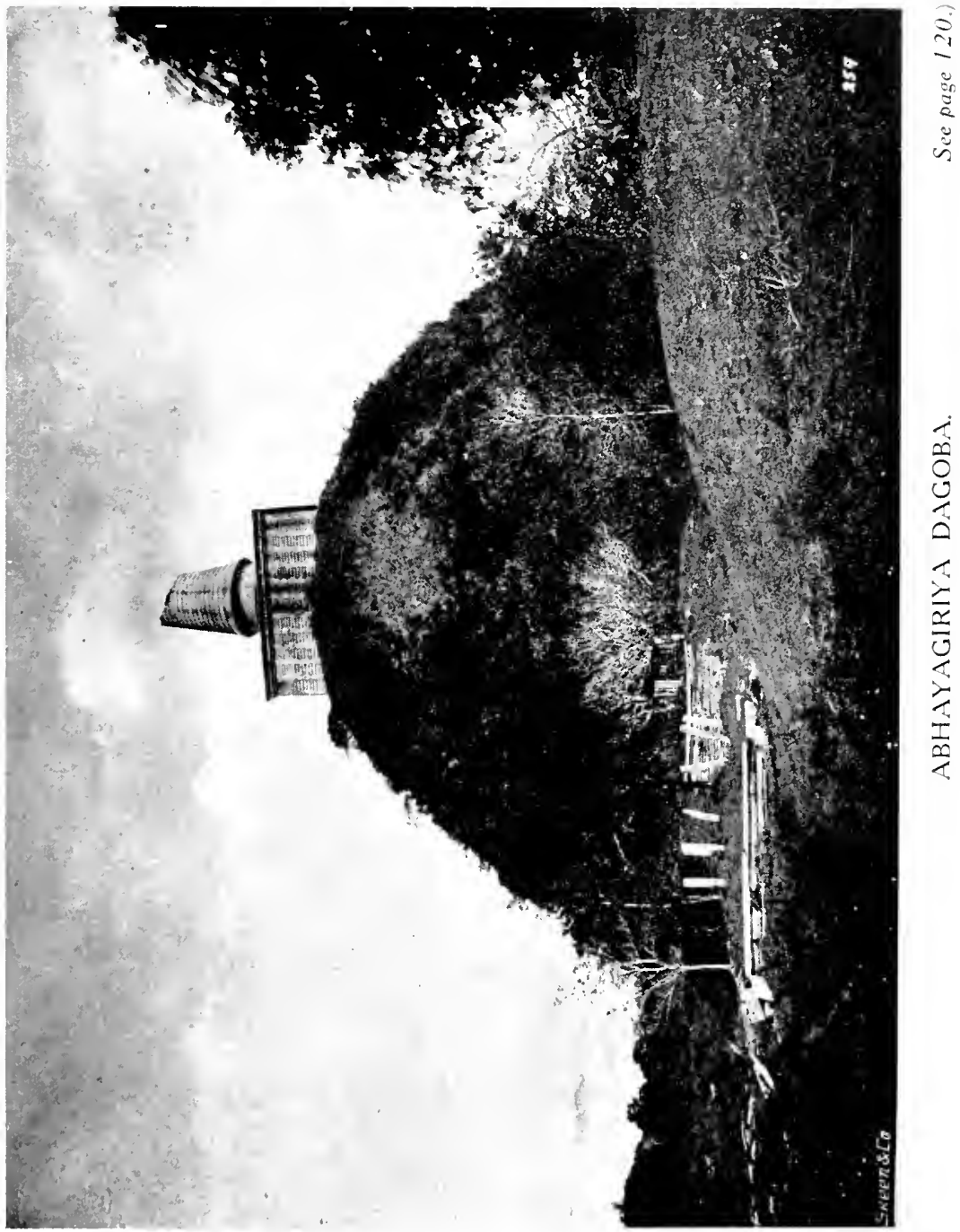



The visitor should next go southwards from the Resthouse along the sacred road, and will soon come to the enclosure round the sacred Bo-tree (p. 65). This grew from a branch of that under which, at Buddha Gaya in North India, Gautama attained his Buddha-hood, and was bronght with great pomp to Cerlon (p. 78 ) in $28 S$ B.C., so that if the present tree be in reality the original one (as to which there is some shadow of doubt) it is about the second oldest tree of which there is any historical reeord, the oldest being the tree of Confucius, which dates back to 500 B.C. Its platform has been gradually built up, and is now very high, the separate branches of the tree emerging from the soil at some distance apart. The fallen leaves are regarded as sacred relics by pilgrims.

At the entrance to the enclosure is a good moonstone, while the balustrades of the steps are formed of quaint mythical animals, half elephant half crocodile. Inside the grove, in which are several Bo-trces, offepring of the original one, is a statue of Buddha, and several other statues, and many half tame monkers may be seen ruming about (p. 19).

Going further south along the Kurunegala road for about half a mile, and turning off to the right across some fields, Isurumuniya Vihara, the most picturesque in Anuradhapura, is reached. It is a rock temple, with a little pool in front of it. The shrine has two terraces, with good steps and janitor stones, while the stone doorway is beautifully carved. The shrine itself has been recently painted. $1 \mathrm{t}$ is worth climbing to the top of the rock for the sake of the view, and a return should be made along the bund of the Tissawewa tank, which is close behind the temple.

\section{MIHINTALE.}

The mountain of Milnintale lies abont 8 miles east of Anuradhapura abong a good road, and there is a Resthouse there (notice should be given). The mountain stands isolated, and is about 1,000 feet high, forming a very conspicumb object. Lpon it (p. 78) Mahinda the son of King Acoka is supposed to have alighted and was there met by King Iewanampiya Tissa, returning form a hunt. After a short interview the king was converted to buddhism, and this was som followed by the conversion of the queen and about 40,000 of the people, si that before very long Buddhism became the national religion of the country.

The summit is approached on the castern side he a vast number of steps, said to be as many ats $1,8,0$, arranged in four flights. Some distance up the third flight is a path on the left 
leading to the remains of an aqueduct near which is a huge stone trough (cf. the stone canoes, p.1 I9). A little further on there are some steps on the left, which lead to the ruins of a shrine, at the entrance to which are some fine inscribed stoncs. Ilalf way up the last flight of steps we may turn off to the right and reach the Naga Pokuna (snakes' bathing place), a large bathing tank at the back of which is a fine five headed cobra carred in the rock. There is a good inscription on a rock near the top of this flight of steps.

Finally the Ambustala dagoba is reached. This is said to mark the spot where Mahinda met the king, and to enshrine the ashes of the former. It is built of stone, instead of brick, and has a terrace round it with fine pillars. Y'et another flight of steps leads to the Mahaseya dagoba, built over a hair that grew between the eyebrows of Buddha. Leaving the Ambustala in the opposite direction to that by which we entered, we come in about a quarter of a mile to Mahinda's bed, a flat slab under a natural arch in a very pretty situation, with a fine view.

\section{SIGIRIYA.}

This wonderful natural fortress lies about $5 \frac{1}{2}$ miles firom the village of Inamaluwa, itself a few miles east of Dambulla on the Trincomalie road, and may be reached by cart or bicycle firom lambulla; the ruad is also practicable for motors. There is a Restlonse at the foot of the rock, but notice of arrival must be given.

Beside a little irrigation tank there rises to a height of about 400 feet (Plate XXI') a wonderful isolated cylindrical rock, upon the summit of which the parricide King Kasyapa I (p. So) trook refuge, and which in those days must have formed a fortress impregnable to assault, though it might be possible to starve the garrison out. Water was collected in large tanks at the summit, so that thirst was unlikely to aid in its subjection.

For many vears nothing was known about the place, though a few adventurous climbers had reached the top, but in 1895 the Areheological Survey began work upon it, and now the aseent hat been made comparatively easy by the affixing of iron stairways with handrails. One risk is that of an attack by bees, of which there are many upon the rock, but mosquito curtains may be taken if this is feared, and if attacked it is better to sit still without morement. Ticks, as in all the dry country, are also very troublesome after March, but may be guarded against by the use of puttees and "Bamber-Green" oil. 


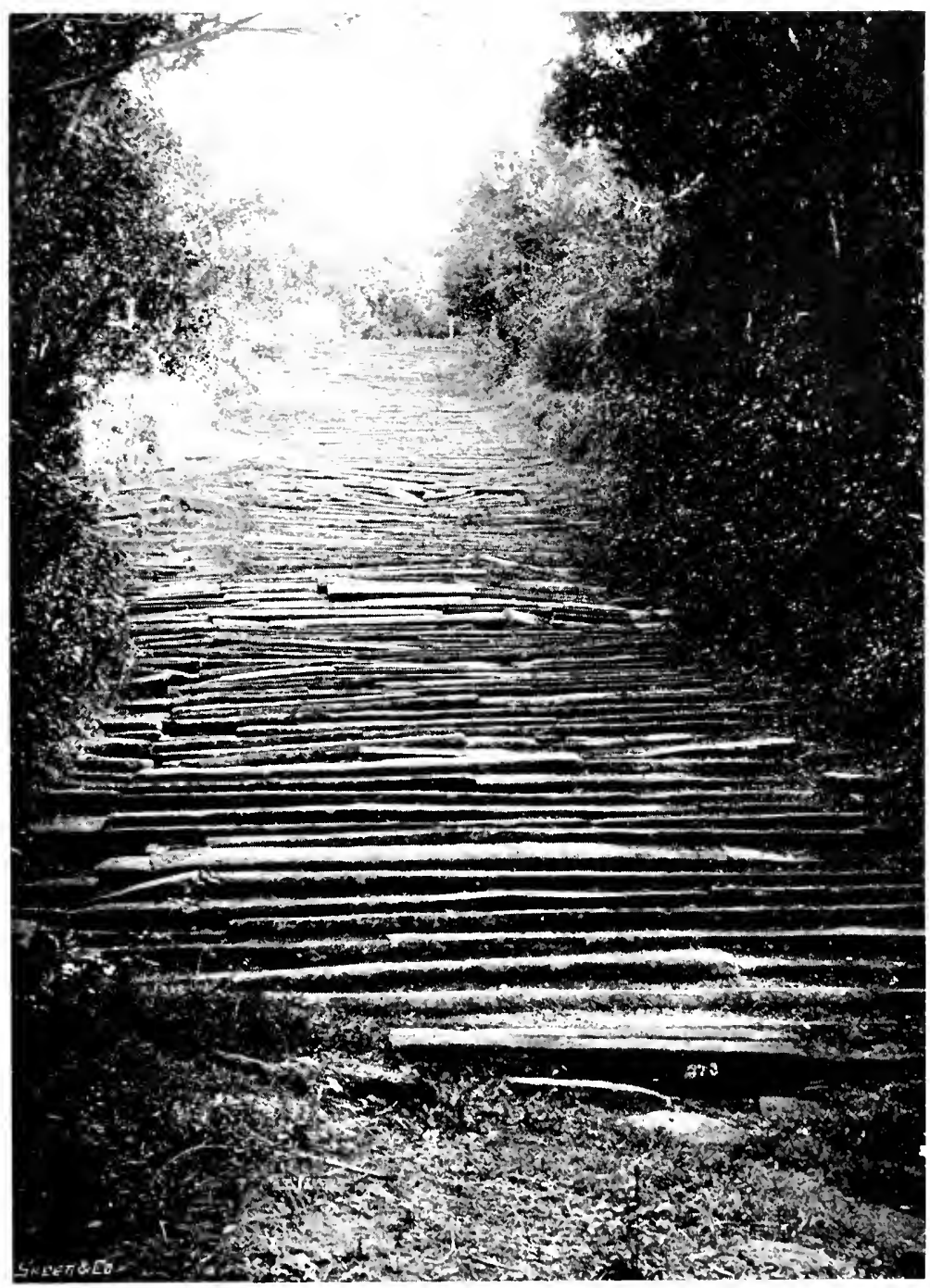

FIRST FLIGHT OF STEPS AT MIHINTALE.

See page 121.) 

Going round below the rock, we soon come to a stone cistern, below which is an Andience Ilall, fincly cut in the solid rock. From the cistern one can work up the rock, partly by the old staireases, partly by the modern iron ladders. On the first platform are some rooms that have been excavated, and at the sides of the flight of steps leading up fiom here are the gleat claws of the lion to which the place is supposed to owe its name (Sinha-giri, the lion rock).

The following description of the excarations upon the summit is given by Mr. Bell:

"Directly in fiont, looking south from the vantage ground of the east to west cross bank, stretched below as far as the central pokuna, is so much of the lower area as lies between the rock's north and eant edges and the high ridge that occupies the western half of the summit. Most here is comparatively level the only level portion of any extent in a citadel where terraced arangement was inevitable from the irregular conformation of the rock's surface. This area was seemingly allotted to court-yards, passages, ard side rooms. Half-way a winding staircase of three or four llights of steps - the longest on the rock, and pierced at its head through tall flanking wallsshows the means of direct communication with the upper area to the west. At the side of these stairs is the magnificently carved "gal-asanava" or granite throne, discovered in 1805.

"On the left, skitting the east edge of the Rock, was a range of minof rooms and passages, doubtless communicating with an outermost corridor, which almost encircled the citadel. This series of side chambers was continued on to near the south end of the Rock, interrupted only at the pond where extra rooms \&c., intervene.....

"That part of the ancient citadel lying south of the pond, and east of the high level strip, was laid out in a series of cross-teraces, east and west, varing in width- and fallins away southwards. Fom the pokmo to the foot of the last staircase at the extreme south are seven or eight distinct teraces... The centre is taken up with an open cont-rard and passages leading to the pond, and round it, on either side, by stairs and intermediate landing - all admirably planned to suit the plysical conditions, and displaying soreat insenuty in turning to full aceount the limited space and surface incepualities of the Rock's stummit.

"More than one of these teraces has been curtailed and

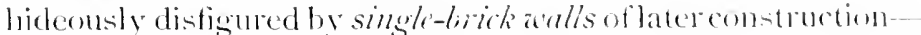
"patehed up into a smoothness and smugness" Ruskin forcibly promounces "more tragie than uttermost ruin."

"The lowest staircase at the south-west colnel of the Rock - leseend with a right angle return to the "watch-cave" 


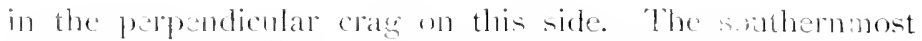
terace, to the eant of these stairs, was clearly dedicated to Cloacina.

"of the higher level half of the summit I have already spolecte a contaning a sucession of apartments, rising in tiers ourthwards.

"The backbone, as it were, of the citadel is found in the pared way, with stepi dezending ever and anon, that was carried along its axis fom end to end, lunging the retaining wall of the upper ridge, and winding with its angles, but for the most part rumbing straisht as an arrow. From this "spinal column" branch off, east and west, staircase "ribs," which would render communication between all parts of the citadel easy and rapid; whilst each section wasequally well served, by the cunningly deaisned interennection of its own component divisions, thremste a maze of mines passages and stairs.

"No lesi perfectly planned was the araler supply. The rock-luewn pokuna, nearly 30 vards square, centrally situated and accesible foum every side, would suffice, when replenished yearly by the northeast momson rains, for ordinary requireimconts diring the ensilug dry months. For drinking water resont was had, in atl probability, to two at least of the three smaller cisterns close to the Rock's north, south-west, and sontli-cast edges.

"A word or two regarding the arditectural comstrmation of the citadel.

"Further lengthening of the deep longitudinal trench, begum last rear firm the extreme southern verge, contions the impresions that the foundations were throushout the low-lerel area, in general, of that form of stonework known as "irregular luorizontal," and run down to the rock core. Lpom this rested brick walls, rertical or in batter, plain or moulded acending to pustion and parpose, but all alike coated thickly with a tombly plititer, white and polished, that has resisted the damp in places to this day. The massiveness of many of th se wall bespaks comsiderable height originally, (lespite the fact that the brickwork was almost druaid and inclifferently bunded crostrise. But in "make" these ancient bricks some a cubit in !ength shame most of our modern outturn, beins as well bunt as they are sharp and close.

"Of the system of reofing we know nothing berond the certainty that it was timbered throughout and llat-tiled, in the stye familiar amone the Anuradhapura ruins.

"I matied teature of the erround plan is the rmatic location of sleps. Is often as not, they are pushed aside fiom the centre of the romms into which the lead, and relegated to all sorts of odd corners. This vasary was no doubt forced upon 
PLATE XLII.

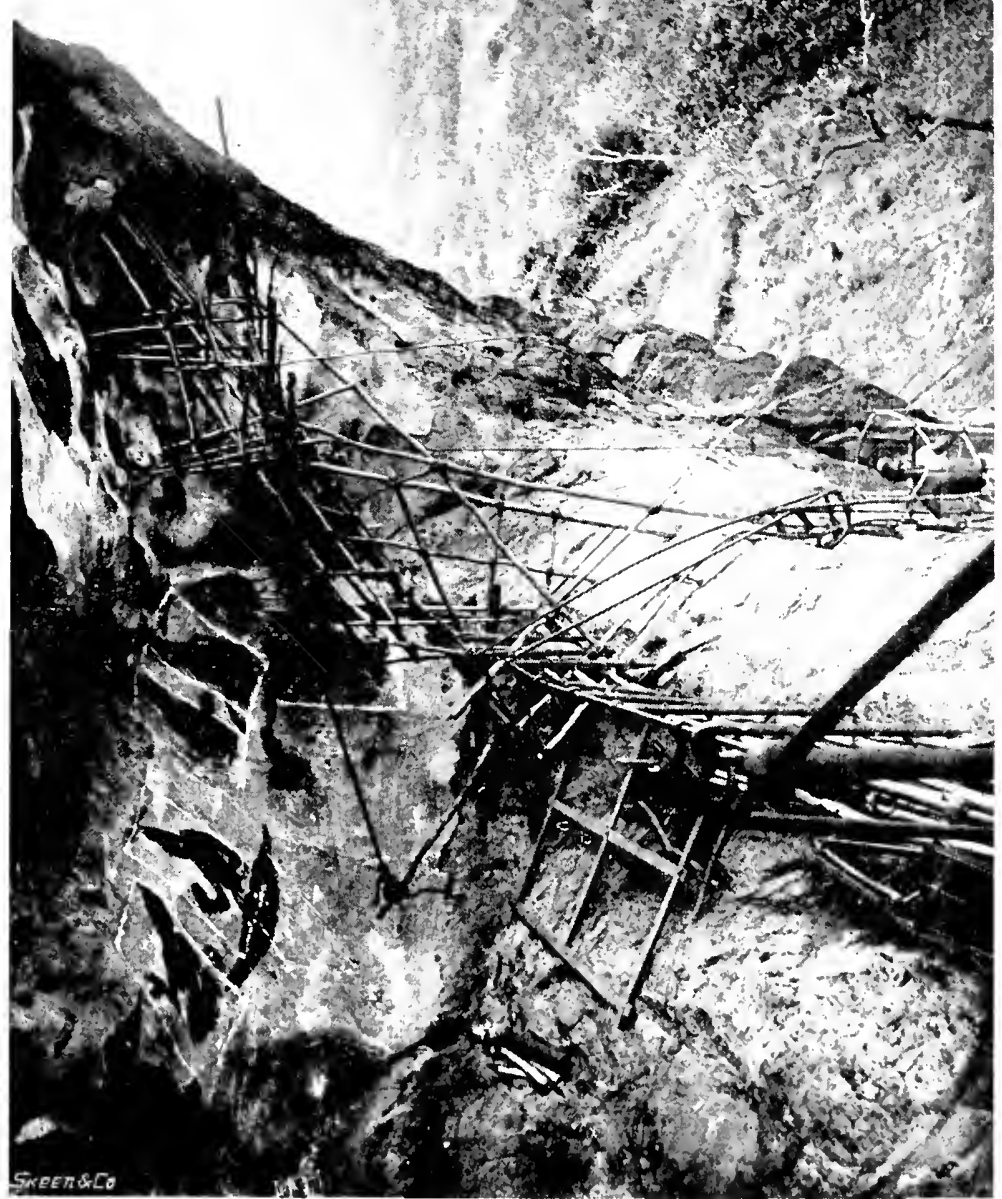

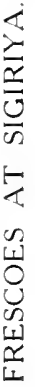



the architects by the uncontormable surtace of the rock, which had to be reckoned with everyhere.

"But noteworthy, above all, is the complete alsence of monolith pillars and slone-caraed donrears, the most salient characteristic of ancient structures in the island. While quartzons steps and flagstones were lavishly employed to enhance the beauty of this peerless citadel, not one fragment of column, door-fiame, or windowsash in stome has come to light on Sigiri-gala. Above the floor all was of brick or wood. As for gneiss, with the sole exception of the noble throne above mentioned-like silver in the daye of Solomon- "it was nothing accounted of," and finds no place in Kasyapa's citadel.

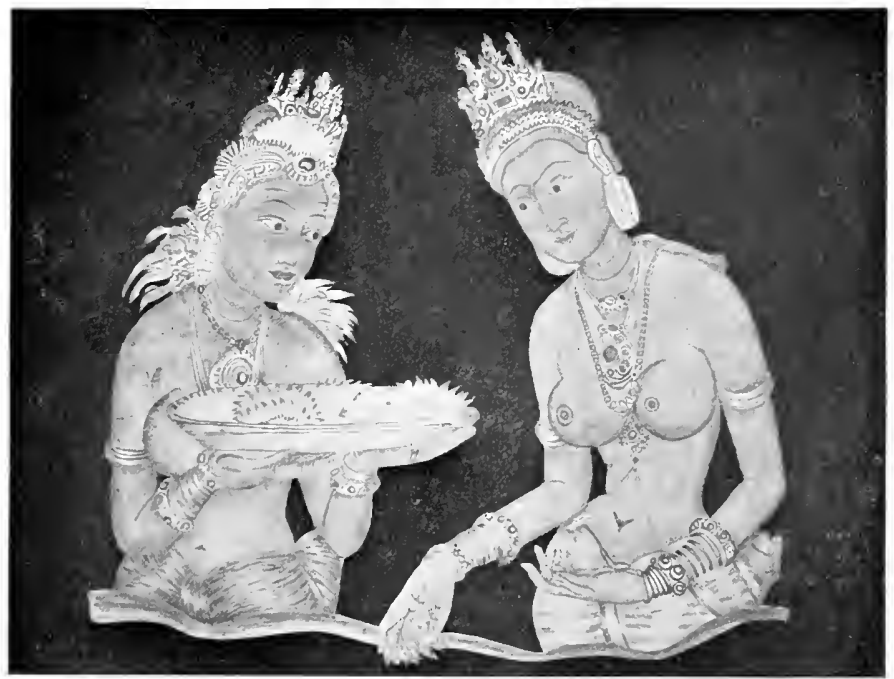

FRESCOES AT SIGIRIYA

"The next place to be visited is the gallery, the plasterom the wall of which is still fiesle in many parts. High abose this is the almost inacessible picture gallery, reached with much difficulty by Mr. Murray of the I'ublic Norks lopartment. The pictures have been eopied in oils by Mr. Perera, the drauglisman of the Archeological Surver.

"The scene intended to be pourtrayerl womld seem to be a procession of the queens and prinesses of Kasyapa's count, with their attenclants, on the way to worship at the Buddhist 
vihara at Piduru-gala, the hill lying about a mile north of Sigriva. The figures are manifestly all moving in that direction, and the flowers held in their hands by the ladies, and carried after them by servant-maids, can hardly bear any other signification..." (Bell).

\section{POLONNARUWA.}

To visit this place is a more arduous undertaking than any of the others, as it is $2 \mathrm{~S}$ miles from the Trincomalie conch road, and there are mo Resthouses, though a bungalow (unfurnished) can sometimes be had (apply to the G. A. at Anuradhapura). The road is a sravel road, and in good enough order fiom January to March. It passes the great tank of Minneriva (below) one of the loveliest spots in Ceylon, where there is an unfumished bungalow on the bund, belonging to the lrigation Department (to whom apply for its use), a beautiful place to stay at were it not for the number of malarial mosquitoes, which are quite likely to bring on a sharp attack of fever unless gruarded against with extreme care.

Polommaruwa became the capital of Ceylon in 769 A.D. and most of the buildings, though rery much ruined, are yet in much better preservation than those at Anuradhapura, which are much older and were more exposed to the invaders. They nearly all lie in a line ruming north fiom the bungalows, which are themselves near the bund of the local tank, the Topawewa.

The first ruin reached is the kotuwa or fort, more probably a palace, with very thick walls of brick, and to the enst of this is a parilion the stones in the wall of which are very gracefully curved.

About $\frac{1}{4}$ mile further north is what is locally known as the I alada Maligawa or temple of the tonth, but which appears really to be a temple of Siva (p. 99), and is of very Hindu design The whole of Polonnaruwa shows much Hindu influence, as indeed is hasdly surprising when we remember the intercourse and conquests that had gore on.

Vorth of this lies the Tluuparama, a large brick building with a squat tower, and almost opposite this is the Wata bage or round relic house, a circular building with four staircases, inside which are a ruined dagoba and a broken Buddha statue. Close to this is the Ata Dage, another relic house, and near this is the Gal-pota or stone book, looking rather like a gisantic collection of olas (palm leaf strips, upon which manuseripts were written with a stylus; many may be seen in the Kandy temple, and they are sold to passengers at 

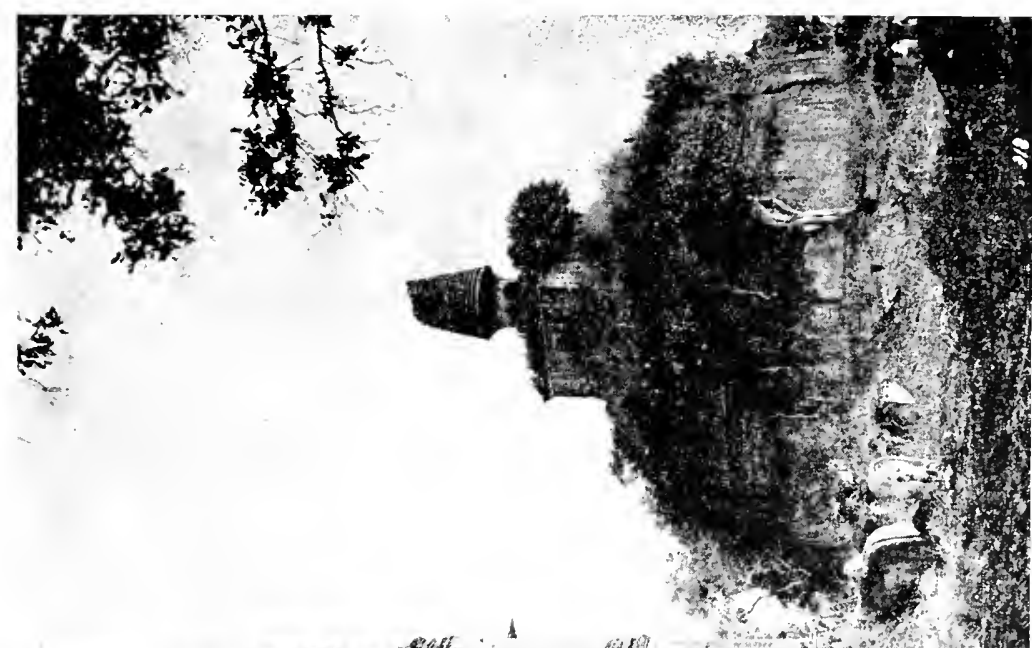

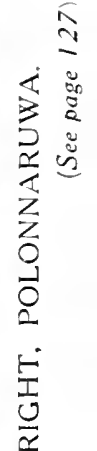

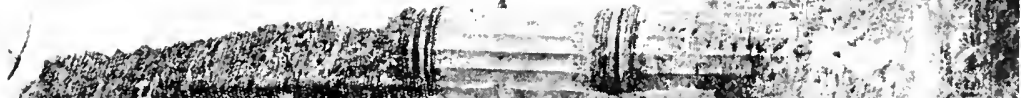

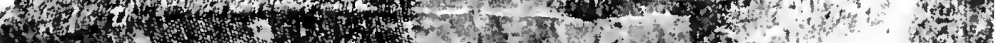

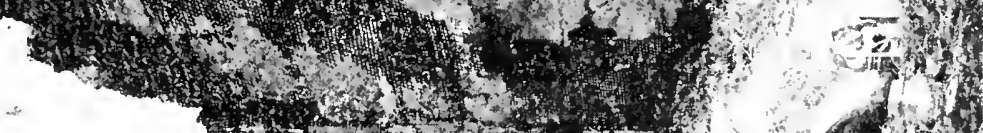

象.

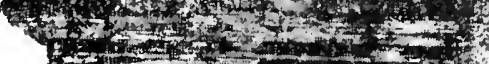

.

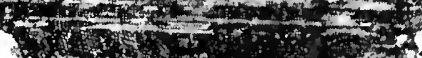

4
1

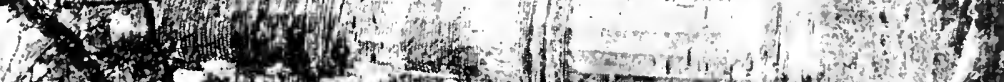

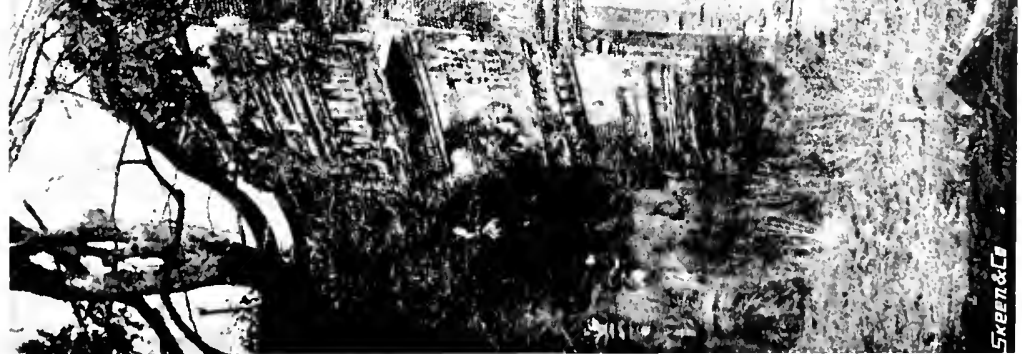

F

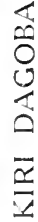

三

$\geqslant$

i

$\frac{1}{3}$

㔻 

the little sluops in the hotel rerandahs). "The "book" records the deeds of King Nissanga (A.I). I 192), and is said to have been brought from Mihintale.

Close beside this is the Sat-malual-prasada, a curious seven-storied building, which is still in fair preservation. What exactly was its use is a matter of some doubt.

Half a mile to the north of this lies the Rankot dagoba, which is 200 feet high, and is still in good order, even the statues round the spire being visible. Passing this we come

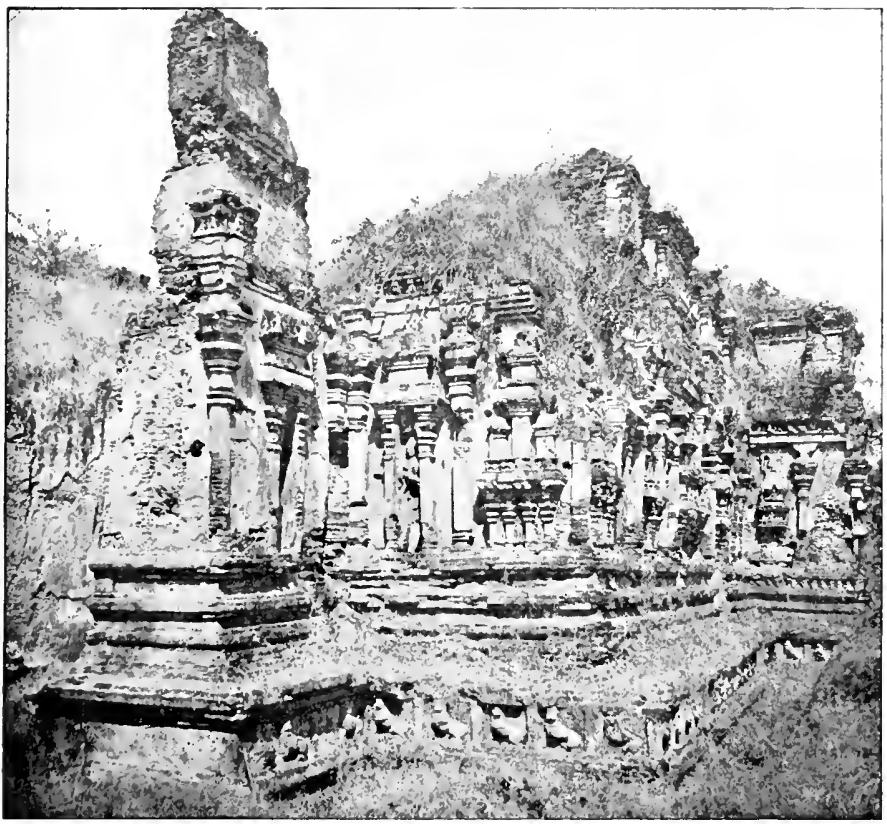

DEMALA MAHA SEYA.

to the Jetawanarama, a fine building about 150 feet long, at the inner end of which is a brick-built Buddlua about bo feet high. Beside this building is the Kiri (nilk) dagoba, about 100 feet light, with a broken spire at the top.

North of this again is the Gal viluara (rock temple), the gem of Polonnaruwa. There is a litkle shrine cut out of the rock and containing a sedent Buddlua, while beside it are three fine stone statues, a buddha seated, his priucipal disciple Ananda, and a beantiful recumbent Buddlua of great length. 
Still another late mile north of this, through a patch of jumgle, is the Demala Malua Seva, the ruins of a large building covered with llindu figures.

To the southward fiom the bungalows there is nothing of special interest except a fine statue of King Parakrama Bahu, carved from the solid rock, about $1 \frac{1}{2}$ miles away. This statue (fig. on P. So) is well worth a risit, and the walk along the bund of Topawewa tank is pretty.

These are the four seat centres for the study of the archandogy of Ceylon, and with the exception of Sigiriva it will be at once noticed that all these ancient remains are "ecclesiastical." The habitations of the people, even of the kings and nobles, have passed away beyond recovery and one must therefore conclude that they were of a very perishable nature, and that however grand and imposing the sacred precincts of the ancient cities may have been, the parts inhabited by the general mass of the population were not so, but were more akin to similar places at the present day.

One relic of ancient times which is not "ecclesiastical," but which in seneral is of little interest unless restored, and which is extremely common, is the remains of the old irigatiun tanks and canals ( $p$. 74 ), of which there are literally thousands. In such places as Kalawewa or Mimneriya, where the breaclues in the old bunds have been filled up, and the tanks thus restored, there are now to be seen some of the most picturesque sights in the island, and every year, as the dead trees which are still standing in the tanks decay and fall, the beauty of these open expanses of water will increase, while as they are at present surounded by forest, they resemble national lakes.

\section{KALAWEWA.}

A very interesting excursion may be made to this now restored tank, and if leave can be sot from the rrigation 1) partment to use the ir lungalow, and furniture and supplies be taken, the night mas be spent there; otherwise a retum must be made to Kekirawa Resthouse, a distance of $\mathrm{S}$ miles.

Proceeding from Kekinawa, the road rises as the tank is approached and at the foot of a little forest-covered hill on the left, reaches the and of the lake, where, if the visit be timed about the end of the rear to get the tank full of water, a fine prospect bursts upon the riew, over about 8 square miles of Water, with the distant mountains in the background. Almost at once the great sluice of the Vodi-cla (p. $7 f$ ) is crossed, and a deseent should be made to the canal, to realise the enormous 
PLATE XLIV.

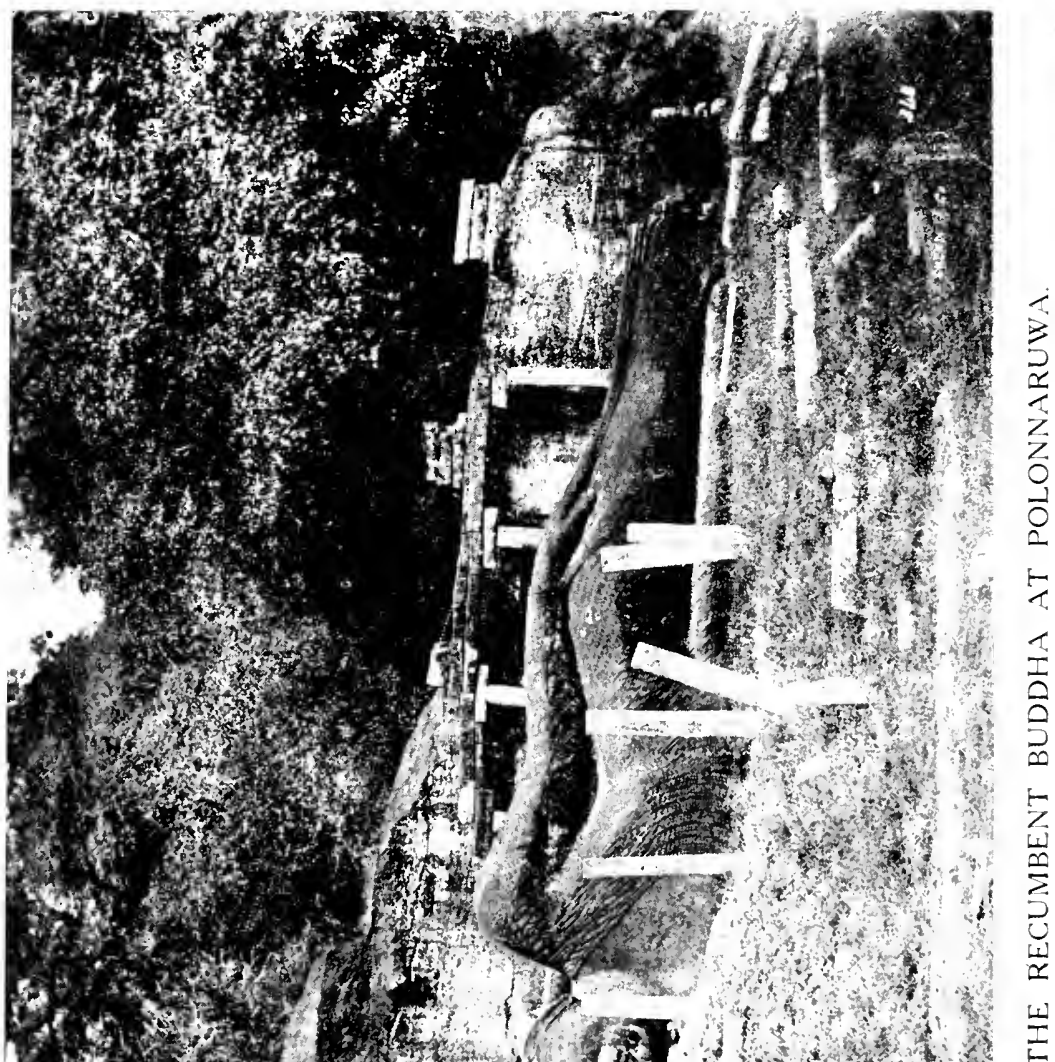

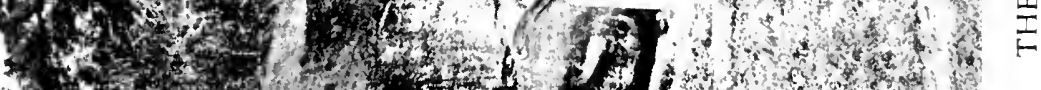

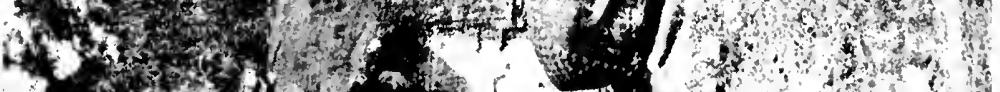

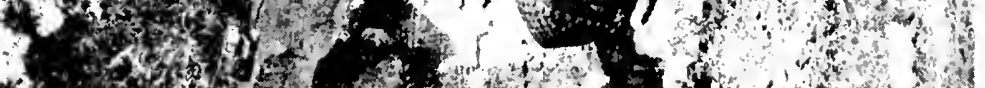
19. 3. 

height of the great bund of the tank, and the size of the stream flowing from it to the minor valleys lower down. Returning to the top of the bund, the road proceeds along it for a couple of miles, and then descends under the ancient spill of the tank, which it will be at once notieed is higher and much shortey than the modern spill which lies bevond it. Uyon this old spill stand a number of curious pillais, made in two sections with stone collass at the joints. At the bottom of this hollow the road crosses the stream. Which is particularly beautiful, oremone by ancient trees, and as clear as crystal. If the bungalow is not to be used, this is by far the best place in which to breakfast of lunch. A little further on the road rises to the bund of the balaluwewa, the sister tank, divided from Kalawewa only by a nawow bund, in which is a breach, and upon which is the lrigation bungalow, in a beantiful and air situation, commanding a lovely view. The total length of the combined bunds of the two tanks is about 6 miles, and ther are about 60 feet high, so that their construction must have meant an emormous amount of labour.

About two miles to the westward of the bund of lialawewa, and to be reached by walking across the ficlds, is the Awukuna Buddha, pertups the finest of all the stone Buddhas in the island. It is carred ont of the rock, to which it is attached by ribs of stone, and is about 34 feet high. Every detail of the drapery is still perfect, and the statue is a singularly beautiful one, white foom it there is obtained a lovely riew.

\section{MINNERIYA.}

This tank, which has been compared by Temnent to an eastern killarney, and which is certainly extrencly beatiful,

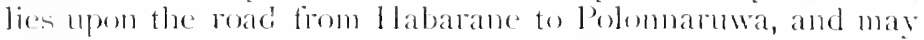
be rearhed by a short detome. Though now restored to something apponching its fommer size, it los always held a fair amoment of water, and consequently does not eontain so hang dead trees as do most of the more recently restored tanks. The view form the top of the ereat homel is verv fine, over many sefuare miles of open water, with weroled hilly promentories and islands, and eleep bass, bateded be the distant momentains of the distriet moth-eat of liandr.

\section{DAMBULLA.}

The striking feature of the plare is a valst isolated bouldere of rock, with smooth sicles, rising to a height of 1,000 foret. Upon this is a touse old rock trmple, built in the reigne of Walagam Babur (sueceeded 10.4 li.C.) one of whose many 
places of refuge this had been during wanderings of fifteen veals while his kinglom was oceupied by Malabar invaders. "The temple is characteristic of the numerous rock temples which are so commen in the Kandran district, but a good deal larger, and eonsists of tive separate cluambers, in which are numerous statues (includines a vers fine recumbent buddha, cared out of the rock, and about 47 feet long), while the soping ront is corered with fiescoes, many of which are very s). The old paintings are much fines that: the modern ones, which contain ton many colours, and are hrbridised with other art.

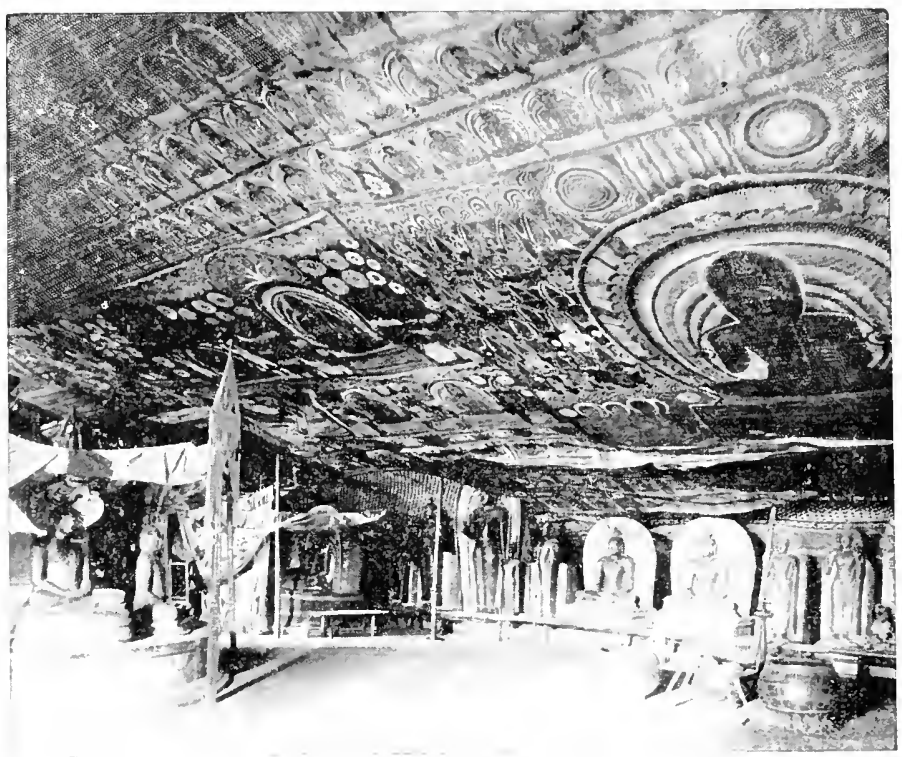

INTERIOR OF ROCK TEMPLE, DAMBULLA.

\section{ALUWIHARE.}

About two miles from Matale is another of the resting places of King Walagam Bahu, rendered famous by the fact that after his recovery of the throne of the kingdom he caused an ascemblage of Buddhist monks to meet here and transcribe the budelhist seriptures, which had previously been handed down by oral tradition from Malninda. It is a fine rock temple in good preservation. 


\section{RITIGALA.}

Ritigala is the isolated mountain which is so conspicums to the south-cast of Anuradhapma. It is 2,506 feet high, and its summit is woth reaching, for the sake of the magnifieent view it commands, wer Cerlon from sea to sea, with irrigation tanks, stretehes of rice fields, smaller hille (including Sigiriva) sce, spread rut below. It may be reached from llabanane Resthouse; and there is an empty bungalow belonging to the Public Worki Lepartment (to whom apply for its llse) at Calpiticala, at the forst. The water here is umusually bad, and all required fould te brought fiom llabarane. The ateent is fairly hard work, the distance being about 3 miles on the level, past the very pretty tank at Caalpitigala, and z miles upward at a -teep angle. St the bottom of the hith, orergom

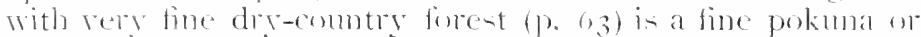
bathing tank, orertowed by some cave dwelling while leading upwards fiom it ic a long stome stairway.

The thora of the top of the momtain is specially interestins, for it so high that it acets rain in both monsouns (p. 13), anslupon its stmmit are numerous plants of the "wet "southern montains, including a number peculiar to the monntain itself.

\section{GADALADENIYA AND LANKATILAKE TEMPLES.}

These temples, though old, are in practically complete preservation, and in resular nise, and it may therefore seem

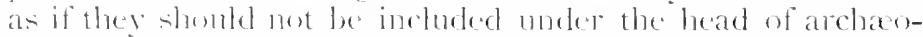
loge, but as nothing similas in now erected, on seems likety to be crected, it is perhaps better to comsider them as alos reprenenting the nearly definct atts of the country.

(of the two, though lankatikate is the more fimous and better linomm, Crataladenisa is the mene interesting and preturesple, and hat the further advantage of being mold more rasily reached. At a little village named Embilnigama, about "miles form Kandy alonge the road to Kadugamawa, is a tomong to Parallagama, along which (it is merely a fiot path) Gadaladenigat temple is reached in alout hatf a mile. From thenee it is about two mikes to lankatilake, and firom

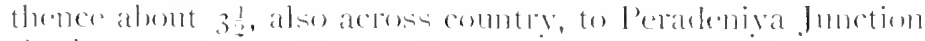
Station.

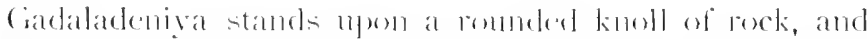

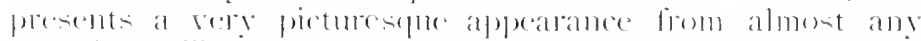

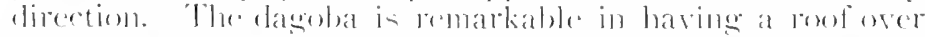
it, and under it in a -inall chambere containing a sedent budellat. Another buddha is on the right side of it, and ret another in 
a chamber at the back, while there are clephante represented all round the walls. Somewlat to the left of the dagotha and belind it is the vihara, while to the right is the pansala (p. 97).

It the entrance to the temple is a momstone, moch wom, while inside is a large silt Buddha, with fine paintings above, and on the left a little lacquer work cabinet containing a beantiful brass-work dagoba corered by anotlex metal dagoba of romsher make. The temple dons are dome in lacquer work. Aluse the temple, and to be reached by steps at the side, is a dagoba-like shrine, under a rouf, from which beatiful riews mas be obtained.

Lankatilake stand mpon a much higher isolated rock, and has a long flight of steps leading up to it, while the temple is larger, and from a distance at any rate more striking. The dagoba is menvered, and stands to the right of the temple, over whose door is a makara-tmana, a soup of thee fabulous monsters, often to be seen in similar positions wer the entrances to Buddhist temples. Within the truple are three large Bucldhas and some fine freseo paintings. On the rock to the left of the temple is a great inscription covering many square yards, and behind is the bo-tree. 


\section{Chapter X.}

\section{GOVERNMENT:"}

CEVton is the richest, and one of the lasesent, of the Crown Colonies, and has mothing to do with the Gorernment of India, though it is gerestaphically so near to that continent, and has on much in common with it. In sucls a colomy the Crown has the entire comtrol of the legislation, though it is in general entrusted to a local legislative Comseit, on which the officials, who are obliged, if required, to sote with the Govermment on mattors not involving religion, are in a majority. The eolomy, too, is adminietered by officials who are ultimately responsible to the Secretary of sitate for the Colonies in lomelon, with whom the Governor of the colomy corresponds directly, and fiom whom be takes bis in-tivictions.

The Coserose is leally provided with administrative power, and is assinted by an Executive Conncil of five menbets the Colonial Secretary, the lireasurer, the Comtroller of Revenue, the reffieer Commanding the Troeps, and the

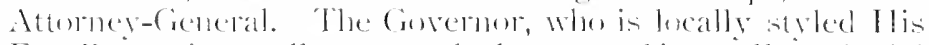
Exeelleire, is usmally a man whe lua served in smallei colonial

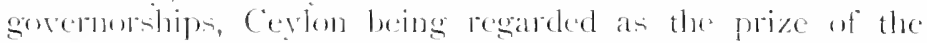
profession, and is mot a man with local training ox experience. In this way the intrenduetion of wider and breezice ideas is sought to be offected.

IBesides the Exerutive Comncil, whosemetings are private, there is a lecgislative Comncil of 15 members the five

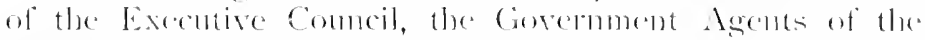
Western and Central l'ovinces, two sthere offecials, and oight mofficial memfers, serving for tire years fiom the clate of

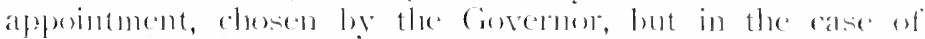
some of the European members usually mominated by the

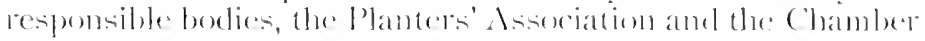
of cimmerese These eight members reporesent the bowcomotry Sinlablese, the Kandyan Sintallese, the 'lamils,

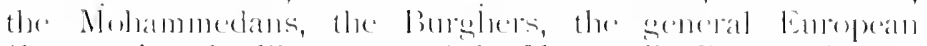
Community, the lyasters, and the Nereantile Commmity.

The author being on forernment emplos, thes chapter is accessirily reduced to the b.1]dest outhine. 
The orders of (iovernment are communicated to subordinate officers through the Colonial Secretary -also, like the Goverom, usually a man of distinction, appointed fiom some othere colony or post nutside of Cerlon - who is the mouthpiece of Cosernment in the Lesistative Council, and whose office in Colombo, the secretariat, is the office of record for the whole colons.

The most important general officers of Govermment are the Goremment Agents, or C. An., corresponding to Collectors in India. There is one of these officer's for each of the nine prosinces, and in the larger and more populous provinces there are usually Asistant Government Agents at one or more of the minor towns, the eapitals of districts, such as Matale or Trincomalie. The Govermment Ient is the head of his province, and is responsible for collecting the revenue at his office, which is known as the kacheheri. He must make constant tours through the proxince, enquiring into local wants, complaints, ace, and getting into touch with the people. He governs though headmen, who are responsible to one another through various grades, controlling larger and larger districts, up to the Mudalivare of low country districts, or Ratemahatmays (R. Nis of Kandran distriets.

Above the Government Agents in preeedence stands the Controller of Revenue, while betow them is the sraduated series of the Civil bervice, some $S 0$ men in all, ranging fiom Assistant Government dgents down to the Cadets or newly joined civilians, recruited by publicexamination (the sameexamination as for the lndian and Home Civil Serviees) in England. The service is divided into four classes, and the salary goes mainly accolding to the class in which an officer stands.

Nit only is much of the minor government of the country in the hands of the headmen, but the ancient institution of Gansablawas, or village courts or councils, is kept up. These bodies collect fund h bo local taxes and are responsible for gond order, fin the decision of minor cases, and for the improvement of their villages.

A few of the civilians also belong to the judicial branch of the service, but the higher posts in this are mainly filled by pofessional lawers, the Chief Justice and some of the Puisne Justices usually coming from abroad. The Supreme Court gues on circuit in the island, and there are District Courts at the chief towns, and many Police Nagistrates. The basis of the law in we in the low country is the Roman-l)uteh Law, and there are alow wher codes, such as the Kandyan law. Decrees of the court are executed by the fircal-usually the Govermment Agent or Asistant - who corresponds somewhat to a sheriff in England. 
The lawyers of Cevlon, who are nearly all natives, this being a favourite profesion with them, and one in which many rise to eminenee, are divided into Adrocates and Proctors, who correspond to barristers and Sonlicitors in England.

The more special work of the Gorernment, such as demands professional training on the part of those who perform it, is carried wut by special departments. Thus the care and construction of roads, bridges, and buildinge is the work of the Public Workis 1 epartment, usually known in Ceylon as the P. WV. I), the survering of the island generally, and of blocks of land for sale, and attention to the meterirulugical statistics, is the work of the Surver Department; Education, Railways, Customs, Irrigation, l'olice, l'risons, Forests, Post Office, Printing, Stores, Museum, all have their own departments, whose work is sufficiently indicated by their title. The agricultural work is done by the Royal Botanic Gardens, aided by the Ceylon Asricultural Socicty. Some of these departments, es. the Post Office and the Customs, are controlled by civilians, but most are under heads professionally trained in the particular kind of work performed.

Local self-goverment has not as yet progressed very far, in a country unused to such things, but there are elective Municipal Councils in Colombo, Galle, and Kandy, and bocal boards in minor places, while Provincial District Road Committees manage the minor roads.

The Revenue in 1906 was Rs. 35,030,661

The Expenditure ", , " $32,64+4,215$

The Public Debt " , " $72,7119,0155$

The estimated population at the middle of lyor was $3,968,5+1$. 


\section{PART III.-DESCRIPTIVE.}

\section{Chapter XI.}

THE ROADS.

$\mathrm{T}^{\mathrm{I}}$

IE object of the present chapter is to give such a briet description of the roadis as may be useful to travellers. To describe them in detail irould occupy too much space and las already been dome in "Fyers' Itineras.y."

"Tavelling along Ceylon roadis has been rendered easy by the establishment of fumished Resthomses at every 14 miles $o$ so. At these, if notice be given, the traveller can usually set all that he requires, on payment of about Rs. 6 to Rs. io a day. If beds, linen, forrl, of other necessaries be taken the cost is reduced.

The roads in Ceylon rary in quality. First class roads, such as those uniting most of the towns, are usually in admirable condition and motors can tharel on them with ease. The minos sravelled roads are not usually suitable for motor traffic, however, the bridges (if any) not being strong enough.

Tolls are demanded at intervals of ten to twenty miles. The toll station has usually a bambus sanding up beside it, which can be drawn down to block the road. The seneral toll for a four-wheeded rehicle is 60 cents.

\section{COLOMBO TO KANDY}

ine Kisglle, т2 miles.

Croming the Kelani-ganga by the Victoria bridge, the road tums to the right, and rums though a densely populated district, honses and mixed gardens (p. +9), with occasional glimpses of paddy fields (p. 4.3) alternating all the way past Mahara Restlusise $\left(8 \frac{1}{2} \mathrm{~m}\right.$.) to the turning to the left at $7 \mathrm{~m}$. for Heneratgoda Resthouse and Railway Station (23 m.). Ciradually the population becomes less dense; at $25 \frac{1}{1} \mathrm{~m}$. is a turning to the left for Veyangoda Resthouse and Railway Station (2 m.). Further on the road gets into prettily 
wonded hilly country (Ambepussa Resthouse $36 \frac{1}{3} \mathrm{~m}$.), and presently kegalle hill, a long hollow-topped ridge with a precipitius left-hand end, appears ahead, and the road from Polmahawela Railway Station and Resthouse (7 m.) cnters on the left. At $49 \mathrm{~m}$. we come to the long village street of Kegalle, with Resthouse, Post and Telegraph Office, de. From the Resthouse it is 7 m. to Rambukikana, 12 m. to Pindenira, $16 \mathrm{~m}$. to Bunatkohupitiva. On leaving Kesalle the Castle Rock, a bofty conical hill with a group of rocks at the summit which look vere like a ruined castle, appears in front. 'This was for some time the refuge of the bandit Sardiel, who was captured in is6.. Mawanella village and Resthonse are pasied at $56 \mathrm{~m}$, and the road then ascends the Kaduganmawa

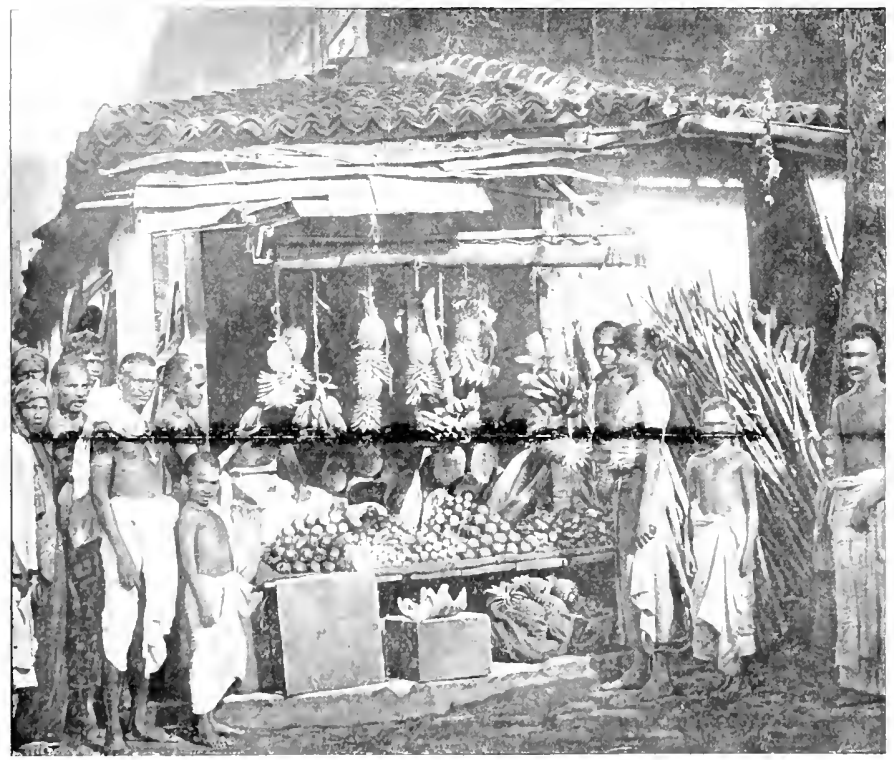

A ROADSIDE BOUTIQUE.

pass, coming out below the railway near Sonsation Rock. It

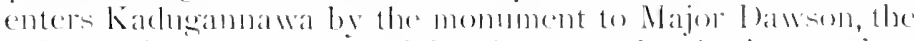

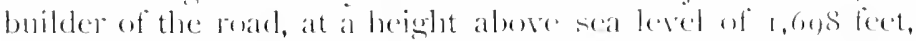
and then roms down a shallow valley to the village of

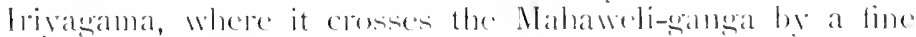

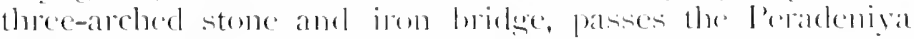
Botanie Gandens on the left, and enters kandy theregh the Katulielle suburb. There is a Resthume at Peradeniya. 


\section{Chief Branch Roads from the above.}

(1) at $17 \mathrm{~m} .$, to the left, a gond wavel road to Heneratgoda station and Resthounc, 23 m. ; branch road on left at $3 ! m$, a little past the paddy ficles, to the Botanic Gardens (worth a risit; sec under I leneraturua in "Towns"); Asgiriva village, with temple on summit of rock, 4 m.; Minuwangoda village and Resthouse $10 \frac{1}{2}$ m.; Negombo, larece coast town with Resthouse 10 $\frac{1}{t}$ m.

(2) at 24,31, , to the left, good road to Veyangoda Station and Resthouse $2 \frac{1}{2}$ m., Minuwangoda Resthuse $11 \frac{1}{3}$ m., and Negombo Restluoune $20 \mathrm{~m}$.

(3) at $243 \mathrm{~m}$, to the right to Ruwanwella Resthouse i $5 \mathrm{~m}$.

(4) at $27 \frac{1}{4}$ m., to the left to Mirigama Restlouse $9 \mathrm{~m}$. Giriulla Resthouse $1+$ m., Narammola Resthouse $23 \frac{1}{3}$ m., Kurunegala Resthouse $35 \mathrm{~m}$. Motors must go ila kegalle.

(5) at $363_{1}^{3} m$. , to the left, minor road, ferred orer the Maha-ova, past Alawwa Station to Polgahawela Station and Resthouse, 10 m., Kurunegala Station and Resthouse $21 \frac{1}{1} \mathrm{~m}$.

(6) at $47 \mathrm{~m}$., sood metalled coach road, suitable for motors, to Polgahawela Station and Resthonse $7 \frac{1}{1}$ m., Kurunegala Station and Resthouse i $\$ \frac{1}{3} m$.

(7) at $47 \frac{1}{t}$ m., to right to Bulatkohupitiya Resthouse $15 \mathrm{~m}$. and Ruwanwella Resthouce $23.3 \mathrm{~m}$.

(S) at 56 m., (Mawanella) to the left a metalled road to Rambukkana Resthouse and Station, $10 \frac{1}{2}$ m.

(9) at $56 \mathrm{~m}$., to the right, a metalled road to Aranayaka (for I olosbage) $8: 3 m$.

( 10 ) at 68 m., on the near side of the Peradeniya Bridge, the road to Gampola and up-country (below), and on the far side of the bridse, to I leltota, $19 \mathrm{~m}$.

\section{COLOMBO TO KANDY}

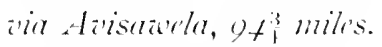

Leaving Colombo by the left bank of the Kelani river, the road passes though a densely populated district of mostly mixed sartens (1) +9) by Kaduwela Resthouse $10 \frac{1}{1} \mathrm{~m} .$, and Hanwella Restlunue is $\frac{1}{j}$ (in a protty situation near the river.) At ro m. is a road to the great Colombo Waterworks reservoir at Labugama, and at Avisawela (29 m., Post and Teleglaph (office, Resthouse, Station), the main road to Ratnapura tmons off to the right (below). At 31 m. is Taldua, with the race-course and club-honse of the Kelani Valley Planters' Association (along a minor road to the left), at $33:$ m. 1niowita Station, at $39 \mathrm{~m}$. Karawanclla Station and on the other side of the Kelani, which is crosicel here, a road to 
Ruwanwella on the left, while at $42 \mathrm{~m}$. we reach Yatiyantota (Resthouse, Station, Post and Telegraph Office). Beyond this the road passes through pretty hilly country, planted with tea and rubber, and begins to ascend past Kitulgala Resthonse $54^{\frac{1}{2}}$ m., up the Gimigathena pass, with fine views on the right, to the simmit $(2,168$ feet $)$ at Ginigathena, where the up-country road (below) goes off to the right, while the Kandy road tums to the left along the valley to Nawalapitiya (Hotel, Station, Post and Telegraph Office, road to l)ikoya) $71 \frac{1}{3}$ m., Gampola Sz m. (Resthoune, Post and Telegraph Office, road to Ramboda and Nuwara Eliva), Peradeniya bridge $90,3 \mathrm{~m}$. (р. 137) and Kandy $94,3 \mathrm{~m}$.

\section{Chief Branch Roads from the above.}

(1) at $19 \frac{1}{1} \mathrm{~m}$., to the right, to Waga Station, 2 m. and Labugama reservoir $6 \frac{1}{2} \mathrm{~m}$.

(2) at $29 \mathrm{~m}$., (Avisawela) to the right, main road to Ratnapura, dc. (below).

(3) at $38 \frac{1}{2} \mathrm{~m}$, to the left, to Ruwanwella Resthouse $2 \mathrm{~m}$.

(4) at $63, \mathrm{~m}$., to the right, to I)ikoya, drc. (below).

(5) at 7 i m. (Nawaiapitiya), to the letit, to Dolosbage.

(6) at $71 \frac{1}{1} \mathrm{~m}$., to the right, to l)ikoya, de. (below). (below).

(7) at $\mathrm{S}_{2} \mathrm{~m}$. (Gampola) to the right, to Nuvaril Eliya

(S) at $903 \mathrm{~m}$. (Peradeniya) to the left, to Colombo (above).

\section{COLOMBO TO PUTTALAM}

aid Negombo and Chilari, Sol miles.

Crose by the Victoria Bridge over the Kelani. The road passes though mixed gardens, coconuts, and cimnamon to Jaela Resthouse $12 \frac{1}{2} \mathrm{~m}$. Beyond Niripitiwela, $17 \mathrm{~m}$., there is a Buddhist temple; at $20 \frac{1}{2} \mathrm{~m}$. is the road to Veyangoda on the right (p. 138$)$, after which we turn to the left lor Negombo Resthouse, Post and Telegraph Offiee de., $23 \mathrm{~m}$. Roads to lleneratgoda, Veyangoda, Mirigama, and Kurunegala. Large town; steamers to Colombo. The road then passes thromgh coconut country to Marawila Resthouse $36, \frac{1}{1}$ m. At Madampe, $40 \frac{1}{3}$ m. is a road to Kumbunegala on the right; Chilaw Resthontese 473 m. (large place, Post and Telesiaph (Office). The road then goes on through more and more thinly populated conntry to Battulu-oya Resthouse $599_{1}^{3} \mathrm{~m}$., Maturankuli Restlouse 713 m. and Puttalam Resthonse So 1 1m. (P'ost and Telegraph Office). A sandy const rond, with no bridgess, rums on firom

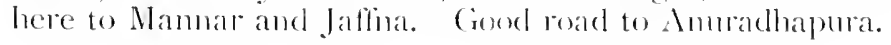




\title{
Chief Branch Roads from the above.
}

(1) Negombo (2.3 m.) to Heneratgoda, see P. 1.37.

(2) Negumbu to Veyangoda, see p. $13 \mathrm{~S}$

(3) Negombo to Mirigama, minol road.

(4) Negombo to Kurunewala, sood road, wio Badalgama Resthonse 1 I 1 1 11., Giriulla Resthouse 23,1 m., Narammola Rethouse $3.3 \mathrm{~m}$. Kurunegala Resthouse $4+1, \mathrm{~m}$.

(5) Madampe (to m.) to Kurunegala, ind Galmuruwa Resthuuse + m., Dandagamuwa Resthouse $10 \frac{1}{3}$ m., Narammola Resthouse $2.3 \mathrm{~m}$., Kurunegala Resthousc $34 . \frac{1}{3} \mathrm{~m}$.

(6) Chilaw $\left(47^{3}\right)$ to Kurunegala, partly minol road, aia Bingiriya Resthouse $9 \mathrm{~m}$., Hettipola Resthouse I $9 \frac{1}{4} \mathrm{~m}$., Wariyapola Resthouse $32 \frac{1}{2} \mathrm{~m}$., Kurunegala Resthouse $40 \frac{1}{2} 117$.

\section{COLOMBO TO HAMBANTOTA}

\author{
ibre Galle, rtitities.
}

The road rums througle the southern suburbs of Colombo,

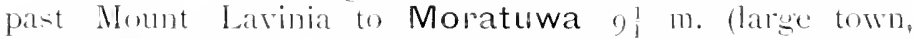
Renthouse, Post and Telewph office) and Panadure $16 \mathrm{~m}$. (laregetown, Resthouse, l'ont and 'Telegraph Office), where the road to Ratmapura (below) branches off on the left. From thence it runs, still though coconuts and mixed gardens, de., to Kalutara North, and across the wide railway bridge ovel. the estuary of the Kalu-sansa (beautiful riew both sides) to Kalutara South (large town, Put and Telegraph Office, Resthouse, road to Neboda left). Continuing though similas. country it comes to Mlutgama, and corses the Bentota river, where Bentota Resthouse is on a promontory on the right, 38.' m. Further on are lagons with mangrove regetation (p. 6,2 ) and Ambalangoda Resthoure $5.3 \frac{3}{1}$ m. (large torn, l'ost and 'lelegraph Office), Hikkaduwa Resthuuse $60.12 \mathrm{~m}$. (road to baddegama left), and Galle(I Iotel, Post and Telegraph Office) $72 \div \mathrm{m}$.

The road then tumn more to the east, along the southern const, through mixed regetation, in which the breadfout is rery con-jucuous, and past open grass expanses of citronella srasis (p. 63) to Weligama, a pretty and prosperous seaside village, with Resthouse $89_{1}^{3} \mathrm{~m}$. and Post and Telegraph Office, and Matara Resthouse (large town, Post and Telegraph (office, station at end of coast line). $993 \mathrm{~m}$. At $104 \mathrm{~m}$. is 1)ondra llead, the southermmost point of the island, with an ancient and celebrated temple, at 1 i 1 Dikwella Resthouse. The comtry now get- rapidly drier, the rainfall being much 
more seanty, and Ilambantosta the driest place in Ceylon. Tangalla Resthouse $122 \mathrm{~m}$., Ranna Resthouse $130^{\circ} \mathrm{m}$., Ambalantota Resthoure I fo m., Hambantota Resthouse $1+7 i 11 \%$.

\section{Chief Branch Roads from the above.}

Numerous minor roads to the left, mp to l'anadure.

(1) at $16 \mathrm{~m}$. (l'anadure) to the lett, the road to Ratnapura (below).

(2) at $28 \mathrm{~m}$. (Kalutara) to the left, road to Tebuwana Resthouse 6 m. and Neboda $8 \frac{1}{1} m$.

(3) at $38 \mathrm{~m}$. , to the left, road to Moragala.

(4) at $60 \frac{1}{2}$ m. (Ilikkaduwa) to the left, road to Baddegama Resthouse (ferry orer river) 7 ill 11 .

(5) firom Galle, wads at Kottawa Restlonse, $8 \frac{1}{2}$ m., to Udugama Restlunse 17 111., and ive Imaduwa Restlouse $13 \frac{1}{3} 11$. , to Akuressa Restlonse $23 \frac{1}{2} 11$.

(6) from Matara, roads to Aküressa Resthonse i $2 \frac{1}{1} \mathrm{~m}$., Morowaka Resthouse $28 \frac{1}{2} \mathrm{~m}$., Deniyaya Restlume to. and to Hakmana Resthouse $15 \mathrm{~m}$.

\section{KANDY TO NUWARA ELIYA}

\section{thid Gimisalhema and Hallon, 75 miles.}

$\mathrm{At}+1 \mathrm{~m}$. Peradeniya b!idge, turo left at far emel, past Peradeniva Junction Station, and along a shallow valley, paddy below, tea, rubber and mixed sardens above, to Gampola Resthouse $1,3 \mathrm{~m}$. and Nawalapitiya (I Iotel) $2.32 \mathrm{~m}$. Road to Craigie lea left. At Cimigatlena, 31 m. join the road fiom Colombo (p. 13y) and procecel mpwards past Watawala $30 \mathrm{~m}$. to Hatton $45 \mathrm{~m}$. (I letel, Pest and Telegraph Office, station). Returning alome the sane track, turn light to Crapie Lea, 5.3 m., past Kotagala station. The road form Nawalapitiva joins hereon the left, and turning to the right we

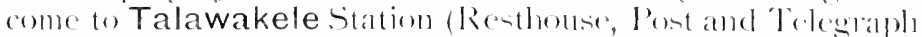

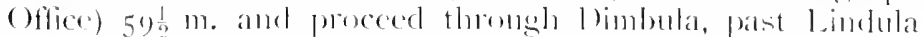

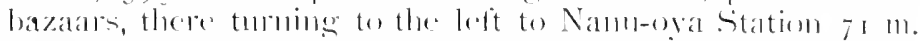

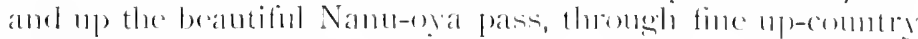
forest $(0.6,0)$ to Nuwara Eliya $75 \mathrm{~m}$.

\section{Chief Branch Roads from the above.}

(1) at $33^{3} m . t(1)$ l) eltota, 10 m.

(2) at Gampola, good road to the left, but ratlere seep and

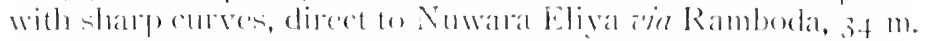


(3) at Nawalapitia, sord road to the lefi, direet to Craigie L.ca, $19.3 \mathrm{~m}$.

(4) at Nawalapitiva, to the right, into upper end of Dolosbage, $103 \mathrm{~m}$.

(5) at I Iatton, to l)ikwa and Maskeliya (bejow).

(6) at Craisic Lea, to Namalapitiva (3 above).

(7) at Lindula, to Agrapatana, sood road, $133 \mathrm{~m}$.

(S) at Nowala Eliva, to L'dapussetlawa, $22 \mathrm{~m}$.

\section{KANDY TO NUWARA ELIYA}

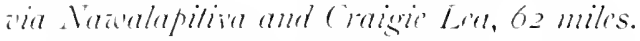

Is last to Nawalapitiva, turo left, and upwards to Craigie Lea $43 \frac{1}{1}$ m. alud then as last.

\section{KANDY TO NUWARA ELIYA}

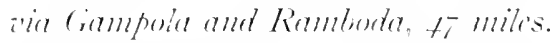

Is lrefore to Campola, then tum lett across the Mahawetisangat to Pundlawa $22 \frac{1}{2} \mathrm{~m}$. and Ramboda Resthouse $3.3 \frac{1}{2}$ m. : then up the Ramborlat pan- hy waterfalls and with beautiful riews, to Nuwara Eliya $47 \mathrm{~m}$.

\section{Chief Branch Roads from the above.}

(1) at $10, \frac{1}{1}$ m. to P(1p)

(2) at $32 \mathrm{~m}$. to the right, to !'molalu-sal and Watagoda Station.

\section{KANDY TO KURUNEGALA AND PUTTALAM}

Tol miles.

leave Kandy along Trineomalie Street to Katugastota Bridge 2l, m. and to Galagedara Resthouse i I m., down the pass to Kurunegala Resthuse $25 \frac{1}{2}$ m. (large town, Station, Post and 'Telesmph (office), and straisht on past Wariyapola Resthouse 30. m. (minom road to Chilaw, left), Padeniva $+2 m$. (road to Anmadhapura risht), Nikaweratiya Resthouse $50 ! \mathrm{m}$. to. Tonigala Restlouse $6,5 \mathrm{~m}$., Wlere is a little tank, with larese masies of rock, and a fone inscription. It the top of l'anakanda (path) is an ancient ruined dagoba, with a fine view, and under the rock is a rock temple with a large recumbent linddha, Puttalam Resthouse $79 \frac{1}{2} \mathrm{~m}$. 
PLATE XLV.

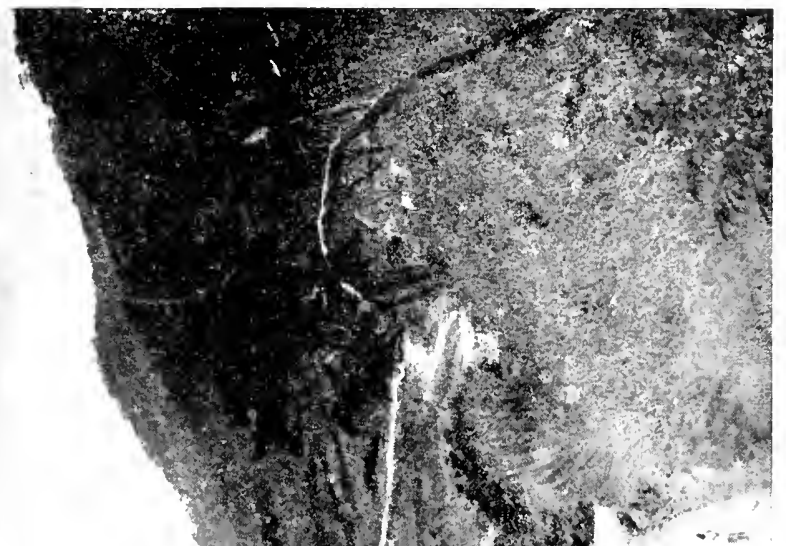

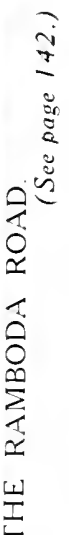

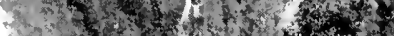

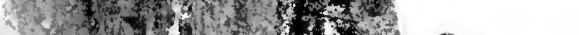

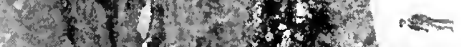

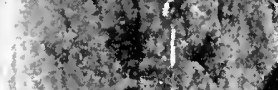

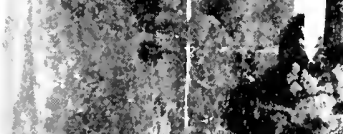

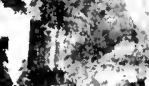

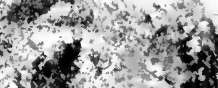

$1+2, x^{2}, x^{3}$

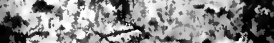

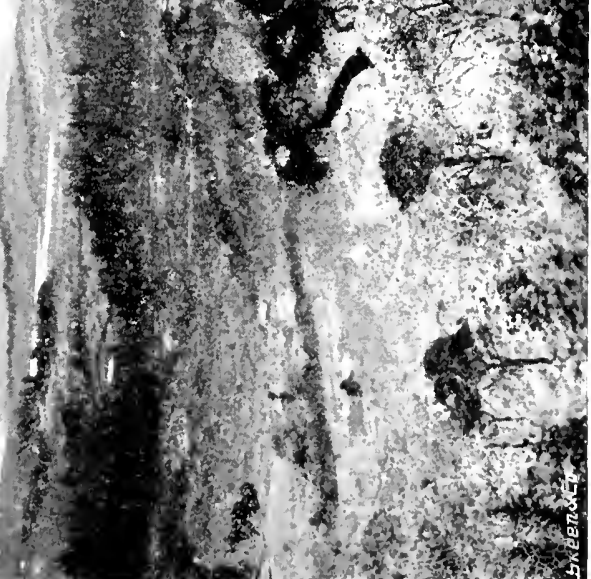

宛

万

2

$\frac{1}{2}$

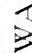

2

$\bigcirc$

U

$\checkmark$

צั

a

닢 



\section{Chief Branch Roads from the above.}

(i) at Kurunceala, to Dambulla, right, $35 \frac{1}{2}$ m. (betow)

(2) at Kurunegala, left, to Polgahawela 1 i $\frac{1}{1}$.

(3) at Kurulegala, left, to Negombo and Colombo $58 \mathrm{m.}$

(4) at IVarivapola, mimol rid to Chilaw $32 \frac{1}{2}$ m. (p. 140 ).

(5) at Padeniya, 42 m. risht, to Anuradluapura fo $^{6} \mathrm{~m}$. ina Balalla Re-t]unce $10 \frac{1}{2} \mathrm{~m}$. and Galgamuwa Restheure $25 \frac{1}{1} \mathrm{~m}$.

\section{KANDY TO JAFFNA}

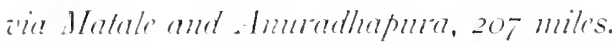

Leave by Trincomalie Street, ner Katugastota Briclue acrose the Malnaweli-sanga, and tum to the right. Branch to the risht to Panwila, ac. Gome dow a rather steep hill, we come to Matale Resthouse $16:$ m. (large village, Post and Telecraph Office, terminal Station, elevation 1, 2os feet). Proceeding through the long bazare, the road tums slightly to the risht at the far end through tea, cacao, and rubber estates to Nalanda Restlumse $30 \frac{1}{1}$ m. and then pasies into "dry" and thinly inhabited country (1). 15) though chenas and firest to Dambulla Restlouse $45 \mathrm{~m}$. Phere is a famous reck temple hele (p. 120). Bevond this the road crosies the Mirisgonisora and turns to the left froad to the right to "lincomalic) throust forest and chena and by tankis and paddy fields to Kekirawa Resthouse. Just before rearling the village there is a fine view of Ritigala momtain (1). 1.31) on the right. Road to left to Kalawewal (p. I2S). Maradankadawela 6,- m. ; road on right tr Ilabarane. Tirappane Resthoune 793 m. and at $753 \mathrm{~m}$. (Cialkulam) tum to the lett

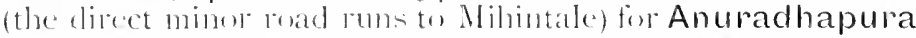
Resthouse $8_{53}^{3}$ m. In entering the town the Mblugagiriva logenba towere up on the right, and the ruine of the brazen palace are on the befit of the roald (1), 117$)$.

leaving by the sime lord, and tmoning olf to the beft, we rejuin the direct rend rin Milnintale at Rambewa and arrive at Madawachchiya Restumse 10,3 m., Vavuniya Rethumse

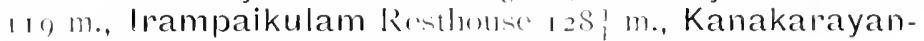
kulam Resthomac 140; $\mathrm{m}$. With a pretly tank lowhel it, Panikkankulam Restlume 151 m., Iranamadu Ro-tlus se 16,2 1 11. and then thromgly sindy serubly country to the

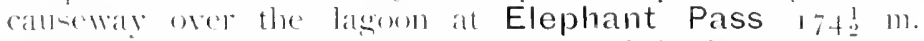
(Kesthorise on the right, on the heach of the Jasom, a rery

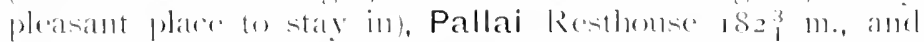

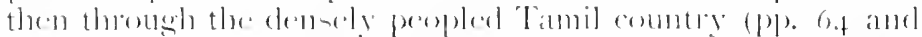

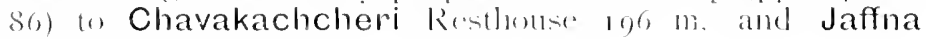
Resthouse $207 \mathrm{~m}$. 


\title{
Chief Branch Roads from the above.
}

(1) at Katugastota, to Kurunegala (j. 1+2).

(2) at l)ambulla, right to Trincomalie below left to Kurunegala below.

(3) at Kekinaw, to the icft, to Kalawewa, $7 \frac{1}{9} \mathrm{~m}$.

(4) at Maradankadawela, right, grasel road, fit for motors, -ivi Cialpitigala (p. 131) to Habarane $15 \frac{1}{2} \mathrm{~m}$.

(5) at Madawachchiya, to the left, to Mannar Resthouse 52171

(6) at $147 \mathrm{~m}$. to the right, to Mullaittivu Resthouse $30 \mathrm{~m}$.

(7) at Io, 3 m. (Kodikamam) to the right, to Point Pedro Resthouse $10 \frac{1}{2} \mathrm{~m}$.

(8) at Chatrakachcheri, to the right, to Point Pedro $14 \mathrm{~m}$.

(9) at Jaffina, to the right, to Point Pedio, $21 \mathrm{m.}$

(10) at Jaffina, to the right, to Kankesanturai, $11 \frac{1}{2} \mathrm{~m}$.

\section{KURUNEGALA TO TRINCOMALIE}

\author{
‘'ia Dembulla, $103 \frac{1}{4}$ milis.
}

Minor road to I ambulla Resthouse, $35 \frac{1}{4}$ m. aia Gokarella Resthouse $11 \frac{1}{1} \mathrm{~m}$. Afterwards first class road, crossing the Mirisgoni-oya and keeping straight on, past occasional simpses of paddy fields, mainly through jungle, to lnamaluwa, to m., where the road to Sigiriva tums off to the right, Habarane Resthomse $50 \frac{1}{4}$ m., Alut-oya Resthouse $66 \frac{1}{4} \mathrm{~m}$. At $78 \mathrm{~m}$. the road rums along the bund of the sreat Kanthalai tank (p. 76$)$ to the Resthouse $7 S_{3}^{3}$ m., Tampalakam Resthouse $88_{+}^{3} \mathrm{~m}$. , Trincomalie Resthouse $103 \frac{1}{4} \mathrm{~m}$.

\section{Chief Branch Roads from the above.}

At lnamaluwa, fo! m., to the right, to Sigiriya Resthouse $5 \frac{1}{3} \mathrm{~m}$.

It llabarane, 50, m. to the left, to Galpitigala for Ritisala, p. 131) and Maradankaclawala, 15.2 $\mathrm{m}$.

At llabarane, to the right, wasel road to Minneriya (p. 129) 15 m. and Polmonaluwa (p. 126) $27 \mathrm{m.}$

\section{KANDY TO MATURATA}

\section{$38 \frac{1}{t}$ miles.}

Metalled roal, learing Kandr by Malabar Street, and going downhill to the side of the Maluaweli-ganga, and though a coconnt and cacan combtry, with pretty views of the north-

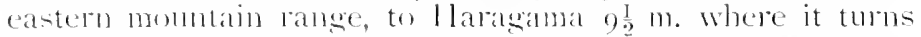
off to the risht into the Maturata villes, to Hanguranketa Resthouse, $17 \frac{1}{2}$ m., Padiyapelella, $25 \mathrm{~m}$., and Kurundu-oya $3 S \frac{1}{t} 113$. 


\title{
Chief Branch Road from the above.
}

At $5.1 \mathrm{~m}$. to the left, over Gonawate ferry to the Teldeniga road (bedrow).

\section{KANDY TO TELDENIYA}

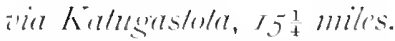

Crosing the Katusastota Bridge tum right to Madawcla, 7 m., where again tum right to Teldeniya Resthous I $5 \frac{1}{4} \mathrm{~m}$.

\section{Chief Branch Roads from the above.}

(1) at Madawela, to the kelt, to Panwila Restluouse $5 \frac{1}{4} \mathrm{~m}$. and into the Madulkele planting district.

(2) at Madawela, straight on, to Elliadmwa, $10 \frac{1}{4}$ m.

\section{NUWARA ELIYA TO BATTICALOA}

\author{
aid liatrilla, rtimiles.
}

Leaving Numara Eliva somthwards along the side of the lake, the road mus almost eontioually steeply downhill, past Mahagesteta or Baker's Farm, the site of the experinents in faming carriced on by Sir Sammel Baker, and llakgala gardens (see llaksala in "Tomms") 6 m. to the village of IVilson's bumgalow, $12 \mathrm{~m}$. In so doing it pasios fiom a distret which is very wet in the sonthwest momson to whe which is very dry, and if the jonmery le made between Jume and beptember, the dange of climate is often rery remartiable (1). 16). It 17 m. We come to. Welimada, 3,500 teet abureceat level (Resthouse), and then the loas aseonde past Etampitio to the smmonit of the pass, 3,000 feet, deseends to l)ikwe Jla $3.3 \mathrm{~m}$. and there joins the roal fiom laputale, rontering

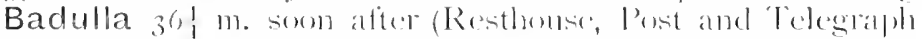

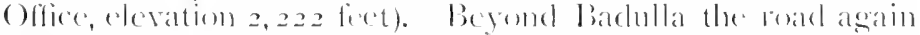

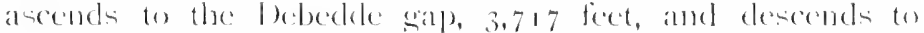

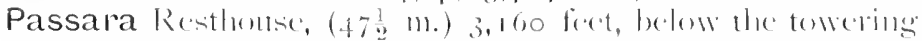
smmmit of Nambinakuli on the right, which has forest (p) (10)

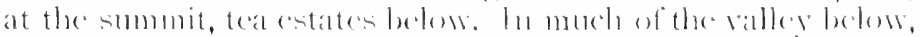

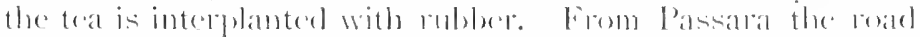

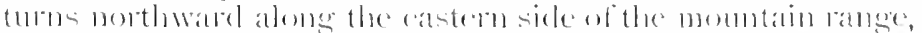

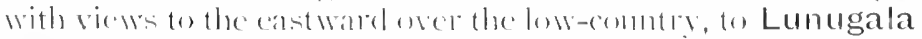

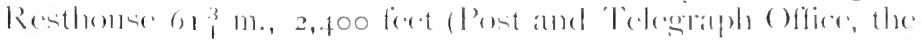

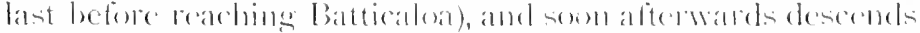

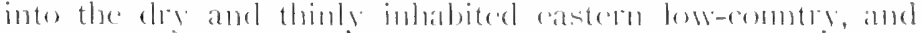

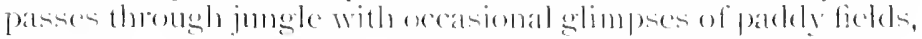


to Bibile Resthouse $723 \mathrm{~m}$., Ekiriyankumbura Resthouse $S_{3 \nmid}$ m., Kallodai Restloulse 93 m., Maha-oya Resthouse $103 \mathrm{~m}$. . Tumpalancholai Resthouse 1 r 6 m., Chenkaladai Resthouse $1299^{3} \mathrm{~m}$. Batticaloa Resthouse $143 \mathrm{~m}$.

\section{Chief Branch Roads from the above.}

(i) at $7 \mathrm{~m}$., to the right, to Ambewela Station, $5 \mathrm{~m}$.

(2) at Welimada, bridle path to Bandarawela, $10 \mathrm{~m}$.

(3) at Badulla, to the left, to Taldena Resthouse, $9 \frac{1}{2} \mathrm{~m}$.

(4) at Passara, to the right, to Naminakuli Resthouse, $5 \frac{1}{2} \mathrm{~m}$., Ella Resthouse, $12 \frac{1}{2} \mathrm{~m}$. and Haputale-Badulla road $15 \frac{1}{2} \mathrm{~m}$.

(5) at Passara, to the left, to Madulsima, $7 \mathrm{~m}$.

(6) at Chenkaladai, to the left, to Kalkudah Resthouse $1 \mathrm{~m}$. and also to Trincomalie, (minor road, many ferries), $90 \mathrm{~m}$.

\section{AVISAWELA TO BADULLA}

i'ia Ratuapura and Haputale, ro7 miles.

The road runs along below the steep and lofty Adam's Peak range of mountains, by Pussella Resthouse, $14^{\frac{1}{2}} \mathrm{~m}$. to Ratnapura Resthouse $266_{4}^{3} \mathrm{~m}$. ( 106 feet above sea level) and then rises slightly to Pelmadulla Resthouse ( 408 feet) $38 \frac{1}{2} \mathrm{~m}$., Madola Resthouse $+7 \mathrm{~m}$., Balangoda Resthouse $53 \frac{3}{7} \mathrm{~m}$., Belihuloya Resthouse $\sigma_{3} \mathrm{~m}$., and then more steeply to Haldummulla Resthouse $76 \mathrm{~m} .,(3.388$ feet), where there are beautiful views out over the south-eastern low-country, and through tea to Haputale pass $83 \frac{1}{4} \mathrm{~m}$. (Resthouse 4,687 feet, Post and Telegraph Office), where it crosses on to the northern side of the mountain range, and rums along to Bandarawela Resthouse, $89 \frac{1}{2}, \mathrm{~m} .4,020$ feet (end of railway, Post and Telegraph Office), and then down a fine open grassy mountain pass, reminding one of the hills of Dumfriesshire, to Naula Resthouse $9 S_{\frac{1}{2}} \mathrm{~m}$., Dikwella and Badulla Resthouse $107 \mathrm{~m}$. (2,222 feet).

\section{Chief Branch Roads from the above.}

(1) at Ratnapura, to Panadure (below).

(z) at Pelmadulla, to the right, to Madampe Resthouse 8 m., Rakwana Resthouse $1+$ m., and beyond into planting district.

(3) at $79 \mathrm{~m}$. , to the right, to Koslanda Resthouse $6 \mathrm{~m}$., Wellawaya Resthouse $22 \frac{1}{2} \mathrm{~m}$., and on to Hambantota $72 \frac{1}{2} \mathrm{~m}$.

(4), at $96 \mathrm{~m}$., to Ella Resthouse 3 m. (see abore). 


\section{PANADURE TO RATNAPURA}

353 miles.

The road ruws ila Horana Resthouse $\$ \frac{3}{4}$ m., Nambapana Resthouse $19 \frac{3}{1} \mathrm{~m}$.

\section{HATTON TO MASKELIYA}

$$
\text { i i miles. }
$$

The road roms down firm Hatton, through Dikoya village and past the chureh into the main Ilikova valley, which is full of tea estates. At Nomorol the road turns to the right, up orer the pasi into the Maskeliva valles, also a tea district, and deseends through it, with fine view of Adam's Peak in front, to Maskeliya village. The Resthouse is some distance beyond this.

\section{Chief Branch Road from the above.}

At Norwood, to the left, to Bogawantalawa $10 \mathrm{~m}$.

\section{PUTTALAM TO TRINCOMALIE} ine Immadlupura, $112 \frac{1}{2}$ miles.

The first Resthonne is Anuradhapura, $46 \frac{3}{4} \mathrm{~m}$, and then the road runs by the side of Numarawewa (tank) to Mihintale Resthouse $5+3$ m., Kahatagasdigiliya Resthouse $67 \frac{3}{4} m$., Horowapotana Resthuse $S 1 \frac{1}{t} \mathrm{~m}$. and Trincomalie Resthouse i $12 \frac{1}{2} m$. 


\section{Chapter XII.}

\section{THE RAILIVAYS.}

$\mathrm{T}^{\mathrm{T}}$ IE railway in Ceylon have been made in easy stages, the line to Kandi having been opened in 1869 , while only 503 miles are open at the plesent time, os of these beins on the nam andere of 2 feet o incles, the rest on the brod sange of 5 feet o inches. It is mot oum intention to go intorny description of the Raliway lopatment or its working, but to sive briefly, and with referemes to other parts of the book where seater detail mas be found, some of the chief pointsot seneral interest to be serof fonthe railway carriage.

Europeans in Ceybon sencrally travel in the first class, the fares in whel are about the same as third class in England. The fares are of comme in rupees, but the sorereign is lecal tender at 15 rupees.

() arrival at the station, bageage, other than rugs or small pareds, suld be bonked thoush to the station at which one is to aliglit; one loundredweight is allowed fiec to a first clats passenser, and receipts are siren for each package, which must be handed wer at the alighting station to chaim the baserase the ordinary Inerican system, in fact. The porter who carries and resisters the bagsage is well tipped witl 5 to 15 cents, and risitors should mot demeralise them by larec tips.

() the day and the up niglet thans on the line to kandy and to Nantersa, there are Refieshment Cars, in which meals ram be olstained, of woud comoh quality and moderate price. ()n the night mails to and fom Nanu-ova there are comfortable slecping rass, fitted with bedding unlike the Indian arangements), for which a cluage of Rs. 2.50 per berth is made, in addition to the firet clase fale.

It Maradana, and at several of the more important stations on the main line, there are bonk-stalls, wheremose, de., may les purchased.

At most of the stations the name is put up in three lansuages, English at the top, simbalese, recognised by the curvel letters, in the middle, and Tamil, recognised by the riglut ander in many of the letters, below.

The times of the principal trains are given but of course flece can be me suarantee of aceuracy the times being firepuenty clangerl, more especially on the coast line.

The Ceylon lines are perhaps unique in the fact that on the main line the trains leaving the cirvital (a) "Ip." 


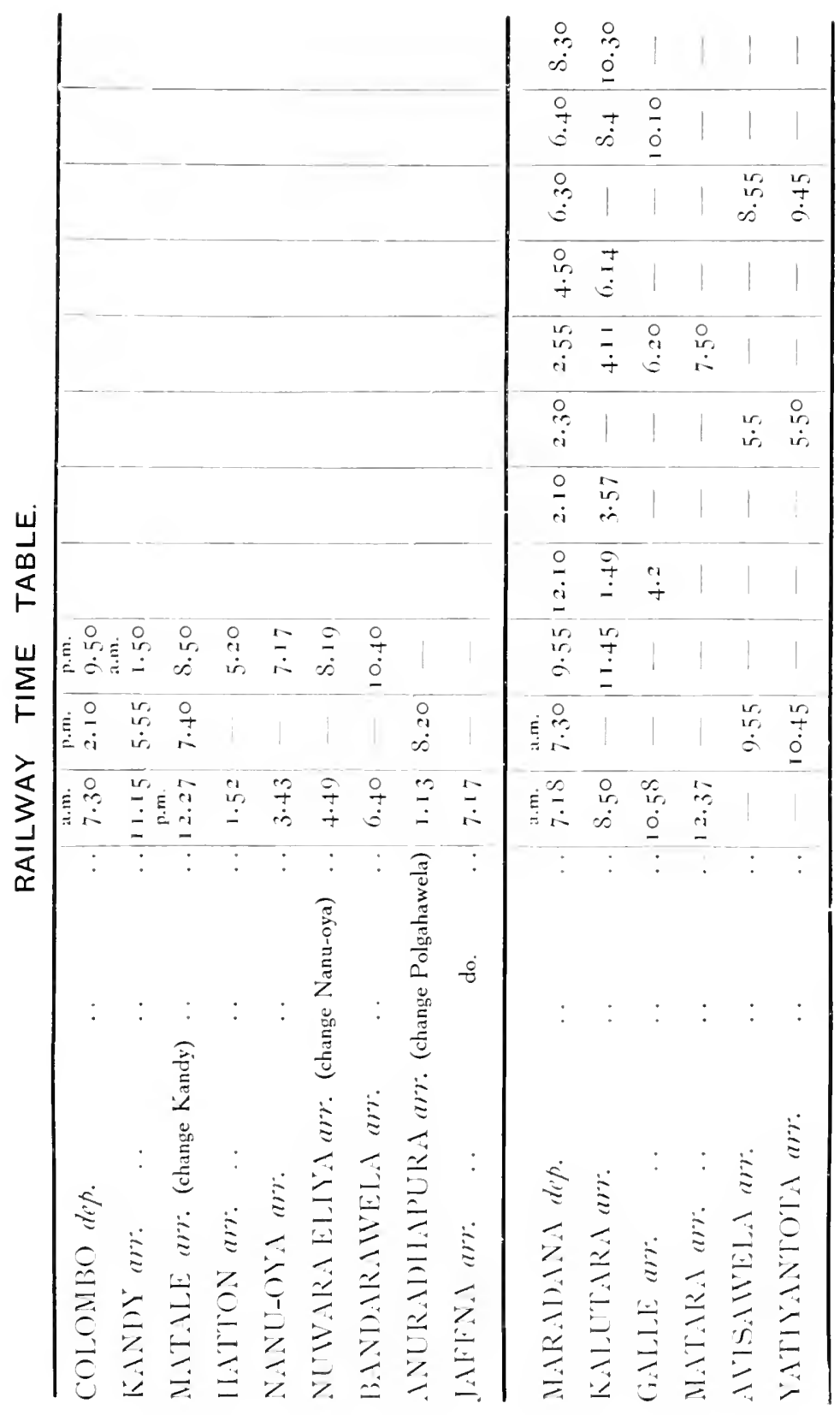




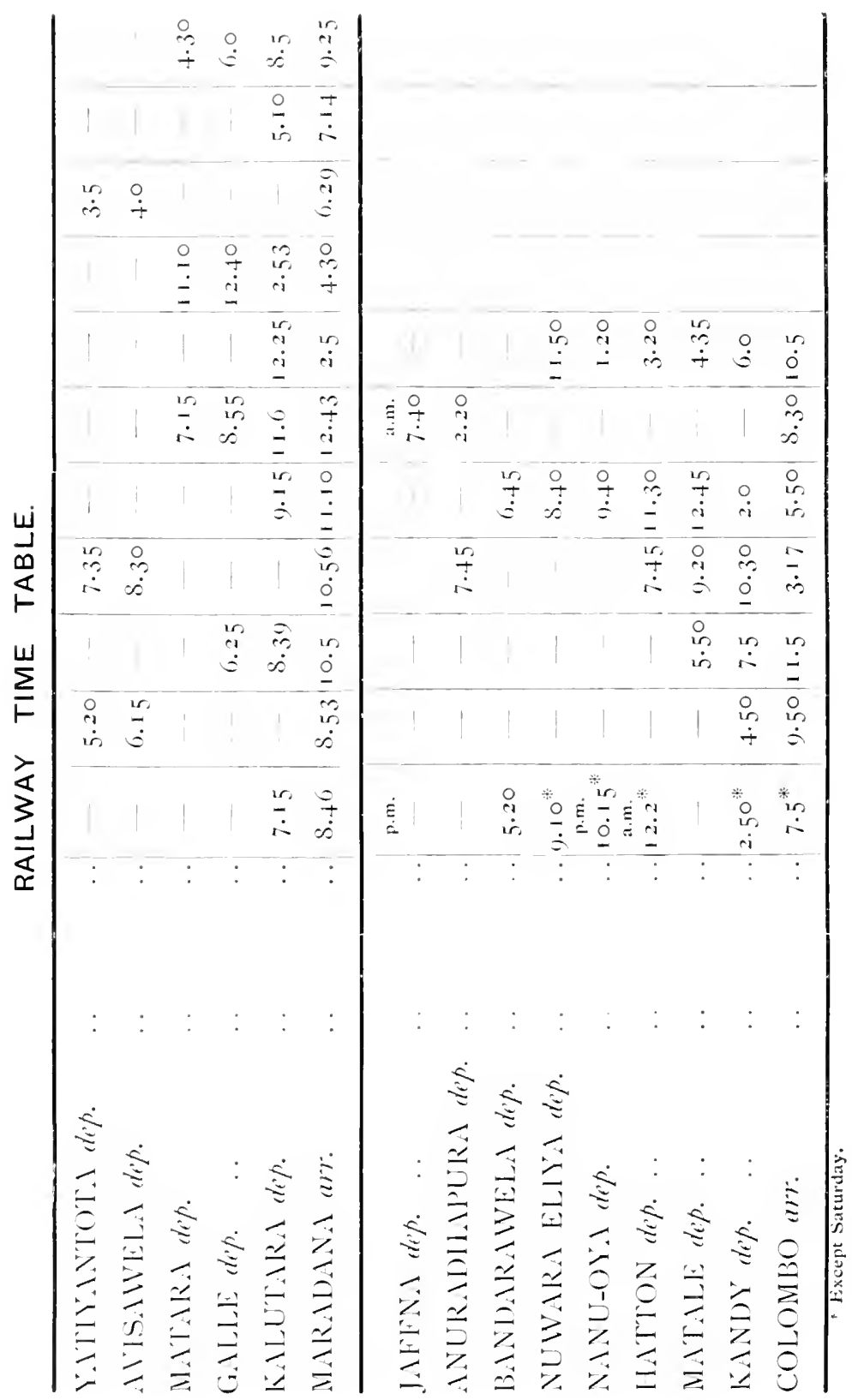


The lines are described below in the following order:--

I. Colombon....kindy.

2. Kandy Matale.

3. Peradenisa Junction-Bandarawela.

4. Namm-oya-Ragalla.

5. Polgahawela Kingesanturai.

6. Maradana Junction--Matara.

7. de. Tativantota.

See also descriptions of vegetation on pp. 42 seq.

\section{COLOMBO TO KANDY}

(righl hand side by fat the best.)

Maradana Junction coast line, and Kelani Valley line trains also start here; bonk-stall: fast trains do not stop for one hour after leaving here, so get into the Refoshment Car if a meal is clecireed).

On left side of Irain.

On right side of train.

Cimmanon gardens (P. 6z) and grasis on both sides.

Corsis road.

Giass tieldeboth sieles.

Cross little river.

Coss ford and canal (p. 10).

Paddy fieldis both sides (p. +3).

Crosi road, and Kelani river, by lomg bridge.

() the river latis of timber, or pada boats (J. 10.4)

may often ixe seren.

Mixed gatelen cultivation (p. fy).

Kelaniya Station (tickets collected luere on leturn to Colomlos).

$$
\begin{aligned}
& \text { Batur's Manure Works. } \\
& \text { Cross road. }
\end{aligned}
$$

Mixed garden cultivation and padd! ficels.

Hunupitiya Station.

Rille range for Violuntecrs.

Mixed garden cultivation (p. +9) and scrub. 
On left side of train.

On right side of train.

Paddy ficlds (p. 4.3).

Branch line to Mahara quary, for stone for harbour wollis.

Ragama cooly camp, where the immigrant coolies ( $p$. 54) are guarantined before soing to the estates employing them.

Ragama Station branch line to Negombo, now under construction, starts bere).

Paddy fields and mixed garlens.

Small tea estate (p. 5.3) with

rubber (p. 5 I) and shade:

pond in fromt of it.

Two cuttings.

School garden, just beyond second cutting (p. 103 )

Mixed gardens (p. 49) and padely fields (p. 43).

Heneratgoda Station; Resthonse; lusy district, great depot for supply of firewond to the railway. Road to Negombo (1. 13i)

Paddy fields and mixed zarden cultivation.

Veyangoda Station (59 feet abose sea; fast trains stop; road to Negombu; plantains, ac., sold on platform). Road to Negombo (p. 1 38 ) and Rumanwella (p. 1,3S).

Cross main street of the village.

$$
\text { Coir mills (p. + } 8 \text { ). }
$$

Paddy fjelds (p. 43), cocomut plantations (p. 47), ac.

Railway begins to reach the ferthills, and patches of forest

(p. 37 , characterised by many climbing plants, appear.

Mirigama Station (164 fiet abore sea) Resthouse.

Mugurugampola school, and satiden (p. 103 '

Street of Mirigama.

Mixed sardens, cocomuts and paddy fields. 
On left side of Irain.

On right side of Irain.

Quary.

Serub on old chena (p. 37 ).

Tumnel.

Mixed gardens, cocomuts and paddy fields.

Ambepussa Station.

Cutting.

Maha-Oya (river; p. 9).

Cross the river, fine view to right.

l'addy fields and mixed gardens.

Maha-Oya.

Alawwa Station.

Jungle and chena on the hills.

Plantains (p. 50).

Rubber clearing (p. 50).

P'retty view up-etream, where

llibl with old chena, planleatre Malsa-Oya. tains, de.

Polgahawela Station (2,1 fect above sea; Resthouse; book-stall ; change for Anuradhapura, Jaffina, de. ; fruit sold on platform; road to kurumegala (p. 1.38) and kegalle (p. 138). Coach to Kegalle.

bouble peak of Mlagala, round which the railwaly climbi, ahead.

P'antation of cocomutis (p. 47), tea (p) 53, and cacao p. 58). Plantains (P. 50).

Necaunts very common

alomg here (p. 52).

I lills close in to the line.

Rubber plantation on both sides, older trees to right ip. 50) P'lutains.

Stream crosinge; pretty view on right.

Rambukkana Station 313 foot abose seal Restlumse; foot of hill; add extra consine; I lour to next station; fout sold on platlorm). 
On left side of train.

(old chena on the hill; and mixed garden cultivation.

$$
\text { Two short tumnel: }
$$

Short tunnel.

beep ralley, withrice (p. 43 ), road, mixed cultivation, plantains and clıenas.

Kadiganuwa siding on left. Keep to right of train.

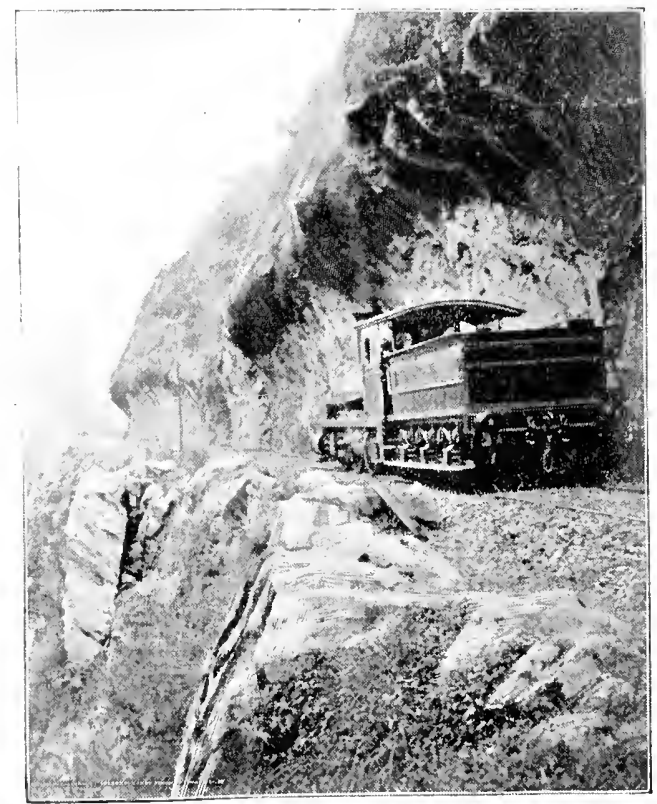

ON THE KADUGANNAWA PASS.

Cacao shaded with Grevillea and Erythina.

Galvanised iron store on left. Long tunnel.

Valley below with rice and mixed cultivation, chena and rubber on the hills, mountains behind. 
I'L.III XINI.

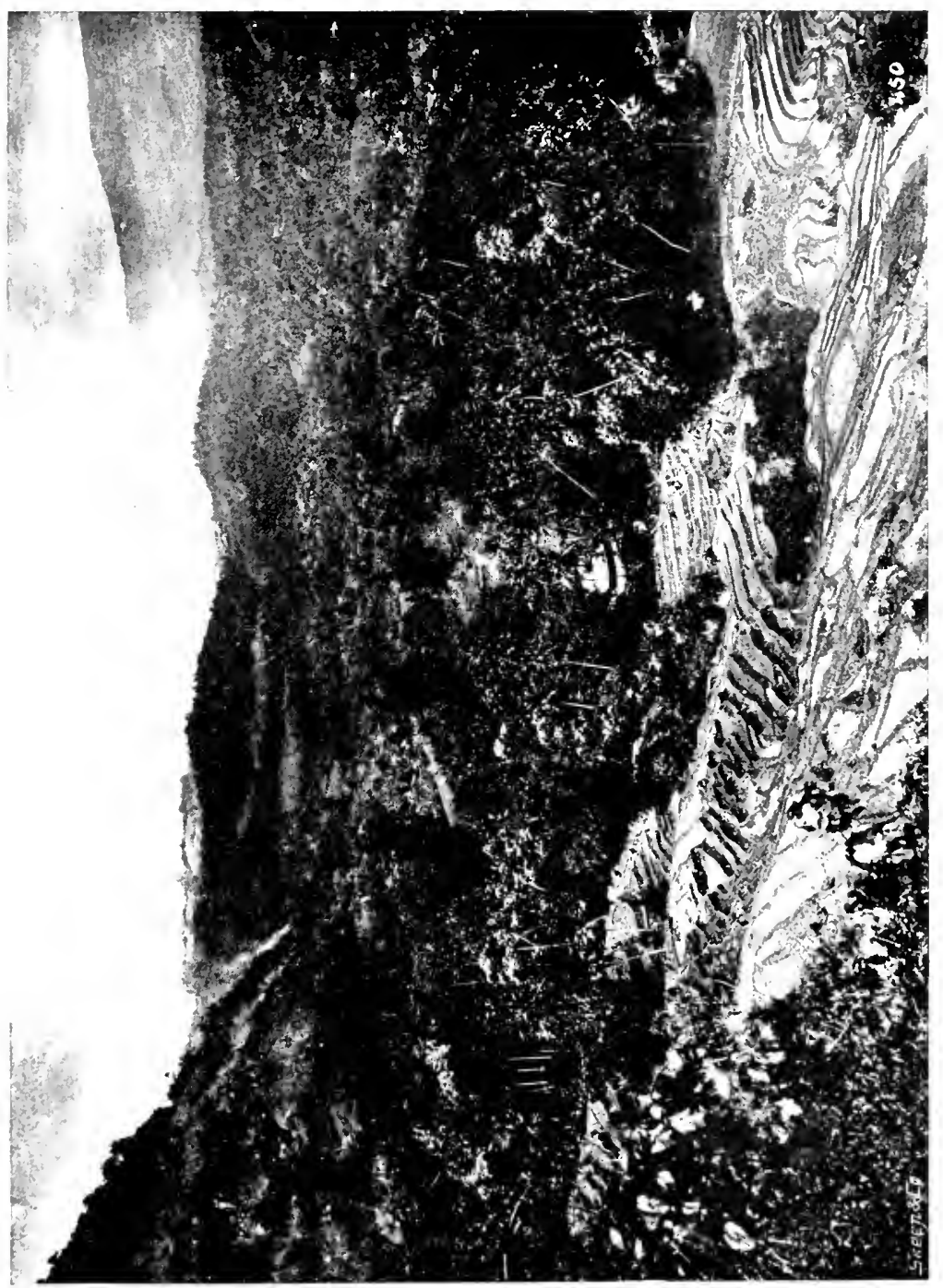



On left side of train.

On right side of train.

Castle Rock (Plate Xl) shoms here and rest of way up, really a rock, but lowking like a ruined castle. It was the refuge of Sardiel the bandit in is64.

Lolig tuinel.

Alagala siding, yol feet abore sea.

The railmar goes romed the comical hill visible alleal to the right.

Bible Rock (I'late Nl I'll) a that topped rock witl precipitoms sides, comming al hill, now visible for the rest of the way.

line curves romed to the right, affording a fine view of Magala Peak, from whose precipitous summit $(3,37$ I feet) the last king of Kandy used to hurl prisoners.

'Two short tumnels.

Line curves to the left, over "Sonsation Rock" where there is a rery steep drop for loundeds of fect.

Cacas plantation (p 5s).

Silort tunuel.

Cilassy valley, full of mana (p. 6, s) sowing on old coffece land (j. 40) recomisable by the patls still risible in it.

Balana siding, 1,405 fect.

Wild plantainsenmmon lece.

loms tumnel.

Coconuts (1). +7).

Long tumnel.

Steep diop from train.

Ilills with chena (1).37.)

Short tumnel througle a rock. 
On left side of train.

On right side of train.

I ligh hill; ucar base the road passes through a loole in a rock. There was a native tradition that Kandy would be subject to invaders who came through a rock and this hole was purposely made in constructing the road.

Short tumnel.

Tea (p. 5.3) and cacao (p.5s) with Grevillea (p. 66) as shade.

Monment to Majom Dawson in the narrow pass at the top.

Kadugannawa Station, 65 miles form Colombo, 1,608 feet above sea. The train divides before reaching the next station, so be sure to be in the Kandy or Gampola carriage as the case may be. This is now Kandyan comntry (p. S6) and the absence of the comb in the hair will at once be noticed in most of the men.

Rice fields, mixed gardens, tea on some of the hills.

Cross road and stream, then stream again.

Check for diviaion of the train.

Peradeniya Junction Station; line divides, one portion soing to Kandy and Matale, the other "up-comntr"y" to Campola, Nawalapitiva, Hatton, Nuwara Eliva and Bandarawela; book-stall.

Cross the Mahaweli-uanga (p. o) by iron girder bridge; on the left may be seen the fine three-arched bridge opened in 1906 to replace the old single-span bridge of satinwood which was tor so long a feature of the place. Immediately bellind it, on the risht, is the Botmic Garden, and in the background the forest-cosered hill of l ledusgala, upon the Coxermment Experiment Station.

Tea cstate haded with Madaps for green manure.

\section{Tea factory.}

Peradeniya (New) Station, 1,572 feet. Resthouse, comfortable, with fom bedrooms, about $\frac{1}{2} \mathrm{~m}$. off, near the gate of the Butanic Gardens. 
On left side of train.

On right side of train.

Village of Getembe, with the Malnaweli-ganea beyond,and hills of Experiment Station.

Bridge over small stream.

Rice fields, mixed cultivation and tea, with llantane mountains behind.

Kandy Station, I,602 feet. Change for Matale. Bonk-stall. Carriages and Rickshaws to hotels. Post Office near Station, in 3 story building on left.

\section{KANDY TO MATALE}

\section{(right hand side the better.)}

Government offices (other than Kacheheri) in three storied building.

Electric Light Works.

Young Womens' Christian

Astociation.

Police Station.

\section{Cutting.}

Barracks.

Nosque.

$$
\begin{aligned}
& \text { Lomg bridge. } \\
& \text { Cutting. }
\end{aligned}
$$

Station Road.

Police barracks.

Market.

Planters' Association Ilal] (with tower:)

Ward Street, at right angles to the railway.

Hill Street.

Mahaiyawa Station, for mortle end of Kandy, 1,726 feet. Kandy Cemetery.

$$
\text { Cross the great North road. }
$$

Rice and mixed pardens ( $(3) .43,4 \%)$

$$
\text { Coss Mahaweli-ganga. }
$$

Katugastota Station, 1,53.t feet.

(acan (p. 58), mostly shated by batay trees, boken by patelues of rice and mixid andens, of small lots of plantains (p. 50.)

Wattegama Station, 1,620 lieet. Ruads to Teldeniyad de (p. $1+5)$. 
On left side of train.

On right side of train.

Ilumasciriga l'eak, 49 fo feet, shaped like a cap of liberty; jungle near the top, srassand tea, shaded witl Grevilleas, belorit.

Plantations of cacas (1). 5s.)

Ukuwela Station, 1,202 feet.

Tea factory.

Tea and Grevilleat.

\section{Cacas.}

Cross estate road.

Oil palmo, with kong feathery leaves: the great staple of West Africa, no longer cultivated in ceylons.

Matale Station, 1,zos fect, Terminus, Resthoure, Post and Telegraph Oflices, Coach to Trincomalie.

\section{PERADENIYA JUNCTION TO BANDARAWELA}

(righle hand side to Kotagala.)

(left hand side to Watagoda.)

(right hand side to Pattipela.)

(left hemd side to Bandarawela.)

Cruse the little stream Namu-Oya.

Tea and rubber, with peeps Narow valley with paddy of hills at intervals. ficlds and mixed gardens.

Curve round to left, through a gap in the low hills, paddy fields, hills with tea behind.

\section{Cutting.}

Mahaweli-ganga, with bambooson bank. Nixed gardens between rail and river, with many arecanuts and candlenuts.

Gampola Station, 1,573 feet. Resthouse, road to Nuwara Eliya (p. 142)

Beautiful view on both sides. 
On left side of Irain.

On right side of train.

Mixed sardens, paddy ficdds, tea behind.

\section{Ulapane Station, I, $S_{4}$ f feet.}

The line mow setting inte more pure ly tea combtry.

l'rettr ane (looking back)

with bridge and tea behind.

Junction of streamis.

Road crosices to the left sicle

of line.

Fine view oree wh coffer. land to the hills.

Nawa!apitiya Station, 1,913 fect. Ke(ep to lisht side

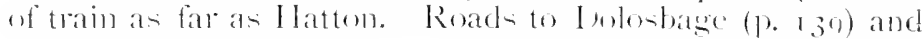
Craigie Lea (]) 1.42)

Pretty vicw, paddy fields ac. Clisis river.

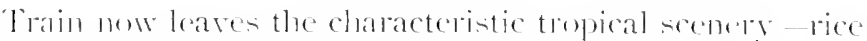
fictels, palms and bambons, and rlimber steadily upwad, with

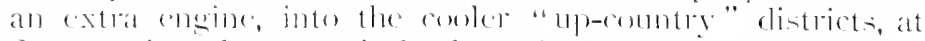
first pascing alomet entirely though plantations of tea.

Rubler (1).50), with stream below:

Fea and firevillear.

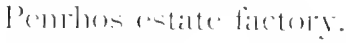

(is)ere witls little. stream which is corsised.

Materlall.

Pmonel (lowk ont on lelt immediatels after.)

Timmel.

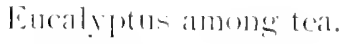

Galboda Sitation, 2,58 i fiet.

Finde vitw deme the valley

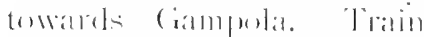

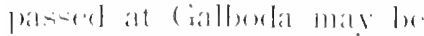

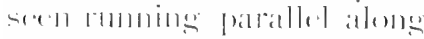
uther sidfe of valley in whiclu station lies. 
On left side of train.

On right side of Irain.

View down the kelani valley to the west. After 3 p.m., the sun may be seen shining on the sea near Colombo.

Jungle covered hills of the Adam's Peak range in backsround.

Enter long shallow valley (Ambegamuwa and Lower Dikoya) leading to llatton.

Watawala Station, 3,259 feet.

River far below.

Tea, shaded mostly with Grevilleas.

Great double curve.

Rozelle Station, $3,7+2$ feet.

Gorge below.

Adam's Peak, recognisable by its sharp couical apex (angle $90^{\circ}$ ) visible orer the other hills.

Cross road.

Hatton Station, 4,141 feet. P. O. on platform. Hotel. Refreshment rom on platform. Book-stall. Coaches to Norwood, Bogawantalawa and Maskeliya (†. v.)

Tumnel.

Tea and Grevilleas, Eucalyptus, do.

Kotagala Station, 4,065 feet. Kcep to left of train to Watagoda.

Tea factory.

Chunch.

Fine view down the valley of the Mahaweli-ganga mainly cultivated in tea.

Splendid waterfall, seen only in short glimpses. The monntain behind with forest (p. 6o) is known as Great Western. 
On left side of train.

On right side of train.

Tea factory.

Tumnel.

Brown and l avidson's works.

Talawakele Station, 3.932 fect. Resthouse, Post and Telegraph office. Crach to Agrapatana. Roads see p. I 1. Cross river; road bringe on

left.

Railway twists upwards through tea estates, backwards and forwaids, with rery sharp loops, though never crossing itself like the line to Darjiling.

River in gorge below, with

little waterfalls.

\section{Cutting.}

Factory on other side of valley, passed between kotagala and Talawakele.

\section{Tummel.}

Watagoda Station, 4,400 fect. Road to Pundalu-oya de. (p. 142 ).

Great Westem mountain, Dimbula valles, the prineiwith forest above the 5,000 pal tea district, with Idam's teet line (p. 60). Peak peeping orer the hills bevend. Mountains at near end of l lorton Plains aliead, sluwing somewhat of a hollowed hat slape: lotapella lett, Kirigalpota right.

Nanu-oya Station, 5,201 feet. Change for Nuwara Eliva. book-stall. Referlment romm. Book sleeping ear berths. Road (p. 1+1).

Tea and slate.

Thin forest.

Cross stream, with protty view of forest-osecerl hill (i) leit.

$$
\begin{aligned}
& \text { Cutting. } \\
& \text { Tea. }
\end{aligned}
$$

Finest, full of nelus (1) 61). 
On left side of train.

On right side of Irain.

Patanas (p.61).

Forest.

Fine crorese, with forest and beautiful waterfall near its head.

Crosestream by high bridge.

Vouded hills.

\section{P'atana.}

Cutting.

Wide expanse of patana, shming ver clearly the sharp defuntion against the forest (p. (1) . A gully in the patana with Rlododendron trees.

Stream, far side steep and wonded.

Stream in the patana, with numerous Rhododendrons.

Ambewela Station, j.ong feet. Railwar Receiving Office. Rond to the Nuwara Eliga - Badulla road (p. 1 45 ).

Patana, dotted with Rhododendrons, and with fortpath. Iligh ridge of l lonton Plains covered with forest, behind. Totapella, the third highest mountain in Cerlon, to the

Pretty wouded valley

$$
\text { left. }
$$

Two rock cuttings.

l'atanawith Rhudodendrons.

Pattipola station, 6,200 fiect. Restluouse. Path to Iorton

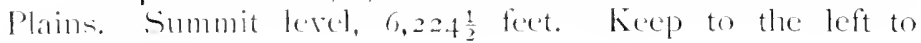
Bandianclat.

Tummel theresh the watershed, sometimes with very markef change of elimate fiom one side to the other (p. 16). licu wer patana country (1) l'a.

'Tunmel. 
Note the jungle theading out into: patana down the hills here (p. 61). The train winds down through the jungle.

$$
\text { longish tumnel. }
$$

Lely plantation of Australian trees (Eucalyptus) on other side of valley, with railway winding though it ; lovely view above.

Bridge, cutting and tumnel.

Ohiya Station, 5,877 feet, Railway Post Office. Shorter but steeper path to llorton Plains, 5 miles. A cool climate in which "temperate" flowers do exceptionally well.

Cuttings. Three tumnels.

fine views across Uva patanas. The camp at 1)ivatalawa visible, with red buildings to the right, white to the left.

\section{Eight tunnels.}

Villages with paddy fields down in the hollows, linking very picturesque.

Three tumnels $\left(\begin{array}{ll}33 & 35\end{array}\right)$.

Forest.

The line is now coming down again to the 5,000 feet line, and getting within range of the rains that come over the llaputale pass, and tea again appears, mostly shaded with Girevilleas.

Little hut, and then at once a momentary slimpse far down into the south-westem low country, for the line is now ruming along the edge of the mountain range.

Tummel 36 .

View down inte the low conntry for a moment.

Line curves romend to the left, and a tine momitan view opers up.

Tea loading station.

finerest. 
On left side of train.

On right side of train.

Patana.

Forest.

lea.

I Iaputale pass clearly visi-

ble ahead.

Haputale Station, 4,855 feet. Resthouse, Post and Telegraph Offices. Very often cloudy, windy, and misty here on the past. A view down to the southem low country at end of station. Road to Ratnapura de., (p. I 46 ).

Village, roots loaded with stones to prevent the sheets of inon blowing off in the monsoons.

Church.

Tea and Eucalyptus

High mountain ridse, with tea on lower slopes and patches of forest abore.

Patanál.

Cutting.

I'atana.

Very short tumnel.

Diyatalawa Station, 4,30, fect.

Camp below, formerly used for boer prisoners, now a naval, surver, ac., sanitarium. P'retty villages with padely fields.

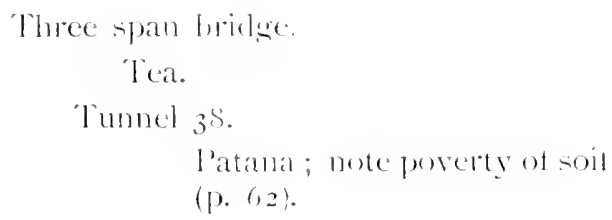

Bandarawela Station, 4,036 feet. Terminus. Post and Telespaph Offices. Resthouse. Roads to Badulla and Batticaloa and to Colombo (pp. 145, 1 f6). Coach to Baduila, Piscala and batticaloa (see Timbs.) 
On left side of train

On right side of train.

\section{NANU-OYA TO RAGALLA}

ina Numara Eliva.

This line is on the narrow sauge of 2 feet 6 inches, and also climbs at the very steep angle of 1 in 23 , with the most extraordinarily sharp curves. Consequently it is somewhat jerky in the movement of the trains as compared with the main line, and the rate of travel is but slow.

The line winds upwards to Nuwara Eliva $(6,200$ feet $)$ throush the beautiful Nanu-ova pass, which after the first mile or two is untouched, and contains fine up-country forest (p, 60)! Towards the summit Scrubs Tea Estate is passed througly, and then the line comes out above the lake, a pretty view being obtainable on the right towards Hakgala. It then runs between the lake and the racecourse, on the far side of which the large reddish building of the United Club stands, and into

Nuwara Eliya Station, 6,199 feet. Iotels. Carriages Roads to Kandy (p. 1 1 1) and to Badulla (p. 145).

The line then runs by patanas (p. 61) and tea estates to

Kandapola Station, and into the Udapuscellawa valley (full of tea) to

Brookside Station, and

Ragalla Station. Restlouse.

\section{POLGAHAWELA TO KANGESANTURA!}

\section{i'us Anuradhapura and laffure.}

Polgahawela Station, (sec p. 151).

Mixed gardens, rice, many arecas, old due mas, cocor uts.

Potuhera Station.

Similar country, with backemound of forest-dast hills.

Kurunegala Station. Rostlouse, Carriages. Roar's to Kandr, P'utalam, I ambulla, Amuradbapma, colombe, Negombro, Poligahawela.

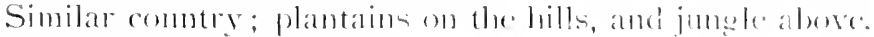
Smontly rock at top of bills.

Wellawa Station.

old chenal, coconouts, packly, ace. 
On left side of Irain.

On right side of train

Ganewatta Station.

Maho Station.

Old chenas.

Ambanpola Station.

Galgamuwa Station.

Tank.

Old chenas and patches of forest.

Talawa Station.

Talawa tank.

Anuradhapura Station, (wait 20 minutes, refieshment room). Resthouse, Post and Telegraph Offices. Roads to Puttalam and Trincomalie.

Paddy fields; Ablayagiriva and Jetawanarama dagobas (p. I 20) in background.

Cross road to Milnintale.

Jungle.

Occarional patches of paddy fields, with the watchers' huts.

Crosi Kanadara-Oya.

Madawachchiya Station. Resthouse.

Cross road to Mannar.

Scrub jungle, tanks, de.

North Road (p. 1+3)

Vavuniya Station. Resthonse.

Scrub jungle.

Puliyankulam stopping place.

Mankulam Station, for Mullaitiou.

Country gets sandy, with patches of scrubby jungle.

Kilinoclichi stopping place.

Paranthan Station.

Jungle still more scrubby and sandy.

Cosis lagoon on causeway.

Resthouse.

Elephant Pasi stopping place.

Scrubby jungle and sandy patches. 
On left side of train.

Un right side of train

Palmy ras and coconut palms (p.6.4) get gradually more common.

Large coconut estate.

Pallai Station. Resthouse.

Palmyras and scrub and paddy fields and coconuts.

Kodikamam Station. Coach to Point Pedro.

Palmylas and coconuts.

Chavakachcheri Station. Resthouse, l'ost and 'Telegraph Offices.

Lagoon.

Paddy ficlds.

Navatkuli Station.

Cross lagoon.

Jaffna Station. Resthouse. Post and Telegraph Offices. Suburbs of Jaffina, mixed gasdens, \&c.

Kokuvil stopping place.

Gardens and palms.

Vegetable sardens-about 30 toms of regetables are sent weekly fiom Chumakam to Cinombo.

Chunnakam Station.

Mixed sardens and palms; note the Jatfina method of irrigation with well sweeps and little enclosures round the plants.

$$
\begin{aligned}
& \text { Tellippallai stopping place. } \\
& \text { Cardens and palms. }
\end{aligned}
$$

Kangesanturai Station. Resthonse. Terminus. Post and Telegraph Offices. Steamers to Colombonand Trincomalic.

\section{MARADANA TO MATARA}

ara (ialle (sia on right).

Lake and dhobies (p. g1) Royal College (p. 101)

Pettah Station, the busiest on the line.

Banyan tree.

I. M. C. А. buildings.

Bathing and dhobies.

Fort Station.

Barracks.

Parade ground. Lake and Galle liace. 
On left side of Irain.

On right side of train.

Slave Island Station.

Coosi am of lake.

New clminds.

Galle race flotel.

Cinpetty humes.

Sea.

Line passes through se aside suburbs of Colombo.

Kollupitiya Station.

Bambalapitiya Station.

Wellawatta Station.

Cirss canal.

Dehiwala Station.

Rockis at Mt. Lavinia.

Mt. Lavinia Station. Ilotel.

Anguiana Station.

$$
\text { lake. }
$$

Lunawa Station. Resthouse.

Moratuwa Station. l'ost and Tilesraph Oftices, Resthouse.

Panadure Stati 11 . Renthouse.

Canal.

Wadduwa station.

fums]y cocomuts ismall proprictors).

Kalutara North Station.

Cirsialu-ganga river by long bridge.

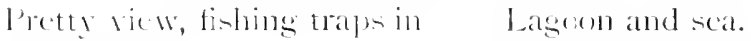

foresistourt.

Ciansiy ciplatuade.

Fint, with new residence

of (i. 1 .

Kalutara South Station. Lalsetomn. Restlouse. Post and Telegraph offices. Road to Neboda.

Katukurunda Station.

l.agoms.

Paiyagala North Station.

Berumela Light Ilouse.

Paiyagala South Station. 
On left side of train.

On right side of trair.

Maggona Station.

Lagon.

Sea and Berumela Light.

Alutgama Station. Resthouse.

Cross Bentota river.

bentota Resthouse.

Induruwa Station.

Padely fields.

Lagoon.

Kosgoda Station.

bieadfruit common now in mixed gardens.

Ba!apitiya Statinn.

Cimmanon cultivation p. 62 )

Lagoon.

Ambalangoda Station. Resthouse.

River.

Lagon.

Beach jungle with screw

pines ( 1.62$)$.

Lagoom.

Hikkaduwa Station.

lagom with maneroses p 6,2 , and with little collchosures in which the rotting of the solt tisstase between the coir libres is carried on (1). 48 .

\section{Dodanduwa Station.}

bie laserent back a bit; beadlinits between station and lasson.

Mangroves and river.

Gintota Station.

Galle Station Momally clange for Matara; carriages; lentel: Post and lelegraph (oflices.)

Talpe Statims.

River with coir pits. 
On left side of Irain.

On right side of Irain.

Ahangama Station.

Much branched papaws along the platform.

River with coir pits.

Weligama Station.

River behind the trees, with

mangroves.

Paddy fields with momntain

background.

Glimpse of pretty lagoon.

Kamburugamuwa Station.

Weedy mixed gardens and coconuts.

Matara Station. Terminus. Resthouse. Coach to Akuressa and Deniyay, and to Tangalla and Hambantota. Post and Telegraph Offices.

\section{MARADANA TO YATIYANTOTA.}

Namore gauser.

Maradana, sec p. 149.

Town and mixed sardens.

Cimmamon and grass.

Cotta Road Station.

Golf Links; pavilion on left.

Cinnamon and grass.

Canal.

Mixed gardens and coconuts.

Nugegoda Station.

Mixed gardens, betel, pepper (p. 52) de.

Occasional rice fields.

Pannipitiya Station.

Mixed gardens, coconuts and cimmamon.

Paddy fields.

Homagama Station.

Mixed gardens, coconuts, paddy ficlds, Sc. 
On left side of train.

On right side of train.

Padukka Station. Whisky and soda de., for sale.

Country now gets hilly, with pretty views.

Cross river from Labugama reservor.

Waga Station.

Mixed gardens and coconuts.

Kosgama Station.

Crosis river.

Tea.

Puwakpitiya Station.

'Tea.

Tea and rubber:

l)agoba (1). 79).

Rubber.

Avisawela Station. Restlunse. Post and Telegraph Offices. Coach to Ratnapura.

Crosiver (Sitawaka-ganga.)

Taldua plattiom. l'retty riems.

Tea on hills.

Dehiowita Station.

Karawanella Station, road to Ruwamwella, $2 \frac{1}{2} \mathrm{~m}$.

Yatiyantota station. Terminus. Resthouse. l'ost and Telegraple (offices. Road to Kitulgala, Kands, and upe-country (j. 138$)$. 


\section{Chapter XIII.}

\section{THE CHIEF TOWNS, VILLAGES, PLANTING}

DISTRICTS, \&c., OF CEYLON, ALPHABETICALLY ARRANGED.

I this chapter we propose to grive a gazetteer of the colony, so that those finding themselves in any town of rillage, o about to visit it, may know what they mav expect to find there. With this end in view, there is given for each place it- province, distlict, road on which it lies, population, elevation above sea, whether it possesses Post or Telegraph Oflices, Resthouse, Clubs, Chumehes, llospitals, Ac.; its institutions, thing worthy of a risit, local officials, rates for carriages \&c. coaches, rail, w steamers, and so on. No responsibility, of enuse, is undertaken for the correctness of information ro times of coaches or trains, or other matters.

ADAM'S PEAK. See Maskeliya.

AGRAPATNA. Central Province, Nuwara Eliya district, neale end of cart road fiom Talawakele, r 13 m. Population 314. Elevation about 4.000 feet. Post and Telegraph Office, Sprots Chol, Many tea cstates. Fontpath to Horton Plains, г 2 m. Coach to Talawakele, leaves Israpatna 7-30, arrives Talawakele ı ; leaves Talawakcle 3, arives Asmapatma 5-30. Fares R- $5,375,2 \cdot 50$.

AKURESSA. Southern l'rovince, Matara district, m road from Matala to Morowak kiole. To Galle 23. m., Weligama $1+$ m., Natara $12 \underset{2}{1}$ m., Kumburupitiva 7 m., Nownaka 16 m., Penivaya $28 \mathrm{~m}$. Population 615. Punt Office and Resthouse. The roud to Kumburmpitiy is rery prottr, and passes several picecs of forest (p. 37), and there are numerous citronella estates in the neighbourhod (1).63). Coach to Matara, leaves Akuresia 1-25, alvives Matara 3-30; leaves Matara 10, arrives Akuresia 12. Fares Rs. 3, 1.50, 1. Coach to Mormaka and lenivara, leaves Akulesia 12-20, arrives l)eniyaya 5-0; learé I tenivava $S-30$ Saturdays 5 p.m. , arrives Akuressa $1-15$. Farcis R. 10, 5.50,3.

ALUTGAMA. Western Provinec, Kalutara distict (on south side of rivel is Sonthem l'rovince), on main road and 
railway from Colombo $38 \mathrm{~m}$, to Galle $34 \frac{1}{2}$ m. Kalutara $11 \frac{1}{2} \mathrm{~m}$. . Ambalangoda $15 \frac{1}{1} \mathrm{~m}$. Road to Moragala $5 \mathrm{~m}$. Population 2,318. Sea level. Post and Telesraph Office, Resthouse. Bentota, on other side of river, with pleasant sea firuntage; a very popular place of resort .

AMBALANGODA. Southern Province, Galle district, on main road and railway from Colombo $533 \mathrm{~m}$., to Galle $183 \mathrm{~m}$. Alutgama $15 \frac{1}{1} \mathrm{~m}$. Mlikkaduwa $6 \frac{3}{t} \mathrm{~m}$., Baddegama $1+\frac{1}{4} \mathrm{~m}$. Elpitiva small planting district, tea and rubber $10 \mathrm{~m}$. Population 700. Sea level. Post and Telegraph Office, Resthouse comfintable, with good and safe sea bathing.) There are sod mangroves se., (p. 6z) on the basoon shores inland.

AMBEGAMUWA. Central Province, Kandy district, about 25 m. lim Kandy by way of Nawalapitiya. Planting district, with about to estates, mostly of tea, but some also with rubber, sc. Hospital and dispensary at Nawalapitiya. Railwaystations Galboda and Watamala. Eleration s,Soc3,000 lict.

ALAGALA. Central Provinceand Sabaragamua Province, about 5-15 m. firm Kandy. Planting district, mostly in tea, lut with a soud deal of rubber, cacao, de. Hospital at Kandy, dispensary at Kadısannaw. Kailway stations Peradeniva Junetion, Kadugamana. Elevation joc-2,700 feet. Magala l'eak $(3,300$ feet $)$ is a fine object ascending the raiłway from Rambukkana to kadusannawa form its summit the last king of Kandy used to throw eliminals.

AMBEWELA. L va Province. It ered of calt load firom ncar llakgala, 5 m. fiom Numara blisa Badullarad. 12 m. to Numara Eliva. Ekeation 5,090 foet. Rahway Receiving Office, Rallway Station. Footpath to llotom l'lains not now well kept up; it is better to go fiom l'attipulal, and to Numaralitival 1 i $m$.

ANURADHAFURA. North Central l'rusire (the capital),

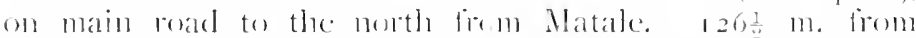

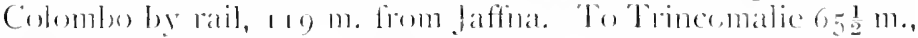

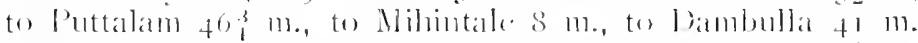

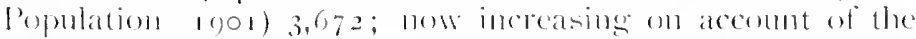
railway commmnication, and estimated at 4,675 in 1007 .

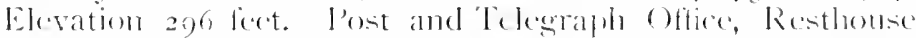
with s bedromes, soun to be replaced by an hotel where is

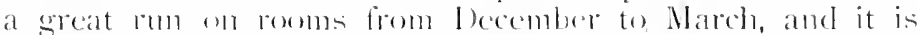

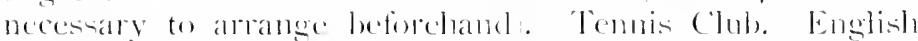
and Reman Catholie Churehes. Ihospital. Climate aee p) 15.

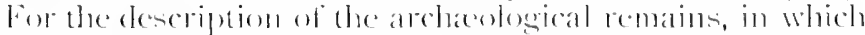

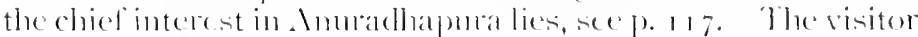
shoukl not tail to see, it lo has the time, the liazen l'alace, 
the Ruwanweli and 'Thuparama dagobas, the Sacred Bo-tree, tsurummiya temple (walking back along the bund of the Tissawewa, best about sunset, the Abhayagiriya dagoba (going to the top for the view of the town and country), the Buddhist railing, the sedent Buddha in the northern part of the town, the Jetawanarama dagoba, the King's Palace, and Nuwarawewa tank, (on the other side of the railway; on the bund there is usually a nice breeze, and it is a good place to have afternoon tea) de. Ile should also visit Mihintale (p. 12 r)

Local officials: Govermment Agent and Assistant; Provincial and l)istrict Enginecrs; Irigation Engineer; Superintendent of Surveys and Medical Officer. Rates for carriages, first class, one-horse, within Local Board limits, 6 a.m. to 7.30 p.m. Rs. \& -; six hours Rs. 2 -; half hour 50 cente, onc hour Rs. I -; every further hour 25 cents. Outside local Board limits 50 cents a mile. Second class carriage $\frac{3}{4}$ less; night 13 more; two horses $\frac{1}{3}$ more.

Trains leave Anuradhapura 7-45 a.m. and 2-20 p.m., arrive Colombo 3-1 7 P.m. and 8-30 p.m. arrive Kandy 5-58 p.m. and r1-40 p.m. Arrange for breakfast or dinner at Polgahawela Resthouse if going to Kandy.

AVISAWELA. IVestern Province, Colombo district, on Kelani Valley railway, and road from Colombo to Nawalapitiya or to Ratnapura, $29 \mathrm{~m}$. firom Colombo, i 3 m. from Yatiyantota, $25 \frac{1}{2} \mathrm{~m}$. from Kitulgala, $42 ! \mathrm{m}$. firom Nawalapitiya, $27 \mathrm{~m}$. from Ratnapura. Population 1,900. Post and Telegraph Office, Resthouse, Temnis Club, Ilospital.

Trains to Colombo leave at 6-15, 8-30, 4-o (week days) arrive Colombos $8-53, \quad 10-56,6-29$; from Colombo leave at $7-30,2-30,6-30$ (week days) arrive at $9-55,5-5,8-55$. Trains also to Yativantota. Coach to Ratnapura \&c, leaves $11-0$ a.m. 9-30 p.m. arrive Ratmapura 3-o, 5-o a.m.; leave Ratnapura 10-50 a.m., 9-o p.ml., arrive Avisawela 3-20 p.m., 5 a.m. Fares by day coach, Rs. $7.50,5.00,3.00$.

BADDEGAMA. Southem Province, Galle district, on the Gin-sanga, and minor road fiom llikkaduwa $7 \mathrm{~m}$, Dodanduwa $7 \mathrm{~m}$. Population 2,953. Post Office, Resthouse. C. M. S. Church and Boarding School for girls. A few rubber, sluar, citronella, dce, estates.

BADULLA. Uva Province, on main road from Colombo wia llaputale to Batticaloa, $136 \frac{1}{3} \mathrm{~m}$. from Colombo. Capital of Uva, is m. from Bandarawela, 12 m. from Passara, $26 \mathrm{~m}$. from Lumugali, $10 \mathrm{~m}$. firom Taldena, 36 m. from Nuwara Eliya, I $9 \frac{1}{1} \mathrm{~m}$. from Welimada. Population 5,924 (6,576 middle 1907). Elevation 2,222 feet. P'ost and Telegraph Office, Resthouse, Roman Catholic English and Wesleyan Churches, Club Tennis Clul, (oolf Clul, Library, Hospital, Y. M. C. A. 


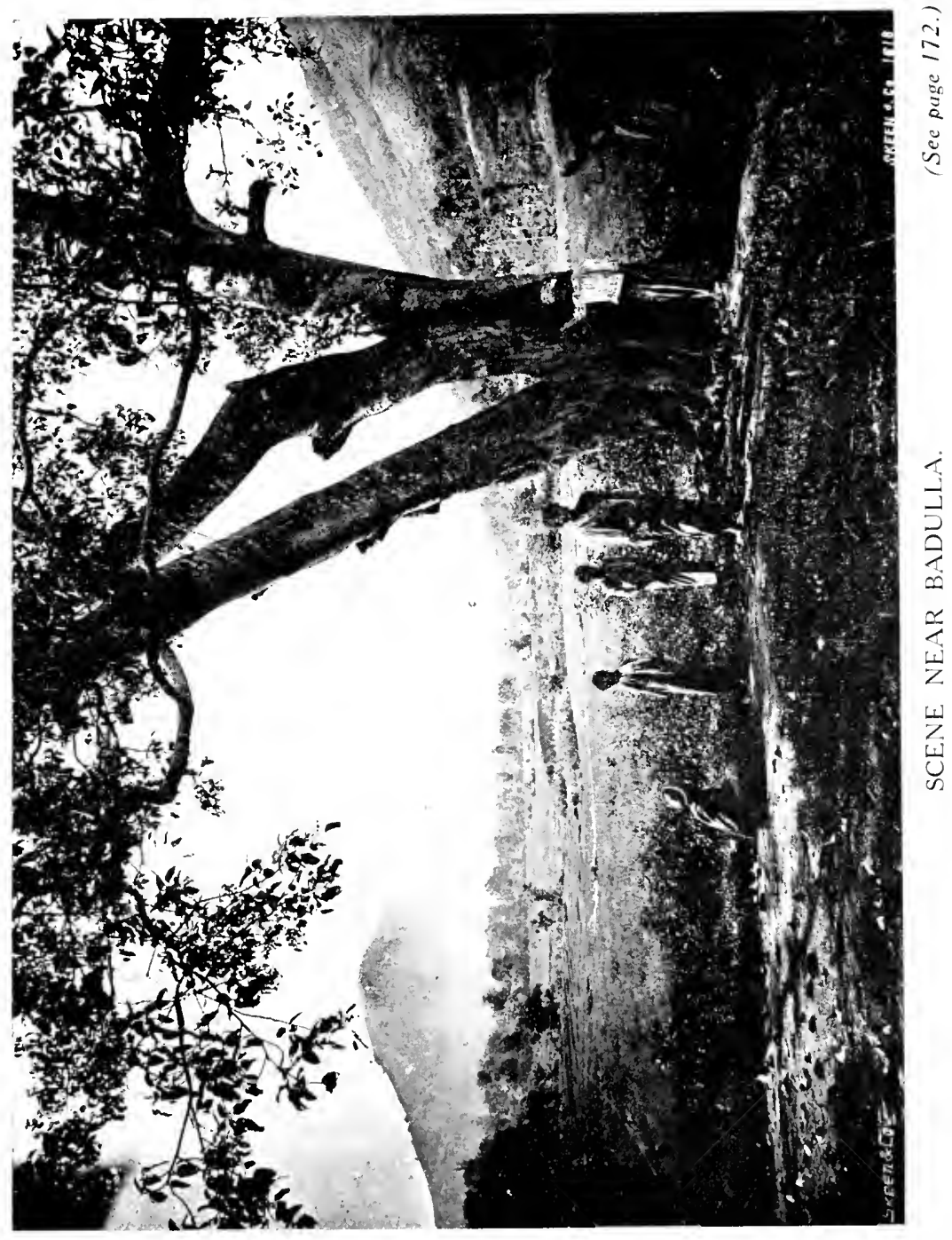



Badulla is a very pretty town, with a pleasant elimate, mean temperature 73 (p. is). Entering by the coach from Bandarawela, there is a fine view across the vallev to the loftr peak of Namina-kuli-kanda, 6,680 feet high, the chief mountain on the eastern side of the centre of the island; it is corered with tea estates to 5,000 feet, but there is untouched forest above that. To the left is the hospital, and beyond that, and nearer to the road, the market, while a little further on is a hill, also on the left, on top of which stands the kacheheri. From this there is a pretty view to the north into a short valley with terraced paddy fields. The river, the Badulla-Ova, runs round bethind the low hill on the right of this view. To the right, below the kachelueri, is the Resthouse, and to the left St. Mark's Church, built in I 854 in memory of Major Rogers, Assistant G. A. of Badulla, who was killed by lightning at Iaputale, and buried at Nuwara Eliya.

Passing between church and resthouse, the road presently turns to the right into the main street, but going to the left rome the jail, we come to an old military gravevard behind it, in which is a tombstone all but covered by the growth of a bo-tree over it, in memory of Sophia Wilson, wife of the Assistant Resident and Agent of Lva, who died $24^{\text {th }}$ May, 1817. There are also other old graves here. Passing the mosque and turning to the left, we come out upon the very pretty raccourse, on the left hand side of which is a little arden, formerly kept up as a branch of Peradeniya, now in the hands of the local board, and a pleasant place of resort. The Grand Stand and the Temnis Club are on the far side of the racecourse and there is a pond in the centre of it. Colf, cricket, and croquet are also played here.

At the end of the main street, which call be reached by going up beside the factory on the far side of the course, is a rery picturesque Buddhist temple, the Mutigangane Vihara, with bo-trees, dagoba, sc. A pretty road rums to the right at the end of the main street, passing the bank of l va; taking the first tuming to the right, we come into the street passing in firont of the resthouse, at the top of the hill in which is the Town llall on the left, then a temple (the Kataragm I)ewala) on the right, and the Government Agent's house on the left, facing a little green, on the far side of which is the l'ost Office.

Local officials: Coveroment Agent and Office Assistant, bistrict Judge, Provincial and l bistriet Engineers, Superintendent of Survers, Provincial Surgeon and Medical officer.

Rates for camiages: first class carrage, with one horse, fiom 6-30 a.m. to 7 p.m. Rs. 4, (3-30 a.m. to noon, or noon to 7 p.m. Rs. 2, one hour Rs. I ; every adelitional hour 50 cents. Second class carriage 13 less; two horses 13 more. 
Coach to bandarawela leaves a prun, arrives $4-15$; leaves Band:uawela 12 , arrives Badulla 2-45. Bullock coach leave- Badulla $\$-30$ p.m., arrives Bandarawela + a.m. ; leaves Bandarawela 7-30 p.m., amives Badulla 4 a.m. Fares by luorse coach Rs. 6, 4, 2, by bullock coach Rs. 3, 2, 1.50. Coach to Pussara and Batticaloa, leaves Badulla 3-30, arrives Passara 5-30; leaves Pasiara 0-45 a.m., arrives Badulla 12. Fares R: $5,3.50,2$.

BALANGODA. Sabaragamua Province, Ratnapura district, on main road from Colombo $S_{3} \mathrm{~m}$. wit Ratnapura $27 \mathrm{~m}$. and Ilaputale $20 \frac{1}{3}$ m.to Batticaloa. Pelmadulla $15 \frac{1}{5} \mathrm{~m}$. llaldummulla $22 \frac{1}{4} \mathrm{~m}$. L'opulation $1, S_{4} S$. Elevation 1,730 feet. Post and Telegrapl Office, Resthouse, Hospital. Many tea and rubber estates in the district.

BANDARAWELA. Lva, at the terminus of the uncombly railway from Colombo $160, \mathrm{~m}$., and on main road

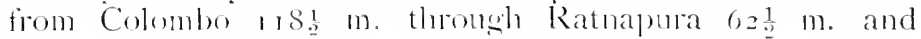
Haputale $6 \frac{1}{\mathrm{~m}}$. to Badulla $18 \mathrm{m.,} \mathrm{Passara} 30 \mathrm{m.}$, Lunugala $44 \mathrm{~m}$. and Batticaloa $125 \mathrm{~m}$. Fontpath to Nelimada $10 \mathrm{~m}$. and path to Etampitiva $17 \mathrm{~m}$. Road to Craig Estate, up the hill, with fune views. Population 1.437. Elevation 4.036 feet. l'ost and Telegraph Office, Ifotel m Resthouse. I laputale Bow Club itemnis and social) mects here. Golf Club. Police Court. Roman Catholic and Enelialu Churches.

This place is situated in perhaps the most bracins, though not the coolest, clinate in the island, and commands splendid mountain views, and it is now on the way to become, with I) ivatalawa, close by, the second sanitarime of the colony. It has its dry weather in the southwest monsoon (p. 15), when Nuwara Eiliva is wet. The country is nearly all patana (p. 6r).

A little war to the north of the hotel is a small lake, from which on the left rums the fortpath to Velimada which is quite a prettr walk, and roms through some patches of forest (p. 60) and by paddy fields, and about 5 m. consies the Uma-ova at a very pietty spot. On the risht is the path to Etampitiva, also worth following. About a m. it runs steeply downhill, and at this point is a path running off to the right acrosic the patana, which if followed a little way ermes to a fine view point, howing down into a little valley containing a village. The road to llaputale is also worth following, and that to Crain commands tine views.

Trains to Colomlur at 6-45 a.m., and 5-20 p.m. (dine at Nann-ova), arrioner at 5-50 p.m., and 7-5 a.m. Coach to

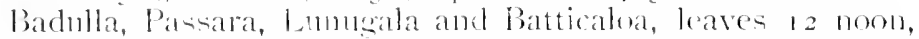

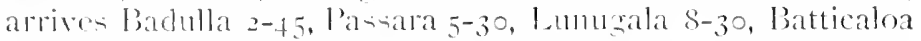
6 p.us. the next nimlit. Leave- Batticalua 5-30 a.m., Lunugala 7 a.m., l'a-iara 0-45, badulla , arrive Bandarawela $4-15$ p.m. 
BATTICALOA. Capital of Eastern Province, on the east coast, $2.43 \frac{1}{2} \mathrm{~m}$. by road from Colombo, through Ratnapura $187 \frac{1}{2} \mathrm{~m}$., Ilaputale $133 \mathrm{~m}$., Bandarawela $125 \mathrm{~m}$., Badulla $107 \mathrm{~m}$. . Lunugala $S_{1} \mathrm{~m}$. To kalkuda (the port of Batticaloa) $20 \frac{1}{2} \mathrm{~m}$., Trincomalie $99 \frac{1}{2} \mathrm{~m}$., (road good, and rery pretty, but with no bridges, and many large ferries to crosis), Kalmunai 23 m., Tirukkovil 45t m. P'opulation 9,960) (1901) 10,369 (1907). l'ost and Telegraph Office, Resthouse, English and Roman Catholic Churcher, Club, Library, Y. M. C. A., Friend in Need Society, Weslevan Central Institution (High School), Planters' Association (there are several coconut estates along the coast, and a commencement has been made in planting under the tanks).

Batticaloa is an old town, laving been in the possession of the I utch and the Portuguese, and close to the Restlouse there is a fine old butch fort, erected in 1682 . The town lies upon a large lagoon (p. y), which enters the sea by a narrow mouth sone three miles lower down. Cloth weaving in still quite an industry here, and may be seen going on in several places; the cloths are sold all over the island. "The district is mainly 'Tamil (p. S6) and more tidily kept than the Sinhalese parts of Cerlon, the houses being mostly fenced in with cadjan fences ( 1 . 47 ).

One great source of interest at Batticaloa is the singing fish, which are to be heard in the lagoon on clear nights. The sound is like distant motor lomper and is supposed to come from a molluse (p. 22). It may be mone clarly heard by putting one end of une's stick in the water, the other in the car.

Crach to Bandinawela leaves Batticaloa 5-30 a.m., Chenkalide $6-50$, a.m., Lumugala 7 a.m. next day, Badulla i p.m., arrives Bandarawela $4^{-1} 5$ p.m. Leaves Bandarawela 12 meon arrives badulla $2-45$ p.m., Passilra 5-30 p.m., l, nnugala S-30 p.m., Batticalon 6 p.m. next night.

\section{BENTOTA. See Nlutwallil.}

BOGAWANTALAWA. Central P'resince, Nuwara Eliya

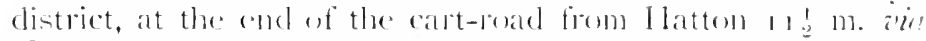

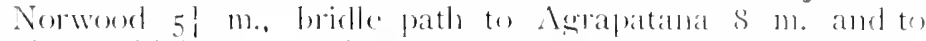
Ilorton l'lains $10 \mathrm{~m}$. P'opulation about 500. Elevation 4,340

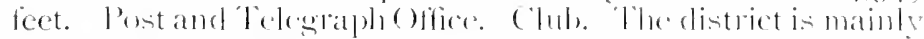
tea estates (1) 5.3) but on the flooten Plains sile there are jungle and patana (1). (,o).

Coach (for l latton, wange at Norwood)-leaves s a.m. and

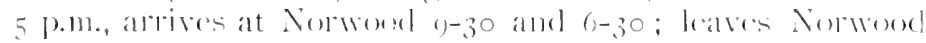

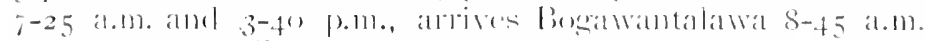

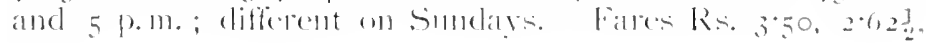
$1 \% 5$. 
BROOKSIDE. Central Provinec, Nuwara Eliva district, I da-l'ussellawa planting district, on road and railway station there) from Nuwara Eliva $10 \frac{1}{2}$ m. ala Kandapola 4 m., to Ragallat. Branch road to Maturata district.

CHAVAKACHCHERI. Northern Provinee, Jaffina district, on road and railway (station there, from Colombo $236 \mathrm{~m}$. rail) ile Anumadhapura $103 \mathrm{~m}$. road, $109 \mathrm{~m}$. rail and Pallai $13 \frac{1}{4} \mathrm{~m}$. to Jaffina 1 s $\mathrm{m}$. Branch roads to Point Pedro $\mathrm{I}_{4} \mathrm{~m}$. and Puttur $8 \frac{1}{2} \mathrm{~m}$. Population 3, $\mathrm{S}_{3}$, Post and Telegraph Office, Resthouse. An interesting open air market is held here (cf. Jaffina). Trains to Jaffina at $8-50,3-45$ and $7-35$ (half an hour) returning at $7-40,1-35$ and +-35 .

CHILAW. North-Western Province, Chilaw district, on road from Colombo $+7 \frac{8}{4}$. wia Negombo $24 \frac{3}{4} \mathrm{~m}$. and Chilaw to Puttalam $33 \mathrm{~m}$. Road (partly minor) to Wariyapola on the road from Puttalam to Kurunegala $4^{6 . \frac{1}{2}} \mathrm{~m}$., first Resthouse at Bingiriya $9 \mathrm{~m}$. Population (1907) 4.466. Post and Telegraph Office, Resthonse, Catholic Church, Hospital.

Local officials: Assistant Government Agent, District Judge.

Coach from Negombo (q. v.) leaves Negombo 6 a.m. and 1 1-30 a.m., arrives Chilaw 1 I a.m. and 4 p.m.; leaves Chilaw 5 a.m. and 1 I a.m. arrives Negombo 10 a.m. and 3-30 p.m. Fares Rs. $5,3,2$.

COLOMBO. Western Province, capital of the province and the island.

Roads and Railways, see Chapters Xl., NIl. Coaches to Negombo, Chilaw and Puttalam (q. v.) and Steamers to Negombo, leaving at $6-30$ a.m., 7-30 a.m., I p.m. and 2-1 5 p.m. Fare Rs. 1.

Population at census of $1901,158,093$, calculated to 1907 , 176,724 . The death rate is higher than the birth rate, owing to the number of unmarried men in the town, and the increase of population is due to immigration.

Post and 'lelegrapl Offices in the Fort, and at several suburban places, e.s. Slave l-land. Telephone Exchange.

Hotels, First-class: Grand Oriental, near the landing jetty; Bristol, a little way up York Street; Galle Face, at southern end of Galle lace walk; Mount Lavinia, about seven miles from the liort, on the coast. Smaller, but comfortable; Globe, British lndia.

Clubs. Colombo Club (general, residential) on Galle Face; Prince's Club (social) at end of Racecourse Arenue, near the course, Carden Club (social, tennis, croquet), by the Muscum, German Club (social), opposite the Museum, Sports Club, Turf Club (Cevlon), Cricket Club (sround in Torington Place), Golf Club (links near Borella), Polo Club, Rowing Club, Sailing Club, Kemnel Club (Ceylon). 
PLATE XLVIII.

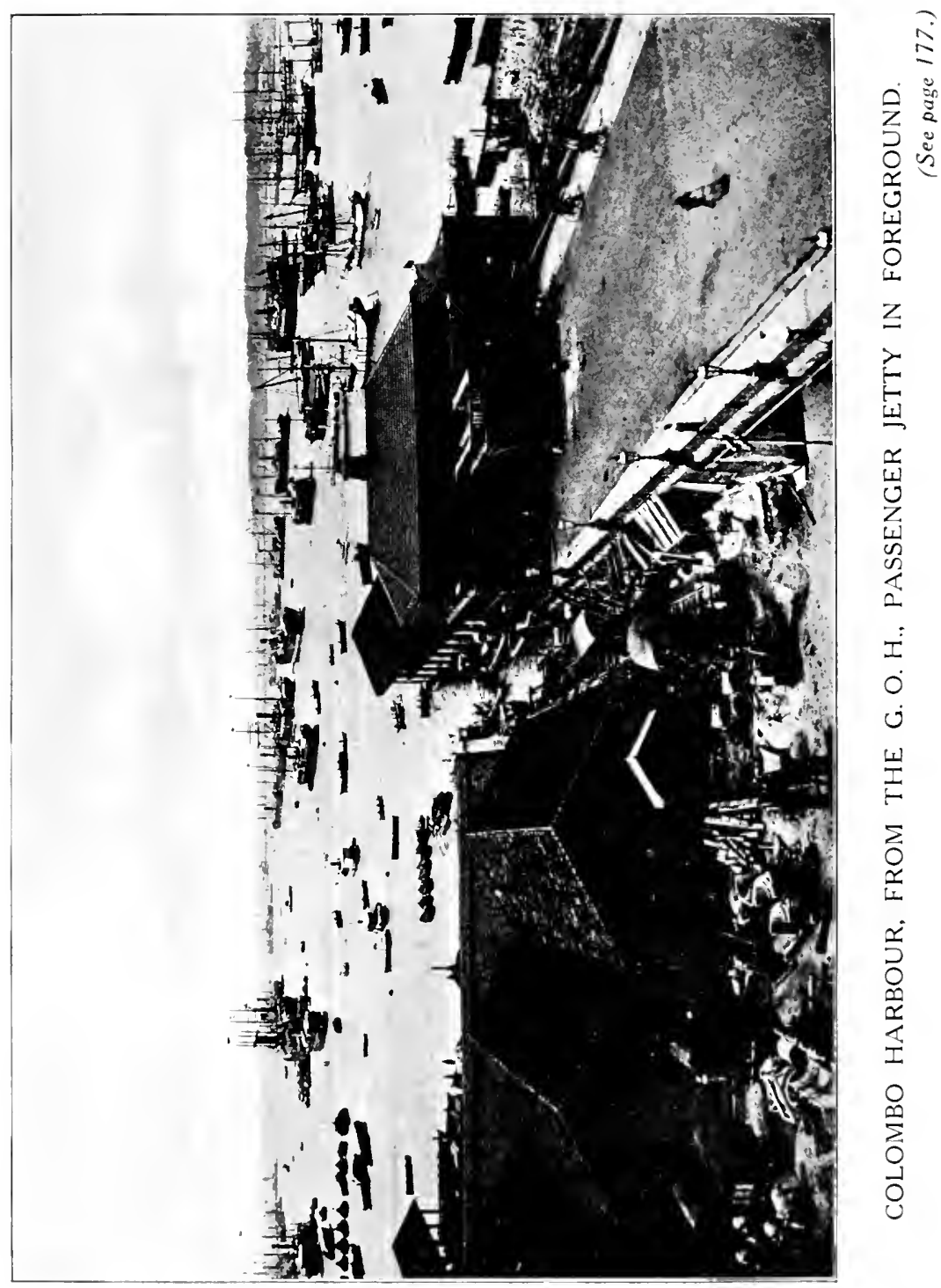



Churches. It is impossible to gire a complete list in the space arailable, but the chicf, arranged by denominations, are

Baptist, Cimmamon Gardens, services at $8-30$ a.m. and 6 p.m.

Church of England, Christ Church Cathedral, Mutwal, services 6 a.m., 7 a.m., $S$ a.m., 4 p.m. and 5 p.m.

Christ Church, Galle Face, services 9-30 a.m. and 5 p.m.

St. Michael's, Polwatte, services 6-30 a.m., 7 a.m., 7-30 a.m. and 3-30 p.m.

St. Peter's, Fort, services $S$ a.m., 9 a.m., $10-15$ a.m. and 6 p.m.

Presbyterian, St. Andrew's, service 9 a.m.

Wolfendahl, services 9 a.m., I-30 p.m., and $4-30$ p.m.

Roman Catholic, St. Lucia's Cathedral, Kotahena, services 7 a.m., 9 a.m. and 5 p.m.

St. Philip Neri's, Pettah, services 7 a.m., 9 a.m. and 5 p.m.

Wesleyan, Kollupitiya, services $8-30$ a.m. and 4-45 p.m.

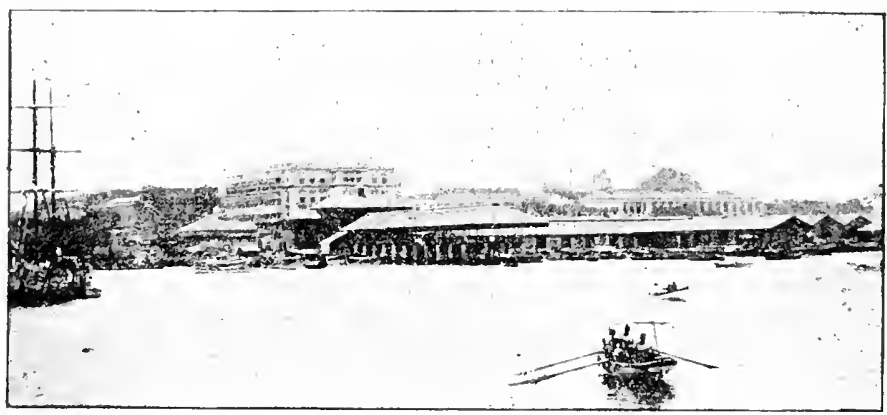

PASSENGER JETTY.

The Approach to Colombo by Sea, Landing, \&c. Approaching Colombo by sea, the mountain range, with Adam's Peak conspicuous in it, may often be seen, especially in dry weather and in the morning. The shore appears like a long forest of coconut palms, but if the approach be from the south, the (white) Mount Lavinia hotel at about seven miles away, and the (red) Galle Face Hotel at a mile away, are both rery comspicuous. The llashing light, upon a tower in the Fort, is visible for about 15 miles from a slip's derk.

The harbour, which is a purely artificial one, is entered between two of the three breakwaters, within which lies a square mile of smooth cnough water. The great south-western breakwater, over 4,000 feet long, with a lightlouse at the outer end, was the first to be built, the foundation stone having been laid by Ilis Majesty the King in the end of 1875 . The 
island breakwater in the middle is about lualf a mile long; and the north-eastern about r, roo feet. The south-western breakwater is a rery favourite promenade during the north-east monson, but in the south-west is swept by heary seas, and is unsate to renture upon (Plate V). Once inside the harbour, the ship is brought to morings, there being no piers or whares alongside of which ships can lie. Towards the north-eastern corner of the harbour is a very large graving dock, into which the largest warship can enter, and between this and the passenger jetty is a patent slip for repairing ships up to r, 200 tons in burden.

The steamer once pasied by the Port Medical Officer, is usually more or less invaded by tambies or merchants, selling jewellery, curios, sc., or exchanging money. It is much better to buy ons shore, rather than pay the extra rates demanded on board, especially as more reliable merchants are generally to be found there. To get ashore one has the

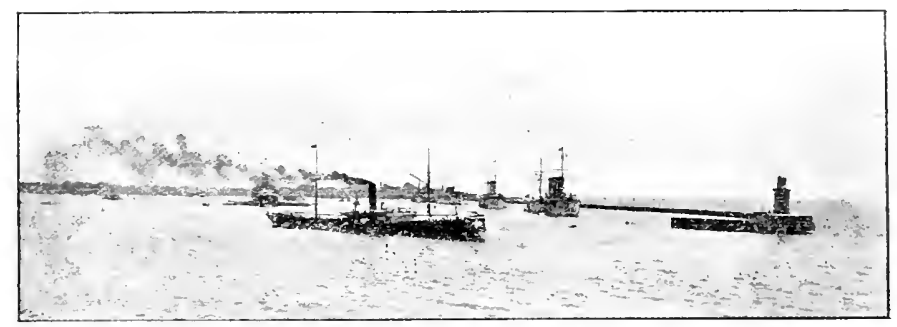

ENTRANCE TO THE HARBOUR.

choice of steam launch (sometimes), jolly boat, or outrigger canoe. The latter are no longer licensed, and will gradually disappear; they are often mistakenly called catamarans by newcomers, but the latter are really the little boats made of three logs of equal size fastened together (the name is simply the Tamil wolds for "tied logs") in which boys of all sizes come out to dive for money around the steamers. The fare for one passenger to go ashore to the Passenger Jetty is 25 cents. Chairs, rugs, and handbags go ashore free with their owncr; small boxes are 15 cents, large 25 cents. Arrived at the jetty, one must engage coolies to carry the luggage to the customs, and thence to a calt, sc. At the Customs one has to pay a small duty on nearly everything except personal clothing and effects. Firearms, on which there is a considerable duty, if not wanted in the island, may be left in bond and reclaimed on going away. The risitor' 
PLATE XLIX.
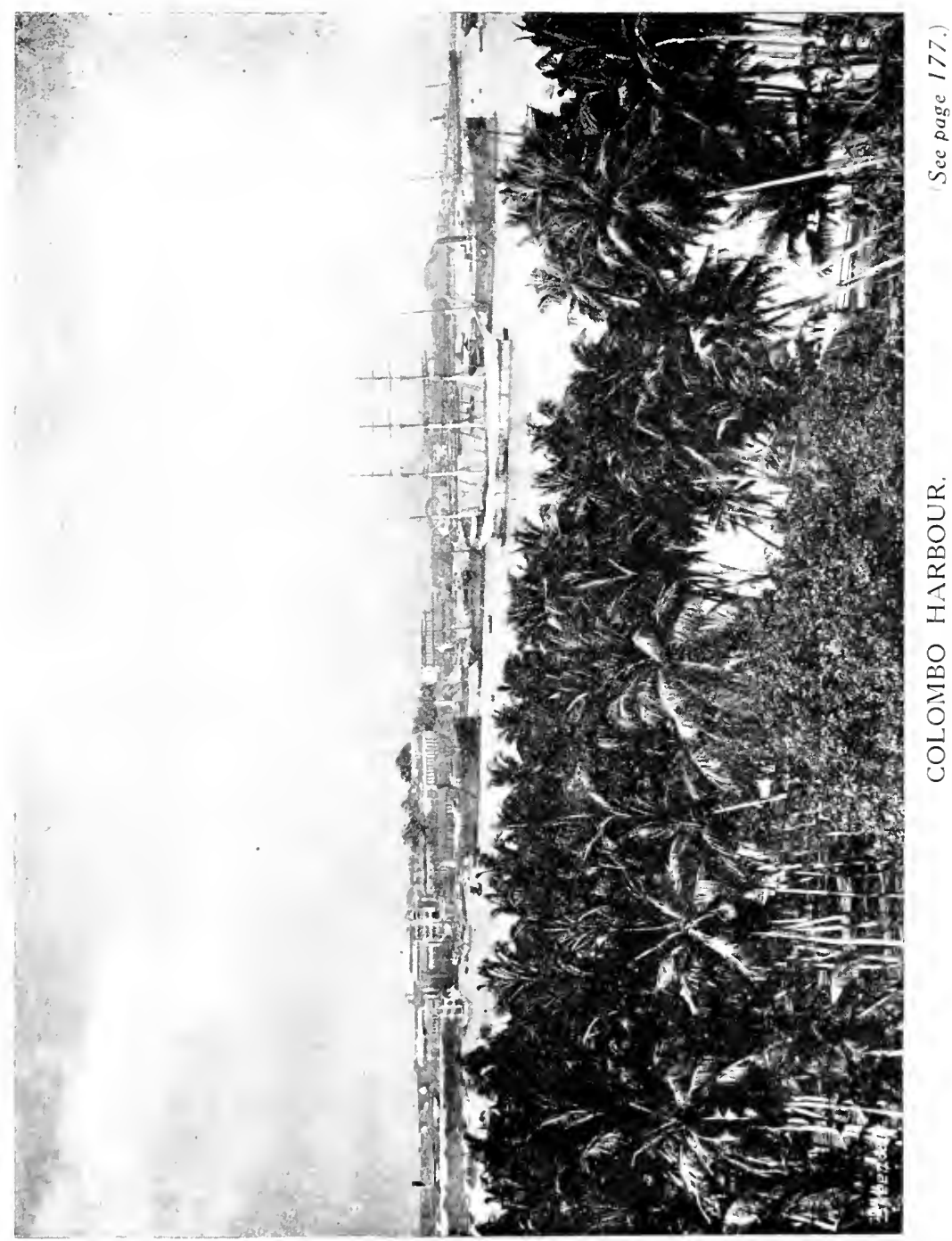

who has much luggage is recommended to hand it over on board the steamer to Cook's man or to one of the hotel peons, but he must of course be at the Customs Office himself to pass it. Passed luggage may then be taken by the same coolies, for a small fee (6-15 cents a package according to size) to a cart or carriage, or if the visitor be going to the Grand Oriental IHotel, to the hotel which is right opposite the jett $y$. Guides in dark blue coats with green facings may be engaged here; 50 cents the tirst hour, 25 cents for cach subsequent houl.

Hotels. The Galle Face has the finest situation and the largest public roms and entrance hall, but the Grand Oriental, familiarly known as the G. O. IH. or (to ghary and ricksha men) as the "peria hot-el" is the most convenient and most comfortable-so far as one can speak of comfort in a climate like this-and the Bristol is also convenient, and has an admirable cuinine. The Globe and the British India, also in the liort, are smaller and cheaper houses, while at Mount Lavinia, seven miles to the south, there is a good hotel, noted for fish tiffurs, and standing in a beautiful situation at the top of a crag projecting into the sea. At most of the hotels Ceylon residents are put up on the American plan - so much a day for everything-and visitors intending to stay more than a day or two are reeommended to make arrangements on the same lines. Jrinks and clectric fans are always of course extras. "The big hotels are admirably managed, and have every convenience.

What to see in Colombo. The principal things to be seen in Colombo are the Fort, the routes of the tramcars, the Cimmamon Gajdens-so-called-the Museum, and a few buildings. Native life, the most interesting phenomenom to a newcomer, is to be secn everywhere. The visitor who intends to spend some time in the interior of the island is recommended to leave Colombo as soom as possible, after a tramway ride or two. On his retum he can appreciate the variety of races, dress, Sc., much better, after laving secen the different races onc at a time, and in the same way will far better appreciate the Colombo Musem. "The visitor with only a few hours at his disposal is recommencled to talie both the tramway rentes, first of all that to Grandpass and back, and then that to Borella, and if he can find a earriage at Borella, not to resum by the ear, but to drive thromgle the Cimamon Gardens to the Galle Face, and along that, visiting the Musemm on the way, and finally to walk thongh the fort and go on boald and change. The risitor with more time at his disposal should alight form the Grandpass car at Nrmom Street and take a ricksha to Kotahena Temple, St. Lucia's Catbedral 
Wolfendahl Church, the Law Courts and Kachcheri. Other interesting drives are along Sea Street (to the north) to Mattakuliva and Grandpass, and southwards to Mount Lavinia (the latter can be done by train). A longer excursion is to Kelaniva temple (below), and railway trips may be made to Mount larinia, or if time permits to Kalutara, 1 leneratgoda, \&c.

The Fort. 'This is the name given to the contral business quarter of the town-corresponding to the City in Londonand reminds one of the former existence of a fort here, originally built by the Portuguese, constructed on more permanent lines by the Dutel, and now all but destroyed as inconvenient, land being very valuable and the old works of conrse nseless. It consists practically of two streets, York Strect ruming straight up from the jetty, and Quecn Street parallel to it to the right, with the various connecting cross streets, viz. the street along the firont, between the jetty and the Grand Oriental Hotel, Prince Street, Baillie Strect, and Chatham Street. We may briefly describe these in order.

lork Street runs up directly from the jettr, where on the left, just outside the building, is a fine marble statue of Her Majesty Queen Victoria, by Wade. On the right is the Grand Oriental Hotel, on the left the buildings of the Victoria Arcade, in which, and in the hotel verandah opposite, are numerous jewellers, and curiosity shops, in which there are now perhaps more articles of Japanese and other foreign make than real Ceylon goods. In the Arcade are the offices of the Peninsular and Oriental Steamship Co., and of Messrs. Thomas Cook \& Son, and at the first corner on the left is the National Bank of India. There are also tea rooms at the near end of the Arcade, while opposite the National Bank is the general shop of the Colombo Apothecaries' Co. The supply of European goods, and of articles for the use of Europeans, has in Cerlon fallen into the hands of a few larse concerns, and with the exception of engineering and irommongery requisites, most of the general business of supplying tinned and other foods, books, clothing, drugs, tobacco, wines, spirits, \&c., is in the hands of the Apothecaries Co., Cargills, Millers, Thompson lhomas s Co., International Stores, Le.

Crossing Prince Street, Cargills' great general store is on the right, and the bristol llotel, with jewellers, \&c., in the verandal, on the left. The strect is here sluaded with fine trees of Pithecolobium Saman, \&e. A little further up, Baillie Street rums up a steep hill to the right, and on the left, past the hotel, is the office of the Registrar-General, while opposite are the stores of Whiteaway Laidlaw \& Co., and Miller \& Co., and then Chatham Street crosses. Beyond it the road runs. 
down bill to the railway crossing, having the Irrigation Department's offices on the left, and the barracks on the right, and then on into Slave lsland.

Tuming to the right along. Chatham Street - the continuation to the left runs between the Survey Department and the buildings of the Chamber of Commerce to the Fort Station, and then along Norris Road to Maradana \&e, - the street is mostly full of jewellers and other miscellaneous shops, but along towards the Clock Tower are the offices of Messrs. Freuderberg (Cierman Consul, office of Norddeutscher Lloyd) on the right, and Brown \& Co.'s enginecring and ironmongery store on the lett. At the Clock Tower, the summit of which is the Colombo lighthouse, with a triply flashing light, the street crosises Queen Street, and runs toward the sea, past the Gilobe and British Judia llotels, and if followed clown, leads to the breakwater, a very pleasant place for a stroll in the erening, except in the southwest monsonn,

Returning to the Clock Tower, the road to the right runs past the barracks on the left, and Carc's store and the officers' quarters on the right, on to the Galle Face Esplanade (below) a pleasant place of resort, with seats at intervals along the edge of the beach. This is the commencement of the coast road to Galle (p. 140 ) and leads in about $7 \mathrm{~m}$. to Mount Lavinia, where there is a good hotel.

Turning to the left at the Clock Tower, the Mereantile Bank of India is on the left, and opposite to it the offices of the Ceylon Independent, the chief native paper published in English. Just beyond this, on the same side of the road, is the Chartered Bank of India, Australia, and China, and the Hongkong and Shanghai Bank, and Baillie Street, to the right.

Queen Street now passes between the fine building of the General Post Office on the right, and Quecn's Ilouse, the Colombo residene of the Governor, on the left, and then Prince Strect turns off to the right. At the Queen's I Iouse gate opposite Prince Strect is a fine statue of Sir Fdward Barnes, Governor of the colony 1824-3I, who did so much for its prosperity, anong other things by being a pioneer of planting in the liills (j). 39.)

On the right, bevond prince strect is the long block of buildings known as the Secretariat, in which are the offices of the Colonial Secretary (p. 134) and other departments of Government, while opposite are the Gordon Gardens, on the site of a former Roman Catholic Cathedral of Portuguese days. At the bottom, the road along the harbour fromt is again reached, and on the beft are the large buildings of the Customs 1)epartment, while on the right, before again reaching 
the C. O. I1., is St. Peter's, which, having been the former banfueting luall of the loutch Covernors, looks like anything but a church.

prince Street. Starting firm York Street, the Apothecaries Co.'s store is on the right, and nearly opposite the French Consulate (office of Messageries Maritimes steamers) then Messr. Whiteawav, Laidlaw \& Co.'s new building, and beyond that the Colombo Library, which is now having to turn out to give more room for Govermment offices. To the left of York Sircet the strect becomes Main Street, and runs between the offices of the 'limes of Ceylon on the right, and Walker \& Co.'s stores (engineering, innmongery, motors Se.) on the left, past the coaling sheols into the Pettain (below).

Baillie Street. Starting from York Street the (brownishcoloured) bank of Madras is passed on the right, immediately facing being the premises of Smith, Campbell \& Co., and then the (pale blue) Austrian Consulate, high up on which is a louteh inscription "IOOOR GEVELT GEVELT, DOOR "T REC'T HERSTELI" (I)estroyed by might, restored by right), the story being that the house was pulled down by Vuist, a tyramical Governor, and restored by his successor. On the left, further on, is the office of the Ceylon Observer.

The Tramway to Grandpass (fare first class 10 cents to Armour street, 20 cents all the way). This starts at the colner of York Street and Main Street, and rums to the left, between Messis. Walker, Sons \& Co.'s Engincering and Irommongery store, and the offices of the Times of Ceylon, passes the coaling sherls on the left, and the open space of the Young Men's Christian Association grounds on the right, crosses the railway branch to the hatbonl works, and enters Main Strect l'ettal, a narow, somewhat odorifcrous, densely crowded street, mainly occupied by the better class of native shops, in which a great valiety of things may be obtained at lower prices than in the Fort. On the right, immediately after entering this street, is an ancient Dutch burial ground, now disused, and on the same side, at the other end, is a Jutch belfiy, the bell in which is still rung every night to warn tavern-keepers to close. Just beyond this the road opens ont a little, in front of the Town Hall, recognised by the numerous little minaret structures on the roof. Behind it are the maket buildings, well worth a visit. A few dozen yarels up a street which runs diagonally upwards to the right just bevond the Town 1 lall, is the kacheheri of the Government Agent of the Western Province (p. 134). The car now rums into a mucl quieter district, first up-hill and then down, and a few native residences begin to appear. At Armour Street rickshaws can be obtained for a visit to Kotahena Buddhist 


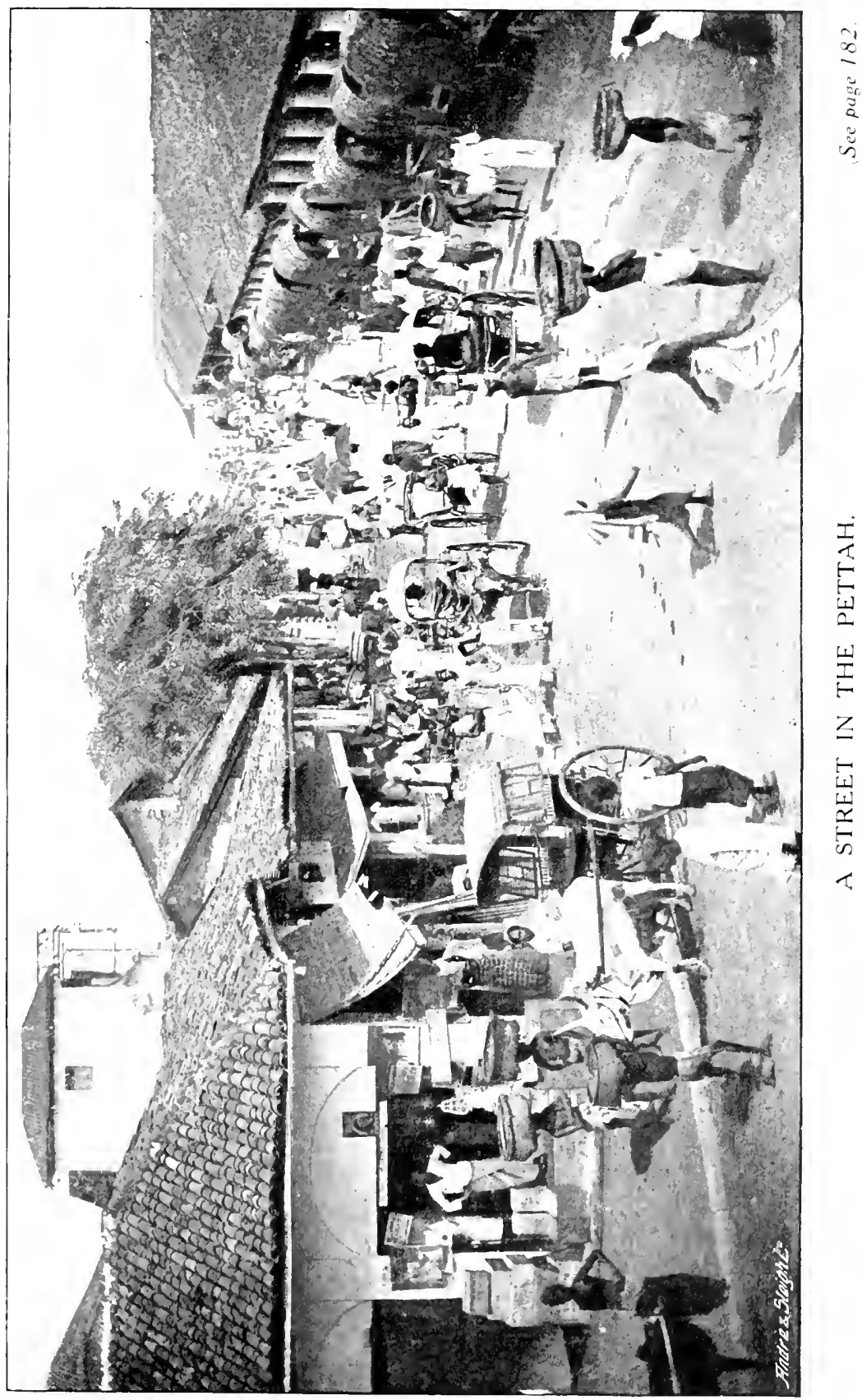



temple, St. Lucia's (Catholic) cathedral, and the old loutch Reformed Church at Wolfendalsl, the Law Courts, de., but this is better reserved for the return journey (sec below for (escription).

beyond this point the tramway goes through broader and quieter roads, until it reaches Crandpass, the scene of the last stand of the Inted against the British. 'I here is a very interesting marliet here, while a little way down Ferguson's Road to the left is the starting point of the Negombo steamers, which rum at 6.30 and 7.30 a.m. and 1 and 2.15 p.m. to Negombo (resthouse), retuming at 6 and 7 a.m. and r 2.30 and 1.30 p.n., and taking 4 hours on the journey. The route is through the Negombo Canal (p. so and Plate IV) into the lagoon at Negombo, and is interesting, but very hot. Fares, first class Re. I each way. Down this road, also, before the steamer offices, we come to the great Victoria Bridge, of seven spans, which crosses the Kelani. Two miles the other side of it is the famous Kelaniva Buddhist temple.

Kelaniya Temple. 'This may be reached by carriage or rickshaw (make a bargain before starting) fiom the Victoria Bridse (toll) and is one of the most sacred temples in the island. It contains a large recumbent Buddha, and many frescoes, while outside there is a splendid bo-tree. The sreat festivals are in Mav, at which time it should be visited after dark. There are also some llindu images in the temple (p. 98 ).

St. Lucia's Cathedral, Wolfendahl Church, Kotahena Temple, the Law Courts \&c. Returning by the car to Armour Street, rickshaws mav be engaged for this round. Proceeding up Armour Strect and taking the scond turning on the right, St. Lucia's Cathedral may be secu straight in firont, on the top of a little emincose, flanked on the right by St. Benedict's Institute for boys, at which some goo boys receive a good middle-class ediucation, and on the right by the Convent of the Good Shepherd Nuns, who also conduct an Euglish selood for girls. The Cathedral was completed in I904, and canseat 6,000. It is a handsome building in the Venetian Renaissance style, smmonnted by a cupolis. Going past it, and turning to the left, we soon come to the kotaluena Buddhist temple, one of the principal Buddhist temples in or near Colombo. It comtains a larese recombent statue of Buddha, and smalles statuesof different persons whot valous tines lave attaincel to the Buddhahood. Ilere also alle llindu deities, and a complicated masomy structure m illustration of the Wessantara Jataka, or bioth of Budellat as King Wessantara. Rotmonimg directly to, and goine straisho om across, Amonor Strect, a short distance brings us to the top 
of the hill on which stands the old Duteh Reformed Church of Wolfendahl (the valley of wolves-really jackals, which used to be common here), an interesting, but not particularly beantiful structure in the shape of a Greck cross. It contains many menentoes of the old Duteh Governors of Ceylon, chiefly their tombstones (their remains were removed here from the site of what is now the Gordon Gardens in the fort, in 1813), and some fine stained glass windows. The keys are to be got from the sexton, Mr. Sicket, in Hill Street.

From this church a direct road may be taken to the new Law Courts on the hill at Itulftidorp (named after General Hulft, of the Dutch army, who lised here). They are in Doric strle, and accommodate the Supreme Court, the District Comrt, and the Attorney-General's department. From them a descent may be made down Dam Street between the kachcheri and Vesey College, one of the largest first class schools for boys in the island (now moving into better quarters in the Cinnamon Gardens, to the Town I lall. It is not worth giving up the carriage here to take the trancar, but a return may be made to the fort in a few minutes. The principal fish market is at the other end of St. John's Road, opposite the lown llall, and is worth a visit in the early morning or the evening.

The Tramway to Borella (tare Io cents to Maradana Railway Brirge, 20 cents all the way). Starting at the same point as the Grandpass cars, the cars rum up lork Street to the next corner, and turn to the left, between the Chamber of Commerce on the left, and the Surveyor-General's and the Public Works Department offices on the right (the P. W. D. office building) to the Fort Railway station for Mount Lavinia, Kalutara, Galle, Sc., see p. 165) and then along Norris Road, with the lake on one side, the Soldiers' and Sailors' I Iome at the first corner on the left, to the Pettah station. Presently the Royal College (p. roz) appears on the left and then the car leaves the lake, and rums down into a hollow, with the Terminus of the main line on the right (soon to be abandoned and used solely for goods) and the large brick buildings of the Technical College on the left, and then up the hill, and round to the right, into Maradana road, which soon passes the Maradana station (p. 149 .

After crossing the bridge, there is a large Mohammedan mosque on the right, and then the headquarters of the police on the left. Policemen may usually be secn drilling here in the cooler parts of the day. "This is a rery busy and crowded street. Some distance further on, upon the left, is the Theosophical lligh School for boys, Ananda College, and yet further, on the right, the offices of the l'rincipal Civil Medical 
PLATE LI.

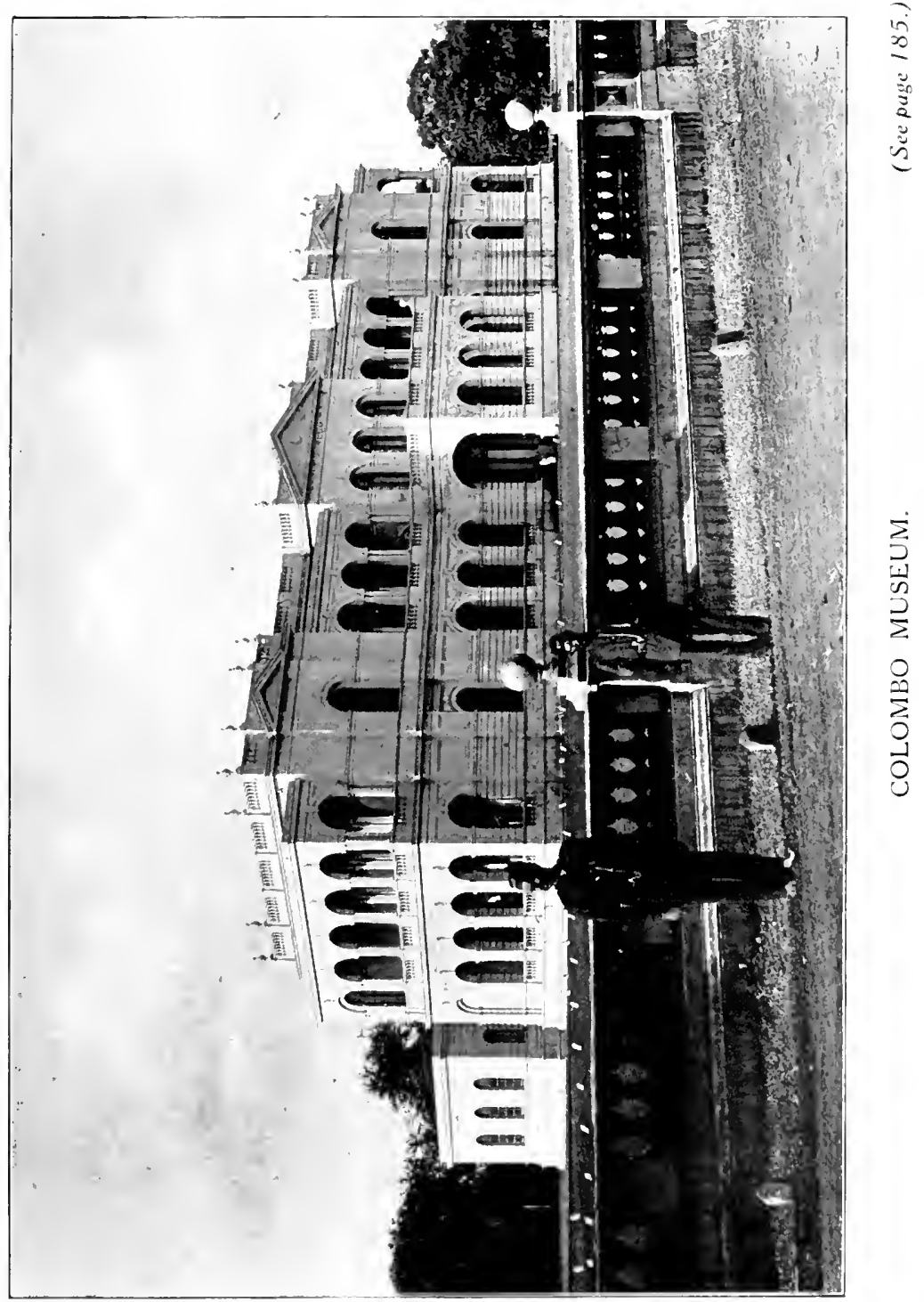



Officer, belund which are the Medical College, Hospital, de. A little further on, to the left, is the Lady Ilavelock Hospital for women and children, and then we arrive at the Borella terminus, where the long base line Road rums across our route, due north and south. If a conveyance can be got herc - usually rickshars at least are to be had - it is recommended to take the following drive, rather than return by the car.

\section{Drive from Borella through the Cinnamon Gardens} to the Museum.* 1)riving southwards (i.e. to the right) along Base tine Road, the gate of the General Cemetery is reached in a short distance, and tuming to the right here, we soon come to the Lmatic Asvlum, where again turn right into Torrington Place. We are here in the outskirts of Colombo, and traces of the cimmanon plantations which gave their mame to this suburb may still be seen though the chief cultivation now is arass for sale for horses' food. 'Torrington Place rums along between the Racecourse and the Cricket Club, with a few handsome bungalows, till it reaches the circular Victoria Park, where a tum to the left leads quickly to the Musenm, a large and landsome building in its om grounds, and to which an addition is now being built.

The Museum. The Colombo Museum forms a department of Government, and is managed by a scientific Lirector. It was completed in 5877 , and in front of it stands a fine statue of Governor Sir William Gregory, to whom its erection was due. The gromend floor contains the ethnological and mineralogical collections, and the library, while upstairs are the zoological collections. Botanical material is not specially preserved here, but is exhibited at the Musemm in the Peradeniya Gardens. The Museum is closed for cleaning on Fridays, and admission is always fiee. The birector has his office in a small building to the left.

The entrance is by a triple door at the front, and immediately facing one who enters is a horizontal glass case, in which are old betel bags, an ola book and its covers (p) 101), charms and yantras, or olas with diagrams, which are attached to the person or kept in the home, and endowed with "life" by repeating certain charms over them a number of times.

On the right luand of the central door is a case of boat models, in which the saling canoe (p. 105), the kattumatran or catamaran (p. I $7 \$$ ), dhomeys or native trading boats, ratts, pearl fishery boats (p. 24), dic., may be seen. Tio the right of

If this drive be started from the lort, it is recommended to go un Sork sitreet and straight on across the railway, with officers quarters dic., on the right, and turn left into

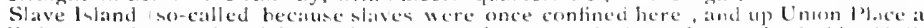
little way, then to the right to the shore of the lake and along this to the l'uble 11 all. then out into the circular l'ictormal l'alk and round thas to the lett (ionger but prettier) or right to the Muserum. 
the right-hand door are cases containing coconut products (p. 47) and palmria palm products (p. 64) respectively and to the left of the left-land don a case of devil-dancers masks for treatment of different diseases (p. 9s). lu this case, too, may be seen a model of the world-wide method of injuring an opponent by sorcery. A model of his body is prepared, and certain incantations performed over it, and then nails are driven into the part to be affected, the name of the rictim written on the image, and the latter buried where the victim will pass orer it. Also a collection of articles from the Maldive lslands, a group of coral reefs about 350 miles southwest of Colombo, and subject to Ceylon.

Behind the case of charms, sc., is a case containing a large number of inages of Buddlua in the three attitudes in which he is usually represented__sitting, standing, or lying. Under these are belts, rings, and other ormamental articles, some of them exquisitely worlicd (p. 100). Right and left of this case are stand; of Kandyan spears, walking sticks, \&c., done in iacquer work (p. 100).

Tuming to the left into the Mediaeval Room, and going round it to the right, the cases contain (r) swords and knives, some very prettily and artistically worked, (2) Kandyan painted pottery, boxes made of calamander wood, a very rare kind of streaked ebony, and of porcupine quills (p. 20), (3) betel loxes and bangles, anklets and swords, (4) chunam boxes (p. 52) and betel mut cutters, some of these very richly ormanchted and worked, and on the other side of the room ( ( ) antique objects made in brass or bronze, such as soblets, dagobas, trays, lamps, sc., including a Sinhalese water-clock, in which a copper bowl with a minute hole in the bottom is set floating in water, which enter's till the bowl sinks, the levels being shown by silver marks at the side of the bowl. The Simhalese lour comsists of 24 minutes, and the larger clock runs for two of these: (2) a case of old aristocratic dress, worn in the low-country; (3) pendants, necklaces, earings, Sc.; (4) a collection of silver and brass boxes (p. 100); and (5) a finc collection of beautiful ivory work of various kinds. Retuming down the midelle, there are two cases containime combs, coins, de.

Entering the Stone Room and turning to the right, there are several carrings of budelhas, Sc., and on the side wall two cases containing models of a Kandran chief in full dress, a Buckllust monk, a low-comntry Mudaliya (p. 134) and a low-comntry Sinhalese bride, while in the centue of this side is the ereat stome lion upon which the thone of King Nisiankil was placed, I $87-96$ A.1). "This lion formerly stood in the ling's Audience I lall at Polonnaruwa, and was 


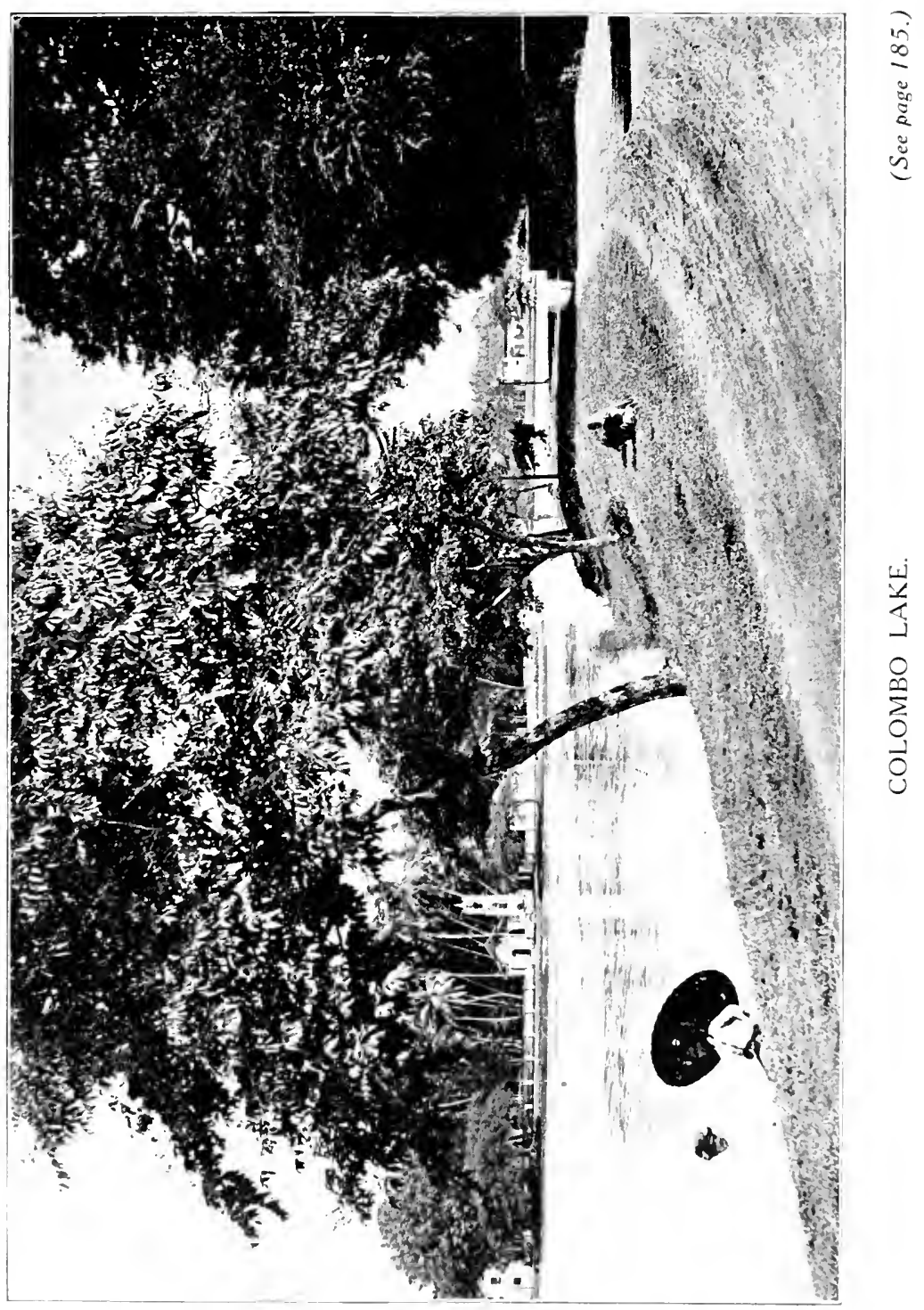



removed to Colmmbo about 30 years ago, with great difficulty. In the verandah at the end of the building are a number of inseribed stones, and inside, on the end wall, a cast of the great statue of Parakrama Bahu at Polonnaruwa (p. S 1 and fig. on p. So). On the left hand side is a case containing models of leddahs (p. 87 , and Plates XXYl., XXY'll.), and in the window a cast of a tine moonstone (p. i s) firom Anuradlapura, while to the left of this is a case of keys, copper boxes, and bronze relies from the varions ancient places of Cevlon. In the contre, on the left, is the beautiful perforated stone window firm Yapahu, about 20 miles north of Kurunegala, where the kings resided in the $13^{\text {th }}$ and $14^{\text {th }}$ centuries (p. SI). Beside this is a fine bronze canldron from Anuradlopura, and a rantra-gal w square stone with numerous square holes cut in it. In the central cases are relics from Sigiriva, Anmadhapura, sc., and on the ceiling, hanging down, the flags of some of the local divisions of Ceylom.

On the right hand side of the central hall (cntrance along the verandah, admission by pemit) is the reading room, attached to a library in which is a very fine collection of works upon Ceyton.

Going upstairs, on the walls are hung facsimile copies of the old frescoes at Sigiriva, done by Mr. Perera of the Archacological Survey (p. iz5), and at the top the first object eome upon is a group showing a leopard attacking a spotted deer, with monkeys above. In the case in the centre is a giant tortoise Timing to the right into the first gallery, and going along it on the right hand side, the cases continin sheils, insects, lizards, beetles, and window-pane oysters (p). 34). At the end, turning to the right into the end gallery, there is a case of bats, fe., then flying squirels, porempines (p. 20), hares, squirels (p. 20 ) loris, ace Then follow the skeletoms of a brar and a huffalo, a case of clk horus (p. 18 , and chapter on sport below, pangolin or sealy anteater, dolplum, de, then monse deer (p. 10) and a small eleplant, then monkeve(p. 19), dece (p. 18, hear (p. 17, and then a case of jackial (p. 19), palm cats, mongoose (p. 19) and otter (p. 20). Them comes a gup of sambur p. IS) and wild bear, with a peacock, then a case of cats and leopards (p. 19), the openius to the forout verandals, and a case of theing foxes (p. 17). Juthe contere of this room are the skeletons of an elephant, and a degonge.

Returning to the gallery first entered, and going along the fromt of it the cases contain ants, mosquitoes, reptiles, equs, crabs, barnades, shells, de., while the centre cases contitin birels, lizards and inserts.

Entering the central hall again, and turning to the lisht, the cases contain birels, sea birds, limalls, and insects. 
Passing unw into the gallery to the left of the entrance, and going along the right-luand (fiment of the building) side of it, the cases contain corals, de, from the pearl banks, and theil tuming into the coss gallery at the end, the cases are full of fish, corals, zoophytes, sponges, de, while along the centre are models of his, sc. Returning to the main fiont gallery, the cases on the lisht contain frogs, snakes, insects, venomous animals, shells, sc., while those in the centre of the gallery are oceupied by birds, snake skeletons, and insects.

Turning to the left at the foot of the stairs, and going through a passage, the mineral gallery may be found. Among other objects of interest here is a model of a plumbago mine (p. 2).

At the back of the Museum is a small collection of living wild animals of Ceylon.

Drive to the North along the sea front (this is given assuming that the tramway route, and the detour to St. Lucia's, sc., have been followed, but of course they may be combined, if the risitor like to drive the whole way, by driving through the Main Street, Pettali to Armour Street as on the car, then to Wolfendahl, St. Iucia's, and Kotabena temple, and from there to St. 'Thomas', then as described below back to Armour Street ria Mattakuliva, and then to the Law Courts and back to the Fort as described above). Leaving by Main Street as on the Giandpass car, and turning to the left so soon as the railway line is crossed, we go along Sea Street where we soon pass some llindu temples (admission is generally allowed if the shoes be taken off, but there is little to see; cf. Plate XXXV.), go through the Chetty quarter (p. $8_{4}$, past llutsou's Engineering Works, and then the road turns uphill past the back of the great new Gaving l)ock (p. I 78 ) passing Christ Church Cathedral and St. Thomas' College, the great Church of England school. Turning to the left soon after we reach Modala Road, along which are three large Catholic Churches, an indication of the great hold this communion has upon the fisher folk, in whose quarter we now are. Turuing to the left after passing St. James' (worth looking into), the second of these, we may go down to the mouth of the Kelani river, where Crow Island is to be seen upon the right, and a long sand spit runs ont towal's the actual mouth. If it be in the cool of the day, a very pleasant stroll may be enjoyed along this spit, and the fishermen mar be seen carying out various operations peculiar to their craft upon the shore. Returning to Modara Road, and going alomg it past the third Church, St. John's, the road turns to the right into Ferguson's Road (p. is 3 ), which if followed leads to Grandpass, from which a return may be made by the trammay route as far as 
PLATE LIII.

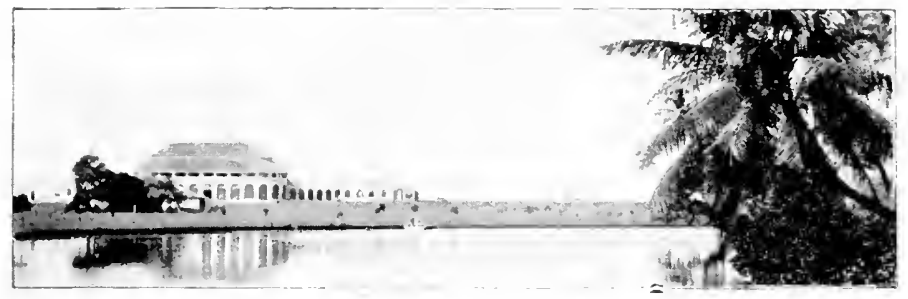

THE BACK OF GALLE FACE PROMENADE.

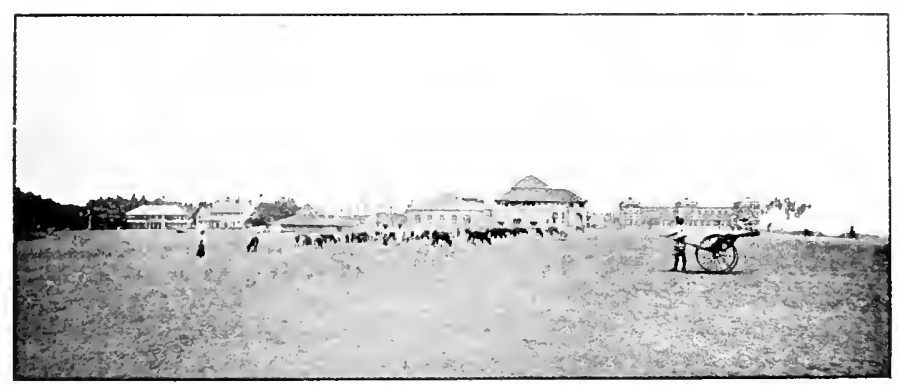

GALLE FACE.

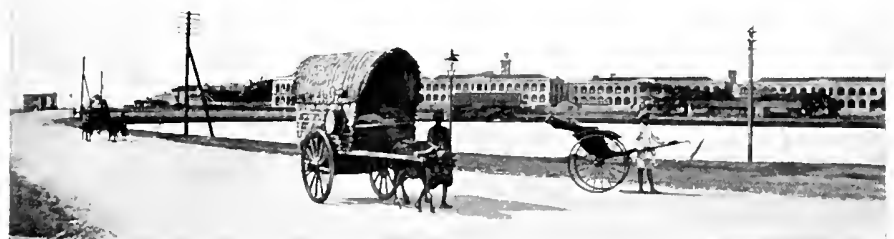

GALLE FACE, THE BARRACKS.

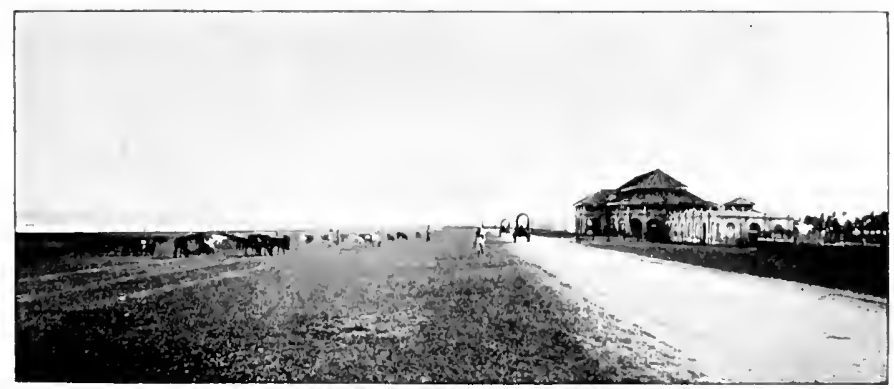

GALLE FACE AND CLUB.

(See page 189.) 

Armour Street, where we turn to the left, and follow the road to Maradana, where, a little beyond the station, we turn to the right into Dean's Road, and follow this down through a native quarter till it comes out at a great crossing of roads in front of the Victoria Eye Ilospital. If it is desired to see a piece of the quarter in which the Europeans live, a detour may be made up IVard Place, to the left, otherwise a return should be made down the long, straight, busy road Union Place, at the bottom of which we may turn to the right direct to the Fort, or go straight on past Slave Island Station and then turning to the right, return along the picturesque back of the Galle Face parade, behind the Colombo Club, or keep to the left, and come out at the Galle Face Hotel, and return along the front.

Drive to the South and Mount Lavinia. Learing the Fort by Queen Street past the Clock Tower, the road comes to the Calle Face, a fine open scaside parade, with seats along the beach. Just before reaching it, the great military barracks are on the left. A red kabuls (p. z) road runs along the beach, which will be found much pleasanter to drive upon than the macadamised roads. Turning up past the Galle lace Hotel, we turn to the right into Colpetty (Kollupitiva) a crowded native street which leads on for miles to Mount Lavinia (q. v.), where there is a gond hotel, but the visitor will likely have had enough of the road before he has gone many miles, and is recommended to take train at Kollupitiva or Bambalapitiya station, go to Mount Lavinia, and return by train to the Fort.

Local Officials. The Government has its headquarters here and there are very many, in almost every department.

Carriage hire. 6 a.m. to 7 p.m. Rs. 450 ; six hours Rs. 2.50; half an hour 50 cents; one hour Rs. I; every further hour 50 cents. After 7 p.m. ${ }_{3}^{1}$ rd extra; two horses $\frac{1}{2}$ extra. Outside the tolls 75 cents a mile. Hackeries 25 cents first and second half hours, 15 cents each subsequent lour. Rickshaws, single journey in the Fort 10 eents; half an hour 25 cents; second half hour 25 cents; every subsequent lalf hour 10 cents.

COTTA. An eastern suburb of Colombo, formerly, in l'ortuguese times, the capital of the kingdom under the native kings.

DAMBULLA. Central Provines, Matale district, at the junction of the roaks from kandy $45 \mathrm{~m}$, and Matale $2 S_{3}^{3} \mathrm{~m}$. a'm Nalande $14 \frac{1}{2} \mathrm{~m}$., and from Kurtuegala $35 \frac{1}{3}$. to the nortl, and at the divergence of the roads to Mnmradhapura $+1 \mathrm{~m}$. and Jaffna and to Ilabarane $15 \mathrm{~m}$. and Trincomalic. To. Kekirawa $1+\mathrm{m}$, to Minneriya $30 \mathrm{~m}$, to Sigiriya $11 \mathrm{~m}$., to 
Topawewa (Polonnaruwa) + 2 m. Population 397. Post and Telegraph Office, Resthouse. Supplies procurable to a small extent.

The chief point of interest is the rock, a large isolated block standing up to a considerable height, upon which there is an ancient rock temple (p. 1 29).

DEHIOWITA. Sabaragamuwa Province, Kegalle district, on the road and rail (station) from Colombo $33 \frac{1}{3}$ m. via Avisawela $4: 2 \mathrm{~m}$. and Dehiowita to Yatiyantota $8 \underset{2}{1} \mathrm{~m}$. Minor road to the Arisawela-Ratnapura road. A number of tea and rubber estates in the neighbourhood. Population rog. Post and lelegraph Otfice.

Trains to Colombo (3 hours) at 5-46 a.m., S-I a.m. and 3-3 I P.131.

DEHIWALA. Western Province, Colombo district, on road from Colombo Fort $5 \frac{1}{1}$ m. to Mount Lavinia I $m$. Railway Receiring Office.

DELTOTA. Central Province, Kandy district, at end of cart roads from Kandy and Peradeniya ig m. Population 658 . Post and Telegraph Office, Hospital. The neighbourlood is mostly tea estates.

DENIYAYA. Southern Prorince, Matara district, at end of cart road from Matara $+\mathrm{I}$ m. and Galle 51 $\frac{1}{1} \mathrm{~m}$. ik Akuressa $27 \frac{3}{1}$. and Morowaka $12 \frac{1}{2} \mathrm{~m}$. Population 925. Post and Telegraph Office, Resthouse, 1 Tospital and Dispensary. There are a good many tea and rubber estates in the district.

Coach to Matara, leaves Denivaya $\$-30$ a.m. (except Saturdays 5 p.m.) arrives Matara $3-30$ p.m. leaves Matara ro a.m. arrives Deniyay 5 p.m. Fares $12 \mathrm{~s} .13,7,4$.

DIKOYA. Central Province, Kandy district. About i m. from Iatton, on the road to Norwood, Post and Telegraph Office, Hospital, Engtish Church. Dikoya and Maskeliya Cricket Club.

I)ikoya is one of the cluef planting districts, containing (including the district of Lower Likova) about 107 estates, with about $+0,000$ acres cultivated, almost entirely in tea, of which a rast stretch may be seen from Norwood, mostly shaded with Girevilleas. The valley itself is now, thanks mainly to the shade trees, by no means umpicturesque, but the prettiest part is the upper end, where it rums into Bogawantalawa.

DIMBULA. The village on the road from Craigie Lea to Nawalapitiva, but the planting district extending up to the foot of the Iforton Plains range, Hospital. The central mecting place of the planting district is at Radella, not very far from Nanu-ova, where there is a racecomse, Athletic and Cricket Club, se. 
The premier planting district of the island, though perhaps exceeded in size by the Kelani Valley. i 26 estates, with about 48,000 acres in cultivation, almost entirely tea, which may be seen in a rast sheet from the railway between Watagoda and Nanu-oya. Railway stations, Kotagala to Nanu-oya, elevation 3,500 to 5,500 feet.

DIYATALAWA. Ura Province, on the rail and road to Bandarawela $3 \mathrm{~m}$. Eleration $43^{6} 7$ feet. Post and Telegraph Offices.

This place, which lies in one of the most bracing climates of the island, was originally a Mission Industrial Institution, which was closed. It was then, after some years, opened as a camp for about 5,000 Boer prisoners, who were guarded by two British Regiments, and for whose accommodation the numerous corrugated iron sheds were put up. Now it is used as a naval sanitarium, as well as by the Survey Department and others, while there are sometimes bungalows to be hired, and witl Bandarawela, it will probably grow into an important sanitarium. There is a little forest on the hills above, but the greater part of the place is open sterile patana (p. 6r).

DODANDUWA. Southem Province, Galle district, on road and railway (station) to Galle, $\$ \frac{1}{2}$ m. Baddegama (Resthouse) $7 \mathrm{~m}$. Population 526. Post and Telegraph Offices, Church Missionary Society Industrial School.

DOLOSBAGE. Sabaragamuwa Province, Kegalle district, $s \mathrm{~m}$. from Nawalapitiya. Elevation of district 2000-4000 feet. Post and Telegraph Offices. 'lennis and athletic clubs.

This is a comparatively ont-of-the-way planting district, not having a road right through it, but only being approachable from Nawalapitiva for the upper end, from Nawanella or Kegalle for the lower. It contains about 50 estates, making up about 15,000 acres, mostly in tea, but with a good deal of rubber.

DUMBARA. Central Province, Kandy district. The: name of the valley of the Mahaweli-ganga east of Kandy, which may be looked over from Lady Maccarthy's Road at Kandy. Roals from kandy to Teldenira, do. Resthonses at Panwila and Teldeniya. 2.4 estates are in the planting district of Dumbara, with about 8,000 acres in cultivation, of which 5,000 are in cacao (p. $5^{8}$ ), with a considerable amount of rubber, coconuts aud tea.

ELEPHANT PASS. Northern l'rorince, Jaffina district on the main road to the sontl from Jaffina, $32 \frac{1}{2}$ m. Stopping place on the raikay. There is a great canseway acoss the lagoon whicl! separates the Jaffina peninsula from the main 
land, and the Resthonse lies upon the northern shore of this, with the water lapping up to the verandah, and is one of the plea-antest places at which to stay in the Jaffina country. Lying just upon the edge of the Jaffina peninsula, and in very low-lying, salt soil, there is almost no vegetation there but Scrub.

ELKADUWA. Central Province, Kandy district, reached by road fiom Kandy aik Wattegama Station, $17 \frac{1}{4} \mathrm{~m}$., Post Office, Gymkluana Club. The district is mainly planted in tea.

ELLA. Uva Province, $12 \mathrm{~m}$. from Bandarawela, $3 \mathrm{~m}$. from Naula, I $_{2} \mathrm{~m}$. fiom Badulla. Village Receiving Post Office, Resthouse. Elevation 3.320 feet.

"The Resthouse stands upon a projecting spur, commanding one of the finest views of its class in the island, looking down the Ella pass to the low-country of the south-east, where the sun may often be seen shining upon the salt lagoons near llambantota. The resthouse is a very favourite spot for excursions from Bandarawela or Badulla, but notice of coming should be given.

GALAGEDARA. Central Prorince, Kandy district, on the road fiom Kandr a i m. to Kurunegala $14^{\frac{1}{2}}$ m. Population 339. Post Office, Resthouse. A few estates of cacao, \&c., in the district.

GALLE. Southern Province, Galle district, $72 \frac{1}{2} \mathrm{~m}$. from Colombo by road and rail, $27 \frac{1}{1} \mathrm{~m}$. from Matara by road and rail, $23: \mathrm{m}$. from Akuressa. Population 37, $6_{5}$ in I901, 39,624 in 1907. Post and Telegraph Offices, Hotel, the New Oriental, in the Fort, formerly the great passenger hotel in the days when the steamers called at Galle. Chub, Tennis Club, Cricket Club, Golf Club, Gymkliana Club, Clumeh of England, Roman Catholic and Dutch Reformed Churches, Tospital, Band of Hope, Young Men's Christian Association, Young Womens' Christian Association, Friend-in-Need Society, lndustrial School, Reading Room, Library, Band.

Galle is a very ancient place, and for long was the harbour of call in Cevlon, though in the last thirty years it has been contirely superseded by Colombo. While the main native population lives along the side of the great liarbour, and back inland, the business quarter, with the chief shops, the hotel, dxc., hies in the Fort, which occupies a tongue of land projecting out into the sea, and which in some ways is one of the most interesting sights in the island. Entering by the main gate, the hotel is round to the left, and immediately in front of it are the ramparti, fiom which a very pretty view may be obtained over the harbour. The harbour is a very large one, and were a considerable amount of money expended upon blasting away some of the dangerous coral reefs at the 
PLATE LIV.

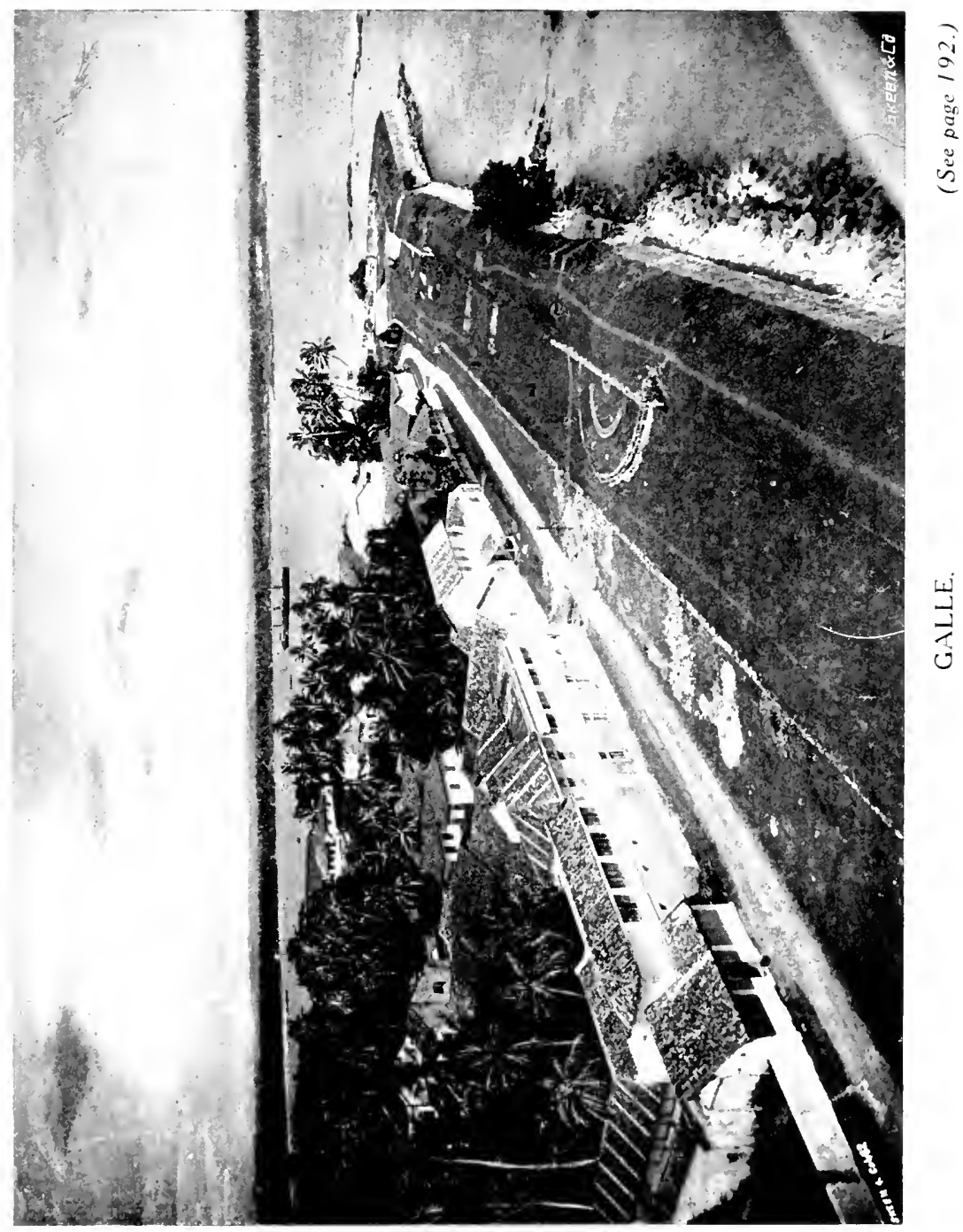



entrance, and a breakwater built to keep out the heavy loll of the south-west monsoon, would be a very valuable prit to the island.

Going down to the right fiom the hotel, an old 1)utclu Church is passed on the right, and then the library, while down the road to the left at this point are the old Bell 'Fower, and the Customs Warehouse, with a fine old Dutch inscription over the door, while the Kacheheri is further along this road and round to the right. Retmoning to the road first risited, the English Church is further along on the right, and then we pass between quaint old Dutch houses, often of two storics, down to the end of the street, where the ramparts may be asain climbed, and turning to the right we pass the Light-lonse, and may walk round upon the wall of the liort for a long distance. Nost of the streets in the Fort are narrow and somewhat quaint in appearance, and are worth walking through.

In the town there is a Dutel burial ground, and a pretty seaside park near to the Fort, while the drive out to Wakwella, where there is a resthouse in a rery pretty situation, is worth takins, the distance being about 5 miles.

local officials: Govemment Agent and Office Assistant, District Judge, Superintendent of Police, Provincial and District Engineers, Superintendent of Surveys.

Carriage and rickshaw rates, within the Municipality. Carriages, from 6 a.m. to 7 p.m. Rs. 4 ; six homs Rs. 2 ; half an hour 50 cents; second half lour 50 cents; crery subsequent hour or portion, 25 cents. After 7 p.m. one fourth more; with two horses one half more. Rickshaws, first half hour 25 cents; every half hour afterwards 10 cents; after 7 p.m. one quarter extra.

Trains to Colombo $(31-33$ hours) at $6-25$ a.m., $8-55$ a.m., 12-40 p.m., 6 p.m., retuming from Fort Station at 7-2S a.m., 1 2-20 p.m., 3-5 p.m. and $6-55$ p.m.

GAMPOLA. Central Province, Kandy district, $1,3 \mathrm{~m}$. from Kandy, by road and rail, $10 \frac{1}{2}$ m. fiom Nawalapitiya (p. 141), 34 m., from Nuwara liliya (p. 142). Population 3,791. Elevation 1,572 feet. Post and Telegraph Office. Resthouse. Athletic and Cricket Clubs. Ilospital.

'There are many tea estates, with a small amount of rubber and other products, in the district, which is very pretty, the Mahaweli-ganga flowing through it, and being bricged upon the road to Nuwara Eliya.

Local official ; Police Magistrate.

Caniage hire: Finst hour 75 cents, second 50 , subsequent hours 25. Ricksliaws, 25 cents a lialf liour: 
HABARANE. North-Central Province, on the road to Trincomalie, I $5 \mathrm{~m}$. from l)ambulla (p. 1 ff). Population 100. Village Receiving Post Office. Resthouse.

Roads to Minneriya (p. 129) and Polonnaruwa (p. 126) and to Galpitigala, for Ritigala (P. 13r), start here.

Coach to Matale leaves I labarane 7-10 a.m., reaches Matale 3-30 p.m.; leaves Matale ro a.m., reaches IJabarane 5-20 p.m. Fares Rs. $9 \cdot 50,6 \cdot 25,5 \cdot 25$.

HAKGALA. The mountain branch botanic garden of the Peradeniya institution, $6 \mathrm{~m}$. from Nuwara Eliya on the Badulla road (p. 1.5). It was opened in 1861 , the site having been largely selected by Sir Clements Markham as well suited for the growth of cincliona (p. 4o), which he bad just brought from Peru. For many years it was simply a cinchona nursery, and during the boom in that product distributed an enormous number of plants, but since $18 S_{2}$ it has been transformed into a botanic garden for the plants that will grow at such high elevations and in such a cool climate the mean temperature of the year being only $61^{\circ}$. The garden is in charge of a European Curator, and there is a laboratory there with two bedrooms, in which scientific visitors may work and sleep, but ordinary risitors must return to Nuwara Eliva, though there is a summer-house in the garden which makes an admirable place in which to have breakfast or tea. There is a shed where horses and earriages may be put up.

Entering from the Nuwara Eliva road, the drive makes a loop round the garden, and from the upper drive there is a bianch to the bungalow of the Curator. Going rome the lower side of the loop, the first object of interest is a little pond on the right, overhung at the farther end by some beautiful native tree ferns (p. 60), and then on the left a little lawn with a seat. Further on is the path to the big summerhouse, on the left, and on the right a herbaceous garden, in which the plants are arranged according to their natural families. Above it is a circular rose garden in which roses and other ornamental flowers are massed together so as to produce a very pretty effect, which is seen to best advantage in February-April. Here is the carriage shed, and from it the road goes up to meet the branch from the Curator's house, and then descends through the beautiful fernery, past the pond, to rejoin the drive from the entrance gate. Ilaving driven round, the carriage should be sent to the shed, and the path turning to the left, down the steps, at the junction of the drive, taken. It passes a little summer arbour, and crosses a little stream by a rustic bridge, and then winds round till it joins the patli leading to the large summer arbour, where turning to the left, we come to the arbour in a few yards. 
This is a good place in which to have a meal, and commands a most lovely view over the Uva patana combly, with the peak of Naminakuli-kande in the centre, rising to a leight of 6,680 feet. Rumning away to the left of it is the long mountain ridge of the Madulsima planting district, while some distance to the right is the high ridge rumning along form bandarawela to the llaputale pass, half way along which, the camp of l)ivatalawa can be made out. In the immediate foreground the way in which as the country becomes drier the forest gives way to patana, can be very well seen (p. 6i). The great plateau spread out below us is the driest part of the mountain district of Ceylon, beings some distance below the I Jakgala range of hills (p. I t), while on Naminakuli the climate is again wetter, and tea is cultivated.

Returning directly up the hill from the arbour, we may pass through the herbaceous garden, the circular rose garden, and upwards past the potting sheds to the grecn-house on the top of the hill by the Curator's house where many pretty pot plants may usually be seen. Proceding past the Curator's house, the path enters the Fernery, which is extromely beautiful, containing a vast number of different species of plants, including many tree ferns, which are in reality, the smaller ones at least, continually planted in the positions in which they grow, but which look as if the belonged to the jungle. Ilakgala was one of the callest valdens to be laid out in this "natural" style which is now so popular, and is one of the most sucecsiful examples of it. From the tree lems we mar go down to the pond, where there is a little arbent, and form there, turning to the right we may malie our waly back to the carrige shed.

An interesting, but fatiguing exeursion may be made to the summit of llakgala rock, overlooking the sarden, but as the path is somewhat complicated, application should be made to the Curator for a suide, and three or four hours allowed.

HALDUMMULLA. Uva Provinee, on the road firom Ratmapura f9 $\mathrm{m}$. to Badulla, $31 \frac{1}{4} \mathrm{~m}$., p. 146. Population 305. Elevation 3,38S fect. l'ost and Telegraphoffice. Resthouse, with a fovely view out over the southeast of the island.

HAMBANTOTA. Southern Province, l lambantota district,

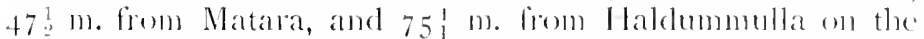
main road form Colombo to Batticaloa. Population $2, s+3$. Post and Telegraph Office. Resthouse. Hospital. Reading RoOn].

The place lies in the driest distriet of Ceylon, and the vegetation is (puite different from that at Matara, which is so near at hand. 'This is oue of the ched districts in which salt, which is a corcrmment monopoly in Ceylom, is collected.

$\mathrm{O}_{2}$ 
All along the coast are shallow lagoons called lewayas, in which, after they have been filled by the rains of the uortheast monson, the salt forms by evaporation from March to September. The oceupation of gathering it is a very precarious one, being liable to interruption from rains, sc., and the amount collected shows variations from less than 2,000 to over $1+5,000$ cwt. in two consecutive years.

There are extensive irrigation works near llambantota, and near Tissamaharama there are some very fine ancient ruins of dagobas, de.

Local officials: Assistant Govermment Ageat, District Engineer, Medical Officer.

Coach from Natara, leaves Matara ro-30 a.m., arrives Hambantota 8 p.m.; leaves Hambantota 5-30 a.m., arrives Natara $3-30$ p.m. Fares Rs. $12 \cdot 50,5 \cdot 50,3 \cdot 50$. Round-theisland steamers call once a fortnight cach way.

HANTANE. Central Province, Kandy district, planting district, lying south of, and close to, Kandy, to estates with 8,000 acres in cultivation, mostly in tea, but with a good deal of rubber. Railway stations, Kandy and Peradeniya. Elevation 2,000 to 3,500 fect.

HANWELLA. iVestern Province, Colombo district, on the road to Avisawela, i $8 \frac{1}{4} \ldots$. from Colombo (p. 138). Population 1,374. Post Office. Resthouse. Nearest station, Waga, $3 \mathrm{~m}$.

HAPUTALE. Uva Province, on the road from Ratnapura $56 \frac{3}{4} \mathrm{~m}$. aic I Faldummulla $7 \frac{1}{4} \mathrm{~m}$. and rail from Colombo, to Bandarawela $6 \frac{1}{4} \mathrm{~m}$. Population 535. Elevation 4,687 feet. Post and Telegraph Office. Resthouse. Bow Club (usually meets at Bandarawela). English Church. Hospital.

This place is the headquarters of a Planters' Association, and the district comprises about 50 estates, covering about 21,000 acres, mostly in tea, but with a little rubber at the lower clevations.

The climate is moist, misty, and windy, the resthouse Iving at the summit of the pass which leads from the low country of the south into the Uva patana comntry. There are often wonderful views to be had both to north and to south. One of the prettiest walks is along the bridle path to Nuwara Eliya, reached by crossing the railway on the Colombo side of the station. It goes through alternate stretches of jungle and patana. A pretty road also is that to I Jaldummulla, and to Bandarawela.

HARAGAMA. Central Province, Kandy district, $9 \frac{1}{2} \mathrm{~m}$. from Kandy on the road to Maturata.

HATTON. Central Province, Kandy district, on the railwaly from Colonbo (p. 158). Roads see pp. I $11,147$. 
Population I,440. Elevation 4,141 feet. Post and Telegraph Office. Hotel. There is a racecourse at 1)arrawella, where the Dikoya Clubs (q. v.) meet. Good stores. Hatton was formerly, before Nuwara Eliya became so easy of access, a rery popular place of resort, but is now rather the centre for the three great planting distriets of Dimbula, Dikoya, and Maskeliya. The walk to Dikoya village, and as far as the church beyond, is pretty, but the pleasantest short excursion is by the Dimbula road to the Dcron falls, and there is of course the interesting trip to Adam's Peak to be made, by way of Maskeliya (q. .

Coach to Norwood, leaves at $6 \mathrm{a} . \mathrm{m}$. and $2-20$ p.m., arriving Norwood $7-20$ and $3-30$, arriving Bogawantalawa (change coach) $8-45$ and 5 , arriving Maskeliya $8-30$ and $4-45$. Fares to Bogawantalawa Rs. $6,4 \cdot 50,3$, to Maskeliya Rs. $5,3 \cdot 75,2 \cdot 50$. Times different on Saturdays.

Carriage hire: First, second, and subsequent hours, 75, 50, and 25 cents.

HENERATGODA. Western Province, Colombo district, on the road from the Kandy road to Negombo (p. 137) and on rail from Colombo (p. 150). Population 1,424. Elevation 33 feet. Post and 'lelegraph Office. Resthouse at end of station platform.

The object of most interest is a little botanic Garden, about a mile from the resthuse, along the Negombo road. Entering, the direct road passes between two small portions of forest (p. 37) to the centre of the garden. About three quarters of the way up, on the right, is a path by which entry can be made into the forest. Just beyond, on the left, is a plantation of large old Para rubber trees. These were brought from South America in 1876, and the garden was opened for their reception; from their secd or progeny the whole of the great rubber industry of Ceylon has sprung up. Thapping experiments may often be seen going on upon these trees or a somewhat younger plantation further on. On the left is the little laboratory building, with an open verandah in which meals may be taken, and behind that is an open lawn. A very pretty path leads round to the rigltt, some distance further on, and returus round the outside of the garden to the entrance, while if the path on the left be taken it also leatlis round to the cutrance, passing a plantation of cinnamon on the way.

A little further along on the road to Negombo is Asgiriya temple, upon a large isolated rock.

HEWAHETA. Central Province, Nuwara Eliva district. Elevation of district 2,000 to 6,000 feet. P'ost and "lelegraph Office. Gymkhana Club. Planting district, with abont 35 estates and i 2,500 acres, mostly in tea. 
HIKKADUWA. Southern l'rovince, Galle district, on the road and railway from Colombo to Galle 12 m., (p. 140). Post ()tfice. Resthouse.

HORANA. Western Province, Kalutara district. On the road from l'anadnee $S_{1}^{3}$ m. to Ratnapura. Population 1,256. Post office. Resthouse.

HORTON PLAINS. The hishest plateau in the island, lying west of the railway line from Smbewela to Ohiya, and to be reached by footpath, on which hroses can be ridden, from Pattipola station, $6 \mathrm{~m}$. or Ohiya Station $5 \mathrm{~m}$. The latter path is rerr steep, and better suited for the deseent, the former for the aseent. There are also footpatles to I Ialdummulla $121 \mathrm{~m}$., to Belibulova $15 \mathrm{~m}$., to. Igrapatana $12 \mathrm{~m}$., ac. There is a good resthouse in the centre of the plains, but either supplies should be taken, or several days' nutice given, as the resthouse-keeper has to get supplies from I Iaputale, and there is of course no postal delivery to the restluouse. It is best to send over a conlie to engage romms, and wait for his return. The resthouse has several bedroums, and a domitory where a number of men can sleep, but is liable to be rery tull at any time fom February to May.

Ilorton Plains is one of the most delishtful places in the island, and shom practically no trace of man, other than the resthouse and the fortpaths. Trout, both ordinary and rainbow, have been introduced into the streams, and the holder of a license may finh for them. They grow to a gond size, and afford excellent iport attracting many tishermen to the plains. Hunting is also largely indulged in up here, and there are several very pretty walks across the patanas and through the forest.

The genceal formation of the plains is fairly typical for high memtain plateaux, whether in the Cerlon or the South lndian mountains a llattish, rolling comintry, with higher hills at the edge, and with forest perhaps most commonly on the ridges, grassy patanas on the slopes, and sedgy, often swampy, patanas in the hollows. "Two of the highest mountains in Ceylon, Kirigalpota (the milk-stone-bosk, so called fiom a book-like exposme of rock near the summit, which looks rery milks after rain, and 'Totapella, stand upon the margin of I Iorton Plains.

The shap distinction of forest and patana, described in p. 61, can be very clearly seen here, and a rery brief insestigation is repuried to find that the plants of the forest and of the patana are almost entirely different, though a few pathiste weeds will be found in both. In the forest many interesting plants will be found, but to identify them is at present a work of some considerable trouble, and requires 
some training in botany, the only book being Trimen's Flora of Ceylon. The writer and Mr. A. M. Smith are however bringing out a separate and more popular flora of the high mountain districts of Ceylon, which may appear in I 9o8. On the patana there is sometimes quite a show of flowers, and a good many familiar European kinds of plants will be recognised, $e$.r. buttercups, sundews, burnet, spurge, skull-cap, hammerheads, gentian, bluebells, valerian, brambles, lady'smantle, agrimony, barberry, anemone, de. All of these are native to Ceylon, but most of them represent the farthest southern migration of these northern forms, and almost none of them are the same species as found in Eumope, though at once recognisable as near relatives. On the patanas may also be seen, especially in the hollows of the streams, large trees of the magnificent scarlet Ceyton Rhododendron.

One of the finest walks is to the precipice known as the World's End. There are two separate places where one may look over the great precipice that terminates the plains on the southwest, both on the same road, and the second is much the finer, and should not be missed. If a fine day be obtained, one can see from the edge of the cliff right away to the southern coast of the island, to the lewayas at Hambantota (q. a.) glittering in the sum. The bulk of this southern country is flat, but there is a lofty ridge of mountains in the Balangoda district, and other summits towards Cialle. the drop at one's feet, especially at the Second World's End, is quite perpendicular, and of remarkable height, though the absurd exaggerations given in several books on Ceylon are absolutely. incorrect. Immediately below in the estate of Nonpareil, the elevation of which is about 5 , Soo feet, while the summit of the cliff is about 7,000. From Nompareil the ground slopes rapidly away to the low country, so that at a distance of some miles from the cliff one is already at quite a low elevation, but the cliff itself is only about 1,000 feet high. The valley below is said to be that where Sindbad the sailor found the diamonds, and whence he was carried away by the roc.

The descent to Ohiya is very pretty, thiough forest all the way from the level of the plains till one comes out upou the railway line at some distance from Ohiya Station (tum to the right).

HUNASGIRIYA. Central l'rovince, Kandy district, a momtain (p. $15^{6}$ ) and small planting district ( 10 estates, with about 4,000 acres, mostly in tea). Resthouse at P'anwila.

JAFFNA. The capital of the Northern Province, in Iaflina district, on the road from Kandly, ind Anmadhapura, $207 \mathrm{~m}$. and the railway from Colombo. Population in 1901, 3.3,879, in 1907, 35,099. Post and Telegraph Office. Resthousc (hot 
and windless). Churches (Catholic, English, \&c.) Hospital, Friend-in-Need Society, Medical Mission, Young Men's Christian Association, Library.

Jaffina is the capital of the northern purely Tamil division of Ceylon, and from the entirely different climate, scenery, agriculture, and people, is a very interesting place to visit. The careful methods of agriculture and gardening practised by the people will of course have been noticed in the surrounding country, and the way in which they irrigate their fields by means of well sweeps - somewhat as is done in Egypt. In the town the striking difference is in the comparatively clean and tidy way in which the houses are kept, each enclosed in its own little compound or garden with a hedge or a cadjan (p. 47) or palmyia leaf fence around it. One of the most interesting places to visit in Jaffina is the large open-air and covered market diagonally opposite to the resthouse, to the right across the large open space in front of it. Ilere may be scen all the produce of the neighbourhood on sale, and many interesting things may be purchased at extraordinarily low prices if one have an interpreter, $c . s$. the palmyra-leaf woven clephants at 6 cents cach, prettily cut circular palmyra fans at 25 cents, woven square palmyra-leaf baskets at 10 cents upwards according to size, and many other things.

The most generally interesting sight in Jaffina is of course the fine old Duteh fort, which lies opposite the resthouse across the grassy esplanade, the road leading past the police barracks. It is a very fine and well preserved specimen of an old fort, and still has the moat, the glacis, \&c., complete. Inside are bungalows, dce, and a particularly interesting old Dutch church, in the form of a Greek cross. Round the walls are quaint old pews, and in the floor are the graves of many of the old Iutch commandants of Jaffina.

Beside the church, between it and the temnis courts, is a path leading to a stair by which one can get up on the walls of the fort, and no one should omit to do this, and walk round to the right, where fine views over the shallow inlet in front of Jaffina are to be had.

$\Lambda$ drive along the sea front road, both right and left from the road leading to the beach from the resthouse, is to be recommended.

Jaffina is full of missions, and the American mission, which has been there since 1824 , may be specially mentioned.

local officials: Government Agent and Office Assistant, District Judge, Provincial and District Engineers, Medical Olficer, Superintendent of Surveys, \&c.

Carriage rates: $6-30$ a.m. to 7 p.m. Rs. $4 ; 6-30$ to noon, or noon to 7 p.m. Rs. 2 ; first hour Rs. 1, second hour 50 cents, stibsequent heurs 25 cents. 


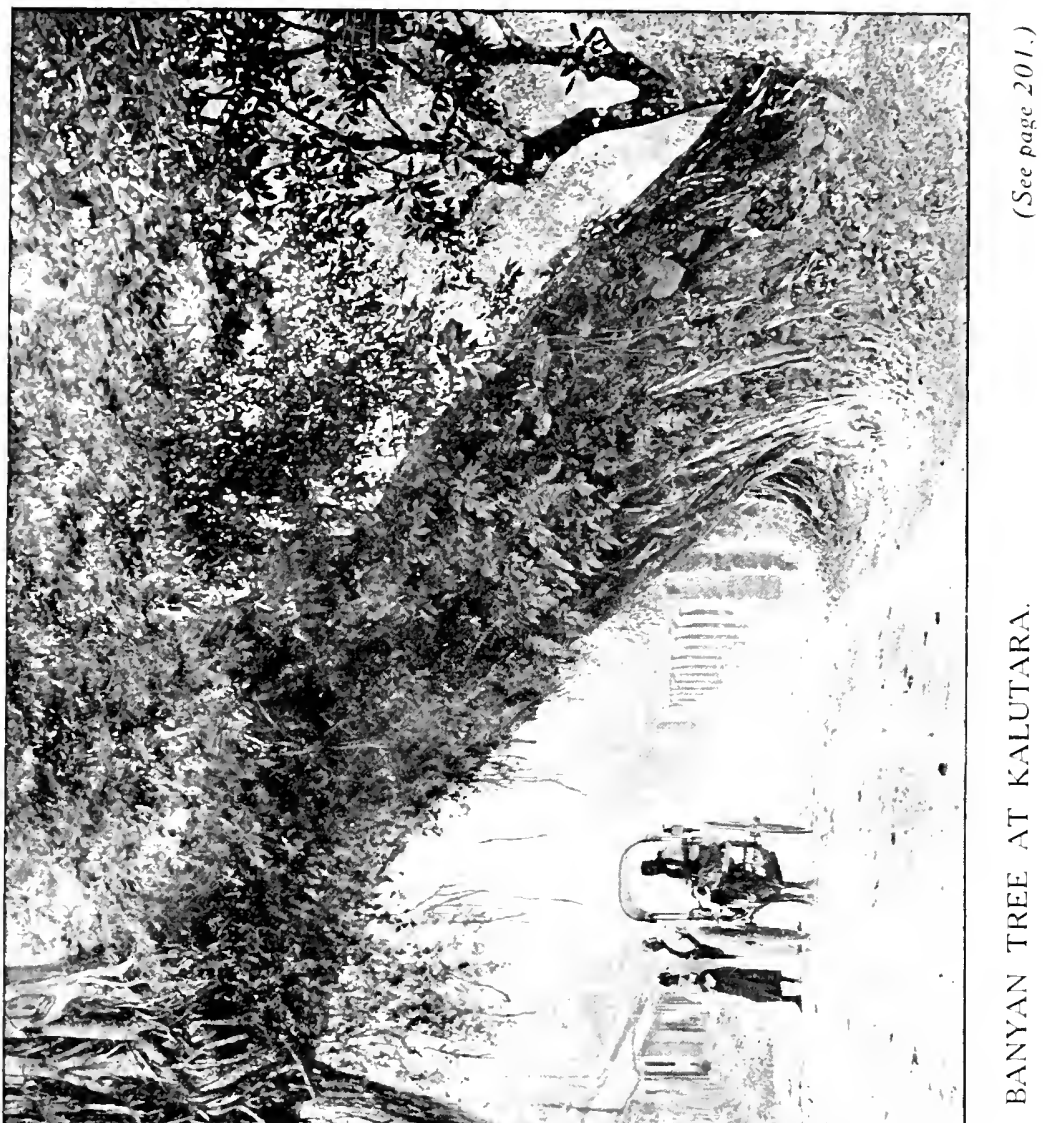



Coach to Kayts, by way of Vaddukoddai (Batticotta), where there is a large mission station, leaves Jaffina 6 a.m., arrives Kayts $9-45$; leaves Kayts $3-30$, arives Jaffina $7-15$ p.m. Fares Rs. $1 \cdot 40,1$ and 70 cents.

KADUGANNAWA. Central Province, Kandy district, on the road and rail from Colombo to Kandy (9 m.) Population I,066. Elevation 3,698 fect. l'ost and Telegraph Office. There is a monument to Major Dawson, the builder of the road up the pass.

KALAWEWA. See p. 128.

KALUTARA. Western Province, Kalutara district, on the road and rail from Colombo $266_{1}^{3} \mathrm{~m}$. to Galle, and at the mouth of the Kalu-ganga river. Population 1901, 11,500; 1907, I1,922. Post and T'clegraph Office. Resthouse. 'T'cmis Club, Cricket and Sports Club. Roman Catholic and English Churclies. I lospital. Reading Room.

'There is a Planters' Association for the Kalutara district, but the estates, some 110 with about 45,000 acres of land, mostly in rubber, but with a fair amount of tea, are mainly some distance inland, around Neboda and Anguruwatota.

Carriage hire: From 6 a.m. to 7 p.m. Rs. 4 ; from 6 to noon, or noon to 7 p.m. Rs. 2 ; first hour and second hom cach 50 cents, subsequent hours 25 cents. Rickshaws, first half hour 20 cents, first hour 35 cents, and subsequent hours 20 cents each.

KANDAPOLA. Central Province, Nuwara Eliya district, on the road and rail from Nuwara Eliya $6 \mathrm{~m}$., to Ragalla $7 \mathrm{~m}$. Population 36o. Post and Telegraph Office. Cricket and Tennis Clubs.

The district is largely planted in tea, though above the 5,000 feet limit (p. 71), land here having been largely sold before the new law came in. On the hills about are large areas of forest.

KANDY. The capital of the Central Province, Kandy district, $7+$ m. from Colombo by rail, 72 by road and Kegalle (p. 136). 'To Lewelle ferry 2 m., (ionawatte ferry (p. 1 45) $5 \frac{1}{2} \mathrm{~m}$., leldeniya by Comawate $12 ! 2 \mathrm{~m}$., Kadugannawa $9 ! 2$ m., Katugastota bridge $2{ }_{1}^{3} \mathrm{~m}$., railway station $33 \mathrm{~m}$., l'eradeniya 4 m., Ciampola $13 \mathrm{~m}$. Population r $901,26,386 ; 1907,29,020$. lilevation of station 1,602 feet, of lake 1,654 feet. Mean temperature 75.50. Post and Telegraph Office near the station.

Itotels. 'The large hotel of Kandy is the Qucen's, at the north end of the lake. The filorence, on the other side of the lake and some distance up it, is very comfortable and quicet for a stay of more than a day, and there are other cheaper places, e.g. Mrs. Warren Waiker's boarding house in IVard Street. 
Clubs, se. The General Club, with residential acconmodation, is in Ward Street, opposite the Mercantile Bank. Tennis Club, at fal end of lake; Race Club, with course at Peradenira; Sports Club. Mercantile and National Banks in Ward Sticet. Churches of all kinds, Roman Catholic, English, Scotch, de. I Iospital. Friend-in-Need Society. Band-of-hope. Industrial School. Young Men's and Women's Christian Associations. High Schools. Library. United Service Library in the Kandran building on the lake shore by the temple. Oriental Library in the temple. Artwork Association.

Kandy is as beautiful a town as one could wish to see, though the approach from the station is not imposing. The central feature of the place is the little lake, 45 acres in extent, which was constructed by the last king, and was one of the few useful or beneficial acts that he performed. A very pleasant walk round the lake, a distance of about $1 \frac{1}{2} \mathrm{~m}$., may be enjoyed in the early morning or in the evening, and there are seats at some of the places commanding the best views. Round the lake are situated many of the best residential houses in the town, but the climate is somewhat steamy so near to the water.

In front of the end of the Queen's Ilotel is the esplanade, upom which has recently been erected an equestrian figure in memors of those of the Cevlon Contingent who fell in the South African War, and at the far end is the characteristic outline of the "Kandyan roof" of the famous "Temple of the Tooth (p. 9S). Kandyan architecture has roofs of this pattern as a regular feature; the upper half of the roof shopes at a steeper angle than the lower, so that there is an angle about half way down. The temple is disappointing in size and grandeur when one thinks of it as in a sense the central worshipping place of the Buddhist religion, but it is worth a visit, especially perhaps at the hour of 9-30 or 5-30, when "services" are going on. The temple was one of the series of buildings grouped about the residence of the king, who himself lived in the Old Palace, as it is now called, the residence of the Government Agent of Kandy, standing on the top of the bank to the left of the temple. To the right of the temple, on the shore of the lake is the United Service Library, oceupying a building which was formerly the bath-louse, and on the island in the lake are the ruins of a summer-house. Behind the temple, up the little street to the left, and on the left side of the little square at the top of it, is the Audience llall of the old kings, now used as the distriet court house. The pillars in the hall are well worth examination, on account of their beautiful carving. Opposite this building is the two-storied modern kicheheri. 


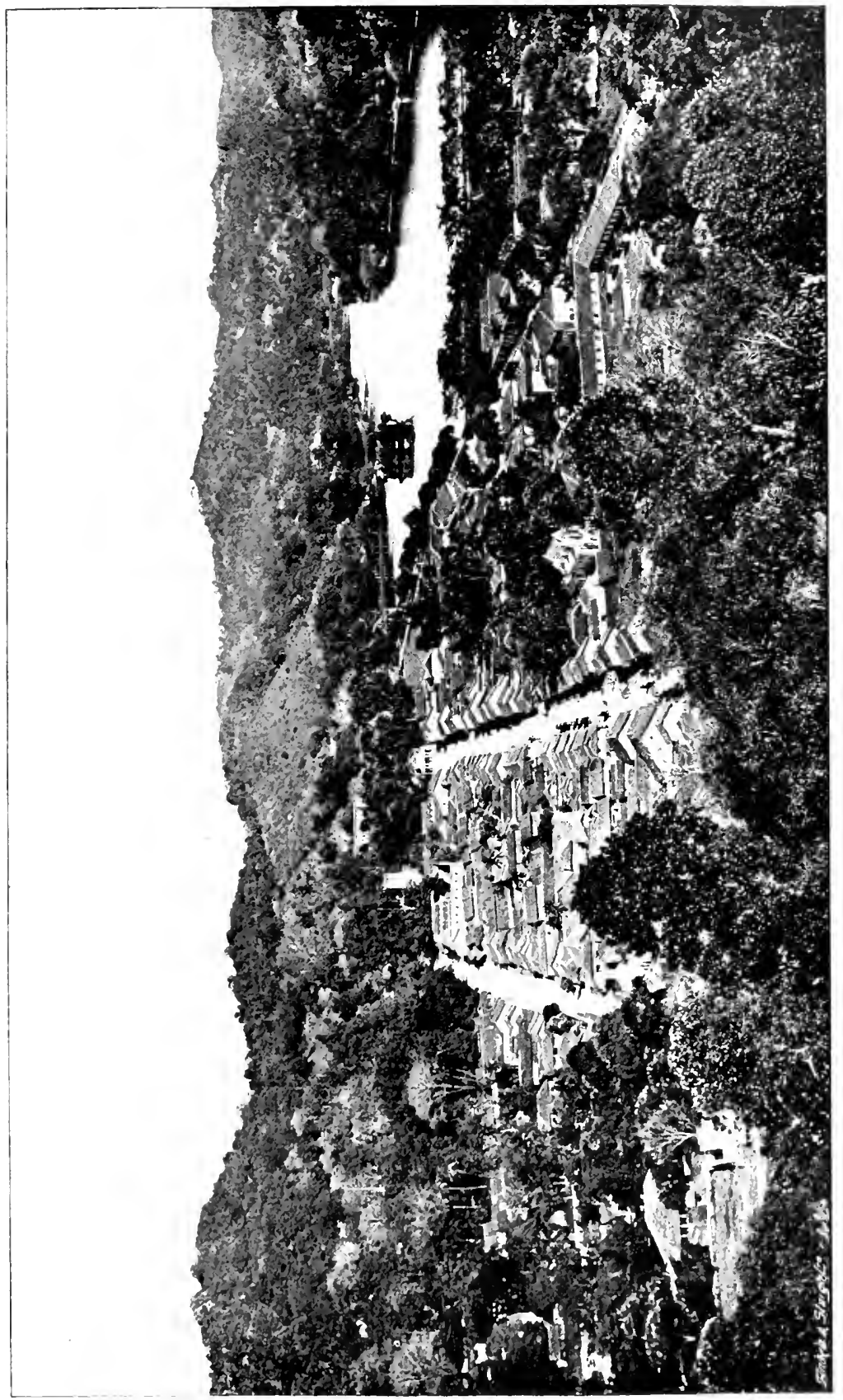

方 

Returning to the temple, and entering from the road that starts opposite the Library entrance and runs along past the Old Palace, we pass through a quadrangular arch, which has two good janitor stones (p. I I $S$ ) and gives upon a flight of steps leading up to the actual temple entrance, on either side of which are some frescoes representing the tortures of the Buddhist inferno. These frescoes are comparatively modern (p. 1oy), and their resemblance to the older Luropean designs of the same nature will at once be noticed, though a few of the punishments, such as that of the spirit who is being plastered, like an advertiscment, on to a prickly palm tree, are new. The main door is a beautiful piece of carving and represents the minor gods who guard the entrance. Within it is the verandah of the temple, and here the visitor, if he has not already experienced it, will be pestered with the attentions of would-be guides, touts and beggars. Buddhist

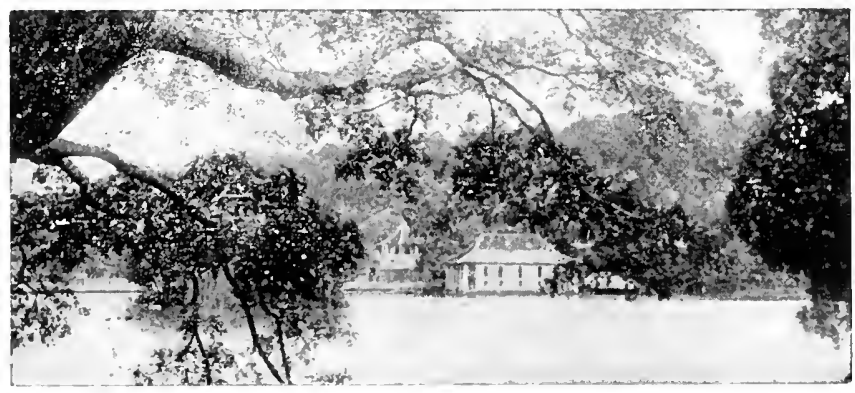

KANDY LIBRARY AND TEMPLE.

priests are forbidden by their vows to accept money, and it is in bad taste to offer it to them, but a guide - well repaid with a small sum - may be usefinl.

Tuming to the right up the steps, the visitor comes to the Oricntal Library, occupying a handsome octagonal chamber, which stands at the corner of the temple, overlooking the grass of the esplanade. Here may be seen a large collection of ola (p. 126) books, which are worth inspection, their covers esprecially being often very handsomely worked. Mlost of the books are written in P'ali, the sacred language of the buchllist priests, but generally with a Sinhalese translation or commentary upon them. The visitor who is anxious to contribute. towards anything in the temple cannot do better than subscribe a rupee or two to this library, placing the money in a box which will be found there. 
Leaving the library and turning to the left up some more steps, a small shrine, containing several images of Buddha, is come upon. The most striking of these is an exquisite image, of a large picce of rock-crystal. Up another flight of steps firom the centrat building is the dark and close chamber in which is the sacred tooth, enclosed in cover upon cover, getting more and more richly ornamented as we get neares to the tooth, which itself is only produced upon rare occasions, such as a visit of royalty. "The actual tooth is a discoloured piece of ivory, too large to have been a human tooth. The original tooth is said to have been captured by the Portuguese at Jaffina, and destroyed by the Archbishop of Goa, but most Buddhists maintain that the original tooth was not at Jaffna--which indecd seems a curious place for it-and that the one destroyed was a counterfeit.

Coing out by the steps facing the entrance to the quadrangle, the visitor will come to the Audience llall (above), and going down the road from it will come to the Museum of the Kandyan Artwork Association, which should be visited. Here he will sec the actual work of making brass and other ornaments going on, and may purchase such at fixed prices. The Association is endeavouring to keep in regular employment many of the old hereditary craftsmen of the kandyan country, and though the visitor may at times pay a trifle more than for similar articles in the shops in the town, he has the satisfaction of knowing that he is helping to keep up an almost extinct but very beautiful art, and that the articles he buys are genuine.

Returning again past the library and the front of the temple, we may so along the road between the Old Palace and the Nata Dewale, a large temple sacred to Nata, in which are several dagobas (p. 79 and figure on p. 98). Over the entrance is a makara-torana (p. 132), while opposite, on the other side of the road, is the Mala Dewale, another Hindu temple sacred to Vishnu, in the garden of which is a very ancient bo-tree, one of the first cuttings taken from the tree at Anurathapura. Beyond this again is St. Paul's Church, completed in 1853 , and the principal place of worship of the Church of England in Kandy. Next to it, as we return to the hotel past the front of it, is the Police Court, and past this a fountain erected br the planters on the occasion of the visit of the present King in $8_{75}$. Beyond this, upon the esplanade, is a statue of Sir llenry Ward, Governor from 1855 to i 860 , and on the right the memorial to the Ceylon Contingent in South Africa.

Returning from the hotel past St. Paul's Church, and going straight on, we may, if the Governor be absent, enter 


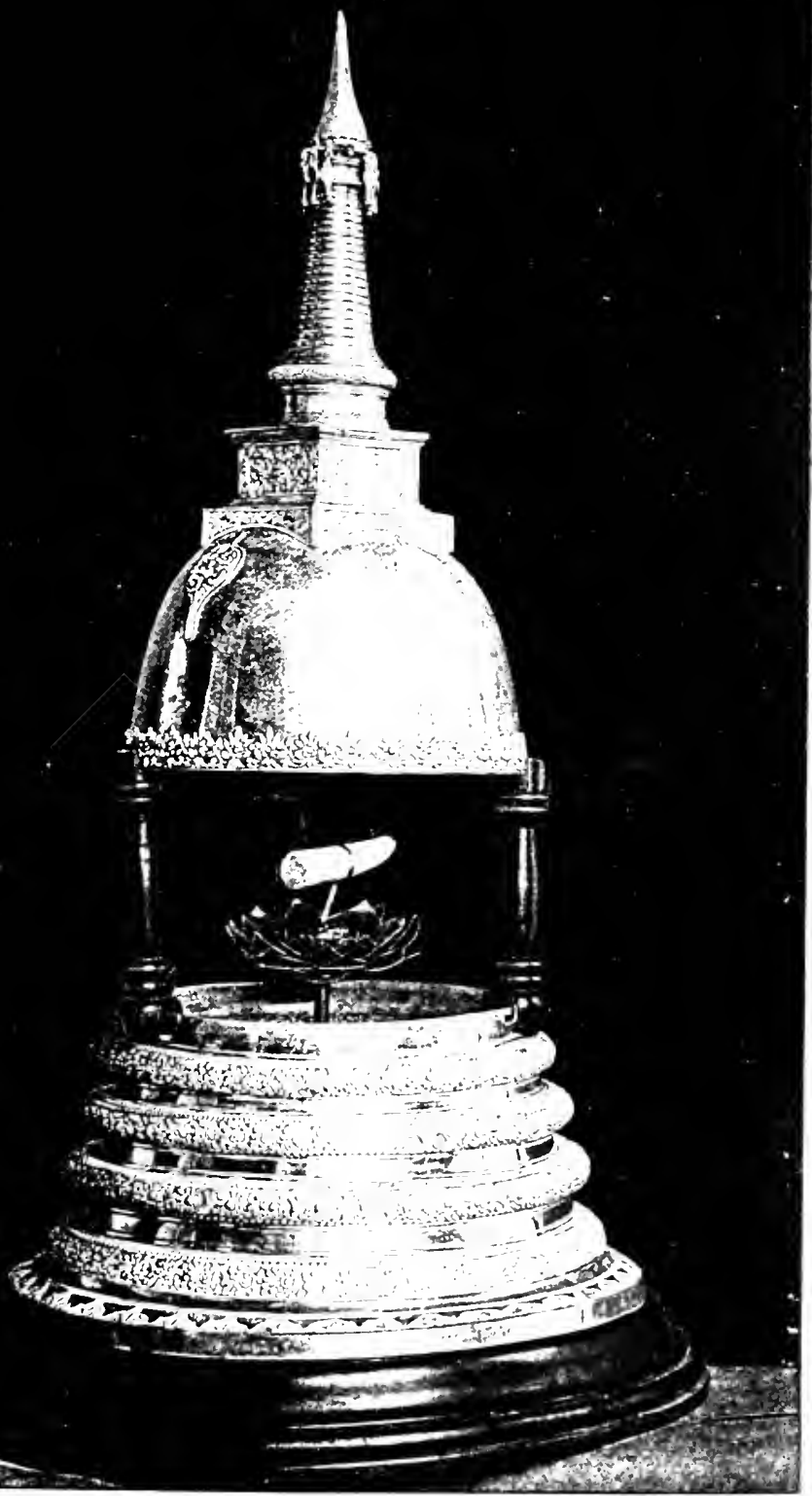

MODEL, OF THE TOOTH REIIC, KINDY

[Photo by A. H. Andrec. $\sec$ puge $2(14)$ 

the grounds of the Pavilion, his Kandy residence, in which are some very striking specimens of vegetation, notably an Assan indiarubber tree (Ficus elastica), with luge creeping almost snake-like roots, a candle-tree, whose fruits look like tallow candles hanging upon the stem, a splendid cotton-tree (p. 65) in front of the house and others. Groing out by the farther gate, and turning to the right, we come in a few yards to the Industrial School, where good work in carpentry, boot-making, sce, is carried on.

The visitor who does not mind a little walking should go up the hill on the northem (Queen's llotel) side of the lake, by way of Lady llorton's Walk, the entrance to which is beside that to the Pavilion near to St. Paul's Cluurch. The paths upon the hill are somewhat complex, but all are pretty, and there are seats along them, while they command lovely views over kandy and its surromdings.

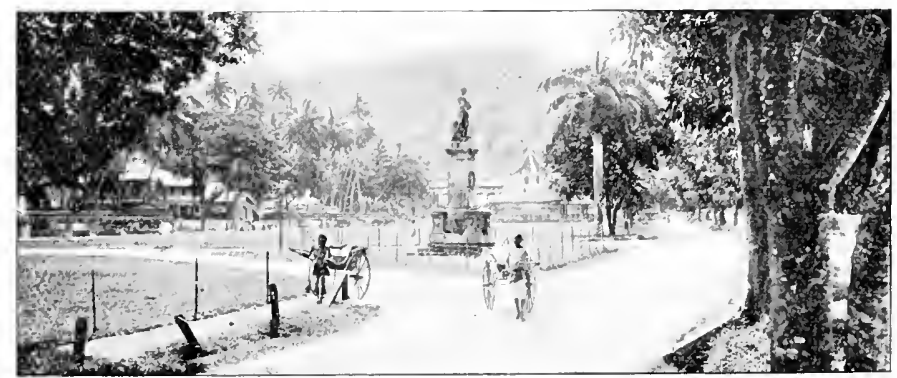

ESPLANADE AND TEMPLE.

The visitor who does not care to walk should drive down Trineomalie Street to the farther end, passing the Scots Church on the left, and Trinity College (a first rate boys' school, with a cluteh attached) on the right, and turn ip Lady (iregory's Road at the far end. This winds ronnd and sradually up the hill, and at several points commands lovely views, notably at places overlooling the vale of I numbara, northeast of Kandy, a great cacao-growing district witl the Maluaweli-ganga winding throngh it, and with the ligh monntain range of the knuckles (the top of which is not unlike the middle knuckles of the fingers) in the backigronnd, and Ilunasgiriya l'eak (p. 156) to the left. 'The road finally comes down at the upper end of Malabar street by which a descent may be made directly to the Queen's I lotel, or Lady longden's Drive may be taken to the left, leading to the top of the lake. 
The road round the lake should also be driven over, if not already seen, and the Malwatte temple, almost opposite the Queen's Hotel, risited. This is an important temple, at which, or at Asgiriya, every Kandyan priest is supposed to take the vows.

One of the most beautiful drives in Kandy is to be obtained along the Upper Lake Road, which is reached by soing past the head of the lake for some distance up the road, and then turning to the right up a gravel road. Splendid views of the Knuckles range and Hunasgiriya Peak (p. 156) are to be obtained, while from a point where there is a stone bench, there is a fine view of kandy, looking straight down Trinconalie

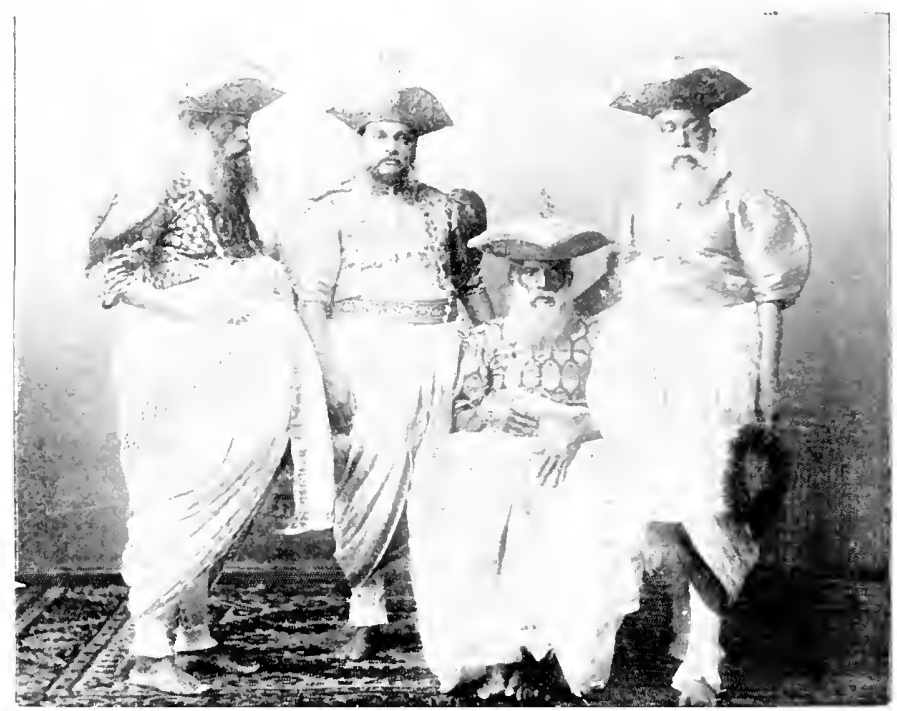

KANDYAN CHIEFS.

Street to the pointed tops of the Matale hills in the background. Before turning down at the westem end, a detour may be made to the reservoir of the Kandy waterworks, which is pretty, and the little IVace Park may be visited, commanding fine views. The deseent is above the jail, behind which is the very pretty Bogambra recreation ground, on which cricket, football, sce, are played.

An excursion which slould not be omitted is to the Peradeniya Botanic Gardens (q.i'), and others of interest are to see the elephants belonging to IV. Dunuwille, Dissawa, a great Kandyan chief, bathing in the Mahaweli-ganga at 
Katugastota, to Gadaladeniya and Lankatilake temples (p. 1 31 ), and the return from this or the Peradeniya excursion by Lady Blake's 1)rive, which is entered by turning to the left about a mile on the Kandy side of Peradeniya, and which leads down a beautiful gorge of the river to the llalloluwa road, by which we return to Kandy. Yet other drives of interest are by way of Malabar Street to the Gonawatte ferry, about $5 \frac{1}{2}$ miles, to Katugastota, about 3 miles, and along the Ampitiya road at the head of the lake, while it is worth going to the rock temple at Hindugala, following the road that turns left to Deltota between the gate of the Peradeniya gardens and the bridge. There is a considerable climb to the temple, but it contains some frescoes, and commands a fine view of Adan's Peak. One of the best spots from which to obtain the latter is the Grand Stand on the Peradeniya Racecourse.

History. Kandy has but little. At the beginning of the ifth century a temple was built for the tootls, and in I 592 it became the capital of the Sinhalese monarchy. After undergoing many destructions at the hands of the Portuguese and Dutch, it was finally captured by the English and the king deposed in 1815. A few historical relics are still to be seen, e.g. round the laboratory and offices of the Peradeniya Experiment Station are the remains of the earthworks in which a Portuguese detachment sheltered itself, and in which it was slaughtered by the Kandyans in 1638 ; and near Katugastota is "Davie's tree," the scene of the massacre of the British troops that were left (under Najor Davie) to garrison Kandy after it had been captured by General Macdowall in 1803.

Local Officials: Government Agent and Office Assistant, District Judge, Police Nagistrate, Provincial and District Engineers, Superintendent of Surveys, Medical Officer, sc.

Carriage hire: 6 a.m. to 7 p.m. Rs. 5 ; six consecutive hours Rs. $2 \cdot 50$; first half hour 6o cents; first hour Rs. I’20; each subsequent lour 30 cents. Rickshaws, first half hour 30 cents, second half hour 30 cents, subsequent half hours 15 cents; after 7 p. $m 1.35,35$, and zo cents respectively. Weekday trains to Colombo, see 1.148 ; to Matale at $7-45,11-23,2-45$, 6-35 (see p. 1.48); to llatton \&ce at 7-5, 10-30, 1-5, (see p. 148).

KANGESANTURAI. Northerm l'ovince, Jalfira district, $11 . \frac{1}{2} \mathrm{~m}$. by road from Jaffina, and at the terminus of the morthern railway. Post and Telegrapl, Office. Restlouse. There is little to see in the village, but the inland comntry towards Jaffina is a model of careful and laborious cultivation. Steamers. run fortuightly in each direction, on the "pomel the island" trips, to Pansins and Colomber, and to l'oint Pedro and Trincomalie sic. Train to Colombo at 7-5 a.m1.; to Jaffina also at $\mathrm{I}-\mathrm{O}$ and $3-55$. 
KANTHALAI. Eastern Province, Trincomalie district, $24 \frac{1}{2} \mathrm{~m}$. from Trincomalie, $43 \frac{1}{2} \mathrm{~m}$. from Dambulla. Village Receiving Office. Population 156. Resthouse. There is a magnificent tank here, on which there is good sport to be obtained, and the place is very popular with sportsmen. Coach to Matale at 12 p.m., arriving at 3-30 p.m. ; leaves Matale so a.m., arrives Kanthalai 1 a.m.

KARAWANELLA. Sabaragamuwa Province, Kegalle district, on the road from Colombo (39 m.) and on the rail from Colombo to Yatiyantota. The station for Ruwanwella, $2 \frac{1}{2} \mathrm{~m}$. distant across the Kolani, from the bridge over which river is one of the most beautiful views in the island. Railway Receiving Post Office. Train about i m minutes earlier or later than Yativantota (q. v. p. 148).

KATUGASTOTA. Central Province, Kandy district, about $3 \mathrm{~m}$. from Kandy on the north roak $(\mathrm{p} 143$ ), and on the railway to Matale (p. 155.) Elevation 1,534 feet. Post Office. There is a tiue girder bridge of 330 feet loug (over the water). Elephants may often be seen batling in the river (P. I S).

KEGALLE. Sabaragamuwa Province, capital of the Kegalle district, on the main road from Colombo (49 m.) to Kandy (23 m., p. 136). Cross road, passable for motors, to Bulatkohupitiya resthouse and Ruwanwella resthouse, through district largely planted in rubber and tea ; and to Polgahawela station and Liurunegala, also suitable for motors. Population 2,340. Elevation 780 feet. Post and T'elegraph Office. Resthouse (nive notice as it is liable to be inundated by planters). Churches. llospital. Library.

There is a Planters' Association in the district, which has about 50 estates with i 5,000 acres opened, mostly in rubber and tea. The district is steeply hilly and very rainy.

Kegalle has a very long bazaar, in which is a pretty ambalam or native resting place, and a small esplanade. There is a pretty walk of about 2.111 . along a road which turns off almost exactly opposite the resthouse and runs round into the Bulatkohupitiya road.

No conveyance can be got but hackeries drawn by bullocks, at 25 cents a mile. Coach to Polgalnawela at 6-45 a.m., and $1-45$ p.m., arriving at $8-30$ and $3-30$; returning at 9-30 and 4-30, arriving at Kegalle $11-15$ and $6-15$. Fares Rs. $2 \cdot 50,1 \cdot 50,1$.

KEKIRAWA. North-Central Province, on the road from Dambulla $14 \mathrm{~m}$. to . Muradhapura $26 \frac{1}{2} \mathrm{~m}$., (p. 143). Population 423. Village Receiving Post Office. Resthouse, kept by a Kaftir who was instrumental in the taking of the bandit Sardiel (p. 153). Good road to Kalawewa tank, which should be 
visited (p. I $2 S$ ); Anuradhapura may be reached thence aid Talawa Station, passing Maha-iluppalama Experiment Station (a branch of Peradeniya) on the way ; the road is sood for motors. There is also a very rough cross road, only passable by bullock cart, for about $+\mathrm{m}$., to the road from Maradankadawela to I labarane, from which the ascent of Ritigala may be made.

KELAN! VALLEY. The sreat valley of the Kelani river, which reaches the sea at Colombo, and which is now opened up by the K. V. narrow gauge line to Yatiyantota. The lowes part of the valley, below Arisawela, is mainly oceupied with native cultivation, but above that the comtry becomes very luily, and is largely ocenpied by Eumpean estates, this being the largest planting district in the island, and having about I60 estates of about 60,000 acres, mostly in tea and rubber. 'The Planters' Association las its headquarters at Taldua, about a mile from Arisawela, and has there a club house, racecourse, tennis courts, \&c.

The upper part of the valley is one of the most beautiful districts in the island, and from the lovely view off the bridge at Karawanella to the summit of the pass at Cinigathena, there are but few dull portions.

KELEBOKKE. A planting district northeast of Kandy (resthouse at Panwila) with about 15 estates of 9,000 acres, mostly in tea.

KiTULGALA. Sabaragamuwa Province, kegalle district, on the main road fiom Colombo mp-country (p. 1,3S). Population 955. Village Receiving Office. Resthouse. The place lies in a very prettr but extremely rains situation, beside the river, w the far side of which is forest (p. 37).

KNUCKLES. The high range of mountains northeast of Kandy, and with a l'lanters' Association. About r 7 estates, with about 5,000 acres, mostly in tea.

KODIKAMAM. Northem Province, Jaffina district, 15. m. from faffina on the main road to the soutl. Station on the railway. Population 700. Railway Receiving Post Office. Coach to Print Pedro and Valvettiturai, leave Kodikamam S-40 a.m. and 7 p.m., 21 hours to Point l'edro, 3 homs to Valvettiturai; leave Valvettiturai $\$-45$ a.m. and $2-45$ P.m. Fares Rs. 2, 1.50, 1 .

KOLLUPITIYA (Cinpetty). A somthern subub of Colombo (q.v.). Post and Telegraph oflice.

KOSGAMA. Western Province, Colombo district. Station on the Kelani Valley line, \& hour nearer Colombo than Avisawela. Railway Receiving Post office.

KOTMALE. Central l'rovines, Kandy distriet, $7 \mathrm{~m}$. from Nawalapitiya, on the Craigie lea road (p. 142). Post 
and Telegrapl Office. Sports Club. Planters' Association; about 25 estates, with about 10,000 acres, mostly in tea.

KURUNEGALA. The capital of the North-Western Province, on the railway from Colombo to Jaffina. I $\frac{1}{4} \mathrm{~m}$. from Polgahawela, $35 \frac{1}{1} \mathrm{~m}$. fiom Dambulla, $54 \mathrm{~m}$. from Puttalam, $44 \frac{1}{2} \mathrm{~m}$. from Negombo. Roads see pp. 138, 140, 142, I 4 . Population in $190 \mathrm{5}, 6,48_{3}$, in $1907,7,83 \mathrm{~s}$. Elevation 400 feet. l'ost and Telegraph Office. Resthouse. Tennis Club. Churches. Hospital. Library.

'There is a Planters' Association; the district comprises about to estates with about 16,000 acres, mostly in cacao, rubber and tea, while coconuts are very largely planted and there are several important areas of plantains in the neighbourliood.

The town is pretty, and has a nice esplanade. The pleasantest walk is along the bund of the artificial irrigation lake, and an excursion to the top of the Elephant Rock is also interesting, and commands lovely riews.

Local officials: Government Agent and Office Assistant, District Judge, Provincial and District Engineers, Superintendent of Surreys, Medical Officer.

Carriage hire: Twelve hours Rs. 4 ; six hours Rs. 2 ; first half hour 50 cents, second the same, subsequent hours 25 cents. Rickshaws 12 hours Rs. 2 ; six hours Rs. I; five minutes 10 cents; half an hour 25 cents; detention ro cents the half hour. More at night, after 7 .

Trains to Colombo at 8-10, 1 1-45,3-0, 5-55; from Colombo at $7-30,2-10,5-5$ (2 $\frac{1}{2}$ to $3 \frac{1}{2}$ hours); to Anuradhapura at $10-12$ and 5-5; from Anuradhapura at 7-45 and $2-20$ ( $3 \frac{1}{2}$ bours).

LABUGAMA. Western Province, Colombo district, $25 \frac{1}{1} \mathrm{~m}$. from Colombo (p. 139) the site of the great reservoir ( 76 acres) of the Colombo water works by which the port is supplied with what is about the best water to be got in any tropical port. The reservoir was built in $1882-6$ and has a maximum depth of 60 feet, while it can supply 1,233 millions of gallons.

LINDULA. Central Province, Nuwara Eliya district, 3 m. from Talawakele. Population 395. Elevation 4,200 feet. Post and 'Telegraph Office. Hospital. Coach from Talawakele, leaves Talawakele 3 p.m., arrives 4; leaves Lindula 9 a.m., arrives Talawakele 10.

LUNAWA. Western Province, Colombo district, $\mathrm{S}_{1}^{3} \mathrm{~m}$. from Colombo by road or rail on the Galle line. Population 1,566. Railway Receiving Post Office. Resthouse.

LUNUGALA. Ura Province, $14 \mathrm{~m}$. from Passara on the road to Batticaloa (p. 145). Elevation 2,400 feet. Post and Telegraph Office. Hospital. Resthouse very comfortable. 
PLATE

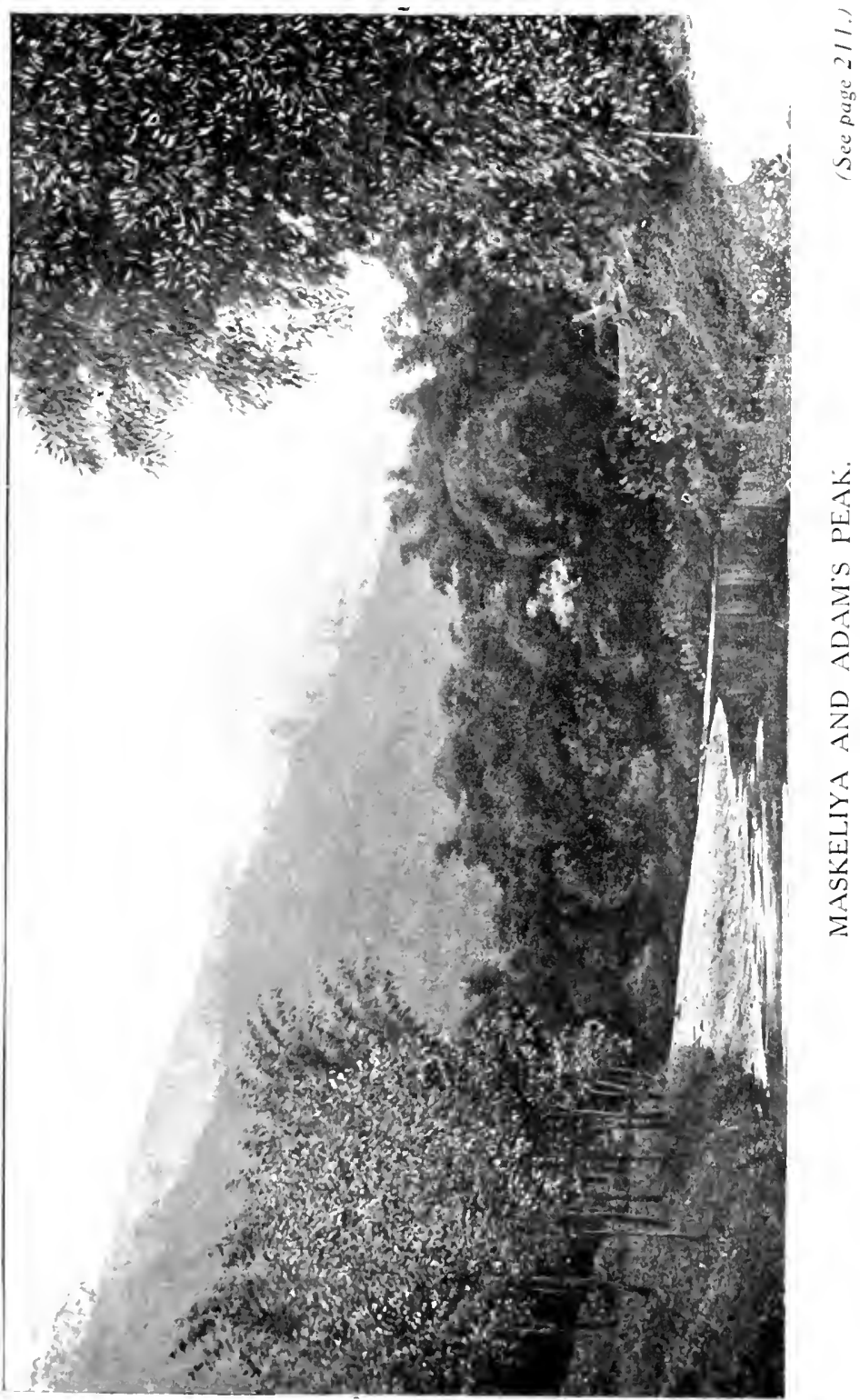



A prettr planting district. Coach to Passara, Badulla, and Bandarawela at 7 a.m. reaching Passara 9-30; leares Passara 5-30 p.m., reaches Lunugala $S-40$. Fares $R s .5,3,2$. Coach to Batticaloa leares at 9 p.m. Fares Rs. 25,15 and 10.

MADAWACHCHIYA. North-Central Province, on the road (p. 14.3) and rail (p. 164) to the north, i $7 \frac{1}{4} \mathrm{~m}$. from Anuradhapura. Vi]lage Receiving Post Office. Resthouse. Population 228 .

MADULSIMA. Uva P'rovince, $7 \mathrm{~m}$. from Passara (p. 1.66). Elevation 4,400 feet. Post and Telegraph Office. Planters' Association. 23 estates with about 12,000 acres, mostly in tea, at 2,000-5,000 feet.

MAHA-ILUPPALAMA. An Experiment Station kept up in the irrigable country of the north, as a branch of Peradeniya, for experiments with cotton, rubber, \&c. $103 \mathrm{~m}$. from Kekirawa, on the road to 'lalawa Station. 'To view, apply to the Superintendent, at the two-story house on the road.

MANNAR. Northern Province, the capital of the Mannar district, oin the west coast south of Jaffina, and $52 \mathrm{~m}$. from Madawachchiva by road. Population 5,332. Post and Tetegraph Office. Resthouse. Churches. Hospital.

In the neighbourhood are some fine specimens of the banbab tree, a native of tropical Africa, supposed to have been introduced by the Arabs. The district is almost the driest in Ceylon, having only 38, ins. of rain a year.

Local official: Assistant Government Agent.

MASKELIYA. Central Province, Kandy district, $11 \frac{3}{4} \mathrm{~m}$. from llatton aia Norword (p. 147). Population 992. Elevation 4,000 feet. Post and Telegraph Office. Resthouse. Ilospital. Planting district, with about 60 estates and 19,000 acres, practically all tea.

Though the district is pretty, the chief interest in it is Adam's Peak, the ascent of which is well worth making. The coach from Hatton, which runs to Maskeliya village, will for a rupee a passenger extra, go on to the resthouse, or l'eak View Ilotel. If there are threc of more people a carriage may be taken from Ilatton for an equal or less cost. The coach descends from llatton through Dikoya village, crosices the little siver, and runs patst the church into the main valley of Dikova, which is almost a continuous sheet of tea, but with the rowth of the slade trees is becoming quite picturesque. At Norwood, at the crosing of the river, the coach changes horses, and runs up over the pass into the Maskeliya valley, which is a good deal mole picturesque than I Dikoya, and has the splendid outline of the Peak at the end. There is still a sood deal of forest on the upper part of the hills, and the district is very rang. 
The hotel or resthouse is about 7-8 $\mathrm{m}$. fiom the summit of the l'eak, and more than 3,000 feet below it, so that at any rate of hours should be allowed for the ascent. As the chief thing to be seen is the sumise and the shadow which then appears (in farourable weather), it is best to leave the hotel at night, between 12 and $1-30$, accolding to walking capacity. Ladies can be caried in chairs tor the first fou miles. Guides with lamps must be taken, and warm waps should be provided, for it is cold on the summit, and one is liable to be very hot with the exertion of walking up. Provisions for making early tea at the top must not be forgotten. The summit should be reached not later than 5-30, as the sun rises soon after. The ascent is best made at the full moon of Januar, Februar or March, as there is likely to be clear reather then, and lare numbers of pilgrims also ascend.

The first few miles of the walk are through tea estates, and then up a steadily narowing valley with steep sides, through bits of forest, and past a little hamlet where pilgrims often rest and set provisions. Bevond this one turms shaply to the left across the stream, and the steep ascent begins, up a rough path which in wet weather is simply a watercourse, in places worn out $4^{-6}$ feet deep, and in which there are many roots, high steps, de. This ascent is troublesome for ladics, who should wear short skirts. The path leads up through dense forest for a long way, and then, a few hundred feet (reptically) below the summit, the little lamlet of Usamalle is passed, and the climb of the actual cone begins. The ascent of this is rery simple, and the ridiculus exagrerations which have often been printed about it, making of it a climb that rivals that of the Matterhorn, are quite untrue to fact. It the steepest parts of the ascent, where it goes up almost naked rock, steps have been cut in the rock, a stout iron hand rail provided, and an ancient chain, dating very lar back, and rery picturesque with its hand-made links of different sizes and shapes, hangs over the rock and may be used as an aid in the ascent. No one should howerer try to make this ascent in Swiss mountaineering bosts, as the steps are rather slippery with the constant polishing they underge fiom the naked feet of innumerable pilgrins. Ordinary smosth leather soles are pertups the best. Lnless one be rery giddily inclined, there is not the very slightest difficulty abont the aseent, and the dorp is nowliere rery serious, perbaps to feet being the livgliest.

The funal ascent is by a flight of steps past a little hut, on to the flat rock forming the summit, and which is about 30 rarels square, with a wall round it, and a ligher rock in the centre. On the summit of this is a little temple corering the 
footprint, which is simply a depression in the rock, artificially "improved," but which is sacred to the Buddhists as the footprint of Buddla, to the Ilindus as that of Siva, the Mahommedans as that of Adam, and even to some of the Catholics, at least in Portuguese times, as that of St. "Thomas. If, as should always if possible be the case, the ascent be made at the full moon of one of the drier months, January, February, or March, large numbers of pilgrims will be seen arriving at tha summit, while yet others will have spent the night there. They come up with shouts of "Sadu," worship at the footprint, ring the very ancient sacred bell at the north end of the enclosure, and soon depart after sumrise.

At about a quarter to six, the sun rises over the mountains to the east, often with great splendour, and if it be a line morning a wonderful sight is presented. As soon as it is above the horizon one should goround to the other side of the summit to look for the famous shadow. If one be lucky enough to see it, for it is only sometimes risible, it presents itself as a rast dark triangle lying over the country to the west, and apparently reaching the sea at or near Colombo. In reality this shadow is like the spectre of the Brocken, for it is thrown on a fine mist which in the northeast monsoon olten occupies the valley between the peak and the hills to the westward, but it looks as if it lay horizontally. As the sun rises it shrinks in and disappears.

After admiring the beautiful views in every direction that present themselves firm the summit of the Peak, the descent may be made by the same path, and the resthouse reached for breakfast. There is also a path down the western side of the mountain to Ratnapura, but the distance and the height are much greater. It is not however as dangerous as is sometimes made out. On our last ascent but one, we saw a blind man and a lame man arive at the summit by this route.

Coach to Hatton, leaves Maskcliya $8-30$ a.m. and $5-15 \mathrm{P} . \mathrm{m}$., arrives $10-40$ and $7-30$; leaves 1 latton 6 a.m. and $2-20$ p.m., arrives $8-30$ and $4-45$. Different Saturday and Sunday.

MATALE. Central Province, the capital of the Matale district, $16 \frac{1}{2} \mathrm{~m}$. from Kandy by road (p. 143) and rail (p. 155). Population in 1901, 4,951, in 1907, 5.497. Elevation 1,208 feet. Post and Pelespoph Office. Restlouse. Cricket and Tennis Clubs. Churches. Hospital. Reading Room.

Matale is a pretty little town, with a bazan of plienomenal length, a fact probably to be accounted for by the former arrival of most of the estate coolies (p. 5.4) by the north road, so that every one was tempted to go further and further down the road to catch the new arrivals first. Coolics now arrive by Tuticorin and Colombo. Coing out from the station and 
turning to the left, we soon come to the resthouse, opposite to which is the Post Office. A little distance behind the restlouse is the pretty open space of the Esplanade, on which, to the left, is the Borron Memorial Hall, in which the local Planters' Association, and other bodies meet.

The district has (for Ceylon) an musually good and deep soil, and in conscquence is largely planted in cacao and rubber, both of them products liking such conditions. There are about 133 estates with $+5,000$ acres cultivated, mainly in tea, cacao and rubbcr.

Local officials: Assistant Govermment Agent, District Engineer, Medical Ofticer.

Carriage hire: 6-30 a.m. to 7 p.m. Rs. 4 ; 6-30 to noon, $\mathrm{Ol}^{\circ}$ noon to 7 , Rs. 2 ; one hour, Rs. I ; second hour 50 cents, subsequent hours 25 cents. For trains see p. Ifs. Coach to Trincomalic at $\mathrm{o}$ a.m., arring at Trincomalie 9 a.m.; leaves Trincomalie 3 p.m., arrives Matale 3-30 p.m. next day.

MATARA. Southern Province, capital of the Matara district, $27 \frac{1}{2} m$. by road (p. I.to) and rail (p. I6S) from Galle. $47 \frac{1}{2} \mathrm{~m}$. fiom Ilambantota. Roads see pp. 1 40, I 41. Population 1 I, 848 in 1901, 13,043 in s907. Post and Telegraph Office. Resthouse. Temis Club. Churches. Hospital. Reading Room.

Natara is a pretty little town on the soutl coast, and worth a risit. There is a fine old Dutch fort, joined to the main part of the town by a bridge over the Nil-ganga (on the far side of which is a little outlying fort), and in it is the resthouse, Se. Close to the fort is a little island, joined to the mainland by a causeway, and it is well worth going out upon this in the cool of the dar, for the sake of the vicws it commands. A pretty waik is from the resthouse to the nouth of the Nil-ganga. The famous old temple of Dondra Ilead, the southemmost point of the island, should also be risited, and a rery interesting trip in to go by boat for a few miles up the river, taking care, on account of the crocodiles (a protected bathing place may be seen near the bridge), not to put the hand or foot in the water. Good specinens of mangroves mas be secn along the banks of the stream, and many fine nests of the wearer bird.

local officials: Asistant Goremment Agent, District Judge, Police Magistrate, Assistant Superintendent of Police, District Engincer, de.

Carriage live: from $6-30$ a.m. to 7 p.m. Rs. 4; 6-30 to noon or nom to 7 p.m. Rs. 2 ; first half hour 50 cents, second 50 cents, every subsequent hour 25 cents. Rickshaws, first half hour 20 centr, second 15 , every subsequent lour 20 cents. "Trains see p. Ifs. Coach to Akuressa, Moromaka and 
Deniyaya, at 10 a.m., arrives 5. Fares Rs. I 3, 7, 4. Leares Deniyaya $8-30$, arrives 3-30. Coach to Tangalla and Flambantota at $10-30$, arrives $S$; leaves 1 lambantota 5-30, arrives 3-30. Fares Rs. 12.50, 5.50, 3.50. Coach to Taugalla at $1-30$ p.m. returning at 6 a.m. (4 hours).

MATURATA. Central Province, Nuwara Eliya district, the upper end of the valley reached from Nuwara Eliya by Brookside, the lower end from Kandy (p. I 44). Population 78. Eleration 3,500 to 5,600 feet. Post and Telegraph Office. Hospital. The valley is very pretty, and has about 22 estates with 7,000 acres cultivated, mainly tea. There is a l'lanters' Association.

MIHINTALE. North-Central Province, $S$ m. from Anuradhapura (see pp. 143, 147). Resthouse. For description of the rery interesting ruins, see p. 121.

MINNERIYA. North-Central Province, i $5 \mathrm{~m}$. from Habarane (p. I4t). There is only a bungalow belonging to the Irrigation Department here, and quite unfurnished. See p. 129.

MINUWANGODA. IVestern l'rovince, Colombo district. Population 677. Post Otfice. Restlouse. Bullock Coach to Negombo, leares 6-30 a.m., arrives 9-30, leaves Negombo 3-30, arrives 6-3o. Road see p. $13 \mathrm{~S}$.

MIRIGAMA. Western Province, Colombo district, on the railway to Kandy (pp. I $38,140,155)$. Elevation 16,4 feet. Post Office. Resthouse, in a situation commanding a pretty view. There is a good school garden in the town (Mugurugampola, see p. 103).

MONERAGALA. Uva l'ovinee, a long way fiom anywhere, and perhaps the most out of the way of planting districts. Post and Telegraph Office. There are about 8 estates, witli about 4,000 acres, mostly tea, rubber and cacao. The district is muluealthy.

MORATUWA. Viestern Provinec, Colombo district,

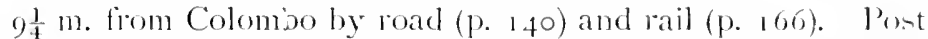
and Telegraph Office. Resthouse. Crolists' Tnion. Population 29,600. The large town is practically a seaside sulbull of Colombo. 'There is a larese boys' school, the prince of Wales' College, there.

MORAWAK KORLE. Soutluern Proviuce, Matila district, reached by coacls from Matara (q.v.). I'illige Receiving l'ost Office at Morowakal. l'lanters' Association. 17 estates, with 4,000 acres, mostly teat.

MOUNT LAVINIA. I somblem suburb of Colomber, reached by road or rail, $6 \mathrm{~m}$. fiom the fort. "There is a good first-class lotel there, formerly the residence of the Governor, and a favourite resolt with passengers who are 
only in Colombo for a few hours. It has passable bathing, and is famous for its fish tiffins. Post and Telegraph Office.

MULLAITTIVU. Northern Province, capital of the Mullaittivu district, on the east coast, reached by road of $32 \mathrm{~m}$. from Mankulam Station on the northern railway, by bullock coach. Population 1,308. Post and Telegraph Office. Resthouse. Hospital. Coach leaves Mankulam 7 p.m. and Mlullaittivu 8 p.m. and travels all night. Fares Rs. $5,3 \cdot 75,2 \cdot 50$.

Local official: Assistant Government Agent.

NALANDE. Central Province, Matale district, $14 \mathrm{~m}$. from Matale on the north road (p. 143). Population 28I. Resthouse. Formerly a very pretty district, now largely

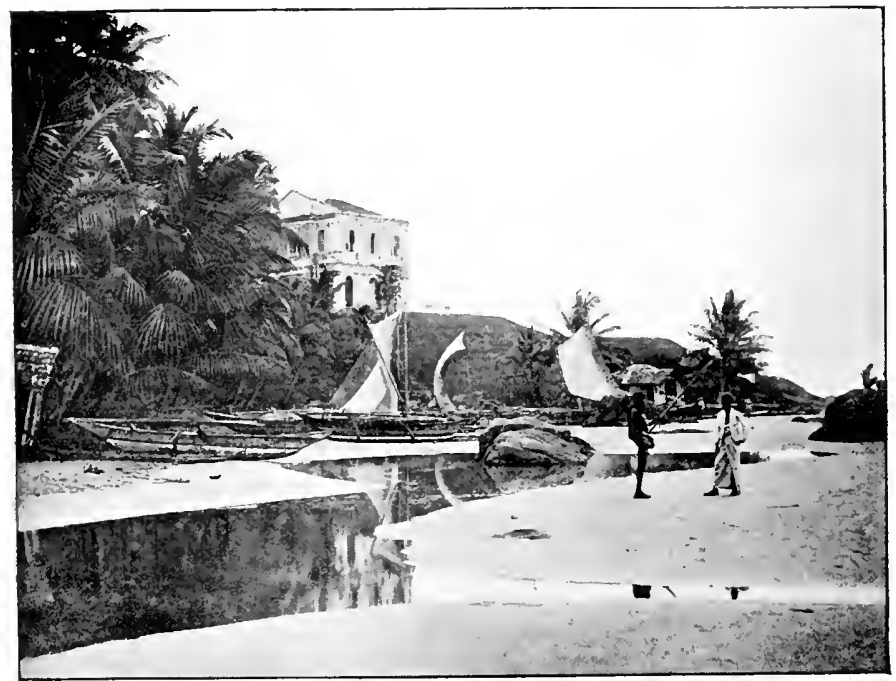

MOUNT LAVINIA.

planted up with rubber, but containing some fine pieces of forest. There is a very handsome tamarind tree in the garden of the resthouse.

NANU-OYA. Central Province, Nuwara Eliya district, on the main line of railway from Colombo (p. r 59 ) and $4 \mathrm{~m}$. from Nuwara Eliya by road (p. i 4 I). Post and Telegraph Office. Population 567. Elevation 5,291 feet.

NAWALAPITIYA. Central Province, Kandy district, on the railway to Nanu-oya (p. I 57) and road to Nuwara Eliya. Population 3,454. Elevation 1,913 feet. Post and Telegraph Office. Hotel. Hospital. 


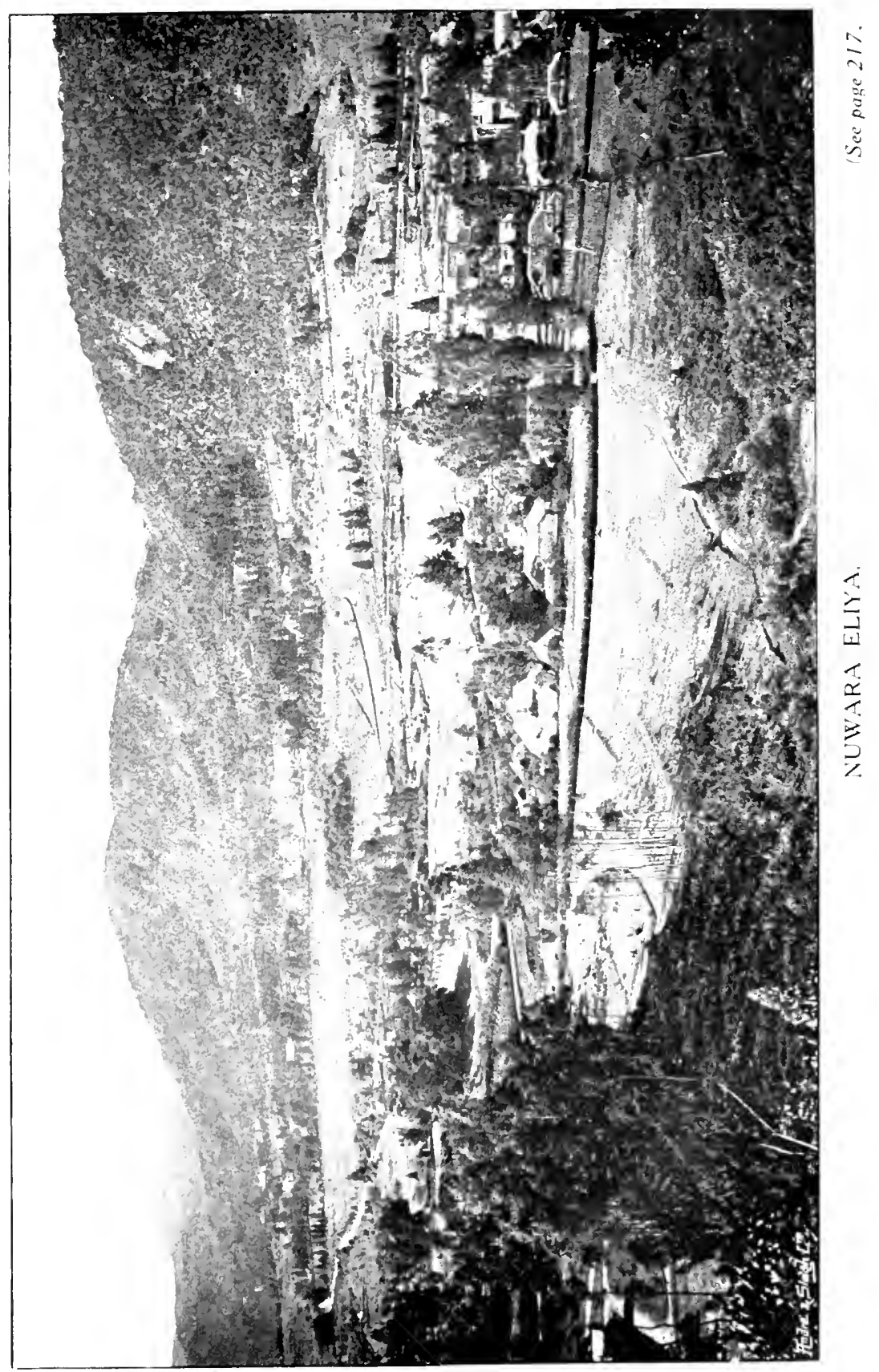



NEBODA. Western Province, Kalutara district, $8 \frac{1}{2} \mathrm{~m}$. from Kalutara. Population 600. Post and Telegraph Office. Hospital. The neighboullood is mainly cultivated in rubber.

NEGOMBO. Western Province, Colombo di-trict, $23 \mathrm{~m}$. from Colombo on the Puttalam road, reached by coach or steamer, soon to have a railway. Population (1901 19,819 (1907) 20,401. Post and Telegraph Offece. Restliouse. Temnis Club. Churches. I Iospital. Reading Roum.

Negombo is a pretty, and very healthy, coast town, and will probably become a popular place of residence when the railway is opened. Very enjoyable sails may be had upon the Jagoon, and the beach is a very pleasant place of resort, while there is good bathing in places. The islands in the lagoon are very farourable for the study of mangroves (p. 62).

Local officials: District Judge, District Engincer, Medical Officer.

Carriage hire: 6 a.m. to 7 p.m. Rs. 4 ; six hours Rs. 2; first half hour 50 cents; second 50 cents; each subsequent hour 25 cents.

Coach to Colombo at 7 a.m. and $3-45$ p.m. arriving at $10-30$ and 7-1 5 ; leaves Colombo at 7 and 2, amiving Negombo 10-30 and 5-30. Fares Rs. 3, 2, 1.50. Steamers leave Negombo for Colombo on week days at 6 and 7 a.m., $12-30$ and $1-30$ p.m.; leave Colombo at $6-30,7-30,1$ and $2-15$. Fare Rs. 1 .

NEW GALWAY. Uva Province. A small planting district near Ilakgala, with 7 estates of 1,300 acres, mostly tea, but with a little camphor.

N!LAMBE. Central Province, Kandy district. A small planting district, with about 16 estates and 7,000 acres, mostly tea.

NITRE CAVE. Central Province, Kands district. A small planting district northeast of Kandy, with two or three estates of 500 acres, mostly in cardamoms.

NORWOOD. Central Province, Kandy district, $6 \mathrm{m.}$ from Hatton (p. 147). Post and Telegrapl Office. Tennis Club. Coach to Hatton at $9-35$ and $6-30$ (except Saturday) from IIatton at 6 and $2-20$ (one hour; fares Rs. 2.50, 1.87 .1 , 1.25). Alio to Bogawantalawa and Maskeliva (q.v.).

NUGEGODA. Western Province, Colombo district, on the Kelani Valley line. Railway Receiving Post Office. 20 miles by rail foom Colombo.

NUWARA ELIYA. Central Province, the capital of the Nuwara Eliya district reached by road (Pp. 1+1, 1+2) or rail (p. 163). Population 5,026 in 1901, 7.515 in 1907 . Elevation 6,200 feet. Post and Telegraph Office. Ilotels: Crand, St. Andrew's, Grand Central. Ilill Club, with residential accommodation. United Club, with spolts, tennis, cricket, 
library, Ac. Boat Club. Golf Club. Civmklnana Club. Hocker and liootball Club. Clumches. 1lospital. Schools. Friend-in-Need Societr. Jibrary.

Nuwara Eliva is the ereat sanitarium and pleasure resort of Ceylon, and is rearly growing in favour with risitors from India, the Straits and Europe. Lying as it does over 0,000 feet above the sea, it has an averase ammul temperature of merely $58 \cdot 3^{\circ}$, and has consequently to some degree the climate of ltaly. lourng the earlier part, at any rate, of the southwest monsonn, i.e. usually fiom June to August, it is very wet, misty, and disagreeable, and again in October-l)ecember, but in the rest of the vear it is a very pleasant place to live in, and the climate in September is usually particulary delightful, showing much less range of temperatme than in what is usually called the "season" fiom February to May, when the day temperatures are higher, and at night, in the first two monthis at any rate, it may freeze. There is usually a sharp drop in the temperature as soon as the sun gets behind the westem hills, and the visitor sitting out should be provided with wasm wraps, to put on then.

Nuwara Eliva lies upon one of the open plateaux which oceur in the high mountain regions, and are usulally, contrary to what one would expect, corered, not with forest, but with grass (patanas, p. 61). It was first discorered by Europeans in 1826 , and Gorernor Sir Edward Barnes soon afterwards openced a military sanitarium there. It has steadily grown to a place of importance, and beconne more and more accessible. At firt reached by coach from Gampola, then from llatton, then form Nanu-ova, it is now reached by a narrow gauge railway from Nanu-ova.

There are many beautiful and interesting walks and drives round the place. The risitor with limited time is recommended to walk to the top of Pedurutalagala (if of good capacity for excrtion), and through the park, to drive round the lake on the westem side and back by the Moon Plains, to drive to I Iaksala, and to the Ramboda Pass.

Pedurutalagala. This, the highest mountain in Ceylon, 8,206 feet high, lises, cosered entirely with forest, upon the nortlueat side of the ralley. There is a good footpath, starting form berond Carsills store at the north of the town by a roud rumning up the hill. The distance is about $2 \frac{1}{2}$ miles, and 2,000 feet have to be ascended, so that plenty of time must be allowed. Though many of the smaller plants, and most of the oredids, have been stolen, there is still enough of torest life to be of interest. The trees are of small height, very much gnaled, and often covered with a growth of mosices, ferns, orchids, sc. Near the actual summit the forest 
shrinks to a kind of shrubbery, and many beautiful flowering slrubs will be noticed. At the very top there is a cairn, from which in fine weather there is a marvellous view, comprising most of the centre of the island. Several pieces of patana (p. 61) are passed on the way up, and it is from such pieces that the great extent of patana further east is supposed to have arisen (p. 62).

The Park. This has only been laid out a few years, but is rapidly coming into a state of considerable beality. The maze, on the lines of the famous one at Ilampton Court, may be noticed, and at the end nearest to the railway station, there is a small area kept up as a branch of Peradeniya botanic gardens, in which many beautiful flowers, and an ornamental lake may be noticed. The pretty avenue of conifers at the Post Office end is one of Cupressus macrocarpa, the Monterey cypress of Califomia, only known wild on the little wind-swept peninsula of Monterey, but proving to be one of the best conifers for general cultivation in many partis of the world.

Round the Lake. A driving road goes completely round the lake, and affords many beautiful views, especially perhaps about a mile from the near end of the lake, on the south side, where a causeway is passed over with a little piece of lake on the other side. "The bund by which the water of the lake: which is artificial, is hedd up, is on the far side of this little piece of water.

Moon Plains. These very pretty open patanas may be reached from the road round the lake, by turning ofl to the right soon after the main road to Badulla hats been left for the return on the north side of the lake. Following the road it comes out ultimately upon the Barrark Plain on the north side of Nuwara Eliya, where there is another lake.

Ramboda Pass. This is the way by which the direct road rums to Gampola, and is wortl following to the summit of the pass, fiom which there is a splenclict view in buth directions (See Clapter Xi Roalds).

Hakgala. The road to Ilakgala (q. v.) rums along the southern side of the lake, and then fown a pretty glen, finally coming inte full view of the line range of love momntans, which are invisible from Nuwara Eliya. No one, howeres slont their time in the station, should omit this ditive. Other pretty walks are to the lover's Leap waterfatl on the Nalnu-oyal roat (carriage can wo), round by the dhuter, round the lake, oxer the links and racecomisc, ste.

Local Officials: Asnistant forertument Isent, P'olice Magistate, Distriet Engineer, Medical Offiecer, de.

Planters' Association 23 cstates, 5.000 acres, teat). 
Carriage hire: Witl one horse, 6-30 a.m. to 7 p.m. Rs. 6.50 ; 6-30 to noon, or noon to 7 p.m. Rs. 3.50 ; one hour, Rs. 150 ; second hour, Rs. 1 ; subsequent hours, 75 cents. With two horses, Rs. ı。, 6, 2, 1·50, and i respectively. Round Moon Plains, round the lake, to Mahagastota and back, or Ramboda and back, with not more than 3 passengers, Rs. $35^{\circ}$; each additional passenger, Rs. $1{ }^{\circ} 5$; one hour's detention allowed; Rs. 1 per hour for additional detention.

From the railway station, per seat in coach, for one mile, for each passenger, 50 cents by day, 75 by night; for a private carriage, within one mile, per half hour, one-horse carriage for two passengers, Rs. 1 ; two-lorse carriage for three passengers Rs. 1 '50. One quarter extra after 7 p.m.

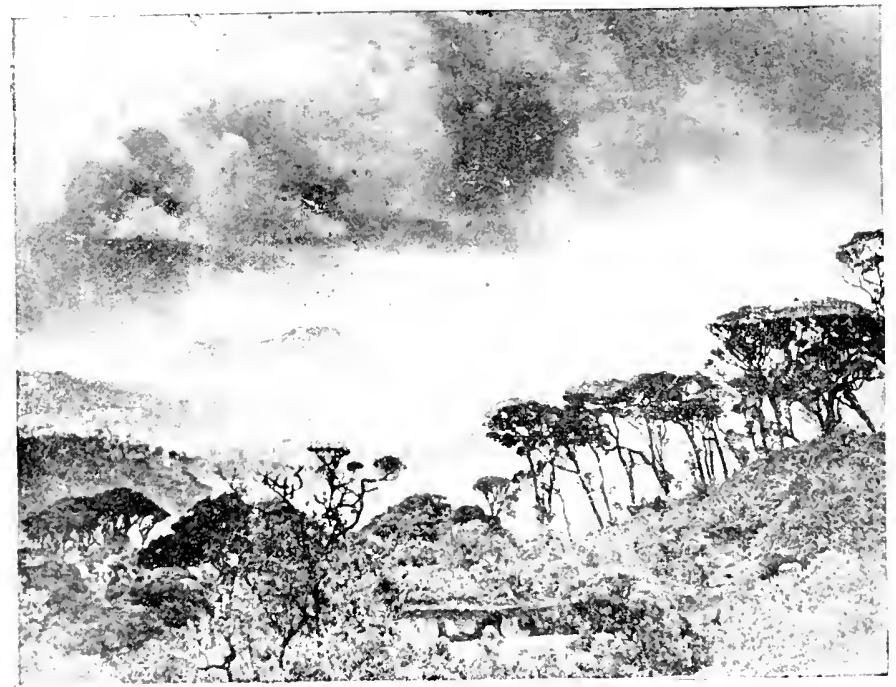

NUWARA ELIYA FROM THE RAMBODA PASS.

To I Hakgala and back, allowing two hours detention at the gardens, for 3 passengers, Rs. 6 ; to Nanu-oya and back, R.s. 5 ; to Kandapola and back, Rs. 6 . Eacl extra passenger to Hakgala or Kandapola, Rs. 2; one or two extra to Nanu-oya, Rs. 3 .

Rickshaws, with one coolie, first hour 50 cents, second hour 25 cents, subsequent hours 25 cents; with two coolies, 75 and $37 \frac{1}{2}$ cents (two are necessary to go to Hakgala or on any of the hilly roads). Special rates, to Hakgala and back, Rs. 3 ; to Nanu-oya and back, Rs. 3.50 ; Ramboda Pass and back, Rs. 150 ; round Moon Plains or round the lake, two coolies, Rs. 2. Trains, see P. 14 S. 
OHIYA. Uva Province, on the railway to Bandarawela (p. 161). Elevation 5,877 feet. Path to Horton Plains (q. v.). Railway Receiving Post Office.

PADUKKA. Western Province, Colombo district, on the railway to Avisawela, I hour 20 minutes from Colombo. Population 1,097. Post and Telegraph Office.

PALLAI. Northern Province, Jaffina district, $2+\frac{1}{3} \mathrm{~m}$. from Jaffina on the road (P. $143^{\prime}$ and railway (p. 16,5) to Colombo. Post and Telegraph Office. Resthoure. Ginod tobacon is grown in the district.

PANADURE. IVestern Province, Colombo district, $16 \mathrm{~m}$. from Colombo by road (p. r 40 ) and rail (p. 166). $35 \frac{3}{4}$ m. to Ratnapura (p. 147). Population 3,845. Post and Telegraph Office. Resthouse. Ilospital.

Local official: Police Magistrate.

PANNIPITIYA. Westem Province, Colombo district, on the railway to Avisawela, 40 minutes from Colombo. Railway Receiving Post Office.

PANWILA. Central Province, Kandy district, 3 m. from Wattegama station (p. 1.45). Village Receiring Post Office. Resthouse.

PARANTHAN. Northern Province, Jaffna district, on the railway, about $6 \mathrm{~m}$. south of Elephant Pass, 2 hours from Jaffina.

PASSARA. Uva Province, on the road from Badulla ( $11 \frac{1}{4}$ m.) to Batticaloa (p. 145). Roads to Naminakuli and Madulsima (p. 146). Population 450. Elevation 3, I60 feet. Post and 'Telegraph Office. Resthouse. Gun Club. I'lanters' Association (9 estates, with 6,000 acres, mostly tea). Coach to Badulla leaves 9-45, arrives Badulla 12 ; returus $3-30$, arrives Passara 5-30. To Lunugala leaves 5-40, arrives 8-30 p.m., leaves Lumugala 7 a.m., arrives Passara (n-zo.

PATTIPOLA. Uva Province, near the summit level of the railway (p. 160). Path to Ilorton Plains, $6 \mathrm{~m}$. Railway Receiving Post Office. Resthoure. The climate here, at 6,200 fect, is pleasant, and the neighboutrood las fine forest and patana, and good fishing (license required).

PERADENIYA. Central Provinee, kandy district, $4 \mathrm{~m}$. from Kandy on the Colombo road (p. 1.37. Ko leelota io m., to Gampota 9 m. Elevation 1,572 feet. Post and Telegraph Offiec. Excellent Restlunse, in which roons are reserved for scientific risitors.

There is a fine bridge over the Malaweli-ganga, from which, and from the far side of which (toll), exeellent views are to be obtained, but the interest of the place centres in the world-famous Botanic Cardens. Visitors motally make the mistake of coming at midday, when it is hot for walking, and 
when there are no long shadows, but the gardens can be seen to much greater advantage by coming after + p.m. or before 9 a.m., when the shadows add immensely to the beauty of the views. The southern half, at least, of the garden, should be explored on foot. Complete illustrated guides, costing Rs. 2, prepared by Mr. Macmillan, the Curator, can be procured at the entrance, where visitors are invited to leave their names in a risitor's' book which contains many signatures from all parts of the world.

The visitor who desires to thoroughly study the garden is recommended to stay a night at the resthouse, and buy the local guide book, but the following brief account may serve for those who only spend a couple of hours there.

Entering by the gate upon the Kandy road-the only entrance into this horseshoe-shaped garden, which is almost surrounded by the river - a fine almost circular clump of palms confronts one. Among these may be noticed the coconut $($ p. +7$)$, the arecanut (p. 52), the West African oil palm, the small palm-like Carludonat palmata of Central America, from whose leaves, cut into strips and bleached, Panama hats are woven, the date-palm, and many others.

Taking the road to the left at the gate (Lake Road), there will be noticed to the left, across a strip of grass, a fine but now rapidly decaying aremue of the indiarubber trees of Assam (Ficus clastica), whose immense roots, prolonged above the sround into plank-like buttresses, wander over the soil for considerable distances, twining like great snakes. At the first curve, the road passes under a tree of Amherstia nobitis, perhaps the most beautiful flowering tree of the tropics, but extraordinarily difficult to propagate. The large pink flowers have a superficial resemblance to orchids, and are produced at all times of the year, but especially from December to March. The young leaves are pinky brown in colour, and hang down in a bunch as if they had been "poured out of the bud." The explanation of this phenomenon, which also occurs in Brownea and Saraca, likewise to be seen in the gardens, is somewhat difficult. Just beyond this tree, on the left, is a Brazil nut (Bertholletio), and opposite to it, a little way back in the grass, is the tall straight trunk of the famous Upas tree of Java (Antimis tovicumil), a harmless enough tree, about which terrible stories were put into circulation a century or so ago. beside it is the Ceylon form of the same tree, Antiaris immoxia. A little further on Jonville Drive turns off to the right, and continuing straight on, we pass on the right a jak tree (p. 66), and then tum to the left, between two very tall clumps of bambon, past the pond. The bamboo on the right is the large bamboo of Java, (Gigantochloa aspera), while that 
on the left is the truly magnificent giant bamboo of the Malay Peninsula (Dendrocalamms gisantews), for which the Peradeniya garden is famous, and of which thereare many clumps scattered about. It grows to a height of 100 feet or over, and has a thickness of 8 -ro inches at the base. 'The young' shoots appear like shoots of giant asparagus, round the edge of the clump, in Jume of each rear, and rapidly grow to their full height, at a rate often of 15 inches a day. In the pond are several trees of the pith tree (Heminiora). The tree is of lowly growth, but the base of the stem thickens out very much, and the wood of this thickened portion is like pith. It is cut into thin shavings, from which the pith hats, or topecs, of commerce, are made.

Passing the pond, and the footpath to the left, there lic upon our left a number of trecs of the cacao, cocoa, or chocolate, Theobroma Cacao, which is now so largely cultivated in Ceylon. These trees are all of the Forastero varieties, which have in Ceylon largely replaced the Caraccas kinds formerly grown, and which yielded beans of lighter colour, selling for higher prices. Just beyond the cacao, on the left, will be seen, some way back fiom the road, a plantation of a dozen or so of tall trees with spiral markings on the lower part of their trunks. These are the famous Para rubber trees (I/erea brasiliensis, now so much planted in Ceylon, and the spirals are the marks of old tappings (p. 52). A few yards further on, we cnter the avenue of talipot palms (p. 68) which is now in perhaps the finest possible condition. Behind it, on the left, is the herbaceons garden, in which the smaller plants are grown, arranged by families, and just beyond it, on the right, a small plantation of the kola nut of West Africa (Cole). On the left, at the fork of the road, is a tree of the breadfruit (p. 65), with large divided leaves, and then taking the right hand road, we pass the systematic collection of bamboos on the right, of palms on the left, while some way ronnd is a fine view of the bridge over the Malaweli-ganga.

Retuming past the pond, we may tum to the left round the Java bamboo and in a few yards come out upon the river bank. On the right, at the comer, is a plant of Petran, which when in flower is a lovely sight, with its purple and turpuoise flowers, produced in large mumbers. A fine clump of grant bamboos is on the left, and a miscellaneous rockery on the right, at the end of which we tum to the right up the Jonville Drive, along the side of the Gieat lawn, the riews acloss which are particularly beantiful in the morning or evening. The trees on the elge of the lawn are mostly sapus p. 68 ; Michelia). The forest-covered hill in the backgromel is upon the Experiment Station on the other side of the Mahaweli- 
ganga. Arring at the cross roads, the turn to the right may be taken, and the Gardner monument visited, which stands in a rery beautiful position on the crest of the hill. Gardner was Director of these gardens in $1845-9$, but is better known as a sreat Brazilian traveller. Returning straight from the monument, along Monument Road, on the right at the cross roads is a tlee of the large fan-leafed palm Lodoiced Selchellarmm, the famous double coconut of the Seychelle Islands, whose curious firut used to be found floating in the Indian Ocean and sold for high prices before the native place of the plant was known. Monument Road presently crosses the main drive, recognised by its long shady aspect, and is continued

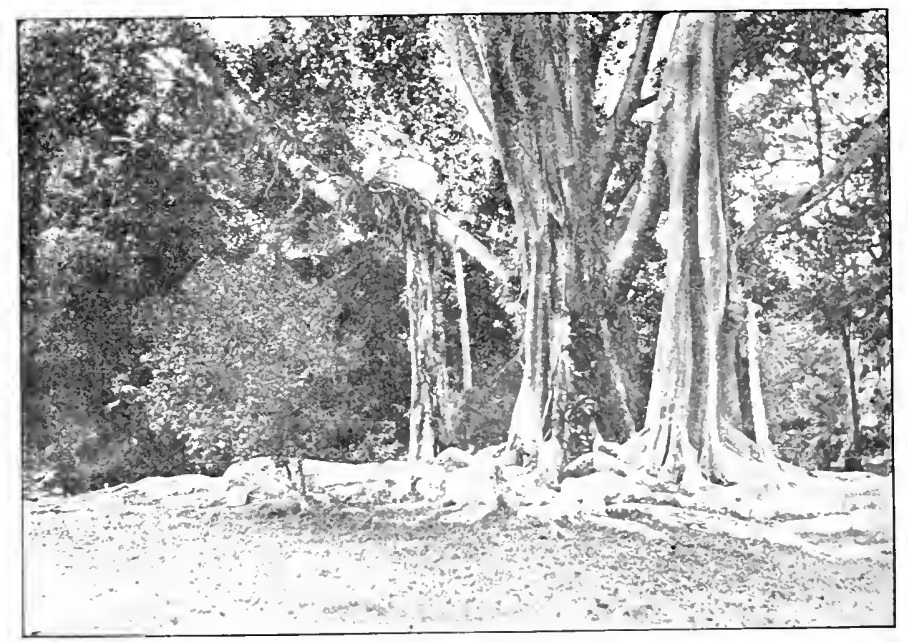

ASSAM RUBBER TREE.

as Liana Drive, which should be followed, and which is one of the most striking roak in the sarden, on account of the tall ancient trees, covered with heaven-aspiring climbers, with which it is shaded. Coming out presently at a little tank, there is on the right, and also in front, a magnificent tree of the Assam indiarubber (above), while at the entrance to a shady path going in to the right, are the extraordinary stems of a Bauhinia climber.

To the left is the flower sarden, in which are two comservatorics. The nearest should be first risited, and is an wrchid house, in which, more especially in the dry weather, many orchids and other flowers are to be seen. From the 


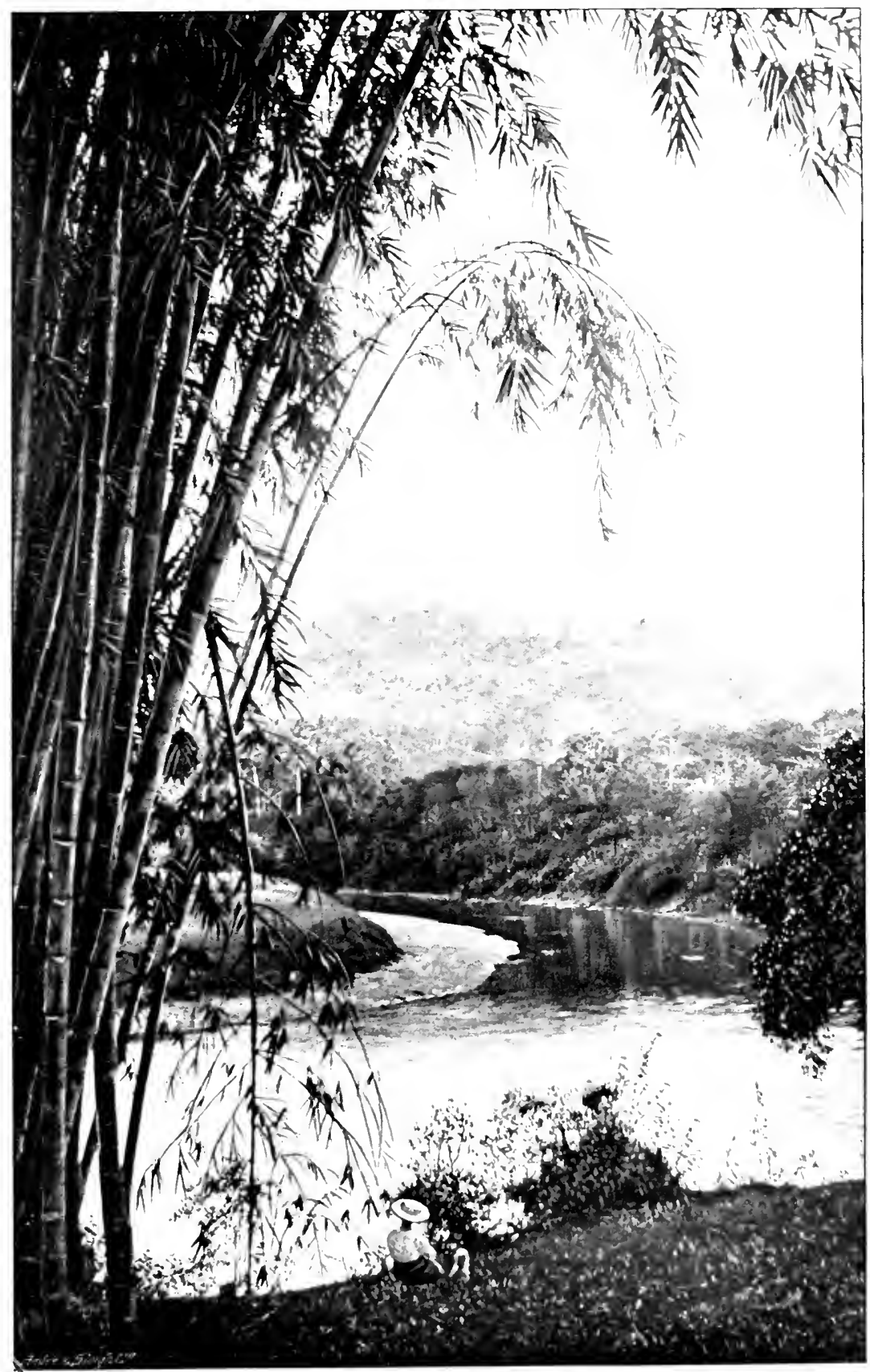

VHEW IN PLRADFNIY I GNRDENS.

(See frape 225.) 

seat just beyond it there is a pretty view. Turning to the left we come to the octagon conservatory, in which are all kinds of ornamental foliage plants. Between the two bouses, and round about, are numerous beds of flowers de., arranged on the general principle of massing single colours in large masses. Among the most striking of these are the beds of Poinsettia, a plant with the little inconspicuous flowers sumounded by large scallet leaves, which last much longer than the flowers.

lurning to the right out of the octagon house, we come to the very beautiful fernery, in which all kinds of ferns and shade-loving plants are grown under the shade of ancient trecs, often themselves hung with splendid crecpers. Emerging fiom the fernery on the right, we may return down another path, past the end of the avenue of Palmyla palms (p. 64) to the orchid house, and rejoin the carriage.

Continuing along the same load, we presently come to the bank of the river, under four masnificent specimens of Pillucolobium Samum, the great shade tree of the Ceylon roads (p. 6S) and may drive round by the river tor a couple of miles. About 50 vards from the l'ithecolobium trees is a clump of giant bamboos on the river bank, past which there is one of the best vicws in the garden (see Frontispiece). On the left is the nursery, beyond which on the left is the avenue of Palmya palms (p. 64 and above), and then we pass through an old avenue of the royal palm of Cuba, now decaying. Beyond this we go into a depression of the road between some magnificent clumps of giant bamboo, and here there is often to be seen a large colony of the flying-fox, banging up in the trees (p. 17). At the cornes of the North Drive further on, there is a pretty view up-strean, and then we pass on the right the path leading down to the ferry that rums to the experiment station. Beynd this, the point of the garden is occupied with what is intended ultimately to be a Ceylon junse, but which at plesent is in the untidy transition stage. briving down the other side of the garden, we pass a seat where there is a lovely view up-stream to the bridge, and then come to the West Road, where we turn to the left and enter the Great Circle, a large lawn with a clump of palms in the centre. Driving romul this to the left, there are passed many handsome trees. The first road on the left is a voung avenue of royal palms, then connes the Nortlu East Walk, and then a path up to the pretty Kandyan building that forms a memorial to Dr. (i. Il. K. Thiwates, who was Director here form 1849 to 1880 . The building should be visited for the sake of the riew from it. Contiming lound the cincle, and taking tlue lirst road to the left, into the Main Drive, this is 
one of the most striking and beautiful roads in the garden, and should be followed to the first cross roads.

(Here there are two roads on the right; the right hand one leads to the departmental offices, that on the left to the new Economic Museum, which will probably be ready for opening about June Igos; guides will be for sale at the Museum, and as it is not yet arranged, there is no need to describe it here).

Continuing down the main drive, we arrive at the clump of palms near the gate. On the left hand side is the nutmeg grove, a footpath leading between old trees of nutmeg and clove to a little fernery, in which there will soon be built

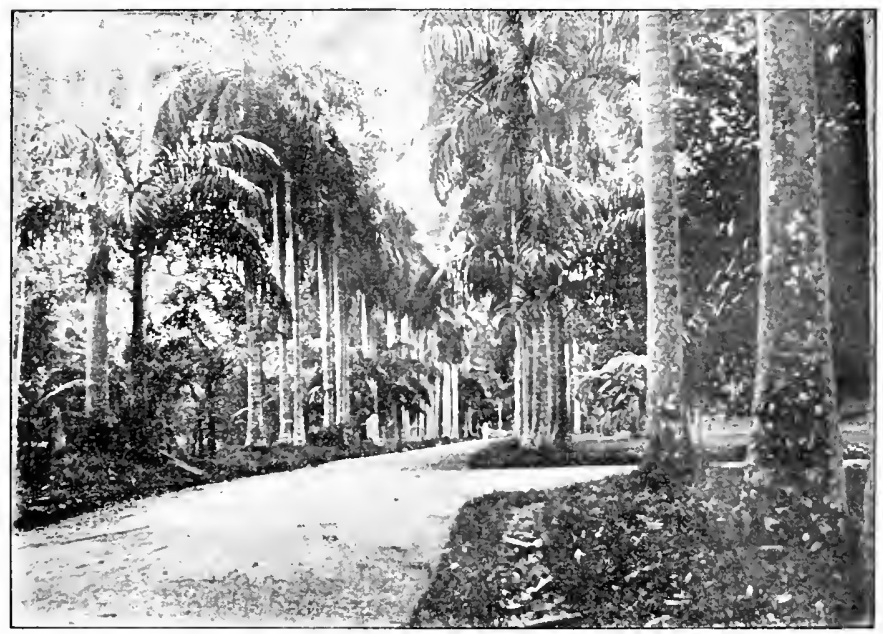

AVENUE OF ROYAL PALMS.

a conservatory for plants requiring always to live in an extremely damp atmosphere. Bevond this are some plant houses, one roofed with glass, in which are some interesting forms (a fine collection of ferns in the one to the right), and beyond are the offices of the Curator in whose charge the garden is, where seeds \&c., may be purchased.

The department of the Royal Botanic Gardens, though the old title is retained, is really a department of agriculture, and keeps up four botanic gardens: Peradeniya, Hakgala near Nuwara Eliya, Nuwara Eliya and Heneratgoda; two time jet. 
experiment stations, for experiment with agricultural crops, at Peradeniva (on the other side of the river; for permission to risit apply to the Superintendent in charge) and at Mahaihuppalama near Anuradhapura; a scientific staff consisting of Assistant Director (who is also botanist to the institution), Entomologist (who attends to insects and diseases due to them), Mycologist (who does the same for fungi), and Chemist. It also has charge of the school gardens (p. 103) of which there are now over roo in different parts of the island. 'The headquarters of the department, which is in charge of a lirector, are at Peradeniya.

PERADENIYA JUNCTION. A station on the Kandy railway (p. 154), with Railway Receiving Post Office.

POINT PEDRO. Northern Province, Jaffina district, at the extreme northern point of the island, $10 \frac{1}{2} \mathrm{~m}$. from Kodikamam, $14 \mathrm{~m}$. from Chavakachcheri, $2 \mathrm{~lm}$. from Jaffina (p. 144). The round the island steamers call here and the town is worth a visit. Population 3,000. Post and Telegraph Office. Resthouse. Hospital.

Going up from the wharf, a Hindu temple is passed on the right, and a large bathing tank, and presently we come to the large open-air and covered market, where palmyra leaf elephants and many other interesting articles can be bought very cheaply (cf. Jaffina). At the side of the market, on the left, is a fine old tamarind tree, under which Baldaeus, an early missionary of Dutch times, preached. Further on, upon the left, is a road leading to another Hindu temple, beside which may usually be seen a car of Juggernath-under which victims do not throw themselves in Ceylon.

Coaclı to Kodikamam leaves at 5-30 a.m. and 4-30 p.m., arrives Kodikamam 8 and $6-45$; leaves Kodikamam 8-40 a.m., and 7-45 p.m., arrives Point Pedro $\mathrm{s} 1-\mathrm{ro}$ and 10 . Fares Rs. $1 \cdot 50,1 \cdot 12,75$. Steamers round the island call here fortnightly in each direction.

POLGAHAWELA. North-IVestern Province, Kuruncgala district, a station on the line to Kandy (p. 15I) and $8 \mathrm{~m}$. by road from Kegalle, $17 \frac{1}{4}$ m. from Kurunegala. Population 700 . Elevation $2+1$ feet. Post and Telegraph Office. Resthouse. Trains to Colombo (2 -3 hours) at 4-53, 7-8, 9-14, 9-30, $12-40$, $4-0,4-25,6-35,8-10$; to Kandy (2 lonlls) at $9-15,10-33,4-3$, $9-27,11-46$; to Kununegala (1 lour) at 9-30, 1-0, 4-20, 8-20. Coacl to Kegalle at 9-30 and 4-30, arring at $11-15$ and $6-15$; returning from Kegalle at $6-45$ and $1-45$, ariving at Polgahawela 8-30 and 3-30. Fancs R.s. 2.50, 1.50, 1.

POLONNARUWA. North-Central l'rovince, $27 \mathrm{~m}$. fiom llabarane by gravel road, passable for motors in the early part of the year. There are one or two bungalows there, 
which are sometimes unoceupied (apply to the G. A. at Anuradhapura), and a resthouse is being constructed. For the interesting ruins see p. 126.

PUNDALUOYA. Central I'rovince, Nuwara Eliya district. A planting district with about 12 estates and 5,000 acres, mostly tea. Outlet rict IVatagoda Station, or aria road to Gampolia (p. 1 +2). Post and Telegraph Office at Pundaluoya village.

PUSSELLAWA. Central Province, Kandy district, on the road from Kandy to Nuwara Eliya (p. 142). Post and Telegraph Office. Ilospital. Planters' Association. About 47 estates with I 7,000 acres, mostly tea.

PUTTALAM. North-IVesterin Province, capital of the Puttalam district. Population 1901, 5,115. 1907, 5,205. Post and 'Telegraph Office. Resthouse. Hospital.

Local officials: Assistant Govermment Agent and District Judge.

Coach to Chilaw, leaves 5 a.m., arrives 10-30; leaves Chilaw 4-10 p.m., arrives 9-30. liares Rs. 7, 4, 2.50.

PUWAKPITIYA. Western Province, Colombo district, a station on the Kelani Valley Railway, with Railway Receiving Post Office, 2 hours from Colombo, 20 minutes from Avisawela.

RAGALLA. Central Province, Nuwara Eliya district, at the terminus of the narrow gauge line from Nanu-oya. Restliouse.

RAGAMA. IVestern Province, Colombo district, on the railway to Kandy (p. 150). The cooly camp, in which the immigrant coolies from lndia are quarantined for some time after arrival, is close to the station, and the great stone quarries, from which stone is obtained for the Colombo llarbour works, are at Malara, close by, where also is a convict station. The new line to Negombo, now under construction, starts here.

RAKWANA. Sabaragamuwa Province, Ratnapura district, I 4 m. fiom P'elmadulla and $26 \mathrm{~m}$. from Ratnapura, (p. 146). Population 839. Post and Telegraph Office. Restlouse. Ilospital. Planting district, with about 24 estates of 5,000 acres, mostly tea and rubber. Coach to Pelmadulla and Ratnapura, leaves Rakwana 5-20 a.m., arrives Pelmadulla S-20, Ratuapura 10-20; leaves Ratnapura 3 p.m., Pelmadullia 5-15, arrives Rakwana $8-15$. Fares to Ratnapura Rs. 10 , 7,3 .

RAMBODA. Central Province, Nuwara Eliva district, on the road from Gampoli, $20 \frac{1}{2}$ m., to Nuwara Eliya $13 \frac{\mathrm{I}}{2} \mathrm{~m}$. (p. 142). Population 160. Elevation 3,500 feet. Post and Telestraph Office. Resthouse. Iospital. Planting district, with about 13 estates and 4,000 acres of tea. 
PIATE LXI.

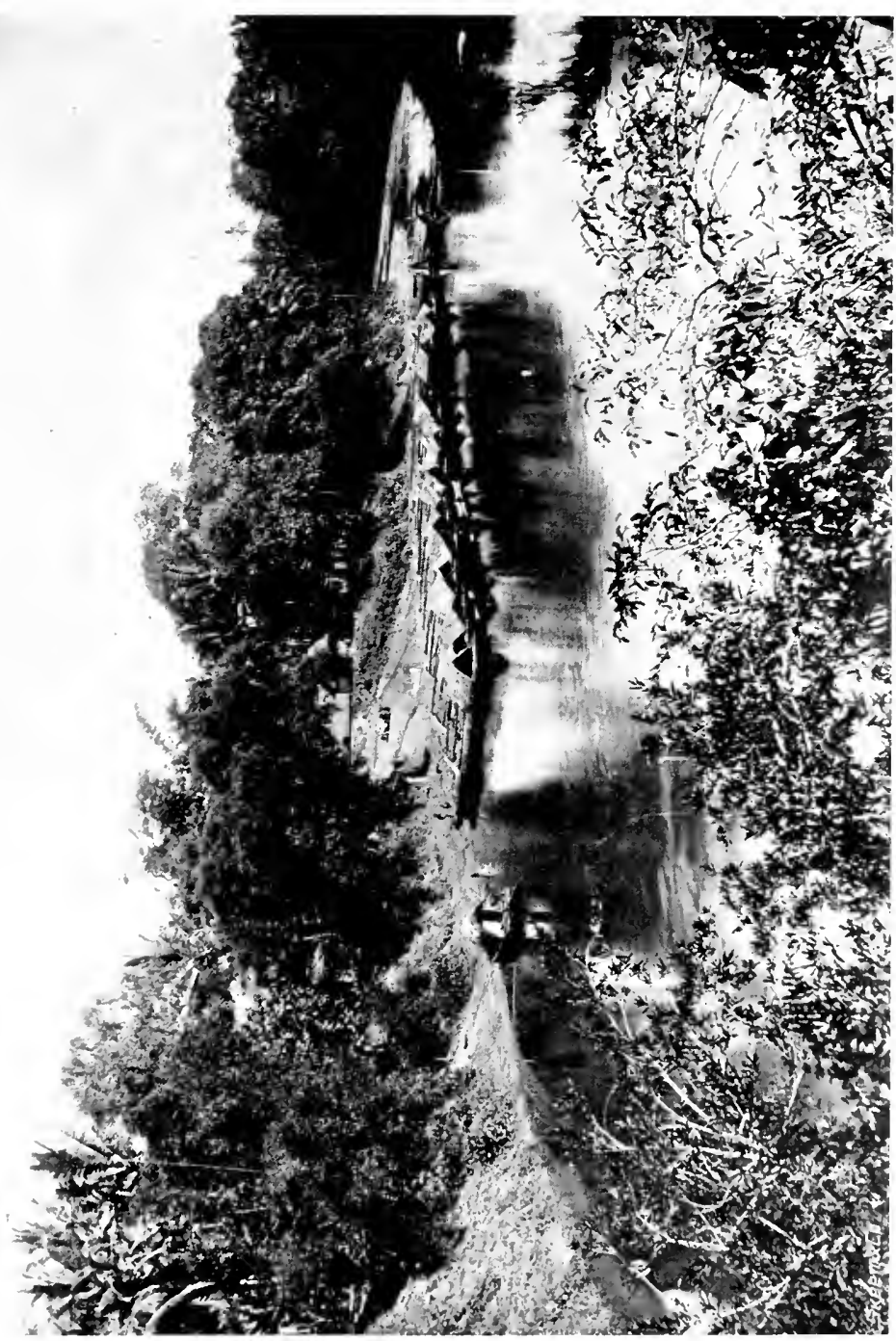



RAMBUKKANA. Sabaragamuwa l'rovince, Kegalle district, on the railway from Colombo to Kandy (p. 151). $10 \frac{1}{2} \mathrm{~m}$. by road to Mawanella (p. 138). l'opulation $33^{6}$. Elevation 313 feet. Post Office. Resthouse. Trains to Colombo at $4-34,6-40,8-50,12-20,3-40,7-50$, to Kandy at $9-35,11-5$, $4-25,10-0,12-15$.

RANGALA. Central l'rovinec, kandy district, $4 \mathrm{~m}$. from Teldeniva. Post Office. Planting district, with about it estates and 6,000 acres, mostly tea and cardamoms.

RATNAPURA. The capital of the Sabaragamuwa l'rovince, $263 \mathrm{~m}$. from Arisawela, $3513 \mathrm{~m}$. from Panadure, $27 \mathrm{~m}$. from balangoda (roads see pp. 146, 147). P'opulation 1901, 4,084. $1907,4,481$. Elevation 109 feet. Post and Telegraph Office. Resthouse. Library. Literary Club. Ilospital.

A pretty little town, in a very rainy situation (rainfall 152 inches a year, mean temperature 79.2"). Planting (listrict, with about 30 estates of 15,000 acles of tea, rubber, se.

Local officials: Government Agent, Office Assistant, District Judge, P'rovincial and District Engineers, Assistant Superintendent of Surveys, Medical Ofticer.

Carriage hire: 6-30 a.m. to 7 p.m. Rs. 4; 6-30 to noon, or noon to 7, Rs. 2 , first hour Rs. I, second 50 cents, subserquent hours 25 cents. After 7 , one quarter more. Hackeries, per bour 25 cents, per mile 20 cents.

Coach to Arisawela, horse, leaves Ratnapura 10-50 a.m., arrives Arisawela 3-20; leaves Avisawela 11 a.m., arrives Ratnapura 3 p.m.; bullock, leaves Ratnapura 9 p.m., arrives Avisawela 5 a.m.; leaves Avisawela 9-30 p.m., alrives Ratmapura 5 a.m.

RATTOTA. Central P'ovince, Matale district, $6,3 \mathrm{~m}$. from Matale. Post Office.

SIGIRIYA. Central Province, Matale distriet, $5 \frac{1}{2} \mathrm{~m}$. firom Inamaluwa on the Trincomalic road (p. 1 $4+4)$. Restlouse. For ruins see p. 112 .

TALAWA. North-Central Proviuce, $8 \mathrm{~m}$. from Mumadhapura on the Kurunegala road (p. 1+2) and $23 ! \mathrm{m}$. from Kekirawa. Railway Receiving l'ost Office.

TALAWAKELE. Central Province, Nuwara Eliya district, on the railway to Nann-oya. (p. 159), and on the road to Lindula and Nuwara Eliya (p. 141.) Elevation 3.932 feet. Population 745. Post and Telegraph office, Resthense.

There are some fine falls on the river on the way as Craigie Lea, and pretty walls near the town. Coach to Agrapatna leaves 3 p.m., arrives 5-30; leaves Agrapatma 7-30 a.m., arrives Talawaliele 10.

TANGALLA. Southern I'roxince, I Iambantota district, $22 \frac{1}{4} \mathrm{~m}$. from Matara, and $25: \frac{1}{1} \mathrm{~m}$. from llambantota $\left.(1) 1+1\right)$. 
Population 2,333. Post and Telegraph Office. Resthouse. Hospital. Coach from Matara, leaves at $10-30$ and $\mathrm{I}-30$, arrives $2-30$ and 5-30; leaves Tangalla 6 and $11-30$, arrives 10 and 3-30. Fares R.s. 5, 2·50, 1·50. Coach also to Hambantota.

TEBUWANA. WVestern l'rovince, Kalutara district, $6 \mathrm{~m}$. from Kalutara, in a rubber planting district. Village Receiving Post Office. Restlonuse.

TELDENIYA. Central Province, Kandy district, $15 \frac{1}{4} \mathrm{~m}$. from Kandy aia Katugastota, $13 \mathrm{~m}$. ain Gonawatte ferry. Population 7 г 2 . Post and Telegraph Office. Resthouse. Hospital. The neighbourhood is very pretty, and pleasant walks may be had by the river, especially on the far side from the resthouse. Pobacos is a good deal cultivated in this district.

TRINCOMALIE. Eastern Province, capital of the Trincomalic district, $68 \mathrm{~s}$. from Dambulla by road (p. I 44). Population I 1,295. Post and Telegraph Office. Resthouse, kept by "Tamby," who has a fund of recollections of Trincomalie and its inbabitants. Club. Churches. Hospital. Friend-in-Need Societr.

"Trinco" is one of the most beautiful and interesting places in the island, and slould be visited if possible. The coach is very slow and wearisome, and the simplest way to see it is to take the round the jsland steamer on its "north-about" journey, when it calls at Trinco on Saturday morning, and does not as a rule leave till Sundar night.

The steamer enters first the outer harbour, a large almost circular bay, sereral miles across, in which the water is too deep for anchorage, and into which, on the south side, the Mahaweli-ganga may be seen to enter as a long brown line, gradually widening. The north side of this bay is rocky, the south flat. The north has a projecting cape, the south side a less hilly one (Foul Point, with lighthouse). The steamer soon turns to the north into the imner harbous, in which though the water is deep to the edge, it is not too deep for anchorage. This harbour is much broken up by bars running into the land, and has Sober lsland-, great and small, so-called because no liquor could be procured upon them, standing almost in the entrance. On the far side of Great Sober Island is French Passage, through which the French fleet escaped as the Englich entered. The steamer enters the second castern bay, and the hill on the right is covered with naval and military buildings, while the civil town is to the left, mostly lying on the flat and narrow strip of land here separating the harbour from the open sea. Going straight to the resthouse by one of the roads leading up from the jetty, we look ont from thence over the esplanade to the sea, while 
PLATE LXII.

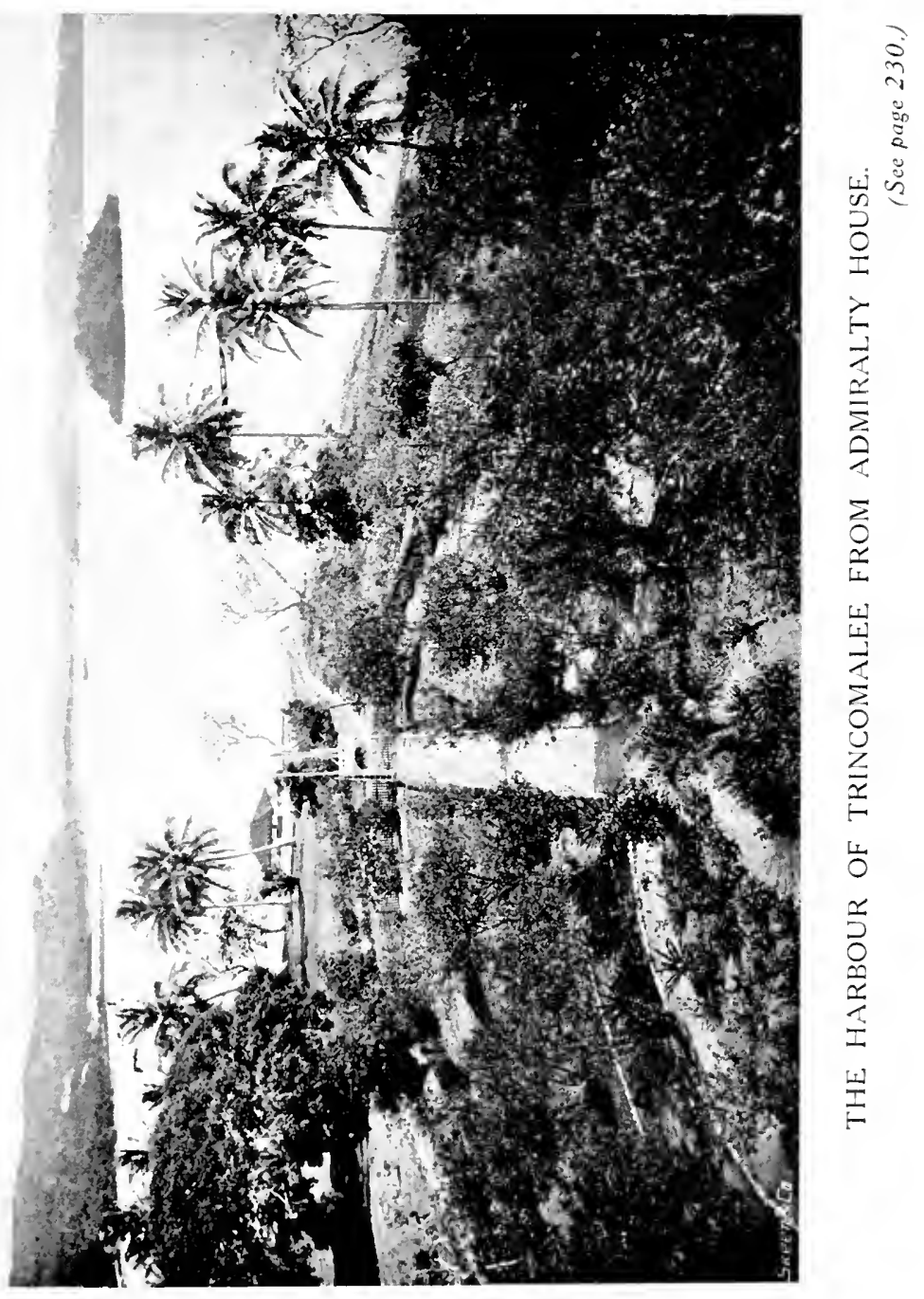



Fort Frederick stands on the hill a little to the right. Various curios are usually brought for sale, including very pretty shells not seen elsewhere in Ceylon as a rule, such as nautilus, and sponges that will not hold water.

Fort lirederick is the most interesting thing to be seen; it is an old Dutch fort standing on a fine rocky promontory said to have been formerly an island, the esplanade having been made by filling up an arm of the sea that formerly lay here. The fort is now deserted, and the great gun on the summit of the rock looks pitiful to see. Beyond it is the Swami rock, to which numerous Hindu pilgrims resort every year, and which is a particularly sacred spot. Here also is a pillar to the memory of a Dutch girl who is said to have thrown herself firom the rock when deserted by the man to whom she was engaged to be married. Trips to Sober Island, and to other parts of the harbour and town are also to be recommended.

Local officials: Assistant Government Agent, Police Magistrate, District Engineer; Medical Officer.

Carriage hire: 6-30 a.m. to 7 p.m. Rs. 4 ; 6-30 to noon, or 110011 to 7 , Rs. 2, half an hour 50 cents, an hour Rs. I; each subsequent hom 25 cents.

Coach to Dambulla, leaves 3 p.m., arrives Dambulla 10-30 a.m., next day. Matale 3-30; leaves Matale 10, Dambulla 3 , arrives Trincomalie 9 a.m. next day.

UDAPUSSELLAWA. Central Province, Nuwara Eliya district, $22 \mathrm{~m}$. from Nuwara Eliya. Population 195. Post and 'Telegraph Office. I Iospital. Planter's' Association, with 27 estates and I r,000 acres, mostly tea.

VAVUNIYA. Northern Province, Mullaitivu district, on the rail and road to Jaffna (pp. 143,164 ). Population 566. Post and 'Telegraph Office. Resthouse. Hospital. The little tank to the east of the town is pretty, and there is a pleasant walk along the bund. Trains to Colombo ( 8 hours) at $12-20$ and to Jaffina ( $+\frac{1}{2}$ hours) at $3-40$.

VEYANGODA. Western Province, Colombo district, on the rail to Kandy (p. 150 ) and with roads to Negombo $17 \frac{1}{3} \mathrm{~m}$. and to the main Kandy road (p. 138). Elevation 59 feet. Population 356. Post and Telegraph Office. Resthouse. The neighboullood is mostly eocomut plantations, mixed gardens, and padely ficlds. Trains to Colombo ( $1-1 \frac{1}{2}$ hours) at $5-4+4,7-0,8-30,10-3,10-45,1-45,4-50,5-40,7-28,9-0$; to Kandy 3 hours) at $8-25,9-10,3-9,8-5,10-52$.

WAGA. IVestern Province, Colombo district, on the line to Arisawela, 1 hour fo minutes from Colombo. Railway Recciving Post Office.

WATAGODA. Central Province, Nuwara Eliva district, on the railway to Namu-oya (p. 159). Road to l'undaluoya 
and to the Kandy-Nuwara Eliya road (p. 142). Post and Teleyraph Oftice.

WATTEGAMA. Central Province, Kandy district, on the railway to Matale (p. I 55) and $8 \frac{1}{2}$. from Kandy by road. Roals to Elkaduwa, Teldeniya, kc. (p. 1+5). Population 47 1. Elevation 1,620 feet. Post and 'Telegraph Office. Resthouse. There are many cacao estates (p. 5s) here.

WELIGAMA. Southern Province, Matara district, $17 \frac{1}{4} \mathrm{~m}$. from Galle and ro $\mathrm{m}$. from Matara (p. 1 40 ) by road or rail. Population 7,58z. l'ost and Telegraph Office. Resthouse. This is a pleasant place at which to stay, lying on a beautiful bay fueing south. Professor I taeckel has written a somewhat enthusiatic account of it in his "Ceylon."

WELIMADA. Uva Province, on the road from Nuwara Eliva 17 m., to Badulla, $19 \frac{1}{4}$ m. (p. $\left.1+5.\right)$ Footpath to Bandarawela, very sumny, but quite pretty, ro m. Post Office. Resthouse.

WELLAWATTA. A southern suburb of Colombo, on the way to Mount Lavinia.

WELLAWAYA. Uva Province, on the road to Hambantota (p. 146). Post Office. Restlouse.

WILSON'S BUNGALOW. Uva Frovince, on the road from Nuwara Eliva to Badulla (p. I 45). Village Receiving Post Ofice. The country round is composed of dry and sterile patanas, but in the village there are many vegetable sardens, for the supply of Nuwara Eliya.

YAKDESSA. A divicion of Dolosibage.

YATIYANTOTA. Sabaragamuwa Province, Kegalle district, on the road from Colombo to Kandy ain Ginigatheria (p. 139) and at the terminus of the narrow gauge line from Colombo (p. 169). Post and Telegraph Office. Resthouse. The district is hilly, mostly planted in tea and rubber.

Trains to Colombo (3t hours) at 5-20, 7-35, 3-5, returning at $7-30,2-30,6-30$. 


\title{
PART IV._GAMES AND SPORTS.
}

\section{Chapter XIV.}

\section{SPORT IN CEYLON}

\author{
BY HARRY STOREY.*
}

$\mathrm{O}$

NE great attraction which Ceylon offers to visitors is undoubtedly the sport to be obtained with gun and rod, although, in common with all other sporting countries, the march of progress and civilisation, modern weapons, cheap ammunition, and, in Ceylon's case, lax administration of the game laws, have caused such a diminution in the numbers of game of all species as to threaten some species with a near approach to extermination, and may end, if matters do not improve, in putting Ceylon ont of the list of sporting countries altogether. However, if the visitor knows where to so, a fair amount of sport may still be indulged in, though it is not easy even for an experienced resident to secure what may be called a fair "bag," and good trophies are very difficult to obtain.

The list of Ceylon game, great and small, comprises the following:-

Elephant (same species as the Indian elephant).

Buffalo (Bos bubalus, the Indian buffalo).

Elk (so-called; ('rans unicolor, the Indian sambhur).

Spotted l)eer (Corus aris, the ludian chital).

Red Deer (so-called; Corins muntjac).

Black Bear (Indian sloth-bear; Melursus msimus).

Leopard.

Wild Boar.

Crocodiles.

Hares (Lepus migricollis, the black necked hare).

Various species of Wild-cats and Civets.

Peafowl.

\footnotetext{
* I am mach indebted for this chapter to Mr. Sitorey, now well known as the author of "Hunting and Shooting in Ceylon." (Longmans, 15s., to be oht anted locally from The Colombo Apothecaries Co.. Lt].) a book which should he in the hatuls of every one interested in sport in the island. J. C. 11 .
} 
Jungle fowl.

Snipe (the pin-tail).

l'igeons (half a dozen varieties).

Quail (three varieties).

Grer and Painted P'artridge.

Teal and Duck.

And many other species of birds and small mammals of interest ti) naturalists.

As to distribution and habits, taking the list in order, dephants may be said to inhabit every portion of Ceylon, from sea level to the highest hills, wherever there may be found jungle enough to afford them cover. It is hardly necessary to suggest any particular portion of the country to which to go for the purpose of shorting clephants, as they may be found in practically any remote or sparsely inhabited part of the country. They may be said, however, to be most numerous in the eastern, southern, north-westem, northcentral, and northem provinces.

They usually remain in the jungle during the day, resting, or feeding quietly on the leaves and bark of forest trees, and commence to travel abroad in earnest about 5 p.m., coming out into open "park" country or villagers' cultivated lands in search of luxurics during the night, returning to cover at davbreak.

Their sight and hearing are both rather deficient, but their sense of scent is rery keen, so that the wind must be rery carefully noted when making an approach for a shot. Ther are usually tarkled in the jungle, and the Cevlon practice is to get to the closest possible quarter's and then aim for the brain, either by the front shot (between the eres), the temple shot (midway between eye and ear), or the ear shot (full into the orifice of the ear, or near it). Each of these shots, if successful, will find the brain and cause instant death. Any modern rifle, from ' 303 upwards, with nickel covered projectile, will suffice to kill an elephant.

Permission is readily given to kill a dangerous rogue, but a liecnse to kill an ordinary elephant costs Rs. 100 and can be granted or witheld at discretion by the Goremment Agent of the province in which it is desired to shoot.

The buffalo is usually to be found in any remote portion of the low-country jungles, frequenting country where there is plenty of grass and water, such as the ancient irrigation tanks and swamps to be met with here, there and everywhere. If undisturbed thes will lie in the water all dar, and graze during the night, early morning, and evening. They are usually pretty wide-awalie, and need careful approach, as they may at times turn "nasty." A license to shoot a buffalo 
costs Rs. 25 and the issue is discretionary as in the case of the elepliant.

The elk (so-called) may be found at all elevations from the low-country jungles to the forests of the highest hills. In the low-comintry it is being rapidly exterminated by the natives, but in the hills it is more carciully protected by the sporting planters for luunting "to the knife." "The low-country sportsman will get little chance of a shot at an elk, as they seldom come out into the open except at night.

The spotted deer are the most numerous of the deel species in Ceylon, and are frequenters of the low-comntry wherever there is grazing ground such as parks, plains and irrigation tanks. Ther are gregarious, and by no means nocturnal in their natural habits, though driven to be so in parts of the country where they are most harassed and shot at. The bucks cary elegant antlers, and afford very execllent stalking sport, or "still hunting." "The best country for deer is in the north-central, eastern, Lva, and southern provinces.

The red deer (muntjac) is also met with in the low-comntry, and is usually a forest dweller and not sregarious, so that a sportsman will only see an occasional one, perhaps darting across a path, or will hear one barking in the adjacent forest. 'They also inhabit the hill forests up to a fairly high elevation, and here afford good sport with clogs.

The black or sloth bear is to be met witls in almost any remote part of the low-eountry. It is a forest dweller, but likes to be within reach of "park" country in whicls to roam at nights. Its food consists of fiuit, honey, and the larve of ants and insects. During the wet season of the year these animals may be occasionally met with wandering in search of food, but, as they are very shy animals, they frequent only the most remote jungles, and the only certain methond if shooting them is by water-hole watching at night during the dry season. They can be very dangerous at times if ther take it into their heads to attack.

The leopard fiequents any country where his favourite ford (deer) mas be found, but he is not averse to an ocasional bullock, pis, of dos. Ile late mo fixed abode, and is only likely to be met with by aecirlent, or by wateling over a kill or bait or at a wates-lose. lecoparis are fairly plentitul in the low-country, and also hame the: hill jumgles to the highest clevations.

Wild boar are ubiepuitous and ane very common in Cevlon. lhey may be shot in the low-country, or lounted with doss in the lills. Ceylon does not contain any "pig-sticking" collutry. 
Crocodiles may be found in any tank or river in the low-country, and are very plentiful, often reacling a very large size.

Peatowl are nowhere very plentiful except perhaps in portions of the southern province. These grand birds are protected by a close seacon.

Jungle fowl are to be found in all parts of Ceylon, and afford excellent sport for an "off-clay." The species is peculiar to Ceylon, differing in some degree from the Indian bird.

Snipe come in September-October, and remain until April, and may be shot in any low-comutry swamp or paddy field. In a favourable year they visit the country in vast numbers, and afford splendid sport.

Pigeons abound everywhere, particularly in the lowcountry and during the fruiting season offer fine sport.

Quail may be found in any grassy land or "dry grain" cultivated lands, but nowhere in such numbers as to promise a big bag.

Grey partridges are to be found on the northwest and northern coasts and islands in fair numbers, and afford good sport over dogs. The painted partridges are only found on the Ura patanas, and about Bandarawela.

Teal and cluck abound in the low-country tanks, swamps, and lagoons, and give grand sport to anyone visiting the low-country.

Hares abound all over the country, and afford good sport on estates, where possibly no other game animals exist. Most planters keep hunting dogs of some sort or other, and these hunt the hares rery eagerly.

The cirets, mongooses, and wild cats also afford an irresistible attraction to dogs, and they will ron themselves to a standstill over these strong-scented animals.

A license to shoot "game," which includes elk, spotted deer, red deer, and peafowl, costs Rs. 3.50 and may be obtained at any Government kachcheri.

Bears, lcopards, pig, and "vermin" require no license, but nay be shot anywhere and at any time.

A license is required to "posicsis and carry a gun" and costs Rs. 2 for any but a single-barrel non-magazine gin (RS. 1).

Ordinances relating to "Wanton destruction of Game" are No. 10 of 1 Sol and No. I 1 of 1902 , and may be procured at the Record Office, in Colombo, or at any kacheheri. 
Close Seasons.

Western Province

Central"
Northern
Southern
Southern (Maga
l'att
Eastern
Nortl-Western
North-Central
Uva
Sabaragamuma

Game

liscols, se.

Peafowl

(iame

(iame

Peafowl

Game

Game
Peafowl
Game
Peafowl
Came and Peafowl
Game and Peafowl
Game and Peafowl
Game and Peafowl

Ist June to 31 int Oct. ist Mar. to 31 st May Ist Nor. to 3 ist Mar. ist June to 3 ist Oet. ist May to zotl Sept. ist Nov. to zust Mar. ist June to 3 ist Oet.

Ist Jume to 3 ist Oct. ist Nov. to 3 ist Mar. ist Jume to ist Sept. ist Jume to 3 ist Oct. 3oth Juncto 3 ist Oct. ist June to 31 st Oct. ist Jume to 3 ist Oct. ist July to 31 st Oct.

Yisitors to Ceylon who do not "know the ropes," or have not the advantage of linowing friends in the island, will probably have to depend upon a professional "shikari" hired in Colombo. The names of these men can usually be ascertained at any of the hotels, and they will if required provide everything for outfitting a jungle trip.

Off the railways, transport is usually by means of native bulleck carts or carriers, and sucl carts can be hired at firom Rs. 1.50 to Rs. 5 per day inclusive - all depends on the locality where the carts aie hired, and the combly to be visited. Carriers would cost from Cts. 50 to Rs. I per day each.

Camp cquipment requires tents, camp beds, chairs, tables, cookins utensils, table funiture, blankets, mosquito curtains, towels, clothingin an air-tight tin box on uniform case, medicines such a quinime, arseninus acid, chlorodrne, corrosive sublimate tabloids as antiseptics, lint, bandages, lancet, tweezers, sacking needles, twine, coir rope, axes, billhooks, buckets, lunting knife, skimning knives, skin preservatives, pocket steel tape, compass, matches, travellers' filter, candles and water bottles. Maps on various seales can be procured at the Survey Office, Colombo, and are almost a necesity.

l'ovisions mus incluele ample supplies of rice and curre stuffis for the men-usually very diflicult to procure in jumsle comntry, so that they should be purchased at the stanting point of last point of "civilisation."

1 visitom can purclase anytlung and everything in the way of timned goods, preserved soups, de., in Colombo or Kandy, but must remember that transpolt is not easy in the jungle, 
so that soda water and such like will not be easily carried. Water is usually pretty bad in the low-country, and should always be filtered before use, though if used for teamaking unliltered the boiling will have about killed all germs.

For chothing khaki is excellent, or the greconish coloured "lunnting clotli" - alwass bearing in mind the intense heat of the low-eometry. A solar topee must always be worn when any walking has to be clone in the sun - this is an imperative uccessity.

Is space is somewhat limited, of necesitr, complete details of the foregoine matters cannot be fully dealt with, but the visitm will find the whole ground of Ceylon sport fully covered and brought up to date in Storey"s "llunting and Shonting in Ceylon" (Lonemans, Green di Co.)

finally, visitors are informed that there exists a "Cerlon Game Protection Sinciety," the address of the IIon. Secretary of which can be ascertained from the Directory. A letter to the I Iom. Secretary, and a donation to the Socictr, would be the means of procuring valuable assistance and information. 


\section{Chapter XV.}

\section{SPORTS AND GAMES.}

A BRIEF word may be given to this subject. Sport with chapter. Sport with the iod is chicfly congaged in about Nuwara Eliva and Iforton Plains, where trout have been introduced, and where there is a fishing club, fiom whom licenses must be obtained. Hunting is indulged in np-conntry, where packs are kept for the pursuit of elk (sambur), jackal, pig, hares and red deer.

Racing is rigorously pursued in Colombo, and at Kandy, Nuwara Eliva, Darravella, Radella, Badulla, Taldua, and Galle. Boating and rachting only in Colombo.

Polo is played in Colombo, Nuwara Eliya, and Elkaduwa, but the vigour with which this sport is pursued usually depends upon the tastes of the military and of the staff at Givernment Ilouse.

Cricket is probably the most popular game in the island, and there are many good clubs. The standard of play among the younger natives, more particularly, is high, and the Colts. Club, in Colombo, is the strongest in the island. Temmis is played evervwhere, on sravel courts, anc the standard of play is high. Football especially Rugby-and hockey are also popular, and golf has a great hold upon the community, very fune linki being available in Colombo, Nuwara Eliya, se. 


\section{PART V.-MISCELLANEOUS.}

\section{Chapter XVI.}

\section{NATIVE OR OTHER WORDS IN USE IN CEYLON, NOT IMMEDIATELY INTELLIGIBLE TO A NEWCOMER.}

\section{$\mathrm{T}$}

IOUGH English people in Ceylon do not so completely interlard their conversation with native and other words as do their confreres in Northern India, there are yet many words in use here which must sound strange and unintelligible to the newcomer, and a list of the more common is therefore given here.

Adrocate, a barrister.

A. G. A., Assistant Government Agent.

Almira, a detached cupboard or wardrobe, p. ios.

Appu, a head servant, p. ro6.

Arachchi, the lowest grade of headman, p. 134; rank sometimes homorary.

Asweddumize, to bank up and irrigate (for paddy).

Bandicoot, a large rat, p. 20.

Bandy, a hackery.

Banian, an undervest; banian day, the day before beef-day.

Barbecue, a drying ground.

Bazaar, a street of shops.

Beef-day, the day, usually Tuesday and Friday, when supplies of meat are to be had in the markets.

Betel, Areca, p. 52.

Bloodsucker, a large lizard, p. 22.

Bo, p. 65 .

Bontique, a shop in a Sinhalese village, p. 105.

Boy, a servant.

Breakfast, p. 94.

Break of monsoon, p. It.

Bulk, p. 57 .

Bund, an earthwork dam, p. 74 .

Burgher, p. 85 .

Cadjan, a plaited coconut leaf, p. 47. 
Caste, p. 96.

Cake, p. 4 S.

Ceiling cloth. The ceiling in a house is often made of canvas, stretched tightly and whitewashed.

Chatty, an earthenware pitcher, p. 94.

Cleckioll, the register of conties and of the days' work that they do.

Cheddi (lam.), scrub regetation.

Cheetal, a leopard, p. 19.

Chekku (Sinh.), an oil mill, consisting practically of a large pestle and mortar, tumed by cattle or buffaloes.

Chena (Sinh. hena), p. 37 .

Chetty, a Soutl Indian caste of money-lenders, p. 84.

Chit, a note.

Chumam, lime, p. 52.

Cloth, the waist cloth of a coolic, de., p. SS.

Coast, India. A coolie is said to have sone to his const when he has left for India. Coast bull, p. is.

Coir, p. 48 .

Comboy, a cloth, p. SS.

Compound, the garden round a house.

Conductor, the native under-superintendent of an estate.

Coolic, p. 54 .

Coppersmith, a bird, p. 2 r.

Copra, p. 48 .

Creeper, a pupil on an estate, p. 54.

Combly (lam.), a coolie's blanket coverios.

Curry, p. 93 .

Dagoba, p. 79 .

Dhoby, a washerman, p. y).

Dhomi (lam.), a boat.

Dhomri, a rug.

Dry srains, cereals, Sc., that can be grown without inrigation.

j)urai (Tam.), master.

Early tea, the first meal of the day, p. 94.

Ela, an irrigation canal.

Elephalut kiaal, p. 19.

Elk, a sambur deer, p. Is.

Estate, a plantation worked ly hired labour, p. 53.

Firing, drying (tea), p. 57.

Fiscal, p. 134 .

Fhush, the young shoots of tea, [) 5.5.

Fut, see l'liut

(i. A., Govemment Agent, 1). 134.

Gansabhawa, p. 134.

Gecku, a wall lizald, p. 22. 
Gharri, a horse carriage.

Ghee, native butter.

Godown, a store-room or outhouse.

G. O. H., the Grand Oriental Hotel.

Govermment Agent, p. I34.

Gymkhana, a "games" meeting.

I Hackery, a passenger bullock carriage, p. I I 3 .

Headman, p. 134 .

Jaggery, palm sugar, p. $4^{8 .}$

Jak, a tree, p. 66.

Jât, kind, species, race.

Jungle, forest or high scrub.

Jute hessian, the coarse canvas of which tea tats, \&c., are made, p. 56.

Kabuk, p. 2 .

Kachcheri, the office of the G. A., p. 134 .

Kaddy, a small shop.

Kanak, an account.

Kanakiapulle, an accountant.

Kangani, an overseer, p. 54.

Kantoor, an office, p. $10 \$$.

Katti (Tam.), a knife.

Kitchen coolie, p. 106.

Kitul, a palm, p. 66.

Kondé (Sinh.), a hair knot, p. 90.

Kurumba, (Sinh.), a roung coconut.

Land wind, the north-east monsoon, which blows more off the land.

Leaf, the picked tea leaf, p. 56 .

Lewaya, a salt lagoon, see llambantota in Towns.

Lines, coolies' dwellings, p. 54 .

Long chair, a chair with prolongations to the arms, on which the legs can be rested.

Longshore wind, p. 15.

Lovegrass, p. 67.

Low-country, the country below the clevation of, say, Kandy.

Mamoti (Tam.), a digging hoe.

Mana grass, p. 67.

Monsoon, p. 13.

Moorinan, p. 87 .

Mud and wattle, p. 92 .

Mudaliyar, p. 134 .

Muhandiram, the rank below Mudaliyar, but above Arachchi.

Muttu (Tam.), a horsekeeper. 
Name, a coolie who is entered in the checkroll as having done a fill day's work is said to get his name, if half a day, half-name.

Nelu, p. 6ı.

Ola, p. г 26.

Paar, a bauk on which pearl oysters may grow, p. 24.

Pada boat, p. 104 .

Paddy, rice in the lunsk, p. 4 .

Pandal, a triumplial arch of areca palms, \&c., woven over with leaves, Sc.

Pansala, a priests' dwelling, p. 97.

Pariall-dog, p. 20.

Patana, a grassy expanse, p. 6 I.

P. D., periya durai.

Perahera, a religious procession, p. $9 S$.

Periya (Tam.), great; periya durai, chief superintendent.

Peon, a messenger.

Phut ; to go phut, to collapse or abort

Pingo, a "yoke," p. 52.

Plantain, a banana, p. 50 .

Podivan (Tam.), a small boy.

Pokuna, a bathing tank, p. 117.

Poochic, an insect.

Poonac, p. 4 S.

l'opadam, p. 94.

Proctor, a solicitor, p. 135.

Pucka, permanent, first rate.

Puja, worship.

Puttce, a spiral leguing.

P. IV. D., Public WVorks Department, p. 135.

Raincoat, a macintosh.

Rajakariya, forced labour, P. I I 5.

Ramasami, a Tamil coolic, p. 99.

Resthouse, a roadside inn, kept up by the Government, P. 136 .

Rice, meals ; go to your rice (addressed to a servant, sc.), go to your meal.

R. M., Ratemahatmaya, p. I34.

Roll, p. 57 .

Sambal, 1).94.

Sannas, all inscribed stone, p. I I ).

Santosum, a tip or present.

S. I., sinna durai, assistant superintendent.

Secr, a fish, p. 22.

Slueflower, p. 68 .

Shuck, goocl-for-nothing.

Sima (Tam.), idly. 
Tamasha, a "function," p. I I 5.

Tambs, a merclant on the small scale.

Tank, an irrigation lake, p. 74.

Tappal, post (letters).

Tapping. p. 51 .

Tat, a mat of canvas or split bamboo, often humg in front of a rerandal to keep out the glare; used for tea withering.

lavalam, p. 105.

Terai hat, a soft felt hat.

'Tick, an unpleasant insect, which bores into the skin, p. I 22. Tiffin, lunch.

'Todds, p. 47 .

Topec, a sum-liat.

Totum (thottan, Tam.), an estate or yarden.

Tundu (Tam.), a note, generally used for the notes sent round among planters announcing that so many coolies will be paid off on receipt of the amount owed by them in debts. Up-comotry, the anntry above or about the Kandy level.

V. A., visiting agent, p. 54 .

Vedarala, a mative doctor, p. I 14.

Vilara, a lusuce for the images, p. 100.

Village, p. $7 \mathrm{~S}$.

Vanderoo, a monkey, p. 19.

Wattle and daub, p. 92.

Windbreak, a belt of trees planted through an estate. 


\section{Chapter XVII.}

\section{NOTES AS TO HEALTH, CLOTHING, \&c.}

$\mathrm{T}^{\mathrm{T}}$

IE following few notes may prove useful, but ererone residing here for more than a few months should procure Dr. Chalmers" "Simple Medical Directions

(Record Office, Rs. i.)

The three common, troublesome, and often dangerous complaints which affect the health of Europeans in this country, are malaria, dyentery, and enteric lever, and there is ino reason why with proper precautions one should suffer from any of them. Onee infected with malaria, it may of couse recur numerous times without a fresh infection, but to set that first infection one must apparently be bitten by an Anopledes mosquito. This is the slim, rather needle-like mosquito, which is very common in most of the low-country, especially to the north, and which sits upon the skin, and also bites, with its body sloping upwards, so that the tail is much higher than the head. The Cules and other hambess mosquitoes, on the other hand, sit, and bite, with their bodics parallel to the skin. The Anopheles rarely flies during the full light of day, but comes out lieely about 5-30, and as a fair proportion of these mosquitoes are carrics of tever, the great thing to be attended to is to avoid being bitten. They are especially prone to attack the ankles and insteps, so that boots should be worn, not shoes. The chair in which one sits should have a cushion or other article on the scat, and the knees, which may be bitten through the clothes, should have an extra protection in the form of a second covering, or be well oiled with protective oil. There remain then only the hands and face to be protected and this may be dome by oiling them witl citnonella oil, or better, with the mixture of citronella, cocoment, and kerosene oils, known as "Bamber-(i)een oil," and to be procured at local denusts. The hands may be protected with thin kid sloves if the mosquitoes are really very troublesome, and the head enveloped in a veil. If one should, in spite of all precaution, be mulucky enongh to get an attack of tever, reference must be mate to 1). Clabmers' bonk, of to tha nearest medical man.

bysentery and conteric lever are mainly earied by impme water and milk, two things about which the newcomer tends 
to be careless. It must be cleary recognised that water should always be boiled and filtered through a Pastem or Berkefeld filter (which must be kept clean, and that milk should be boiled. Personal attention to this is desirable, at any rate in outlying districts, and care must be taken to see that the serrants (as not infrequently happens) do not bore holes in the filter candles to ensure rapid "filtration." If these simple precautions be taken, there is almost no reason to fear an attack of either of these complaints.

One great rule of health in the tropics is to aroid chills, which are more readily taken the wamer the climate, and which may lead to all kinds of complications. If one is not infected with malaria or drsentery they will usually only give rise to dianhoea, but if the infection be in the system, these complaints are likely to appear. If the weather be wet, one is rery liable to catch a chill in the thin suits of white drill or Colombo cloth often worn in the low-country. The safest kind of clothing for general wear is the thin flannel now made in all sorts of tweed-like patterns. A body belt of woollen is a rery useful guard, but is difficult to leave off after it has once been worn. For up-country a sweater or coat is requiled to put on at sundown, when it often gets suddenly chilly. A very important point to be carefully attended to is to cliange the clothes if damp, and never to sit in a draught in such circumstances.

Exposme to the sun should be avoided where possible, and one should never go out till about 5 p.m. without a sun-hat or topee. Fashions in these articles change, and the present fashionable one in the island is the khaki-coloured "pig-sticker."

For tramping about up-country, and to keep out leeches and ticks, the ordinary Indian spiral lesging or puttee is generally employed. Brow boots are more popular than black. "Temnis is played in flat leather" shoes. A macintosh, (1) raincoat as it is locally called, is almost indispensable in this rainy climate, and ais umbrella is habitually carried in the towns.

Ceylon is not a particularly depresing climate, and alcohol is not necessary till after sumdown. Scotch Whisky is perhaps the safeit drink but slould be avoided during the day. The kurumba (p. $4^{S}$ ) is the safest doink when travelling in the low-country.

No one should trarel in this comntry without a supply of quinine, chlorodyne, and citronella oil. 


\section{Chapter XVIII. BOOKS ON CEYLON.}

$\triangle$ FEW of the many berkis upon Ceylon are mentioned $A$ below, and chicfly those which can be fairly easily ubtained, and read with pleasure.

Knox, An historical relation of the island of Ceylon. London, 1681. (Knox was for many years a prisoner in Kandy, but finally escaped).

Percival, An account of the island of Ceylon. London, $18 \mathrm{SO}_{3}$.

Cordiner, A description of Ceylon. London, 1807.

Forbes, Eleven years in Ceylom. London, 1840.

Tennent, Ceylon. london, is 59 .

Baker, Eight years in Cevlon. London.

Baker, with rifle and hound in Ceylon. London.

Cumming, Two happy years in Ceylon. London, 1892.

Cave, Golden Tips. Lindon, 1900.

Cave, The ruined cities of Ceylon. Lendom, 1897.

Wijesinha, The Mahawansa. Colombo, I889.

Copleston, Buddhism. London, isoz.

Trimen, Flora of Ceylon. Lundom, is S13-1900.

Temnent, Natural llistory of Ceylon. London, isor.

Storey, llunting and slowting in Ceylon. London, 1907. Ferguison, Ceylon I landbook and Directory. Colombo.

Skeen, Guides to Colombo and Kandy.

Still, (inide to the buried cities.

Macmillan, Cuide to the Peradenira gardens.

Ceylon Civil tist, ace. 



\section{INDEX.}

PAGE.

PACH:

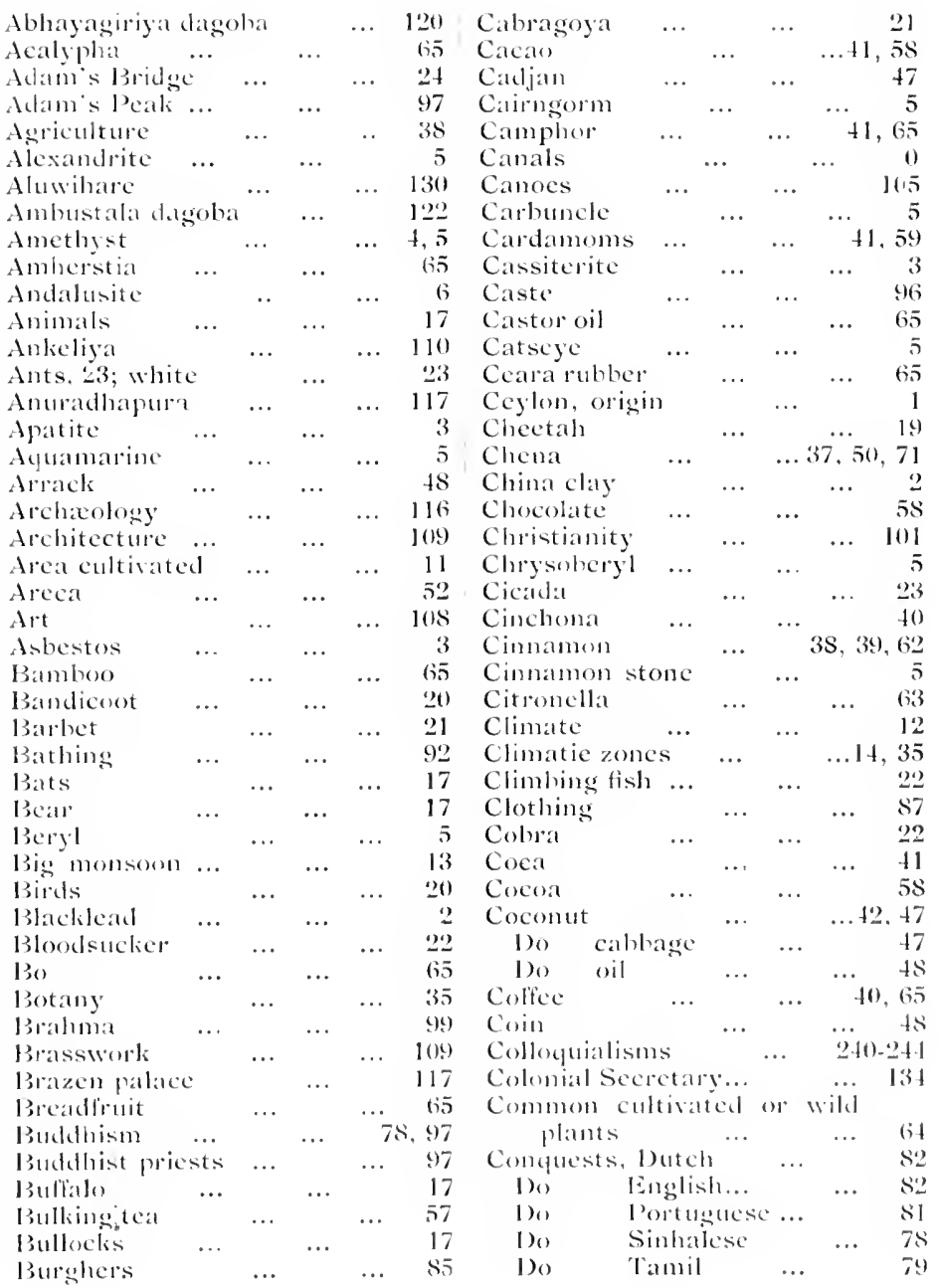


Parit.

Coolies

Coppersmith

Coprar

Cordicrite

Corundum

Cosmas Indicopleustes...

Cotton

Cottontreo

Creeper

Crocodile

Croton

Curry

Customs

Datap

1):agoha

Jambullat

Dampress of ai

1)eer.

Devil dancers

Dhohy

Dos

1) rink

Dry Country chena Do forest

1) utch conquest

Education

Elephant, 19; Kraal

Elli

Emerah

English conquest

Estates

Europeans

Exactim

Exccutive Council ...

Felspar

Finctics

Firing tea

Fish

Do walkins

Do singing

Jo climbing

Fishing

Food

Forest

linermation of pear

Fions

Furerax

Furniture

Gadaladenisa $\cdots$

Galle

Games and sports ..

Gausalolnat

Gavelen cultivation at jaffua

Gallnets

(iecilis

Gems

Geosianliy

Gineiss

(jold

48

6)

3

7

65

65

54

61

93

114

66

79

129

13

98

94

20

94

$\begin{array}{ll}\cdots & 63 \\ \ldots & 63\end{array}$

82

101

19

18

4. 5

82

40

St

66

.. 133

23

57

. 10

37,7

3

6

- 60

.. 13

1.

110

134 t'. 54

$1 \mathrm{~s}$

63

6

2

$\begin{array}{rlllllr}64 & \text { l.aterite } & & \ldots & & \ldots & 2 \\ 5 & \text { Lealfinsects } & \ldots & & \ldots & & 23\end{array}$

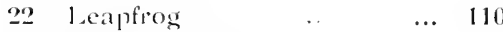

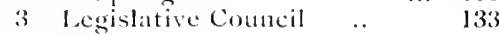

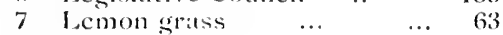

$\begin{array}{llllll}\text { I Leopard } & \ldots & \ldots & & 19\end{array}$

$\begin{array}{llllll}3 \text { lime } & \ldots & & \ldots & 67\end{array}$

Pigi:.

$\begin{array}{lllr}\text { Golden oriole } & \ldots & & 21 \\ \text { Government. } 133 \text {; Agent } & & 134\end{array}$

$\begin{array}{llll}\text { Granites } & \cdots & \ldots & 2 \\ \text { Graphite } & & & \end{array}$

Green manuring $\quad . . \quad 58$

Greentea $\quad$... $\quad \ldots \quad 57$

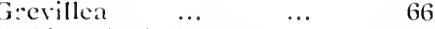

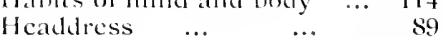

Health $\quad \ldots \quad 245,246$

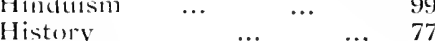

Hospitals $\quad \ldots \quad$...

$\begin{array}{lllll}\text { Houscs } & \ldots & \ldots & 92\end{array}$

Hyiene $\quad \ldots \quad$... 113

Indiarubber $\quad \ldots \quad$.. $\quad 41$

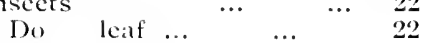

Do stick $\quad \ldots \quad$...

lrigation $\quad$.. $\quad \ldots .74$

lsurumuniya vihare $\ldots . \quad 121$

$\begin{array}{lllll}\text { Jacinth } & \ldots & \ldots & & \\ \text { Jaclial } & & & \end{array}$

Jackal $\quad$... $\quad \ldots . \quad 19$

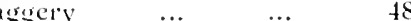

Jarion $\quad$... $\quad$...

Jetaranarama dagoba $\quad \cdots \quad 120$

Jungle fowl $\quad \ldots \quad$.. $\quad 21$

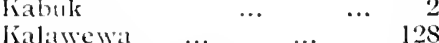

liandy, conquest of... $\quad$... 83

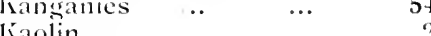

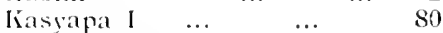

liins's palace $\quad \ldots \quad$... 119

$\begin{array}{llllll}\text { lionde } & \cdots & & \cdots & & 90\end{array}$

Iurumba $\quad \ldots \quad$...

54

Gi

9

07

131

66

6

97

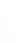

63


Limestone ... … "3

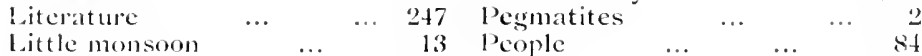

Pearl fishery ...

23,24

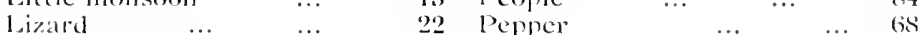

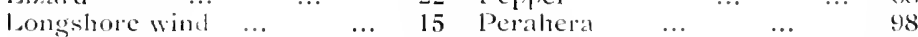

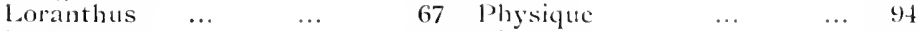

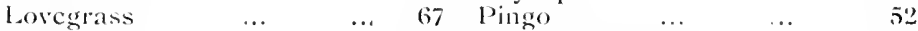

19 Pithecolobium $\quad$... $\quad$... 68

Nagpic robin $\quad \ldots \quad \ldots \quad \ldots \quad 26$ Nantains, cultivation of $\quad 50$

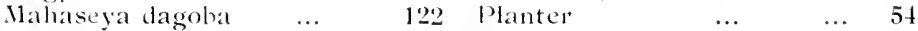

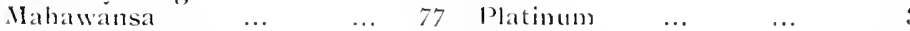

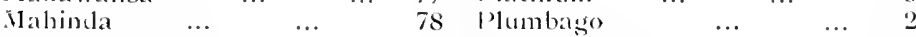

$\begin{array}{lllllll}\text { Malabar invasions... } & \ldots & 79 & \text { Polonnarwwa } & \ldots & \ldots & 126\end{array}$

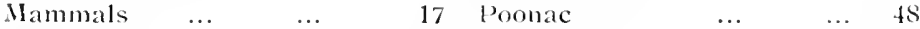

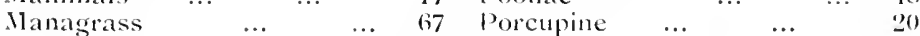

Mlango $\quad$...

6 Portugucse conquest $\quad$... $\quad 81$

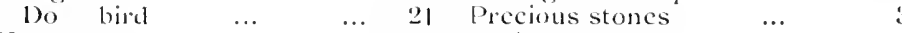

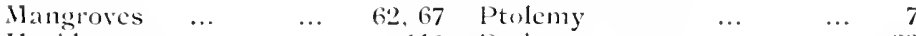

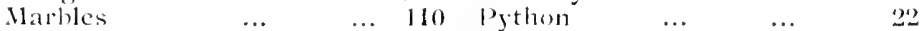

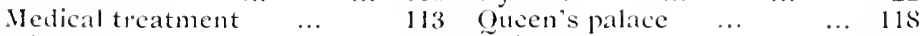

Mica

Nice

Mibintale

2

Ouinine $\quad . .6 \quad \ldots \quad 40$

Nikania

Railways,

10,148

Minerals

Rajakariya

115

)

Ramasami

Ranliot dagoba

Rats

Mixed surden cultivation

Molammodanism

49

Ratsinalie

I00 Religion

Mohammedans $\quad \ldots \quad$... Sl

Mollusis

Molybuenite

Mlongoose

Monkey

Nonks

Ilonsom

Mloonstore

Nloormen

Resthouse $\quad \ldots \quad$... $\quad 136$

Rhododendrons

Rice

Rice fields

Ritisala

River's

1:3 Roads

Nountain

Nousedeer

Music

Mussienda

Names

Nightjar

Occupations

()ange

Orenisl

Otter

paras

Parda boats

Rocks

99

o()

Rodiyas

Ruwanweli dagoba

Rubber.

Ruby

Do

Sitcred bo

Sambur

104

Sipp

1) water

1) blat

Silpu

b)

ladely ficlds

School gadedens

seoppion

Secer

Sensitive plant

Painting

Palmyara palms

Dapali

P'aradise flycatches.

Servatlis

Shore Howe

$\because 1$

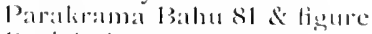

Sloop liceping

shore platus ...

Siginis

piarot

l'cafowl

Silk corten tree

learls

Silver work

Sinclband 


\begin{tabular}{|c|c|c|c|c|c|c|c|c|}
\hline \multirow[b]{2}{*}{ Singing fish } & \multicolumn{4}{|c|}{ PAge. } & \multicolumn{4}{|r|}{ PNGE. } \\
\hline & & $\cdots$ & .. & 22 & Tinstone & & & $\cdots$ \\
\hline Sinhalese & $\ldots$ & & $\ldots$ & 85 & $\mathrm{~T}_{0}$ & & $\ldots$ & 22 \\
\hline Siva & & $\ldots$ & ... & 99 & Toddy & $\ldots$ & & $\ldots$ \\
\hline nelting & $\cdots$ & & $\ldots$ & 3 & Topaz & & $\ldots$ & 4,5 \\
\hline & & $\cdots$ & $\cdots$ & 23 & Tourmaline & $\ldots$ & & $\ldots$ \\
\hline $\mathrm{es}$ & $\ldots$ & & $\ldots$ & 22 & Towns & & $\ldots$ & 10 \\
\hline ow & & . & $\cdots$ & 21 & Travelling & $\ldots$ & & $\ldots \quad 113$ \\
\hline$r$ & $\ldots$ & & $\ldots$ & 23 & Tree fern & & $\ldots$ & (i), 69 \\
\hline 1 & & $\ldots$ & $\ldots$ & 5 & Types of vegetation & & & $\ldots$ \\
\hline el & $\ldots$ & & $\ldots$ & 20 & Up-country forest & & $\ldots$ & 60 \\
\hline by & & $\ldots$ & $\ldots$ & 4 & patan: & lats & & $\ldots$ \\
\hline pphire & & & $\cdots$ & 1 & Van & & $\cdots$ & 41 \\
\hline Steel & & $\ldots$ & $\ldots$ & 3 & Ver & .. & & 77,87 \\
\hline ts & $\cdots$ & & $\ldots$ & 23 & ation & & $\ldots$ & 35 \\
\hline 111 & & $\ldots$ & $\cdots$ & 68 & $\mathrm{Vi}$ & $\ldots$ & & .. 109 \\
\hline tree & $\ldots$ & & $\ldots$ & 99 & $V^{\prime}$ & & $\ldots$ & $7 S$ \\
\hline 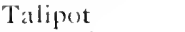 & & $\cdots$ & $\cdots$ & 68 & $\mathrm{li}$ & & & $\ldots$ \\
\hline 11d & $\ldots$ & & $\ldots$ & 68 & ng fish & & $\ldots$ & 22 \\
\hline at & & $\ldots$ & & 86 & roo & $\cdots$ & & $\ldots$ \\
\hline at & $\ldots$ & & $\ldots 74,78$ & 8,79 & apphire & & $\ldots$ & 6 \\
\hline a & & $\ldots$ & $\ldots$ & 52 & 8 & $\ldots$ & & 110 \\
\hline Tavalam & $\ldots$ & & $\ldots$ & 105 & $w$-country & ege & tation & 36 \\
\hline eal & & $\ldots$ & & 1.53 & WI & & $\ldots$ & 23 \\
\hline re & $\ldots$ & & $\ldots$ & $1: 2$ & ire & & & 3 \\
\hline tree & & $\cdots$ & 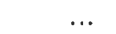 & 68 & 11 & & $\ldots$ & 77,78 \\
\hline es & $\ldots$ & & $\ldots$ & 23 & Wind & $\ldots$ & & $\ldots 14$ \\
\hline he & & $\ldots$ & ... & 7 & oyste & & $\ldots$ & 34 \\
\hline The & $\cdots$ & & $\ldots$ & 7 & mise & 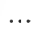 & & 51 \\
\hline rhu & gend & & $\ldots$ & 118 & Yircon & & $\ldots$ & 5 \\
\hline ic-polonga & $\ldots$ & & $\ldots$ & 22 & Zoology & $\ldots$ & & $\ldots$ \\
\hline
\end{tabular}

For towns \&c. see Chap. Xlll.

.. colloquialisms, , XV1. 

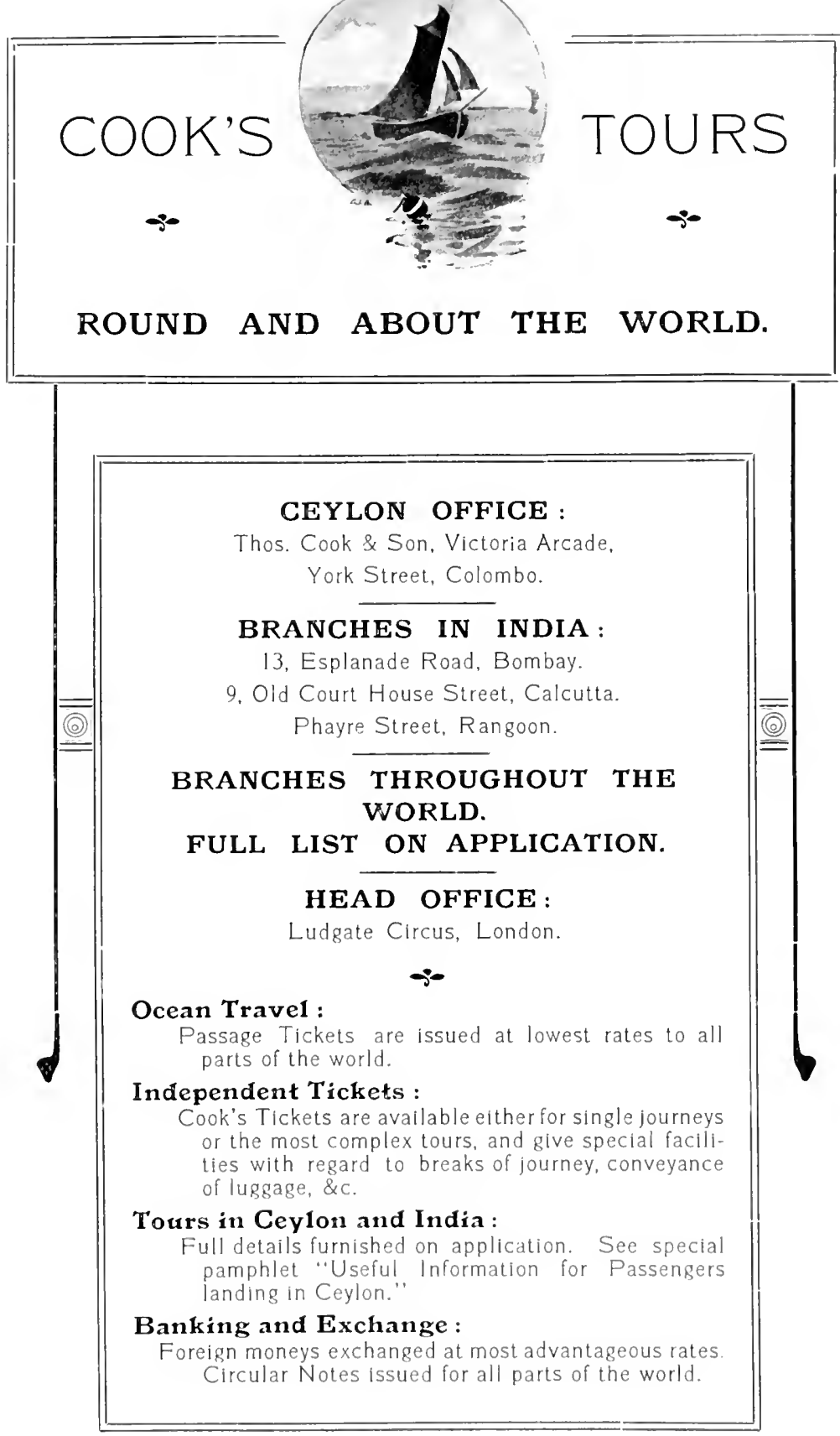


\section{-2. Austrian Lloyd's Steam Navigation Coy.}

SERVICES FROM COLOMBO.

Monthly to Aden, Suez, Port Said and Trieste.

Monthly to Bombay, Karachi, Aden, Suez and Trieste. Monthly to Calcutta.

Monthly to Penang, Singapore, Hongkong, Shanghai, Yokohama and Kobe.

Steamers fitted throughout with electric iight. Carry Doctor and Stewardess.

For rates of passage apply to the Agents for Ceyion.

DARLEY, BUTLER \& Co.,

ColomBo.

\section{COLOMBO WALKERS KANDY}

TOURS ARRANGED TO ALL PARTS OF THE ISLAND.

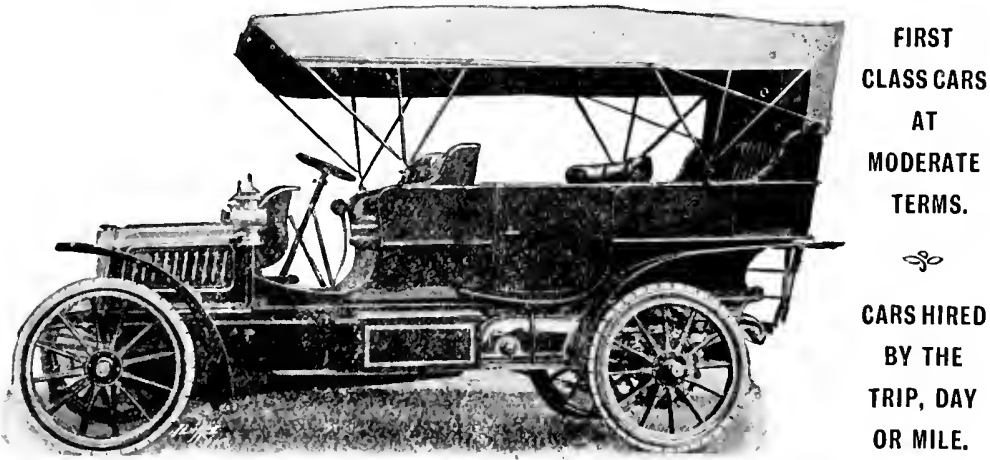

GARAGES AT COLOMBO \& KANDY.

WALKER, SONS \& Co., Ltd.,

Furnishers to the Automobile Club of Ceylon.

Telegraphic Address:-" NOMAD" Colombo. Codes: A.b.C 5 th Ed.. LIEBers a Bentleys. 


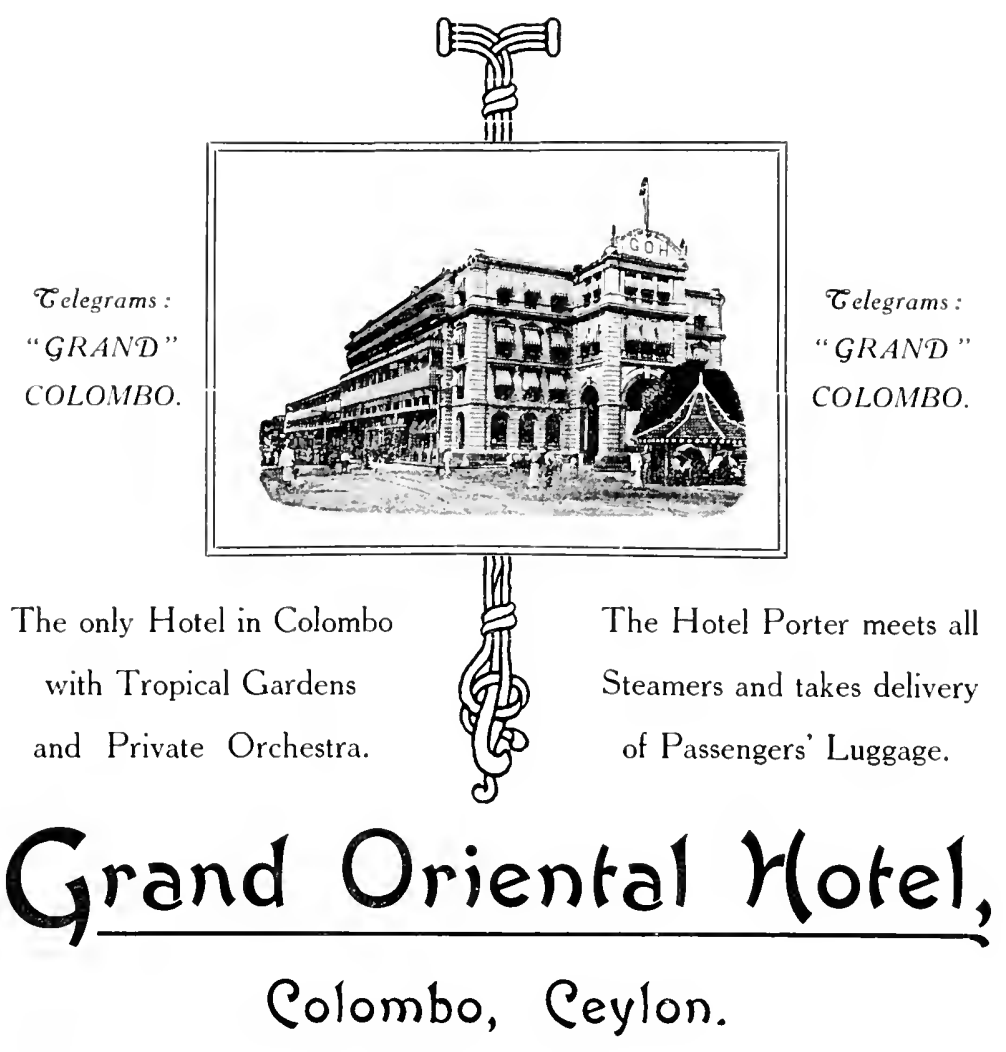

THIS Hotel has a world-wide reputation as the first Modern Hotel known in the East, and has been entirely re-constructed to meet modern requirements. Lift, Electric Light and Electric Fans in Bed Rooms and Public Rooms.

One hundred and fifty Bed Rooms and Sitting Rooms.

\section{EXCELLENT CUISINE.}

Single Rooms . From Rs. 3.00 . 4 s. upwards.
Double Rooms . From Rs. 4.50 .
Daily Board rate if desired.

THE COLOMBO HOTELS Co., Ltd.,

Proprictors.

USEFUL INFORMATION FOR PASSENGERS.

Boat, Launch, or Canoe hire from Steamer to Landing Jetty, 25 cts. each up to 7 p.m., 40 cts. atter 7 p.m.

Hire of Carriages or Rickshaws from the Door Porter or Enquiry Office at the Hotel. Thos. Cook \& Son's Office opposite the Hotel. 


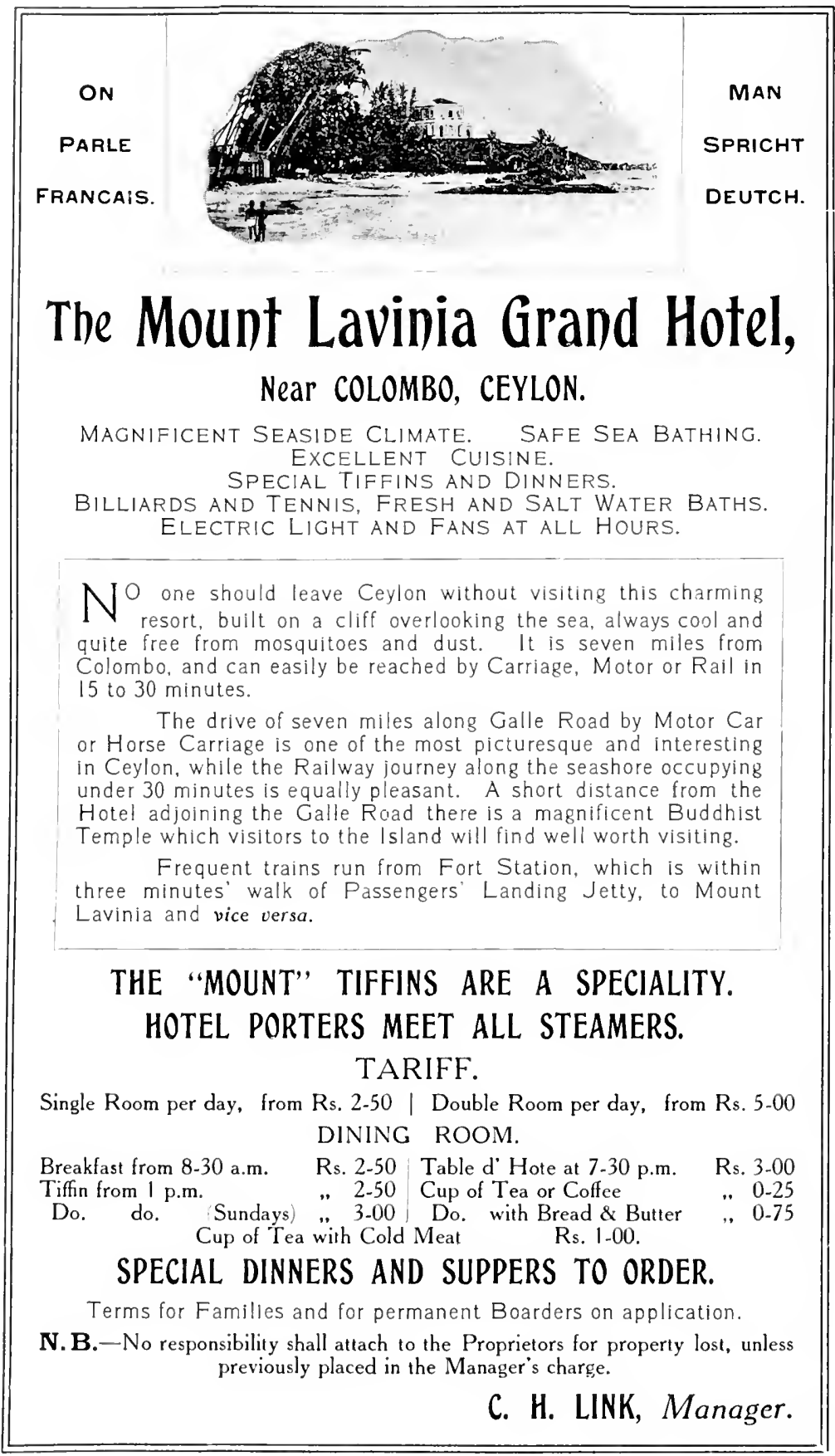




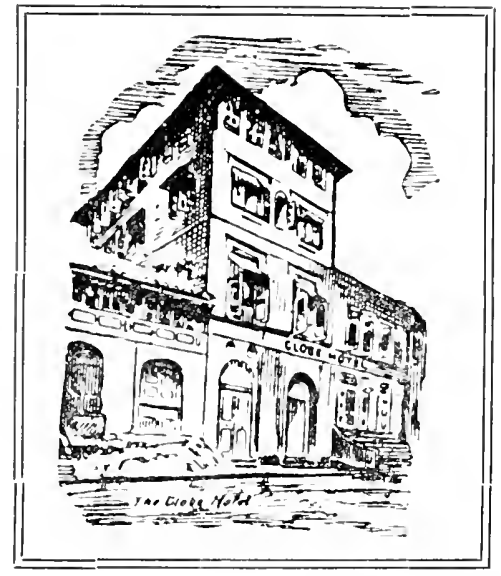

\section{THE \\ Globe Hotel \\ Colombo, \\ Ceylom.}

THE MOST-UP-TO-DATE HOTEL.

Electric Light, Fans, Bells and Telephone. Lofty, Airy, and Comfortable Rooms facing the Sea, three minutes from Landing Jetty.

WINES, SPIRITS AND CUISINE THE BEST.

Cleanliness and Civility a Speciality.

Daily Rates Rs. 5 - or 6/8 per diem.

ARTHUR E. EPHRAUMS, Janager.

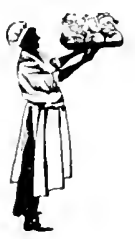

Florence Hotel,

KANDY.

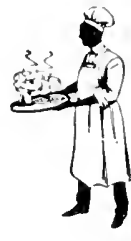

THE HOTEL stands in its own grounds and can be confidently recommended for the prettiness of its surroundings and quiet comfort.

TERMS MODERATE. -:- NO EXTRAS.

Apply:- MANAGER. 
The best situated and most comfortable Hotel in the Sanitarium.

\section{SPECIAL RATES}

for Families and Visitors making a prolonged stay.

6,400 feet above Sea level.

The Gentlemen's Golf Links adjoin the Hotel Grounds and Golfers are taken in at a special rate.

A Tennis Court is provided as is also a Darkroom for Amateur Photographers.
Over 30 large well furnished and airy Bedrooms, large Dining, Drawing, 81. Smoking, Reading and Billiard Room AITDRHTK'S $\quad \begin{gathered}\text { and } \\ \text { Lounge. }\end{gathered}$

\section{6,400 feet} above Sea level.

NUWARA ELIYA,

CEYLON.

Private Carriages and

Rickshaws.

gio

For particulars apply to

A. Humbert, Proprietor.
Stabling for Horses.

Excellent Cuisine.

Moderate Charges

Every Comfort.

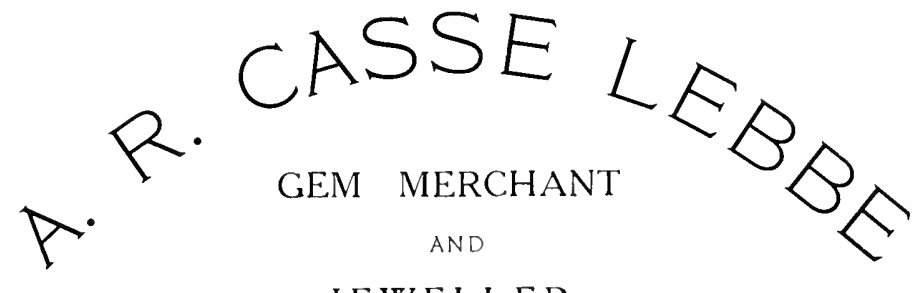

JEWELLER.

DEALER IN ART WORKS AND KANDYAN CURIOS.

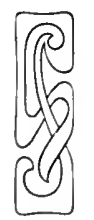

Awarded Gold Medal at the Kandy. Agri-Horticultural Exhibition, in 1903, for the best specimens of Gold u'ork.

Patronised by H. R. H. The Prince of Walcs, H. R. H. Princess Louise Augusta of Schleswcig.Holstein, H. R. H. Duke of

Connaught \& H. E. Sir H. A. Blake, late Governor of Ceylon.

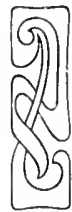

All Articles Warranted Genuine.

-:- Orders Promptly Executed.

INSPECTION RESPECTFULLY SOLICITED.

No. 4, TRINCOMALIE STREET, KANDY. 


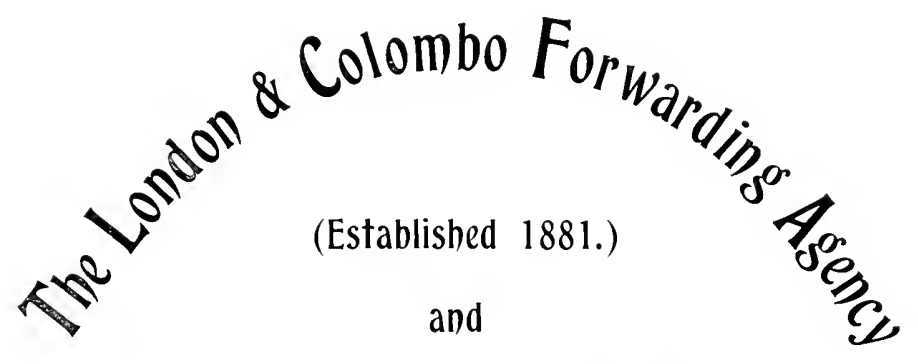

The Foreign Parcels Agency.

Goods and packages forwarded to all parts of the World.

Bills of Lading received and goods cleared through Customs.

The originators of the "One charge" System. Forwarding charges may be paid in Ceylon or at destination, value of goods collected on behalf of the sender.

Agents for The American Express Company, Pitt \& Scott, and many of the First Forwarding Agencies of the World.

The forwarding of 'Travellers' Collections of Curios is specially looked after.

AGENT IN CEYLON:

E. B. CREASY,

12, BAILlie ST., COLOMBo. 


\section{SPECIAL NOTICE}

\section{TO THE RUBBER PLANTING WORLD.}

PARA, CASTILLOA, CEARA, \&c.

SEEDS AND STUMPS FORWARDED TO ALL PARTS OF THE WORLD.

B. N. BORNEO.-The Manager of a Rubber Plantation Company B. N. Borneo, writes 29th May. 1907:- "We have pleasure in acknowledging your lavour of the 22 nd ultimo with invoice for seeds and stumps amounting to Rs. 4.250, and in advising that these have all come to hand in very good condition. We are very satisfied with the quality of the stumps : as to seeds we shall advise you in due course."

SAMOA.- Touching a shipment of 100.000 para stumps, Mr. Francis Harman. Managing Director, Upolu Cacao Company, Samoa, writes to the Ceylon Observer of 22nd February, dated 17th January. 1907:- - Our Rubber stumps, purchased from William Bros. Henaratgoda, were a great success. We have about 90 per cent good in the nursery." Subsequently Mr. Harman writes in March, 1907, touching a further shipment:- "The stumps turned out wonderfully well considering the long time they had been on the way."

UGANDA.-A Colombo Firm in ordering a further supply of Hevea seed for Uganda, writes to our Agent. Mr. E. B. Creasy, at Colombo. 26th February, 1906:- "We have been informed that Hevea seeds forwarded from Messrs. Willjam \& Bros, have turned out very good, one lot showing 100 per cent. germinated seed."

DOMINICA. - The Curator of a Botanic Garden in Dominica in ordering four separate lots of Para Rubber seed, writes 3rd May, 1907 :- " 1 hope you will be able to do your best for us, as we have given you a good advertisement in this part of the world by publishing your Circulars in the Official Gazette and the local papers.

LIBERIA. The Secretary of a large Rubber Corporation in ordering a supply of Hevea seeds for Liberia, writes, London, 3rd September. 1906:- "I am strongly recommended by the authorities at - who are interesting themselves in the experiments, to obtain a consignment of Hevea seed from Ceylon. They have kindly furnished me with your name and address as Merchants of Hevea seed who can be thoroughly trusted."

ZULULAND.--Our Agent. Mr. E. B. Creasy, writes 30th June, 1907:- "1 am in receipt of an enquiry from a firm- - of Zululand re Para Rubber seed, and they mention your firm as supplying reliable seed."

MEXICO.- J. B. Sanborn, Esq., President. Orizaba Rubber Plantation Company, (Mexico), writes dating General Office, 21 Quincy Street, Chicago, III. U.S.A.: "Referring to the shipment of 5,000 Hevea stumps from you last summer, I beg to advise you that after being 85 days on the ocean these plants were received at the plantation (in Mexico), and I am pleased to advise you that out of the 5,000 plants we have at the present 4,188 trees apparently growing with every prospect of success. I send you this information as it may be of interest to you, as it is gratifying to us."

FIJ].- In giving a repeat order for Para stumps, a Fiji Planter writes 2nd April, $1907:-$-"The last lot sent in January last proved most satisfactory."

The India Rubber Journal of 19th November. 1906, quotes from the "Tropenphlanzer," touching one of our Para stump shipments : - "The writer saw 100.000 of these stumps which had just been planted out, none were dead, and many were putting out new roots. The Ceylon consignors, J. I'. William \& Bros. Henaratgoda, guarantee a mortality not exceeding 25 per cent. and the Manager of the Upola Company. estimated the loss on this batch at 2 per cent only. This is decidedly the best method of transporting Heveas."

Seeds and Plants of numerous Commerclal Products supplled, including Tea, Celebrated Caravonlca and Spence Cotton, Arablan Liberlan Hybrld Coffee, Cocoa, Kola, Sisal and other Fibres, \&c.

For Green X Canuring-Albizzla Moluccana. Erythrina Lithosperma, Crotolaria Strlata. Vigna Ground Nuts, \& c.. Seeds.

Six Descriptive Catalogues with Circulars and Special Offers post free to Foreign Countries. Separate Price List for Ceylon.

"SOUTH AFRICA."- The great authority on South Alrican affairs ol 25th March, 1889, says :-"An interesting Catalogue reaches us from the East. It is issued by WILLIAM BROS. Tropical Seed Merchants of Henaratgoda. Ceylon, and schedules all the useful and beautiful plants which will thrive in tropical and semi-tropical regions. We fancy Messrs. Williams should do good business, for now that the great l'owers have grabbed all the waste places of the earth. they must turn to and prove that they were worth the grabbing. We reconmend the cai Powers and Concessionaries under them to go to William Brothers.

Awarded Gold, Silver, Commemorative and other Medals, Diplomas, Merits, and Certificates at various International Exhlbitions, Including St. Louls, 1904.

Awarded Bronze Medal with Diploma for Para \& Castilloa Rubbers at St. Louls Exhibition, 1904

Telegraphic Address:-WILLIAM. HENARATGODA, CEYLON.

LEIBER'S, A.I. AND A.B.C. CODES USED, ALSO PRIVATE CODES.

Agents in London:-Messrs. P. W. WOOLLEY \& Co.. 90, Lower Thames Street.

Agent in Colombo, Ceylon :- E. B. CREASY, Esq.

\section{J. P. WILLIAIM \& BROTHERS,}

TROPICAL SEED MERCHANTS,

HENARATGODA, CEYLON. 


\section{CARGILS ITD.}

\section{COLOMBO.}

Established

1844.

THE LEADING STORE IN THE ISLAND.

BRADNCHES :

KANDY - NUWARA ELIYA.

DEPARTMENTS.

\section{LADIES' DRAPERY}

in all its branches. Latest English fashions. Experienced English Assistants, Milliners and Dressmakers. Dresses made to order on short notice.

\section{GENTLEMEN'S}

TAILORING AND OU'T. FIT'TING.

Every requisite for Gentlemen's wear. Sun Hats, Hosiery, Travelling Requisites, Shirts and Collars, \&c. Light Suits, and Cool Clothing made to order in twenty-four hours.
WINES AND OILMAN. STORES.

This Department is most complete, only the best and most reliable brands being stocked.

Specialities.-Finest Ceylon Teas, Biscuits, Chocolares, and Confectionery. Tobaccos \& Cigars. Perfumery and Toilet Requisites.

DRUG \& DISPENSING DEPT.

Prescriptions accurately dispensed at all hours by qualified Dispensers. Patent Medicines. Druggist Sundries. Sun Glasses, \&C.

\section{CARGILLS LIMITED,}

\section{KANDY.}

COLOMBO.

NUWARA ELIYA. 


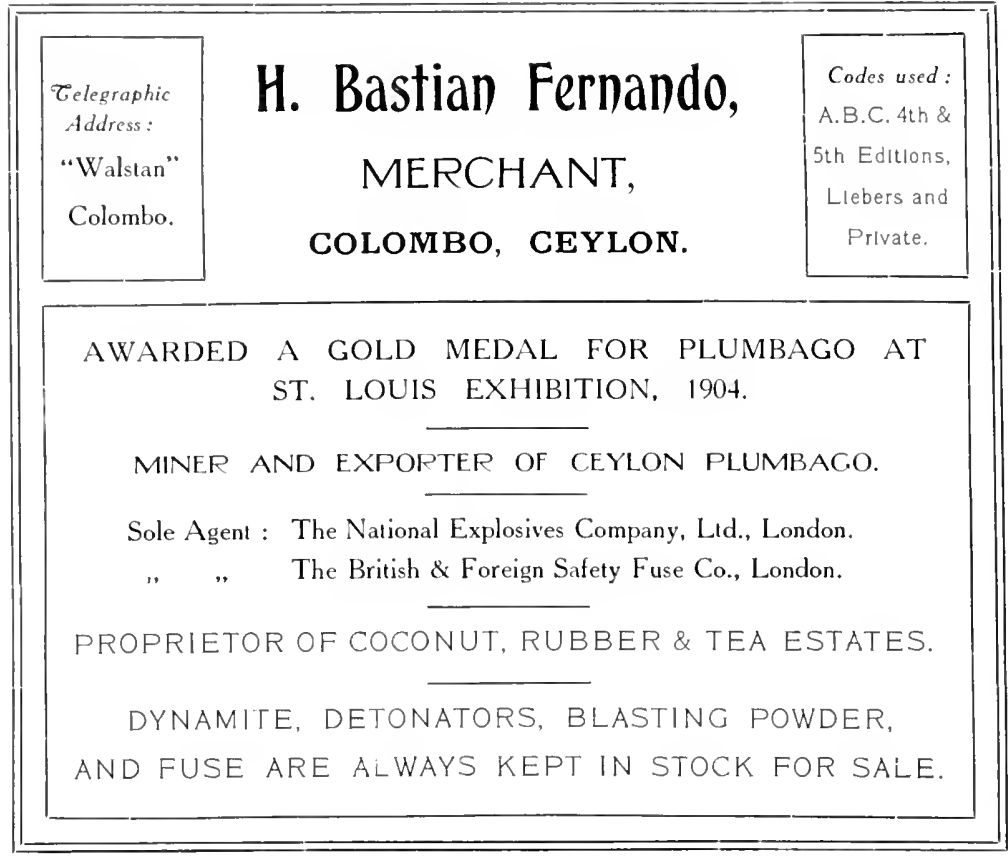

\section{H. Don Carolis \& Sons, s2. First cross STREet. \\ H. Don Carolis \& Sons, $\quad$ colomiso.}

Furniture J Tanufacturers, Upholsterers and Complete House Furnishers. ESTABLISHED 1860.

Telegraphic Address:- "HEYWA," COLOMBO.

The Most Varied Selection of Inexpensive and Artistic Furniture in the Colony.

China and Glass Departments. Dinner, Dessert, Tea and Breakfast Services, Table Glass, Toilet Services, Etc.

These Departments have been fully stocked with a large variety of all the latest Productions of British and Japanese Potteries.

Lamps, Hanging, Table, Wall and Standard Lamps of every variety.

Clocks and Watches Seth Thomas' and other reliable makes.

Carpets and Floor Maltings, Iron Beds, Bentwood Furniture, Genuine Mangalore Tiles, American 4 pt. Barbed Wire, Minton Tiles, Family Sewing Machines, Enamels, Cement, Etc., Etc.

ILLUSTRATED CATALOGUES FREE.

H. DON CAROLIS \& SONS,

STEAM WORKS, SLAVE ISLAND, COLOMBO. 


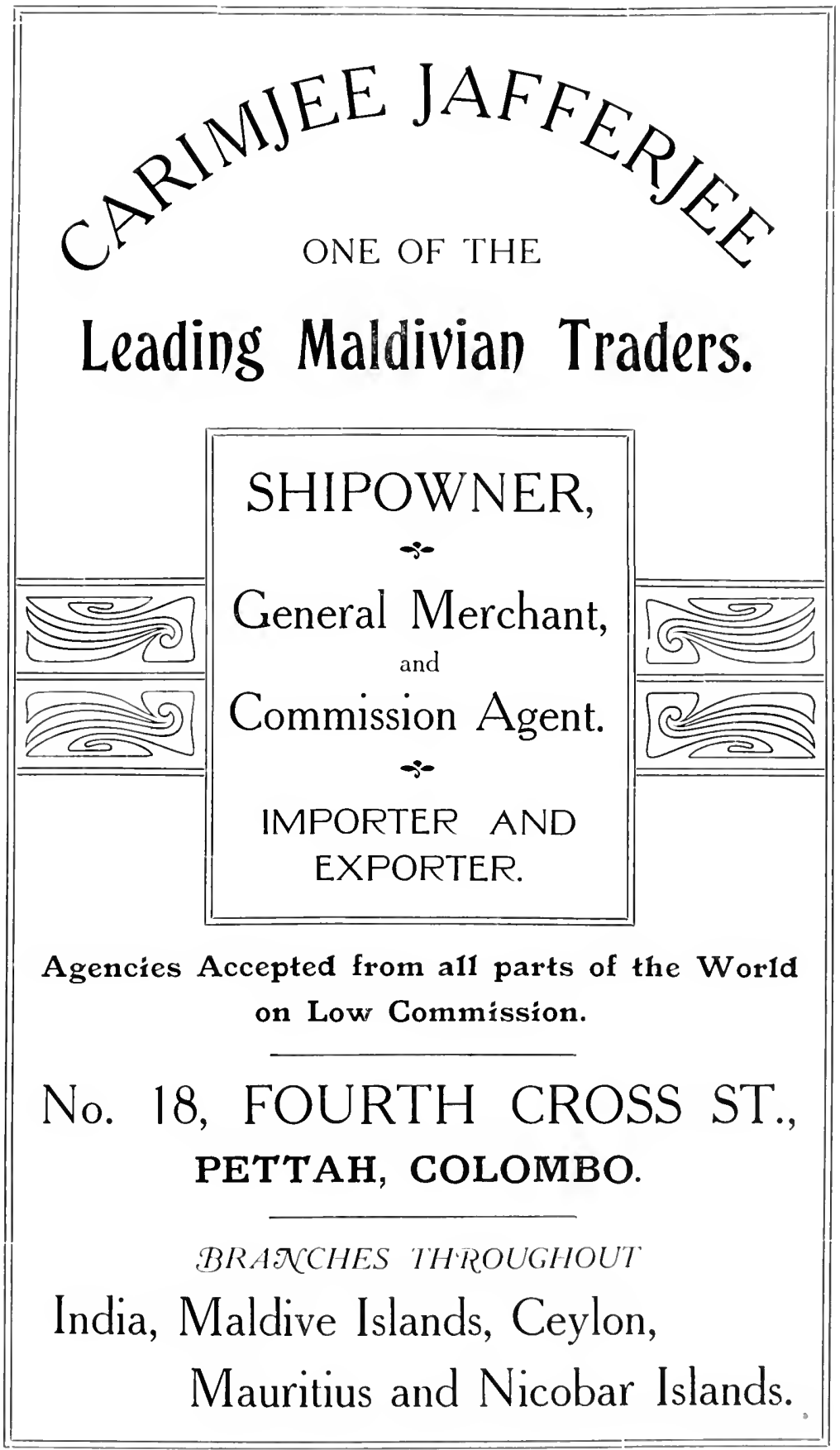




\section{Freudenberg \& Co.}

COLOMBO, CEYLON.

\section{$-9$}

\section{EXPORTERS OF}

COCOANUT OIL, COCOANUT POONAC, PLUMBAGO, CINNAMON, COCOA, RUBBER AND OTHER CEYLON PRODUCE.

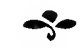

FIRE, LIFE, MARINE INSURANCE AGENTS.

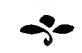

BANKING :

AgENTS OF the LEADING CONTINENTAL BANKS.

(5) 


\section{Freudenberg \& Co.}

COLOMBO, CEYLON.

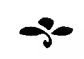

\section{IMPORTERS OF}

COTTON PIECE GOODS, METAL, CEMENT, AND HARDWARE, EXPLOSIVES, ESTATE REQUISITES, AND HABERDASHERY.
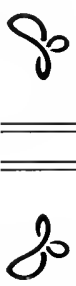

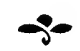

AGENTS FOR THE FOLLOWING STEAMSHIP COMPANIES:

NORDDEUTSCHER LLOYD, BREMEN.

Deutsch-Australische Dampfschiffs Gesellschaft, HAMBURG.

Deutsche Ost-Afrika Linie, HAMBURG. 


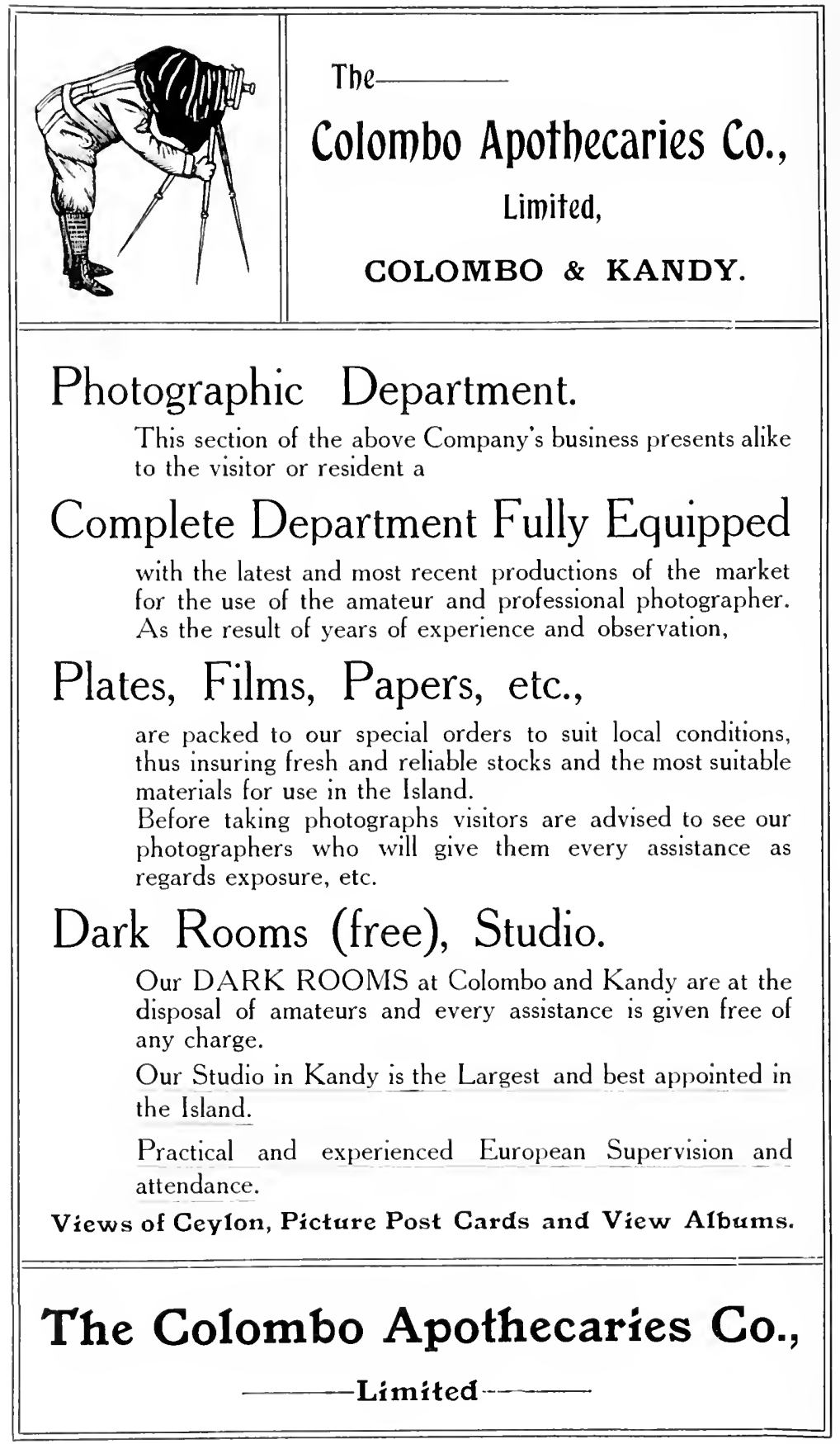




\section{Darley Butler \& Co., Colombo. \\ ESTABLISHED 1847.}

CORRESPONDEXTTS

\begin{tabular}{|c|c|c|}
\hline $\begin{array}{l}\text { DARLEY ' BUTLER } \\
\text { GEORC.E ROBINSON } \\
\text { WW. J. BUTTFIELD. } \\
\text { S. L. JONES 'C CO. } \\
\text { F. WW. HEILCERS 'C }\end{array}$ & $\therefore \mathrm{CO}$. & $\begin{array}{l}\text { LONDON. } \\
\text { MANCHESTER. } \\
\text { NEW YORK. } \\
\text { SAN FRANCISCO. } \\
\text { CALCUTTA. }\end{array}$ \\
\hline
\end{tabular}

General Import and Export Merchants. Shipping, Coaling, Estate, Insurance and Commission Agents.

\section{AGENCIES.}

SHIPPING. The Queensland Line of Steamers.

The Austrian Lloyd's Steam Navigation Co.

The Chargeurs Reunis.

INSURANCE. The Northern Assurance Co.

The Western Assurance Co.

The Maritime Insurance Co., Ltd.

The Union Insurance Society of Canton, Lid.

The North Queensland Insurance Co., Lid.

The Sun Life Assurance Co. of Canada.

COALING. Depot at Colombo Harbour for Heilgers" " Standard " Bengal Coal.

Telegraphic Address:-

"DARLEY," COLOMBO.

\section{BEFORE YOU DECIDE}

\section{WHERE TO BUY}

Your Liquor

and Stores
Ask for-

Our Complete

Retail List

and compare our prices with those of others.

\section{WE NEVER SACRIFICE QUALITY.}

\section{The International Stores, Colombo.}

Emporium for: British and Continental Table Delicacies,. . Oilmanstores, Preserved Provisions, Household Sundries, Wines, Spirits, Malt Liquors, Cigars and Tobaccos, Patent and Proprietory Medicines, \&c., \&c., \&c. 


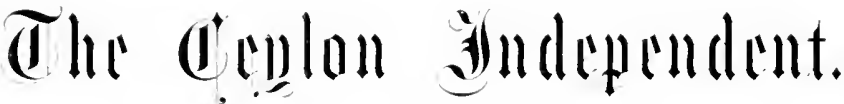 \\ PRICE FIVE CENTS.}

R ECENTLY enlarged; consists of 10 pages daily, except Saturdays R when a 12 page issue (with special Commercial Supplement) is published.

The "Independent" was the first penny paper in the East, and has steadily been advancing in popular favour since its establishment in July 1888. It receives the support of all classes and has more than double the circulation of any other Journal in Ceylon.

No advertising scheme of the Island is complete without it and its superiority as an advertising medium is unquestionable.

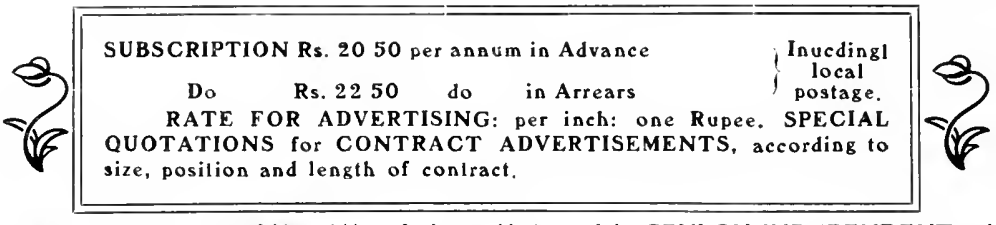

"Thl" ("illoll itlail" Is the weekly issue of the CEYLON INDEPENDENT and in India, Straits Settlements, Europe, America and Africa.

A compendium of Ceylon news every week for only Rs. 10.50 a year.

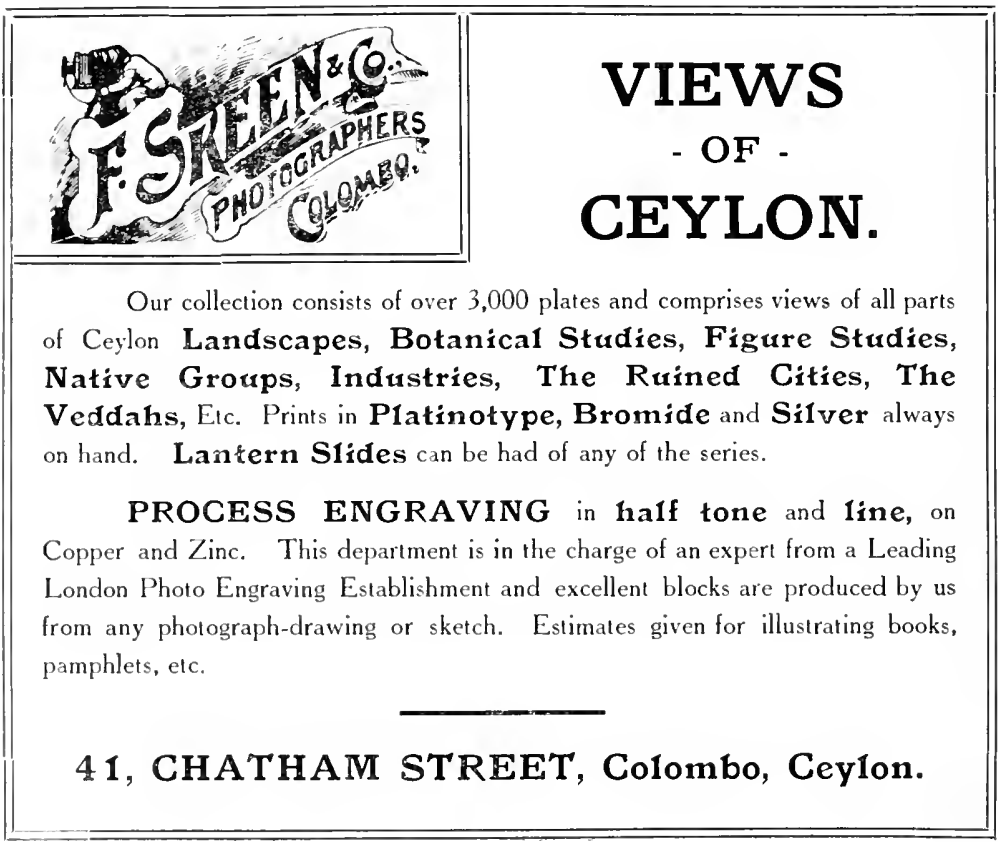




\section{A. B. CASSE LTBBE}

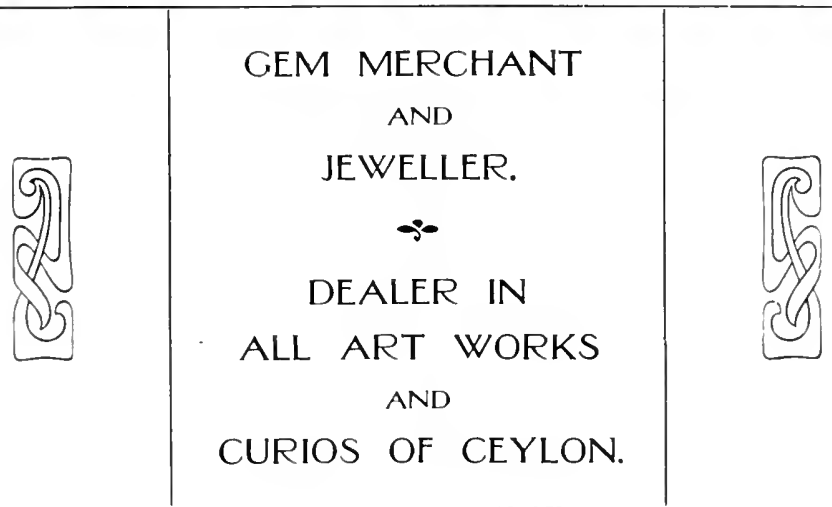

No. I, TRINCOMALIE STREET, KANDY.

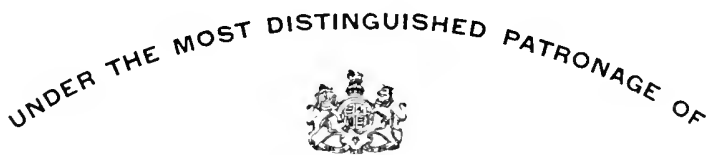

T. R. H. THE DUKE \& DUCHESS OF CONNAUGHT, PRINCE WALDEMAR OF DENMARK, \&C.

\section{DON THEODORIS \& Co.,}

\section{SINHALESE JEWELLERS,}

40, CHATHAM STREET, FORT, COLOMBO.

Dealers in Precious Stones and Articles in Tortolse Shell, Ivory, Sandalwood,

Ebony, Carved Curiosities and Antique Sinhalese Jewellery, \&c., \&c.

Prize Medals and Diplomas, Paris Exhibition, 1900.

Prize Medals and Diplomas, St. Louis World's Fair, 1903 \& 1904.

Quality of Stone \& Gold Guaranteed. Inspection Respectfully Solicited.

A call at our Shop will enable any person to get a valuable Memento of his or her visit to Ceylon.

CHARGES MODERATE. 


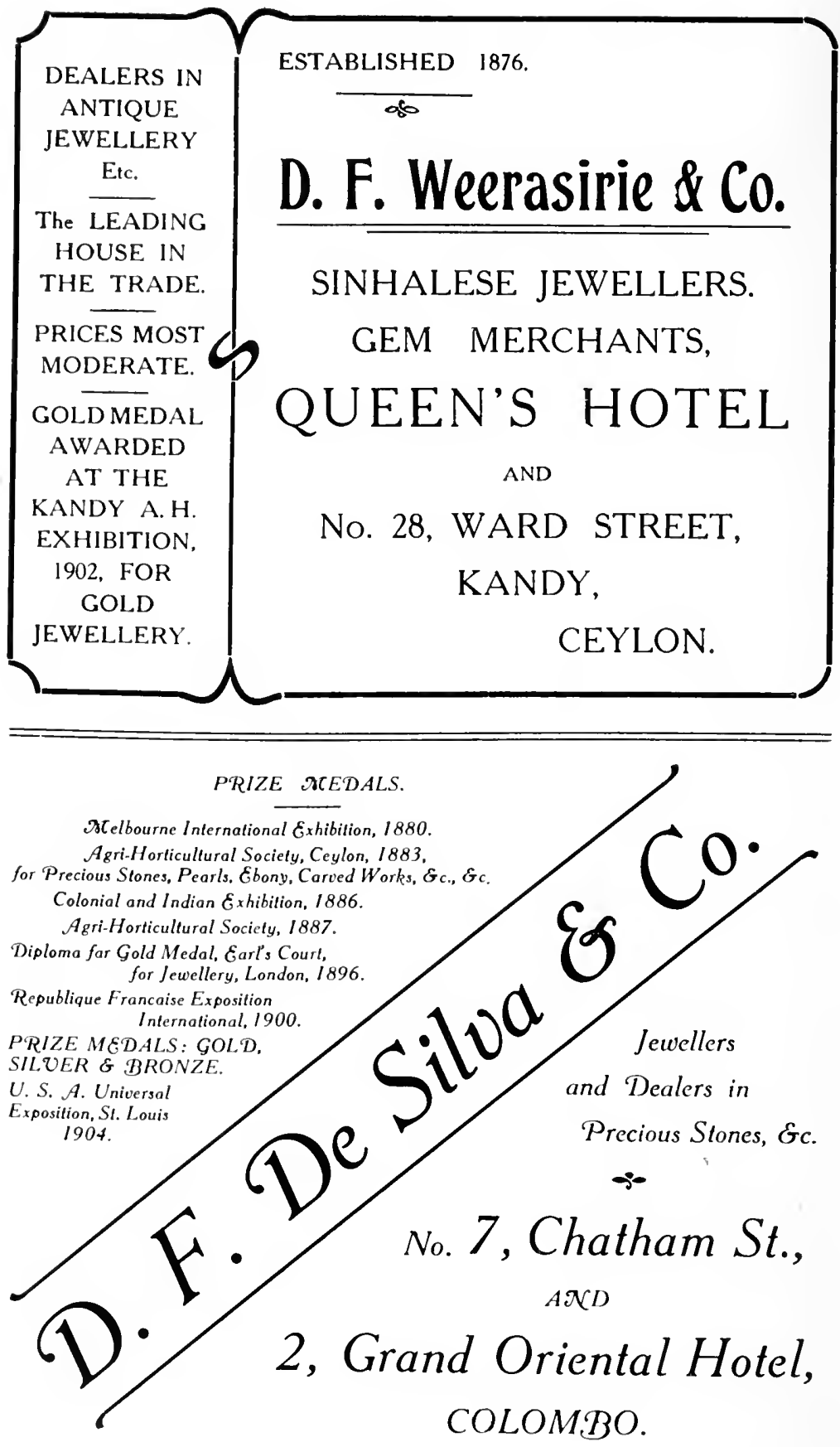







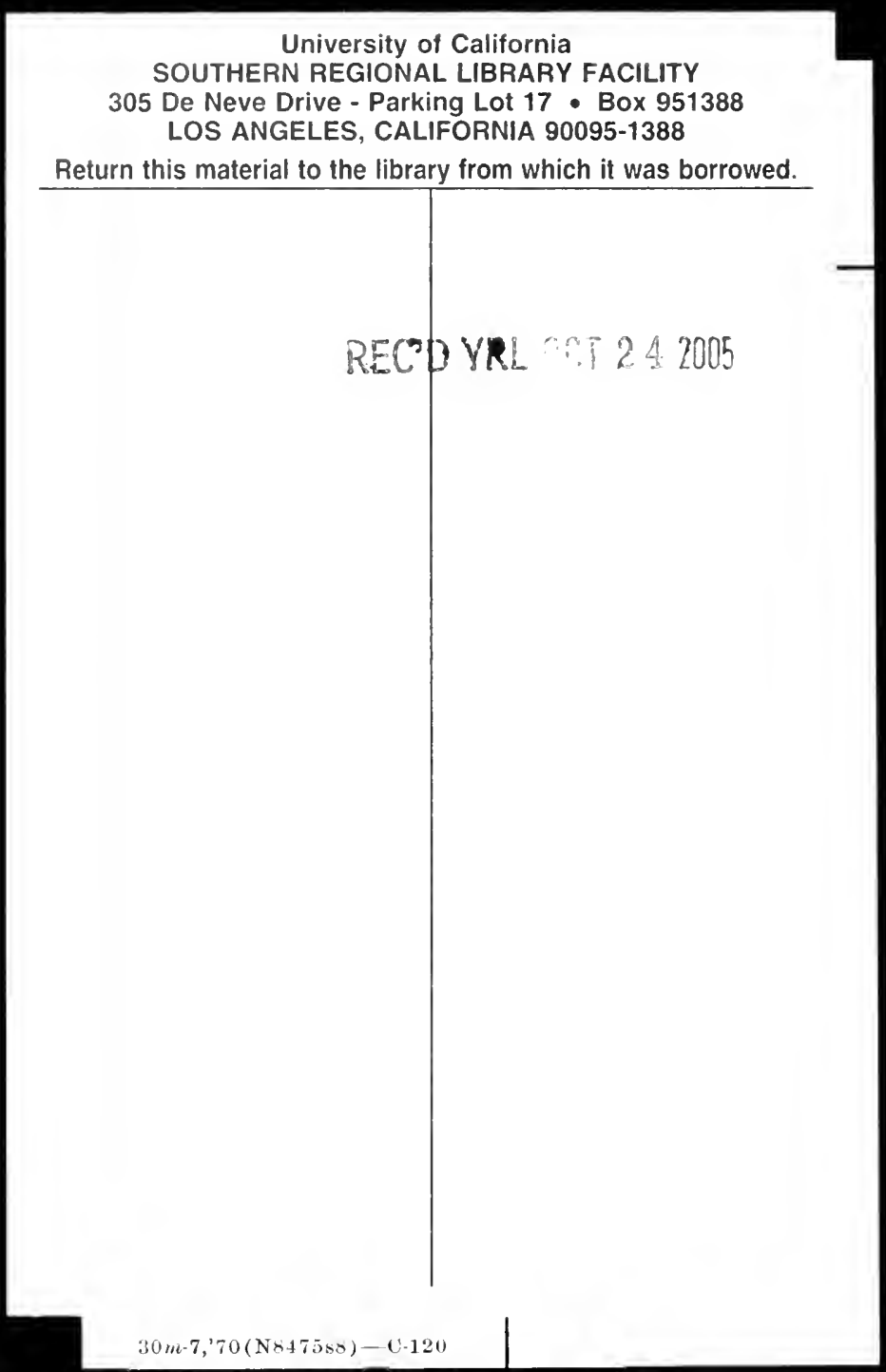




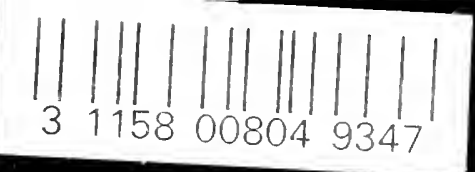

UC SOUTHERN REGIONAL LIBRARY FACILITY

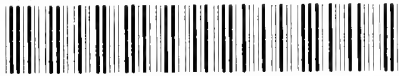

AA $001125275 \quad 6$

Col, Apoth Co. Lid.

orinters alla 2 .

2. Hookbinders. 
